\title{
LINA E LUCIO
}

\section{Marcelo Suzuki}

Tese apresentada ao Programa de Pós-Graduação em Arquitetura e Urbanismo do Departamento de Arquitetura e Urbanismo da Escola de Engenharia de São Carlos da Universidade de São Paulo, na área de concentração Teoria e História da Arquitetura e do Urbanismo, como parte dos requisitos para obtenção do título de doutor.

Orientador:

Prof. Dr. Carlos Alberto Ferreira Martins

São Carlos - 2010 
AUTORIZO A REPRODUÇÃO E DIVULGAÇÃO TOTAL OU PARCIAL DESTE TRABALHO, POR QUALQUER MEIO CONVENCIONAL OU ELETRÔNICO, PARA FINS DE ESTUDO E PESQUISA, DESDE QUE CITADA A FONTE.

E-MAIL: marcelosuzuki.arq@ superig.com.br

Ficha catalográfica preparada pela Seção de Tratamento da Informação do Serviço de Biblioteca - EESC/USP

Suzuki, Marcelo

S968L Lina e Lúcio / Marcelo Suzuki ; orientador Carlos Alberto Ferreira Martins. - São Carlos, 2010.

Tese (Doutorado - Programa de Pós-Graduação em Arquitetura e Urbanismo e Área de Concentração em Teoria e História da Arquitetura e do Urbanismo) - Escola de Engenharia de São Carlos da Universidade de São Paulo, 2010.

1. Lina Bo Bardi - arquiteta. 2. Lúcio Costa - arquiteto. 3. Arquitetura moderna brasileira. 4. Arquitetura no Brasil - século XX. 5. Arquitetura e técnica. 6. Ecletismo. 7. Patrimônio. I. Título. 


\section{AGRADECIMENTOS}

Tudo começou com um escambo: ao cruzar, por coincidência com Carlos Martins, no corredor da Arquitetura em São Carlos, e apesar de saber muito bem que ele não saiu de uma lâmpada por minha causa, fiz-lhe três pedidos (na verdade dois, mas o terceiro surgiu durante o escambo). Como sempre faz, respirou fundo, olhou demoradamente para cada um dos lados, e depois de outro suspiro, olhou de frente e respondeu: V. me fez dois pedidos, antes de responder sim ou não, te faço outros dois, aí vamos ver. O seu segundo era: V. vai fazer pós-graduação. Como disse sim aos seus dois, ele respondeu sim aos meus, daí mandei o terceiro: Só se v. for o orientador. Com seu sim ele juntou o terceiro dele: Não vá me fazer só sobre Lina! Respondi OK, e então do terceiro só cumpri exatamente metade. Carlos foi mais que um orientador, ao que agradeço muito, mais ainda o fato de que a jornada só fez aumentar nossa amizade.

Será impossível, mas hei de tentar sempre, retribuir a generosidade de Maria Elisa, em me dar atenção, ler e discutir textos comigo, lembrar de coisas e me passar, alertar para meus erros, me indicar caminhos; tenho uma enorme dívida com minha amiga-irmã, cuja amizade nasceu sob os auspícios e os cuidados da mãe Violeta Arraes Gervaiseau, que tanta falta nos faz.

Para todas as pessoas, amigos, gente próxima, gente que eu não via há tempos, colegas, conhecidos e conhecidos só-de-vista, colegas da EESC, a equipe toda do Instituto Lina e Pietro, do SESC - Fábrica da Pompéia, pessoal da UFBA e os amigos da Bahia, da UFRGS, os companheiros de MASP, todos os Professores, ex-sócios, alunos e ex-alunos, mas rigorosamente todo mundo que, diante da notícia de que eu estava cursando a Pós-Graduação, abriam-me o maior sorriso franco de alegria e incentivo. Rola, como numa seqüencia rápida de Power-point, a lembrança desses sorrisos tantos. Não tenho como, não caberia nesse pequeno espaço, e minha memória poderia me trair, omitindo alguém, citar a todos, todos, de modo que deixo esse agradecimento vasto e coletivo.

Sonho, através dos sorrisos de meus irmãos, sobrinhos e de meus filhos, Jorge e André, os de meus pais, os iniciadores desse incentivo para algo incerto de tão imprevisível.

Wally, Luiz Ossaka e Paulinho; todos os companheiros da vã

filosofia irrigada...

\section{Lina.}

a Marina, que depois trouxe Anita, para me ajudar. 



\section{RESUMO}

Lina Bo Bardi e Lucio Costa foram importantes intelectuaisarquitetos brasileiros do século XX. Suas trajetórias, muito diferentes nos princípios e nas causas, têm muito em comum nos seus efeitos. Relatar a importância de suas atuações públicas em todos os abrangentes aspectos relativos à inteligência e à arquitetura está sendo objeto de muitas novas pesquisas, com renovado interesse.

Nesse aspecto, apresentamos nossa versão de suas atuações, desenvoltas, na arte e na técnica - antigas ou modernas -, no plano político e social, na vida cotidiana e na vida urbana, e, numa palavra, Arquitetura.

Procura-se, nas duas diferentes trajetórias, localizar e identificar pontos de atuação comuns ou díspares, inserir os comentários relativos ao que estava ocorrendo paralelamente ou à margem deles, inseridos nos contextos históricos, ou vertiginosos na história - venturas, mas muitos mais dissabores -, pelos quais passaram, e que não foram poucos. Mas reagiam e prosseguiam. A inteligência das diferentes reações - no mais das vezes veementes - somadas ao ânimo de continuar no afazer do ofício é impressionante.

Os capítulos que tem por nome obras específicas, acabam por ser ziguezagueantes, pulando para outras obras ou fatos, na tentativa de se explicar processos técnicos ou até mesmo fatos históricos nos quais estas obras estão inseridas.

Palavras-chave: Lina Bo Bardi; Lúcio Costa; arquitetura moderna brasileira; arquitetura no Brasil século XX; arquitetura e técnica; ecletismo; patrimônio. 


\begin{abstract}
Lina Bo Bardi and Lucio Costa were brazilian important intelectualarchitects of the 20th century. Their pathways, very differents in their principles and in their causes, have a lot in common on their effects. Relating the importance of their public actions in all the aspects concerning intelligence and architecture have been the object of lots of new researches, with renewed interest.

In this aspect, we present our version of their actions, developed in art and in technique - antique or modern -, in political and social foreground, in everyday life and urban life, and, to say one word, Architecture.

The intention is to locate and identify the differences and the common points of actions in their trajectories and also make comments concerning what was happening among them or in spite of them. In their history context, the adventures and, most of all, the discontentments that they have been through - and they were many-. But they reacted and carried on. The impassioned intelligence together with the cheer to labor on is impressive.
\end{abstract}

The chapters that are named by specific works tend to be a bit zigzagging. They jump from works to facts in the attemp to explain technical processes and historical facts in which this works are inserted.

Key-words: Lina Bo Bardi; Lucio Costa; brazilian modern architecture; architecture in Brazil 20th century; architecture and technique; eclectism; legacy. 


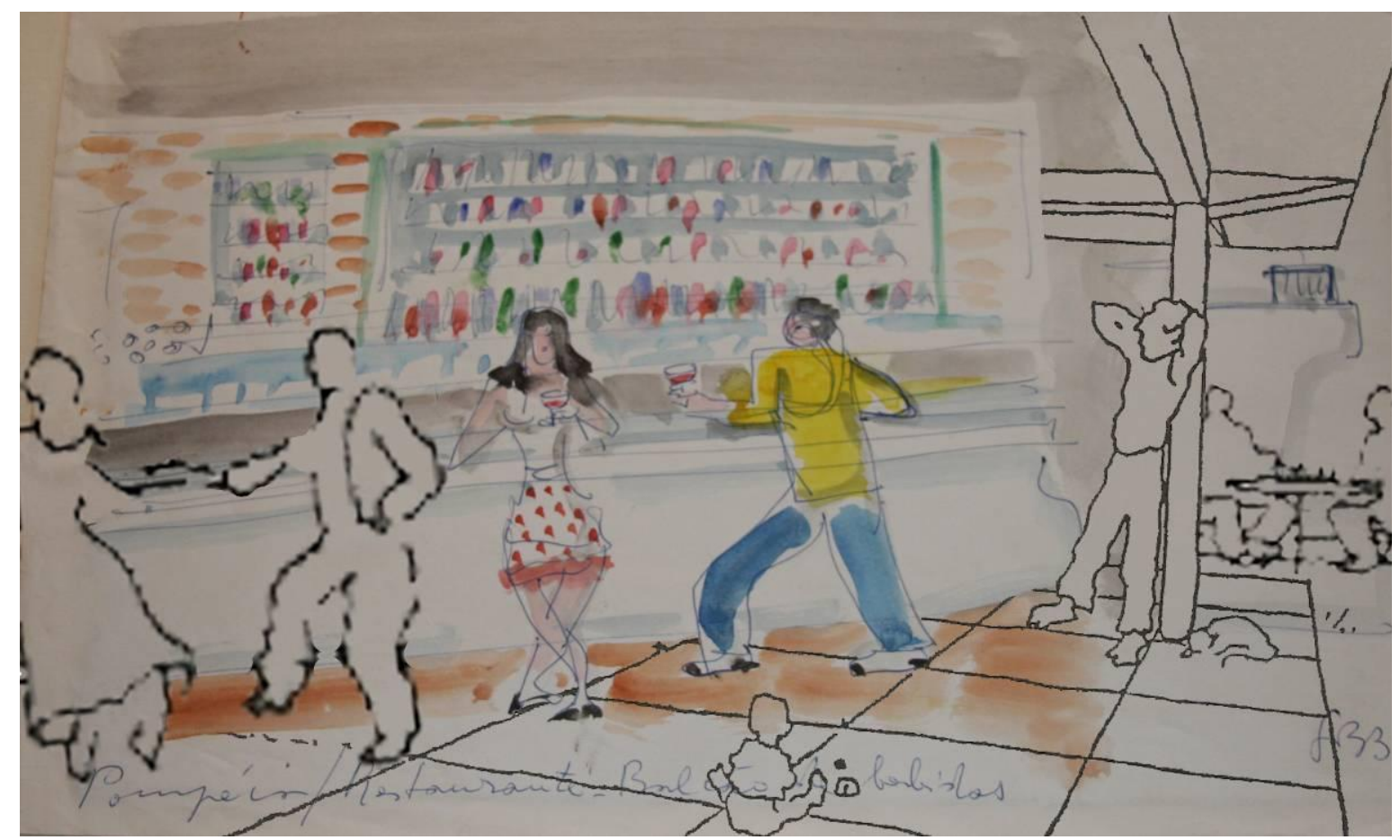

Desenho com interferências: sobreposições parciais de desenhos de Lucio para o Projeto Monlevade - 1934 -, com o desenho do bar de Lina para o SESC Pompéia - 1981. 



\section{ÍNDICE}

\section{PARTE I}

$\begin{array}{ll}\text { INTRODUÇÃO } & 15\end{array}$

$\begin{array}{ll}\text { Lina e Lucio } & 20\end{array}$

ECLETISMO NECESSÁRIO 29

$\begin{array}{ll}\text { O inimigo ao lado } & 38\end{array}$

PAVILHÃO E PALÁCIO $\quad 44$

$\begin{array}{ll}\text { Ornamento } & 51\end{array}$

PAISAGEM CONSTRUIDA 56

$\begin{array}{ll}\text { Enquadramentos vivos } & 60\end{array}$

SABER. SABER-FAZER 66

TÉCNICAS TRADICIONAIS E MODERNAS 82

\section{PARTE II}

MUSEU DAS MISSÕES $\quad 99$

As ruínas da Igreja 101

$\begin{array}{ll}\text { Consolidar, conservar } & 108\end{array}$

As ruínas do entorno da Igreja 113

O “simples abrigo" 117

$\begin{array}{ll}\text { A construção } & 125\end{array}$

SESC - FÁBRICA DA POMPÉIA 133

$\begin{array}{ll}\text { Onde e o que } & 139\end{array}$

$\begin{array}{ll}\text { Buracos } & 150\end{array}$

$\begin{array}{ll}\text { Vocação } & 167\end{array}$

$\begin{array}{ll}\text { OUTEIRO DA GLÓRIA } & 175\end{array}$

$\begin{array}{ll}\text { O Aterro do Flamengo } & 175\end{array}$

$\begin{array}{ll}\text { Igreja de Nossa Senhora da Glória } & 178\end{array}$

Em defesa do patrimônio ambiental 181

$\begin{array}{ll}\text { Diretrizes de projeto urbanístico } & 184\end{array}$ 
$\begin{array}{ll}\text { Projeto e obra } & 189\end{array}$

$\begin{array}{ll}\text { Caminho suave } & 191\end{array}$

PARQUE GUINLE 199

Edifício Nova Cintra 208

$\begin{array}{ll}\text { Edifícios Bristol e Caledônia } & 217\end{array}$

$\begin{array}{ll}\text { Escadas e cores } & 227\end{array}$

$\begin{array}{ll}\text { Fachadas ao poente } & 230\end{array}$

$\begin{array}{ll}\text { SOLAR DO UNHÃO } & 237\end{array}$

Janelas vermelhas 252

$\begin{array}{ll}\text { Tempos de grossura } & 265\end{array}$

$\begin{array}{ll}\text { Volta à Bahia } & 273\end{array}$

CONCLUSÃO: OS BRASIS DE LINA E LUCIO 281

\section{PARTE III}

\section{ANEXOS}

ANEXO I - Lucio Costa - homenagem aos seus 90 anos de vida 301

ANEXO II - Palácio Monroe 323

ANEXO III - Entrevista com Aldo van Eyck 330

ANEXO IV - Praça da Soberania 334

ANEXO V - Solar do Unhão 341

ANEXO VI - Catálogo Triennale de Milane 360

ANEXO VII - Carta a Celso Furtado / Resposta /
Carta do Ministério da Guerra

GLOSSÁRIO

ÍNDICE ICONOGRÁFICO

$\begin{array}{ll}\text { BIBLIOGRAFIA } & 394\end{array}$ 


\section{PARTE I}



Lucio Costa é um intérprete e defensor dos caracteres "nacionais" (já dissemos em que sentido entendemos essa palavra *1), da arquitetura brasileira. Em suas realizações, encontramos, com efeito, tais caracteres, como se dá no conhecido Conjunto do Parque Guinle, no Rio, do qual reproduzimos um detalhe. Ele remonta às origens da autentica arquitetura brasileira, descobrindo seu caráter genuíno não na arquitetura "oficial" portuguesa, mas na "popular", transferida - na pessoa dos antigos mestres e pedreiros "incultos" - para a nossa terra". Ele acha, nesse início, ótimo, aquilo que deu à arquitetura brasileira "esse ar despretensioso e puro que ela soube manter, apesar das vicissitudes por que passou, até meados do século XIX”. E ainda: "A nossa casa se apresenta assim, quase sempre, desataviada e pobre, comparada à opulência dos "palazzi" e "ville" italianos, dos castelos de França e das "mansions" inglesas da mesma época, ou à aparência rica e vaidosa de muitos solares hispanoamericanos, ou ainda ao aspecto palacetado e faceiro de certas residências nobres portuguesas". E esse caráter de domesticidade e de modéstia, tão claramente focalizado, e quase recomendado, caráter que se encontra intacto nas primeiras arquiteturas de Oscar Niemeyer e dos outros arquitetos seus contemporâneos, explica o sucesso da arquitetura brasileira, que apareceu de repente ao mundo, saído de uma experiência sangrenta, da guerra contra a retórica, como um apelo a um sentido honesto e jubiloso da vida.

\title{
Lina Bo Bardi \\ Contribuição Propedêutica ao Ensino da Teoria da Arquitetura 1957
}

Todos os grifos são meus. Reitero:

\author{
genuíno e popular; \\ despretensioso e puro; \\ desataviada e pobre $* 2$; \\ domesticidade e modéstia; \\ honesto e jubiloso;
}

E insisto:

da vida...

*1 É este o sentido autêntico do termo "nacional", o qual, destituído de vazias significações político-nacionalistas, levará a uma colaboração internacional, com a contribuição efetiva e vital das atividades particulares, que satisfaçam a necessidades espirituais e materiais de cada país. Essa soma de contribuições, sintetizado numa linguagem internacional será a base de uma nova cultura que, como acreditamos, não será mais a "européia" ou "americana", e sim a cultura mundial. BARDI, Lina Bo. Contribuição propedêutica... (p 70) ccc

*2 Sobre como e porque Lina e Lucio usam a palavra pobre, em muitas instâncias, se verá ao longo do texto que ora apresentamos. 



\section{INTRODUÇÃO}

Até a Segunda Guerra Mundial, os Estados Unidos da América do Norte vinham causando espanto, tal o dinamismo, a capacidade coletiva de propor e inventar coisas, de buscar caminhos próprios, inclusive para sair da grande crise de fartura, causada por eles mesmos, que foi o grande Crac de 1929. O árduo e importante levantamento realizado por Giedion em seu A mecanização assume o comando apresenta um vasto testemunho desse surto criativo - coletivo-, que então aquela sociedade soube levar a cabo. ${ }^{1}$ Tinha-nos ocorrido usar a expressão lampejo criativo, mas não foi nada efêmero, considerando-se um início em meados do século XIX até o Pós-Guerra temos 100 anos de eventos sucessivos de esforços realmente inovadores.

Após a Guerra, com os americanos do norte saindo da situação como os grandes protagonistas vitoriosos e, na verdade, com grandes lucros aferidos na própria sustentação da guerra, além dos benefícios de que não ocorreram combates em seu próprio território, os Estados Unidos tornam-se a maior potência econômica do mundo, passando a ser o dólar o padrão internacional de moeda.

Porém, a partir daí, algo se perdeu. Talvez por excesso de autoconfiança, desconforto de se estar na posição proeminente de líder mundial, maccartismo interno censurando e perseguindo os intelectuais, enfim, uma série de fatores fazem com que aquele maravilhoso empuxo social pelo novo, pela invenção, saia do papel principal, na cena que vinha representando. A Guerra Fria estabelecida para barrar o avanço soviético, é a senha para aumentar o poder e a hegemonia da grande potência, mas sem a liberdade criativa que caracterizava a etapa anterior. Apesar disso, o país sem- nome $e^{2}$, os Estados Unidos da América do Norte, continua sendo o país que mais investe em pesquisa e, conseqüentemente, em invenções, de todas as ordens:

\section{(...)Sorriso de quase nuvem \\ Os rios, canções, o medo \\ O corpo cheio de estrelas \\ O corpo cheio de estrelas}

Como se chama amante

\section{Desse país sem nome}

Esse tango, esse rancho

Esse povo, dizei-me, arde

O fogo de conhecê-la... (grifo nosso)

Os próprios norte-americanos se caricaturizavam como um turista, de camisa florida, bermudas, tênis com meias três-quartos listradas, chapeuzinho de palha - às vezes de caçador - e máquina fotográfica pendurada no pescoço, sempre acompanhado de uma malajambrada mulher mais para gordinha, de roupa também estampada. As caricaturas retratam um desajeito em relação a todo o resto do mundo, incômodo e barulhento. E, trata-se de uma auto-caricatura!

\footnotetext{
${ }^{1}$ GIEDION, S. La mecanización toma el mando. Barcelona: GG Colección Tecnologia y Sociedad, 1978.

${ }^{2}$ VELOSO, C. Verdade tropical. São Paulo: Companhia das Letras, p.14, 1997.

${ }^{3}$ CAPINAN, J. C., GIL, G. e NETO, T. Soy loco por ti América, 1966.
} 


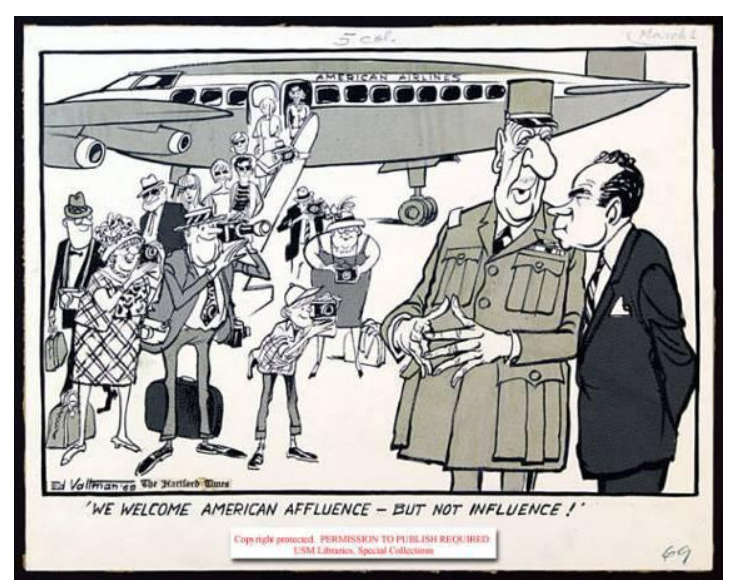

Figura 1. Charge norte-americana datada de 1969. "We welcome American affluence, but not influence!"

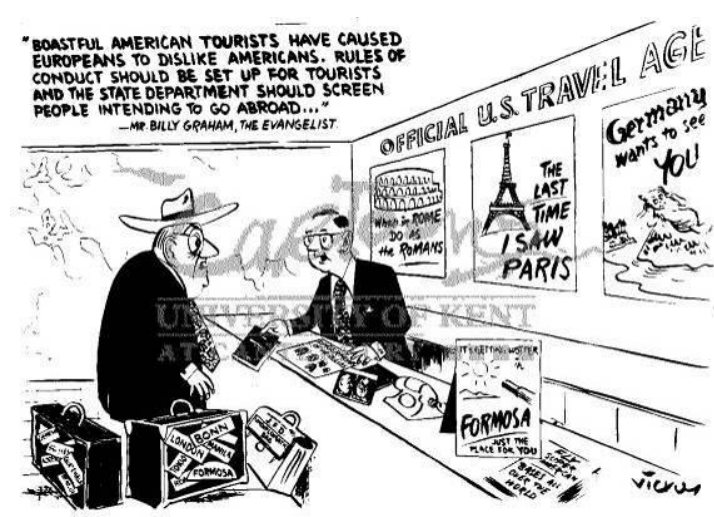

Figura 2. Charge londrina datada de 1954. “... and here, Mr Dulles, is our little brochure on how to win friends and influence people..."

A partir da década de 80, os japoneses invadiram o mundo com seus grupos de turistas gastadores, sendo, portanto, bem-vindos nos lugares onde aportavam, fruto do boom econômico que aquele país atravessou, naquela década. Eram tão incômodos e desajeitados - os flashs espocando mesmo onde não se é permitido, os grandes grupos impedindo de se ver os quadros nos museus -, quanto os norte-americanos das caricaturas, ou grupos de classe média alta de brasileiros chatos, tanto faz, isso só comprova a regra de que todo turismo por si só, é só devastador e que os malefícios são maiores do que a possível renda - a maior razão alegada para que se incentive esse tipo de coisa - que levem a qualquer lugar.

Mesmo durante a Guerra Fria, a Europa reagiu, pelo menos por um certo período. Por exemplo, a França, que se negou, inicialmente, a compor a OTAN. Mas a maior reação contra a potência hegemônica ocorreu mesmo quando se formou um bloco europeu, a princípio chamado Mercado Comum Europeu, na tentativa de contrapor o enorme poderio econômico dos norte-americanos, depois CE - Comunidade Européia, atualmente União Européia.

A queda do Muro de Berlim e o desmantelamento da União Soviética vêm somar-se aos acontecimentos, à mudança ocorrida em toda a Europa e marcar uma etapa nova de re-estabelecimento de mercados, já superada a fase das multinacionais.

Algumas reações, como o protecionismo de mercado em certas áreas continuaram, algumas de comportamento também, por exemplo, na área de alimentação e gastronomia - França e Itália principalmente e como era de se esperar, pela enorme tradição que têm nessa área -, para que não se perdesse, de vez, os costumes locais, como resistência à globalização dos costumes. Mas a reação acontece mesmo na área econômica, de mercado; do ponto de vista do comportamento ocorreu, sim, a americanização do mundo, que nesse sentido, venceram.

O que se está assistindo, mesmo, é a perda total da elegância. $O$ americano da caricatura já não é mais só o norte-americano, é todo mundo. O turismo que avassala qualquer lugar do mundo, hoje, perturba a todos, é barulhento e mal-educado, e, 
na verdade, os turistas estão auto-centrados, e não interessados, poderiam estar em outro lugar, ficou indiferente.

Viajar perde cada vez mais o glamour, antes as pessoas se aprontavam- se vestindo chiques - para ir ao aeroporto -, hoje não precisam mais, ficou corriqueiro: Firenze, Tóquio, Berlim, Ilhas Fiji, tanto faz...

Não tem mais a lição corrente, contada aqui, no Brasil e até mesmo lá em Barretos, na minha juventude: um gentleman jamais usaria um sapato novinho em folha. Ou, que chic mesmo era ter um bom carro velho bem tratado, pelo uso correto por parte do velho e bom chauffeur. Acabou o fato de que chic podia ser, desde uma coisa extremamente singela, até a verdadeiramente chic Confeitaria Colombo: agora o luxo é ostensivo, ofensivo, esnobe. Antes isso era uma vergonha, coisa de novos-ricos, hoje é o lugar-comum: colunas sociais sempre existiram, mas agora existem revistas caras como Caras, em tudo quanto é canto - parece que surgiu na Argentina e se alastrou pelo mundo. O mundo globalizado é o do mau-gosto, dos neo-novos-ricos.

Os discursos são horrendos, o politicamente correto acompanhado do esnobismo: ONG, empresas com responsabilidade social, green-card, etc. etc, tudo bancado por empresas que, quando não aferem mais lucro, direta ou indiretamente da exploração disso, conseguem atropelar a concorrência desprovida de meios para competir com tal ordem de grandeza dos investimentos necessários para a construção de tais dispositivos de marketing de contrôle.

A arquitetura não fica isolada, pertence a esse conjunto de disfarces: sustentável, ecologicamente correta, com acessibilidade universal e... caríssima; esnobe ela também: passada a era dos edifícios inteligentes, que na verdade são edifícios tecnologicamente super-equipados - ou até, e simplesmente, mais equipados que o dos vizinhos -, surge a onda da diferenciação exacerbada, como disse Adrian Gorelik ${ }^{4}$. Prédios espalhafatosos fazem a paisagem de Dubai, e assombram tanto pelo luxo excessivo quanto pelo alto custo, enquanto seduzem pelo emprego de altíssima tecnologia. Eventos, tais como as Olimpíadas, carregam novas dessas invenções para todos os novos lugares-sede, etc. etc. Respingam por todo lugar. A arquitetura não tem conseguido como devia se isolar da imagem e do marketing.

\footnotetext{
${ }^{4}$ GORELIK, A. Professor da disciplina "Tópicos especiais: seminários de pesquisa em teoria e história da arquitetura e urbanismo latino-americanos", 18/09 a 08/10/2007 (citado de memória, de agora em diante como sigla: c.d.m).
} 


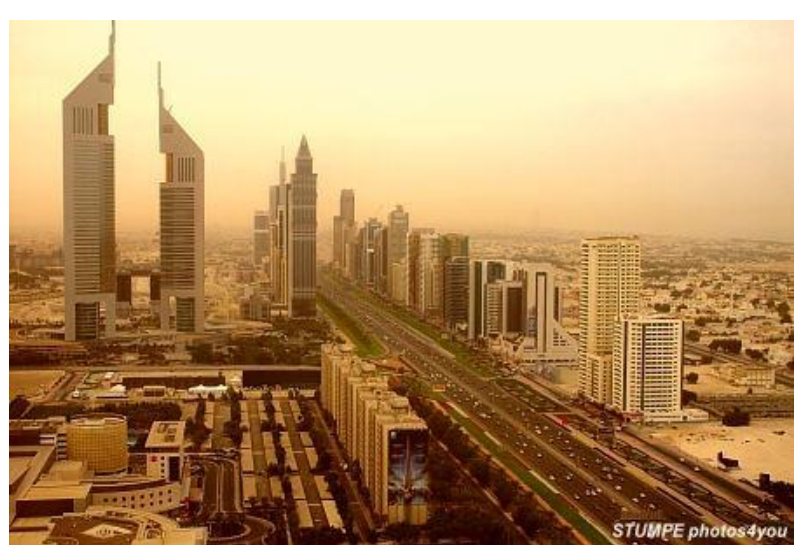

Figura 3. Imagem representativa da cidade de Dubai.

O marketing, por sua vez, é cada vez mais agressivo, embora sempre tente, também, mascarar-se com o discurso do eco-politicamente correto. A sociedade de consumo, atributo quase que exclusivo da sociedade norte-americana, há pouco tempo atrás, globalizou-se, mas os produtos são cada vez mais discutíveis, ou cada vez mais descartáveis - quase sempre também dispensáveis. O marketing do segmento da construção civil anuncia mirabolantes edifícios onde algo chamado qualidade de vida, que não passa de quantidades de coisas que se quer ter, sem querer, de brinquedos à disposição, com muita segurança, áreas verdes e um possível lazer. Os condomínios horizontais que proliferam hoje, em todas as cidades brasileiras, batem nessa tecla, para fazerem seu marketing: área verde, ar puro, como se todos devessem morar num meio falsamente rural. Como "poderia ter dito" Lucio: trocam o bucólico por um arremedo de pitoresco, que quer ter algo - um ligeiro toque - de silvestre.

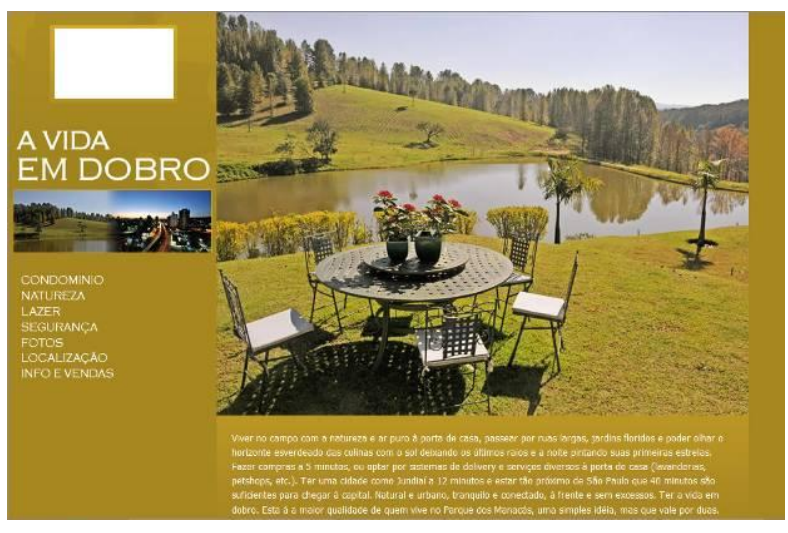

Figura 4. Propaganda de condomínio horizontal, captada aleatoriamente na Internet, mas todas as outras passam a mesma imagem pitoresca. Viver em dobro é um pouco demais, como promessa...

Quem sabe um período de mudanças tal qual estamos vivendo, nesse exato momento, não seja também a exata oportunidade para se sair dela revendo toda essa questão destrutiva do consumo absurdo; quem sabe não teremos a oportunidade de recuperar a elegância, traço característico de, cada um a seu modo, Lina e Lucio.

Chamá-los assim pode soar estranho: Lina sempre foi Donna Lina, assim chamada por todos, inclusive por seu marido, o Professor Bardi. Quando começamos a trabalhar com ela, no canteiro de obras do SESC - Fábrica da Pompéia, nós ainda isolados de seu meio, - ela era desconhecida -, e com a irreverência ou impertinência peculiar de alunos da FAU, daquela época, passamos a chamá-la assim 
simplesmente, de Lina. Com o aumento da convivência, vimos que todas as pessoas de seu entorno estranhavam que tivéssemos essa ousadia, fato que ocorreu inclusive quando fomos com ela em seu retorno à Bahia, em 1986, por parte das pessoas que tinham a conhecido lá, antes, para quem ela era sempre Donna Lina.

Lucio sempre foi Doutor Lucio, para todos que trabalhavam com ele ou o conheceram nessa condição. Lygia Martins Costa descreve a seguinte cena:

- Dr. Rodrigo tinha uma admiração profunda por Dr. Lucio, e falava constantemente nele, no seu conhecimento de causa, no seu bom senso. ${ }^{5}$

O poeta - chefe de gabinete do ministro Gustavo Capanema -, Carlos Drummond de Andrade relatou dessa maneira:

Lucio não tinha hora fixa de chegar e sair. Dizia-se mais consultor de Rodrigo M. F. de Andrade, diretor do SPHAN, do que um burocrata responsável pela Divisão de Estudos e Tombamentos. ${ }^{6}$

Em 1991, ele apareceu no MASP, repentinamente, acompanhado de Maria Elisa, sua filha. Estávamos lá, um grupo de arquitetos, literalmente de joelhos, colando cartazes para um dos eventos do Congresso que levou o seu nome ${ }^{7}$, e surpreendido com sua presença, estendi a mão para cumprimentá-lo do jeito que estava mesmo, de joelhos. Ele cumprimentou, sorriu e disse: continue seu trabalho, não quero atrapalhar, gentilmente, para tirar o nosso desconcerto. Elogiou o MASP, o progresso e o desenvolvimento de São Paulo e foram-se, até que na manhã seguinte Lina estava na mesma mesa com ele, encerrando o Congresso.

Fiquei muito amigo de Maria Elisa, trabalhamos juntos por cinco anos no sertão sul do Ceará, para a URCA - Universidade Regional do Cariri, quando então era Violeta Arraes a Reitora, ela que, por sua vez tinha sido amiga de Lina, se conheceram nos tempos de exílio, Lina já falecida, na época em que estivemos pelo Cariri. Da amizade com Maria Elisa talvez tenha vindo essa intimidade de tratar aqui o Doutor Lucio simplesmente de Lucio - ela muitas vezes se refere assim, quando fala de seu pai.

Lina Bo, Acchylina di Enrico Bo, nasceu em 1914, em Roma, Itália e naturalizou-se brasileira em 1951, país que ela adotara em 1947, logo ao final da Segunda Guerra Mundial. Fez o Liceu Artístico e a Faculdade de Arquitetura da Universidade de Roma. Faleceu em 1992, em sua residência, em São Paulo.

Lucio Costa, Lucio Marçal Ferreira Ribeiro de Lima e Costa, nasceu em 1902, em Toulon, França, e só passa a morar no Brasil em definitivo em 1916. Matricula-se em 1917, na Escola Nacional de Belas Artes. Como, desde logo, teve que trabalhar, perdeu dois anos, formando-se Engenheiro-Arquiteto em 1924. Faleceu em 1998, em sua residência, no Rio de Janeiro.

\footnotetext{
${ }^{5}$ COSTA, Lygia Martins, in: WISNIK, G. org. O Risco: Lucio Costa e a utopia moderna. Rio de Janeiro: Bang Bang Filmes Produções Ldta, p. 76, 2003.

${ }^{6}$ Costa, L. Registro de uma vivência. São Paulo: Empresa das Artes, p. 435, 1995.

${ }^{7}$ XIII Congresso Brasileiro de Arquitetos Lucio Costa. De 28 de outubro a 02 de novembro de 1991.
} 


\section{Lina e Lucio}

Lina e Lucio: ao estudar esses arquitetos, vieram-me esses pensamentos todos, a respeito dos tempos atuais, que eles chegaram, com um certo contragosto, a vislumbrar. Parece que eles nos ajudariam a encontrar uma saída com suas atitudes tantas vezes, e, justamente, de intransigentes modernos. Adotando o mote de Ana Nobre, poderíamos dizer que fazem uma falta enorme:

É claro que supor que a produção atual em arquitetura no Brasil se alimenta da ausência de crítica seria reduzir o problema a apenas um dos seus fatores. Mas pode ser pertinente pensar em que medida nos convém nesse momento a recusa à investigação, ao questionamento. E neste sentido basta ler Lúcio Costa, nosso primeiro e mais irredutível crítico de arquitetura, para entender como o profundo comprometimento entre arquitetura e crítica teve papel determinante na construção do projeto que nos pôs no mundo. Um projeto não por acaso estreitamente vinculado a uma convicção, um compromisso, um ideal hoje anulado. ${ }^{8}$

Lina, na ocasião da obra do SESC - Fábrica da Pompéia, recusou-se a fazer o primeiro centro brasileiro especializado em terceira-idade, que hoje é hipócrita e estranhamente chamada hoje de melhor idade. Dizia que:

- Velha sou eu! Vou fazer um centro especializado em tudo! Não há nada mais bonito do que ver crianças passeando com seus avós, ouvindo histórias... É assim que se aprende a vida... Me recuso a fazer o "baile da saudade”. (c.d.m.)

E isso se realizou, é notável o uso desse centro, por parte de todos, sem discriminação de idades, ao contrário, juntando-as.

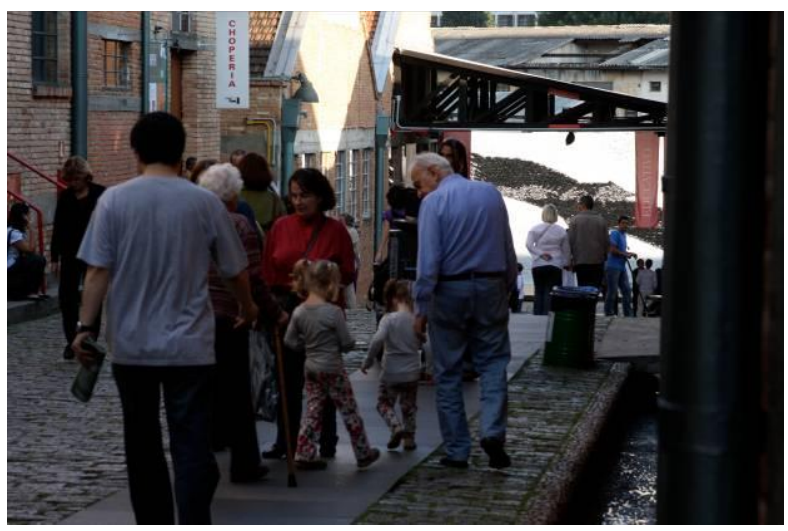

Figura 5. O caminho "tapete" em granito bruto foi feito 15 anos depois da inauguração, por exigência do Ministério Público, para atender as normas de acessibilidade pelos arquitetos André Vainer e Marcelo Carvalho Ferraz.

Ainda na mesma época, sobre acessibilidade, disse:

- Deficientes somos todos nós! Esse é um país em que se pega no colo, em que se abraçam as pessoas! Aprendemos isso com os índios e com os negros, que pegam no colo. Na Europa - nos Estados Unidos também - se você tocar uma pessoa ela se ofende! Aqui não, as pessoas se ajudam, se precisar, carregam no colo... e é egoísmo não fazer isso! (c.d.m.)

\footnotetext{
${ }^{8}$ NOBRE, A. L. A falta que nos faz. Crítica e Arquitetura no Brasil. Vitruvius, São Paulo, jul. 2000. Seção Arquitextos. Disponível em: < http://www.vitruvius.com.br/arquitextos/arq002/arq002_02.asp >. Acesso em: 27 jul. 2009.
} 
Lina se referia ao egoísmo das pessoas sãs, que ao mesmo tempo em que, por estar agindo de modo politicamente correto, se desencarregam, se livram das que têm problemas.

Quando chegou o comunicado da diretoria do SESC avisando que estava decidido que aquele novo centro viria a se chamar Centro Cultural e Desportivo Dr. Fulano de Tal - não se sabe mais o tal nome -, exclamou:

- Não! Eu não sei quem é esse fulano, ninguém sabe. E não é Cultural. Nem Desportivo. É um centro de Lazer, Cultural só afasta as pessoas, assusta. E arte já não interessa mais a ninguém e eu quero aqui cheio de gente. E esporte também é para lazer, sou contra esporte competitivo. Vai chamar Centro de Lazer Fábrica da Pompéia e acabou! (c.d.m.) ${ }^{9}$
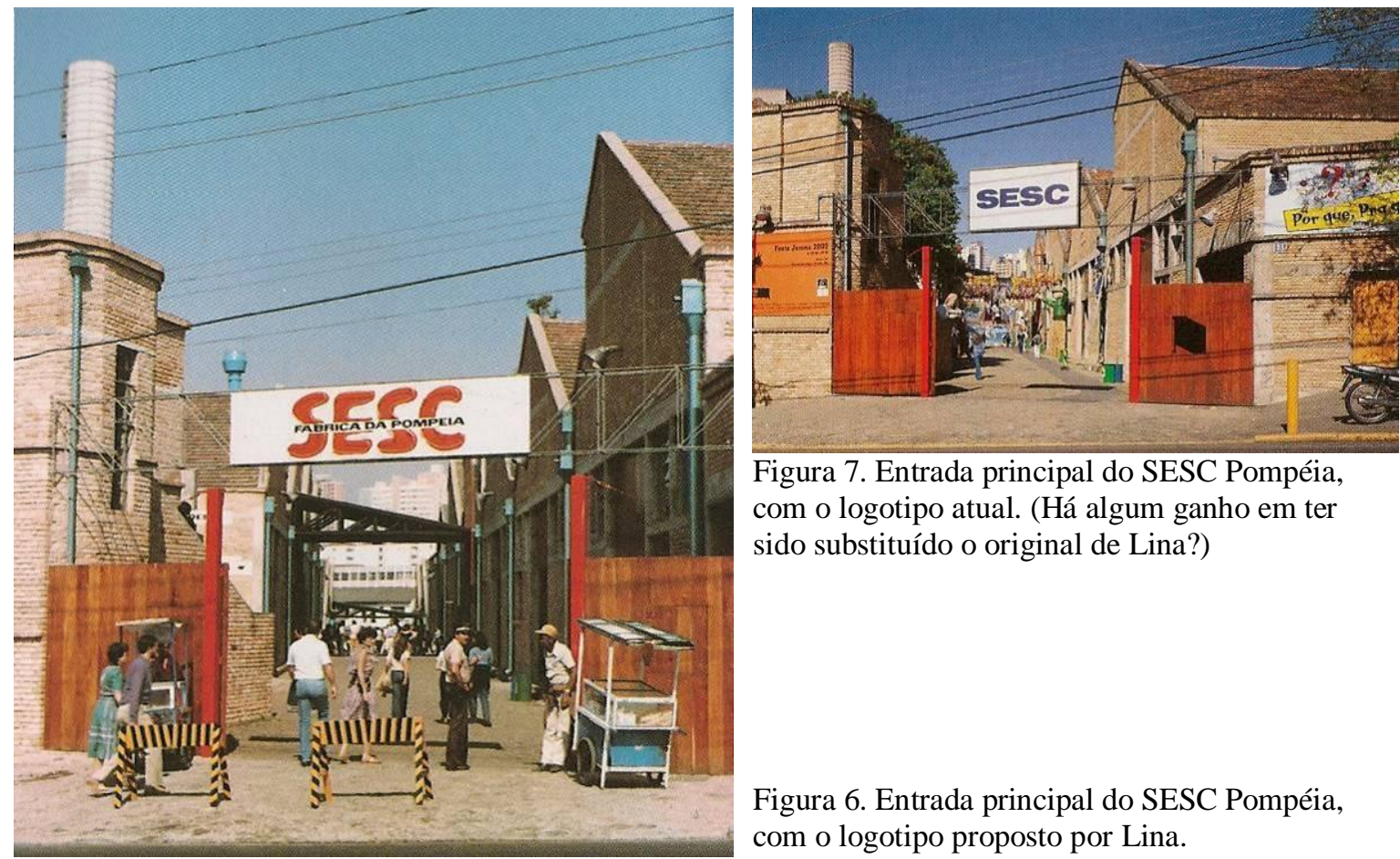

Figura 7. Entrada principal do SESC Pompéia, com o logotipo atual. (Há algum ganho em ter sido substituído o original de Lina?)

E levou a cabo seu intento, até que a diretoria do SESC sumariamente a despediu da direção cultural do Centro Fábrica da Pompéia, com as obras do Bloco Novo ainda em finalização.

Quando da construção de Brasília, um dos poucos projetos arquitetônicos, de construção civil a que se auto-destinou, e se empenhou muito, Lucio, foi a Rodoviária: estranhamente uma ausência de arquitetura, um quase nada. O edifício some, como se não existisse, e, no entanto ele está lá, muito complexo no cumprimento

\footnotetext{
${ }^{9}$ Conforme Malavoglia: Não sendo o SESC um museu, nem um centro cultural, nem um espaço de arte, mas sim um local cujo pressuposto básico é a convivência (daí o nome Centro de Lazer), a própria frequiência (...), indo do catedrático ao engraxate, encontrou (...) o espaço ideal para se sentira à vontade. in: MALAVOGLIA, F. Centro de lazer SESC "Fábrica da Pompéia". Boletim da Associação Brasileira de Museologia. São Paulo, n. 9, ago. 1995. in: FERRAZ, M. C., VAINER, A. Cidadela da Liberdade: Exposição realizada no SESC Pompéia - 19 de novembro a 30 de dezembro de 1999, São Paulo, SESC / Instituto Lina Bo E P. M. Bardi, 1999.
} 
de todas as suas funções. Uma pequena obra prima, mesmo que muito grande em tamanho.

Ali, ele fez o que todo arquiteto deseja fazer: o não-edifício. É uma aula de como realizar um edifício resolvendo toda articulação da cidade: ora some, ora aparece, e você chega sem saber que chegou. Assim é a rodoviária, por isso ele fez tanta questão de desenhá-la - é um projeto seu. (.... ${ }^{10}$

Essa compostura e discrição, que não diminuem em nada um grande e importante projeto de arquitetura, ao contrário, podem realçar a razão própria de sua existência e esta intuição já estava anunciada em sua importantíssima missiva em defesa do projeto de Oscar Niemeyer para o Grande Hotel de Ouro Preto, onde Lucio colocou os seguintes termos:

(...) uma solução que, conservando integralmente o partido adotado e respeitando a verdade construtiva atual e os princípios da boa arquitetura, se ajustasse melhor ao quadro e, sem pretender de forma nenhuma reproduzir as velhas construções nem se confundir com elas, acentuasse menos ao vivo o contraste entre passado e presente, procurando, apesar do tamanho, aparecer o menos possível, não contar, melhor ainda, não dizer nada (assim como certas pessoas grandes e gordas mas de cuja presença a gente acaba se esquecendo), para que Ouro Preto continue à vontade, sozinho lá no seu canto, a reviver a própria história ${ }^{11}$. (grifo nosso), (ver Anexo I).

O papel da Plataforma Rodoviária é fundamental como articulação funcional da cidade, mas isso não torna obrigatória a presença de mais elementos a se agregar ali, exatamente entre os pontos equilibrados da Praça dos Três Poderes e a Torre.

Conforme relatou Maria Elisa:

Durante a construção, com os prazos tão apertados, Lucio chegou a sugerir que a grande plataforma rodoviária no cruzamento dos dois eixos fosse feita mais tarde, no governo seguinte. Resposta do presidente: - "Não senhor! O seu projeto depende dessa plataforma, se ficar pra depois o próximo governo não faz... Quero deixar a estrutura da cidade pronta - e iluminada!" 12

Juscelino demonstrou aí uma grande compreensão do papel da Rodoviária no todo do projeto, indispensável para a cidade funcionar.

\footnotetext{
${ }^{10}$ Depoimento de Ciro Pirondi. in: WISNIK, G. org. O Risco: Lucio Costa e a utopia moderna. Rio de Janeiro: Bang Bang Filmes Produções Ldta, p. 125, 2003.

${ }^{11}$ COSTA, L. Parecer apresentado a Rodrigo Mello Franco de Andrade, Diretor do SPHAN, sobre o projeto de O. Niemeyer para a construção do Hotel de Ouro Preto in Martins, C. A. F. Arquitetura e Estado no Brasil. São Paulo: FFLCH - USP, 1987.

${ }^{12}$ COSTA, M. E. Brasília e eu. Texto não publicado. (em andamento).
} 


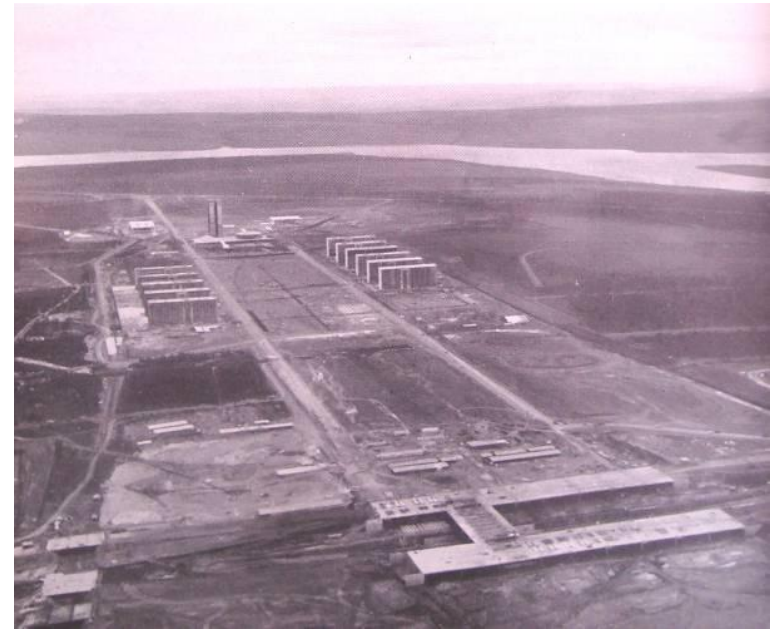

Figura 8. Esplanada dos Ministérios e, no $1^{\circ}$ plano, a construção da Rodoviária de Brasília.

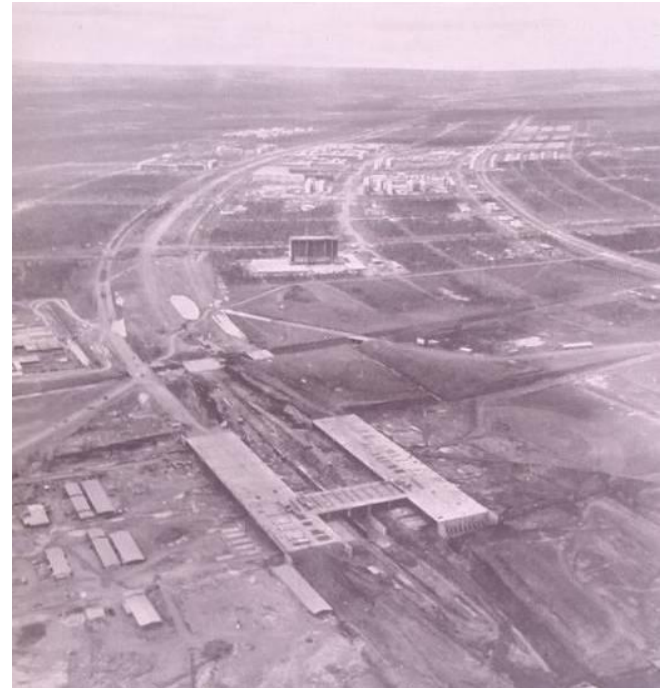

Figura 9. Construção da Rodoviária de Brasília, com vista para a Asa Sul.

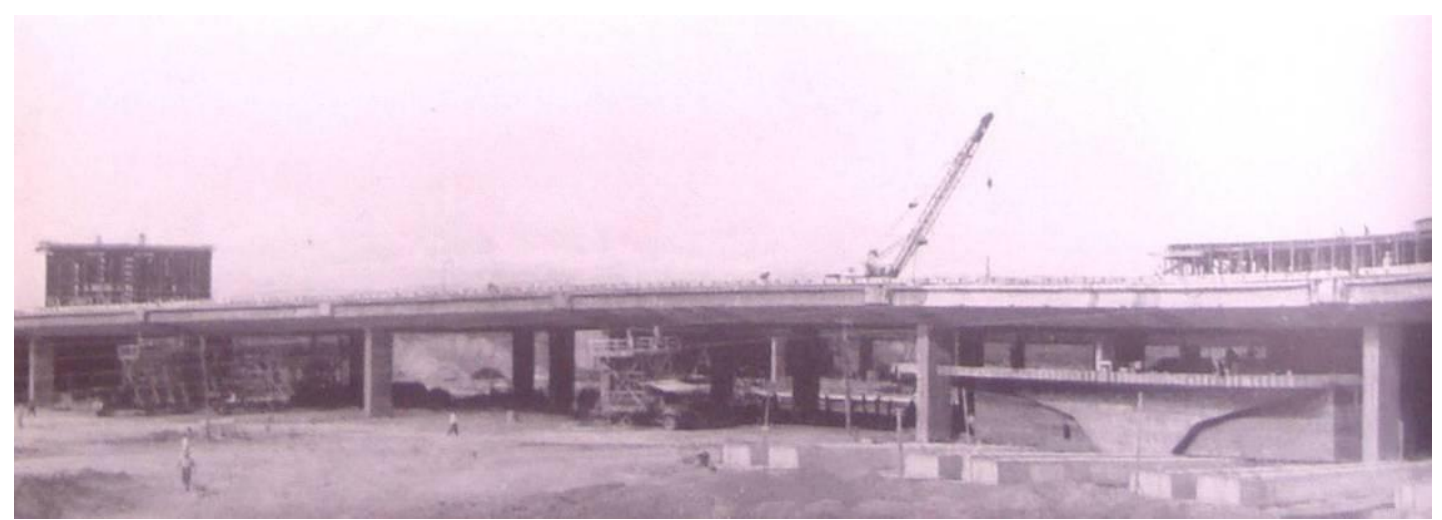

Figura 10. Construção da Plataforma Rodoviária de Brasília. À direita vê-se o pilar "T" dos mezaninos ainda escorado, em fase de concretagem.

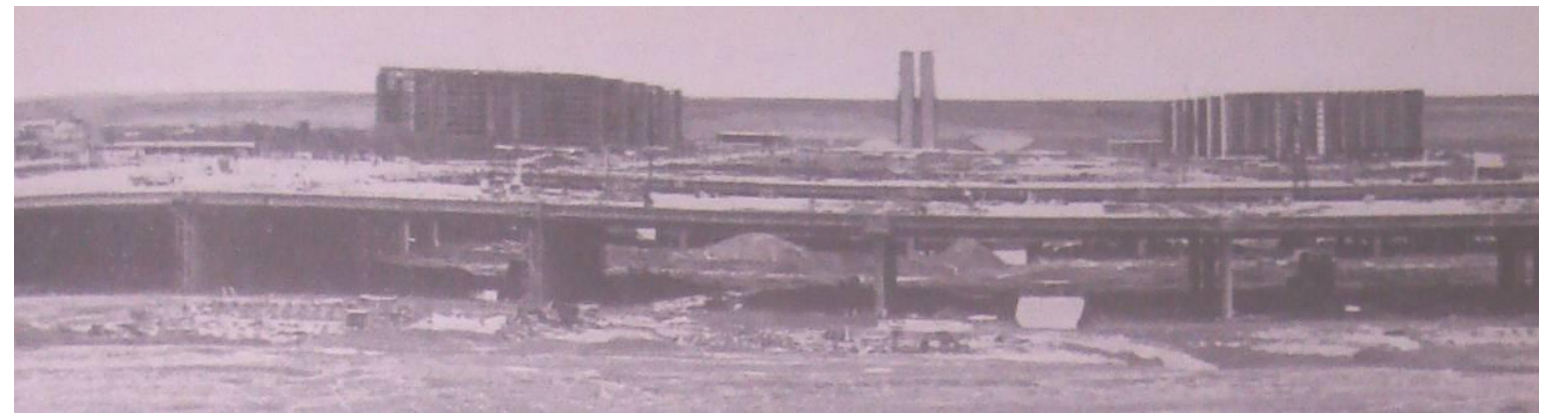

Figura 11. Construção da Plataforma Rodoviária de Brasília, com vista para a Esplanada dos Ministérios Eixo Monumental. 


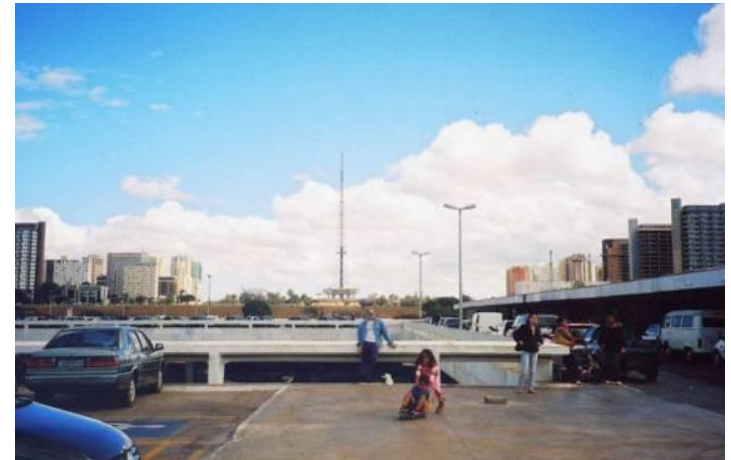

Figura 12. Rodoviária de Brasília. Vista para a Torre de TV - Eixo Monumental.

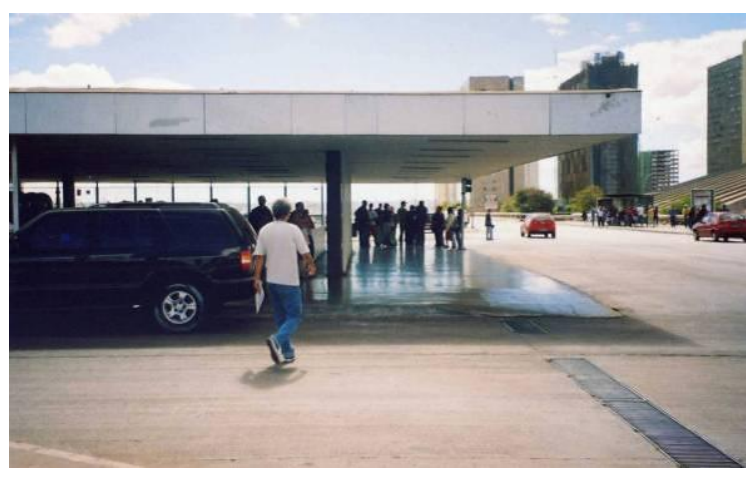

Figura 14. Rodoviária de Brasília: a marquise é tão singela que quase não se percebe sua importância no todo do funcionamento da cidade.

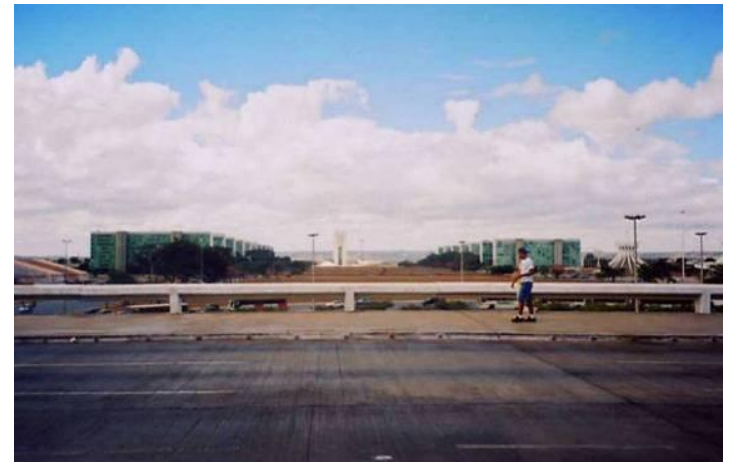

Figura 13. Rodoviária de Brasília. Vista para a Esplanada dos Ministérios - Eixo Monumental.

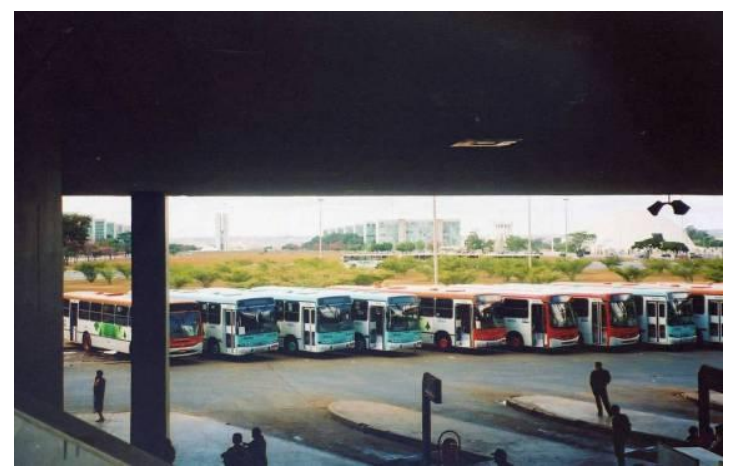

Figura 15. Rodoviária de Brasília: é uma enorme varanda que propicia conforto, sombra e ventilação, contra o sol escaldante do Planalto Central.

Das várias vezes em que estivemos em Brasília, só na última, recente - julho de 2008 - atentei melhor e freqüentei a rodoviária, parando aqui e ali, tomando um café, depois uma cerveja, observando o povo se movendo, seu comportamento educado, apreendendo-a. Há uma onipresença, os viadutos que formam o Eixo Viário-Residencial, passam cortando o Eixo Monumental, constituindo uma grande cobertura, como um imenso avarandado, bem largo, com uma sombra deliciosa, o vento passando livremente pelos rasgos de grande vão. Na medida em que se sobe pelas escadas rolantes, a sensação de varanda aumenta, e se descortina a visão nas duas direções do Eixo Monumental: de um lado a Esplanada, com a Catedral iniciando o desfile dos Ministérios, até a marca inconfundível do Congresso, de outro a Torre da Antena.

Como escreveu Maria Elisa:

$O$ (...) projeto do Congresso, onde o Oscar teve a sabedoria de fazer a vista principal não ter nenhum vão: proporcionou impecavelmente as empenas cegas das duas lâminas do anexo e as duas cúpulas, e ganhou a parada (imagine, naquela correria, se era o caso de depender de requintados detalhes de esquadria!) Os vãos - caixilhos - ou são laterais ou estão visualmente protegidos pela laje sobre a qual repousam as cúpulas. Só o Oscar consegue fazer projetos que viram logomarcas... ${ }^{13}$

Os Ministérios são transversais, e não alinhados ao longo do Eixo Monumental, os prédios perfilados ficam mais bem postos do que alinhados, porque as

${ }^{13}$ COSTA, M. E. Depoimento ao autor. 2008 
empenas fechadas - Lina odiava que falassem cegas -, também, mais fáceis de executar do que caixilhos, por nossa mão-de-obra aprendiz, valorizam a direção principal, os prédios, no outro sentido, oposto ao Eixo, poderiam crescer ad infinitum, para cada lado de fora do Eixo, sem incomodá-lo. Continua Maria Elisa:

(...) pra mim nasceram assim, até porque o partido já estava "incubado" desde o projeto da cidade universitária... ${ }^{14}$

De fato, essa implantação repete a proposta que Lucio já tinha feito, para a Universidade, em 1936/37, com as escolas transversais ao eixo, no fim do eixo o Hospital, no seu começo o Pórtico, a Reitoria, Biblioteca e Grande Auditório.

(...) São cem metros de largura, dos quais reservamos vinte de cada lado, ao longo do muro dos pátios para vegetação frondosa, e duas faixas de nove metros para os veículos; o espaço restante foi então tratado de várias maneiras, no exclusivo intuito de enriquecer o percurso com impressões sempre renovadas. (...) ${ }^{15}$ Parece Brasília, mas ele está falando de seu projeto para a Universidade. Segundo Maria Elisa, sua maior mágoa profissional foi essa, o poder público não ter aceito e edificado esse projeto, o que é mesmo uma lástima.

Do outro lado, ainda olhando da Rodoviária: a continuação do Eixo, marcado ao centro pela Torre, outra obra sua, que como ele mesmo disse, re-estabelece o equilíbrio nas duas direções, em termos do peso advindo da atenção, do olhar. A Torre tem valor simbólico importantíssimo, talvez hoje não seja mais possível sentir a dimensão do significado de sua proposta: Torre da Televisão. Para aquele ermo, para o fim-domundo, para aquele lugar nenhum, mas era para onde estava indo a Capital, por decreto, comunicação era tudo. E a televisão era o veículo de comunicação mais moderno que se pudesse dispor na época, seu maior símbolo, recém chegada no Brasil. Se internet existisse na época, e se internet necessitasse de antena, seria a torre da internet a que teria sido feita. A torre como símbolo é recorrente em qualquer civilização, a torre, símbolo de comunicações, também, inclusive com os deuses. Mas essa Torre é uma necessidade.

Símbolo que não anula a obrigação plástica de existir algo material que dê contrapeso a visada da Esplanada, que culmina na Praça dos Três Poderes, e aqui se fala do projeto mesmo, de plástica, mesmo, de um sentimento que ocorre no instante do parto do projeto urbanístico e de arquitetura: sua base triangular é o rebatimento da Praça dos Três Poderes, que é conformada no sítio por uma delimitação triangular.

\footnotetext{
${ }^{14}$ COSTA, M. E. Depoimento ao autor. 2008.

${ }^{15}$ COSTA, L. Registro de uma vivência. São Paulo: Empresa das Artes, p. 173, 1995.
} 


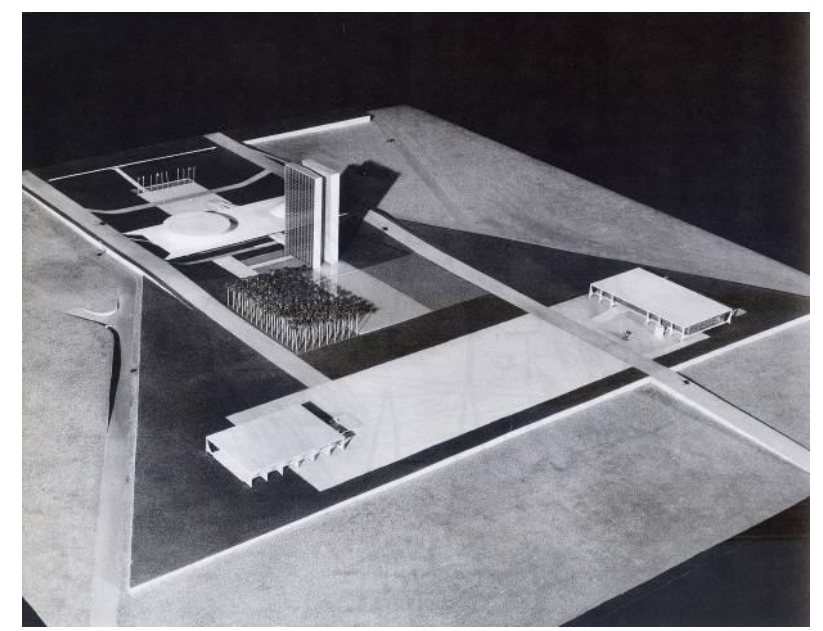

Figura 16. "Contribuição arquitetônica de Oscar Niemeyer para a praça que projetei - e batizei". Lucio, Praça dos Três Poderes, Brasília - A maquete é anterior às obras, é uma maquete $d e$ obra.

O desenho da Torre é bipartido. Na base, toda a coerência com o sistema construtivo em andamento, na época, em obras, por toda a volta, a poeira: concreto armado; em cima, o mais alto tecnicamente possível: metálico, portanto. E pronto.

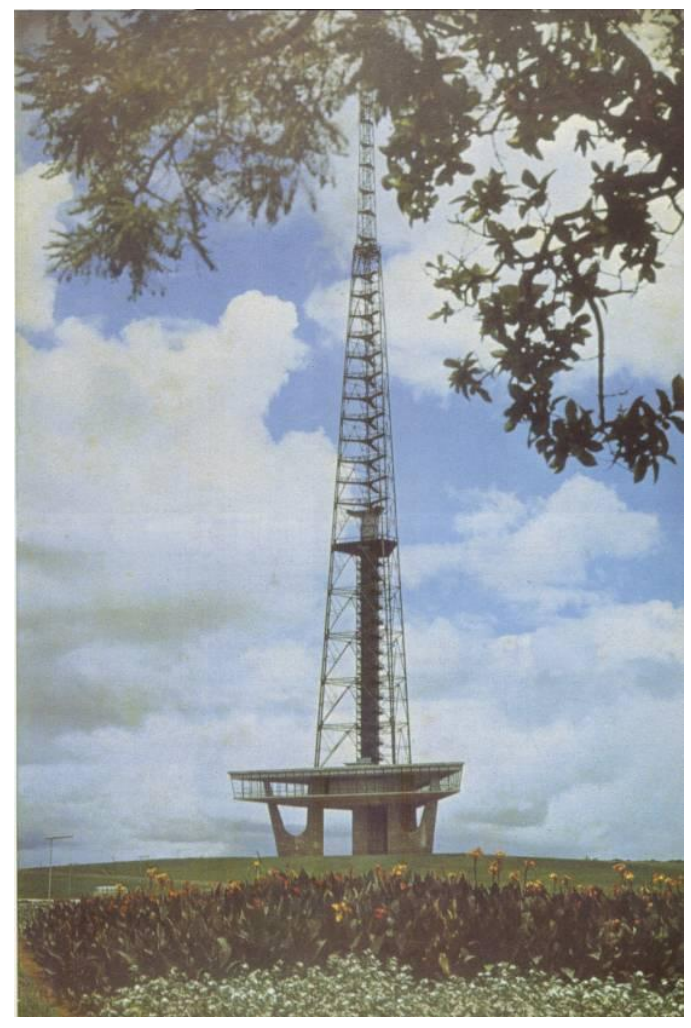

Figura 17. Torre de TV. Brasília.

Notável é que a Torre foi, e continua sendo local de encontro popular, cheio de barraquinhas em volta, que são elas, testemunhas da grande visitação. Visitam a torre, querem olhar e fotografar Brasília. Foi declarada a intenção de se remover a feirinha ao pé da Torre, recentemente, pelos poderes públicos. A Torre mais famosa, com todas as devidas e merecidas razões, a Eiffel, também é assim. Todo mundo quer subir, para olhar Paris; muita gente, até hoje, ainda quer desmontá-la, achando que a 
existência dela agride Paris. Mas ela é o símbolo de Paris. Também tem barraquinhas ao seu pé, vendendo torrinhas.

Mas, dali, da Rodoviária, na sombra da varanda abre-se ainda uma terceira visão: a da própria Rodoviária, uma visão à cavaleira, vê-se as pessoas circulando, as barraquinhas, o movimento dos ônibus. Nesse nível encontra-se uma série de bares e restaurantes, lugares para sentar, esperar a partida do ônibus, encontrar, conversar. E as funções necessárias para administração e demais demandas internas ficam em singelos fechamentos em caixilhos, de piso a teto, com vidro leitoso, quase não se percebe a existência.

Subindo mais, chega-se a uma simples marquise. Em volta, as pistas tranqüilas, não as agitadas, dos Eixos, e sim as locais, já se está entre os Centros Comerciais. Parece uma saída de Metro, Metros mais antigos, de cidades que já possuíam Metro de longa data, que possuem essas saídas de Metro singelas, sem estardalhaços - até mesmo os de Paris, de Guimard, em pleno Art Nouveau, pois apesar do rebuscamento escultórico e ornamental, é só uma entrada ou saída de uma escada. São assim, não há construção.

Essa surpresa ocorre também porque o que era o nível natural ou original do terreno não existe, ou não existe mais, em Brasília. Em qualquer direção, para onde se vá, o terreno foi trabalhado, perde-se a noção do que é exatamente solo original, solo modificado, ou laje, em que se está pisando. Isso permitiu com que os diversos edifícios tivessem, cada um ou em grupos, uma relação diferente com o que parece ser um piso térreo, comum com o que sentimos como térreo em um outro lugar qualquer. Lá isso some, trabalhado por um projeto de implantação e terraplenagem em escala inusitada - na pequena escala isso já se encontra no Parque Guinle e vai ser executado com maestria nas Rampas do Outeiro -, com um ajuste preciso entre terrapleno e níveis construídos.

\section{(...) Então eu senti esse movimento, essa vida intensa dos}

verdadeiros brasilienses, essa massa que vive nos arredores e converge para a Rodoviária. Ali é a casa deles, é o lugar onde se sentem à vontade. Eles protelam, até, a volta e ficam ali, bebericando. Eu fiquei surpreendido com a boa disposição daquelas caras saudáveis. (.... ${ }^{16}$

Confirma sua própria previsão de que a rodoviária seria um grande ponto de encontro em Brasília, o cuore, apesar de na continuação do texto acima ele negar que ele tenha feito isso, que o povo é que tomou conta. Foi ele, sim. O povo também.

É um lugar sofisticado como tudo que é verdadeiramente simples, despojado e popular, como é também o SESC - Fabrica da Pompéia, os predicados são os mesmos. A rodoviária de Brasília é o próprio Lucio: liga tudo com tudo, vê tudo, aparece o mínimo. Sobre o seu recato falaremos mais adiante.

Uma chaminé sozinha pode ser a reminiscência de uma antiga fábrica, galpões sozinhos talvez não. Por isso Lina fez tanta questão de reconstituir a

\footnotetext{
${ }^{16}$ COSTA, L. Registro de uma vivência. São Paulo: Empresa das Artes, p. 311, 1995.
} 
antiga chaminé, ruída, da Mauser, na forma da torre da caixa d'água do SESC- Fábrica da Pompéia.

Sem a chaminé a fabrica não teria a referência:

- (...) enquanto soa o apito de uma chaminé de barro, porque não atende ao grito tão aflito da buzina do meu carro?..."17

A relação de época da indústria, o símbolo da produção, é a chaminé fumegante - todos os cartazes russos da revolução se reportam a essa imagem. Fábrica sem chaminé, nem pensar, então Lina faz a torre, com formas trepantes, marcando cada etapa de concretagem, 1,2 m por dia, de maneira definitiva, escorrida, como as famosas 5 TORRES, de Barragán, na Cidade do México. Só descobrimos isso depois.

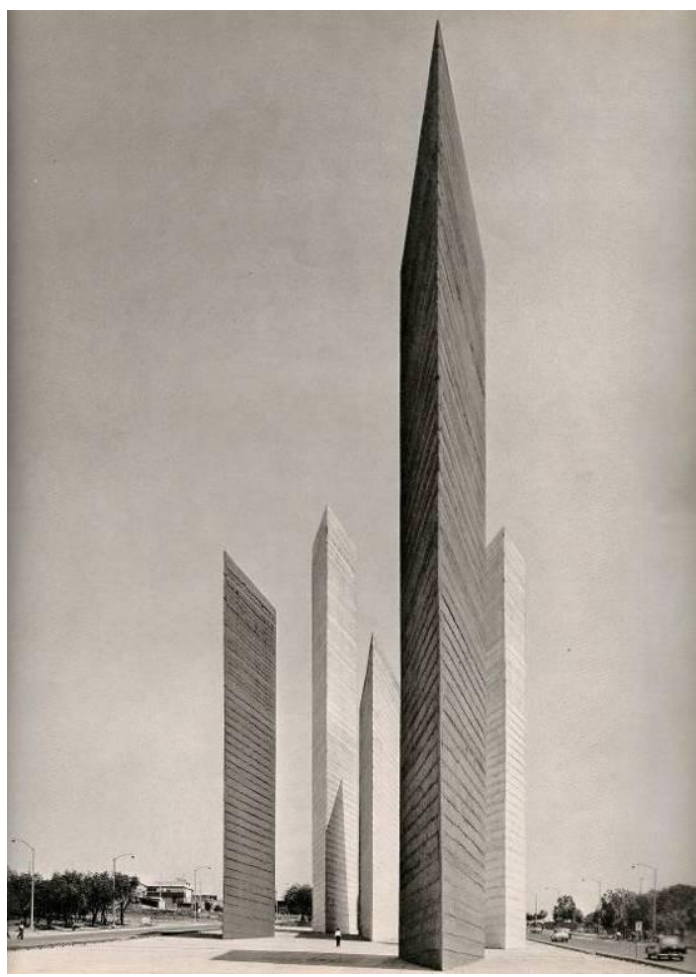

Figura 18. Torres da Cidade Satélite, Cidade do México, Luis Barragán

${ }^{17}$ ROSA, N. Três apitos. Rio de Janeiro: 1936. 


\section{ECLETISMO NECESSÁRIO}

A $1^{a}$ manifestação cultural do recato burguês foi, assim que assumiu o poder, a burguesia adotar o Neoclássico como estilo, como a maneira de se apresentar, de se demonstrar não tão ignorante quanto a aristocracia a achava, ou seja, com que cara cultural se se mostra em público, qual é a sua fachada para a rua, para a cidade: "com que roupa eu vou, ao samba que você me convidou?..." ${ }^{1}$

Não há ruptura, desde o Renascimento e o Maneirismo, passando pelo Barroco e o Rococó, o Neoclássico aparece como "natural", como um suceder de proposições que se encaixam numa pilha "evolutiva" - lembrando que evolução não quer dizer melhoria. Quer dizer movimento, mudança. O que equivale também à adaptação, no mesmo sentido da "evolução das espécies" darwiniano.

Por adaptação entendemos o que aconteceu com o Neoclássico: fora o período denominado “Terror”, da Revolução Francesa, não houve ruptura, foi um pacto de acordo entre a decadente e endividada aristocracia européia e o inusitado enriquecimento da nova classe, que, ao mesmo tempo em que a derrubava, queria ser igual, copiar seus hábitos, continuar invejando sua cultura.

Assim é que, em sua feição pública, novos programas são apresentados a público, no meio das cidades em franco crescimento: se, banco não existia antes, qual a fachada de um banco? Agiotagem sempre existiu, mas o órgão, a instituição financeira que demanda se apresentar na forma de um prédio, como imaginar, e se apresentar? Um prédio em uma rua importante, de então, na cidade: Neoclássico... - ao que se saiba os primeiros grandes agiotas foram os pompeianos, que emprestavam, a juros, capital para empreendimentos das esquadras romanas. A atividade existia, não existia a instituição. O primeiro prédio feito para esse fim foi em Londres, propriedade da então burguesa e posteriormente, aristocrática família Rotschilld. Impossível imaginar ruptura ou até mesmo uma invenção totalmente diferente, nesse contexto. Os novosricos e os aristocratas estavam se unindo, para tomar uma outra, mas única, frente: os Novos Mundos.

Sennett descreve essa passagem preciosa:

(...) Além do mais, os cafés desempenhavam uma função que os trona ainda mais fáceis de serem romanceados, retrospectivamente: eram os centros de informação mais importantes em ambas as cidades - Londres e Paris - nessa época. Neles eram lidos os jornais, e, no começo do século XVIII, proprietários de cafés londrinos passaram a editar e imprimir seus próprios jornais, reivindicando, em 1729, um monopólio nesse ramo. Negócios tais como o de seguros, ligados à necessidade de informações sobre a probabilidade de sucesso em uma transação particular, cresceram nos cafés. Por exemplo, a Lloyd's começou como um café. ${ }^{2}$

\footnotetext{
${ }^{1}$ ROSA, N. Com que roupa. Rio de Janeiro, 1929. Mais que a pura imagem, as datas dessas músicas são muito significativas: em 29, Noel denuncia a pobreza, a falta de roupa para se apresentar em um lugar apresentado, surpreendentemente, como chic, onde há que se ir apresentável. Em 36, a modernidade, o meu carro.

${ }^{2}$ SENNETT, R. O declínio do homem público. São Paulo: Companhia das Letras, p. 108, 1989.
} 
Quer dizer, o banco moderno nasceu num bar, ainda não tinha roupa! Quando passa a ter: Neoclássico.

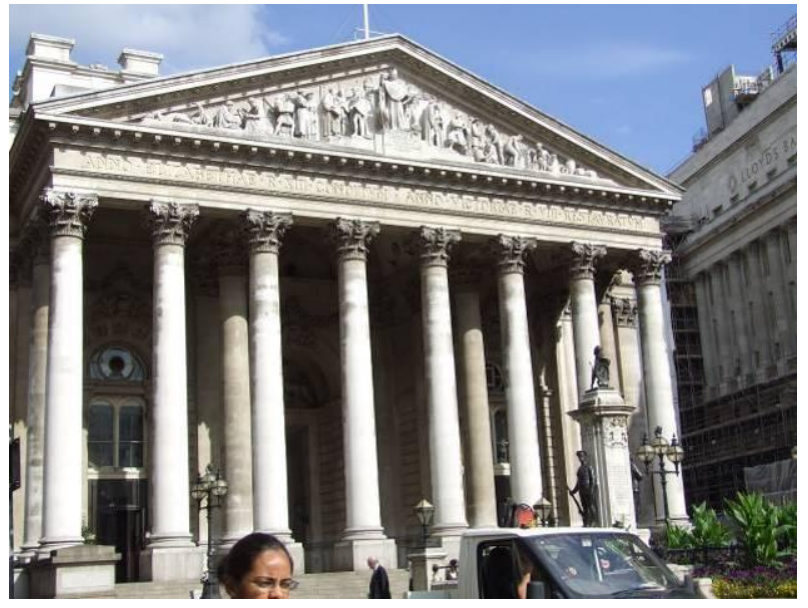

Figura 1. Fachada de Bancos em Londres. Primeiro plano: Royal Exchange e segundo plano, à direita: Lloyd's Bank. O pórtico da entrada se reporta ao Panteão em Roma, com a dupla fileira Colossal.

A questão "com que roupa", que parece insistente ao longo da história, retorna também nos sistemas ditatoriais estabelecidos na primeira metade do século XX: o fascismo de Mussolini, o nazismo de Hitler e o realismo socialista de Stalin. Em todos os casos, adotou-se um "Neoclássico" como o discurso oficial para a formação de sua imagem pública.

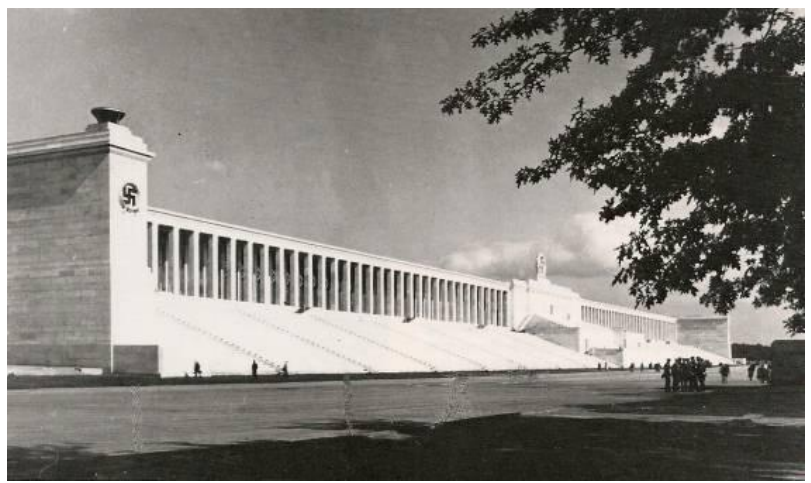

Figura 2. Albert Speer, Zeppelinfeld, Nuremberg, 1936.

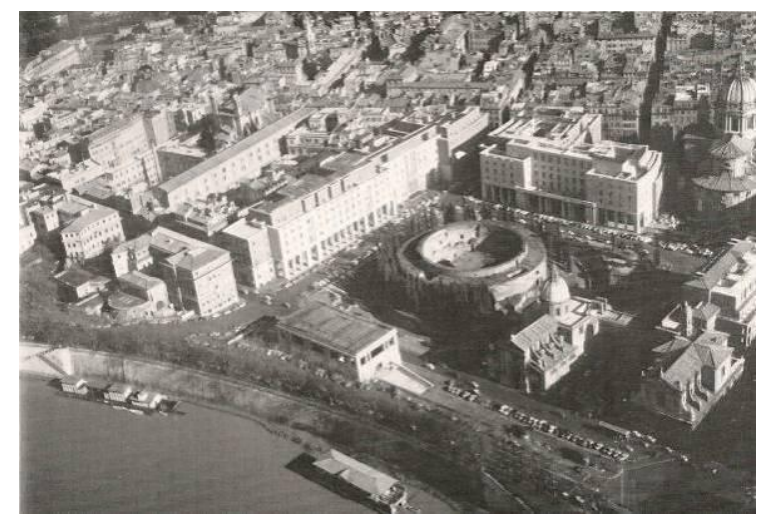

Figura 4. V. Ballio-Morpugo, clearance around the Mausoleum of Augustus, Rome, 1937.

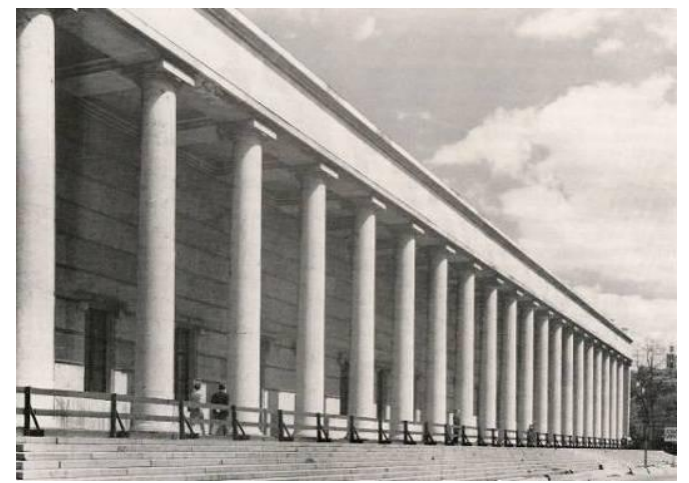

Figura 3. Gerdy Troost, House of German Art, Prinzregentenstrasse, Munich, 1934-6.

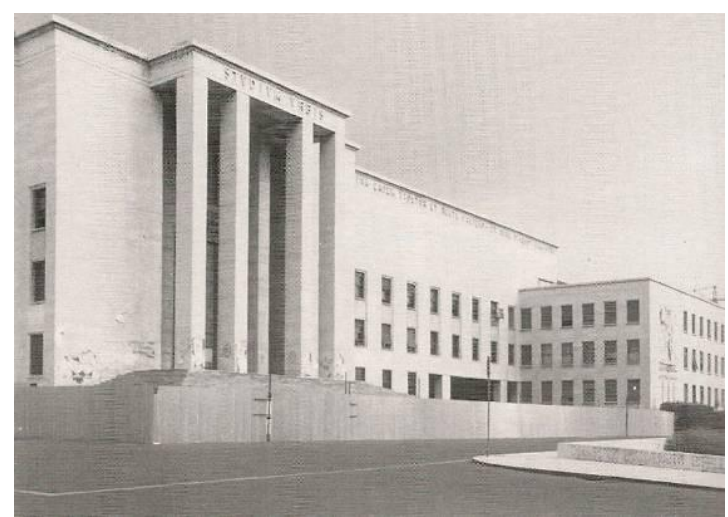

Figura 5. M. Piacentini and associates, University of Rome, Senate building, 1935. 
No primeiro caso, o fascismo se estabeleceu em um momento confuso, em que a Itália precisava urgentemente de uma política modernizadora, para isso capitalizando inclusive as atenções de intelectuais e arquitetos importantes, defensores da arquitetura moderna, ali chamados racionalistas, que viram seus esforços acabarem no EUR, com um "Neoclássico-fascista" que não deixa de ter ingredientes modernos em seu repertório, apesar da submissão à ordenação clássica:

$O$ resultado será a oficialização de um estilo de formas clássicas simplificadas e facilmente reprodutíveis cuja melhor expressão será o EUR de 1942, com seu eixo demarcado pelo Palazzo della Civilitá Italiana, de Guerrini. ${ }^{3}$

Carlos Martins também cita Frampton, em sua análise do capítulo:

La arquitectura y el Estado: ideologia y representación, 1914-1943, que indica uma mais fácil compreensão da linguagem clássica - lição já aprendida, standard - do que a necessária abstração para a arquitetura moderna, extremamente intelectualizada: para o estado autoritário o discurso mais claro. ${ }^{4}$ Mas tivemos oportunidade de conviver com o professor Bardi, que foi personagem diretamente envolvido com essa questão:

Bardi opõe ao neoclássico de Muzio o racionalismo dos seus amigos - e até ali a impertinência era suportável -, mas opõe também, à política dos palazzi, das torres, das despesas de representação, uma grande despesa pública para as casas populares e seus serviços: e isto era intolerável.

Na metade de julho de 1933, na véspera da viagem de Marselha à Grécia com os congressistas do CIAM, depois de uma última correspondência entusiástica sobre a nova empresa aeronáutica de Balbo, de partida para a Exposição Internacional de Chicago, a assinatura de Bardi desaparece para sempre das colunas do "L'Ambrosiano". 5

No segundo caso, é preciso lembrar que a Bauhaus, entre outros movimentos importantes, já estava em franco andamento quando o nazismo passa a imperar na Alemanha. O filme Arquitetura da destruição é um relato impressionante, impactante do que se passou sob Hitler, um admirador da arte clássica e, ao contrário da mesa dos horrores (Tavolo degli Orrori), que Bardi apresenta a Mussolini, para demonstrar o anacronismo das coisas não-modernas, os nazistas organizam uma exposição de arte degenerada: arte moderna. ${ }^{6}$

\footnotetext{
${ }^{3}$ MARTINS, C. A. F. Arquitetura e Estado no Brasil-elementos para uma investigação sobre a constituição do discurso moderno no Brasil; a obra de Lucio Costa (1924-1952). São Paulo: FFLCH USP, Dissertação de Mestrado, p. 87, 1988.

${ }^{4}$ FRAMPTON, K. História crítica de la Arquitectura Moderna. Barcelona: Editorial Gustavo Gilli, p. 212220, 1991.

${ }^{5}$ TENTORI, F. P.M. Bardi: com as crônicas artísticas do "L'Ambrosiano" 1930-1933. São Paulo: Instituto Lina Bo e P.M. Bardi / Imprensa Oficial do Estado, p. 63, 2000.

${ }^{6}$ ARQUITETURA da destruição. Direção: Peter Cohen. Narração: Bruno Ganz. Suécia, 1992. (121 min.). Esse documentário traça a trajetória de Hitler e de alguns de seus mais próximos colaboradores, com a arte. Muito antes de chegar ao poder, o líder nazista sonhou em tornar-se artista, tendo produzido várias gravuras, que posteriormente foram utilizadas como modelo em obras arquitetônicas. Destaca ainda a importância da arte na propaganda, que por sua vez teve papel fundamental no desenvolvimento do nazismo em toda a Alemanha. Numa época de grave crise, no período entre guerras, a arte moderna foi apresentada como degenerada, relacionada ao bolchevismo e aos judeus. Para os nazistas, as obras modernas distorciam o valor humano e na verdade representavam as deformações genéticas existentes na sociedade; em oposição
} 


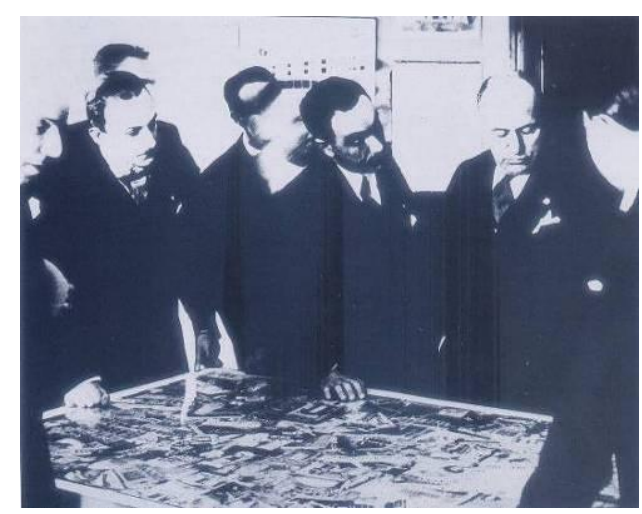

Figura 6. Na exposição do MIAR, Bardi explica a Mussolini sua criação polêmica contra os estilos classicizantes, batizada "Tavolo degli Orrori".

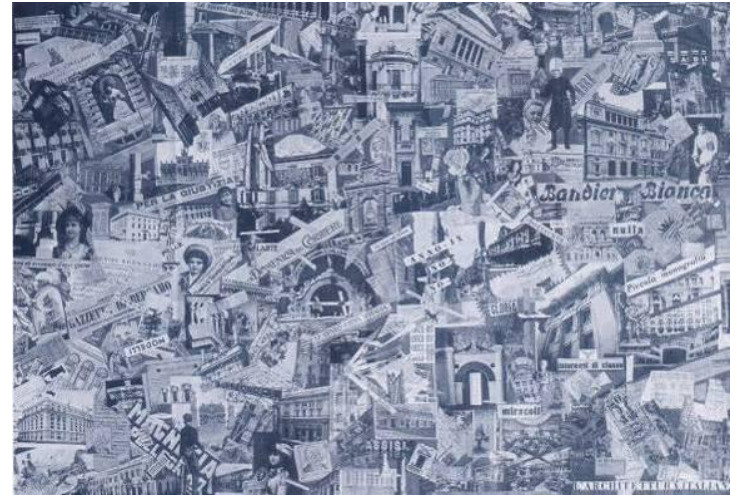

Figura 7. "Mesa dos horrores", de Bardi: colagem que reproduz exemplos de arquitetura acadêmica misturados com moda, gráfica e costumes claramente anacrônicos.

E, no último, a ditadura soviética solapou o movimento

Construtivista, uma aventura extraordinária, exilou artistas de vanguarda, calou artistas importantes e, de sobra, boicotou mais uma das inúmeras tentativas de Le Corbusier, a de ver uma obra sua realizada, o Palácio dos Soviets, que se porventura fosse executado teríamos a primeira obra de mega porte do mestre franco-suíço. Suas maiores obras até então, foram o Centrosoyus, na própria Russia, e a Cité de Refuge, em Paris ${ }^{7}$. E, nesse caso, sob o stalinismo, nem se vislumbra alguma coisa modernizante como no caso italiano, ali se projetou e construiu verdadeiros bolos-de-noiva.

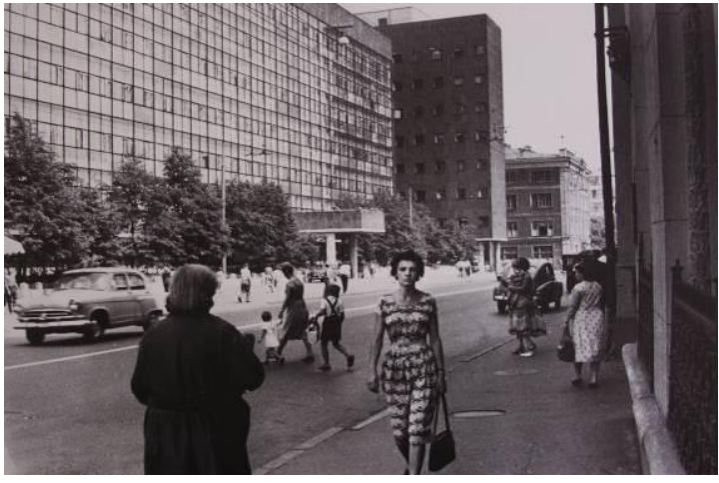

Figura 8. Centrosoyus - edifício do governo russo, em 1930, Moscou, visto da rua, de Le Corbusier.

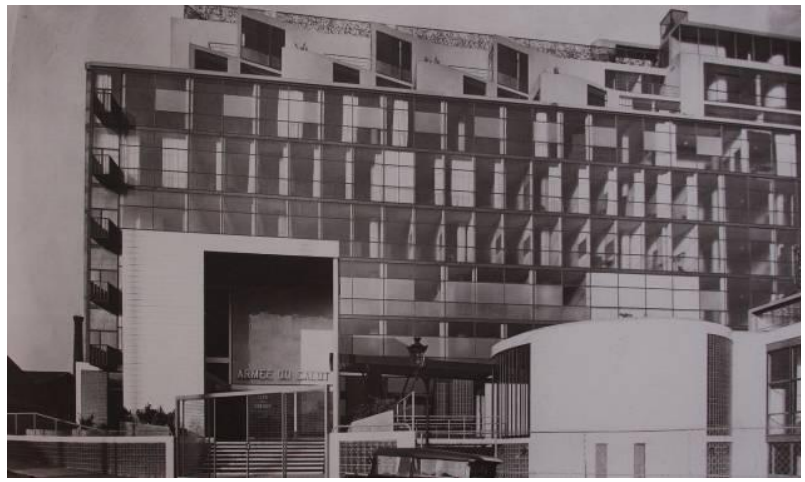

Figura 9. Fachada principal da Cité de Refuge, em Paris, 1929-1933, de Le Corbusier.

defende o ideal de beleza como sinônimo de saúde e consequentemente com a eliminação de todas as doenças que pudessem deformar o "corpo" do povo. Disponível em: 〈http://www.historianet.com.br/> 7 'I thought that under the aegis of 'constructivism' (a Russian architecture movement) I would find enemies on the lookout - all the more so since I was here to try for an enormous commission. Surprise, surprise, I'm proclaimed the great father - the father, no less! And signs of affection and esteem endlessly, endlessly, for the last ten days." - Le Corbusier emu ma carta à sua mãe, 16 outubro de 1928. In: COHEN, J. L. Le Corbusier Le Grand, the man with a Hundred Faces. London: Phaidon Editors, p. 236, 2008. 


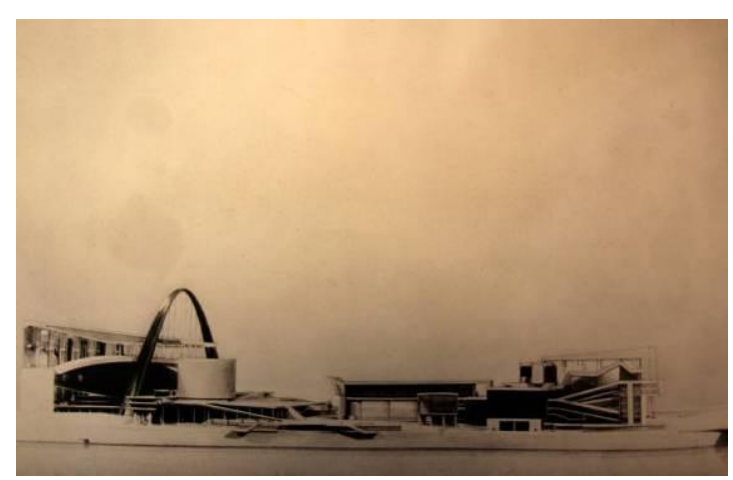

Figura 10. Projeto para Palácio dos Soviets 1931. Projeto recusado de Le Corbusier.

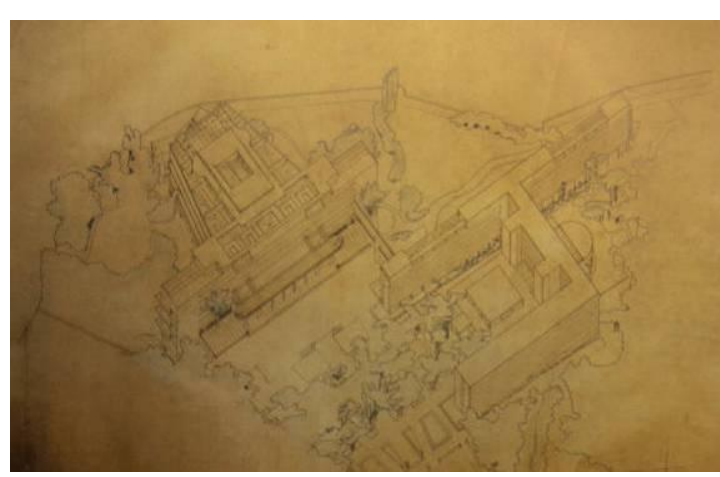

Figura 11. Projeto para o Palácio das Nações - 1927. Projeto recusado de Le Corbusier.

Em carta a Le Corbusier, Lucio se refere assim, à sua situação de caixeiro-viajante arquitetura moderna:

(...) E uma penosa sensação de angústia abateu-se sobre nossos corações, ao imaginarmos o gênio de uma época vagando de um continente a outro, $e$ batendo de porta em porta a reclamar o que lhe é devido. (... $)^{8}$

Ele próprio encerra seu ciclo de palestras em Buenos Aires, em 1929, dizendo assim:

Daqui a alguns meses uma nova viagem me levará a Manhattan e aos Estados Unidos. Sinto-me apreensivo ao enfrentar o campo do trabalho árduo, as terras da seleção na violência dos negócios, os lugares alucinantes da produção desenfreada - o citado Crac ocorreu nesse mesmo ano -. Nos trinta graus do frio de Moscou estruturam-se coisas de um interesse dramático; os Estados Unidos é um Hércules cujo coração, segundo me parece, é tímido e ainda hesitante. Nós, de Paris (...). Os senhores, na América do Sul, estão numa região velha e jovem; (...).

Mas, voltando bastante na História, a tomada dos Novos Mundos estava se dando sob outras ordens, já não mais a simples pilhagem, iniciada com as Cruzadas e prolongada ao longo das "descobertas" e colonização de "lugares novos" a se apossar, mas através de lucrativos negócios, que se avolumavam de maneira inimaginável, até mesmo com seguro para novos empreendimentos, ainda que resolvidos, ou negociados, num bar, como foi visto acima.

Desde o tempo da mera pilhagem até os lucrativos negócios, do consórcio burguesia emergente com a aristocracia sobrevivente, a intelligentsia acumulou informações, preciosas para a manutenção de um saber específico: quem está sabendo, está "por dentro", quem detém a informação, detém também o poder. Saber e poder, juntos, são relações simbióticas, isso vem de muito antes, mas cuja análise fica fora do âmbito desse trabalho.

Nessa evolução “em espécie” surge então o momento em que o poder do saber já pode se mostrar: o colecionismo, iniciado no Renascimento, já pode ser aberto a público, na forma do Museu, organismo também novo, surgido exatamente na

\footnotetext{
${ }^{8}$ COSTA, L. Sobre Arquitetura. Alberto Xavier org. Porto Alegre: Centro de Estudantes Universitários de Arquitetura, 1962. Idem: revisão fac-símile com comentários de Lucio Costa. Porto Alegre: Editora UniRitter, 2007.
} 
Revolução Francesa. Mostrar o que se juntou re-afirma o poder de quem juntou, re-afirma o poder do saque. Napoleão é o maior exemplo, tanto do quanto a Revolução precisou voltar atrás, para o caminho que a aristocracia tinha traçado, quanto no quanto o saberpoder acumulado precisava ser demonstrado, quanto o novo caminho permitia abrir a "coleção" ao público, sem medos. Não é por acaso que é nesse momento em que se abre o Museu do Louvre, como museu, antigo palácio do Rei, mais central do que Versalhes, no centro da cidade de Paris. ${ }^{9}$

O colecionismo gerou também uma nova espécie de intelligentsia: a demanda burguesa, os arquitetos, os colecionadores queriam, romanticamente, se reportar a qualquer coisa sabida, como demonstração de seu eruditismo. Surge o Ecletismo, como a nova demonstração de que o conhecimento acumulado pode ser "citado", a torto e a direita, uma vez feito com o "conhecimento de causa" que inspirava tanto o consumidor, quanto o produtor dos artefatos. E, no principio, o eruditismo está no Ecletismo Classicizante, mas por evolução passa para as mesclas, e das mesclas para os nacionais, num caminho quase linear e aproximadamente nessa ordem.

Vale notar que o período do chamado Iluminismo não conseguiu construir alguns projetos geniais, especialmente de Ledoux e de Boullée, e os que foram construídos são bem aquém dos deixados em projeto, em pleno período do Terror. Vale também notar que o Romantismo é quem abriu portas para o Moderno, por um viés um pouco inesperado, porque é a imagem romântica que inspira o Ecletismo.

Todo esse grande estilo de arquitetura reduzido aos princípios simples da geometria se enuncia como um projeto e permanece irrealizado. Sua linguagem, como a dos princípios e a da regeneração social, já está formulada antes de 1789. Uma cidade harmoniosa, uma cidade do começo dos tempos - auroral, colossal, irrefutável - existe nos porta-fólios de alguns arquitetos, bem antes da tomada da Bastilha. A Revolução não terá nem o tempo nem os recursos, nem, talvez a audácia de pedir-lhes para realizar seus grandes projetos cívicos; ao contrário, ela se lembrará, para censurá-los, dos trabalhos dispendiosos que esses mesmos arquitetos realizaram para as autoridades e os privilegiados do Antigo Regime. (...) Ledoux (...) conhecerá a prisão. ${ }^{10}$

Parece assim que o Ecletismo era mesmo etapa inevitável, e que os projetos do Iluminismo estavam precoces demais para serem ensejados, não só pelo exposto acima, mas à luz da história da técnica, dificilmente eles teriam conseguido executar projetos daquela monta em preços e prazos viáveis, compatíveis com os interesses do Estado de então. O necessário Ecletismo torna-se algo não desprezível, sua leitura surge outra, a partir desse entendimento.

Mas no Brasil, tudo acontece um pouco às avessas, "pau que nasce torto": o único Império que se muda para uma Colônia, um "Imperador Republicano", que foge dos franceses de Napoleão, mas importa franceses para ensinarem as artes e a cultura... Neoclássica, exatamente dos revolucionários republicanos da França (como já se viu, por lá também se adaptou uma coisa à outra).

\footnotetext{
${ }^{9}$ CHOAY, F. L'allégorie du patrimoine. Paris: Éditions du Seuil, 1992

${ }^{10}$ STAROBINSKI, J. 1789. Os emblemas da razão. São Paulo: Companhia das Letras, p. 61-62, 1988.
} 
Durante os primeiros anos de República do Brasil, tentou-se, em vão, manter o Neoclássico como linguagem oficial, mas por um lado já se espalhara o Ecletismo, generalizou-se, com alguma qualidade nas classes ricas, para as igrejas e alguns organismos oficiais, mas na maior parte desajeitado e mera colagem de ornamentos importados, que, quando mais requintados de cobre, chumbo ou ferro fundido, nos mais baratos de argamassa moldada; por outro lado, na falta de conhecimento e de mão de obra especializada, executaram-se verdadeiras caricaturas, macaqueações do que pudesse aparentar um padrão aceitável de ser visto nas ruas (assim como um bom terno branco, de linho, um chapéu, para os homens, para as senhoras o tecido e o corte dos vestidos, a sombrinha, também o chapéu). De qualquer maneira se lutava para ser apresentável em público... Do outro lado, os cortiços e o povo.

Como disse Yves Bruand, o panorama da arquitetura no Brasil desde a $2^{\text {a }}$ metade do século XIX até finais da década de 30 é totalmente negativo. Falta criatividade e demonstra um profundo complexo de inferioridade. Os estilos ecléticoclassicizantes marcam a produção do período, com ampla aceitação na classe dominante, inclusive para edifícios públicos. ${ }^{11}$

E Richard Morse completa a imagem, particularmente sobre a Cidade de São Paulo e mais especificamente sobre Ramos de Azevedo:

Seu "estilo" era pretensioso, sem nobreza, de imitação e melhor descrito como ecletismo promíscuo...(grifo d.a) ${ }^{12}$

Conforme descreveu Martins:

Saudosismo ou vontade de afirmação de uma nova camada de imigrantes enriquecidos, expressão arquitetural de uma mentalidade fortemente positivista, parisianismo das elites ou infludência de uma mão de obra treinada e qualificada nos quadros técnicos e culturais da Europa, o ecletismo é a ordem de visibilidade dominante nas cidades brasileiras até pelo menos a metade da década de $20 .{ }^{13}$

Bruand segue analisando o período, no capítulo Os estilos históricos, e, particularmente o período do Neocolonial, quando, primeiro em São Paulo, com Ricardo Severo, mas sem muita força, em seguida no Rio, principalmente com José Mariano que surge como um arauto, esse estilo surge como uma alternativa nacional ao gosto eclético afrancesado dominante.

O discurso nacionalista ganha materialidade na Exposição Internacional do Rio de Janeiro, de 1912, onde destacam-se as obras do Pavilhão das pequenas indústrias, de Nestor de Figueiredo e C. S. San Juan, e o Pavilhão das grandes indústrias, de Memória e Cuchet, que apresentam suas versões de edifícios no estilo Neocolonial.

Bruand, no seu enfoque, nem dispensa tempo e atenção para uma corrente derivada do Neocolonial, que adota o estilo Novo México, uma alternativa

\footnotetext{
${ }^{11}$ BRUAND, Y. Arquitetura Contemporânea no Brasil. São Paulo: Perspectiva, p. 33-59, 1999.

${ }^{12}$ MORSE, R. M. Formação histórica de São Paulo. São Paulo: Difusão Européia do Livro, p. $257,1970$.

${ }^{13}$ MARTINS, C. A. F. Arquitetura e Estado no Brasil-elementos para uma investigação sobre a constituição do discurso moderno no Brasil; a obra de Lucio Costa (1924-1952). São Paulo: FFLCH USP, Dissertação de Mestrado, p.130, 1988.
} 
americana, contra o europeísmo dominante, ou seja, alegava motivos ideológicos também, não de uma nação, mas das diferenças entre Novo versus Velho Continente. Embora tenha sido até mesmo mais disseminado em quantidade que o próprio Neocolonial, também não cabe aqui, no escopo desse estudo, uma avaliação dessa vertente.

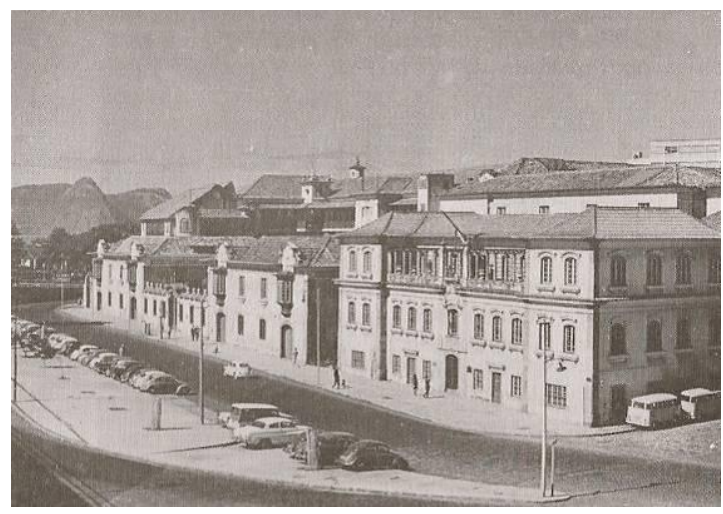

Figura 12. Neocolonial: Pavilhão das Grandes Indústrias, hoje Museu Histórico Nacional. 1922

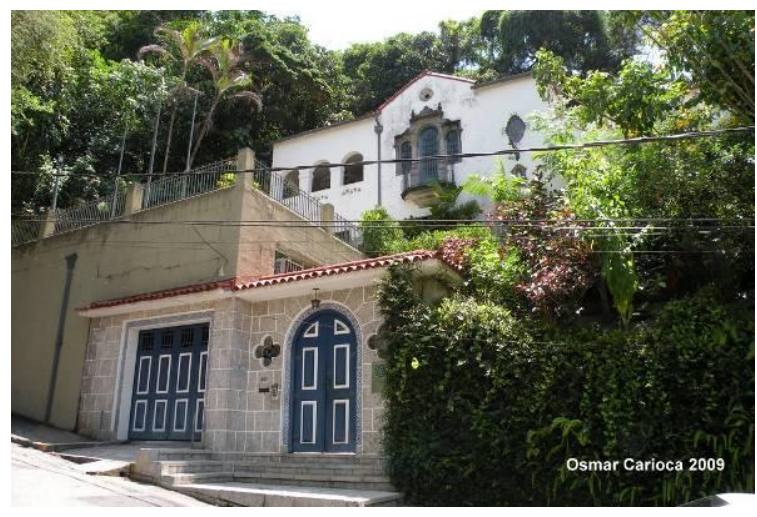

Figura 13. Neocolonial: Projeto para a casa de Raul Pedrosa, no Rio de Janeiro. Lucio Costa e Fernando Valentim. 1925.

Segue-se então uma seqüência de obras com esse caráter, inclusive de Fernando Valentim, com quem Lucio Costa se associou, até a época em que se dá conta de que se tratava de um falso colonial, e muda seu próprio caminho.

De qualquer maneira, o período propicia o olhar de arquitetos e engenheiros brasileiros sobre o passado, com o intuito de aprender com a arquitetura antiga, o que dá sentido de importância a essas obras e acaba por propiciar seu reconhecimento pelo patrimônio existente e engendrar sua conservação. Toda a primeira leva de preocupações com o patrimônio histórico e artístico do país foi levada a cabo pelo pessoal moderno: Rodrigo Mello Franco de Andrade, Mario de Andrade, Carlos Drummond de Andrade, Manuel Bandeira, Lucio Costa, entre tantos outros, inventaram o patrimônio brasileiro.

Além disso, (...) seria um erro, porém, desprezar o aspecto psicológico da questão e considerar a moda do Neocolonial como um episódio inconseqüente. Esse movimento foi na realidade a primeira manifestação de uma tomada de consciência, por parte dos brasileiros, das possibilidades do seu país e da sua originalidade. $^{14}$

Tanto Lina como Lúcio se formaram dentro do Ecletismo, com as escolas que freqüentaram priorizando essa linha: ela fez o Liceu Artístico, em seguida a Faculdade de Arquitetura da Universidade de Roma, formando-se em 1939, ele a Escola Nacional de Belas Artes, formando-se em 1922, com dois anos de atraso, pois teve que trabalhar enquanto freqüentava o curso - a turma dele formou-se em 1920.

E, um eclético-acadêmico torna-se um erudito, inclusive na Academia se usava a denominação Ecletismo-culturalista. Mas um eclético-acadêmico-

\footnotetext{
${ }^{14}$ BRUAND, Y. Arquitetura Contemporânea no Brasil. São Paulo: Perspectiva, p. 33-59, 1999.
} 
arquiteto estudava para o saber-fazer, para executar de novo se for o caso, e não simplesmente saber por ter estudado, e parar aí. Era para citar, para construir de novo, na prática, com seu conhecimento, aí sim, erudito, como nos lembrou Maria Elisa.

O que os impeliu em direção à postura moderna se dá de maneira bem diferente: segundo Lucio, foi sua descoberta de Diamantina, que o fez rever o que se estava propondo com o Neocolonial, mas que não o levou diretamente ao moderno, contra o que ele alimentou ainda suas precauções, como se verá adiante.

Ele foi a Diamantina para realizar levantamentos, teve cerca de 1 mês de duração, da qual cerca de 10 pranchas de desenho foram produzidas por ele, com o objetivo de se documentar o colonial brasileiro.O impacto de Diamantina, um lugar de construções pobres quando comparadas às de Ouro Preto ou Mariana, vai marcar para sempre Lucio Costa e modificar sua posição em relação ao movimento Neocolonial que vinha se impondo como a alternativa nacional de um estilo.

Em 1922, comissionado pela Sociedade Brasileira de Belas Artes, conheci Diamantina. (...)

\section{Lá chegando caí em cheio no passado no seu sentido mais} despojado, mais puro; um passado de verdade, que eu ignorava, um passado novo em folha para mim. Foi uma revelação: casas, igrejas, pousada dos tropeiros, era tudo de pau-a-pique, ou seja, fortes arcabouços de madeira - esteios, baldrames, frechais enquadrando paredes de trama barreada, a chamada taipa de mão, ou de sebe, ao contrario de São Paulo onde a taipa de pilão imperava. ${ }^{15}$

A pesquisa tinha sido encomendada exatamente pelo pessoal do Neocolonial, mais especificamente pela Sociedade Brasileira de Belas Artes, de quem, ele vai exatamente se afastar.

É que, embora retardatário, pois tomei conhecimento da existência de Le Corbusier somente em 1927, acidentalmente, e só estudei a fundo a sua densa mensagem, escrita e construída, durante os anos de "chômage", (de 32 a 35) depois que larguei a direção da Escola, - esse evento - essa revelação - me deixou, como que, em "estado de graça." ${ }^{16}$ (grifo e aspas d.a.) (obs. d.a.)

Lina intensifica sua trajetória em direção ao movimento moderno quando saiu de Roma, onde se formou, e vai para Milão, a mais européia das cidades da Itália, onde havia uma atmosfera já impregnada do espírito moderno.

Como apontam Marina e Silvana:

Se para arquitetos nascidos na virada do século, com Lucio Costa, a ruptura com o academicismo e a adesão ao modernismo podia ser relatada como uma conversão - caso também de Charles Edouard Jeanneret, que ao se estabelecer em Paris adotou o pseudônimo de Le Corbusier - para os nascidos pouco depois a situação era outra: quando Lina iniciou seu aprendizado e ensaiou seu ingresso, formada, no mundo

\footnotetext{
${ }^{15}$ COSTA, L. Registro de uma vivência. São Paulo: Empresa das Artes, p. 27, 1995.

${ }^{16}$ COSTA, L. Registro de uma vivência. São Paulo: Empresa das Artes, p. 121, 1995.
} 
dos arquitetos, já havia na Itália diversas correntes modernas estabelecidas, ainda que em meio a tensões e disputas, que não deixavam de expor seus matizes ideológicos ${ }^{17}$

\section{O inimigo ao lado}

É natural que o inimigo, de imediato, seja aquele que ainda está vivo, na sua frente - e frente aqui, soa muito estranho, melhor ao lado. Não são só rompimentos que geram antagonismos, sucessões também. E, se não houve ruptura, como vimos acima, qualquer mudança também parece algo assustador, mesmo em sucessão: por que mudar? Diz-se, em time que está ganhando não se mexe, mas há uma tendência inercial generalizada, medo de qualquer mudança.

Cada mudança que pareceu romper com tudo, até com os vínculos com sua própria gênese, quando revisada com um distanciamento crítico que o próprio tempo acaba propiciando, mostra uma face muito carregada de um saber anterior, de um aprendizado técnico incorporado e que pode ser, então, e por isso mesmo, superado, mesmo que, na aparência, demonstre antagonismo e ruptura.

A curta experiência do Art-Nouveau, muito bem aceita em sua própria época, confirma essa proposição, porque foi uma mudança que mudou pouco, embora de características muito importantes. $\mathrm{O}$ artefato industrializado antevê um novo caminho com a pré-fabricação de componentes e a utilização de novos materiais e técnicas. Por isso mesmo o Art-Nouveau inicia e se acaba, contradição é interna, não houve sobrevida para o objeto ornamental pré-fabricado:

$O$ ornato no sentido artístico e humano que sempre presidiu à sua confecção é, necessariamente, um produto manual. O século XIX, vulgarizando os moldes e formas, industrializou o ornato, transformando-o em artigo em série, comercial, tirando-lhe assim a principal razão de ser - a intenção artística -, e despindo-o de maior interesse como documento humano. ${ }^{18}$

È essa curta experiência do Art-Nouveau, e poderíamos acrescentar a curta experiência do De Stijl, esta mais confinada à Holanda, até a integração de grande parte de seus membros na Bauhaus, esta sim, uma tentativa cujo efeito é mais permanente, que mantém Lucio ressabiado - com um- pé- atrás, como se diz - em relação ao movimento moderno, que ele só vai endossar de vez após o período de chômage - conforme ele mesmo batizou seu período sem trabalho:

- E estudei a fundo as propostas e obras dos criadores, Groupius,

Mies van der Rohe, Le Corbusier, - sobretudo este, porque abordava a questão no seu tríplice aspecto: o social, o tecnológico e o artístico, ou seja, o plástico, na sua ampla abrangência. ${ }^{19}$ (grifo d.a.)

O inimigo vivo e ao lado, foi o Ecletismo, e, mais diretamente, para Lucio, foi o Neocolonial, como vimos. Ficou comum se ouvir, agora: os modernos

\footnotetext{
${ }^{17}$ RUBINO, S.; GRINOVER, M. Lina por escrito: Textos escolhidos de Lina Bo Bardi 1943-1991. São Paulo: Cosac Naify, p. 24, 2009.

${ }^{18}$ COSTA, L. Registro de uma vivência. São Paulo: Empresa das Artes, p. 115, 1995.

${ }^{19}$ COSTA, L. Chômage 1932-36 in: Registro de uma vivência. São Paulo: Empresa das Artes, p. 83, 1995.
} 
odiavam o ecletismo! Em parte isso é verdade, em parte há um novíssimo interesse pela preservação de obras ecléticas, coisa que não ocorria então, mas foram os modernos que se lançaram na tarefa de avaliar, documentar e proteger o passado, que criaram o Instituto do Patrimônio, e aí não há nenhuma contradição: os modernos viam no passado uma prospecção, algo a ser lançado para o futuro.

Doravante, se dirá que os modernos inventaram o patrimônio brasileiro, com o sentido explícito das intenções que moveram essa invenção. A preocupação com o passado e, até mesmo, sua re-invenção, já existiam, o próprio interesse da corrente Neocolonial é prova disso, como vimos. Assim descreve Lauro Cavalcanti:

(...) Menos evidente, à primeira vista, é o seu triunfo (dos modernos) na disputa da gestão do patrimônio histórico e artístico, sobre correntes competidoras que pautavam suas atuações justamente por preocupações históricotradicionalistas.

A principal tendência concorrente aos modernos com vistas à gerência federal do patrimônio situava-se na Inspetoria de Monumentos Nacionais do Museu Histórico Nacional, dirigido por Gustavo Dodt Barroso. ${ }^{20}$

Essa condição tinha sido promulgada por um decreto presidencial de Getúlio Vargas, em 14 de julho de 1934, mas, naquele mesmo ano, o ministro Gustavo Capanema e seu chefe de gabinete Carlos Drummond de Andrade relegam suas atividades para funções de menor relevância. Conforme Lauro:

A corrente neocolonial foi a principal competidora dos modernos pela primazia da condução oficial da renovação arquitetônica nacional e pelo estudo do passado nacional. ${ }^{21}$ Mas (...) Condições muito específicas, portanto permitiram aos modernos o controle concomitante da feitura de sue mapa astral e árvore genealógica. Parece-me fundamental, nesse processo, o episódio da construção, sob a égide do Sphan, de um hotel moderno projetado por Oscar Niemeyer no centro de Ouro Preto - cidade antiga brasileira mais importante, verdadeira "capital" do Brasil pretérito, decretada "monumento nacional" em 1933, quatro anos antes da criação do próprio Serviço de Patrimônio. (...) Vislumbram os modernos brasileiros ocasião impar: a legitimação de dominantes no presente pela justificativa ética de uma ação futura e o domínio do órgão encarregado de selecionar o que é relevante no passado. ${ }^{22}$

Tudo isso ocorreu sob intenso bombardeio recíproco, no meio intelectual, na academia e na grande imprensa; não foi uma luta simples, na qual um lado, ganha ostensivamente e a outra perde, sem delongas, mas, para o assunto que ora tratamos, continuaremos então a considerar os modernos os inventores do patrimônio arquitetural, histórico e artístico brasileiro. Como Lauro remata:

\footnotetext{
${ }^{20}$ CAVALCANTI, L. P. Moderno e brasileiro: a história de uma nova linguagem na arquitetura. Rio de Janeiro: Ed. Jorge Zahar, p. 98, 2006.

${ }^{21}$ CAVALCANTI, L. P. Moderno e brasileiro: a história de uma nova linguagem na arquitetura. Rio de Janeiro: Ed. Jorge Zahar, p. 102, 2006.

${ }^{22}$ CAVALCANTI, L. P. Moderno e brasileiro: a história de uma nova linguagem na arquitetura. Rio de Janeiro: Ed. Jorge Zahar, p. 106, 2006.
} 
Além de árbitros do bom gosto estatal, passam a ser, eles mesmos, objetos da "sacralização", com o tombamento da igreja da Pampulha, em 1947, e do prédio do MES, em 1948 (ambos apenas cinco anos após suas edificações). ${ }^{23}$

Os detalhes dessa luta ficam para outra oportunidade; mas importa ressaltar quatro monumentos simbólicos dessa marcha:

- O Pequeno Abrigo, na redução de São Miguel Arcanjo das

Missões Jesuíticas é de 1937, de Lucio;

- O Grande-Hotel de Ouro Preto, de Oscar Niemeyer é de 1940, mas acompanhado pelo magnífico monumento de papel, que é a carta em defesa de sua construção, manuscrita anteriormente por Lucio, e sem a qual, certamente a obra não existiria;

- O projeto para a recuperação do Solar do Unhão é de 1958, mas sem a interferência de Lucio, certamente a obra de Lina não seria feita como o foi, e se verá isso mais adiante;

Mas a sensibilidade artística de Lucio permitia a ele e sua equipe inclusive reconhecer que algumas obras feitas nos mais diversos moldes ecléticos, mas que tinham valor, qualidades arquitetônicas suficientes para se considerar sua relevância e até preservação, ou não, também existiu. Na perspectiva vôo-de-pássaro que Lucio faz para apresentação da implantação dos seis prédios do Conjunto do Parque Guinle e, no primeiro plano, está lá, a bela mansão dos Guinle: não se vexam. Tanto que também está lá na perspectiva o portão, que já não serve como tal, mas cuja presença é importante por si só. Nada impediria que Lucio tivesse tirado o portão e o fato dele constá-lo no desenho indica a intenção clara e específica de mantê-lo.

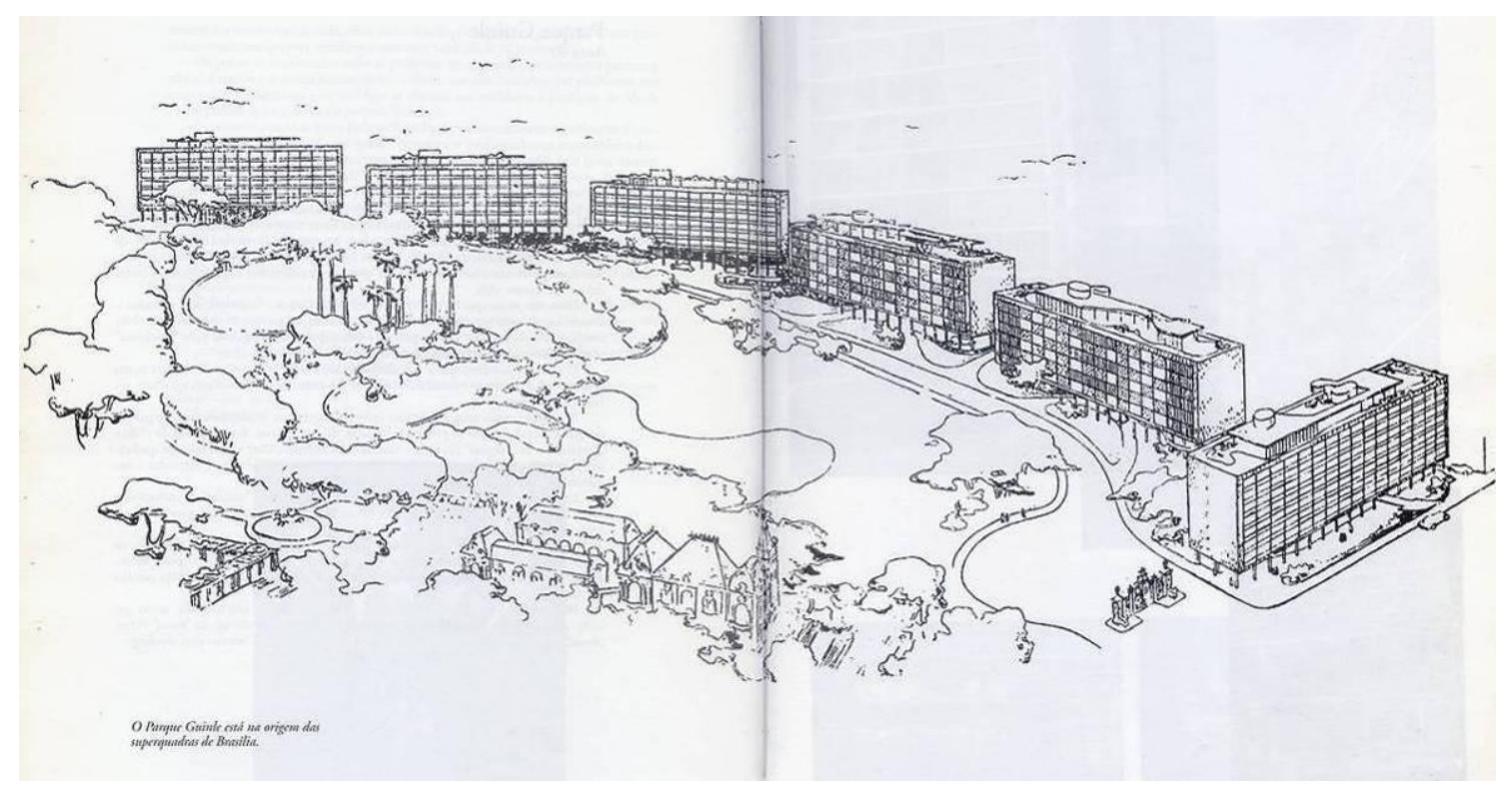

Figura 14. Projeto do Parque Guinle, com a mansão no primeiro plano e o não-portão que demarca a entrada, na vista em vôo-de-pássaro do desenho original de Lucio - c. 1940.

\footnotetext{
${ }^{23}$ CAVALCANTI, L. P. Moderno e brasileiro: a história de uma nova linguagem na arquitetura. Rio de Janeiro: Ed. Jorge Zahar, p. 115, 2006.
} 


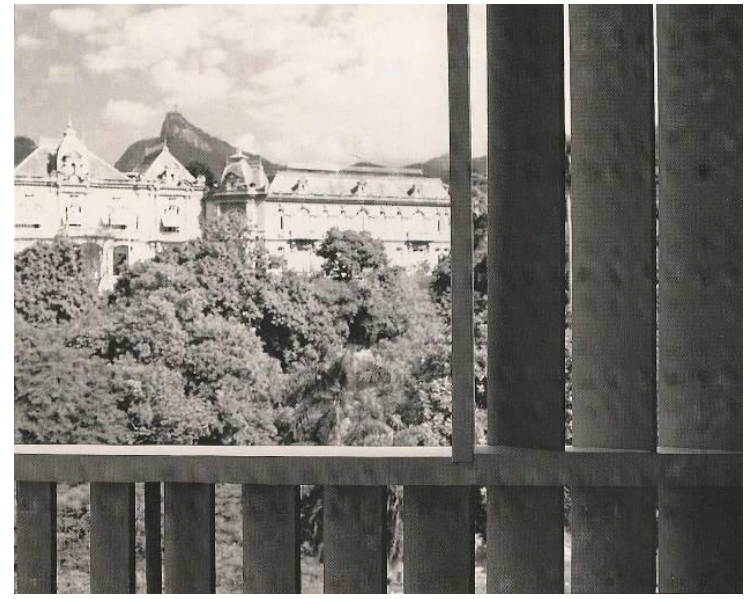

Figura 15. Mansão da família Guinle, vista de dentro da loggia de um dos apartamentos do Edifício Bristol. Ao fundo o Cristo Redentor.

Lygia Martins Costa, que substituiu Lúcio no cargo de diretora da Divisão de Estudos e Tombamento do SPHAN, relata dessa maneira:

Havia, naquela época, um certo desprezo pela arte do século XIX, porque era uma coisa muito recente. Era preciso proteger aquilo que estava mais ameaçado, que eram, naquela altura, os grandes complexos coloniais. Depois é que se começou a olhar para o século XIX... E Dr. Lúcio tinha muita pena de não ter protegido a tempo os edifícios da avenida Rio Branco. Quando ele viu, dizia, de uma hora para outra aquilo desapareceu. Foi como se um raio tivesse caído sobre a Avenida Rio Branco, sem esperar, de um modo imprevisível. Tinha muitos edifícios de grande qualidade ali, e foi tudo derrubado quase de uma só vez. (grifo d. a.) ${ }^{24}$

Lucio mesmo tinha dito, referindo-se ao clima de "guerra santa":

(...) Especialmente no que diz respeito ao nosso país, onde tudo ainda está praticamente por fazer, - e tanta coisa por desmanchar (... $)^{25}$ (grifo nosso)

É preciso considerar que obras de grande significado do Ecletismo estavam situadas nos locais que tinham sido importantes na configuração das cidades e, que, portanto, foram áreas alvo de grande interesse da especulação imobiliária, na passagem do século XIX para o XX, notadamente em São Paulo, cujo boom econômico ocorre exatamente nessa época. No Rio de Janeiro ocorreu o mesmo, com esse crescimento econômico associado às necessidades da Capital Federal. Por isso mesmo foram mais rapidamente botados abaixo, demolidos. Alguns prédios de grande interesse sobraram pelo deslocamento das investidas da especulação imobiliária, saídas das regiões centrais das cidades para novas regiões e bairros. Outros que ainda sobrevivem, de menor interesse, agora são alvos de tentativas de preservação, mesmo porque o sentido de preservação é que está se ampliando, assim como se está ampliando o sentimento de preservação do meio ambiente. Esse sentimento generalizou, inclusive em cidades sem nenhum patrimônio significativo para as artes ou para a arquitetura são encontrados, mas basta a vetustez relativa ser identificada, para ocorrer uma noção geral da necessidade de preservação.

\footnotetext{
${ }^{24}$ Depoimento de Lygia Martins Costa. in: WISNIK, G. org. O Risco: Lucio Costa e a utopia moderna. Rio de Janeiro: Bang Bang Filmes Produções Ldta, p. 77-78, 2003.

${ }^{25}$ COSTA, L. Razões da nova arquitetura. in: COSTA, L. Registro de uma vivência. São Paulo: Empresa das Artes, p. 111, 1995.
} 
O primeiro diretor do INEPAC, Alex Nicolaeff, escreveu sobre aquele momento: "Além da quase total indiferença por manifestações mais simples de arquitetura, prevalecia a nível de obras eruditas, um certo descaso pela arquitetura de ferro da Revolução Industrial e exemplares ecléticos. A demolição do palácio Monroe em 1975 ilustra a situação. Para valorizá-los procuramos divulgar informações sobre arquitetura e ecletismo nos Encontros do Patrimônio Cultural, na revista "Artefato" e na coleção "Coisas Nossas". (...) Procuramos estender o conceito a imóveis modernos como a Obra do Berço de Oscar Niemeyer e o Teatro Armando Gonzaga de Afonso Eduardo Reidy. ${ }^{26}$

\section{Lina era a favor do tombamento da Avenida Paulista como um}

todo, no final da década de 60, após a inauguração do Museu, até por um interesse específico: uma avenida só de casarões senhoriais, dos Barões do Café ${ }^{27}$ e... o MASP, com o contraste novo/velho acirradíssimo, como sempre interessou aos modernos. Mas plenamente justificável, porque assim ficava preservada a condição de belvedere, com o vão-livre do MASP, e ficaria lá a história do caminho para a vida urbana, a urbanização dos senhores rurais do café, com construções ecléticas de nível muito desigual na qualidade arquitetônica, mas com testemunho de um conjunto, muito mais eficaz do que sobras, como a Casa das Rosas, ou como se tentou, de maneira pior, o tombamento da Mansão dos Matarazzo. A preservação de conjunto ser muito importante já estava reconhecida na Carta de Veneza: relíquias isoladas podem até aumentar sua importância individual, mas perdem a capacidade de testemunho histórico, de um todo.

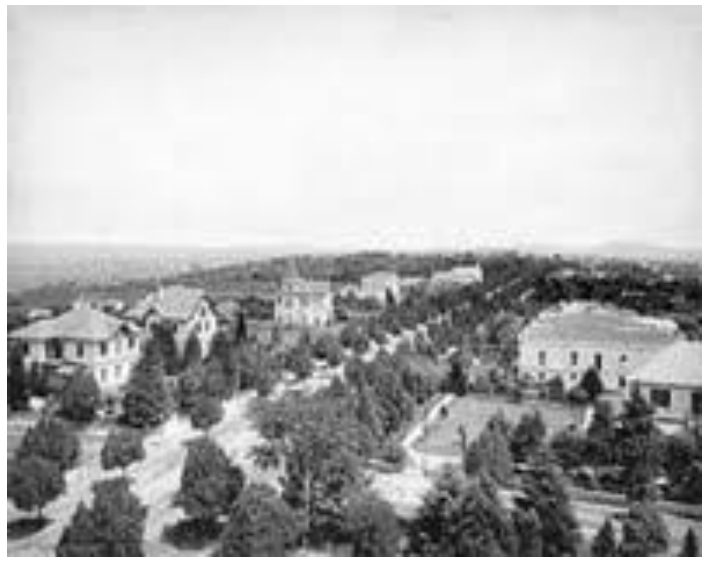

Figura 16. Avenida Paulista em 1902.

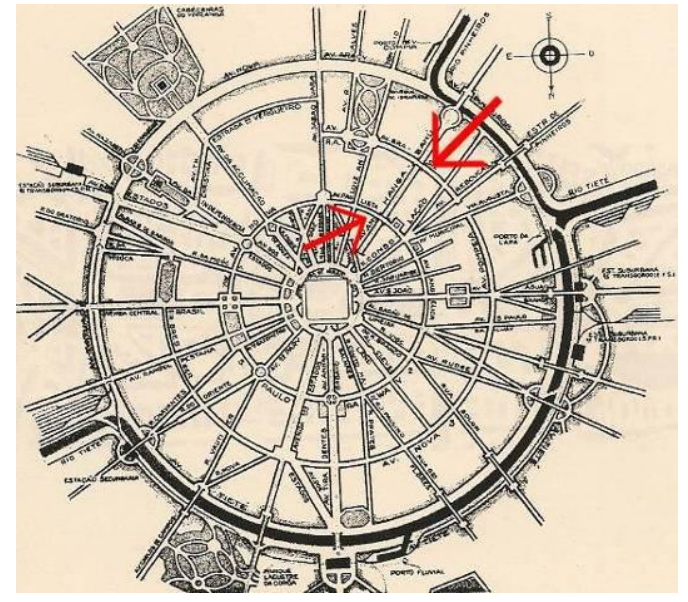

Figura 17. Esquema Teórico do Plano de Avenidas de Prestes Maia, de 1930. Seta maior: Av. Brasil. Seta menor: Av. Paulista.

\footnotetext{
${ }^{26}$ ROCHA-PEIXOTO, G. INEPAC: Um perfil dos 25 anos de Preservação do patrimônio Cultural do Estado do Rio de Janeiro. Arquitetura Revista, Rio de Janeiro: FAU / UFRJ, n. 8, 1990.

27 "Nos últimos anos diversos artigos já vem contradizendo o senso comum que batizou a avenida Paulista como reduto dos "barões do café". A expressão, que no mais das vezes apenas indica a elite cafeeira surgida em meados do século XIX, não pode ser aplicada a esse endereço especificamente, visto que proporcionalmente foram poucas as famílias ligadas diretamente a essa cultura a residir na avenida." Lima, B. de T. em entrevista para a Folha de S. Paulo, 07 set. 2007. Ver também em: LIMA, B. de T. Álbum iconográfico da avenida Paulista. São Paulo: ExLibris, 1987.
} 
Por isso Lina dizia que, com a perda da maioria dos casarões, a vinda dos espigões era inevitável, transformando uma via secundária - que ia do nada para o lugar nenhum, como repetia - no objeto da alta especulação imobiliária que realmente aconteceu, nas décadas de 60 e 70, em São Paulo. A Avenida Brasil, paralela à Paulista, demonstra mais ou menos o perfil que Lina dizia: transversal a vários dos eixos radiais da cidade, acabam com trânsito intenso, em tal medida que se torna impossível o uso residencial, mas demonstra aproximadamente o que seria uma transversal do radiocentrismo de São Paulo, sem tantos investimentos viários feitos para transformar o local, e como sobreviveria sua escala, sua densidade de ocupação. O alargamento da Paulista, seu entroncamento com a Consolação, Rebouças e Dr. Arnaldo, a continuidade no sentido da Vergueiro, no sentido Vila Mariana, obras iniciadas pelo Engenheiro Figueiredo Ferraz, quando então Prefeito de São Paulo, e, ele próprio, engenheiro calculista do MASP, propiciaram uma outra escala para a Av. Paulista.

A questão é que o Ecletismo se propõe infinito, na medida em que se pode combinar ad-infinitum as inúmeras formas conhecidas, as consagradas de forma erudita - inclusive por seu exotismo -, e aceitas como tal, portanto há uma negação do futuro. O modernismo, que é uma espécie de estilo, e que não tem nada a ver com a postura moderna defendida por Lina e Lucio, que tantas vezes tentaram esclarecer isso em textos contundentes, cai na mesma armadilha, vira uma questão de combinação de efeitos - por isso mesmo, defeitos. E, como vimos, os modernos tinham, na visão do passado uma prospecção, exatamente uma visão de futuro, nada mais incompatível. Como foi dito, não há contradição nos modernos olharem o passado, com atenção, para aprender outra coisa.

Mas melhor diz Lucio:

Depois de uma coisa vem outra; ser moderno é - conhecendo a fundo o passado - ser atual e prospectivo.(...) (grifo dele)

Só faltava Lucio ter redigido: depois de uma coisa vem outra, naturalmente!

Para Maria Elisa:

Assim, fica natural o seu modo de lidar com a preservação e a renovação concomitantemente - para ele, não houve ruptura, mas retomada de uma postura sadia em relação à arquitetura. (grifo nosso)

E se somaram as duas convicções, num e noutro sentido, ambas apaixonadas - tanto lutar pela preservação, como ser o grande batalhador pela renovação arquitetônica no país, enfrentando todas as dificuldades na defesa da nova causa e conseguindo abrir na muralha da inércia conservadora as fendas que permitiram que fluísse e ganhasse corpo a obra de todos. ${ }^{28}$

\footnotetext{
${ }^{28}$ COSTA, M. E. Apresentação. in: COSTA, L. Lucio Costa: Documentos de trabalho. José Pessôa org. Rio de Janeiro: IPHAN, p. 10, 1999.
} 


\section{PAVILHÃo E PALÁCIO}

Há uma gritaria meio sem sentido contra o fato de se ter desmontado o Palácio Monroe, em 1975, há inclusive uma corrente via Internet que clama pela sua re-construção, coisa que o ex-prefeito César Maia aventou de realizar. (ver Anexo II)

Dizem, inclusive e, erroneamente, que foi demolido, mas ele era pré-fabricado e desmontável, sim, tinha sido primeiro montado na Exposição de Saint Louis, Estados Unidos, em 1904, depois, desmontado, e re-montado no final da Avenida Rio Branco, em 1906. Houve muita discussão sobre desmontá-lo ou não, até que, por fim consultaram Lucio, nessa altura já aposentado de seu cargo no IPHAN. Seu parecer é a favor de remover o Palácio, liberar aquele espaço. O desafogo daquela área se impõe. ${ }^{1}$

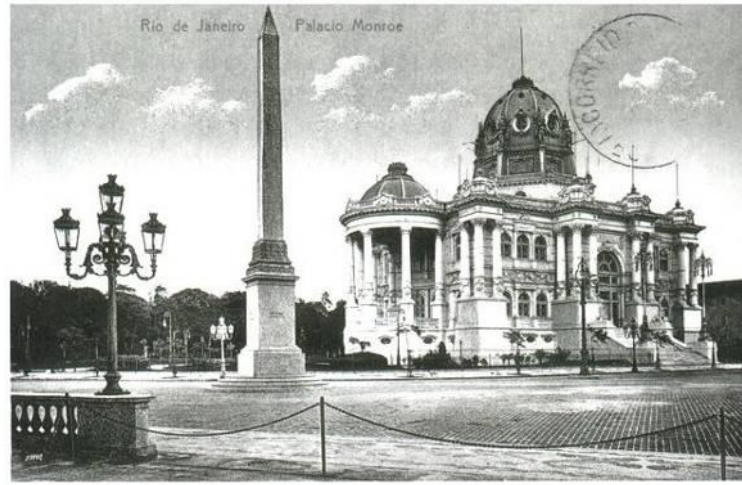

Figura 1. Palácio Monroe. Cartão Postal.

Figura 2. Re-montagem, no Brasil, do Palácio Monroe - 1904-1906.

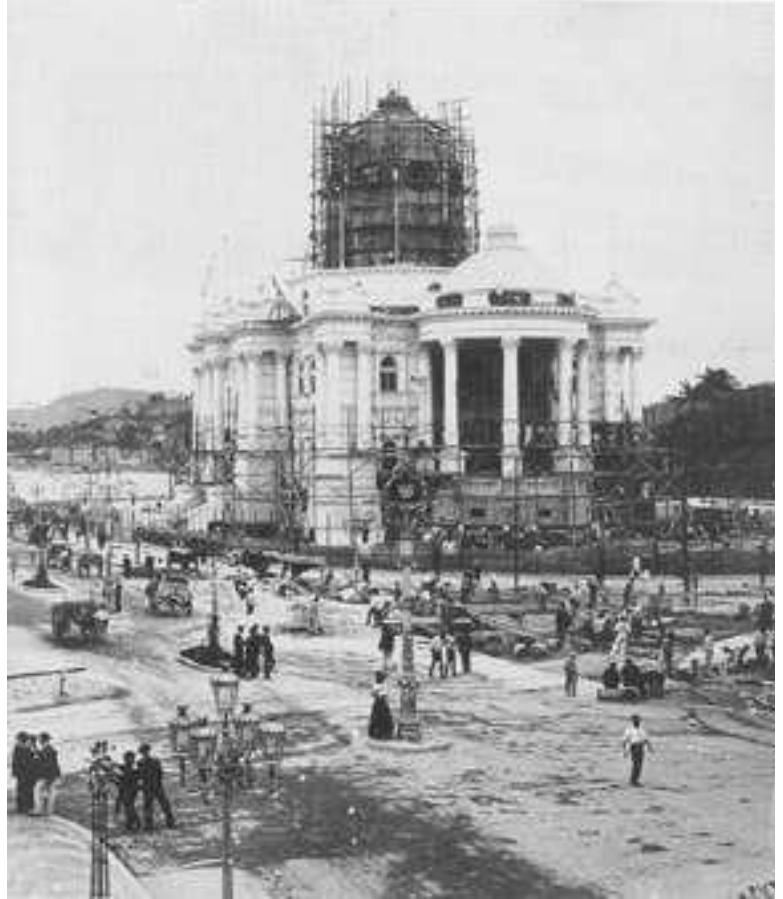

${ }^{1}$ COSTA, L. Citado em SANTOS, C. R. Problema Mal Posto, Problema Reposto. In: NOBRE, A. L.; KAMITA, J. M.; LEONÍDIO, O.; CONDURU, R. orgs. Um modo de ser moderno: Lucio Costa e a crítica contemporânea. São Paulo: Cosac \& Naify, 2004. 


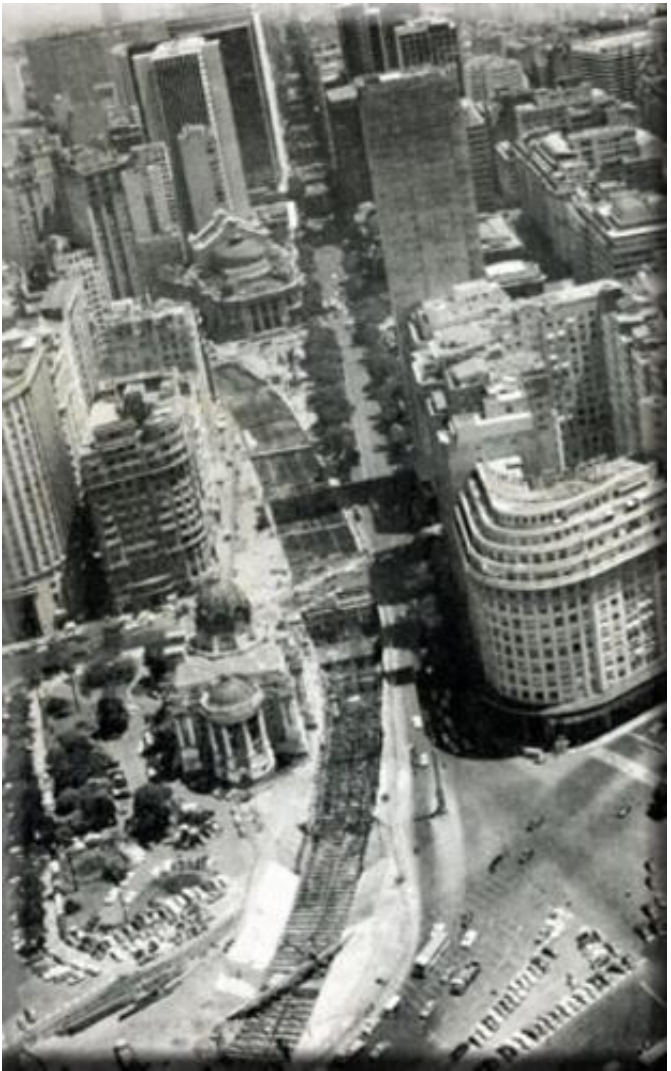

Figura 3. Palácio Monroe e a construção do metrô. Em segundo plano, o Teatro Municipal e o Eixo da Avenida Rio Branco. Primeira metade da década de 70 .

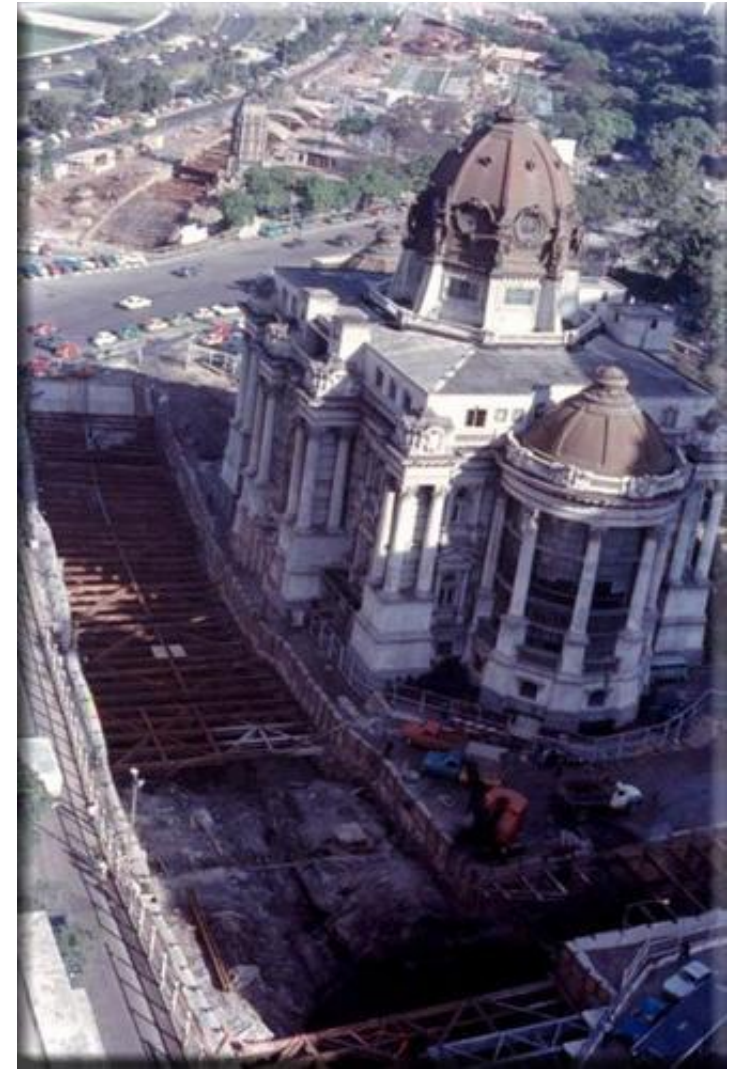

Figura 4. Palácio Monroe e a construção do metrô. Primeira metade da década de 70 .

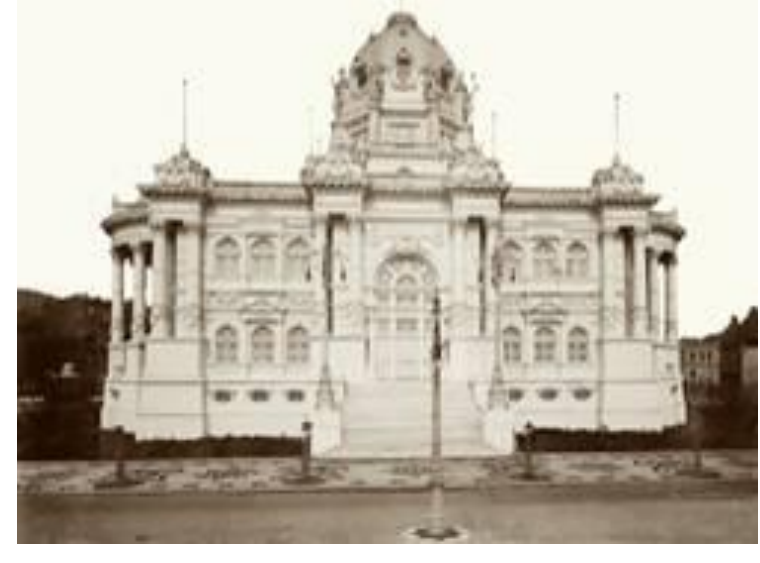

Figura 5. Palácio Monroe: fachada - 1910.

É de espantar que o ânimo que leva à proposição de re-constituir o Palácio, é o mesmo que leva à grita a proposição pela demolição - desmontagem - da Torre Eiffel: há uma proposta de cidade, há uma proposta de harmonização das partes componentes da cidade, ou trechos dela, de maneira completamente equivocada, que tem pressupostos e leituras que não se fecham: a Torre é uma agressão, tem que demolir, o Palácio nunca deveria ter sido demolido, tudo em nome de uma autoridade que não se sabe de onde vem, ou em que é baseada.

O Palácio era uma construção em aço, disfarçada por uma grande quantidade de ornamentos em mármore branco, de Carrara, de boa execução. A planta 
paladiana, cruciforme simétrica em ambas as direções, com as escadarias das quatro entradas ladeadas pelos oito leões rampantes, esculpidos lá em Carrara mesmo, também de boa execução. Tratava-se de um verdadeiro bolo-de-noiva, totalmente anacrônico e, segundo Lucio, pessimamente localizado, atravancando a avenida e tirando completamente a visual que ela permite, de certa forma, um eixo hausmmanniano, eixo feito por Agache.

\section{Goodwin escreveu em 1943:}

A Avenida Rio Branco, na capital federal, ostenta a sua grande biblioteca, um museu, um magestoso (sic) teatro e o palácio Monroe, antiga sede do Senado. Talvez seja melhor não falar deles. Aparentam uma imponência de acordo com os grupos estatuários monumentais que os circundam. Rio de Janeiro, como Washington, foram vítimas da mania internacional do carregado à Palladio. A correção acadêmica se preferiu a uma arquitetura viva e adequada à terra e o efeito pretencioso e pesado só encontrava igual na sua esterilidade. ${ }^{2}$

É muito significativo que Morse tenha usado promíscuo, como já vimos, e, agora Goodwin ter usado esterilidade, para completar o panorama negativo de que falou Bruand.

As peças foram vendidas, e grande parte delas, inclusive dois dos leões rampantes, encontram-se em uma fazenda em Uberaba, Minas Gerais, os leões, ladeando a entrada da sede da fazenda, eternos guardiões.

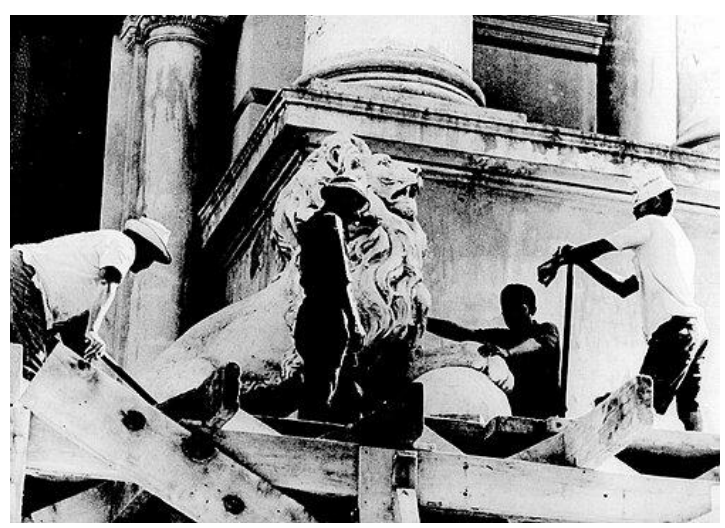

Figura 6. Os leões sendo retirados do Palácio.

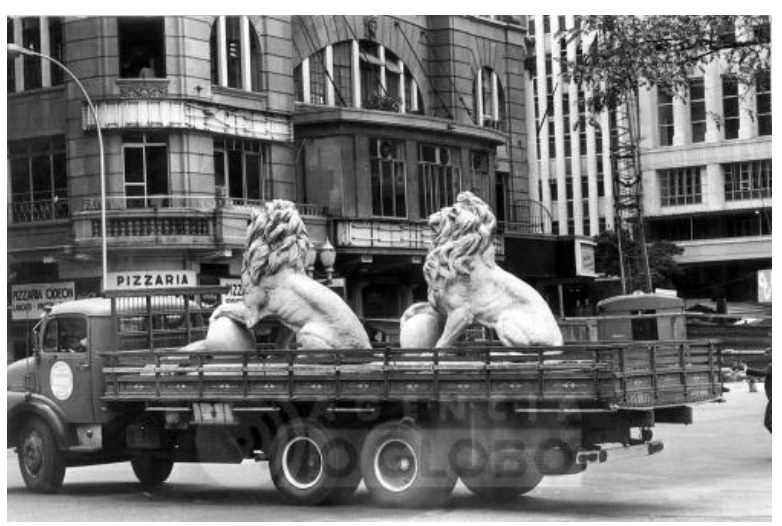

Figura 7. Os leões rampantes batendo em retirada... para Uberaba.

\footnotetext{
${ }^{2}$ GOODWIN, P. L. Brazil Builds: Architecture new and old 1652-1942. New York: The Museum of Modern Art, p. 25, 1943.
} 


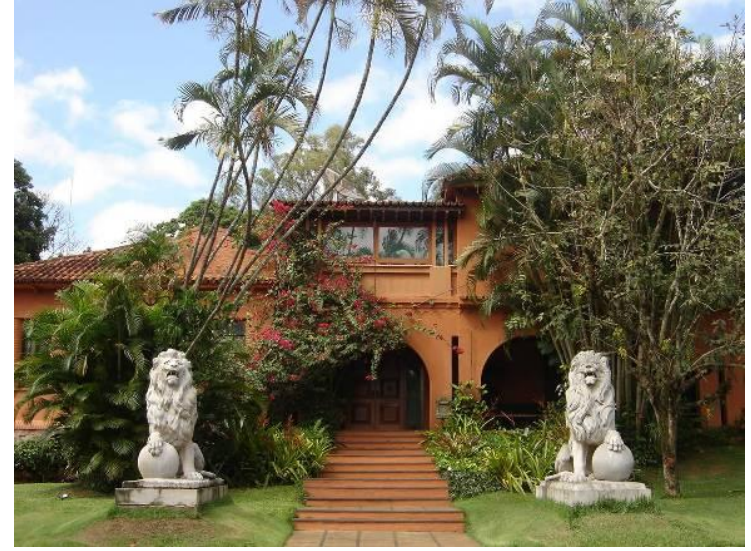

Figura 8. Leões postos a postos, agora em Uberaba.

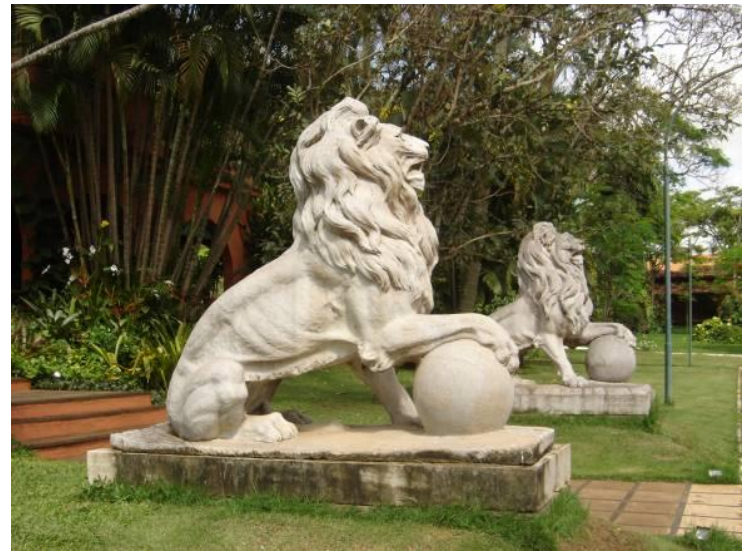

Figura 9. Idem.

Isto leva à questão de juízo de valor, trabalhar com Patrimônio é estabelecer critérios de sim e não e seus porquês, mas mesmo a partir desses critérios ainda há aspectos arbitrários, de ordem subjetiva. Até mesmo o restauro científico e o restauro crítico, ainda válidos, formulados e aceitos pelos arquitetos modernos na Carta de Veneza geram grandes polêmicas, verdadeiros atritos, entre os especialistas, ou seja, é científico, mas é muito discutível. O Palácio Monroe, redescoberto por leigos, é um desses exemplos, mas a polêmica continua, mesmo já sem razão de ser.

Os que gritam pela re-construção não têm a menor idéia do que fazer com aquilo e baseado no exemplo que vai se seguir, explica-se a enorme dificuldade de se dar novo destino a velhas edificações, que sem um uso que se amolde perfeitamente a condições modernas - que inclui interferências às vezes contundentes, mas necessárias à adaptação e, sem dúvida, interferências dissonantes, enquanto linguagem, para destacar e dar nitidez à diferença novo/velho -, o tal patrimônio volta a entrar em decadência e decrepitude, retorna inevitavelmente ao estado ruinoso inicial, até ser abandonado novamente.

Talvez remontá-lo em outro local e outro contexto, como já tinha sido feito entre Estados Unidos da América do Norte e Brasil, por mais uma vez. Como Lucio fez com o portal frontispício da antiga Academia Imperial de Belas Artes, levandoo para o Jardim Botânico, tivesse sido a solução - mas esse portal era de uma obra de Grandjean de Montigny, nada menos, e no final da alameda de palmeiras reais, ficou num local condigno. Talvez, então, ter se remontado o Monroe em um lugar onde complementos modernos, justapostos, coisa impossível onde estava, que pudessem dar vida útil ao Pavilhão - ou Palácio, nessa nova condição -, fosse a solução, mas não ali, atravancando o trânsito, inutilmente. Agora também é tarde demais para isso, as peças estão espalhadas por aí, a estrutura metálica - que era o que ainda poderia interessar a todos - ninguém sabe, as poucas peças felinas que estão em Uberaba não são suficiente para reconstituí-lo. 


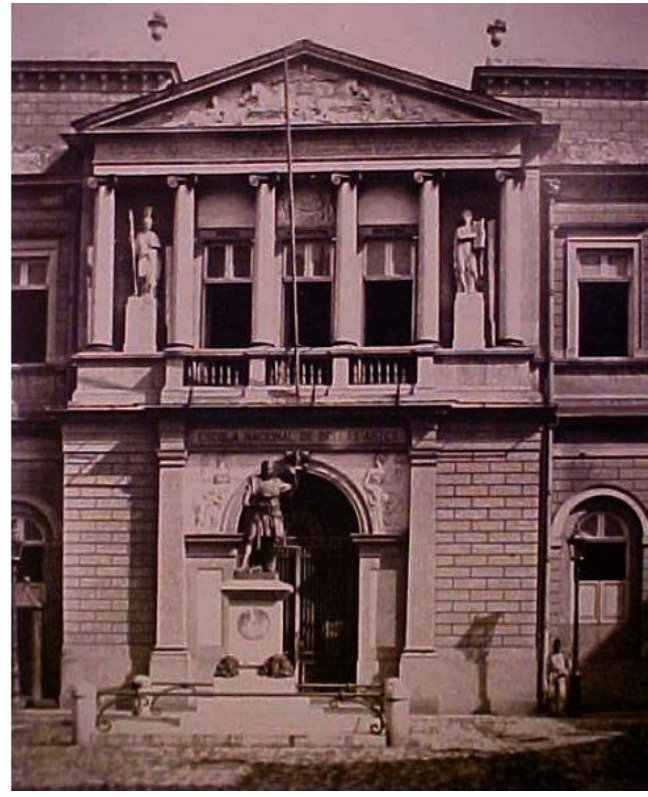

Figura 10. Corpo central em granito e mármore da Academia Imperial de Belas Artes. Prédio demolido em 1938.

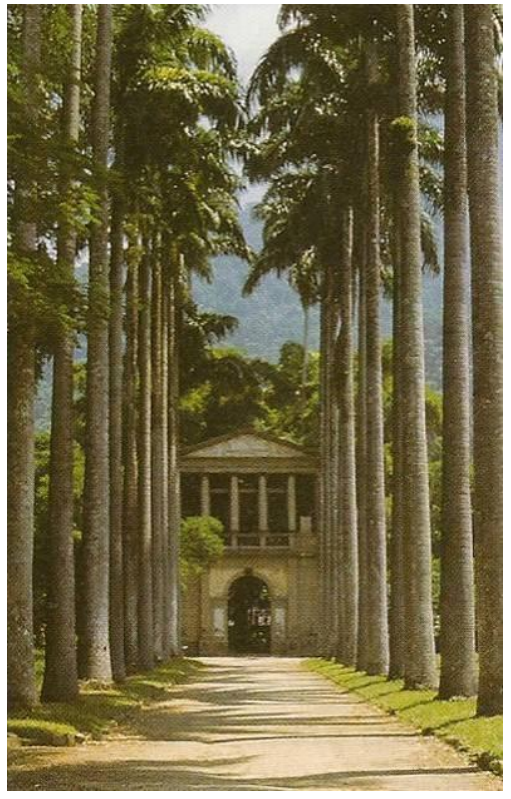

Figura 11. Atualmente o pórtico se encontra no Jardim Botânico do Rio de Janeiro, re-locado segundo orientação de Lucio Costa.

Segundo Cecília Rodrigues:

(...) dr. Lucio está principalmente a fazer a distinção necessária entre preservar e tombar. $O$ fato de um objeto não ter sido julgado "digno representante da cultura nacional" para assim ser merecedor de inscrição em um dos livros de tombo federal não deveria condená-lo ao desaparecimento. Pelo menos não é condenado pela instituição que estudou e elaborou esse juízo. Trata-se de uma mensagem clara desse parecer e um dos principais argumentos em defesa de dr. Lucio quanto à culpa histórica pelo desaparecimento do pavilhão, mesmo que no caso ele fosse a favor do "desafogo" da área. ${ }^{3}$

Mas, partindo para outro exemplo dessa mesma discussão, quando em 1990, Lina foi chamada para fazer a sede da Prefeitura Municipal de São Paulo, a se instalar no Palácio das Indústrias, disse:

- Vamos fazer um prédio novo, aquilo não presta para nada, fica só para as coisas áulicas, assinaturas dos atos, festas, coisas desse tipo. Em outros tempos teríamos demolido, agora não dá mais... Vamos pintar tudo de branco, assim fica mais "bolo-de-noiva" ainda, puro "glassê"! (c.d.m.)

O agora não dá mais se deveu a vários motivos: Lina era a favor do deslocamento da Prefeitura, que se encontrava no Parque do Ibirapuera, para a área central da cidade; era totalmente a favor da gestão política que se instalara recentemente no comando da Prefeitura, com a eleição de Luisa Erundina como Prefeita; para completar, o Palácio estava tombado pelos Conselhos Municipal e Estadual de Patrimônio, COMPRESP e CONDEPHAAT, que não cabia contestação. Para consolo

\footnotetext{
${ }^{3}$ SANTOS, C. R. dos. Problema mal posto, problema reposto. in: NOBRE, A. L.; KAMITA, J. M.; LEONÍDIO, O.; CONDURU, R. orgs. Um modo de ser moderno: Lucio Costa e a crítica contemporânea. São Paulo: Cosac \& Naify, p 141, 2004.
} 
dizia: - o que eu gosto é que no lugar de leões rampantes tem umas vacas... só no Brasil, mesmo, acontece uma coisa dessas! (c.d.m.)

Trata-se do grupo escultórico "O Progresso", do escultor Nicola

Rollo, de 1925.

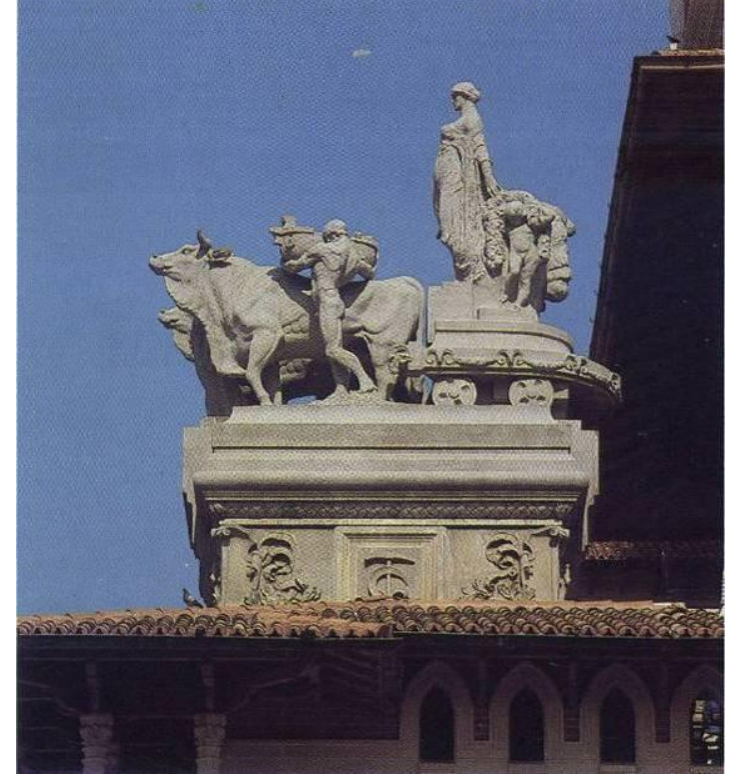

Figura 12. Grupo escultórico “O Progresso”, de Nicola Rollo, instalação anterior a 1921.

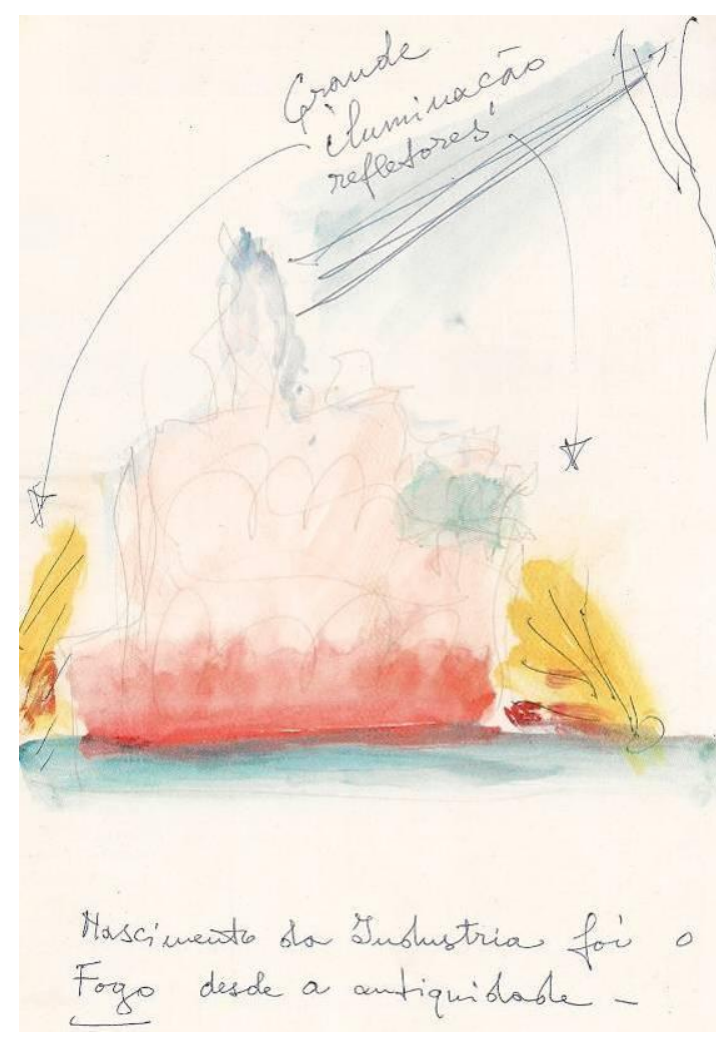

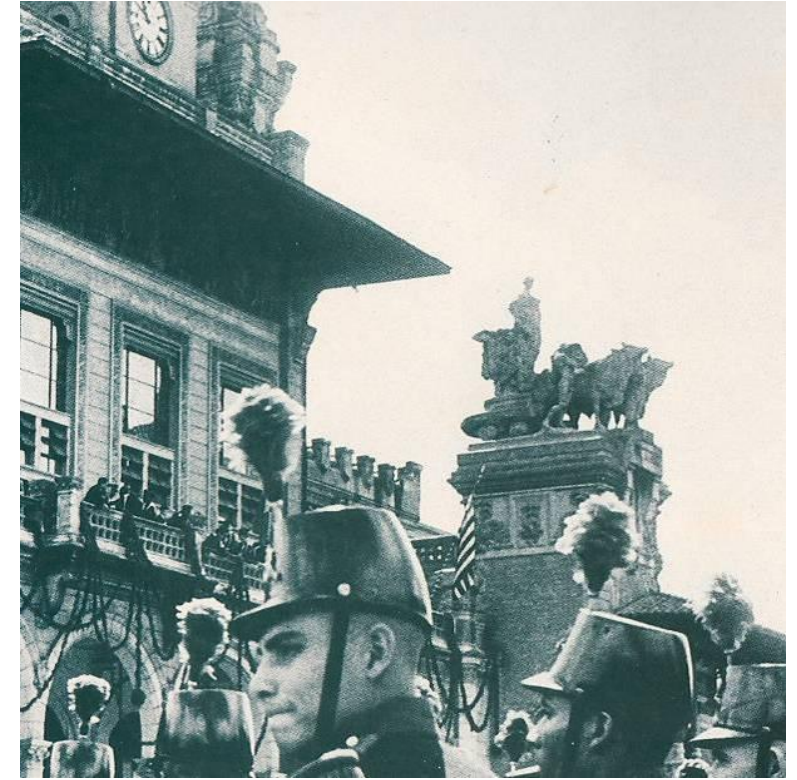

Figura 13. 1959, época em que foi ocupado como Assembléia Legislativa, uma das inúmeras tentativas de mudança de uso desse lugar. Banda militar, ao fundo as "vacas".

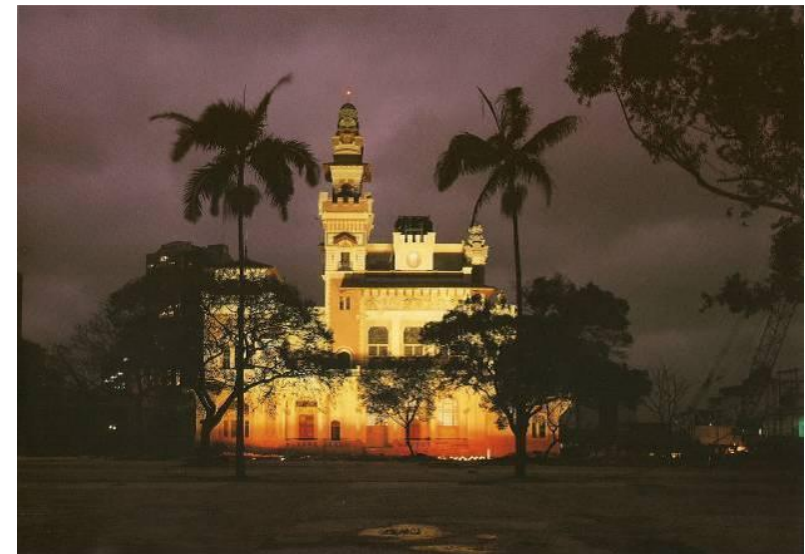

Figura 15. Fachada do Palácio das Indústrias, quando da reinauguração, em 1992.

Figura 14. Especificações de Lina para a iluminação noturna da fachada principal do Palácio, com o efeito de simular um incêndio, que acentuasse a efusiva ornamentação e a pseudo-assimetria - há uma simetria de justaposições de quadriláteros, em diagonal. A projeção das luzes sobre as fachadas pintadas de branco, como Lina queria, seriam mais eficientes.

O caso do Palácio das Indústrias foi um desses, uma obra que foi quase que impingida ao poder público, por Ramos de Azevedo, o empreendedor da época, 
nasceu torto e de difícil uso: sua finalidade, exposições, após apenas duas tentativas não servia mais para isso e foi abandonado. Inúmeras tentativas, de outros usos, se sucederam, todas com grandes dificuldades de ocupação de seus espaços.

Seu projeto reuniu grande parte do corpo técnico dos atelliers criados por Ramos, sob comando do arquiteto Domiziano Rossi, e resultou numa coisa híbrida, à la Coppedé - Gino Coppedé (1866-1927) ${ }^{4}$, que fizera um certo e efêmero sucesso no norte da Itália, no final do século XIX, comecinho do XX -, já que esses técnicos e artesãos eram contratados na Itália onde já não tinham muito mais o que fazer: lá, tinham caído de moda, aqui ainda tinham serviço.

Lina morreu durante as obras de restauração do Palácio, e o Bloco Novo, como chamávamos, nunca foi construído. Sem ela, nós, da equipe de colaboradores, não tivemos força suficiente para convencer os técnicos daqueles Conselhos a pintar todo o prédio de branco. Teria ficado melhor do que ficou - restaurado tintim por tintim -, e a maquete de apresentação do projeto mostra bem esse fato, mas desde que o Bloco Novo tivesse sido feito.
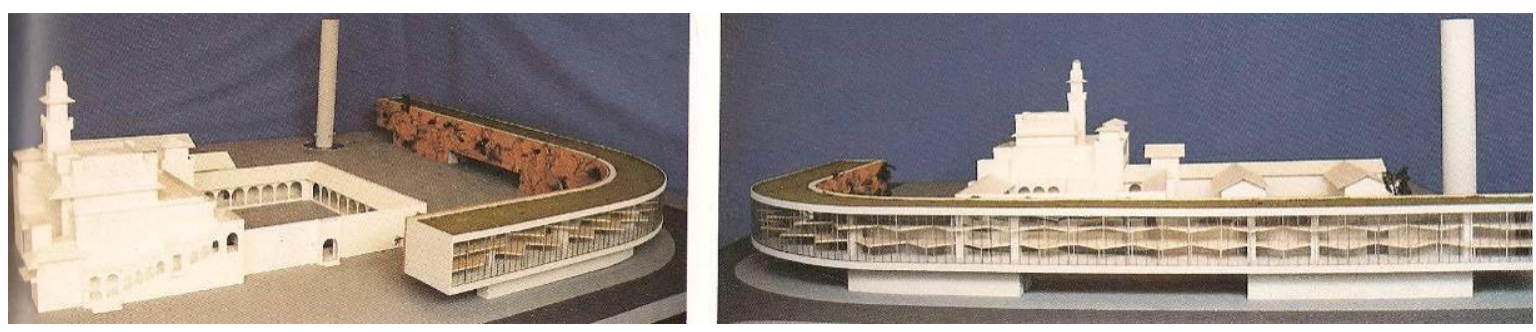

Figura 16. Maquete do Palácio das Indústrias, com o Bloco Novo. O antigo deveria ser caiado de branco e a parede- jardim-vertical é a máscara de ornamentos do Bloco Novo. Projeto da Nova Prefeitura de São Paulo.

O Bloco Novo tem proposições importantes: o volume é horizontal, com uma altura equivalente a cinco pavimentos, ficando sempre abaixo dos torreões da face Leste do Palácio, e bem abaixo da sua torre principal.

Todo ele, em sua longa extensão, é voltado para a Rua Mercúrio, com toda sua caixilharia voltada para fora, de costas para o Palácio, com a curva abraçando o espaço que os separa. A face voltada para o Palácio é fechada - cega-, e, na sua superfície. Lina propôs o jardim-vertical.

Funcionava então como um grande pano de fundo, um fecho para o Parque Dom Pedro, na sua direção Norte, mas um fecho virtual, porque todo o conjunto é suspenso em dois andares, apoiado apenas nos pontos de acesso, ficando grandes vãos livres, com 6 metros de pé-direito, sem ser um pilotis, tal como Lina já fizera no MASP, cujo pé direito é de 7 metros, mas, nesse caso, esse 1 metro a mais tiraria a altura precisa que se desejava, para não sobrepujar o Palácio.

O jardim-vertical tinha, em seu projeto executivo, detalhes muito interessantes, desenvolvidos com participação do arquiteto Lelé - João Filgueiras Lima: uma segunda parede, justaposta à parede do Bloco Novo, que era a estrutural, seria feita

\footnotetext{
${ }^{4}$ DOUCHKIN, T. bibliot. Palácio das indústrias: Memória e Cidadania. O restauro para a nova Prefeitura de São Paulo. São Paulo: Ed. DPH / Método, 1992.
} 
em argamassa armada, com um afastamento de 20 centímetros para que a umidade do jardim não atacasse a estrutura. A argamassa armada seria feita in loco, como nas obras de Pier Luigi Nervi, que Lina conhecia muito bem, e não pré-fabricados como os já desenvolvidos nos Centros de Tecnologia por Lelé. A armadura seria dupla e a mais externa seria toda deformada, formando bolsões irregulares.

Como a argamassa armada com concretagem in loco é feita em camadas sucessivas, as primeiras teriam o traço areia e cimento normal, conforme os estudos que ficariam a cargo de Lelé. A cada camada se diminuiria a quantidade de cimento e se adicionaria terra, até que por último se daria uma camada final, só de terra, possivelmente tabatinga, como se faz nas casas de pau-a-pique. Lina conhecia bem a tabatinga, é um saibro esbranquiçado, já tínhamos usado, sob seu comando, na exposição CAIPIRAS, CAPIAUS E PAU-A-PIQUE, no SESC - Fabrica da Pompéia, em 1983. Como Lucio, que também já tinha proposto no projeto Monlevade, descrito por ele como terra armada, uma versão antiga do novo concreto armado.

Os bolsões seriam enchidos com terra boa para plantio e, na parte de baixo, drenantes, eles seriam furados com pequenos buzinotes, fazendo com que a água em excesso fosse percolando de um bolsão a outro, criando um ambiente propício para o desenvolvimento das plantas, fato que seria ajudado pela posição na face Sul, dessa parede. Seriam espécies da Mata Atlântica, que Lina especificou e de que nos deixou um belo desenho.

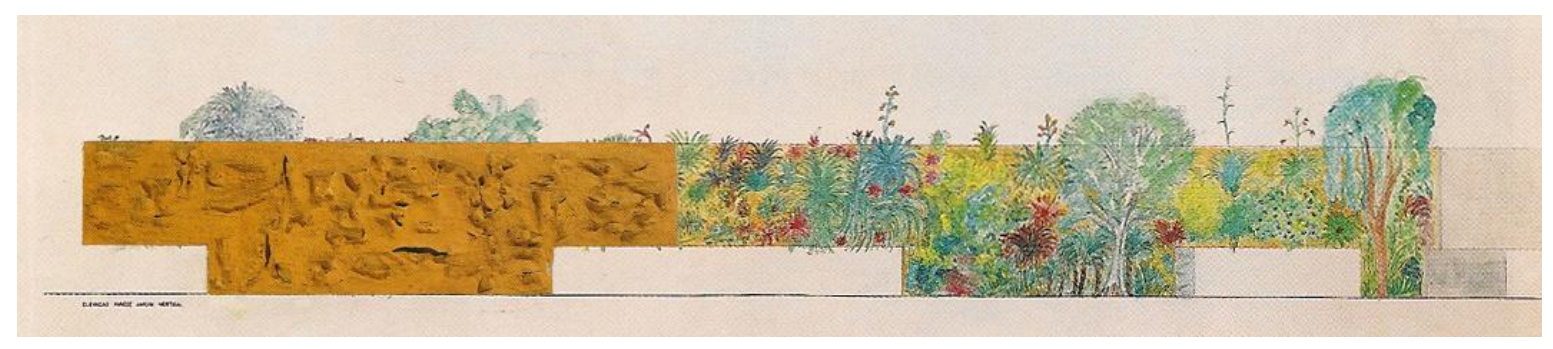

Figura 17. Parede-jardim-vertical - imagem com a sobreposição da maquete dos bolsões em argamassa armada - canteiros para a plantação - com o jardim tropical do desenho de Lina.

\section{Ornamento}

Sophia Silva Telles, há cerca de seis anos atrás, me ligou perguntando: Você acha que a parede jardim-vertical era um Ornamento? Respondi prontamente - Claro que sim! É o único ornamento possível! (c.d.m.) Como foi um diálogo, e só telefônico, nunca trocamos textos sobre o assunto, pressupus e aqui transcrevi Ornamento com letra maiúscula, ela estava se referindo à importância do Ornamento na História e principalmente na História da Arquitetura, que é de tal monta que mesmo a arquitetura moderna não se libera dela, o Ornamento ressurge de outras maneiras, sob outra ótica.

Virar o prédio de costas para o Palácio das Indústrias, extremamente ornamentado, bolo- de- noiva que é, apresenta dupla significação: o ornamento inevitável viria da resolução e textura criada pelos caixilhos, novamente eles. 
E uma vez que o edifício precisa mesmo dos caixilhos, o jeito foi virá-los todos para a rua, negando, mas por isso mesmo respeitando o Palácio. Como a parede jardim-vertical também é um ornamento, este surgiria dessa maneira singular, a ornamentação resultante não teria sido feita por nós, e sim, literalmente, brotaria de algo natural - de novo a palavra.

Fica claro também que aí está colocada a possibilidade moderna de, tecnicamente controlada, reproduzir a imagem do Romantismo - no sentido específico do termo, dentro da História da Arte: nostalgia do distante e do não compreensível, do não controlado, que relaciona o Romantismo com a Arte Moderna, e não sentimentalismos individuais - e adotar a invasão da vegetação sobre ruínas - ou que apresentam um quê de solitário e abandonado - como dados de projeto. Foi visto assim, por Lina, invadido, todo o paredão em cantaria da divisão Cidade Alta/Cidade Baixa, em Salvador; foi feito assim o arrimo de contenção do Hotel de Ouro Preto, de Niemeyer, está assim nas contenções das rampas de subida ao Outeiro da Glória, a agressividade do mato foi tecnicamente controlada por Lucio nas ruínas das Missões, e, assim, as árvores cercam as superquadras de Brasília. ${ }^{5}$
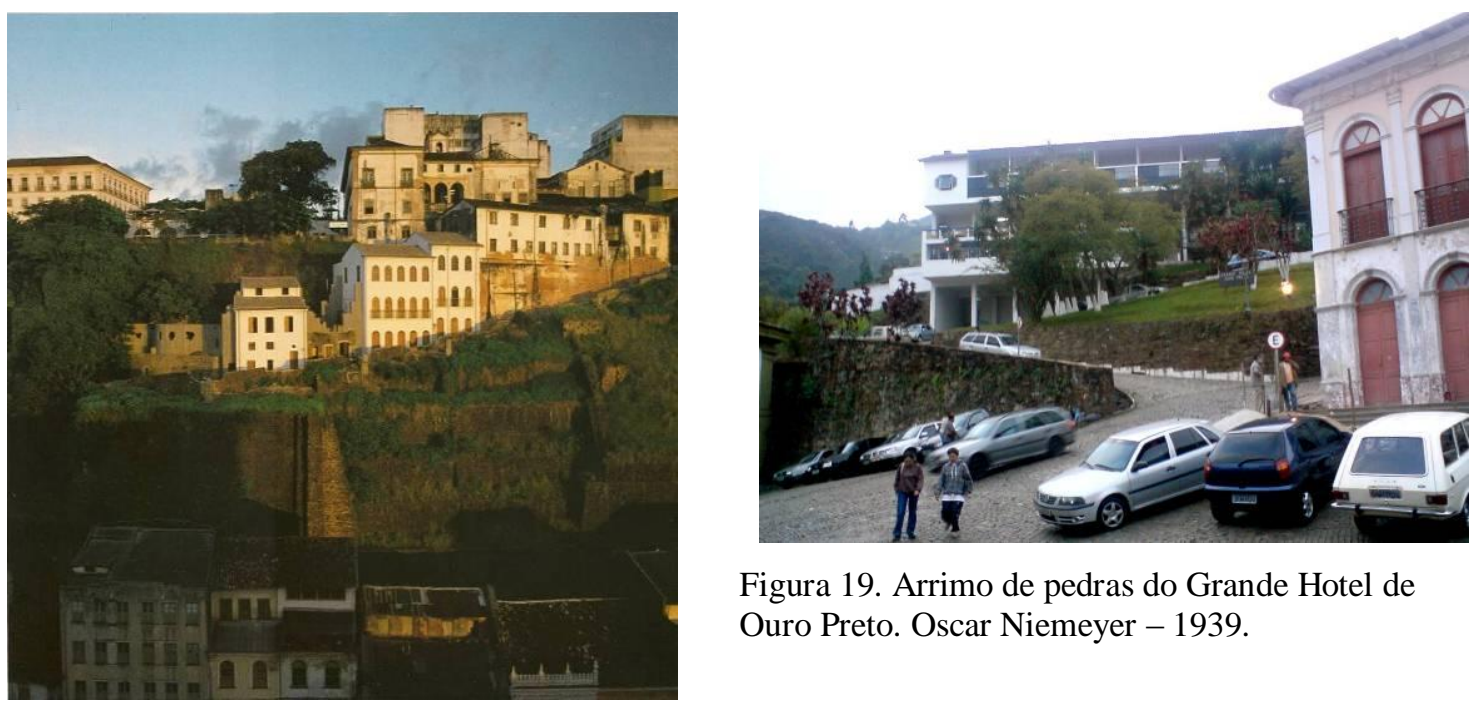

Figura 19. Arrimo de pedras do Grande Hotel de Ouro Preto. Oscar Niemeyer - 1939.

Figura 18. Ladeira da Misericórdia, Salvador. As muralhas são eternamente invadidas pela vegetação.

\footnotetext{
5 Aliás, uma das características do romantismo é, em certo sentido, a sujeição ao "acontecimento", aceitando-o como fatalidade e, mais ainda colocando-se a seu serviço (...) in: BARDI, L. B. Contribuição Propedêutica ao ensino da Teoria da Arquitetura. São Paulo: Instituto Lina Bo e P. M. Bardi, p. 16, 2002.
} 

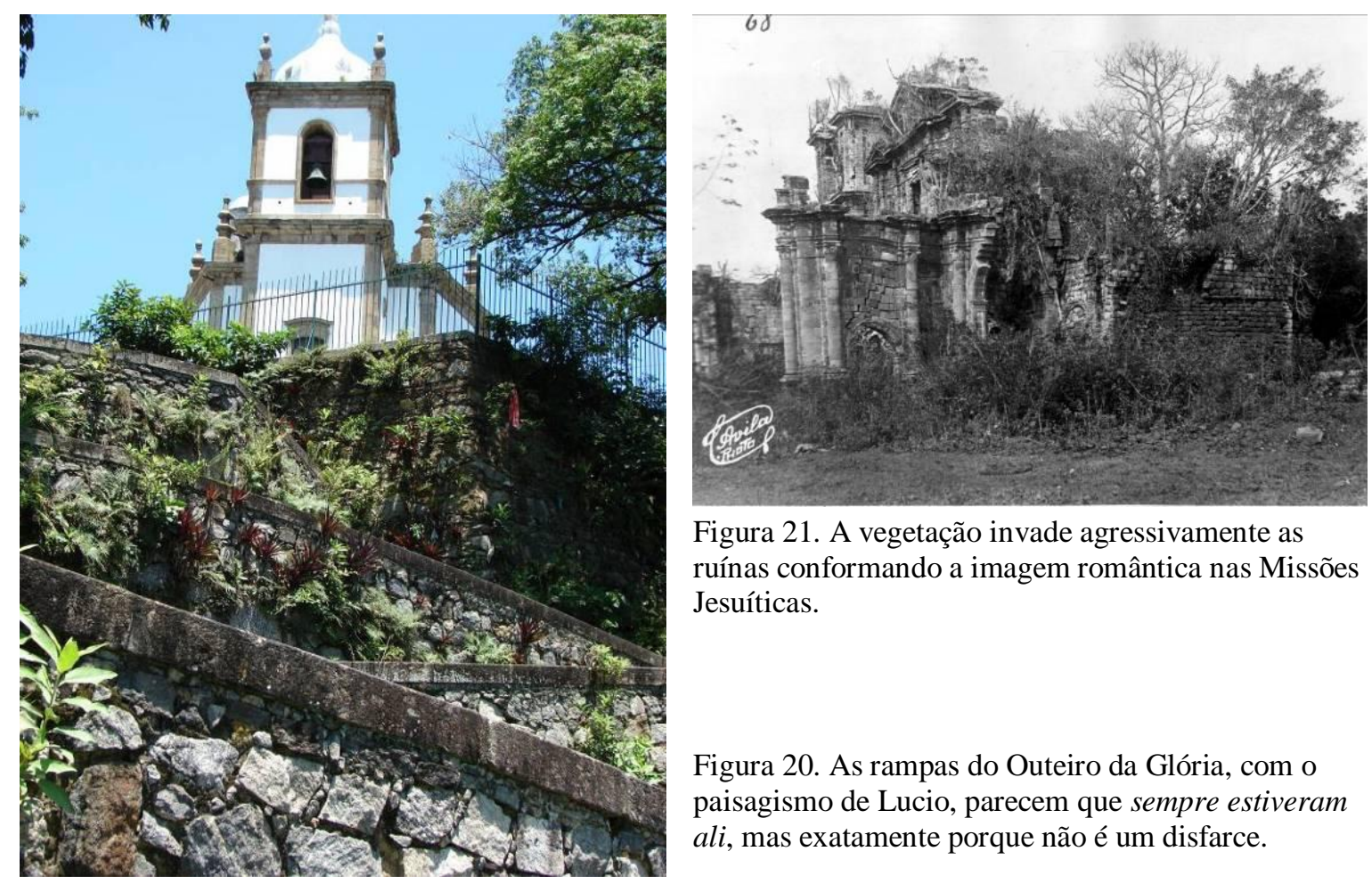

Figura 21. A vegetação invade agressivamente as ruínas conformando a imagem romântica nas Missões Jesuíticas.

Figura 20. As rampas do Outeiro da Glória, com o paisagismo de Lucio, parecem que sempre estiveram ali, mas exatamente porque não é um disfarce.

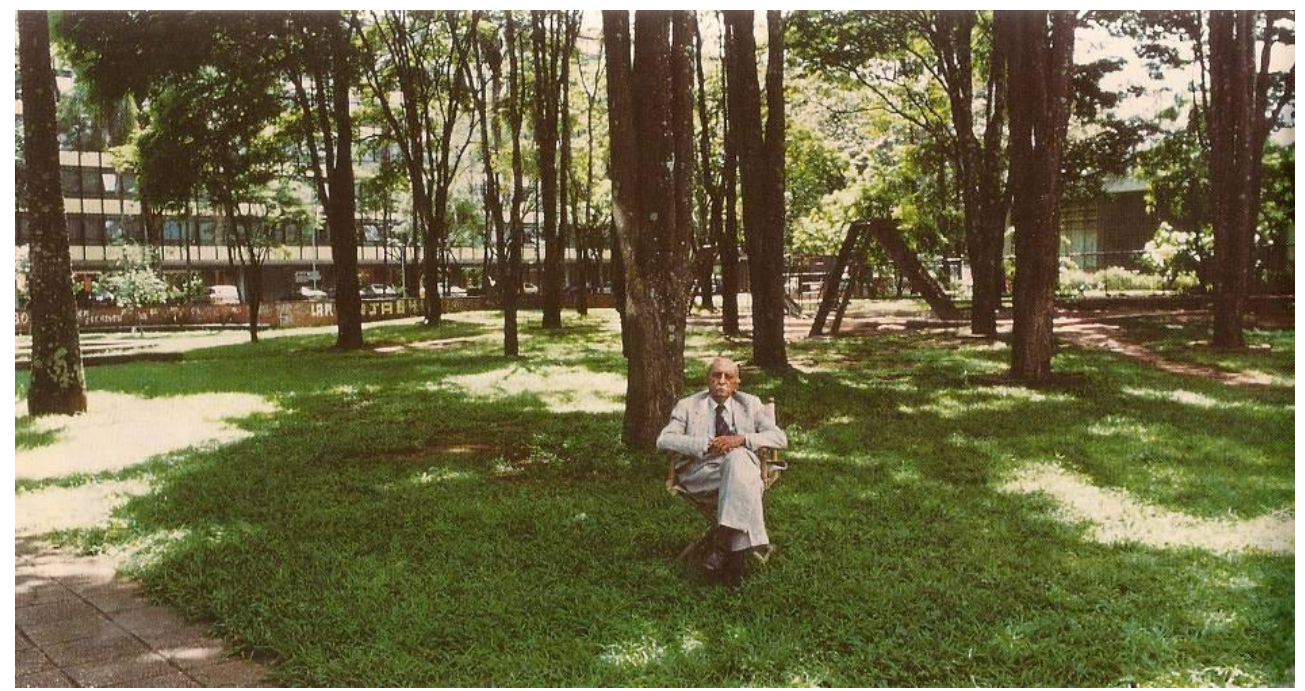

Figura 22. Lucio em uma Superquadra, cercada pela área verde que planificou.

É a proposição moderna, que, pela disponibilidade técnica, pode incorporar elementos do Romântico. Só assim a vegetação pode grudar nos muros, só assim árvores podem ficar tão próximas da construção - o pilotis e sua fundação concentrada não entra em conflito com as raízes - as copas ficarão no nível das janelas contínuas - só assim os terraços poderão ser jardins, etc. 


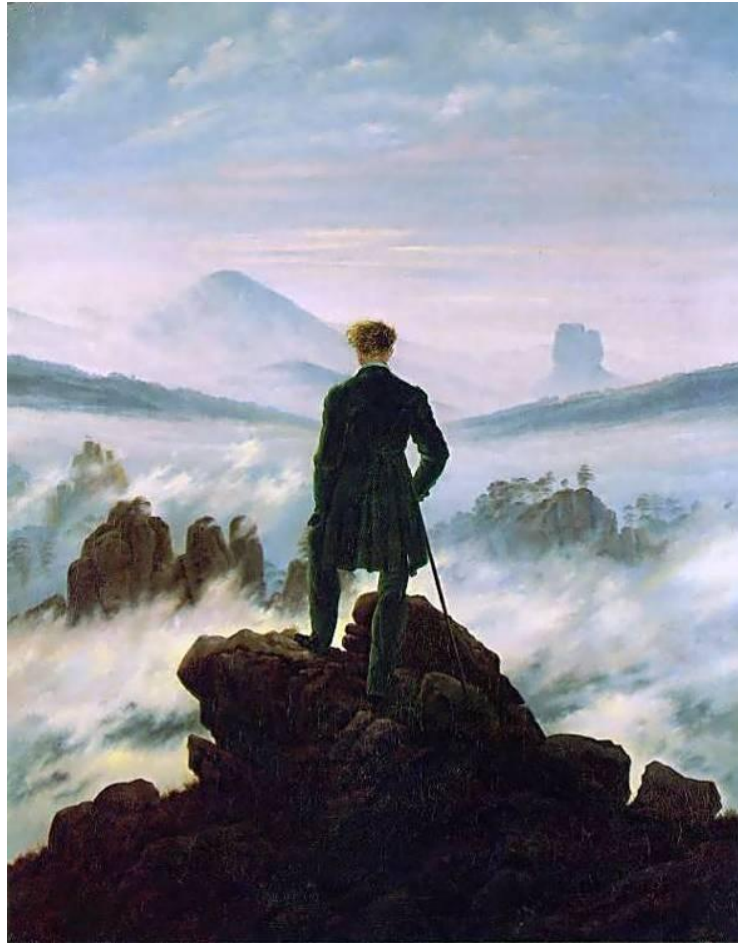

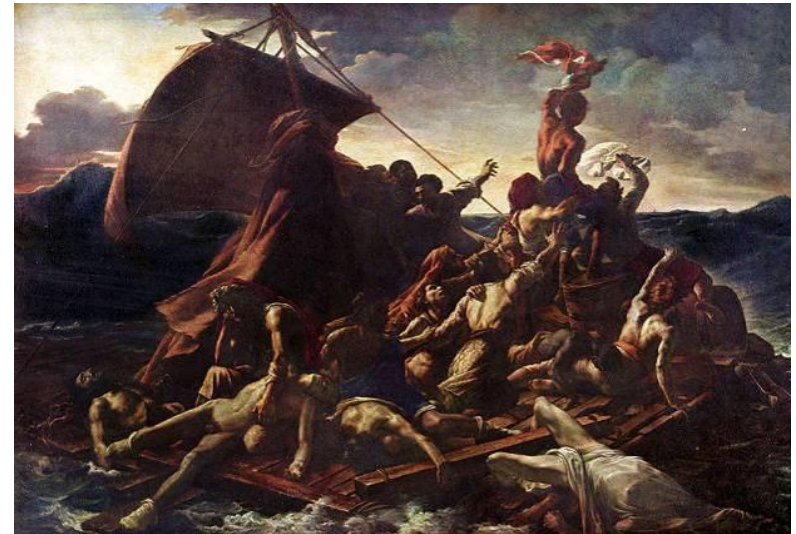

Figura 24. Théodore Géricault: A balsa da Medusa, 1818-1819.

A figura do não controlado e do desconhecido na visão Romântica.

Figura 23. Caspar David Friedrich: O peregrino sobre o mar de névoa, 1818.

(...) é certo que, em grande parte e no tocante a inúmeros aspectos, estamos vivendo as conseqüências - talvez últimas - de tudo aquilo que caracteriza o romantismo, entendido sobretudo, (na medida em que é possível sintetizar suas várias e por vezes contraditórias vivências) com o anseio indeterminado, a insatisfação e, por isso mesmo, a polêmica contra todas as regras fixas e definitivas; início, neste sentido, da consciência historicista contemporânea. ${ }^{6}$

Em uma palavra, a imagem Romântica reiterada nas pinturas, nos quadros, pode finalmente e tecnicamente ser construída, não mais distante, agora, real. Os medos das infiltrações e umidades controlados pela técnica, os conhecidos problemas com as raízes resolvidos, possibilitam a proposição de um Ornamento Moderno. Os terraços-jardim, de Le Corbusier, já estavam na antevisão dessa proposta como plenamente possível, e, mais que isso, desejável. Hoje já se deve até dizer ecologicamente correto...

No MESP, o terraço-jardim, no nível do andar do Ministro terceiro andar -, coincide com o volume das copas das árvores e palmeiras, plantadas lá embaixo, na praça; essas copas conformam um interior para esse ambiente suspenso e aberto. O paisagismo, tanto da praça como o do terraço, projetado e executado por BurleMarx $^{7}$, é o prolongamento externo do gabinete do Ministro, coincidindo exatamente com seu espaço para recepção e espera e que da especificidade e caráter a esse lugar.

\footnotetext{
${ }^{6}$ BARDI, L. B. Contribuição Propedêutica ao ensino da Teoria da Arquitetura. São Paulo: Instituto Lina Bo e P. M. Bardi, p. 35, 2002.

${ }^{7}$ Manteremos a grafia Burle-Marx com hífen, sinal diacrítico, conforme a grafia internacional, constante inclusive em GRAF, A. B. Tropica. N. York: Roehrs, 1978.
} 


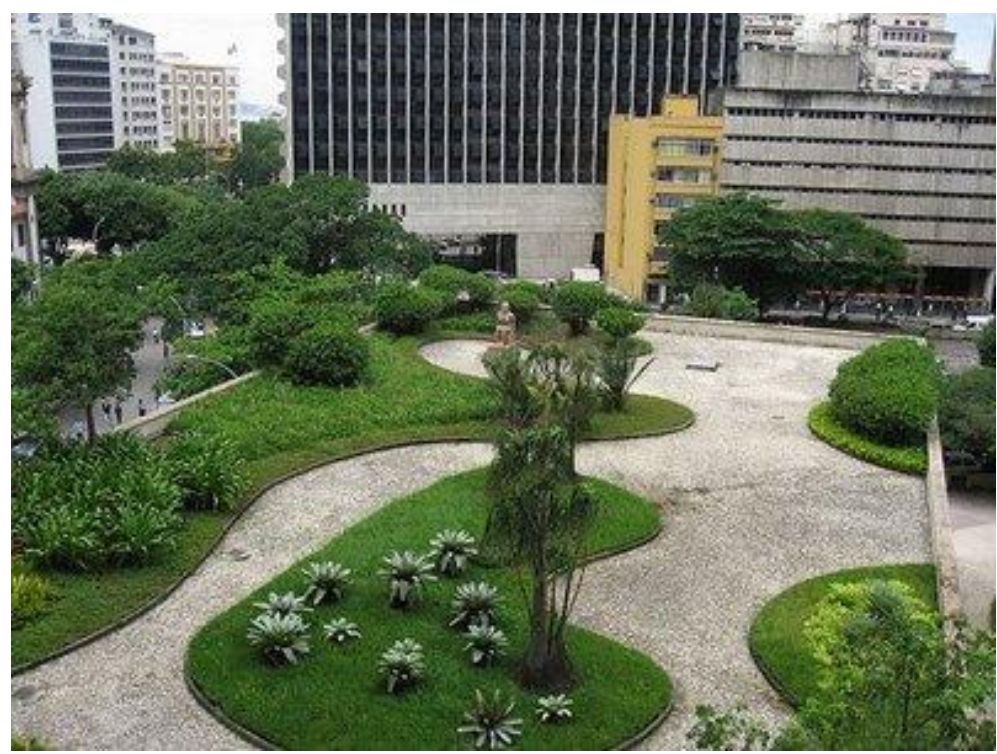

Figura 25. Terraço de Burle-Marx - Terceiro andar do MESP - as copas das árvores lá de baixo, da praça, conformam a sensação de um interior abrigado.

A face voltada para o terraço é com caixilhos e vidros de piso a teto, que dá a amplitude expandida do interior para o exterior; na face oposta, também ocupando todo o pé-direito, encontra-se o mural de Portinari, "Jogos Infantis", como que a sempre lembrar a função precípua do Ministério: educação e saúde, crianças! E é comovente o texto de Lucio sobre esse mural: (...) - belo e plástico embalo de puro amor. 8

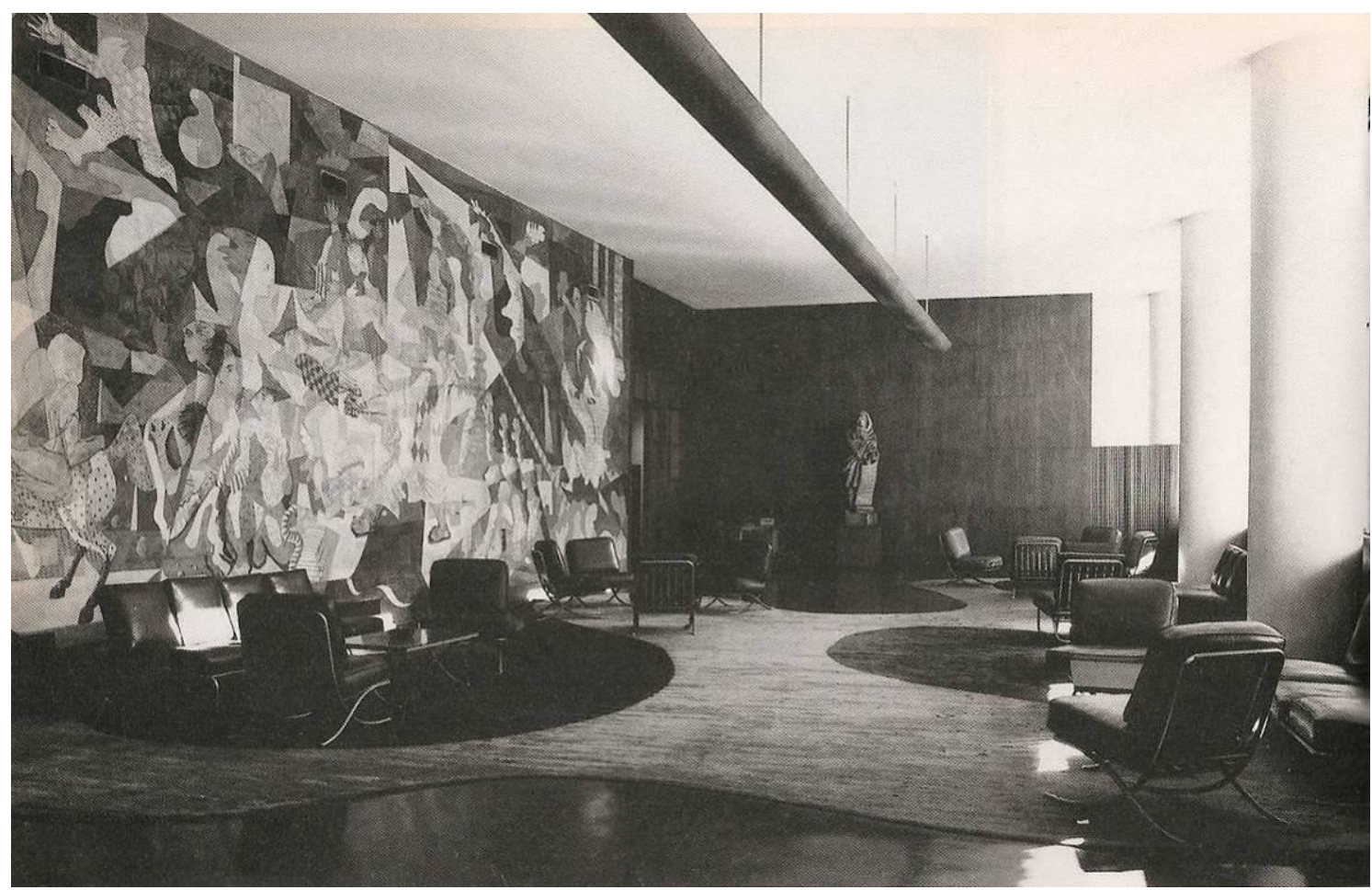

Figura 26. "Jogos infantis", de Portinari. Luminária em madeira com o perfil de uma piroga.

${ }^{8}$ COSTA, L. Registro de uma vivência. São Paulo: Empresa das Artes, p. 128, 1995. 


\section{PAISAGEM CONSTRUÍDA}

Lina era uma hábil paisagista. E fica evidente que aprendeu muito mais sobre isso aqui no Brasil, o que ela demonstrou em várias de suas obras, mostrando fluência na utilização da flora nativa, embora desde sua formação, na Itália, o tema Cidade-Jardim tenha sido extremamente estudado e debatido entre os modernos, exatamente o grupo alvo dos interesses de Lina, que ainda tinha a facilidade de se informar com o Professor. ${ }^{1}$

Isso nos leva a outro diálogo com Sophia Silva Telles, também na época, ela me perguntou, em versão aproximada, dado a distância do diálogo ocorrido: Por que você acha que Lina deixou as árvores chegarem tão perto da Casa de Vidro? Ter feito de todo o terreno uma floresta? (c.d.m.) Bem, dessa vez a resposta é mais longa e não cabe só o que respondi na época.

Sophia está se reportando ao projeto para Monlevade, e, principalmente, a Brasília, assim como na pergunta anterior, ornamento, com O Maiúsculo, era o pressuposto. Mas aqui se levanta um aspecto importante: tanto Lucio quanto Lina eram estrangeiros, continuaram sendo estrangeiros, no modo de olhar tudo, todo o exterior, ou seja qualquer coisa exterior à eles mesmos, pleno usufruto da potência cognitiva, de que fala Martins, uma enorme capacidade de apreender o que está fora. Em outros termos, Le Corbusier já tinha afirmado: Saber permanecer em estado de julgamento! ${ }^{2}$

O grau de precisão, o olhar certeiro, estava em todos os pormenores, o que evidentemente incluía o paisagismo, quando Lucio observa: (...) a lamentável presença das palmeiras imperiais recentemente plantadas, características do século XIX, destoa da ambientação original, enquanto ele está descrevendo construções do século XVII e XVIII, particularmente a fazenda do Colubandê, no Rio de Janeiro, (...) estilo de casa típico dessa região, confrontando a sua planta com o esquema da casa romana - o peristilo, o impluvium, o triclínio, ou a sala de jantar, aos fundos, como ficou na nossa tradição. ${ }^{3} \mathrm{O}$ paisagismo e a escolha dos espécimes têm que estar em acordo com a ambientação, inclusive e necessariamente da ambientação desses sítios que são patrimônios históricos. O julgamento é plenamente embasado no conhecimento. Lucio foi certeiro quando colocou o pórtico do corpo central da Academia Imperial de Belas Artes no final da alameda de palmeiras reais, mandadas plantar por D. Pedro II, reconstituindo a ambientação que nos foi dada pelo século XIX.

\footnotetext{
${ }^{1}$ Tanto as propostas de Garnier, quanto as citações de Le Corbusier, já eram de pleno conhecimento dela, via Professor Bardi, que frequentou os primeiros congressos dos CIAM, mesmo antes de ter vindo para o Brasil.

${ }^{2}$ LE CORBUSIER. Prólogo Americano - escrito em 1929, indo embora da América do Sul, depois de sua primeira viagem. in: Precisões: sobre um estado presente da arquitetura e do urbanismo. São Paulo: Cosac\& Naify, p. 26, 2004. E reiterado no pósfacio de MARTINS, C. A. F. com: Mas há uma condição prévia ao pleno usufruto da potência cognitiva desses modos de ver. É necessária uma predisposição, uma preparação que deixe o sujeito criador com os sentidos e a mente abertos ao fluxo de sensações, disposto a compreender, a "estar sempre em estado de julgar". in: Idem, p. 280.

${ }^{3}$ COSTA, L. Anotações ao correr da lembrança in: COSTA, L. Registro de uma vivência. São Paulo: Empresa das Artes, p. 503, 1995.
} 
No Brasil até o terceiro quartel do século XX, todo mundo cimentava toda a volta da casa, quintal era o local dos negros, da cozinha suja, dos porcos e galinhas, no fundo da casa a mangueira ou jabuticabeira, talvez. Na frente, em canteiros isolados, as roseiras importadas. A Casa das Rosas já foi aqui citada, como a urbanização dos senhores rurais - já se viu também que na Avenida Paulista não era exatamente assim -. A mata, o mato, o lá fora era o perigo, a incivilização, o atraso.

Burle-Marx foi fundamental para a mudança de gosto na escolha de espécies da vegetação adequada para o jardim brasileiro: incluiu espécimes brasileiros, coisa renegada, até então. Como disse Cavalcanti, sobre o MÊS: (...) jardim público criado pelo paisagista Roberto Burle Marx - utilizando, pela primeira vez, espécimes da flora nacional considerados, até então, pouco dignos para tal fim. ${ }^{4}$

Renato Anelli nos alertou para o papel de Mina Warchavchik nos projetos paisagísticos, presentes nos projetos de seu marido, Gregori, desde o projeto dele, da Casa Modernista, de 1927: Os jardins de sua mulher Mina, empregam pela primeira vez elementos próprios da flora brasileira, como o cactus, então símbolo do tropicalismo. (sic) ${ }^{5}$ Mas não cabe repetir aqui repetir discussões de pioneirismos, que já causou tanto pano-pra-manga, com a interpelação de Geraldo Ferraz sobre o fato de o pioneiro da arquitetura moderna no Brasil ser Warchavchik e não Lucio, o que é seguido de resposta, mas que iniciou a contínua implicância de Ferraz com todo o grupo do Rio. Isto já foi bastante estudado e sedimentado entre nós. ${ }^{6}$

Lina fala assim de Burle-Marx, em carta para ser publicada no exterior:

\section{O antigo terror pela floresta hoje foi substituído por uma visão} mais serena, que aceita evitar a destruição onde esta não seja necessária, dando lugar a plantações. $O$ terror se transformou em amor. O grande viveiro que o arquiteto (sic) Roberto Burle Marx possui próximo ao Rio de Janeiro é uma coleção única de plantas tropicais prontas para serem colocadas nos jardins particulares e públicos, escreveu Lina, e continua: Se houve alguma inovação na arquitetura de jardins, esta veio justamente através de Burle Marx; a visão dos jardins brasileiros com suas belas plantas tropicais, os movimentos de água e os painéis de cerâmica colorida dão ao visitante europeu, acostumado a jardins municipais e oficiais, um sentimento de liberdade e de alegria primitiva. ${ }^{7}$

O preconceito contra a flora autóctone, incrustado na nossa formação ibérica implicava num plano urbanístico seco, sem vegetação - e quando havia, eram composições de espécimes exóticas. Até o mar representava o de onde vem o perigo, sejam os invasores, sejam piratas, sejam doenças - alemães imigrados para o Rio de Janeiro, no início da década de 30 são os primeiros a nadar, escancaradamente, no mar de Copacabana, iniciando um ritual impressionante até hoje em dia. Os rios, também,

\footnotetext{
${ }^{4}$ CAVALCANTI, L. Moderno e brasileiro. Rio de Janeiro: Jorge Zahar Ed., p. 56-57, 2006.

${ }^{5}$ CORONA, E., LEMOS, C., XAVIER, A. Arquitetura moderna paulistana. São Paulo: Pini, p.12, 1983.

${ }^{6}$ Ver: FERRAZ, G. Depois de tudo. São Paulo: SMC / PMSP / PAZ E TERRA, 1983 e COSTA, L. Depoimento, 1948 in: COSTA, L. Registro de uma vivência. São Paulo: Empresa das Artes, p. 198, 1995 ${ }^{7}$ BARDI, L. B. Lettera dal Brasile. (s.d.) in: Lina Bo Bardi. Marcelo Carvalho Ferraz org. São Paulo: Instituto Lina Bo e P. M. Bardi, p. 95, 1993.
} 
tratados sempre, na nossa formação urbana, como meros canais de esgotos, nunca representaram algo significativo na urbanização e na paisagem das cidades brasileiras. As cidades eram voltadas para dentro, de costas para o mar ou para o rio, conforme litorânea ou no interior. Os exemplos são alguns dentre muitos outros, por todo o país.

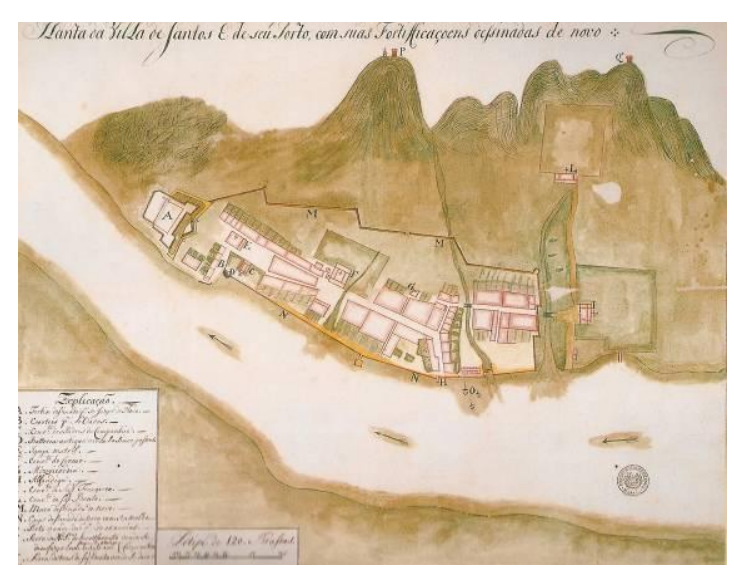

Figura 1. Descrição original da imagem: "Planta da Vila de Santos... ”. Original de João Massé Arquivo Histórico Ultramarino, Lisboa. ca. 1714. Pág 371.

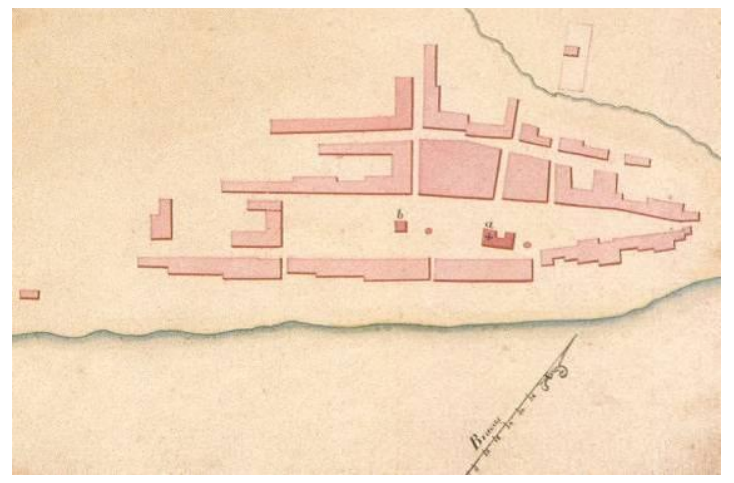

Figura 2. Descrição original da imagem: "Villa de Iguápe". Detalhe de uma das "CARTAS Corographicas e Hydrograficas...”, de João da Costa Ferreira, Sociedade de Geografia de Lisboa. ca. 1815. Pág. 374.

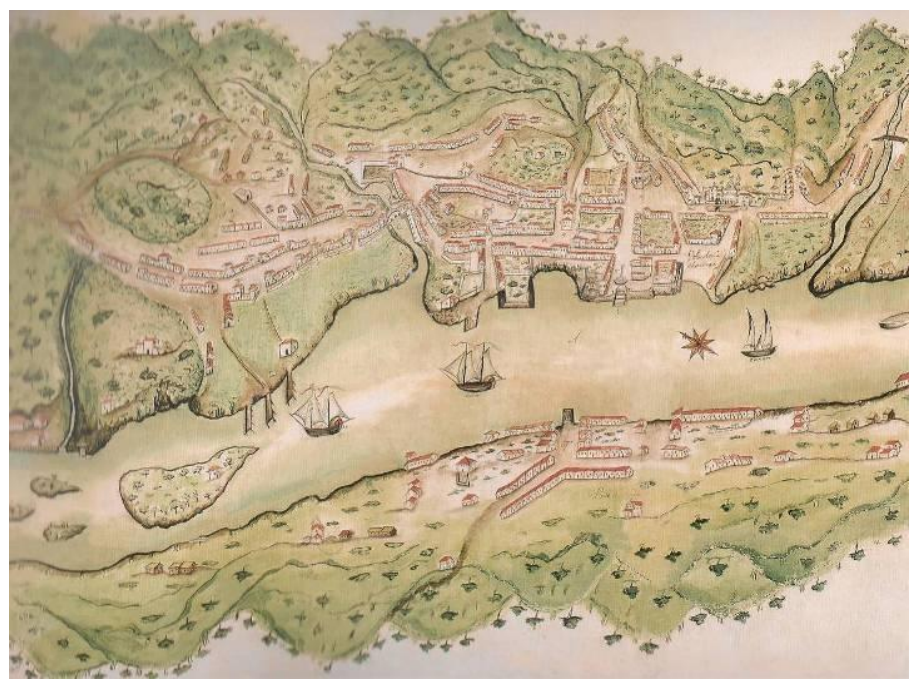

Figura 3. Cachoeira, no Recôncavo bahiano, está às margens do belo rio Paraguaçú. Descrição original da imagem: "Villa de Cachoeira”. New York Public Library. ca 1792. Pág 320.

Nesse sentido, Flavio Motta ensina:

O homem aprendeu a distinguir, na paisagem, aquilo que ele não precisava, nem precisa fazer. Tal atitude tida como de pura contemplação ou constatação, está intimamente ligada a uma série de determinações sociais nas quais há, ainda, tensos momentos subjetivos para as novas relações de trabalho. Quando deslocada para os "trópicos", ou melhor, para os "países de formação colonial mais recente", esta atitude tende a uma lúcida autonomia. Por força dos próprios antecedentes históricos, os povos de passado colonial (e quantos não o tiveram!) 
acumularam problemas humanos, cujas soluções visam ao conhecimento de uma nova conduta e de uma nova condição paisagística. ${ }^{8}$

Já Bruand coloca a questão em termos da atitude e da cultura brasileiras bastante difundidas:

Deve-se inicialmente frisar que os brasileiros nunca se mostraram sensíveis à natureza, especialmente no que diz respeito à sua preservação.

Os primeiros colonos portugueses se depararam com um meio hostil e perigoso, o qual era necessário dominar por meio da destruição a fim de tornar possível a agricultura. As queimadas foram e continuam sendo prática corrente, resultando daí uma reação hostil da população a tudo quanto for vegetação, tanto a das matas quanto das cidades, onde a maioria dos administradores não tem o menor respeito pelas árvores e pouco se preocupa em criar ou preservar áreas verdes. ${ }^{9}$

Bruand segue com uma afirmação estranha, de que a exuberante vegetação brasileira haja influído na arquitetura, de modo a torná-la mais exuberante. Influído como um caso de inspiração? Acaso a arquitetura moderna brasileira não foi acusada de espalhafatosa, tal exuberância e barroquismo, por seus detratores? Niemeyer vive recorrendo à paisagem do Rio e às curvas da mulher brasileira, como suas fontes de inspiração, o que geralmente lhe rende severas críticas. Mas se se inspirasse na vegetação, não ocorreria o mesmo?

Carlos Martins detecta um aspecto importante dessa questão:

Bruand incorre aqui num certo deslizamento de conceito, quando confunde natureza com vegetação, ignorando a noção de paisagem, o que não é um equivoco menor quando se trata de analisar seja a arquitetura brasileira seja a própria produção de Le Corbusier (...).

E mais adiante:

(...) Redesenhá-lo, tratar a paisagem como ready-made nada tem a ver com a tradição francesa da imposição geometrizante sobre a paisagem e a vegetação. - referindo-se à implantação que Lucio propõe para Monlevade, em seu memorial, implantação essa que não tem caráter corbusiano. ${ }^{10}$

Mas não é só no Brasil onde se observou esse o problema, pois tratava-se de um problema para os modernos enfrentarem, nas cidades do século XX. Como apontava Le Corbusier, em vários de seus textos, como por exemplo, em 1929:

De tudo o que já dissemos depreende-se que a cidade moderna será repleta de árvores. É uma necessidade para os pulmões, é uma ternura com respeito a nossos corações, é o próprio tempero da grande plástica geométrica introduzida na arquitetura contemporânea pelo ferro e pelo concreto armado. ${ }^{11}$

E reafirmava, em 1947:

\footnotetext{
${ }^{8}$ MOTTA, F. L. Roberto Burle Marx e a nova visão da paisagem. São Paulo: Nobel, p. 2-4, 1984.

${ }^{9}$ BRUAND, Y. O meio brasileiro e sua influência sobre a Arquitetura. in: BRUAND, Y. Arquitetura Contemporânea no Brasil. São Paulo: Perspectiva, p. 14, 1999.

${ }^{10}$ MARTINS, C. A. F. Arquitetura e Estado no Brasil-elementos para uma investigação sobre a constituição do discurso moderno no Brasil; a obra de Lucio Costa (1924-1952). São Paulo: FFLCH USP, Dissertação de Mestrado, p. 46 e 160, 1988.

${ }^{11}$ LE CORBUSIER. $6{ }^{\text {a }}$ Conferência: outubro de 1929. in: LE CORBUSIER. Precisões: sobre um estado presente da arquitetura e do urbanismo. São Paulo: Cosac \& Naify, p. 156, 2004.
} 
There are no trees in the city! That is the way it is.

Trees are the friends of man, symbols of every organic creation; a tree image of a complete construction. A delightful spectacle which appears to us in the most fantastic, yet perfectly ordered arabesques; a mathematically measured play of branches multiplied each spring by a new life-fiving hand. Leaves with finely placed nerves. A cover over us between earth and sky. A friendly screen close to our eyes. A pleasant measure interposed between our hearts and eyes, and the eventual geometries of our hard constructions. A precious instrument in the hands of the city planner. The most concentrated expression of the forces of nature. The presence of nature in the city, surrounding our labors or our pleasures. Trees are the millenary companions of man! ${ }^{12}$
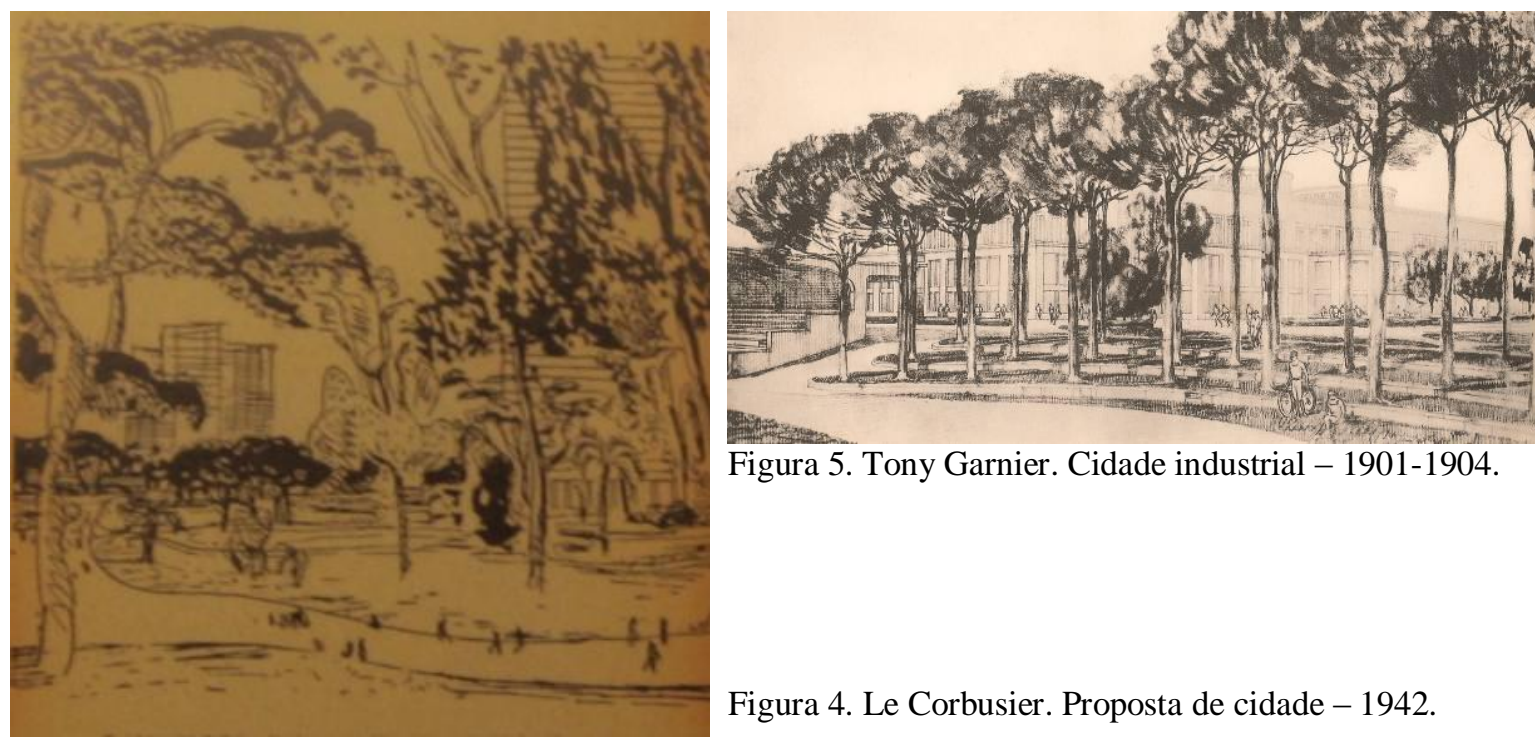

Figura 5. Tony Garnier. Cidade industrial - 1901-1904.

Figura 4. Le Corbusier. Proposta de cidade - 1942.

Tanto em Lina quanto em Lucio, o estrangeirismo dessa visão da natureza explosiva, da vegetação exuberante local, somou-se à postura moderna, de fazêla participar, tanto quanto às questões técnicas da construção civil propriamente dita, quanto das questões ambientais, urbanísticas e paisagísticas. Burle-Marx também. Mas, como se viu, mais que uma postura estrangeira, tratou-se de uma questão levada adiante pelos modernos.

\section{Enquadramentos vivos}

Lucio também, hábil paisagista, já no projeto Monlevade (1934), no memorial para o concurso, especifica:

Quanto à vegetação, além do aproveitamento das árvores existentes - previsto no edital - seria de toda vantagem um plano completo que não se limitasse às ruas e praças, mas incluísse nos seus cuidados os próprios jardins das casas, contribuindo assim para a harmonia do conjunto. A administração da vila deveria

\footnotetext{
${ }^{12}$ LE CORBUSIER. When the cathedrals were White: A journey to the country of timid people. New York: Reynal \& Hitchcock, p. 71, 1947.
} 
também proibir terminantemente a poda das árvores ou arbustos em formas bizarras ou geométricas, pois constitui um dos preceitos da urbanização moderna o contraste entre a nitidez, a simetria, a disciplina da arquitetura e a imprecisão, a assimetria, o imprevisto da vegetação. (... $)^{13}$

A perspectiva panorâmica que Lucio apresenta para o concurso é precisa: a implantação urbanística e a vegetação estão inter-relacionadas como o projeto requer, especifica e determina, e não como um recurso para o complemento da plasticidade do desenho. Já está representada toda a intenção que hierarquiza simultaneamente arquitetura, paisagismo e urbanismo: áreas livres de vegetação, digamos, esplanadas, com os prédios principais, a gradação escalonada para edifícios secundários, a diluição para resguardar o ambiente familiar. Apesar de isso não ser comprovado numa mera observação desse desenho em si, ele é complementado pelos desenhos de pormenores, em todos eles se repete a escala e a proporção desejada para cada trecho do paisagismo se relacionar com a construção.

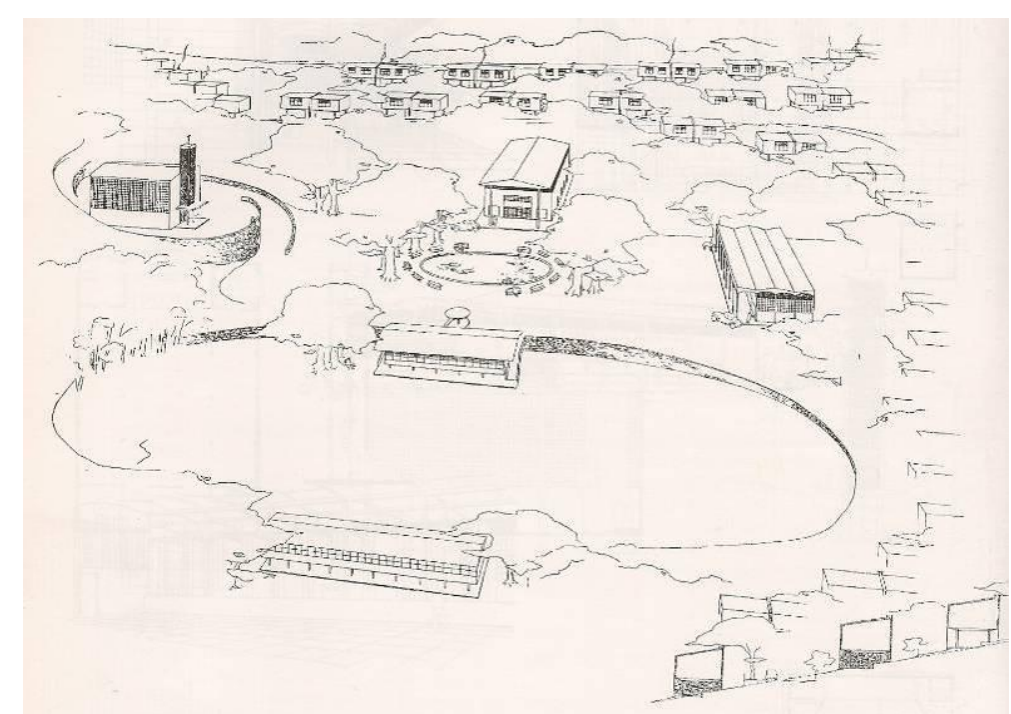

Figura 6. Perspectiva de Lucio para o Projeto de Monlevade - 1934.

Em 1952, sobre Arte Contemporânea, ele declara:

Monumentalidade - do urbanismo, da arquitetura - que não exclui a graça, e da qual participarão as árvores, os arbustos e o próprio descampado como complementos naturais, porquanto o que caracteriza o conceito moderno de urbanismo, que se estende da cidade aos arredores e à própria zona rural, é, precisamente, a abolição do "pitoresco", graças à incorporação efetiva do bucólico ao monumental. ${ }^{14}$

E é fundamental essa distinção: pitoresco versus bucólico. Lucio vai ressaltar essa distinção em seu parecer sobre o acesso, na encosta do Outeiro da Glória. Foi Lucio quem deu a chance para Roberto Burle-Marx iniciar-se no paisagismo

\footnotetext{
${ }^{13}$ COSTA, L. Monlevade - 1934 - Projeto Rejeitado. in: COSTA, L. Registro de uma vivência. São Paulo: Empresa das Artes, p. 98, 1995.

${ }^{14}$ COSTA, L. Sobre Arquitetura. Alberto Xavier org. Porto Alegre: Centro de Estudantes Universitários de Arquitetura, p. 226, 1962. Idem: revisão fac-símile com comentários de Lucio Costa. Porto Alegre: Editora UniRitter, 2007. Nessa edição consta a observação: Perfeito, 30/1/66.
} 
profissional, paisagista e pesquisador individual de botânica, que já era, quando o convida para executar o jardim do terraço da Casa Schwartz, em 1932, projeto de Lucio, obra da parceria com Warchavchik, quando então ainda havia a empresa Sociedade de Construções Warchavchik \& Lucio Costa. E de lá em diante ele seguiu o caminho, de grande importância no re-pensar a paisagem brasileira.

Lucio retoma a mesma proposição de Monlevade, em detalhe, em Brasília, da seguinte forma, descrita na Memória Descritiva do Plano Piloto de seu projeto para o concurso de Brasília, item 16:

Quanto ao problema residencial, ocorreu a solução de criar-se uma sequência de grandes quadras dispostas, em ordem dupla ou singela, de ambos os lados da faixa rodoviária, e emoldurá-las por uma larga cinta densamente arborizada, árvores de porte, prevalecendo em cada quadra determinada espécie vegetal, com chão gramado e uma cortina suplementar intermitente de arbustos e folhagens, a fim de resguardar melhor, qualquer que seja a posição do observador, o conteúdo das quadras, visto sempre num segundo plano e como que amortecido na paisagem (fig. 13).

Disposição que apresenta a dupla vantagem de garantir a ordenação urbanística mesmo quando varie a densidade, categoria, padrão ou qualidade arquitetônica dos edifícios, $e$ de oferecer aos moradores extensas faixas sombreadas para passeio e lazer, independentemente das áreas livres previstas no interior das próprias quadras. (...) ${ }^{15}$

Explica ainda mais:

Para conciliar a escala monumental, inerente à parte administrativa, com a escala menor, íntima, das áreas residenciais, imaginei as superquadras - grandes quadrados com 300m de lado - que propus cercadas em toda a volta por uma faixa de $20 \mathrm{~m}$ de largura plantada com renque de árvores cujas copas se tocam, que mexem com o vento e respiram, formando assim, em vez de muralhas, enquadramentos vivos, abrindo amplos espaços internos. Creio que houve sabedoria nessa concepção: todos os prédios soltos do chão sobre pilotis, no gabarito médio das cidades européias tradicionais - antes do elevador -, harmoniosas, humanas, tudo relacionado com a vida cotidiana: as crianças brincando à vontade ao alcance do chamado das mães, com a escola primária na própria quadra; no acesso a cada quatro delas, um núcleo comercial com "lojas de bairro", e nas demais entrequadras, alternando-se, escola secundária, igreja, clube, cinema, supermercado. Com isso, as "áreas de vizinhança” justapostas não são estanques, - se permeiam.

Assim, do cruzamento dos dois eixos, seis quilômetros para cada lado, duas sequências contínuas de superquadras, geometricamente definidas no espaço pelas cercaduras arborizadas, enfileiradas em cadeia, contíguas às pistas de trafego mas independentes delas e tendo como fundo o vasto horizonte, o céu e as nuvens do planalto - o monumental e o doméstico entrosam-se num todo harmônico e integrado. ${ }^{16}$

\footnotetext{
${ }^{15}$ COSTA, L. Memória Descritiva do Plano Piloto - 1957. in: COSTA, L. Registro de uma vivência. Paulo: Empresa das Artes, p. 291-292, 1995.

${ }^{16}$ COSTA, L. Eixo Rodoviário-Residencial. in: COSTA, L. Registro de uma vivência. São Paulo: Empresa das Artes, p. 308-309, 1995.
} 


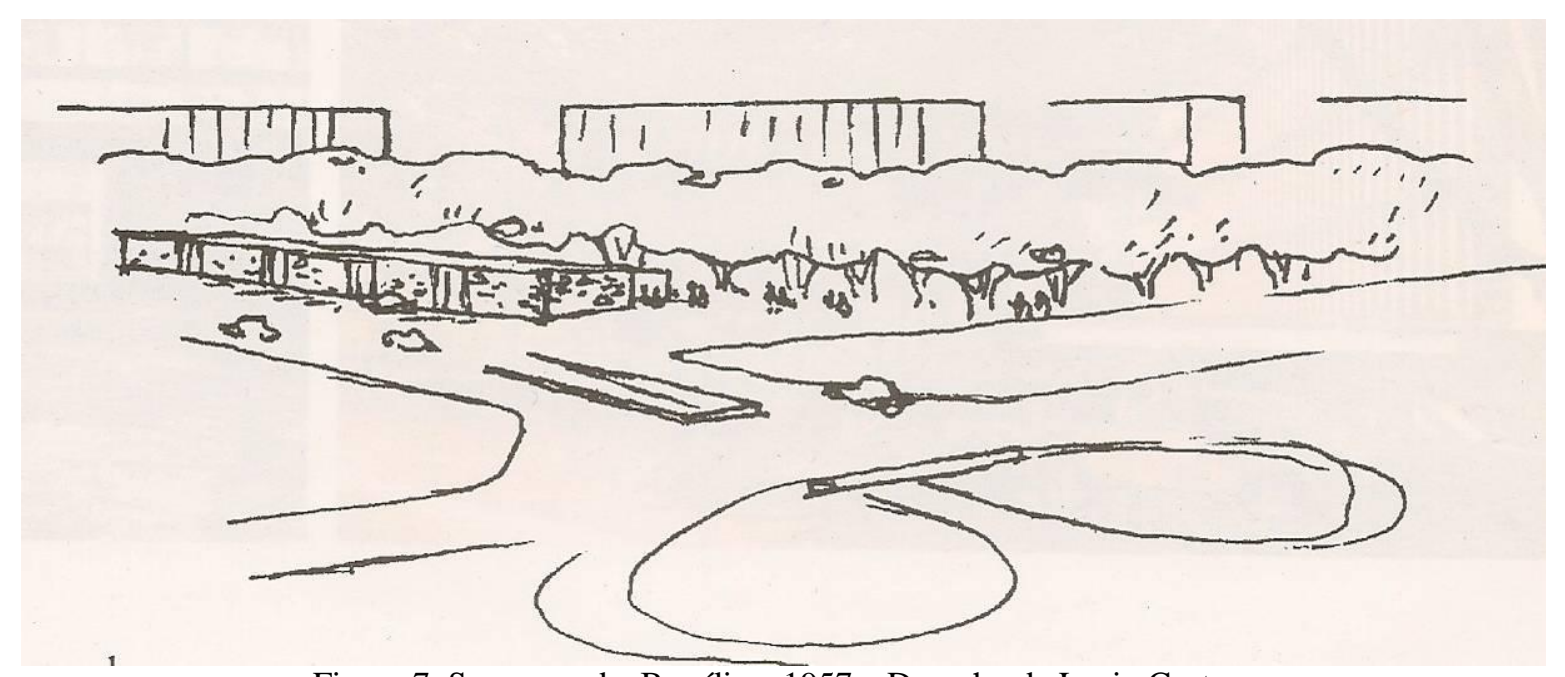

Figura 7. Superquarda. Brasília - 1957 - Desenho de Lucio Costa.

Para ele próprio, nada disso era uma coisa nova, trilhava o já sabido, e dá a dica: no gabarito das cidades européias tradicionais - antes do elevador, ele, europeu de nascimento, primeira formação e inúmeras viagens de estudos para lá, também sabedor do que uma frase dessas provoca por aqui.

Os enquadramentos vivos, fornecidos pela vegetação, já estavam no projeto para Monlevade. O gabarito já experimentado, tanto no Parque Guinle, quanto na Casa do Brasil na Cidade Universitária de Paris. Da vida cotidiana não lhe escapava nada, não só como espectador atento, que era, mas a começar da dele próprio, sempre, mais ainda, viúvo, duas filhas para cuidar.

300 x 300 m também não é algo tão arriscado assim, para um arquiteto tão experiente como Lucio, embora, até hoje, enquanto número assuste qualquer um, desavisado: resulta um quadrado útil de 260 × $260 \mathrm{~m}$, descontada a faixa dos $20 \mathrm{~m}$, em todos os lados, das áreas verdes; cada prédio do Parque Guinle tem aproximadamente 70 m na longitudinal; cabem, então, 3 prédios em linha, numa mesma direção; os das pontas já tem $20 \mathrm{~m}$ de área verde, sobram então $25 \mathrm{~m}$ no entre-prédios. Fora as outras implantações ou posições possíveis, representadas por tracinhos, em diversas posições possíveis, no seu esquema das superquadras, e apesar de ser um croquis, cada tracinho tem, aproximadamente, $70 \mathrm{~m}$, conforme pode-se verificar. ${ }^{17}$

\footnotetext{
${ }^{17}$ Ver também BRINO, A. C. Brasília: Superquadas Residenciais, in: $5^{\circ}$ SEMINÁRIO DOCOMOMO BRASIL, São Paulo: USP, v. 1, 2003.
} 


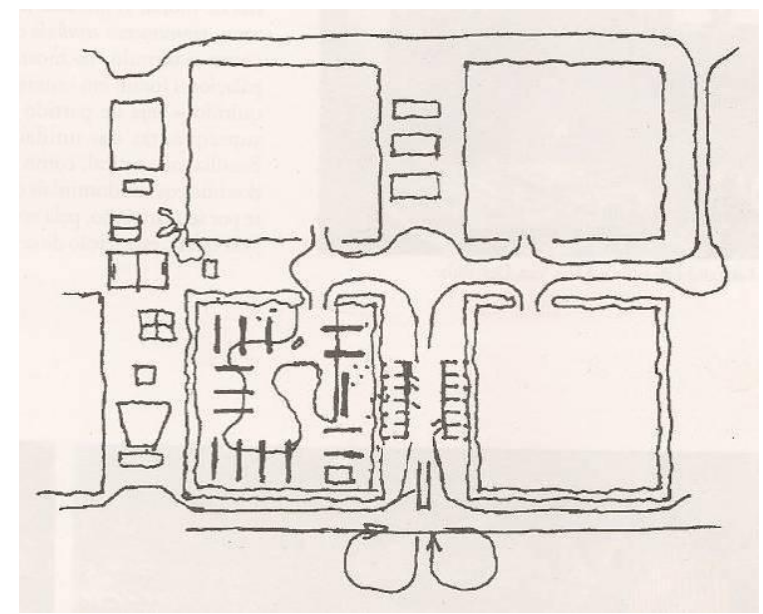

Figura 8. Superquarda Brasília - 1957 - Desenho de Lucio Costa.

Sobre o conjunto do Parque Guinle, ele já havia considerado:

Aconselhei então uma arquitetura contemporânea que se adaptasse mais ao parque do que à mansão, e que os prédios alongados, de seis andares, fossem soltos do chão e dispusessem de" loggias" em toda a extensão das fachadas, com vários tipos de quebra-sol, já que davam para o poente. Foi o primeiro conjunto de prédios construídos sobre pilotis e o prenúncio das superquadras de Brasília. ${ }^{18}$

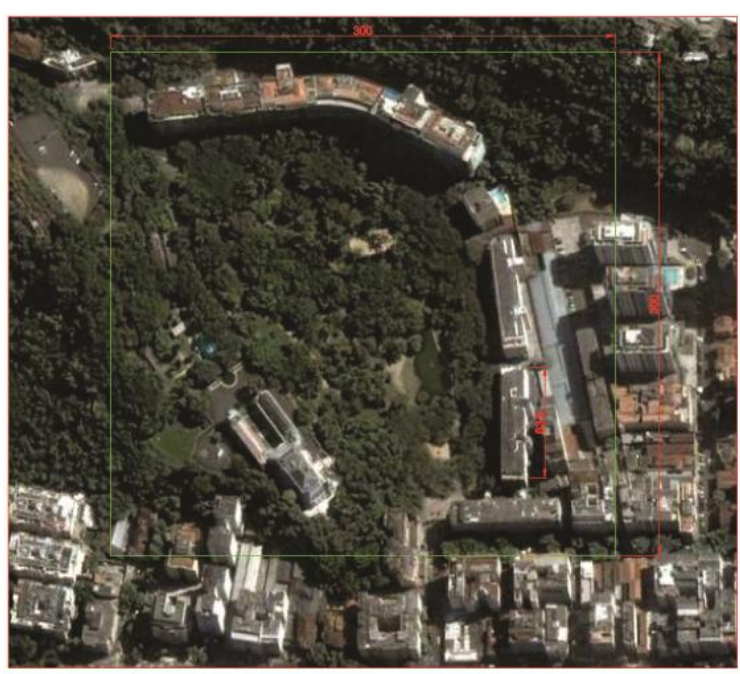

Figura 9. Parque Guinle - foto de satélite - c. 1940.

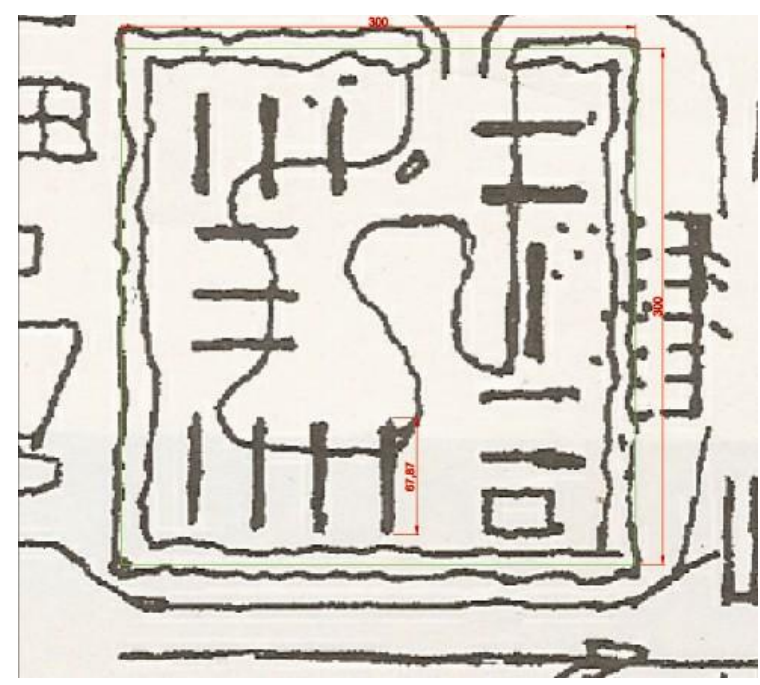

Figura 10. Superquadras de Brasília - ampliação (na mesma proporção da imagem ao lado) da figura 64.

\footnotetext{
${ }^{18}$ COSTA, L. Parque Guinle - Anos 40. in: COSTA, L. Registro de uma vivência. São Paulo: Empresa das Artes, p. 205, 1995.
} 


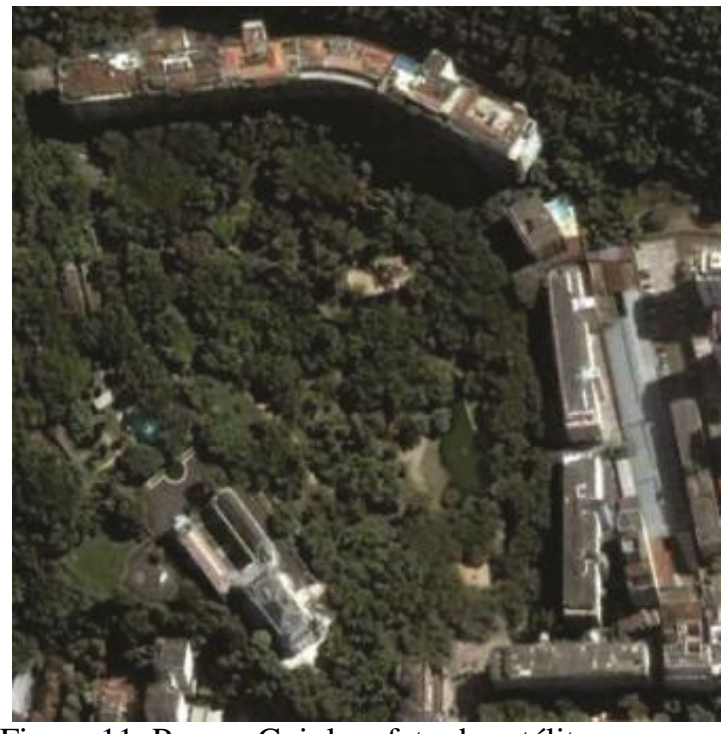

Figura 11. Parque Guinle - foto de satélite - c. 1940.

A envolvente da implantação e a Mansão.

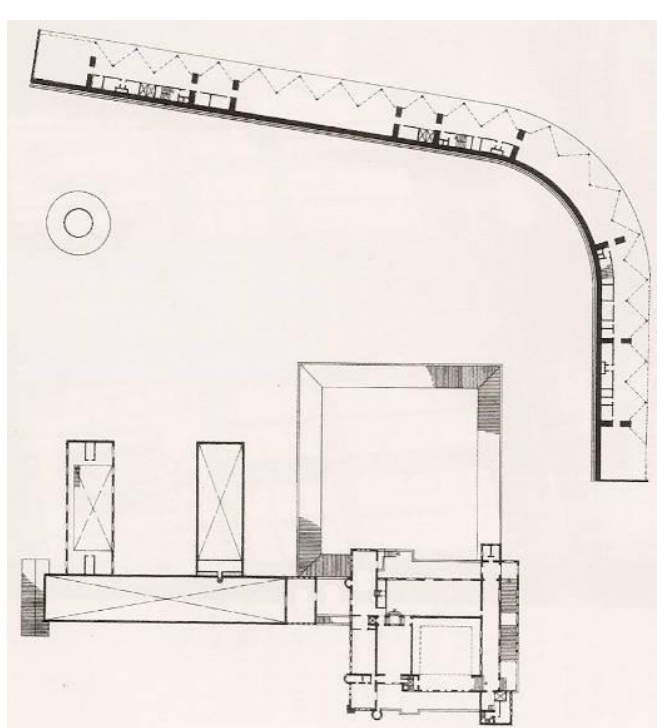

Figura 12. Planta do Palácio das Indústrias - 1990. A envolvente da implantação e o Palácio.

Como narra Sophia Telles:

Em 1958, Lucio participa de um debate sobre as cidades-capital com alguns arquitetos estrangeiros. Ao ser interrogado por Peter Smithson sobre as superquadras, Lucio tem uma resposta surpreendente: "Eu desejo ver o mínimo de casas. Desejo esquecê-las (...). A vista principal é simplesmente a avenida com as árvores em volta,(...)sente-se a intensidade arquitetônica apenas na parte central.(...)Mesmo que a área residencial se estenda por 6 quilômetros, é quase como se estivéssemos fora da cidade quando se deixa o centro". À objeção de Arthur Korn de que não se poderia esconder 500 mil pessoas (a população prevista para Brasília), Lucio responde simplesmente que essa era uma forma de anular a presença dos edifícios, cuja qualidade arquitetônica seguramente não poderia ser garantida no futuro. ${ }^{19}$

Para ele, Lucio, não é novidade, tranquilamente, faz parecer natural, tanto que declara que houve sabedoria nessa concepção, coisa que em sua costumeira modéstia - recato - não falaria nunca. Lucio tinha chamado a atenção de Oscar Niemeyer para o fato de que ele, Lucio, tinha feito a implantação das quadras habitacionais de Brasília protegidas por uma larga faixa de vegetação, e, à réplica dele, explicou que como não se poderia garantir a qualidade constante das inúmeras obras a se executar no interior dessas quadras - vale dizer que não seriam eles, Lucio e Oscar, outros do grupo mais próximo, que projetariam tudo - pelo menos através da vegetação estaria garantida a continuidade da leitura do conjunto da cidade. Há uma cautelosa percepção do outro, da existência inevitável da ação dos outros, coisa que, se contém alguma generosidade, contém também uma visão absolutamente realista. Há muita sabedoria também em contar o que poderia vir - porvir -, qualquer que ele seja.

\footnotetext{
${ }^{19}$ TELLES, S. S. Lucio Costa: Monumentalidade e intimismo, Revista Novos Estudos, São Paulo: CEBRAP, n. 25, p. 91, 1989.
} 


\section{SABER. SABER-FAZER}

Como os trabalhos nas Missões, o Ministério foi construído durante a $2^{\text {a }}$ Grande Guerra. No distante e precário país, tudo contribuía para que esse grande projeto não se consumasse. Metal era objeto de interesse estratégico militar, faltava aço para os caixilhos e brises; a indústria brasileira, incipiente e despreparada, não produzia uma série de produtos fundamentais, como por exemplo, dobradiças e maçanetas. O país nem sequer fabricava vidros planos de qualidade.

Warchavchik já padecera do mesmo mal, anteriormente. Para executar suas obras, teve que recorrer a subterfúgios para a apresentação da arquitetura moderna no país, às vezes tendo que se contentar só com a aparência do que se queria demonstrar, não conseguindo construir com a essência técnica moderna. Mas acabou por demonstrar, o que já é muito, como, disse Lucio:

\section{(...) num país ainda social e tecnologicamente subdesenvolvido foi} construído com otimismo e fé no futuro, por arquitetos moços e inexperientes, enquanto o mundo se empenhava em autoflagelação. ${ }^{1}$

As dificuldades de execução, o atraso tecnológico, a guerra, mundial, toda a sorte de empecilhos, fazem com que, nos detalhes de execução surjam preciosidades, tamanha a simplicidade e engenhosidade dos mecanismos. Há um destaque para essa simplicidade de comando dos quebra-sóis, tanto os do Ministério, quanto da Obra do Berço, de Niemeyer, já, e em close no Brazil Builds. ${ }^{2} \mathrm{O}$ comando do movimento dos brises, invenção de Le Corbusier, é por uma alavanca que move a barra articulada, basculando as paletas, tal como num tradicional vitraux.

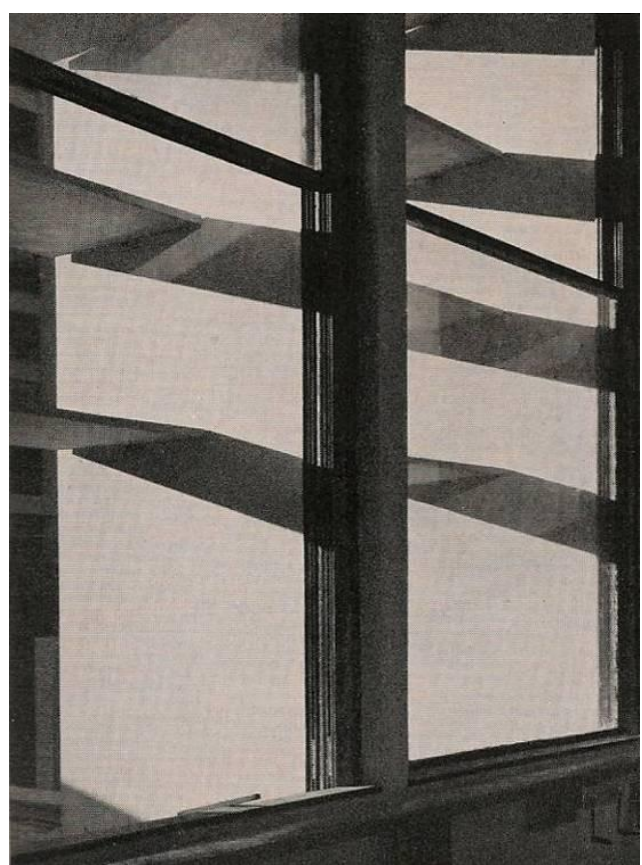

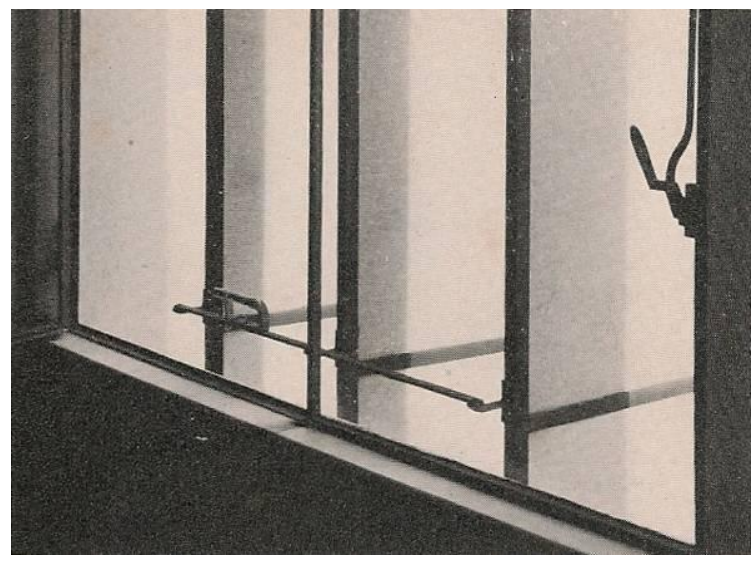

Figura 2. Brises da Obra do Berço - 1937. Detalhe construtivo simples, mas já destacado no livro Brazil Builds, publicado em 1943.

Figura 1. Brises do Ministério de Educação - 1936. Detalhe construtivo simples, mas já destacado no livro Brazil Builds, publicado em 1943.

\footnotetext{
${ }^{1}$ COSTA, L. Relato Pessoal-1975. in: COSTA, L. Registro de uma vivência. São Paulo: Empresa das Artes, p. 138, 1995.

${ }^{2}$ GOODWIN, P. L. Brazil Builds: Architecture new and old 1652-1942. New York: The Museum of Modern Art, p. 84-86, 1943.
} 
O caixilho com divisão em 3 partes do MESP - do lado dos brises a parte de baixo é substituída por peitoril em alvenaria -, com sistema de contrapeso, trecho do peitoril em folha fixa e as duas partes acima contrapesando, uma contra outra, é muito inteligente, considerando as dificuldades técnicas já descritas. Quem detalhou? Quem o detalhou, exatamente durante a $2^{\text {a }}$ Guerra Mundial, sabedor de que poderia ou não ser executado, dependendo do que era viável sob aquelas condições? Não se sabe, a equipe, numerosa, talentosa e com muita energia... todos eles. Seguramente a proporção de 3 partes foi de Lúcio, interpretação baseada em seu conhecimento filológico anterior.

Lina sempre teve enorme dificuldade com os caixilhos, sempre, não só pelas questões tecnológicas - a falta delas - como já foi dito, mas o fechar e abrir, enquanto projeto, sempre aparece em sua obra como um momento tenso. Sua própria casa, que hoje é sede do Instituto Lina Bo e Pietro Maria Bardi, sua primeira obra construída no Brasil, já tinha esse indício: faltavam tecnologia e materiais no Brasil, para executá-los. Os vidros originais, vindos da Bélgica, ainda podiam ser vistos quando da manutenção na casa, em 1992.

Vendo de perto o tamanho de cada plano de vidro, espantosos para uma residência daquela época, - e, principalmente, vendo in loco a dificuldade do seu assentamento a prumo da fachada, nos idos de 1993, quando fiz uma manutenção na casa, logo após a morte de Lina, com o professor Bardi ainda morando lá,- fica-se imaginando o que teria sido a operação em 1949. Com o terreno, lá fora, em declive abrupto, sem nenhuma possibilidade de se chegar perto com gruas ou munkes como teria sido a operação original? E no MESP? E no MASP?

Só agora, com a recente manutenção da Casa de Vidro, realizada entre 2006 e 2007, foi possível um levantamento executivo do caixilho, em suas diversas partes componentes. Mas quem detalhou? Não se sabe. Lina dizia que tinha sido a firma $\mathrm{Fichet}^{3}$, uma grande empresa que já não atua mais no Brasil, quando a conhecemos. Ela dizia também que tinha sido essa empresa a responsável pelo desenho e execução dos caixilhos telescópicos do MASP, cuja execução parou um lado da Avenida Paulista, uma operação de guerra. O resultado é assim analisado por Comas:

Embora o vidro não tivesse sido uma primeira escolha e sua transparência possa ser tomada como irrelevante, controlada por persianas internas como nas primeiras instalações do museu, o seu brilho é fundamental, transmitindo uma mensagem muito mais rica que a textura de giz antes imaginada. Adicionalmente, os montantes pouco espaçados dão ao volume uma textura corrugada que o assemelha a um container de carga. ${ }^{4}$

Que se dirá então de se ter transportado vidros de grandes tamanhos até São Miguel das Missões? Como descreveu Lúcio, uma viagem bastante penosa. Deve ter sido mais uma das operações de guerra, com as estradas péssimas, de terra, as distâncias enormes, os veículos e as comunicações precários, conseguir chegar e instalar

\footnotetext{
${ }^{3}$ FICHET \& SCHWARTZ-HAUTMONT - executou grande parte dos caixilhos de Rino Levi e vários em Brasília; depois não se tem mais notícias.

${ }^{4}$ COMAS, C. E. Três variações sobre a domesticidade e a transparência no pós-guerra. Arquitexto 8, 2006. Disponível em: < http://www.ufrgs.br/propar/publicacoes/ARQtextos/PDFs_revista_8/8_Carlos\%20 Eduardo\%20Comas.pdf $>$. Acessado em: 26 jan. 2010.
} 
os caixilhos. Já na visita em que Lucio gerou o Relatório, foi impossível ir até a sétima das reduções a visitar, São Borja, pois a estrada estava intransitável, devido às chuvas curiosamente, não se visitou exatamente a terra de Getúlio Vargas.

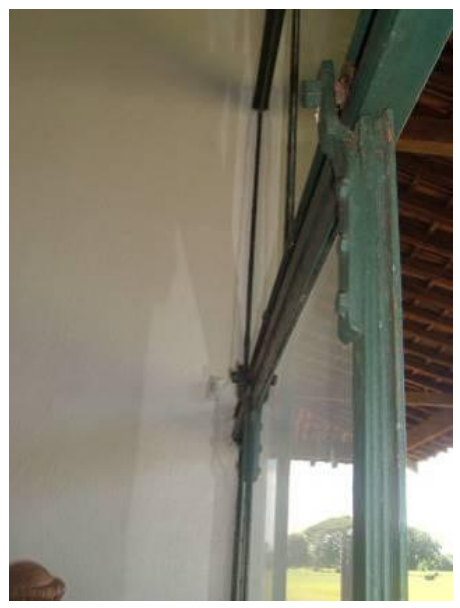

Figura 3. Caixilho do Museu das Missões, de Lucio.

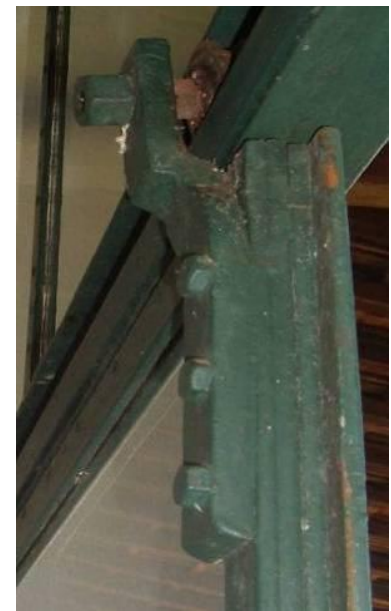

Figura 5. Detalhe do nicho-suporte do rolamento do caixilho do Museu das Missões. O rolamento corre interno ao grupo - trilho fechado.

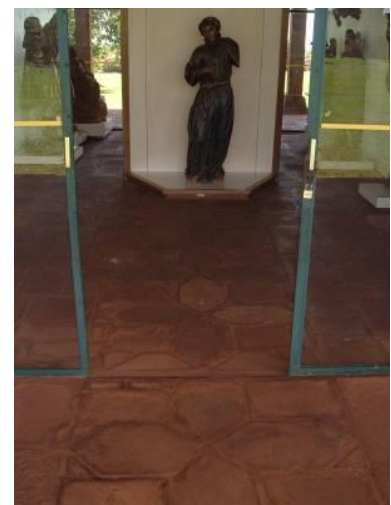

Figura 7. Detalhe do trilho-guia junto ao piso, do Museu das Missões.

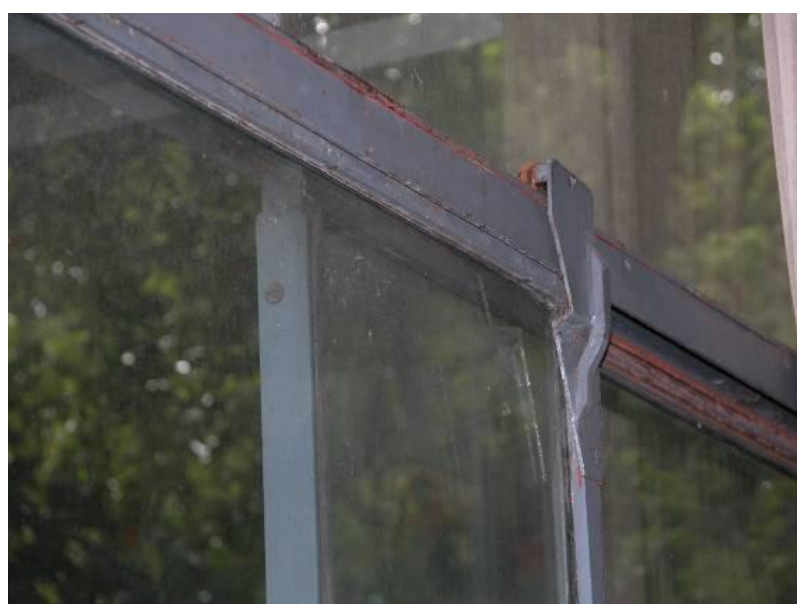

Figura 4. Caixilho da Casa de Vidro, de Lina.

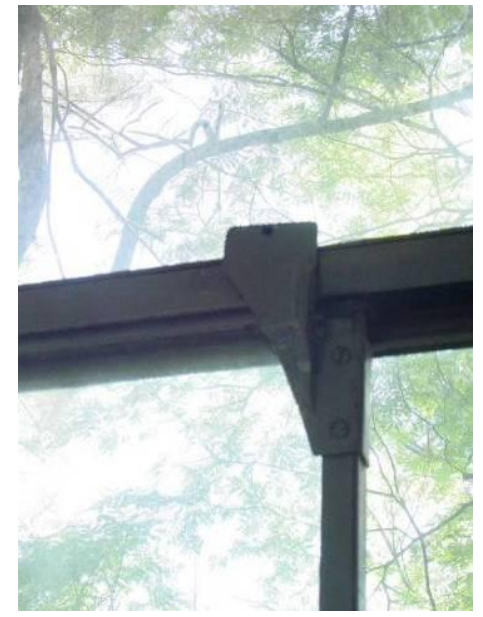

Figura 6. Detalhe do nicho-suporte do rolamento do caixilho da Casa de Vidro. O rolamento corre sobreposto ao grupo - trilho aberto.

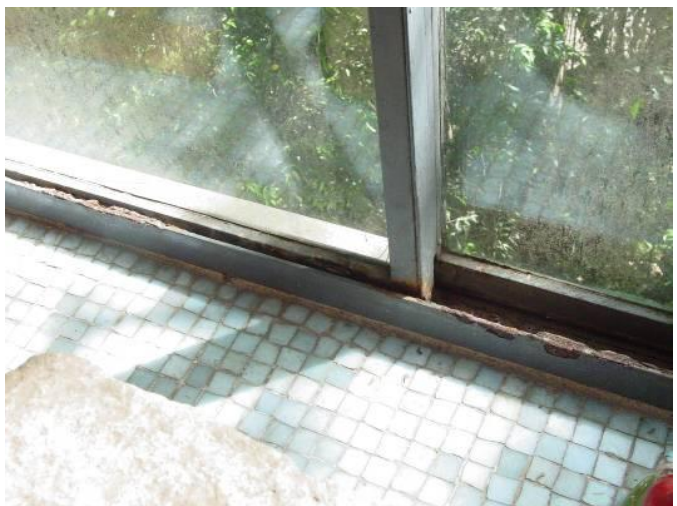

Figura 8. Detalhe do trilho-guia junto ao piso da Casa de Vidro. 


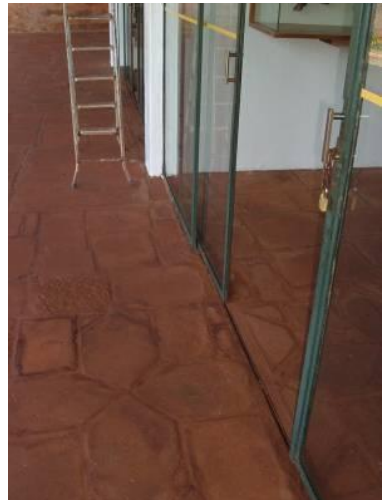

Figura 9. Detalhe trilho-guia do Museu das Missões.

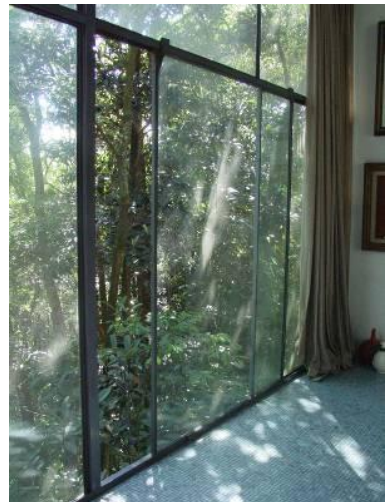

Figura 10. Vista do caixilho da Casa de Vidro, semiaberto.

É sabida também a importância do atellier Jean Prouvé, na execução dos detalhes artesanais, ainda faltantes na indústria, tanto para as difíceis peças móveis ou articuladas da construção civil, quanto para a execução de mobiliário. ${ }^{5}$ Esse papel ainda é necessário até hoje, da pessoa do artesão-prototipista, insubstituível, também foi fundamental para o boom do design italiano a partir do final da década de 50, na pessoa de Giovanni Sacchi. ${ }^{6}$

Tanto Lina quanto Lucio desenvolveram também projetos de mobiliário e equipamentos, porque era necessário, no Brasil da época. Faltava de tudo no país, principalmente objetos adequados à arquitetura moderna; o jeito era fabricar. Por iniciativa de Lina, junto com Giancarlo Palanti fundou-se o Studio de Arte Palma, na tentativa de se criar móveis fabricados de produção manufatureira (não bem industrial) ${ }^{7}$, que realmente funcionou para suprir a carência, mas com breve sobrevivência. Na Casa de Vidro e nos apartamentos do Parque Guinle, até mesmo as maçanetas foram projetos deles, respectivamente, e fabricadas especialmente, sob encomenda.

\footnotetext{
${ }^{5}$ SEGUIN, J.; NAVARRA, E. Jean Prouvé. Paris: Galeries Josse Seguin / Enrico Navarr, 1998.

${ }^{6}$ POLATO, P. Il modello nel design, la bottega di Giovanni Sacchi. Milano: Hopeli, 1991.

${ }^{7}$ BARDI, L. B. Lina Bo Bardi. Marcelo Carvalho Ferraz org. São Paulo: Instituto Lina Bo e P. M. Bardi, p. $231,1993$.
} 


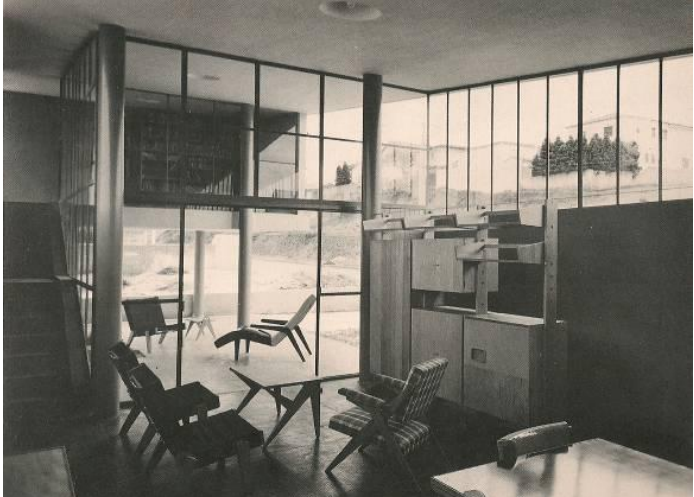

Figura 11. Cadeiras do Studio de Arte Palma (Lina e Giancarlo Palanti.) na Residência Mario Bitencourt, de Vilanova Artigas, em São Paulo.

Figura 12. Park Hotel em Nova Friburgo: parte dos móveis foi comprada no mercado, e parte deles - camas, mesas de cabeceira, escrivaninhas - desenvolvidos por Lucio.

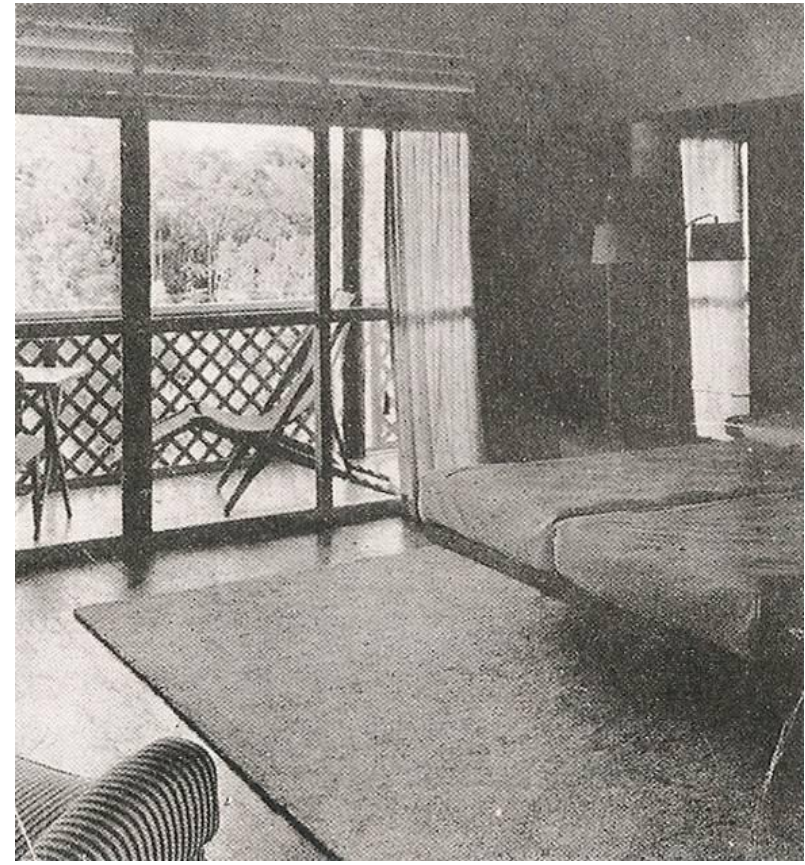

Charlotte Perriand teve uma enorme e formidável contribuição para a evolução dos projetos de mobiliário no sentido moderno, conforme disse Lucio:

As novas gerações, que receberam de mão beijada a revolução arquitetônica, já como fato consumado, não têm a menor idéia do que foi a violência da ruptura desse mobiliário com a compostura e os usos e costumes da época - ou seja, a aceitação da nova tecnologia de ambientação de interiores.

Conhecemos Charlotte, no final da década de 80, graças a sua amizade com Lina, em que havia enorme admiração recíproca. Ela tinha grande amizade com Lucio, morava no Rio, quando da jornada, na qual, acompanharam o funeral de Le Corbusier. Lucio deixou registrado, na continuação do texto acima, também uma belíssima citação, ao vê-la dormindo caída em um banco qualquer de estação, cansada da viagem e inúmeras baldeações, quando tinha sido ela mesma a elegante moça, a modelo fotografada originalmente na famosa chaise-longue, de sua própria autoria. ${ }^{8}$ Ela sempre belíssima, com um sorriso luminoso e incomum, morou no Brasil do início até meados dos anos 60 .

\footnotetext{
${ }^{8}$ COSTA, L. Charlotte Perriand. in: COSTA, L. Registro de uma vivência. São Paulo: Empresa das Artes, p. $78,1995$.
} 


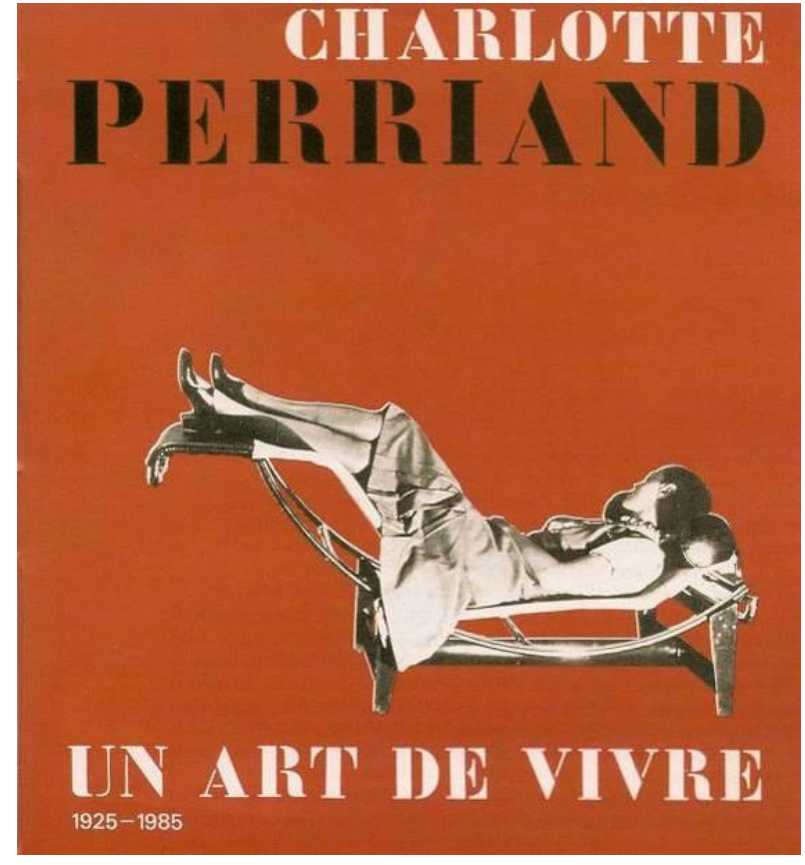

Figura 13. Capa do livro de Charlotte Perriand. Paris: Musee Des Arts Decoratifs, 1985.

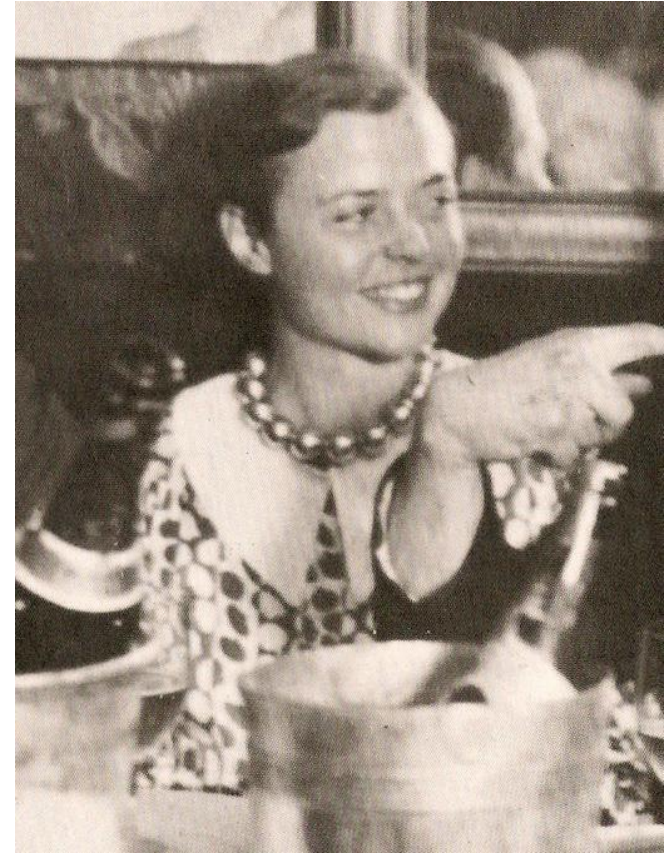

Figura 14. Charlotte Perriand. 1929.

Prouvé estava num dos lugares mais industrializado do mundo, a Europa conhecida. Os Estados Unidos vinham ali, na cola, como se diz, e em seguida, em tecnologia, ultrapassou, como vimos. Usar outra técnica, se apropriar de linguagens locais, também foram recursos dos modernos. Frank Loyd Wright vinha fazendo isso, lá dentro mesmo, dos Estados Unidos da América do Norte. Alvar Aalto foi um dos principais nomes nesse sentido, na distante Finlândia - distante e desconhecida para nós, porque os destinos principais da intelectualidade brasileira eram, com constância, a França, a Inglaterra e, em menor número os Estados Unidos da América do Norte.

Para a industrialização entrar nesse setor foi necessário o papel de designer no arquiteto, que a Bauhaus intentou, heroicamente. Lina sempre falou desse papel heróico, dessa luta do design montado pelo grupo de arquitetos e artistas de então. Como o professor Bardi esteve próximo, não é de se estranhar o quanto ela conhecia dessas investidas. Lina sempre se reportou com o maior respeito a essa tentativa, mesmo que tenha permanecido como uma utopia: A arquitetura moderna tinha um fim: a salvação do homem através da arquitetura. O Bauhaus foi a maior experiência nesse sentido. ${ }^{9}$

Na Casa de Vidro, do lado pesado desse projeto, o lado que se assenta no chão e não está mais sobre pilotis, que corresponde aos quartos e serviços, os caixilhos mudam, eram guilhotinas com contrapeso à la ministério, com proteção de treliça de madeira, muxarabi, de correr, sobreposto ao vão pelo lado externo e não requadrado nesse vão. Há tempos não existe mais, foi substituído por venezianas metálicas, de abrir para fora, uma vez que os caixilhos guilhotinas já estavam posicionados no requadro do vão, mesmo assim, sobreposto ao vão.

\footnotetext{
${ }^{9}$ BARDI, L. B. Arquitetura e Tecnologia. in: XAVIER, A. org. Depoimento de uma geração. São Paulo: Cosac \& Naify, p. 258, 2003.
} 
Contou Marcelo Ferraz que o professor Flavio Motta, em visita ao SESC Pompéia, antes mesmo dele ser inaugurado, num teste para almoços, na "chopperia", e, enquanto ficaram lá, esperando de volta o rolle das visitas - Lina dizia: vão lá, vão vendo, achem o que quiserem, esse negócio de o arquiteto acompanhar as visitas é constrangedor, se vocês quiserem falar mal, podem falar, comigo por perto vão se calar - quando o professor Flávio voltou, disse uma coisa surpreendente:

O grande problema da arquitetura sempre foi a janela, o caixilho. A vedação, só, era fácil, só o caixilho também. Inclusive na arquitetura moderna, com os panos só de vidro, cortinas de vidro, já que não tinha mais paredes, também. Difícil é um com o outro. Lina criou as paredes depois deu um murro, arrombou e pronto! (c.d.m.)

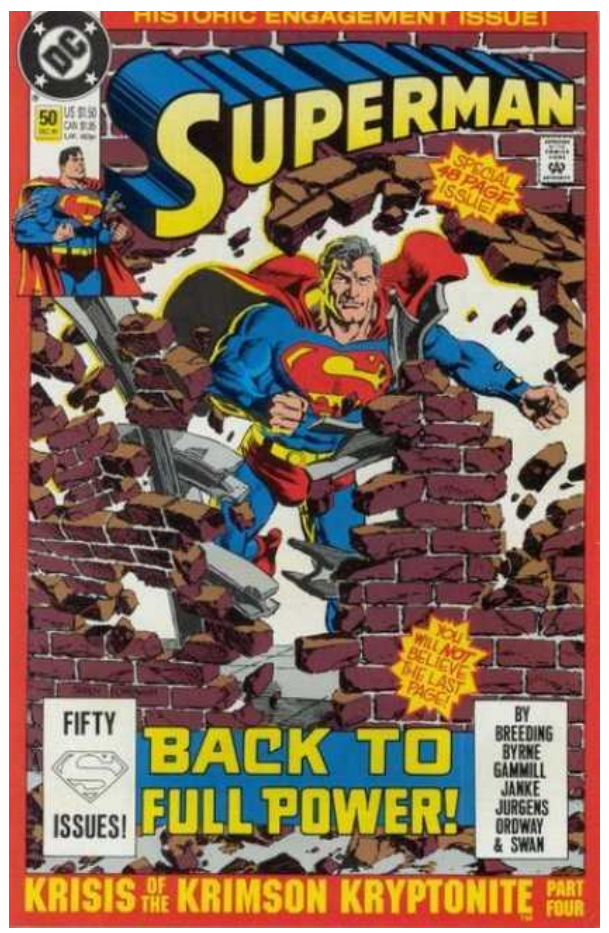

Figura 15. Capa de história em quadrinhos SUPERMAN, com a clássica imagem do herói rompendo paredes; supõe-se que não há aberturas - nem entradas, nem saídas, e ele resolve com um soco.

Causou uma surpresa enorme, recém-formado, eu ainda não havia atentado para a grande dificuldade da relação cobrir versus abrir - dificuldade sempre citada por Sophia Silva Telles, aproximadamente assim: se se constitui o volume, é dificil de abrir; se se faz o plano da cobertura é difícil fechar. (c.d.m.)

Para aquele uso, esportivo, o rombo na parede estrutural de concreto tem amplo sentido: não se pode obter janelas contínuas horizontais sem dividir a carga do grande vão para pilares pré-estabelecidos; os pesos dos pavimentos, de grande carga, la folla saltando, sem apoios intermediários, descarregando toda essa carga, em um grande vão - 30 x $40 \mathrm{~m}$ - diretamente para o perímetro, Lina propôs paredes portantes, contínuas, sem a famosa estrutura independente da vedação. Essa colocação de Le Corbusier leva, inevitavelmente, às fachadas livres e caixilhos horizontais, que continuam seu postulado.

Os buracos são fechados no plano interno, sobrepondo um painel de muxarabi, de correr, ao vão propriamente dito, e, afora o grande tamanho e o fato de 
correr por dentro do ambiente das quadras, idênticos em tudo aos que foram substituídos na Casa de Vidro. No vídeo que acompanhou o catálogo Lina Bo Bardi, André Vainer compara os buracos com as bocas das cavernas, como algo ancestral no ser humano, reconstituído ali. $^{10}$

Para explicar o sistema corbusiano das janelas em extensão, Lucio, em 1983, faz a seguinte colocação:

Ocorrera efetivamente um milagre: em vez da fachada tradicional - onde a abertura de um vão representava uma violência à sua integridade estrutural não se tratava mais de abrir buracos nos muros de sustentação; concluído o arcabouço do prédio, a "fachada" se oferecia toda ela vazada, "aberta", livre de qualquer comprometimento estrutural (...) (aspas dele, grifos nossos: ressaltam a persistência da utilização simples da palavra milagre por Lucio e a opção de Lina de caminhar no sentido oposto da fachada livre, com os buracos). (grifos nossos)

Lucio estava justamente escrevendo sobre os 70 anos da invenção do ar condicionado, e adverte, adiante, no mesmo texto: (...) Com o correr do tempo, "mudaram-se as vontades". A divulgação e comercialização dessa abordagem arquitetônica "miesiana”, a repetição em termos nem sempre adequados desse modo de fazer virou "modismo" e, como reação natural, a prevalência da volumetria tectônica voltou a competir, ostentando as suas concentradas massas estruturais já então entrosadas com os "pans de verre", concepção esta que, na verdade, subsistiria latente tanto no chamado brutalismo de Smithson, como nas realizações da segunda fase de Le Corbusier e na arquitetura do extraordinário, conquanto tardio, Louis Kahn e ainda na dos impecáveis japoneses, isto sem falar nos novos projetos já de intenção especulativoestrutural do nosso Oscar Niemeyer. ${ }^{11}$

Mas nas famosas fachadas envidraçadas da sala da Casa de Vidro, faces Leste, Sul e Oeste, mais o miolo do vazio, tem algo peculiar, mesmo não sabendo quem foi responsável pela sua execução ou detalhamento. Comparados com os caixilhos - posteriores - instalados no Museu das Missões, em São Miguel, no Rio Grande do Sul, há que se notar a incrível semelhança entre ambos: são quase idênticos, para minha grande surpresa, quando estive em visita a São Miguel.

É corrente que, dentro de um país tecnologicamente limitado, o uso repetido de determinadas técnicas vá se generalizando, tanto pelo costume de uso, como pela disseminação - imitação - da técnica por oficinas e artesãos, o modo de fazer vai se espalhando. Como nosso vitrô basculante - vitreaux - qualquer casa no Brasil tem igual, em geral nas áreas molhadas, cozinhas e banheiros.

Também não se sabe ainda quem detalhou os caixilhos do Museu das Missões. Sabe-se que o responsável pelas obras foi Lucas Mayerhofer, e sabe-se o momento em que se tornou necessário o encaixilhamento do pequeno museu, simples abrigo. Esse encaixilhamento foi se demonstrando necessário para a proteção das peças

\footnotetext{
${ }^{10}$ Depoimento de André Vainer. in: LINA Bo Bardi. Isa G. Ferraz e Aurélio Michiles. São Paulo: Instituto Lina Bo e P. M. Bardi, 1993. VHS.

${ }^{11}$ COSTA, L. Registro de uma vivência. São Paulo: Empresa das Artes, p. 237 e 238, 1995.
} 
ali expostas da poeira e da umidade. Mas, precipitou-se por um fato singelo, mas significativo: o primeiro zelador nomeado, que passaria então a morar na casa projetada por Lucio, foi João Hugo Machado, escolhido por ter sido um herói na busca e recolhimento das peças, aquele monte de relíquias, pedaços, fragmentos e algumas peças inteiras, estiveram jogados por aí, espalhados por toda a região, na posse de aldeões, objetos de saque, depredação, re-utilização etc. Ele possuía uma carta do próprio Getúlio, e mostrava a todos como o sinal de sua autoridade.

Mas Seu João Hugo retirava as esculturas para fora do museu, para que os turistas tirassem fotos junto a elas, no gramado; recebeu uma carta de advertência diretamente de Capanema. Só não foi mandado embora por ter sido o herói do período de coleta, requisitando e confiscando peças em nome do próprio Vargas. Então, por uma anedota simples assim, encaixilhou-se o pequeno abrigo ${ }^{12}$, coisa simples para um grupo que estava detalhando a cortina de vidro do Ministério.
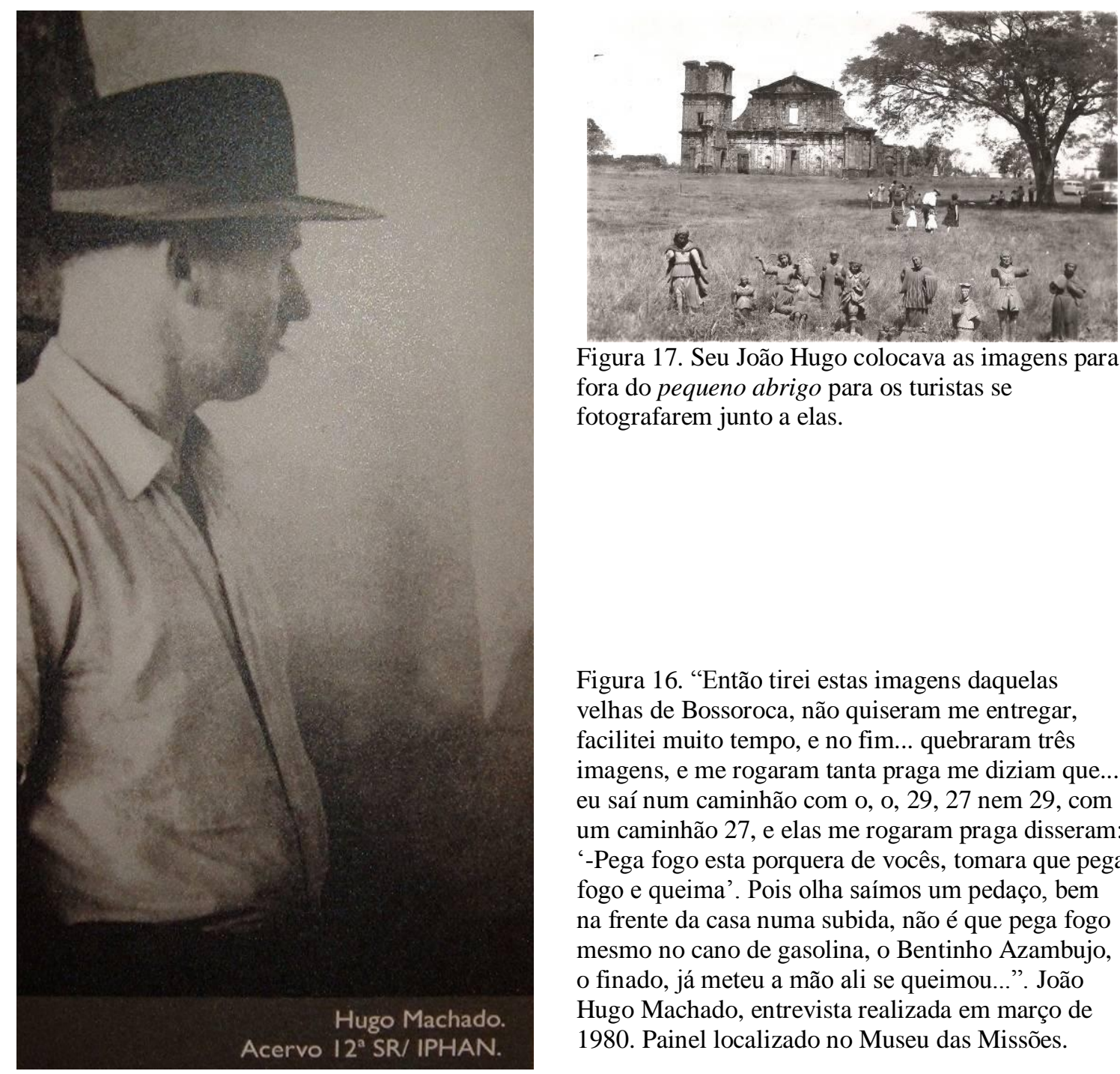

Figura 17. Seu João Hugo colocava as imagens para fora do pequeno abrigo para os turistas se fotografarem junto a elas.

Figura 16. "Então tirei estas imagens daquelas velhas de Bossoroca, não quiseram me entregar, facilitei muito tempo, e no fim... quebraram três imagens, e me rogaram tanta praga me diziam que... eu saí num caminhão com o, o, 29, 27 nem 29, com um caminhão 27, e elas me rogaram praga disseram: '-Pega fogo esta porquera de vocês, tomara que pega fogo e queima'. Pois olha saímos um pedaço, bem na frente da casa numa subida, não é que pega fogo mesmo no cano de gasolina, o Bentinho Azambujo, o finado, já meteu a mão ali se queimou...”. João Hugo Machado, entrevista realizada em março de 1980. Painel localizado no Museu das Missões.

\footnotetext{
${ }^{12}$ Expressão usada pelo próprio Lucio em seu Relatório. in: PESSOA, J. org. Lucio Costa: Documentos de trabalho. Rio de Janeiro: IPHAN, 1999. Mas aqui também tomada emprestada de COMAS, C. E. Simples abrigo, límpida ruína, modernidade real: o museu das Missões de Lucio Costa. in: $1^{\circ}$ SEMINÁRIO DOCOMOMO SUL, Porto Alegre: PROPAR / UFRGS, 2006.
} 
A solução das aberturas, buraco ou não, foi muitas vezes resolvida por eles com o uso das treliças. Já vimos Lina lançar mão do expediente, na sua própria casa e no SESC, como folhas de correr, sobrepostas ao plano da parede, por fora no primeiro caso, e por dentro no segundo. Usou também em outros casos, como na casa Cirell, e, efusivamente, nos galpões/oficinas do Solar do Unhão, cuja intenção, não concretizada, era de ser um importante centro de irradiação da cultura do Nordeste, como tentou fazer, depois, em outra escala, menor, no SESC- Fábrica da Pompéia. No SESC mesmo ela repete o fechamento do Solar no Foyer do Auditório.

Não há muitas obras com treliças no Brazil Builds, a mais visível é o Hotel de Ouro Preto, de Niemeyer, assim mesmo como fechamento de varanda, não como muxarabi propriamente dito: (...) Há outros tipos simples de quebra-luz exterior mais populares, como as rótulas coloniais usadas com felicidade no novo hotel de Ouro Preto, isto é, grades fixas de madeira ou cimento, formando proteção saliente ou não contra o sol. ${ }^{13}$

Já no Modern Architecture in Brazil, de Mindlin, aparecem em profusão, assim como os combogós. Mas neste já está publicada a Casa de Vidro, portanto Lina aprendeu o uso das treliças de outra forma, o que é indício de proximidade com o grupo carioca, sem dúvida, pois em São Paulo, seguramente em função do clima, não se utilizou tanto essa técnica. Só que ela sempre fez com as ripas na horizontal/vertical, nunca em diagonal, como na varanda do Hotel, dizia que era a maneira errada.

Lucio usa as treliças em diagonal, acentuando seu caráter de muxarabi mesmo, sacado da superfície principal da fachada, tal como usado no passado colonial - porque era um fechamento de balcão saliente -, que ele aprendeu com Diamantina, como, por exemplo, na Casa sem dono 1. Este é um belo exemplo de projeto moderno, no seu período de estilo. Usou o recurso com o mesmo domínio em ambas as linguagens. O muxarabi sacado do plano da fachada, é usado de maneira moderna desde o Pavilhão do Brasil em Nova York, de 1939, ali como combogó-brise.

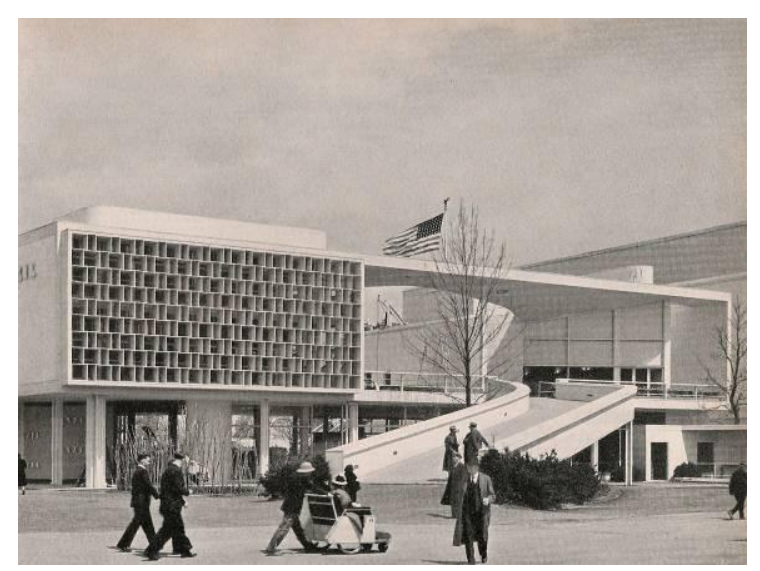

Figura 18. Pavilhão do Brasil em Nova York. 1939. O plano formado pela face vertical da laje de piso segue pelas empenas com a mesma espessura e se encontram na face vertical da laje de cobertura; o combogó é saliente em relação a esse plano, como os antigos muxarabis.

\footnotetext{
${ }^{13}$ GOODWIN, P. L. Brazil Builds: Architecture new and old 1652-1942. New York: The Museum of Modern Art, p. 87, 1943.
} 
Repetindo, em ambos os casos, não estão no plano principal da fachada nem dentro do requadro do vão. Lucio ainda inventou a veneziana de paletas móveis, acionadas por um sistema engenhosamente simples para a feitura do eixo que permite o giro da paleta e o seu comando.

O Museu de Arte de São Paulo - MASP permaneceu longo tempo com a indefinição de fechamentos das faces longitudinais, mesmo com as obras adiantadas, quase que até a véspera da inauguração, podendo ser caixilhos ou não, não se sabe, a não ser pela sequência de fotografias disponíveis nas diversas fontes, inclusive jornais de época, que permaneceu indefinida a decisão de Lina.

Adiantadas essas obras nunca foram, tanto do MESP, quanto do MASP demoraram, cada uma, uma década de duração, passaram por dificuldades e incertezas durante todo esse tempo de construção e contaram com algum milagre, dedicação e preocupações mil de seus autores e, para felicidade geral, existem. O MESP foi projetado em 1936 e inaugurado definitivamente, em 1945 - ocorreram inaugurações parciais a partir de 1942. O MASP foi projetado em 1958 e inaugurado em 1968.

Durante as obras do MESP, a partir de um certo momento, Lucio se afasta, mas como estava por ali mesmo, a vigilância foi intensa, inclusive quando teve que partir em defesa daqueles rapazes tão jovens, a fazer com dedicação e empenho suas tarefas, que ele, de pronto tinha reconhecido a competência:

Éramos todos ainda moços e inexperientes - Oscar Niemeyer, Carlos Leão, Afonso Eduardo Reidy, Jorge Moreira, Ernani Vasconcelos; o mais velho e já vivido profissionalmente era eu (34 anos!). Entretanto agimos como donos da obra, construída sem a interferência de um empreiteiro geral, pela própria Divisão de Obras do ministério, chefiada então por Souza Aguiar, e tivemos como técnico principal para as instalações Carlos Ströebel. Foi uma experiência difícil, tanto mais que a concepção arquitetônica do prédio era tida pela crítica e opinião como exótica, imprópria para a ambientação local, além de "absurda" por deixar o térreo em grande parte vazado. Aliás, o próprio Auguste Perret, de passagem aqui, menosprezou, na presença do ministro, o risco original de Le Corbusier, declarando que o edifício estaria dentro de pouco tempo sujo "devido à falta de cornijas" -, mas apesar desse sombrio prognóstico as suas belas empenas continuam impecavelmente limpas. ${ }^{14}$

Perret, arquiteto cuja qualidade até mesmo Le Corbusier elogiava ${ }^{15}$, estava enganado: ele ainda considerava a necessidade de se usar o coroamento do edifício, marcado no nível da platibanda, com destaque ou saliência sob a qual se constitui a cornija. O MESP não tem a platibanda diferenciada, ela segue a prumada do prisma absolutamente alinhada, constituindo tão somente o peitoril no nível do terraço. Os moços inexperientes fizeram a face superior do peitoril acentuadamente inclinada para dentro, jogando a água pluvial para o terraço - terraço-jardim -, o que impede que a sujeira acumulada escorra para o lado externo, pelas fachadas.

\footnotetext{
${ }^{14}$ COSTA, L. Relato Pessoal-1975. in: COSTA, L. Registro de uma vivência. São Paulo: Empresa das Artes, p. 136-137, 1995.

${ }^{15}$ Le Corbusier. Precisões: sobre um estado presente da arquitetura e do urbanismo. São Paulo: Cosac \& Naify, p. 99, 2004.
} 
O paralelepípedo vertical do MESP é imponente, força a visualização de seu próprio prisma, de um lado envidraçado, de outro, com os brises, faces Sul e Norte, respectivamente, geometria essa que é realçada pelo enquadramento das empenas fechadas, a Leste e Oeste. O recuo maior da face sul, aquela sem brises, defende os ambientes internos de uma visualização de vizinhança, distanciada que está dos demais edifícios do entorno, enquanto a face protegida pode ficar mais próxima desses vizinhos, sem qualquer objeção.

O fato de a outra perna ser horizontalizada contrasta e contrapõe os volumes, reforçando a imponência do prisma vertical. E bastou um pequeno deslocamento para que a empena leste não fique coincidente com a perna horizontal, deixando nítida a visualização desses dois corpos separados, conquistada graças a uma bem engendrada proposição estrutural: as colunas de uma e outra direção se entrecruzam com perfeita disposição, sem perda da modulação de intercolunio, elas, colunas, em ambos os casos são da Ordem Colossal, mantida mesmo no volume horizontal, desta vez utilizando o recurso de rematá-las - como usava Lucio - com a cobertura/terraço-jardim, saliente.

Nesse sentido diz Cavalcanti:

A produção de uma obra monumental, no caso do MES, começa na própria ocupação do prédio, criando enorme praça na acanhada estrutura urbana das "ruas-corredores" no Centro do Rio de Janeiro. Tal efeito é obtido, também, com a verticalização do prédio em 14 pavimentos e a utilização de pilotis em escala monumental, contribuição de Oscar Niemeyer, que duplica a altura estabelecida por Le Corbusier para as colunas. O bloco do auditório, portaria e salão de exposições, desse modo, atravessa por baixo da lâmina vertical, sem interceptá-la, fazendo com que o espaço entre as colunas, embaixo desse grande bloco, funcione como parte coberta do jardim público (... ${ }^{16}$

${ }^{16}$ CAVALCANTI, L. Moderno e brasileiro: a história de uma nova linguagem na arquitetura. Rio de Janeiro: Ed. Jorge Zahar, p. 56-57, 2006. 


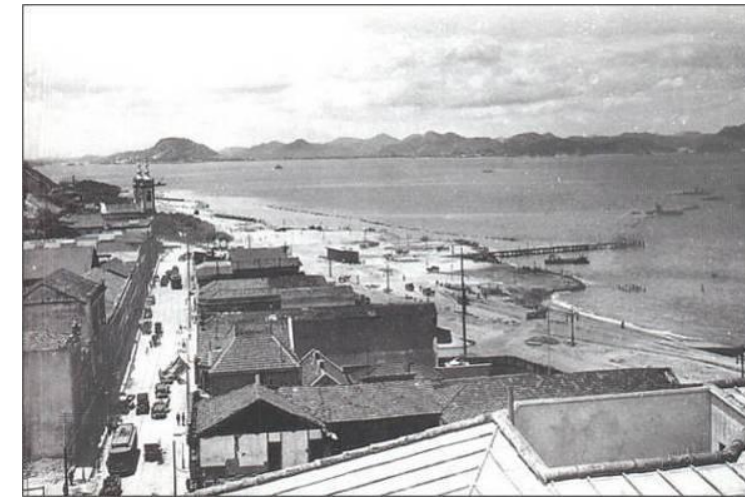

Figura 19. O mar ainda batendo à porta da Igreja de Santa Luzia, antes do aterro que vai conformar a Esplanada do Castelo, com o desmonte do morro do Castelo, nos anos 20.

Figura 20. A Igreja de Santa Luzia e atrás o prisma vertical do MESP, sem marcação de coroamento e encimado pelos volumes curvilíneos em seu ático.

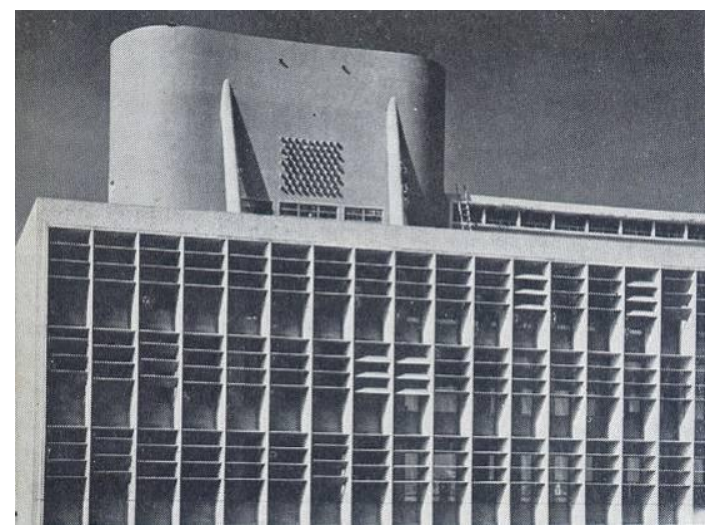

Figura 21. Volume da caixa d'água que se apóia no eixo central de pilares e, através de estroncas, na linha de pilares da fachada Norte.
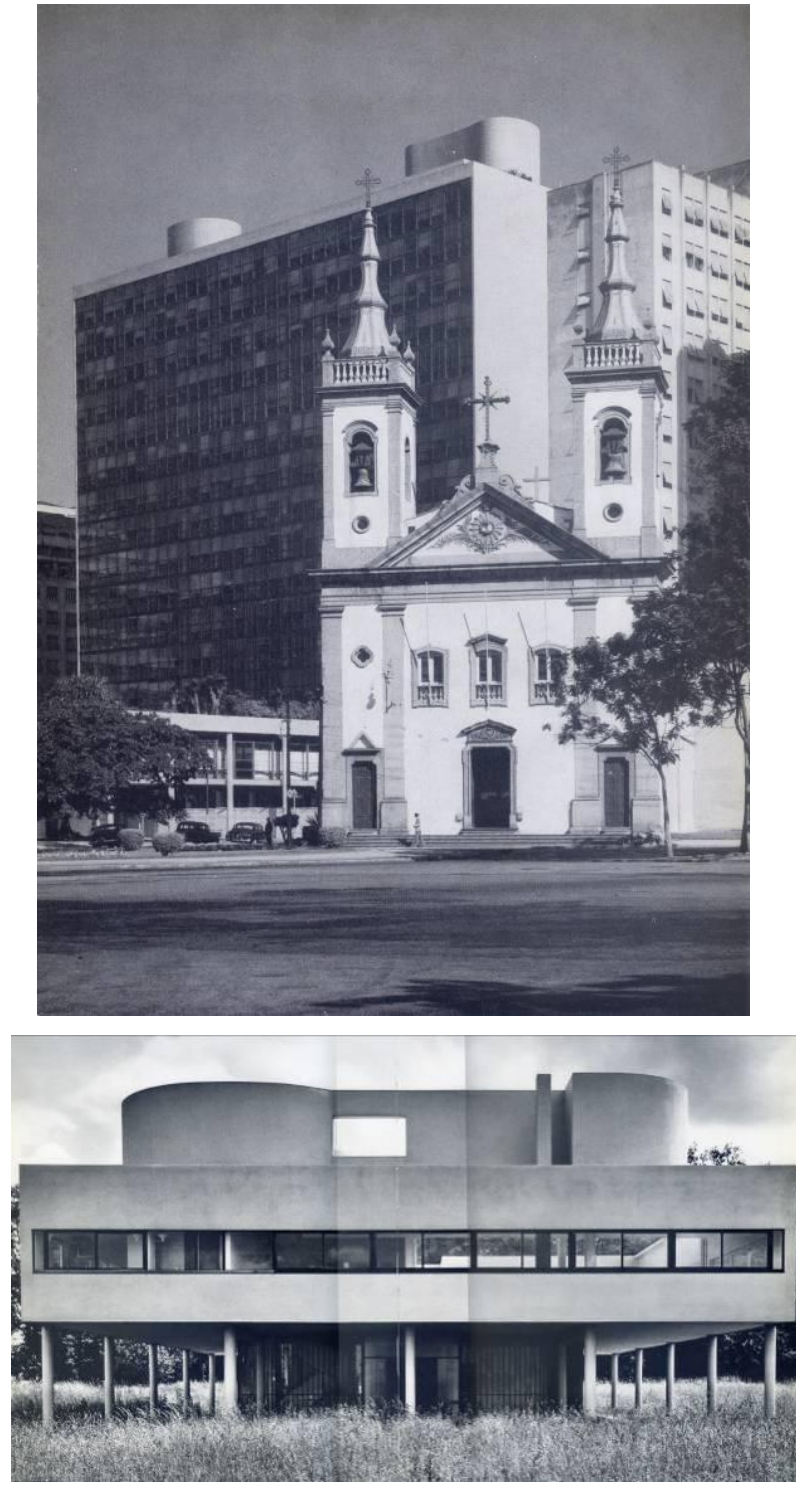

Figura 22. Ático da Villa Savoye. Le Corbusier 1928.

Muito se tem dito da implantação urbanística do conjunto do MES, que contrasta violentamente com a legislação vigente, proveniente do plano Agache. Realmente, a vizinhança dos Ministério da Fazenda e do Trabalho, - a esplanada do Castelo, pelo jeito, foi a primeira esplanada dos ministérios ..., como disse Maia Elisa (c.d.m.) - construídos simultaneamente torna o contraste não só precisamente vigoroso, como acentua a importância da nova postura. A implantação do MES, atravessada no quarteirão contra o quarteirão ocupado pelo perímetro, com centro vazio do plano Agache. E é atravessado no quarteirão nas duas direções e nos dois sentidos, de forma cruciforme assimétrica, com o transepto a um terço de cada barra.

O transepto assimétrico fornece a conexão principal entre as barras, contendo as circulações verticais principais do público e as pontas mais extremas abrigam as circulações secundárias, de serviço e de segurança. Até nisso o prédio é moderno e inovador, muito avançado para o seu tempo. 
É importante notar que essa implantação, ao contrário do precursor prédio da $\mathrm{ABI}$, dos Robertos, anterior, magnífico exemplar dessa nova arquitetura, mantém a disposição da lei advinda do plano Agache, tendo seu verso, o interior do quarteirão, o caráter de fundos, coisa que só com a presença de Corbusier se aboliu, com a implantação cruciforme a relação frente e fundos desaparece, obvia e logicamente. Parado na esquina oposta à $\mathrm{ABI}$, às 3 horas da tarde e um sol escaldante sobre o Rio de Janeiro, fiquei a admirar o jogo de luz e sombra, bem do ângulo apropriado: os brises fixos de ambas as faces trabalhando, belos ornamentos.

No MESP, as colunas se duplicam nos extremos do prisma vertical, e nessa duplicação, além de se obter o contraventamento do edifício, nos pilares internos da modulação, ocos, obtém-se shafts verticais de instalações, inclusive, e surpreendente para a época, a dutagem do ar condicionado para o gabinete do Ministro. Pilares duplos são comuns na arquitetura clássica e no eclético-classicizante, adotar o recurso, mas darlhe novo valor, adaptar a técnica para uma nova função é que foi a atitude surpreendentemente inovadora.

As colunas duplicadas são as dos extremos, mas o fato do conjunto ter, no sentido longitudinal, três eixos de colunas é que apresenta fatos complicadores: os pilares centrais caem exatamente no centro dos diversos salões do andar tipo. Com o estabelecimento de divisórias baixas, de madeira, removíveis e, com os pilares que mudam de seção e geometria, de cilíndricos nos pilotis, os pilares do eixo central viram de-seção-quadrada e, revestidos da mesma madeira das divisórias, simplesmente somem. As divisórias alinhadas pelos pilares propiciam salas maiores para esse lado; para o outro, descontado o amplo corredor central, encontram-se as salas menores.

São esses pilares centrais que no nível da cobertura estão alinhados pelos volumes livres, azuis, da cobertura, livres na face Sul, porque esses volumes jogam sua carga no prumo desse eixo. Mas na face Norte, exatamente para tirar os volumes azuis da prumada dessa fachada, a dos brises, e recuá-los, surgem estroncas diagonais, como mãos francesas, para suportar o peso da caixa d'água. As estroncas existem também no prédio da $\mathrm{ABI}$, e, em ambos, são de difícil tratamento e, para usar uma expressão do próprio Lucio, de difícil remate. As imagens das estroncas aparecem claramente na publicação Brazil Builds, talvez porque a perplexidade da arquitetura que convivia bem com a técnica e a engenharia fosse, ainda o ponto focal e que, então, era importante documentá-la.

No entanto, se nos reportarmos a Villa Savoye, o princípio corbusiano da planta livre aparece com inteira liberdade em relação ao comodulado estrutural, quando surgem volumes acima do teto-terraço, sem o recurso das estroncas. Essa obra prima passou despercebida durante muito tempo, e é importante lembrar que o que foi construído, a Villa Savoye, é a quinta (5a!!) versão estudada pelo próprio Corbusier, para o mesmo programa, e também lembrar que quando chamado para ser o principal consultor do Ministério, ele já tinha elaborado a última versão. No entanto, são esses volumes azuis, no teto do Ministério, que chamam a atenção de Lina desde sua chegada, de navio. Esse terraço, tão importante quanto o famoso terraço-jardim de BurleMarx, lá embaixo, foi feito para conter, além das casas de máquina e caixas d'água, os restaurantes de funcionários e do alto escalão, o espaço para recepções. 
Mais tarde, quando de seu relatório para impedir a construção de prédios na encosta do Outeiro da Glória, Lucio chama a atenção para essas saliências nos tetos serem pessimamente resolvidas, nos prédios que se constroem por aí, indiscriminadamente, com espessa vulgaridade, de novo utilizando sua expressão. Além de seu desenho demonstrando isso, para o próprio Outeiro, há outro, reproduzido no Sobre Arquitetura - que na edição de 2007 aparece o aviso que nem o texto nem os desenhos são dele - mostrando o efeito pretendido para o MESP. ${ }^{17}$

Para a praça, a mudança de altura dos pilotis, com pé-direito simples sob o volume horizontal e duplo sob o prisma vertical, confere mais dinamismo ainda, já presente na tensão entre cheios e vazios da ocupação cruciforme assimétrica. Essa mudança de altura confere atributos diferenciados no estar coberto na praça, quando as pessoas passam em diagonal, ou param à sombra, ou ainda quando se sentam na ligeira mureta que define o percurso cul-de-sac do embarque/desembarque do ministro.

Lúcio explica - com muita ironia, provavelmente contra críticos detratores - o uso dos pilotis:

\section{(...) Nunca se viu, em toda a história da arquitetura, semelhante}

aberração - referindo-se ao peso dos embasamentos, robustez dada artificialmente, não sendo estruturalmente necessária -. E aqueles que se insurgem contra este estado de coisas positivamente anormal são olhados com estranheza. Quanto estranhável é o exigir-se do arquiteto de hoje explicações pela extravagância de deixar o edifício apoiado sobre os seus próprios apoios naturais - tão estranhável em verdade, como reclamar-se dos arquitetos de ontem satisfações por terem ousado apoiar os edifícios deles sobre as próprias paredes. Segundo Lucio, faziam a contragosto, mas honestamente, por não terem outro remédio $(. . .)^{18}$ (grifo dele - obs. nossas)

Lina esteve, por longos períodos, na Bahia, durante a demoradíssima construção do MASP, sem abdicar do acompanhamento intenso do desenrolar dessa obra: o engenheiro Roberto Carvalho Rochlitz e a arquiteta Mayumi Watanabe de Souza Lima assistiram a isso de perto, inclusive aos impedimentos políticos que cercearam Lina, após a inauguração propriamente dita, a partir de 1968.

Certo é que, no MASP, Lina nunca quis usar brises. Pensou, propôs, projetou um museu fechado para a rua, uma caixa fechada que ela retoma no Pavilhão de Sevilha; no caso do MASP, com sheds de orientação Sul; no caso do Pavilhão, fechado definitivamente, sem qualquer luz natural. Ela não gostava de usar a expressão paredes cegas, achava muito feio se falar assim, o que é curioso para uma pessoa que se recusava - e nos proibia de usar bonito, como expressão corriqueira, ordinária nos períodos de trabalho - utilizava gracioso, um italianismo, cuja versão seria, segundo ela, gentil, que serve, que é útil.

\footnotetext{
${ }^{17}$ COSTA, L. Relato Pessoal - 1975. in: Ministério da Educação - 1936. São Paulo: Empresa das Artes, p. $62,1995$.

${ }^{18}$ COSTA, L. Cidade Universitária - 1936-37. in:. COSTA, L. Registro de uma vivência. São Paulo: Empresa das Artes, p. 177, 1995.
} 
Lina nunca usou brises, assim como também nunca usou combogó de elementos vazados, pequena exceção para o tijolo-de-galinheiro, no SESC - Fábrica da Pompéia, que já estavam lá.

Se no MASP, o fechado se tornou estruturalmente impossível, seja pelo aumento de carga dos próprios fechamentos disponíveis à época, seja pela rigidez dos materiais, que aplicados a um conjunto articulado e que se movimenta, o certo é que os caixilhos com vidros se apresentaram como a solução viável, e mais uma vez, com grandes tamanhos dos vidros, foram adotados como a solução definitiva. Os vidros estreitos e altos ajudaram, colaboraram na viabilização daquela empreitada. Os montantes principais ficam sós, na vertical, e acompanham a movimentação da estrutura, os vidros têm espaço, geometria, suficiente para sua acomodação: até hoje não houve nenhum caso de vidro quebrado nessa caixilharia do volume suspenso, graças ao ajuste telescópico em altura, do montante.

Assim como na Casa de Vidro, provavelmente são também belgas os vidros do MESP e no Museu das Missões e do MASP, pois a indústria não produzia vidros planos de qualidade no país, e muito menos em grandes dimensões. Com exceção do MASP, há que se considerar o período de Guerra quando as demais obras foram feitas e a dificuldade da importação dos produtos deve ter aumentado consideravelmente os problemas já levantados.

Todo o discurso de Lina, construído sobre o museu-sem-paredes, não nasce daí, da escolha pela fachada envidraçada, embora esse discurso seja mais vigoroso a partir dessa decisão. O museu-sem-paredes já existia na proposição do salão único da pinacoteca do último andar, a idéia reforçada pelo emprego do cavalete-de-vidro com suporte dos quadros em exposição, hoje, infelizmente, deixado de lado. 


\section{TÉCNICAS TRADICIONAIS E MODERNAS}

Tudo isso quer dizer, tanto para Lina quanto para Lucio, uma proposição muito firme de re-utilização de técnicas tradicionais ou muito antigas, sacadas de seu contexto, por já serem modernas, como se o moderno estivesse em várias coisas, em vários momentos, em vários lugares, precisando ser descobertos, assim como é difícil enxergar o óbvio, mesmo que ele ulule.

Lina explicava isso de uma maneira convincente: o Japão não precisou correr atrás para ficar moderno, já era moderno antes. Basta olhar a casa - a tradicional - deles, já era moderna. Sobre o fato de que eles não inventam, copiam melhorando e, principalmente diminuindo, dizia: eles já faziam isso ante, já faziam Bonsai. Para ela, que esteve no Japão por duas vezes, aquela sofisticada simplicidade era sofisticada demais para o Brasil, não haveria tempo suficiente para formar mão de obra capaz de fazer com aquele requinte o que faziam na construção e nos seus objetos. O mesmo dizia em relação aos índios, cuja produção está muito mais próxima do objeto de Arte, tamanha a qualidade e o requinte da sublimação no ato do seu fazer, do que de uma produção artesanal - e aqui estamos empregando sublimação no sentido freudiano, não no sentido dos historiadores de arte. Tal aconteceu quando, pela miscigenação, surge uma produção tosca, acaboclada, que aí sim, ela via meios de incorporar na produção, para o surgimento de uma nova concepção de design, para ser implantada no Brasil.

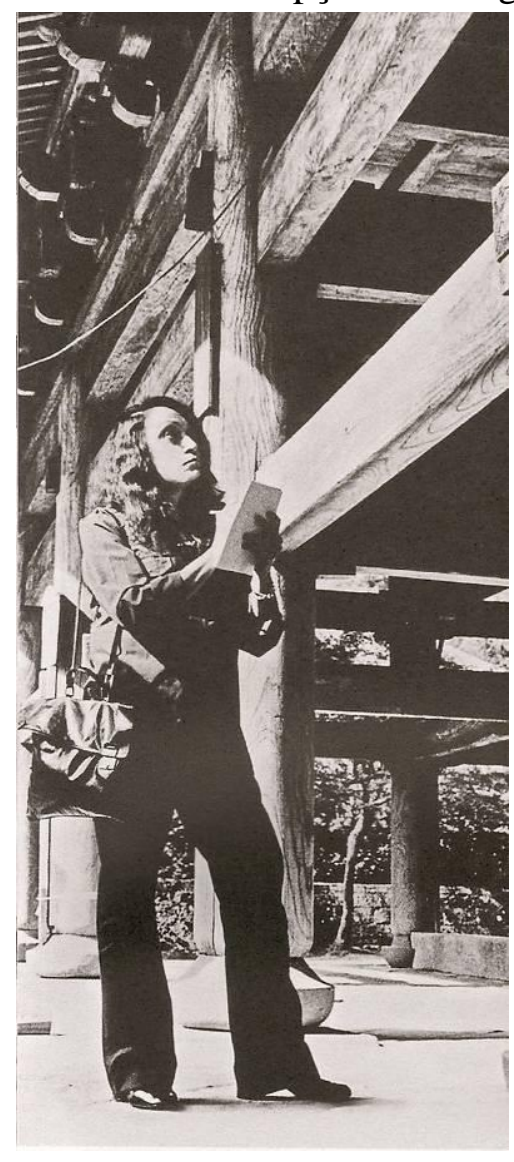

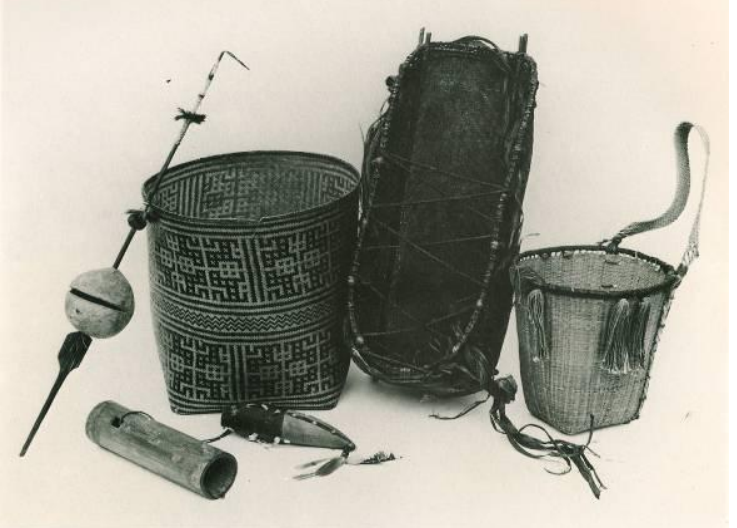

Figura 2. Objetos indígenas escolhidos por Lina, apresentados na exposição "O design no Brasil História e Realidade", de 1982. A cesta da direita tem alça desenhada para se carregar pela testa.

Figura 1. Lina em uma das viagens ao Japão faz levantamentos e desenhos em uma caderneta. Déc. 70. 
Lucio aponta um caminho possível no projeto para Monlevade, propondo a utilização do pau-a-pique, no item $\mathrm{C}$, do memorial, trecho onde está fazendo a defesa do emprego dos pilotis, para as residências:

(...) permite o emprego, acima da laje - livre, portanto, de qualquer umidade - de sistemas construtivos leves, econômicos e independentes da subestrutura, como por exemplo - sem nenhum dos inconvenientes que sempre o condenaram-aquele que todo o Brasil rural conhece: o "barro-armado" (devidamente aperfeiçoado quanto à nitidez do acabamento, graças ao emprego de madeira serrada, além da indispensável caiação); uma das particularidades mais interessantes do nosso anteprojeto é, precisamente, essa de tornar possível - graças ao emprego da técnica moderna -o aproveitamento desse primitivo processo de construir, quiçá dos mais antigos, pois já era comum no Baixo Egito, e que tem, ainda, a vantagem de simplificar extraordinariamente a armação da cobertura, aliviada pelos pés-direitos da própria estrutura das paredes internas. ${ }^{1}$

Desde seu relatório de 1937, sobre as ruínas de São Miguel Arcanjo, Lucio já demonstra seu interesse pelo jeito com que as coisas, todas, são feitas, e retorna ao tema inúmeras vezes:

Não encontramos, porém, nas peças estudadas, vestígios, senão muito vagos, de influência indígena. Aqui, ao contrário do que se observa em Voturuna, por exemplo, o tratamento mais tosco de umas tantas peças, a aspereza do desenho de certos motivos, e por vezes, a maneira especial de "ornamentar" provém, não só da falta de experiência dos "operários" e daquela "guacheria" que aproxima os bárbaros de qualquer raça quando pretendem reproduzir de "ouvido" os elementos da arquitetura greco-latina, mas, também, da colaboração de escultores do centro e do norte da Europa que não foram poucos os que vieram (6) juntamente com os italianos e espanhóis, trazendo com eles aquele renascimento retardatário e impregnado ainda de gosto gótico e até mesmo românico, que durante tanto tempo se manteve ali, lado a lado com o desenvolvimento da escola erudita e latina; provém, repito, talvez mais dessa "mistura" de procedências diversas combinadas com as deficiências do meio, do que propriamente, da influência do elemento nativo. Este, vencida a primeira fase de rebeldia, deixou-se moldar com docilidade pela vontade poderosa do jesuíta. Parece mesmo não ter havido da parte dos irmãos, cientes da superioridade de sua própria técnica, compreensão e simpatia pelo que as interpretações dos indígenas pudessem apresentar de imprevisto e pessoal, e que desprezavam como errado tudo que fugisse às receitas do formulário europeu, estimulando, pelo contrário, as cópias servis - a que, aliás, eles se entregavam de bom grado e com muito "proveito" (7) e impondo, assim, junto com a nova crença e a nova moral, uma beleza já pronta. (...)

Esse texto é impressionante, e vamos retornar a ele em seguida, mas é necessário acrescentar as observações (6) e (7), inseridas no Relatório pelo próprio Lucio:

\footnotetext{
${ }^{1}$ COSTA, L. Monlevade - 1934 - Projeto Rejeitado. in: COSTA, L. Registro de uma vivência. São Paulo: Empresa das Artes, p. 92, 1995. Aqui Lucio emprega pés-direitos para se referir aos pilaretes montantes internos ao pau-a-pique, e não à altura piso a teto; muito interessante, por preciso, o uso de nitidez para se referir ao alinhamento $=$ prumo + esquadro das paredes.
} 
(6) No ano de 1717 chegaram dois padres e quatro irmãos; não bastando este número, determinou o superior geral da companhia, o padre Francisco Retz, em uma circular às províncias alemãs que dessem de preferência admissão a leigos que fossem hábeis arquitetos e médicos; de fato chegaram sempre mais irmãos leigos, Carlos Tenchauer.

(7) Basta, por exemplo, mostrar-lhes uma cruz, um candelabro, um turíbulo, e dar-lhes a matéria de que esses objetos se fazem para que eles façam outro de tal modo semelhante, que seria dificultoso distinguir a sua obra do modelo que lhe fora apresentado, Padre Charlevoix. ${ }^{2}$

O que avulta do texto é a enorme informação de Lucio, antes mesmo de ir até as Missões. Seguramente, partiu para pesquisar informações prévias sobre aquele caso longínquo, e quase desconhecido, na fronteira Sul, do país. Embasou-se e circunstanciou a questão histórica com apuro e acuidade. Mas o que importa salientar neste trecho é que Lucio recém empossado no seu cargo no Patrimônio, e se reportando diretamente ao seu superior, Rodrigo, faz reparar na questão da mão-de-obra, no como foi feito cada coisa. Esse reparo, essa percepção vai tomar conta de grande setor de suas preocupações, o como fazer, o como fazem. De Lina também.

Le Corbusier, da mesma maneira, com o mesmo olhar, relata, em 1929:

\section{Escapou-me uma expressão no Automóvel Cube de São Paulo} quando fizeram-me ver com insistência o álbum de esculturas de um célebre índio que fez. maravilhas para os padres espanhóis. A gente acreditaria estar em Berna, Basiléia, Praga, Cracóvia etc. Este estilo jesuíta (Brillat-Savarin) que destila a clareza helênica com os tormentos da Inquisição: Afinal de contas o que é que os gregos e padres vieram fazer aqui? Estamos na terra vermelha e violenta dos índios e essa gente tinha uma alma. $(\ldots)^{3}$

Maria Elisa relata: - Se eu perguntasse como é que se faz o beiral ou o telhado etc, ele já respondia direto: "eles faziam assim", e mostrava logodesenhava - como era. ${ }^{4}$ No vídeo sobre o Outeiro da Glória, mostrando um remate do acabamento do peitoril - guarda-corpo - no final da escada, ele diz: Olha como eles faziam! Olha que graça eles fazem... (grifo nosso) - apontando para as terminações desencontradas de um peitoril plano com um corrimão inclinado, em um mesmo ponto, onde o artesão - o eles - executou uma voluta. ${ }^{5}$

\footnotetext{
${ }^{2}$ COSTA, L. Lucio Costa: Documentos de trabalho. José Pessôa org. Rio de Janeiro: IPHAN, p. 35-36, 1999.

${ }^{3}$ LE CORBUSIER. Prólogo Americano. Escrito em 1929, indo embora da América do Sul, depois de sua primeira viagem. in: Precisões: sobre um estado presente da arquitetura e do urbanismo. São Paulo: Cosac \& Naify, p. 24, 2004.

${ }^{4}$ Correspondências por e-mail com Maria Elisa Costa.

${ }^{5}$ LADEIRA da Igreja da Glória. Direção: José Reznik. Direção de Fotografia: Mário Carneiro. Disponível em: 〈http//www.casadeluciocosta.org.>. Acesso em: 22 de maio de 2007.
} 


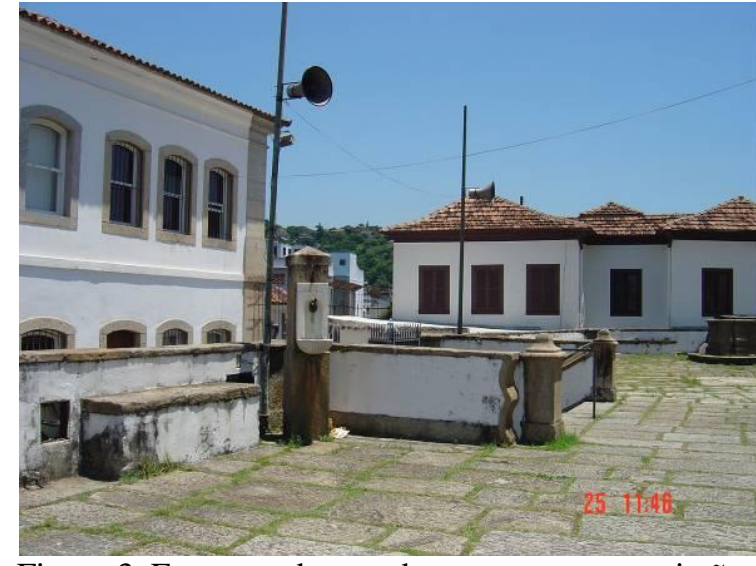

Figura 3. Encontro do guarda-corpo com o corrimão no adro da Igreja de Nossa Senhora do Outeiro da Glória.
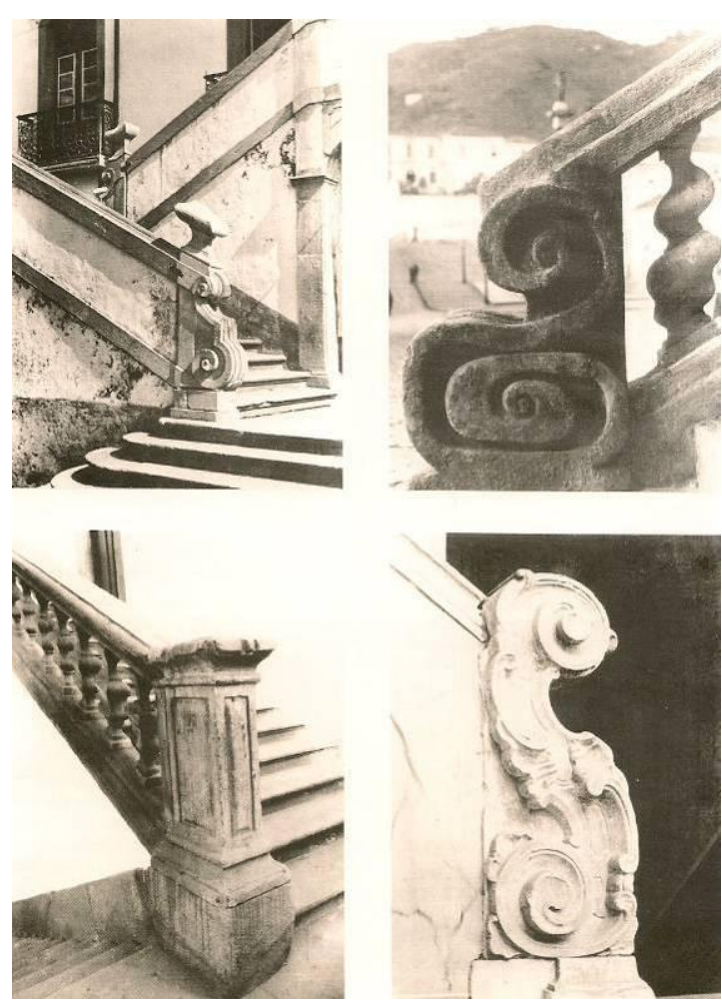

Figura 4. A graça com que eles faziam...

No trabalhos nas ruínas de São Miguel, perdurou uma dúvida por longo tempo, sem que se tivesse achado a resposta, no período: Lucas Mayerhofer procurou incessantemente o possível poço de onde proviria a água para abastecer o enorme aglomerado urbano que se tornara a redução, a mais importante de todas. Sua hipótese de que haveria um poço por ali, naquele ponto mais alto do colinado que constitui a paisagem local, sem que o abastecimento de água fosse detectado. Lucio faz um poço simples, com sarrilho, para abastecer a Casa do Zelador. Só muito depois foi encontrado uma fonte construída, a alguns quilômetros do centro das ruínas, com o chafariz esculpido com três rostos diferentes, um deles já muito destruído. As caras com traços e feições indígenas, jorram água pela boca. 


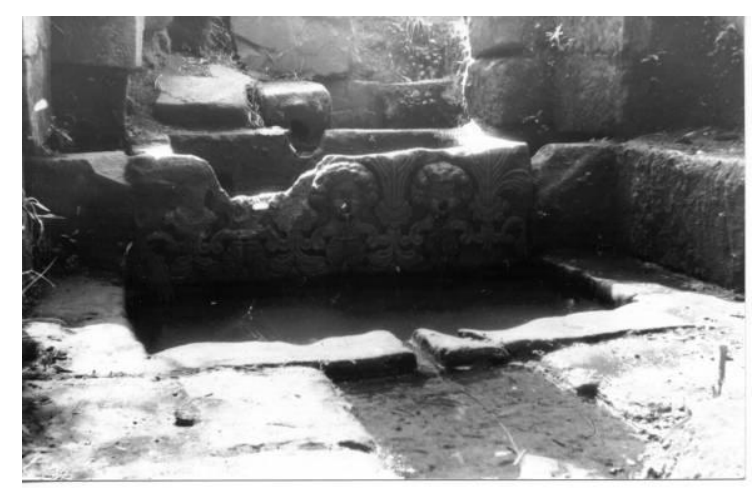

Figura 5. Fonte construída pelos índios a alguns quilômetros do centro das ruínas.

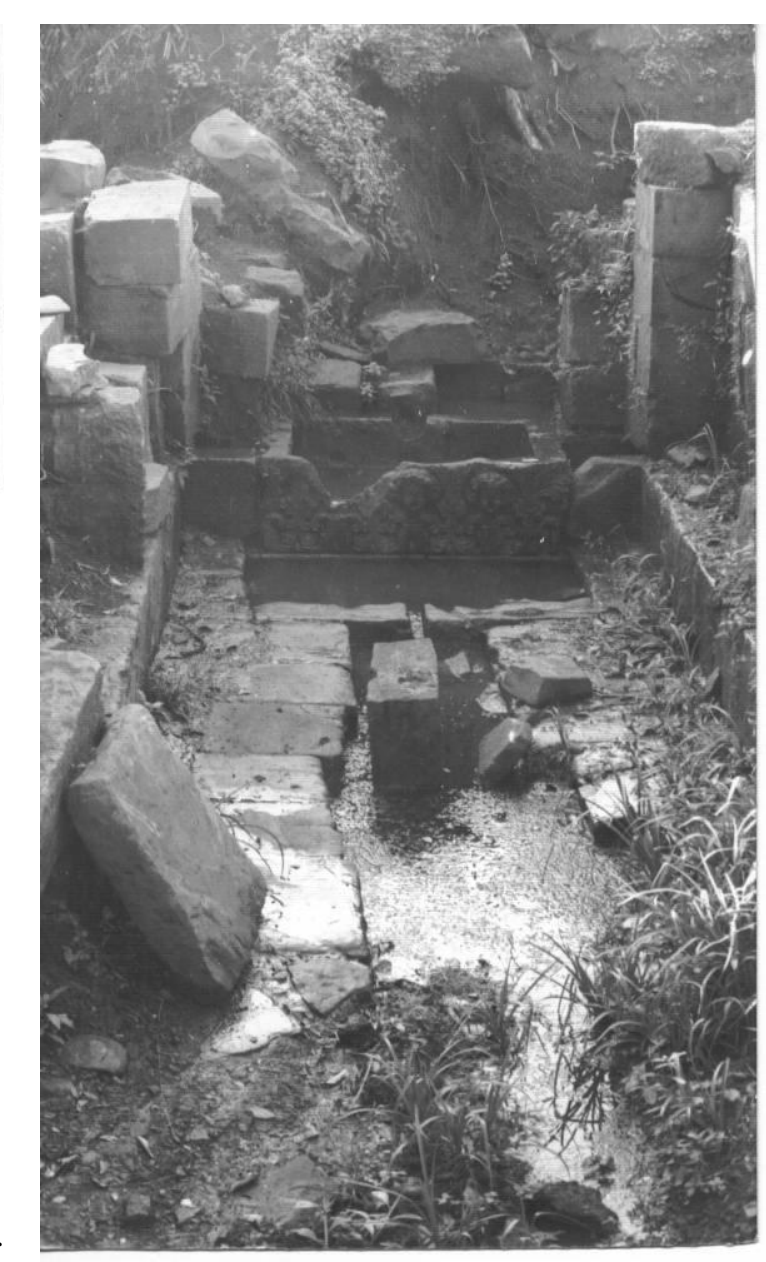

Figura 6. Idem.

Se, por um lado, é interessante imaginar quando será que o livro

Brazil Builds "caiu” nas mãos de Lina, por outro também é de se ressaltar o fato que o pequeno abrigo, como Lucio chamou, o Museu lá nas Missões Jesuíticas tem já apresentação destacada, nessa publicação, o que seguramente não passou despercebido por Lina desde o primeiro olhar dela sobre a publicação. O Ministério também está no livro, mas como já vimos, o caixilho ali é elemento fundamental, fundador, por assim dizer, do conjunto como um todo, enquanto no pequeno abrigo é um detalhe.

Ainda no Ministério, um guarda-corpo de madeira, elegante e esbelto, suspenso por montantes metálicos, serve também de shaft horizontal para instalações de eletricidade. Esse guarda-corpo mantém as pessoas afastadas do caixilho que é de piso-a-teto, coisa temerária em seu tempo; Lina contava o susto que várias pessoas tinham com a sala envidraçada, muitos não chegando nem perto dos caixilhos, temendo a sensação da vertigem; pais de crianças que freqüentaram a casa seguravam-nas pelas mãos, no centro da sala, para que elas não se aproximassem dos vidros.

Do mesmo modo que foi dito que o "com que roupa" da ascendente burguesia foi tentativa de se vestir Neoclássico, numa tentativa classicizante do Eclético, mas que se perde na citação romântica de qualquer coisa possível de citar, o movimento moderno se apresenta como postura clássica, principalmente com Le Corbusier, que, na primeira fase, além batalhar enormemente para convencer o público em geral, mas preferencialmente autoridades, de suas idéias, lutando contra o Ecletismo 
que ainda predominava mundo-afora, além do discurso brilhante e do vá escrever bem assim lá longe! - sempre acompanhados de seus maravilhosos desenhos - o quão embasado e circunstanciado estava nas suas proposições modernas. Entre outras demonstrações de domínio, apresentou a fachada na qual o conjunto e todos os elementos componentes estão dentro da Proporção Áurea - portanto comodulados que ele chamou de traços reguladores - para fazer calar qualquer erudito.

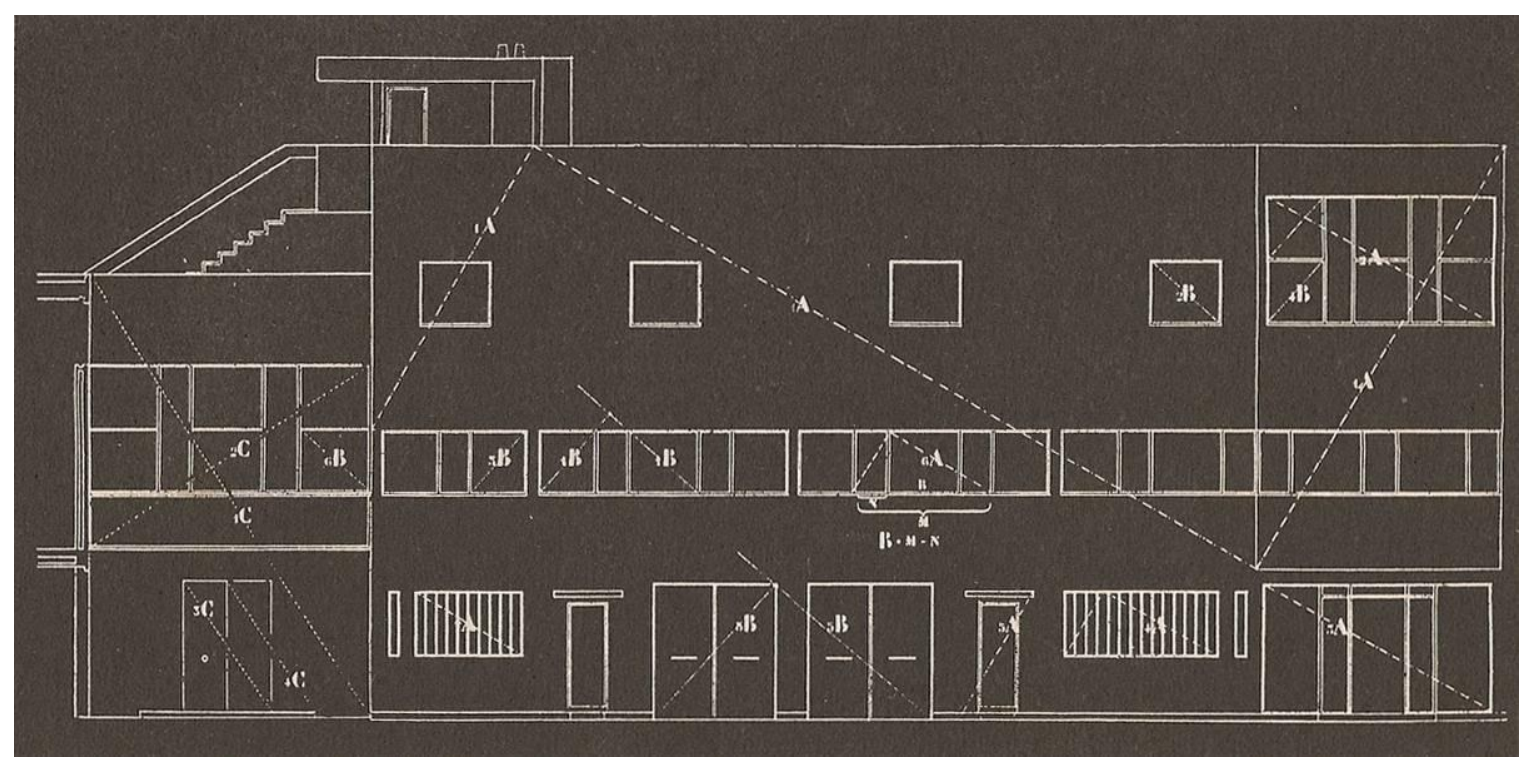

Figura 7. Le Corbusier: Maison La Roche, Paris, 1923 - os traços reguladores comodulam todos os elementos conforme a Proporção Áurea.

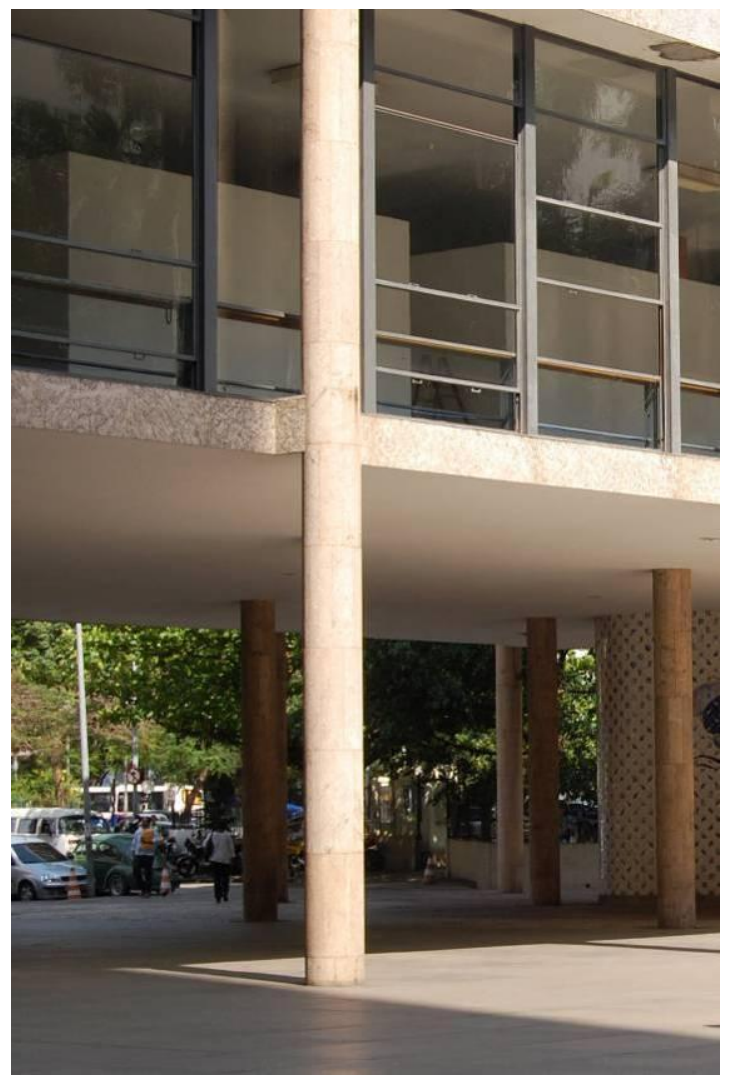

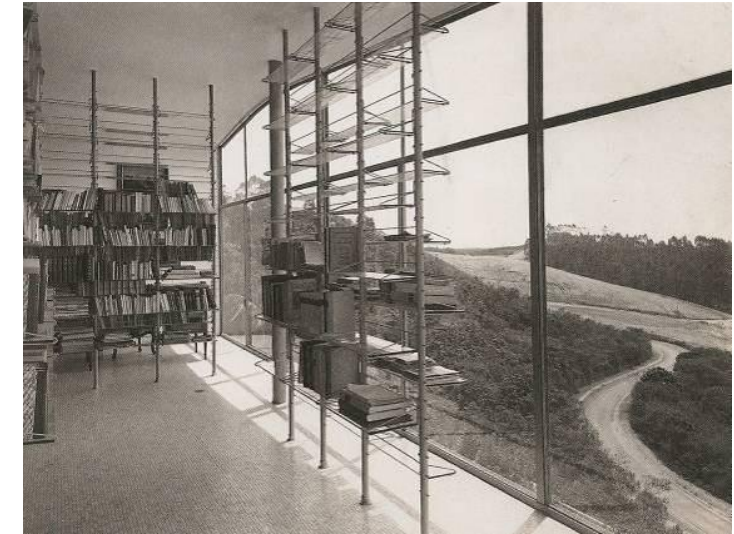

Figura 9. Caixilho da Casa de Vidro, de piso a teto. As estantes da biblioteca também eram de vidro.

Figura 8. Guarda-corpo do MESP, em madeira, com montantes verticais metálicos. 
Naquele andar do terraço-jardim, o andar do Ministro, que descrevemos, tanto na sala de espera quanto na sala principal encontram-se duas belíssimas luminárias de madeira, que remetem à imagem das pirogas, as canoas dos índios, feitas de um único tronco, esculpido. Como contou Maria Elisa, para os demais andares adotou-se um plafon, a coisa mais singela, discreta e decente disponível no mercado nacional de então. (c.d.m.) Dado o pé direito alto, o teto branco, e a disposição regular, todos esses adjetivos acabam por se concretizar, no lugar, ficando normal, como pondera Maria Elisa.

O Capanema, como os cariocas chamam o MESP, hoje rebatizado de Palácio Capanema, introduziu também a retomada da utilização dos painéis de azulejos, com desenhos de Portinari. Essa herança portuguesa dos revestimentos em azulejos, predominando o desenho em azul ultramar sobre fundo branco ou vice-versa, reaparece, incorporada na arquitetura moderna brasileira, de modo deliberado e incisivo, formando uma nova tradição.

Os azulejos eram uma tradição. Aqueles silhares enormes nas igrejas dos séculos XVII e XVIII, em toda parte, salvo em Minas. No norte, muito, principalmente no Maranhão, mas aí já no século XIX. E Porto Alegre? Eu me surpreendi quando fui às Missões para restaurar e instalar aquele museu. Eu não conhecia Porto Alegre e lá havia muitas casas forradas de azulejos, e até com muito cuidado porque encomendavam azulejos especiais, para guarnecer as pilastras, plintos $e$ platibandas. $(. . .)^{6}$

A crítica internacional, depois de um primeiro momento de elogios e admiração, passa a rejeitar diversos aspectos da arquitetura moderna brasileira, rejeição manifestada quando da presença de Max Bill, por aqui, no início dos anos 50. Entre outros comentários, grande parte feita sem maior consistência, encontra-se seu desabono quanto ao uso de pastilhas e azulejos.

(Max Bill) Acha também inúteis e prejudiciais os azulejos. Ora, o revestimento de azulejos no pavimento térreo e o sentido fluido adotado na composição dos grandes painéis têm a função muito clara de amortecer a densidade das paredes a fim de tirar-lhes qualquer impressão de suporte, pois o bloco superior não se apóia nelas, mas nas colunas. Sendo o azulejo um dos elementos tradicionais da arquitetura portuguesa que era a nossa, pareceu-nos oportuno renovar-lhe a aplicação. ${ }^{7}$

Mesmo Lina, de quem Max Bill esteve bem próximo em sua estada brasileira, disse:

\section{"Outra opinião crítica que também projetou a arquitetura} brasileira foi a de Max Bill, que, contudo, achou a nossa "arquitetura demasiadamente exibicionista e individualista, sem a devida responsabilidade social". Entre os dois pólos, é evidente que a arquitetura brasileira tem a importância notável no mundo contemporâneo. "Certas soluções leves - continuou a opinar a arquiteta Lina Bardi - que

\footnotetext{
${ }^{6}$ COSTA, L. Presença de Le Corbusier-1987. in: COSTA, L. Registro de uma vivência. São Paulo: Empresa das Artes, p. 146, 1995.

${ }^{7}$ COSTA, L. Desencontro - 1953 in: COSTA, L. Registro de uma vivência. São Paulo: Empresa das Artes, p. 146, 1995.
} 
constituem os achados da arquitetura brasileira, não se encontram em outros países. No entretanto, a pressa e a falta de reflexão explicam aquela opinião de Max Bill. " ${ }^{8}$

Então a contribuição para a formulação das superfícies azulejadas que vão se tornar tão características da arquitetura moderna brasileira, a tradição de se incorporar murais dos artistas em planos pré-estabelecidos, não pode ser alvo de críticas tão improcedentes. Por exemplo, as ondas de Paulo Werneck sobre a casca-abóboda da Capela de São Francisco de Assis, na Pampulha, é tão apropriada, tão exatamente colocada, na superfície curva da casca, $s o b$ a luz, sobre a pastilha azul celeste, que não invalida o mais do que o famoso mural de São Francisco, no tímpano posterior da Capela, de Portinari.

Sobre essa tradição, trocamos com Maria Elisa alguns e-mails, com o seguinte teor: Athos Bulcão levou a superfície mural a um ponto magnífico: a combinação, não aleatória, pré-estabelecida, de elementos, re-criam uma superfície e não fundo e figura, uma a uma. Por somatória, as precisas posições da combinação, no sentido matemático do termo, geram um plano geral, some o desenho em si, de cada peça. Além disso, Athos lança mão de um verde quase-petróleo, do certo vermelho óxido de ferro, e do tradicionalíssimo azul-ultramar, dos antigos azulejos portugueses, pigmento oriundo lá da península. Essas cores são fugidias, se afastam. São as mais distantes, o azul-ultramar principalmente, como formulou Goethe. ${ }^{9}$

Se o conjunto forma um plano, re-constitui um plano, e não uma textura, com essas cores viram plano de fundo, fundo-infinito, como se diz para os estúdios fotográficos, não ressalta o fundo/figura do seu próprio desenho, perdido na combinação.

No Brasília Palace Hotel, de Niemeyer, Athos faz isso com maestria. Mas já estava também nas conchas-conchas, cavalos-marinhos, cavalosmarinhos, do Ministério, pombas sobem, pombas descem, da Pampulha, etc. Nesses exemplos, sempre domina o navegar preciso do azul ultramar português.

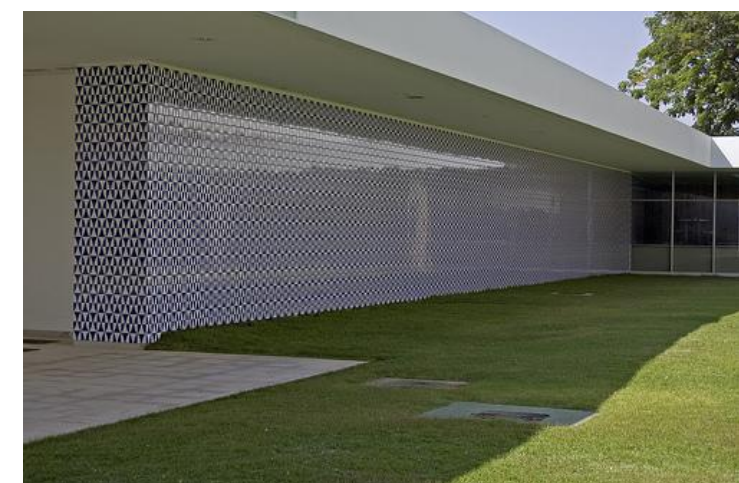

Figura 10. Painel de Athos Bulcão. Brasília Palace Hotel - 1958. O resultado é quase um "fundo infinito" dos estúdios.

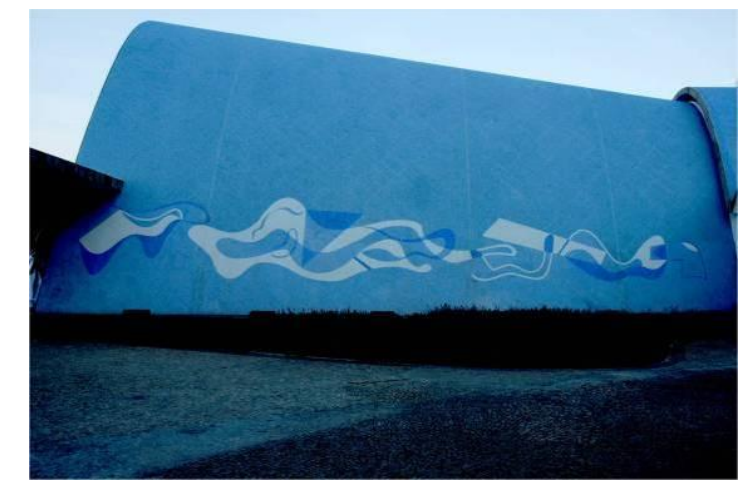

Figura 11. Mosaico sobre pastilhas azul-celeste, de Paulo Werneck, na Igreja de São Francisco de Assis, na Pampulha, em Belo Horizonte - 1943.

\footnotetext{
${ }^{8}$ Diário de Notícias, Salvador, 10 de Agosto de 1958.

${ }^{9}$ GOETHE, J. W. Doutrina das cores. São Paulo: Nova Alexandria, 1993.
} 


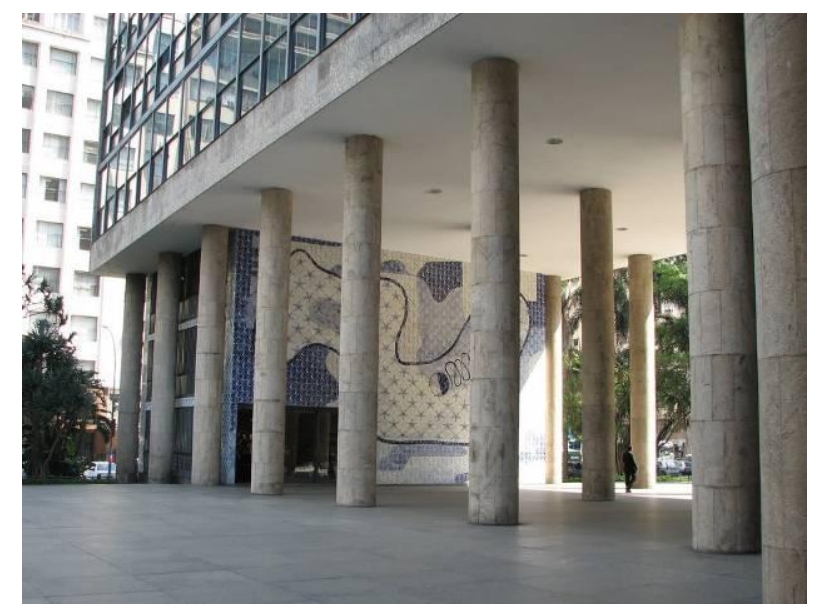

Figura 12. Painel de Portinari. MESP - 1937. Conforme Maria Elisa, o desenho, a combinação e o tom de cor escolhido neutraliza a existência da parede, como quem diz nada, como dizia Lucio.

Essa variação do padrão, dentro de um plano combinatório também se encontra no Parque Guinle, de uma outra maneira: Lucio faz uma troca, a princípio estranha, em cada requadro do combogó, do padrão do elemento vazado, quadro a quadro, no entanto requadra, re-enquadra, todos os trechos no plano geral da fachada. A mudança, que a princípio não parece lógica, recria o plano, abstraem-se as texturas. Surpreendentemente ele relembra a existência de um segundo plano, re-abrindo janelas, na proporção à antiga, nessa fachada, superfície virtual, dominam os dois planos: a superfície da fachada - a textura fica irrelevante - e o segundo plano demonstrado, seja onde falha o elemento vazado e ostenta-se uma varanda, seja pelas aberturas das surpreendentes janelas de caixilhos ausentes, retomando o assunto da dificuldade geral dos caixilhos.

Sophia Telles assim descreve esse projeto:

(...) A extensa superfície do edifício não deixa assim de ser resolvida numa operação compositiva de janelas e varandas que tende a dissolver a ambigüidade entre o interior e o exterior, sugerida pela sucessão dos panos vazados.

A solução de Lucio é evidentemente de grande qualidade plástica: a decisão de abrir "janelas" numa superfície já perfurada, adquire o valor poético de acentuar a disposição de abertura, ao mesmo tempo em que recupera o sentido de vedação da parede construída. O projeto indica uma das questões mais interessantes para a arquitetura desse período, a possibilidade de conciliar a exterioridade da planta moderna com a referência colonial, exatamente oposta, de fechar e defender a intimidade da construção.

O fato é que o uso do cobogó é radicalmente diferente do significado do brise-soleil, embora ambos estejam aparentemente cumprindo uma mesma função. O cobogó tem o caráter de elemento de justaposição, sua escala é artesanal e é uma variante das treliças, que protegem o interior das casas coloniais. Do lado externo, o efeito do rendilhado adquire o valor de uma superfície e, portando de vedação. Como é claro, o seu encanto maior se produz pela vista interior, ao difundir uma luminosidade rebaixada e íntima. De qualquer maneira, a treliça ou cobogó cumprem a função de 
fechamento do edifício, permitindo ao mesmo tempo ventilação e luminosidade onde não se deseja uma relação com o exterior. ${ }^{10}$

Uma leitura bastante parecida com a de Sophia será feita sobre o SESC - Fábrica da Pompéia, como se verá mais adiante.

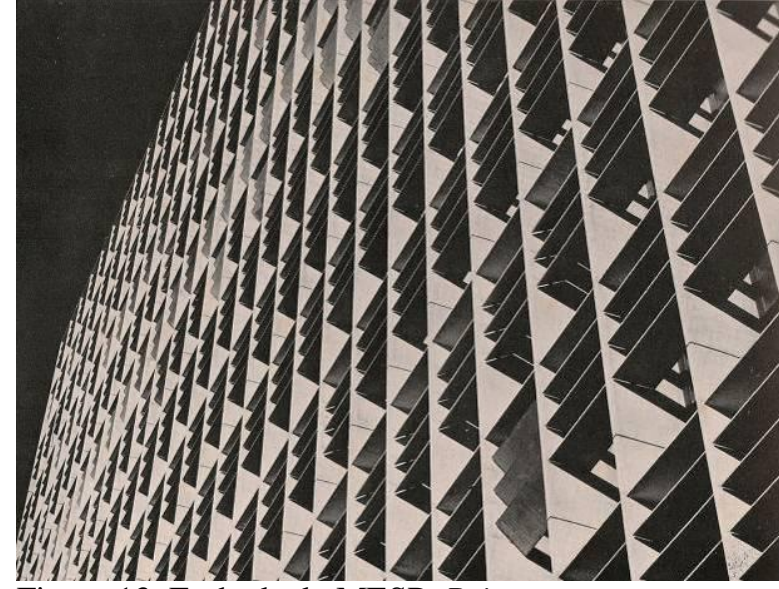

Figura 13. Fachada do MESP. Brises.

Figura 14. Fachada do Edifícios Caledônia: Combogó.

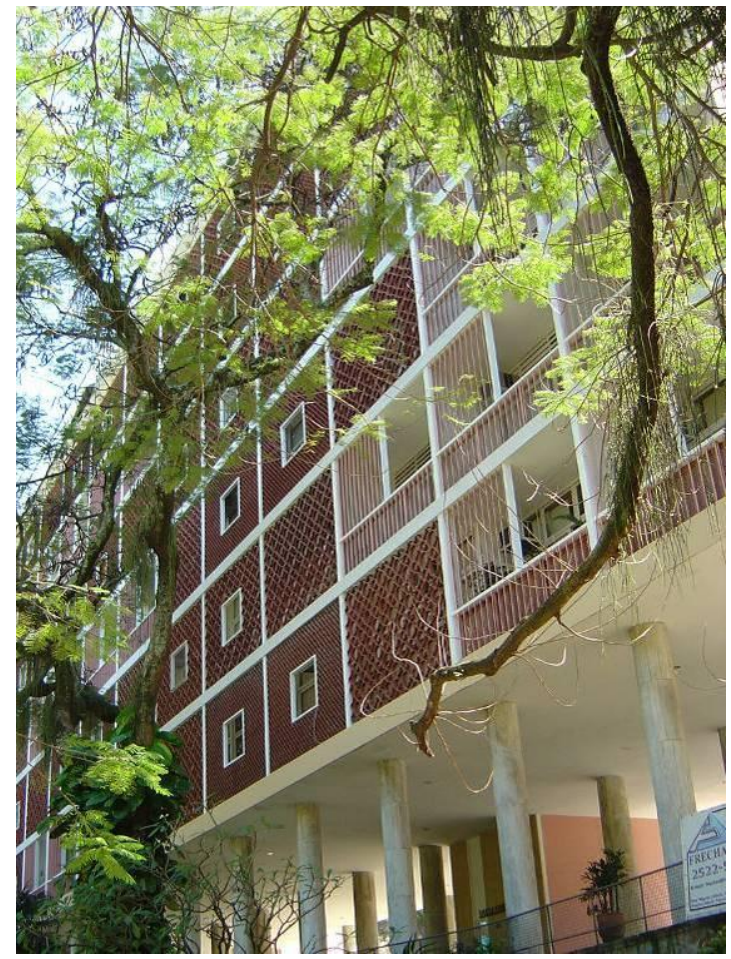

Lina tratava as superfícies de maneira mais dura, misturando os caquinhos: cacos de vidro + cacos de azulejo + pedregulhos + o que estivesse à mão), nesses casos não constituindo planos soltos, como os murais, mas conferindo mais peso ao volume construído. A casa Cirell é de 1958, a do Chame-chame, também. É pouco provável a estudada - aventada - ruptura no trajeto da própria Lina depois de sua ida à Bahia. Ela já tinha usado os caquinhos em sua própria casa, a Casa de Vidro. O mais plausível é que vinha se mantendo informada, o tempo todo, dos acontecimentos. No SESC-Fábrica da Pompéia, usa os azulejos, embora não como painéis, mas como o revestimento de planos, tanto na cozinha quanto na piscina do conjunto.

\footnotetext{
${ }^{10}$ TELLES, S. S. Lucio Costa: Monumentalidade e intimismo, Revista Novos Estudos, São Paulo: CEBRAP, n. 25, p. 85-86, 1989.
} 


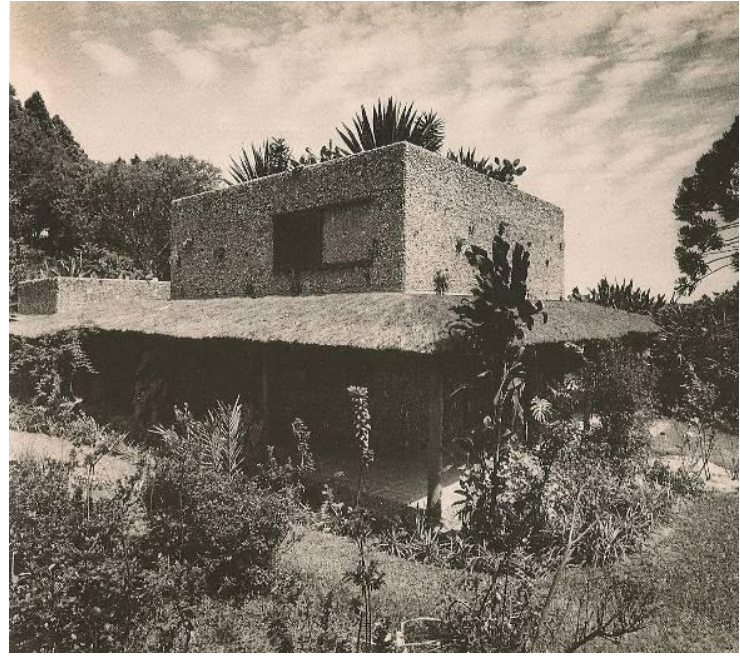

Figura 15. Casa Valéria P. Cirell, São Paulo 1958.

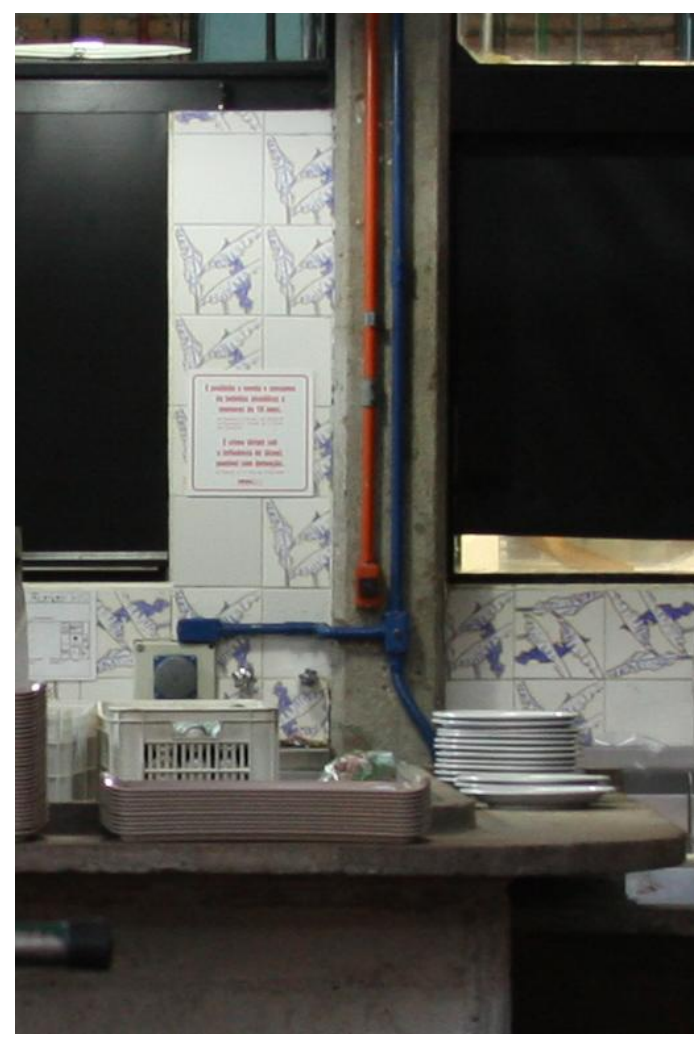

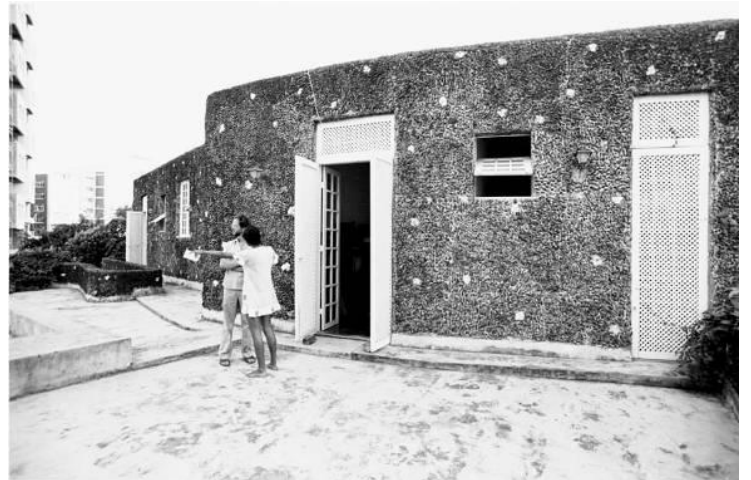

Figura 16. Casa do Chame-chame, Salvador, 1958. As superfícies são ásperas, misturam cacos de vidro, pedregulhos e cacos de azulejos, com plantas que nascem de pequenos buracos deixados para esse fim. Acentuam o peso dos volumes.

Figura 17. Azulejos bananeiras de Rubens

Gerchman. Revestimentos impermeáveis para as áreas que assim necessitam, simplesmente.

Lina vai acirrar bastante esse aspecto, posteriormente, aumentando o emprego de métodos primitivos, rudimentares, em suas obras de arquitetura e design, como uma tese para um desenvolvimento diferenciado - mais ainda - do Brasil em relação ao resto do mundo. Dizia que, infelizmente, o sofisticado requinte do trabalho indígena, de altíssima abstração estava irremediavelmente perdido, e que não se podia correr o risco de folclorizar o que sobrara. E que, como vimos, era inatingível o grau de complexidade atingida pelas civilizações orientais, particularmente o Japão, que ela conheceu de perto, e a China maoísta. Então, propunha ser necessário usar o que restara, da técnica acaboclada, lançar mão da grossura.

No filme O bandido da Luz Vermelha, de Rogério Sganzerla, de 1968, Paulo Vilaça no papel do personagem do bandido - anti-herói -, em close bem 
fechado, diz: - nesse país, para sobreviver tem que ser grosso! É a obra-prima do grupo que se auto-intitulou cinema marginal, quando Hélio Oiticica faz a obra manifesto Seja marginal, seja herói, retratando outro bandido famoso da época, o Cara-de-cavalo. 1968 é também o ano da inauguração do MASP, e no ano seguinte, no salão do primeiro andar do MASP, Lina faz A MÃO DO POVO BRASILEIRO. ${ }^{11}$

Mas, voltando aos revestimentos,

(...) a pedra-de-galho, esse granito originário no Rio de Janeiro, considerado material inferior, bem como a adoção dos azulejos à portuguesa, foram sugestões deixadas pelo próprio Corbusier, para acabamento do conjunto:

- No edifício do Ministério de Educação e Saúde, o uso dos azulejos e do granito foi sugestão dele?

L: É, foi sugestão dele. Eu pretendia usar aquele arenito Ipanema, de São Paulo. É o material da mapoteca do Itamaraty, aquele edifício neoclássico de 1930. É uma pedra cor de palha queimada. Mas ele disse, olhando o gnais dos enquadramentos antigos: "Esse granito é tão bonito, parece pele de onça. Vocês deveriam botar aí." E era uma pedra assim, meio desprezada, essa pedra-de-galho. Eo mais curioso é que os portugueses do tempo da colônia nunca o usavam, porque julgavam os outros granitos mais nobres, com maior afinidade com os granitos de Portugal. De modo que no período colonial ele só vai aparecer já no final, com Mestre Valentim, que o aplicou no portão do Passeio Público, na igreja da Cruz dos Militares e no chafariz da Praça XV. (...)

- Foi assim, então, que o granito e o azulejo foram se reintegrar na arquitetura moderna brasileira... É uma pena que o prédio do Ministério esteja contido no quarteirão onde se encontra.

L: No terreno escolhido por Le Corbusier teria sido muito melhor. Seja como for, resultou num belo projeto que ele só viu em 1962. Três anos antes de morrer, ele veio para conhecer o terreno da embaixada que o governo Frances ia confiar a ele. Só então conheceu o prédio. Do aeroporto fomos direto para lá.

- E ele falou alguma coisa?

beau". Foi engraçado... ${ }^{12}$

L: Ele ficou tocado, batendo, assim com a mão, no piloti. " $C$ 'est

Lucio sempre considerou o lado artístico da arquitetura, uma vez que há o momento subjetivo da decisão, da escolha, e que esse lado fica um instante acima do aspecto técnico, que é, naturalmente, indispensável.

Para Corbusier, como para Costa, a arquitetura se apóia necessariamente na definição racional do problema social e econômico a enfrentar, isto é, no programa e na utilização rigorosa da técnica e do cálculo. Para ambos essa é a condição necessária mas não suficiente da obra de arquitetura. Para Corbusier a arquitetura é o que está para além do cálculo, atingível apenas pela ação individual do

\footnotetext{
${ }^{11}$ SUZUKI, M. org. Tempos de grossura: o design no impasse: Lina Bo Bardi. São Paulo: Instituto Lina Bo e PM Bardi, 1994. Ver também: BARDI, L. B. Planejamento ambiental - "Desenho" no impasse. Rio de Janeiro: MALASARTES, , n. 2, dez./jan./fev. p 4 a 7. 1976.

${ }^{12}$ COSTA, L. Presença de Le Corbusier - 1987. in: COSTA, L. Registro de uma vivência. São Paulo: Empresa das Artes, p. 146-147, 1995.
} 
artista armado de "paixão e do lirismo". Para Costa, é o resultado da intervenção do "sentimento" que ordena e dota de sentido e intenção plástica o que até e então é mera construção. Mais importante: esse "além do cálculo" é "o problema da qualidade plástica e do conceito lírico e passional da obra arquitetônica, aquilo por que haverá de sobreviver no tempo quando funcionalmente não mais for útil". ${ }^{13}$ Como sempre, no entanto, a verdade não vexa: além da benção do sorriso branco - todos têm o seu bocado no colo opulento e acolhedor da babá. Ponhamos, pois, os pingos nos ii. É livre a arte; livres são os artistas - a receptividade deles é, porém, tão grande quanto a própria liberdade: apenas estoura, distante, um petardo de festim, e logo se arrepiam, tontos de emoção. Esta dupla verdade esclarece muita coisa. Assim todas as vezes que uma grande idéia acorda um povo ou, melhor ainda, parte da humanidade - senão, propriamente, a humanidade toda - os artistas, independente de qualquer coação, inconscientemente quase, e precisamente porque são artistas - captam essa vibração coletiva e a condensam naquilo que se convencionou chamar: obra de arte - seja esta de que espécie for. São antenas - embora nem sempre sejam as melhores, os que de melhor técnica dispõem. (...) ${ }^{14}$

Lina tem uma visão diferente, considerava o arquiteto um técnicosensível, desprezava o lado artístico, tinha uma visão do artífice e não do artista. Dizia: Faço o profissional e não o amador. Não sou diletante. (c.d.m.)

Mas ambos consideravam a arquitetura algo primordial, capaz de ensinar, mestres-de-vida, extrema e necessariamente humano, de muita responsabilidade advinda exatamente dessa abrangência.

Lina e Lucio eram disciplinadíssimos pensadores

transdisciplinares. (palavra empregada por Jean-Loup Herbert da École d'Architecture de Saint-Étienne, antropólogo num texto sobre Lucio - estava falando exclusivamente sobre Lucio, a referência a ambos é d. a. - trata-se da versão condensada do Registro de uma vivência em francês e que me chegou às mãos somente a cópia da tradução, feita por Maria Elisa Costa, da APRESENTAÇÃO dessa edição francesa)

(...) nos tempos modernos o arquiteto não se restringia a temas de arquitetura e urbanismo; era o profissional que se pronunciava a respeito da sociedade. Em palavras mais sociológicas, o arquiteto ocupava, então, o lugar ocupado hoje pelos economistas: a sociedade lhes dava o reconhecimento simbólico de por ela falar.

A estética era indissociável da ética, a transformação arquitetônica acompanhava o desejo de mudanças econômicas, assim como a solução formal incorporava, também, proposições sociais. ${ }^{15}$

Para Lucio, esses papéis indissociáveis do arquiteto, são assim

explicados:

\footnotetext{
${ }^{13}$ MARTINS, C. A. F. Le Corbusier e Lúcio Costa: Afinidades Eletivas. in: NOBRE, A. L.; KAMITA, J. M.; LEONÍDIO, O.; CONDURU, R. (org.). Um modo de ser moderno: Lucio Costa e a crítica contemporânea. São Paulo: Cosac \& Naify, p. 79, 2004.

${ }^{14}$ COSTA, L. Razões da Nova Arquitetura - 1934 (no CEUA está como 30, com correção de Lucio 35, na edição de 2007). in: Sobre Arquitetura. Alberto Xavier (org.). Porto Alegre: Centro de Estudantes Universitários de Arquitetura, p. 19-20, 1962.

${ }^{15}$ CAVALCANTI, L. in: COSTA, L. Com a palavra, Lucio Costa. Maria Elisa Costa org. Rio de Janeiro: Aeroplano Editora, p. 7, 2001.
} 
Assim, pois, a simples consideração de um caso particular e atual como este das "unidades de habitação" evidencia claramente a função primordial do arquiteto na sociedade contemporânea. Técnico, sociólogo e artista o arquiteto, pela natureza mesma do ofício e pelo sentido da formação profissional, é o indivíduo capaz de prever e antecipar graficamente, baseado em dados técnicos precisos, as soluções desejáveis e plasticamente válidas à vista de fatores físicos e econômico-sociais que se impõem.

Pelo que tem de técnico, deve mostrar como é praticamente possível resolver de modo verdadeiramente ideal para a totalidade da população, graças aos processos industriais da produção em massa, os problemas da habitação e da urbanização, citadina e rural.

Pelo que tem de sociólogo, cumpre-lhe demonstrar-igualmente isento de paixão ou inibição -, as causas do desajuste, os motivos da generalizada incompreensão e porque o remédio, já tecnicamente manipulado em todos os seus pormenores, ainda tarda.

Pelo que tem de artista, cabe-lhe fazer entender como os novos dados funcionais em que o problema construtivo assenta e a plástica decorrente dessa renovada integração arquitetônica, possibilitam a recuperação da beleza do pormenor, da harmonia do conjunto e do sentido urbanístico global. ${ }^{16}$

E para Lina, esses papéis são assim explicados:

O futuro do arquiteto (...) será a ciência. Mas ele deverá ser também, e sobretudo, o projetista da casa do homem, e até mesmo o mentor que, em certo momento poderia se tornar um fautor de rebeldia contra a "prisão", e perceber que muitíssimos de seus colegas, talvez inconscientemente, vão reduzindo a vida humana a uma aventura sem fantasia, alheia à natureza, num divórcio que não pode ser normal, que contradiz as necessidades orgânicas, tendendo para uma arrogância suspeita, num como que desafio às origens das quais não podemos nos esquecer.

Neste caso é que o arquiteto é artista, e intérprete, não somente de mundos vagos, mas da vida inspiradora de idéias a serem recomendadas e defendias. Sua influência poderá ser, no futuro, ainda mais essencial do que no passado e, naturalmente, diversa. Só a poesia e a música, a pintura, a escultura e a dança, em certo sentido, não mudam - embora sua expressão se apresente em cursos e recursos de crises históricas: a Arquitetura muda, sendo chamada a planificar a casa humana em lugar de edificar a Pirâmide e o Louvre. ${ }^{17}$

\footnotetext{
${ }^{16}$ COSTA, L. O arquiteto e a sociedade contemporânea. in: COSTA, L. Registro de uma vivência. São Paulo: Empresa das Artes, p.270, 1995.

${ }^{17}$ BARDI, L. B. Contribuição propedêutica ao ensino da teoria da arquitetura. São Paulo: Instituto Lina Bo e P. M. Bardi, p. 22-23, 2002. O texto é de 1957 e Pirâmide e Louvre é, hoje, uma engraçada coincidência!
} 


\section{PARTE II}





\section{MUSEU DAS MISSÕES}

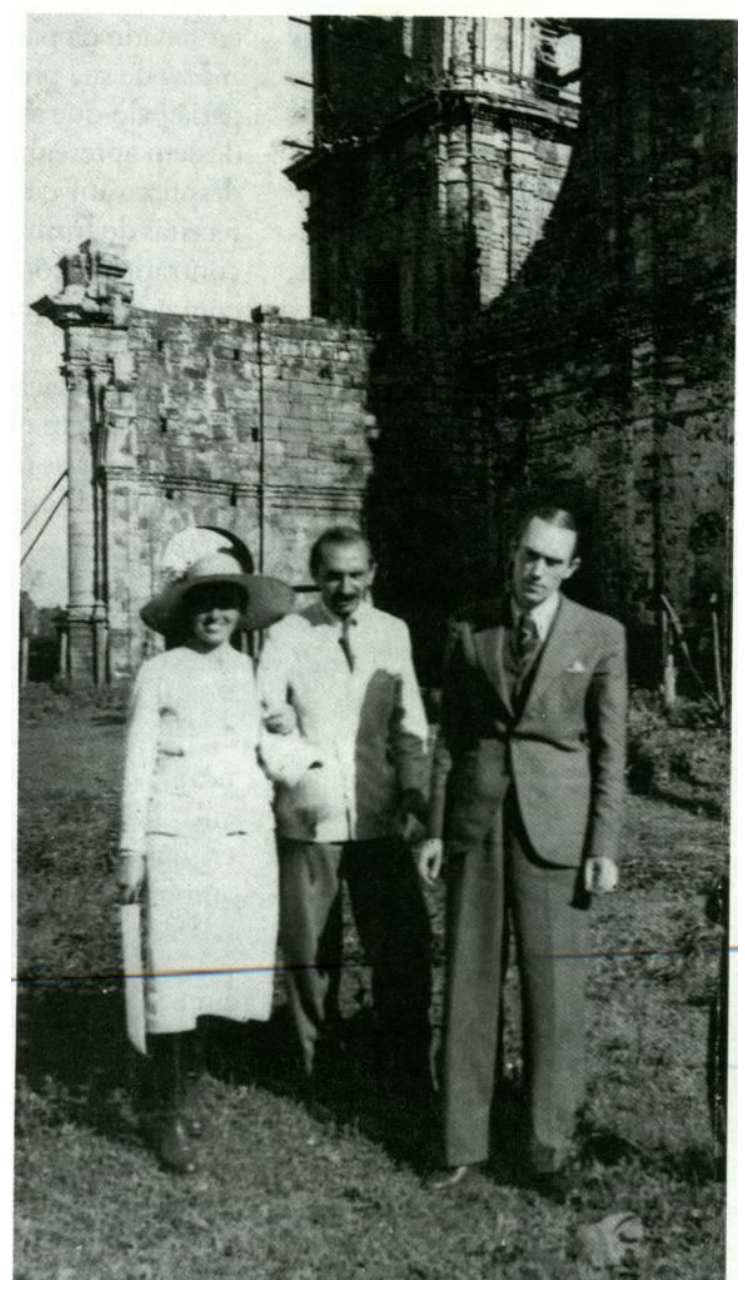

Figura 1. Leleta, Lucio Costa e Augusto Meyer 1937.

"Nomeado para dirigir o Instituto do Livro, o Sr. Augusto Meyer deixou o cargo de Assistente Técnico do Serviço do Patrimônio Histórico e Artístico Nacional da $7^{a}$ Região, sendo substituído pelo engenheiro e historiador paranaense David Antônio da Silva Carneiro, a quem coube dar andamento..." 1

O texto imediatamente acima é do arquiteto Lucas Mayerhofer, encarregado pela $7^{a}$ Região para dirigir as obras de estabilização das ruínas e cuidar das demais obras, junto com o arquiteto Paulo Thedim Barreto, em sua tese para Concurso para a Universidade Federal do Rio de Janeiro, Reconstituição do Povo de São Miguel das Missões.

\footnotetext{
${ }^{1}$ MAYERHOFER, L. Reconstituição do Povo de São Miguel das Missões. Tese de Concurso para a Universidade Federal do Rio de Janeiro. Rio de Janeiro, 1947.
} 
Paulo Thedim Barreto, por sua vez, era do quadro fixo de técnicos do Patrimônio, desde a sua criação, realizou importante levantamento das Casas de Câmara e Cadeia do período Colonial, por todo o Brasil. Ajudou Lucio nas obras de execução das rampas de acesso ao Outeiro da Glória.

O relatório e o projeto citados por Lucio Costa e principalmente o conjunto resultante são exatamente os objetos dessa pesquisa, que tentaremos aqui demonstrar, inclusive porque entre o projeto e a obra se encontram grandes lacunas de informações e falta de desenhos construtivos, e os desenhos iniciais não correspondem exatamente ao que foi construído.

Veremos, adiante, que Lucio não volta até as Missões enquanto as obras foram executadas, o que também abre uma grande brecha para novas incertezas: se as comunicações entre o São Miguel das Missões e Porto Alegre eram muito difíceis, entre Porto Alegre e o Rio de Janeiro, no mínimo atrapalhadas pela distância, - se bem que o Correio Aéreo Nacional sempre foi orgulho desse nosso país - como teria sido o processo de decisões e especificações na obra? Como teriam sido as definições entre Lucio e Lucas?

Por outro lado, enquanto se está fazendo os trabalhos nas Missões, Lucio Costa estava totalmente envolvido com o projeto do Ministério da Educação e Saúde Publica, 1936, nos projetos da Cidade Universitária e, logo em seguida com o Pavilhão do Brasil em Nova York, 1938, além das tarefas de Consultor (como ele mesmo se intitulava) da Divisão de Tombamentos do ISPHAN. Foi mesmo impossível para ele voltar lá no período, Mas, ao mesmo tempo, tem-se a noção de que Lúcio sabia atribuir e distribuir responsabilidades, por exemplo quando deixa Oscar Niemeyer em Nova York para continuar o trabalho do Pavilhão e considera que ele já estava maduro o suficiente para a empreitada.

Grandes trechos dos Relatórios, tanto da incursão de Lucio Costa, quanto da reconstituição, de Lucas Mayerhorfer, serão aqui reproduzidos e, em muitas vezes, entremeados como um diálogo, no mais das vezes em ordem invertida em relação aos textos originais, mas reconstituídos como se tivesse ocorrido um diálogo constante, coisa difícil para a época, como vimos. Para maior facilidade de leitura, serão então omitidas as notas de rodapé, e adotou-se grafar em azul-italic ${ }^{2}$ os de Lucio, e em vermelho-italic ${ }^{3}$ os de Lucas. Isso permitirá então uma leitura corrida, com os textos embaralhados, sem interrupções causadas pelas notas, que, no entanto, continuarão sendo utilizadas para os demais textos.

Então, começamos desse modo, desde já:

"Quanto à execução dos serviços propriamente, julgo imprescindível que o engenheiro ou arquiteto dela incumbido se instale na região, aí permaneça até a

\footnotetext{
${ }^{2}$ COSTA, L. Igreja de São Miguel (Ruínas); São Miguel das Missões - RS - 1937. in: COSTA, L. Lucio Costa: Documentos de trabalho. José Pessôa org. Rio de Janeiro: IPHAN, 1999.

${ }^{3}$ MAYERHOFER, L. Reconstituição do povo de São Miguel das Missões. Tese de Concurso para a Universidade Federal do Rio de Janeiro. Rio de Janeiro, 1947.
} 
conclusão das obras e tenha a seu cargo a totalidade dos trabalhos projetados, desde as buscas de peças até a construção da casa do zelador e instalação do museu. Para as medidas que dizem respeito à consolidação das ruínas, sem dúvida as mais importantes, deverá, por sua própria iniciativa ou por determinação da direção do Serviço, recorrer à experiência de outro técnico de reconhecida competência, como consultor, fixando-se então com segurança e minúcia as condições de ordem técnica a que o trabalho se deverá cingir, isto, porém, depois de já feitos os estudos preliminares, sondagens, etc.

No texto acima, Lucio Costa demonstra sua total confiança de "dever cumprido", sua missão estava realizada, deixando os desenhos e diretrizes para que alguém com competência e empenho, conseguisse continuá-la. Demonstra também sua visão de que o encarregado dos trabalhos, engenheiro ou arquiteto, deveria ser como ele, Lucio, encarregado de um total, técnico e artístico, ao mesmo tempo, abrindo exceção apenas para as técnicas mais diretamente ligadas à estabilização estrutural das ruínas. É sua visão do “artista: legítimo criador de um mundo à parte". "Está aí o seu papel de desbravador e não o de colonizador; ele age como o português semeador e não como o espanhol ladrilhador, como disse e ensinou Sérgio Buarque de Holanda. Roda da fortuna, curiosamente as Missões são de conformação espanhola e não lusitana, como o próprio Lucio avisou...

\section{AS RUÍNAS DA IGREJA}

É claro que Lúcio Costa inteirou-se de todo o farto material histórico disponível no Rio de Janeiro, antes de partir para a visita. O relatório contém citações desses estudos que já havia realizado, portanto ele vai com um excelente cabedal para lá. É certo também que Augusto Meyer, como disse Lucio, um intelectual de primeira categoria, já deveria ter disponibilizado o máximo das informações já obtidas até então.

Não há informação precisa acerca da duração dessa visita, sendo certo que deve ter sido bastante curta e rápida, o que aumenta muito a admiração pela qualidade do levantamento, preciso e minucioso, para ter sido feito em tão pouco tempo. Fato que

\footnotetext{
4 “Como sempre, no entanto, a verdade não vexa: além da benção do sorriso branco - todos têm o seu bocado no colo opulento e acolhedor da babá. Ponhamos, pois, os pingos nos ii. É livre a arte; livres são os artistas - a receptividade deles é, porém, tão grande quanto a própria liberdade: apenas estoura, distante, um petardo de festim, e logo se arrepiam, tontos de emoção. Esta dupla verdade esclarece muita coisa. Assim todas as vezes que uma grande idéia acorda um povo ou, melhor ainda, parte da humanidade - senão, propriamente, a humanidade toda - os artistas, independente de qualquer coação, inconscientemente quase, e precisamente porque são artistas - captam essa vibração coletiva e a condensam naquilo que se convencionou chamar: obra de arte - seja esta de que espécie for. São antenas - embora nem sempre sejam as melhores, os que de melhor técnica dispõem. (...)” in: COSTA, L. Alberto Xavier org. Sobre arquitetura. Porto Alegre: Centro de Estudantes Universitários de Arquitetura, 1962. Idem: revisão fac-símile com comentários de Lucio Costa. Porto Alegre: Editora UniRitter, 2007.
} 
demonstra também além da excelente e já conhecida qualidade dos desenhos de Lucio Costa, seu grande conhecimento filológico, este advindo de sua formação eclético-acadêmica.

\section{São Miguel:}

O povoado compõe-se de algumas casas, entre os quais a do zelador, Sr. Nunes Pereira. As providências tomadas em 1924 pela Comissão de Terras, salvaram-lhe da completa destruição o pouco que ainda resta, e o exame das ruínas veio confirmar o que tive oportunidade de dizer-vos quando me foi mostrada a documentação fotográfica do relatório do senhor Augusto Meyer. Com efeito, não se pode pensar em reconstruir São Miguel ou mesmo recompor qualquer das partes: os trabalhos deverão limitar-se, tão somente, a consolidar e conservar.

Lucio já apresenta aqui o postulado moderno de que a partir de um estado de arruinamento de um patrimônio, não se deve tentar restaurar e sim consolidar e conservar, esquivando-se do deslize de criar contrafações ou utilizar-se de suposições para construir um falso.

A incumbência foi levada a efeito com o cuidado que caracteriza o trabalho artístico desse ilustre patrício (Lucio). Seu relatório acompanhado de excelente documentação, concluiu pelas seguintes providências:

$$
1^{o} \text { - As ruínas da igreja de São Miguel, que, apresentavam grande }
$$
interesse como conjunto arquitetônico, deveriam ser amparadas de forma a prevenir o seu total desmoronamento. (...)

Naquela ocasião também estranhei de ver em construção de tanto "estilo", uma fachada assim, no pórtico, como indica a gravura Romântica de Demersay, "redundância” jamais vista em composição de arquitetura. Ora, verificamos, logo da primeira vista, uma estranha particularidade, sobre a qual, entretanto, não havíamos encontrado a mais ligeira referência em nenhum dos autores que tratam São Miguel, nem mesmo no relatório apresentado pelo Sr. João Dahne. É que as paredes do pórtico estão apenas "encostadas" ao corpo principal, sem qualquer amarração, morrendo de encontro aos capitéis, cornijas e arquitraves desse último de qualquer jeito, tendo sido ele, portanto, construído depois de completamente pronta a fachada da igreja. O mais estranho, porém, é que a sua arquitetura, tanto no conjunto como no detalhe, revela, da parte de quem o projetou e dos que o executaram, conhecimentos seguros de "modenatura" e proporção, senão mesmo um certo apuro. Como compreender, então, que artistas assim "informados" incorressem naquela falta e tolerassem os remates grosseiros resultantes da superposição de perfis e motivos diferentes? (...)" 


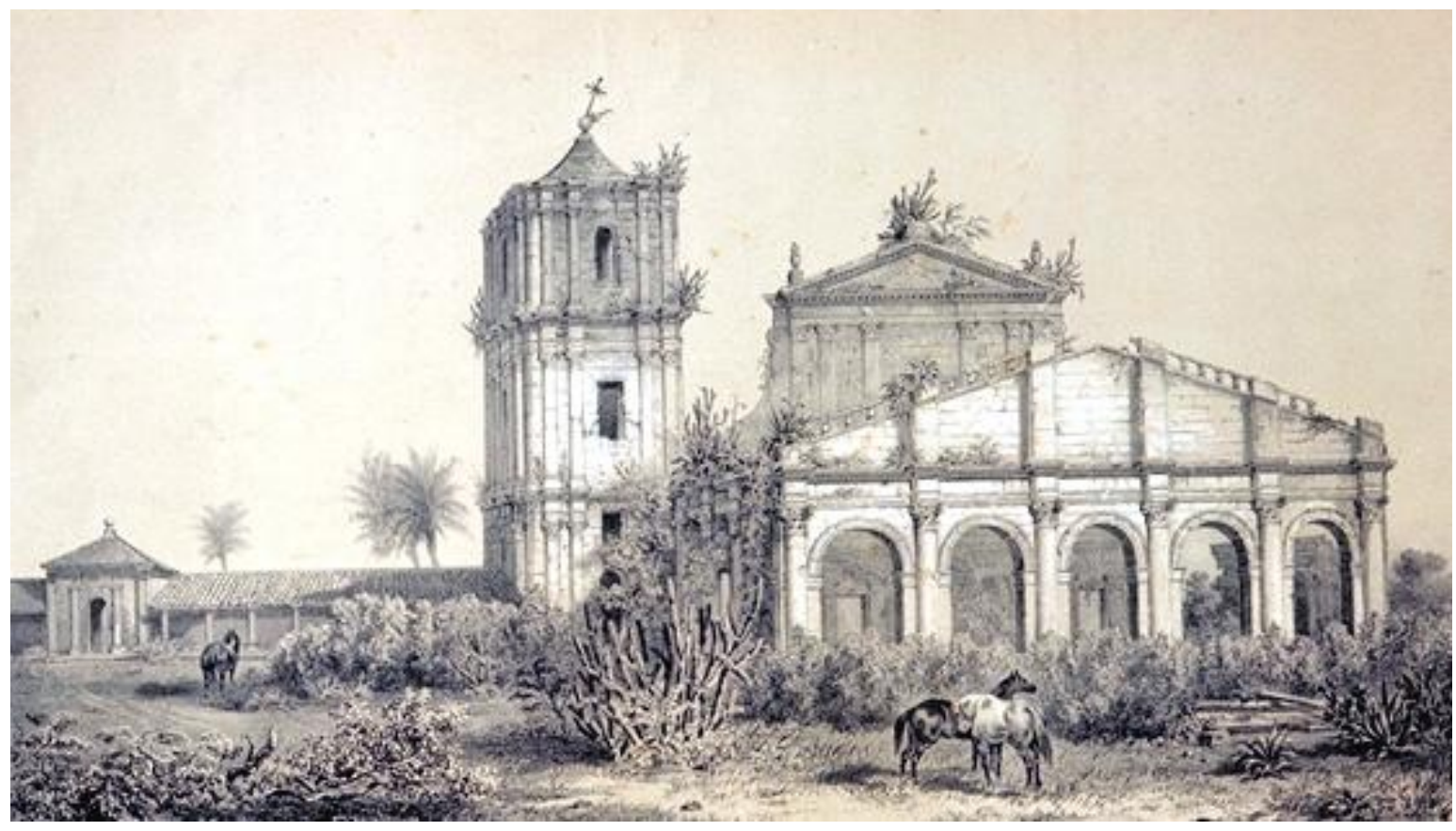

Figura 2. Gravura de Demersay com o pórtico ainda completo e a entrada do colégio, à esquerda, na paisagem Romântica.
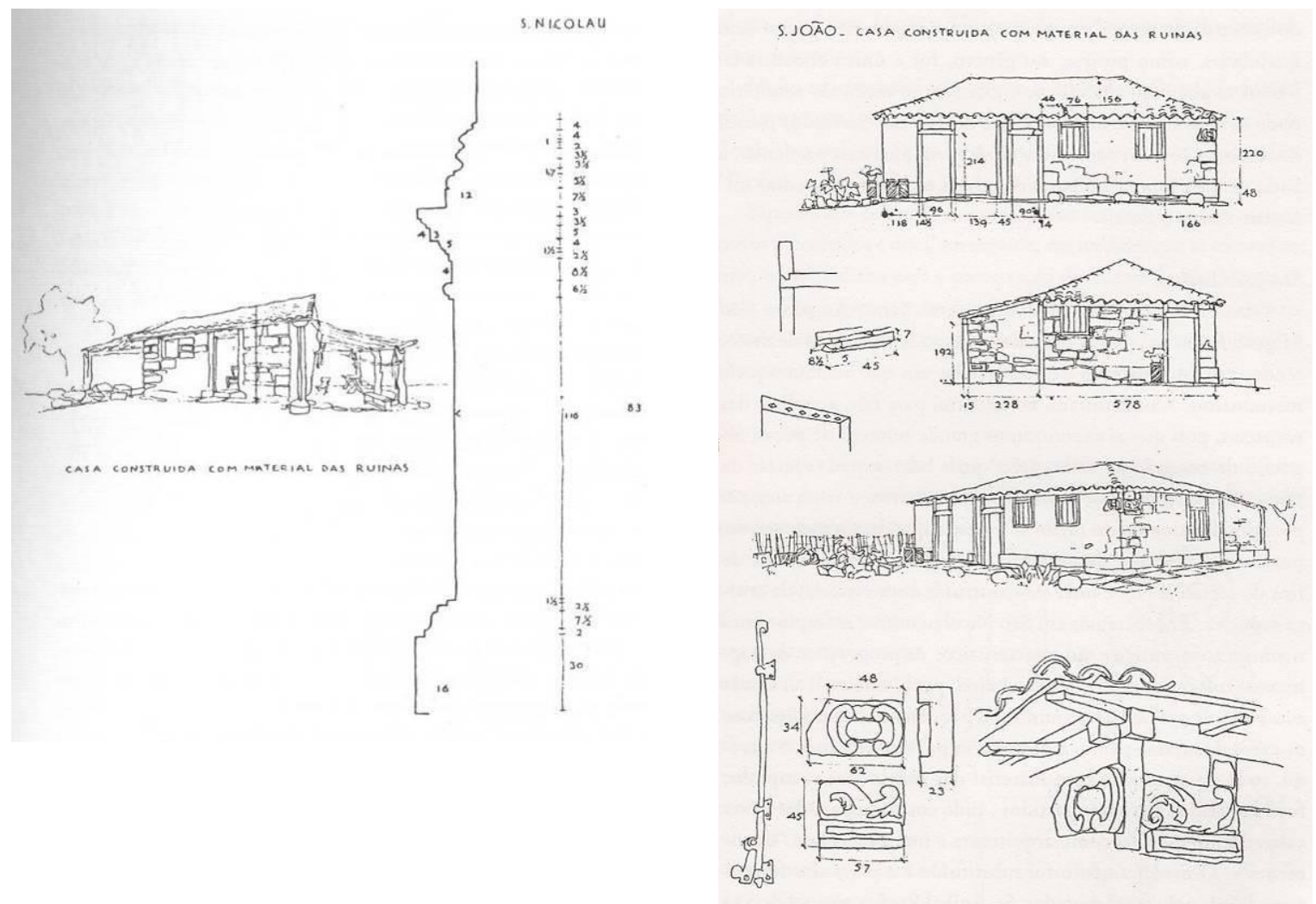

Figura 3. Casa construída com material extraído das ruínas e levantamento de um perfil.

Figura 4. Outra casa construída com material extraído das ruínas. 

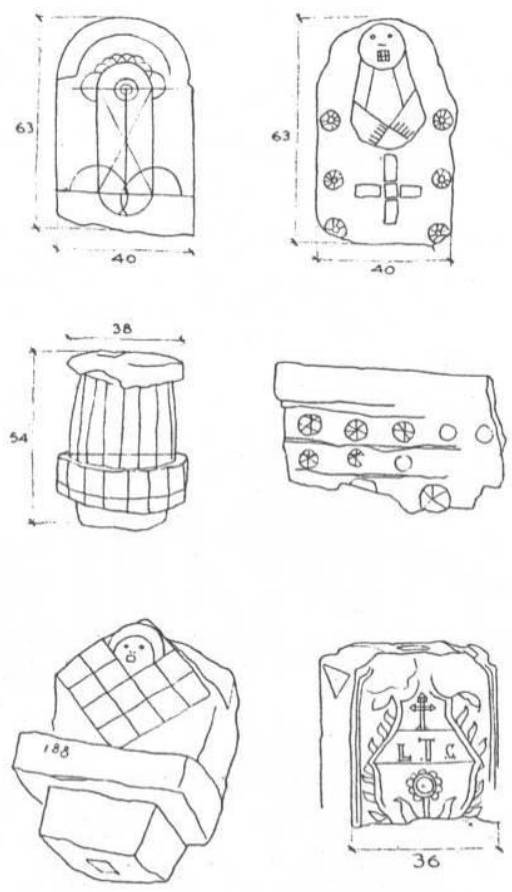

Figura 5. Levantamento.

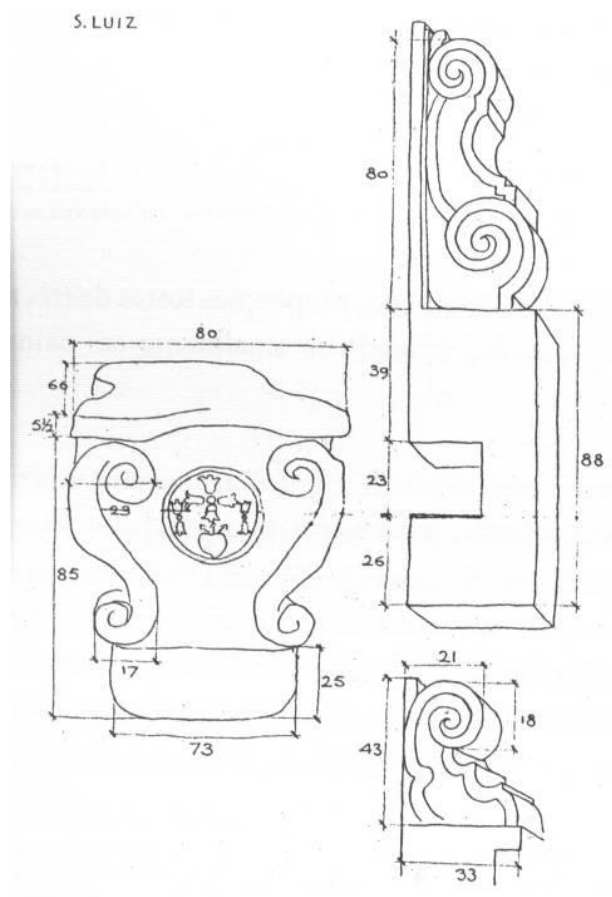

Figura 7. Consolos (peanhas).

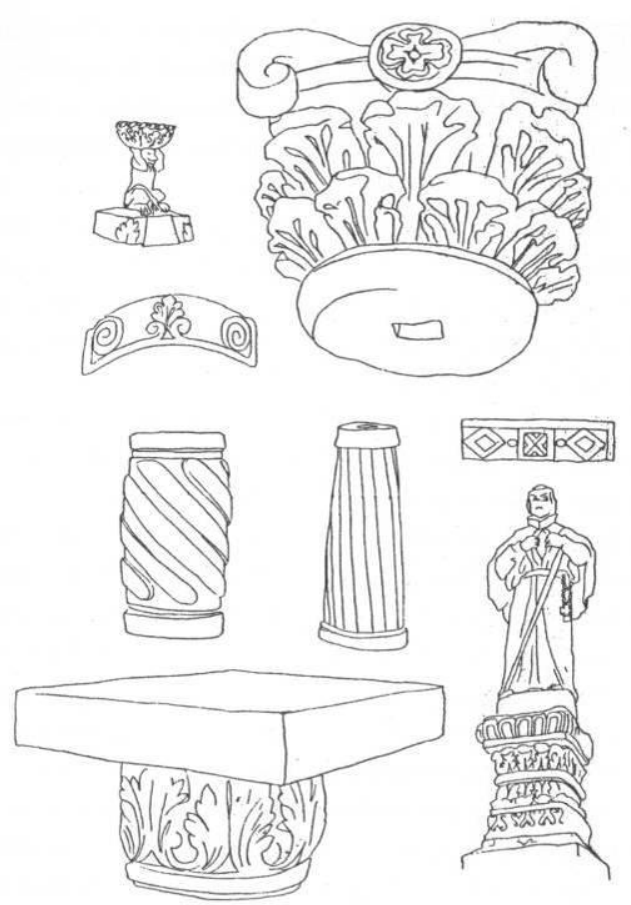

Figura 6. Levantamento.
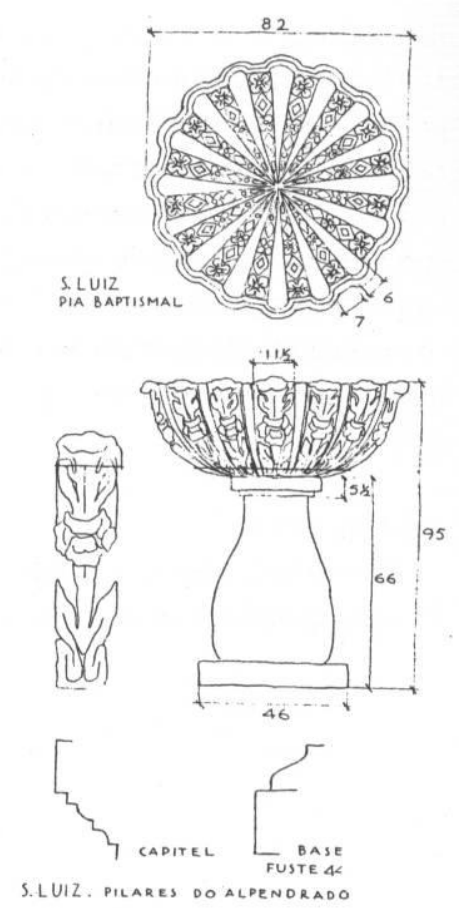

Figura 8. Pia batismal - levantamentos. 


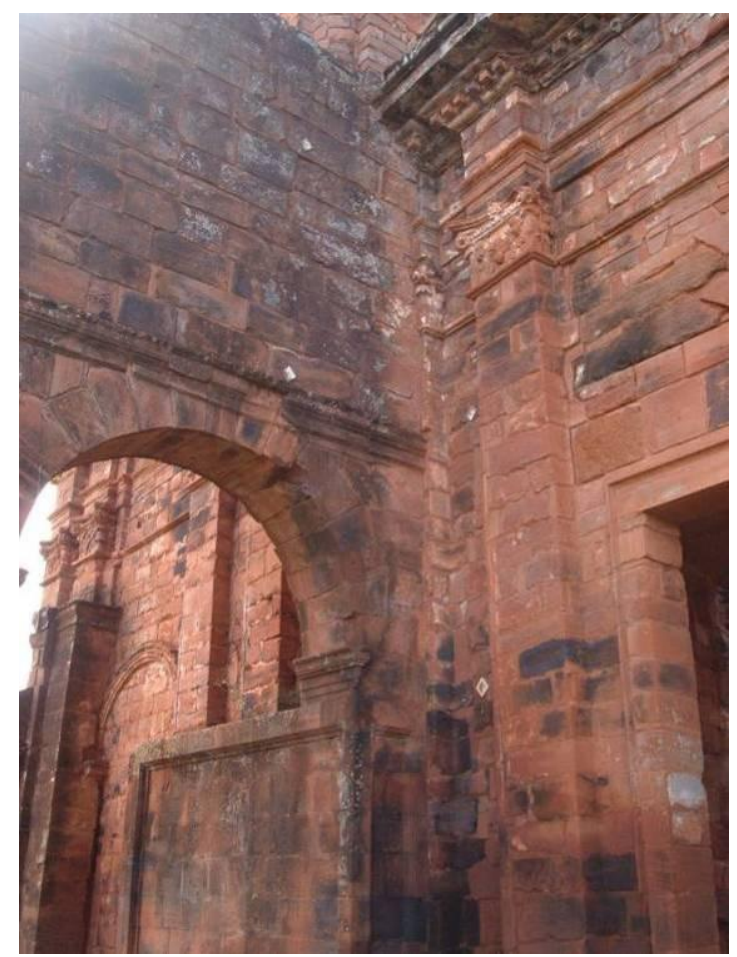

Figura 9. Encontro do pórtico com a fachada (se foi feita amarração, corretamente, não é perceptível (lado esquerdo).

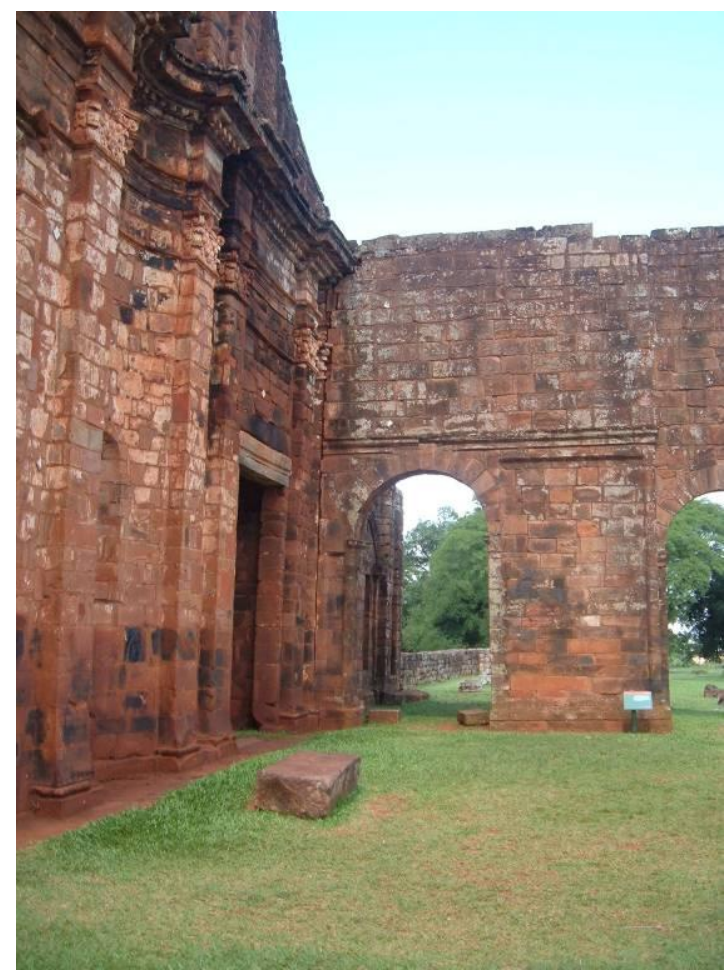

Figura 10. Idem (lado direito).

Realmente houve uma superposição de fachadas, a realizada

posteriormente constituiu um alpendrado de acesso às portas principais de igreja, na fachada antiga. Esta antiga tem como referência clara a Chiesa Del Gesú, em Roma, de Vignola. A Igreja de São Miguel, atribuída ao arquiteto jesuíta milanês Gian Battista Primoli e Francisco de Ribera, co-autor ou colaborador, é possível que seja uma segunda construção, substituindo alguma igreja menor ou com as características das demais reduções, todas elas mais simples na grandiosidade que essa ostenta, o que indica a correspondência ao estado de apogeu das Missões, seu último período. ... do dito alpendre, pelo qual se entra subindo dois degraus de pedra, e andando cinqüenta e quatro palmos para a porta da igreja. ${ }^{5}$

"O programa e o partido original da Igreja de São Miguel, assim como o da Igreja de Jesus, provavelmente não previam a construção de um "pórtico" - o alpendre, assim referido por Lucio Costa, no sentido de porticado ou "loggia". Este elemento, no entanto, já era tradicional na arquitetura das igrejas missioneiras, cujo acesso era geralmente precedido por um grande átrio com três arcos. "6 A construção desse "pórtico",

\footnotetext{
${ }^{5}$ CUSTÓDIO, L. A. B. A Redução de São Miguel Arcanjo. Porto Alegre: Faculdade de Arquitetura da Universidade Federal do Rio Grande do Sul, Dissertação de Mestrado, 2002.

${ }^{6}$ CUSTÓDIO, L. A. B. A Redução de São Miguel Arcanjo. Porto Alegre: Faculdade de Arquitetura da Universidade Federal do Rio Grande do Sul, Dissertação de Mestrado, 2002.
} 
atribuído a José Grimau, foi realmente posterior à saída de Primoli de São Miguel, e existe a hipótese de que sua saída se deve exatamente ao fato de discordar do acréscimo ao seu projeto. Não é de se admirar, portanto, a grande estranheza de Lucio Costa com a sobreposição encontrada.

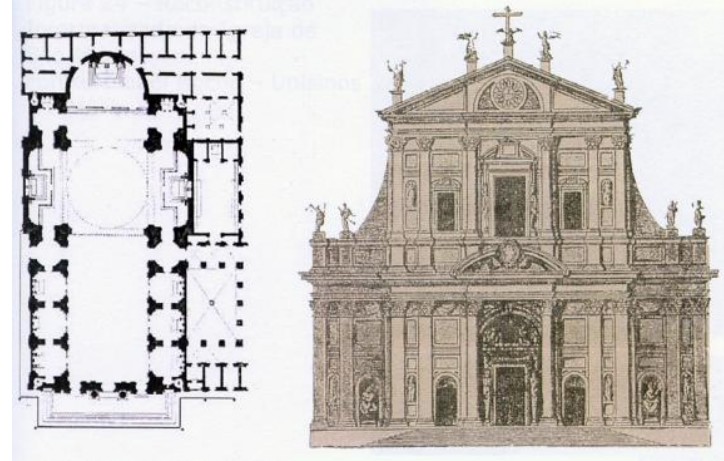

Figura 11. Chiesa del Gesú, Roma.

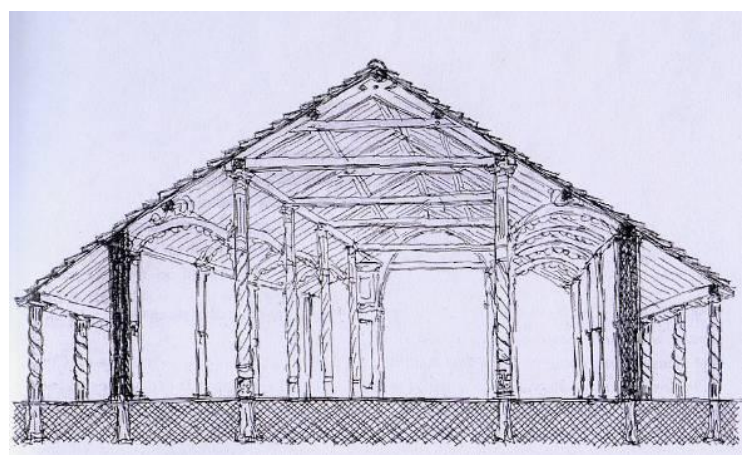

Figura 13. Igreja em S. José de Chiquitos, Bolívia. Na divisão nave principal/ laterais, a de São Miguel é um porticado em arcos portantes.
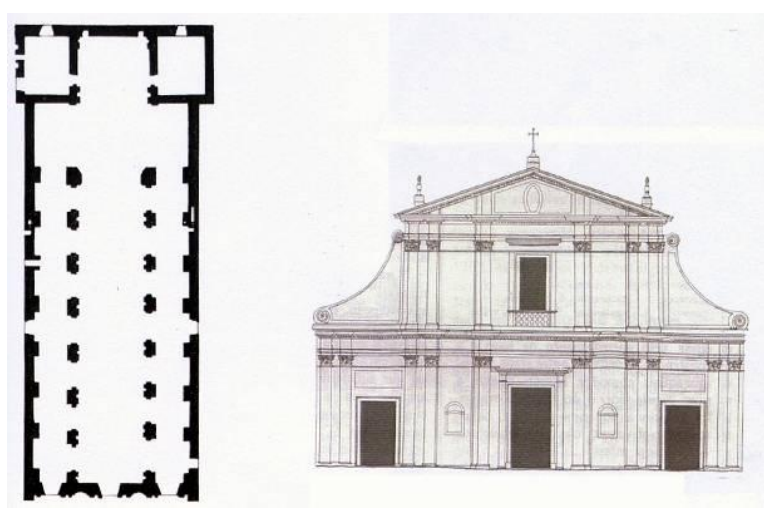

Figura 12. Igreja de São Miguel.

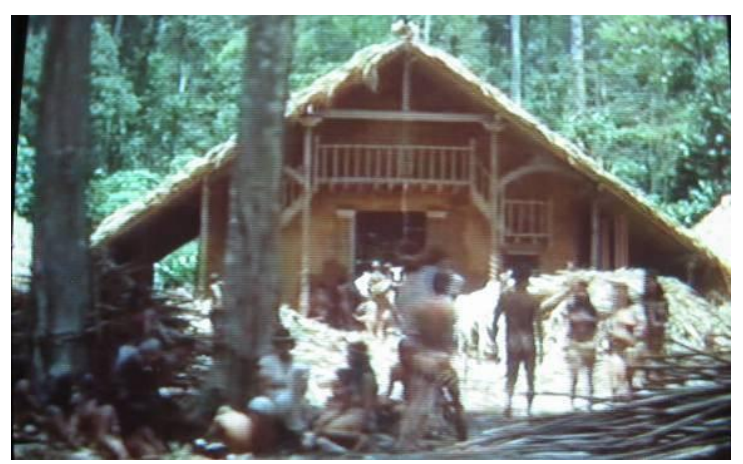

Figura 14. Cenário do filme "A Missão".

(...) E, ainda para maior estranheza, não se vê, em toda fachada, o menor vestígio de amarração da cobertura do pórtico, a qual, apoiada sobre o primeiro entablamento, deveria forçosamente cobrir as bases e parte dos fustes da ordem superior de pilastras. Ou teriam sido os trabalhos interrompidos com as lutas (1752) que precederam a expulsão e o definitivo abandono? E qual teria sido a obra de João Batista Primoli, o "irmão incomparável, infatigável... o arquiteto, o mestre, o pedreiro da obra... que anda sempre ocupado aqui e acolá a ver, a examinar, a levantar planos ? - nesse trecho de seu relatório, Lucio está citando a carta do padre Carlos Gevasoni ao padre Comini, de 9 de Junho de $1729^{7}$, e a constatação de que outro arquiteto fizera a sobreposição ainda não tinha sido encontrada.

${ }^{7}$ COSTA, L. Igreja de São Miguel (Ruínas); São Miguel das Missões - RS - 1937. in:COSTA, L. Lucio Costa: Documentos de trabalho. José Pessôa org. Rio de Janeiro: IPHAN, 1999. 
Não sem constrangimento, verificamos ter sido realmente todo o conjunto, tanto externa como internamente revestido por um reboco de tabatinga, de poucos milimetros de espessura e aplicado diretamente sobre grés (o arenito de tom pardo claro, utilizado na construção), encobrindo-se assim a textura e a cor. Revestimento que ainda se conserva perfeito em muitas das partes protegidas da construção e é sem dúvida, contemporâneo dela, pois o aparelho das pilastras das fachadas mostra muito claramente, em certos trechos, que não se pretendia deixá-lo aparente, notando-se também, nos arcos da nave, de um lado aduelas de cantaria com perfil da arquivolta e do outro alvenaria de tijolo já sem moldura nenhuma. (obs. nossa)

É admirável a honestidade do texto de Lucio Costa em admitir o constrangimento! A beleza da cantaria, a qualidade do assentamento, o tom da pedras de arenito, são para nós, hoje, claramente mais apaixonantes do que imaginar todo o conjunto rebocado em tabatinga, uniformizando superfícies e ornamentos, o que constitui um juízo anacrônico. Como ele mesmo constata, várias das superfícies e principalmente nos arcos arquivoltas - que separam a nave principal das naves laterais são feitas de maneira a demonstrar a necessidade de um acabamento posterior, e essa constatação o faz permanecer dentro do espírito do tratamento moderno ao patrimônio, ou seja, apesar da manifestação de constrangimento, mantêm-se o seu critério de consolidar e conservar. Sobre a seqüência dupla, paralela, das arquivoltas, que separam a nave principal das naves laterais e sobre as dos perímetros laterais, ele continua.

Ao contrário das outras igrejas missioneiras em que o peso da cobertura era aliviado por duas ordens de colunas de madeira ou de pedra, aqui ainda se acham bem conservados a nave e os colaterais.

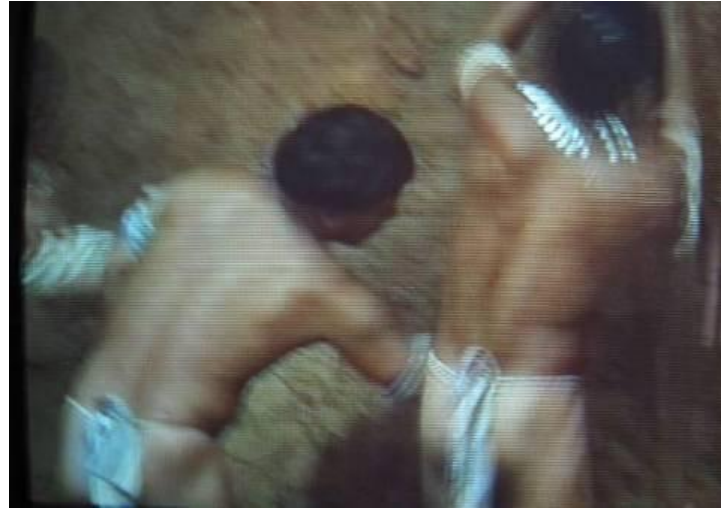

Figura 15. Cena do filme "A Missão": índios rebocando uma alvenaria com barro. (A tabatinga é quase branca, não tem a cor do barro comum)

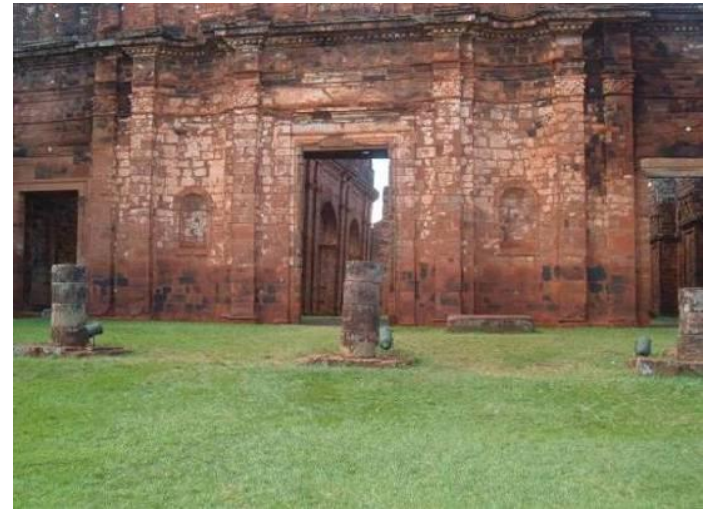

Figura 16 Fachada da Igreja sem visão do pórtico. Note-se o porticado da nave lateral esquerda em desaprumo. 


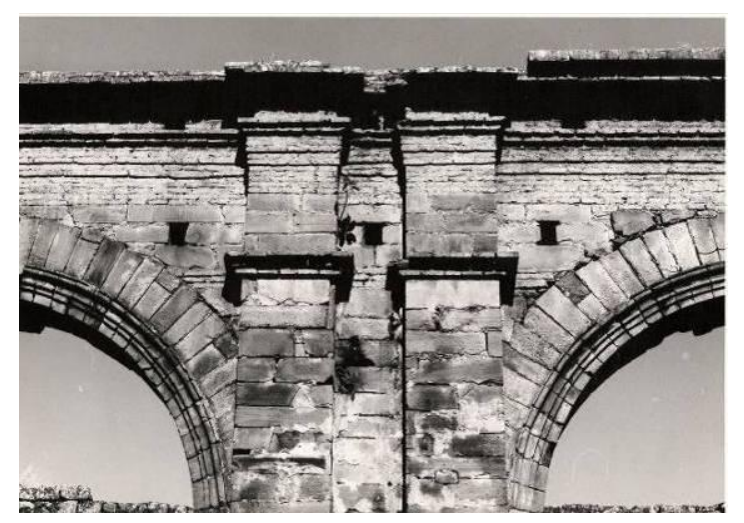

Figura 17. Excelente trabalho de cantaria do porticado.

\section{CONSOLIDAR, CONSERVAR}

Durante muito tempo Lucas Mayerhofer supôs que a igreja tivesse tido duas torres, inclusive desenhou a fachada completa e pormenorizada expondo sua versão. Como encarregado direto dos trabalhos nas ruínas, ele mesmo constatou a inexistência de indícios de uma torre à direita, fato também comprovado pela iconografia coletada posteriormente.

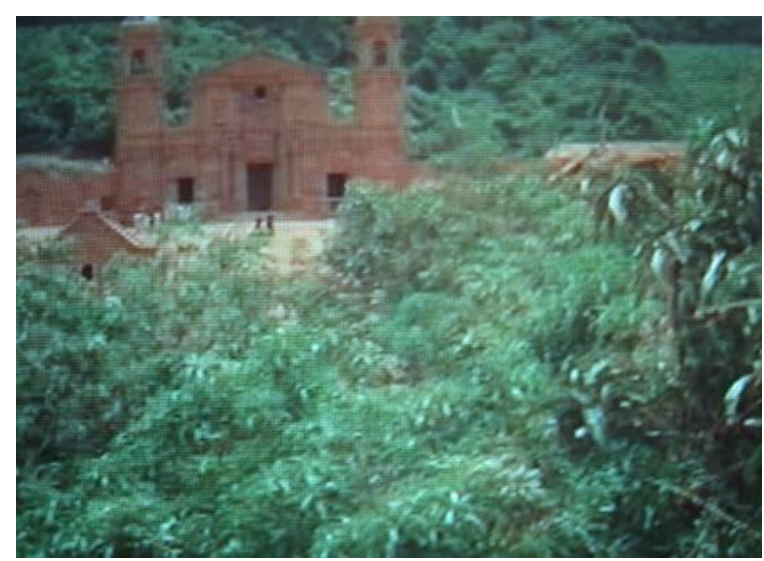

Figura 18. Igreja com duas torres como cenário do filme "A Missão" (talvez o diretor tenha achado mais imponente assim).

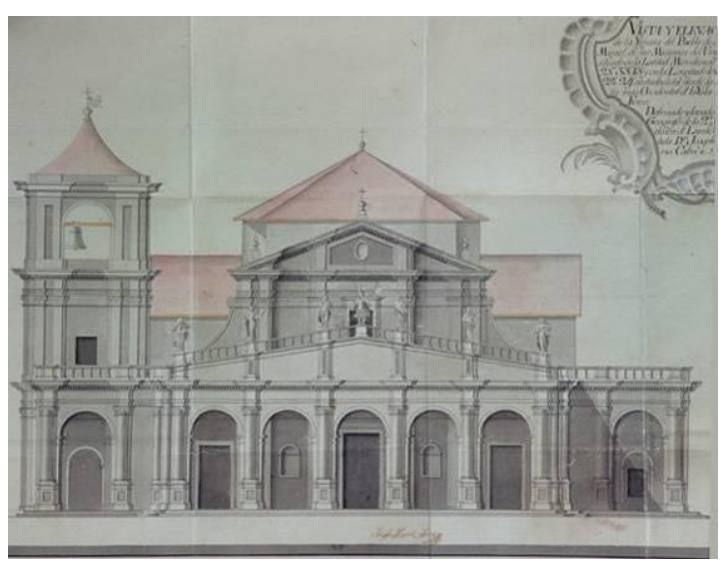

Figura 19. Igreja de São Miguel Arcanjo, 1784, com o pórtico. Cabrer, Arquivo Histórico.

Quando da visita de Lúcio Costa, o Departamento de Obras e Estradas de Rodagem do Rio Grande do Sul, já tinha tomado algumas providências emergenciais para a estabilização do conjunto, notadamente a torre, que, como se pode notar na Fig. 1, ao fundo, já estava sendo escorada. Outras imagens que se seguem ilustram também esse fato. 


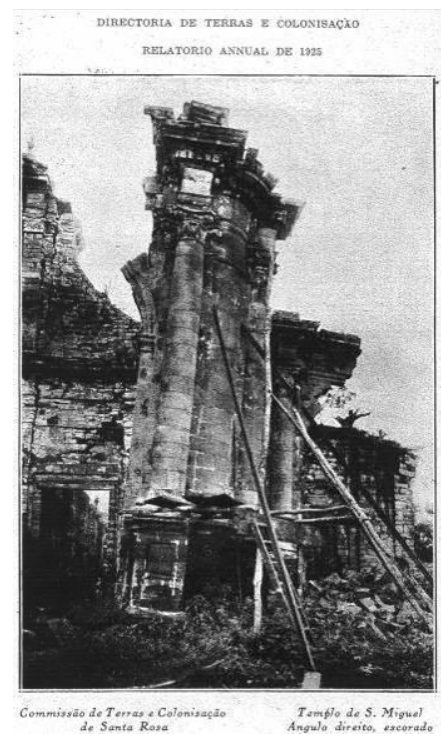

Figura 20. Ruínas.

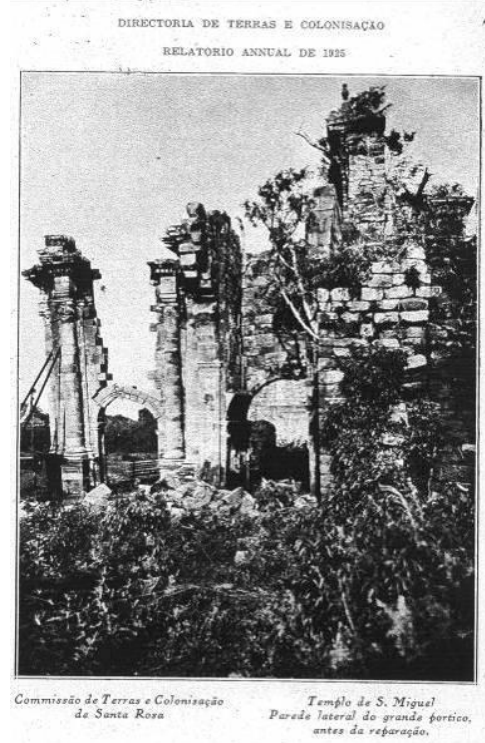

Figura 22. Ruínas.
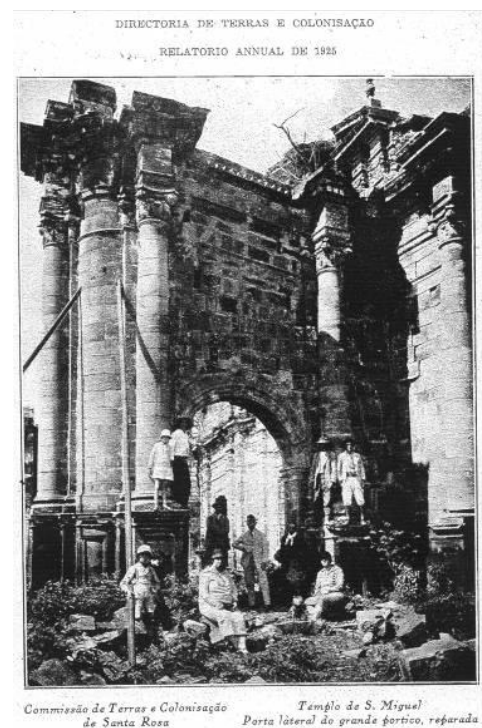

Figura 21. Ruínas.

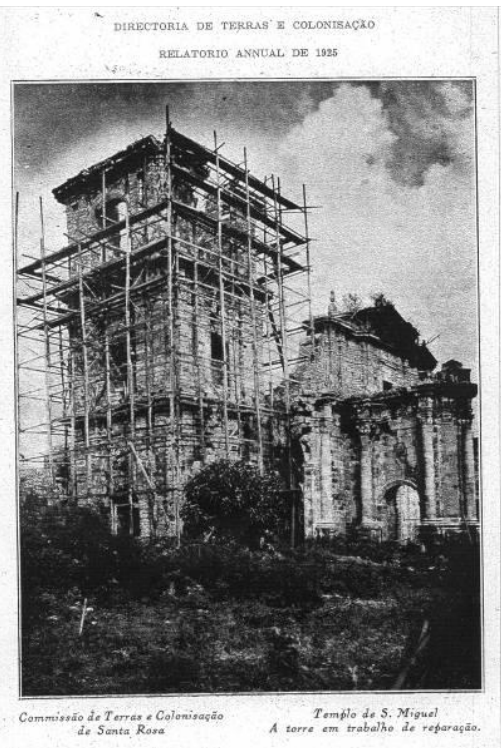

Figura 23. Ruínas.

Em 16 de março de 1938, Lucas Mayerhofer faz uma inspeção mais pormenorizada, da qual estabelecemos o seguinte "diálogo" com o Relatório de Lucio Costa:

As obras de conservações das ruínas, que me parecem urgentes porquanto os trilhos empregados na amarração da torre já se acham bastante deformados e o cunhal esquerdo do pórtico continua a ceder, deverão ser, de acordo com a opinião do Sr. Altamiro Cardoso (?), as seguintes:

$1^{a}$ consolidação do terreno nestes dois pontos e em outros que possam, a um exame mais demorado, reclamar igual providência; ” - ...do grande pórtico da fachada principal restam as colunas e arcadas laterais, muito tombadas, devido à deficiência das 
fundações. Esses elementos deverão ser totalmente demolidos e reconstruídos sobre fundação de concreto armado.

$2^{a}$ amarração dos quatro cunha da torre com braçadeiras e tirantes dispostos em diagonal, suprimindo-se em seguida a amarração existente (feita pelo Departamento citado); - Quanto à torre, todo o lado esquerdo cedeu, a parte superior está fora do prumo cerca de 1,30m (!). Foram causa as fundações deficientes para o peso brutal da torre. Duas soluções se apresentam: $1^{a}$ - o escoramento da parte que ameaça cair, constituído por contrafortes de concreto armado, colocados dois a dois e apoiando a torre em alturas diferentes. Esses contrafortes seriam ligados uns aos outros por vigas e pelas fundações constituídas por sólida sapata de um só bloco. $2^{a}$ - A outra solução, mais elegante e mais dispendiosa, consiste na demolição e reconstrução sobre novas fundações em concreto armado Bastará fazer demolição total e fundações para metade da torre, porquanto a outra metade se manterá aprumada em condições aceitáveis. No caso de se optar pelo segundo alvitre, podes ficar tranqüilo quanto à parte histórica e documentária do monumento. Toda a superfície visível será dividida em quadras, segundo as alturas, e cada quadra terá todas as pedras numeradas. Na demolição, as pedras serão arrumadas sobre o solo, segundo seu número e quadra, de forma a evitar extravio. (interrogação, obs. e exclamação nossas)

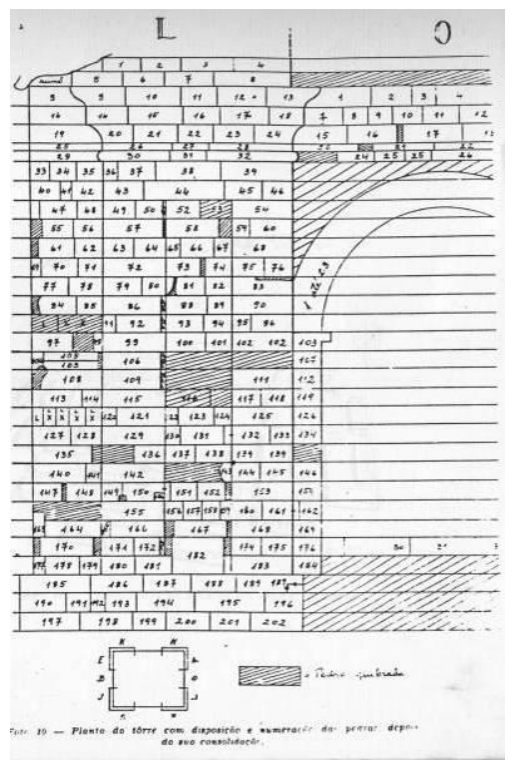

Figura 24. Mapa de localização das pedras de cantaria.

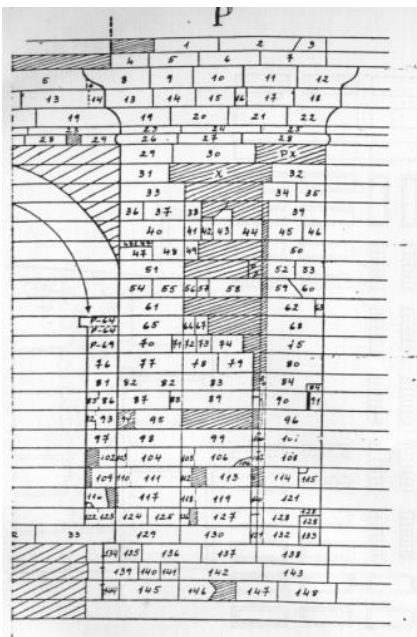

Figura 25. Idem.

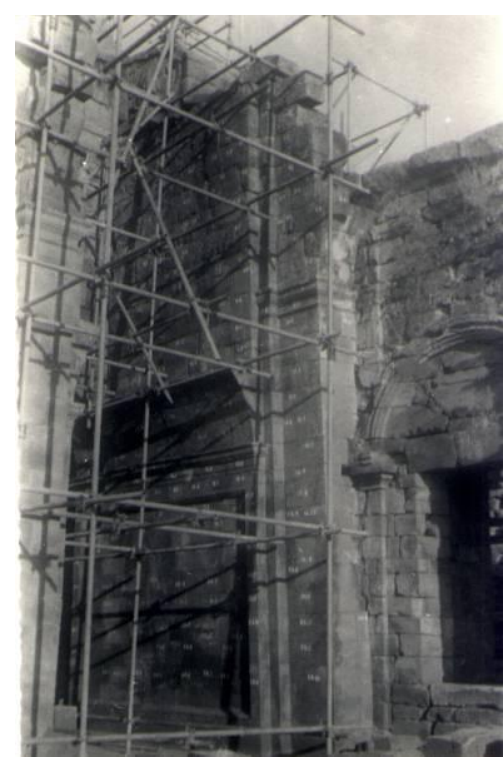

Figura 26. Trabalhos de escoramento nas ruínas, com as pedras numeradas, uma a uma, por Lucas.

As três proposições aqui apresentadas para solucionar a queda da torre parecem, todas, corretas até os dias de hoje. A de Lucio Costa, a mais sutil, seguiria uma linha próxima à já tentada pelo Departamento, e que não estava resolvendo o problema. A 
primeira proposta por Lucas Mayerhofer, de marcar visivelmente a intervenção, mantendo a enorme rachadura como parte integrante da história do conjunto, também é muito correta, faltando algum desenho que desse idéia da aparência final aventada por ele. Acaba por força do destino, a se executar a sua segunda proposição, mas não como se esperava.

Quanto à torre, além das duas soluções que sugerimos, não nos ocorreu outro meio de a proteger contra a ruína total. De fato, a parede da torre, em sua parte superior (a 23 metros de altura), estava fora do prumo da base 1,37m no cunhal NE $e$ $1,57 m$ no cunhal SE. Devido a essa deformação, viam-se no corpo da obra enormes fendas, que aumentavam sempre de importância, visto que se achava igualmente rachada a massa que os pedreiros empregaram, quando trabalhavam no escoramento.

Pela maneira como se deformou a torre, era certo encontrarmos em suas fundações a mesma deficiência que encontramos nas do pórtico... Caso se amarrasse o lado esquerdo, mais desaprumado, ao lado direito, acabaria por ruir todo o conjunto. À vista da situação e devidamente autorizados pelo Diretor do Serviço do Patrimônio Histórico e Artístico Nacional (não se sabe qual, se Lucio Costa ou David Carneiro) adotamos para a consolidação da torre em causa, o critério de sua demolição prévia a fim de reconstruí-la sobre novas fundações... Infelizmente encontramos nas pedras que íamos retirando, a demonstração do esforço exagerado a que elas ficaram submetidas... cerca de $30 \%$ dessas estavam fendidas, quando não esmigalhadas. Tornou-se, pois, necessário que os canteiros preparassem outras iguais para substitui-las, trabalhando ativamente... Na altura das primeira e segunda cimalhas fizemos lajes de concreto armado...escondidos pelos paramentos..”. e também "a superfície de cima da torre...(obs. nossas)

Acabou por ser o procedimento correto - e inevitável, pelo acima descrito - e que se pode perfeitamente constatar no local, uma vez que esse enorme trabalho foi executado com muito apuro.

$3^{a}$ desmonte do pano de parede sobre o arco atualmente escorado com um pilar de alvenaria e que está fazendo pressão sobre o cunhal desaprumado do pórtico; O escoramento que ali tinha sido feito há alguns anos, com trilhos de ferro, não impediria para o futuro a completa ruína do monumento. A demolição e reconstrução sobre novas fundações impunham-se para conservá-lo.

Em volta do pórtico, mas sem apoio nele, estabelecemos, para principiar os serviços, andaimes solidamente construídos. Depois de cuidadosamente feito o levantamento do pórtico, numeramos todas as pedras, divididas em quadras, segundo as alturas (e isso em cada face), e guardamos dessa numeração vários desenhos para garantia do serviço em caso de extravio.

Só após essas precauções, foi iniciada a demolição. 
Sobre novos alicerces de concreto, reconstruímos as duas alas do pórtico.

$4^{a}$ amarração provisória dessa peça à fachada da igreja; Não há comentários de Lucas Mayerhofer sobre esse item, e se foi feito é imperceptível.

$5^{a}$ retificação do seu prumo;

$6^{a}$ recomposição do arco e do pano de parede desmontados; Verificamos que algumas pedras - como a pedra-chave de um dos arcos - não estavam no verdadeiro lugar, naquele que deveriam ocupar na obra primitiva e, pois, que teriam sido assim colocados pelos pedreiros que por ali andaram a fazer o escoramento dos arcos.

Entretanto, como se tinham perdido as primitivas pedras, procedemos a reconstrução do pórtico tal como o encontramos. Novamente Lucas Mayerhofer toma o caminho correto, preservando inclusive uma incorreção anterior, mas que, com as condições encontradas, não havia como remediar, mantendo-se então a incorreção tal como encontrada.

Nota-se a grande preocupação de Lucio Costa com o pórtico, o que é mais uma das demonstrações de seu largo conhecimento - e imensa seriedade - em relação ao Patrimônio. O pórtico que causara estranheza era, até então, o desconhecido, o não sabido e, ainda assim, ou melhor, por isso mesmo, ele traça todas as recomendações para manter a integridade do que restara dele.

$7^{a}$ revisão de todas as vergas, escoradas ou não; Seguem diversas imagens dos diversos tratamentos de dintéis existentes na igreja de São Miguel. Alguns sugerem ser originais, outros demonstram a intervenção posterior, alguns não se pode precisar... Lucas Mayerhofer não faz referências a obras específicas em relação a esse detalhe, em sua reconstituição.

$8^{a}$ quando a segurança de qualquer elemento exigir que as juntas sejam tomadas com argamassa de cal ou cimento, dever-se-á evitar que a argamassa venha até o paramento das pedras, o que prejudicaria o aspecto do aparelho, não se devendo, pelo mesmo motivo, "disfarçar" as juntas com o emprego de corantes. - Essa providência também seria plenamente correta hoje em dia.

Tratando-se de trabalho por sua própria natureza difícil e traiçoeiro, todas as preocupações deverão ser tomadas, ainda quando aparentemente desnecessárias, a fim de prevenir qualquer eventualidade de acidente ou desmoronamento. Como vimos, Lucas Mayerhofer foi cauteloso o quanto pode, mas... ainda assim o transporte dessas pedras brutas foi muito penoso, e tivemos a lamentar inúmeros acidentes com os operários. Não que Lucio Costa estivesse prevendo acidentes com operários, ele estava prevenindo contra descuidos que comprometessem ainda mais as ruínas. Como vimos na hipótese dele ainda seria possível atirantar a torre, pressionando o lado desaprumado no que estava 
estabilizado, o que Lucas demonstrou inócuo, dado o adiantado do arruinamento, e que, na verdade a parte mais desaprumada poderia, sim, arrastar a que tinha condições razoáveis.

\section{AS RUÍNAS DO ENTORNO DA IGREJA}

Famosa já era a iconografia que representava a igreja em ruínas, numa visão romântica, mas, como vimos, Lucio Costa não está, de modo algum, desavisado sobre os fatos que sucederam nas Missões Jesuíticas dos Guaranis, quando parte para sua visita, e demonstra isso também em relação ao entorno da ruína da Igreja, descrevendo as demais funções urbanas da antiga Redução.

Cada povo, isto é, cada burgo - era constituído pela igreja que compunha com a residência dos padres, o asilo, a enfermaria, as aulas, as oficinas, as cocheiras, etc., e também com o cemitério, um grande conjunto arquitetônico, servido por vários pátios, tudo murado, muros que continuavam para os fundos das construções, abraçando a enorme área ocupada pelo pomar e pela horta, ou seja, a quinta dos padres.

Em frente à igreja, havia um grande terreiro ou praça, em volta do qual eram dispostos numerosos blocos de habitação coletiva, composto cada um de muitas células de cinco metros por sete, aproximadamente, verdadeiros apartamentos com porta e janela e construídos com paredes de pedra ou de barro, morando em cada um deles uma família de índios. Um passeio alpendrado circundava esses blocos de habitação que constituíam assim, por si mesmos, verdadeiros quarteirões. Os primeiros blocos construídos eram os que formavam a praça; depois, à medida que o povo crescia, novos blocos eram edificados, paralelamente aos primeiros, surgindo dessa forma, entre eles, numerosas ruas, todas em esquadro à moda espanhola, de conformidade, aliás, com o estipulado no Livro IV, Titulo Sete, das "Leyes de Índias": "De la población de lãs ciudades, villas y pueblos". $O$ edifício do Cabido -ou Cabildo - ocupava, geralmente, a extremidade oposta à igreja - não se localizou até hoje onde foi o cabildo de São Miguel Arcanjo.

Esses povos, com as respectivas estâncias para a criação de gado, ficavam a uma distância razoável uns dos outros, formando a seqüência deles um todo orgânico e perfeitamente articulado. ${ }^{8}$

Do colégio, estão de pé, alguns panos mal ajustados de paredes, e encontram-se espalhadas por toda a redondeza, inúmeras bases, todas com o característico encaixe quadrangular pertencentes às pilastras do alpendrado que circundava as casas dos índios e cujo intercolúnio era de 5,10m, conforme observamos do lado direito da praça, na esquina mais próxima da igreja.

\footnotetext{
${ }^{8}$ COSTA, L.. Registro de uma vivência. São Paulo: Empresa das Artes, p. 488, 1995.
} 
O alpendrado interno do colégio é, na verdade um claustro, uma loggia, justaposta a esse lado esquerdo da igreja, também configurada por um avarandado ou alpendrado - como usado no texto original - com intercolúnio idêntico ao avarandado das casas dos índios. O alpendrado também acompanhava todo o lado externo, como se vê pelos blocos de bases - sapatas. Fig. 27

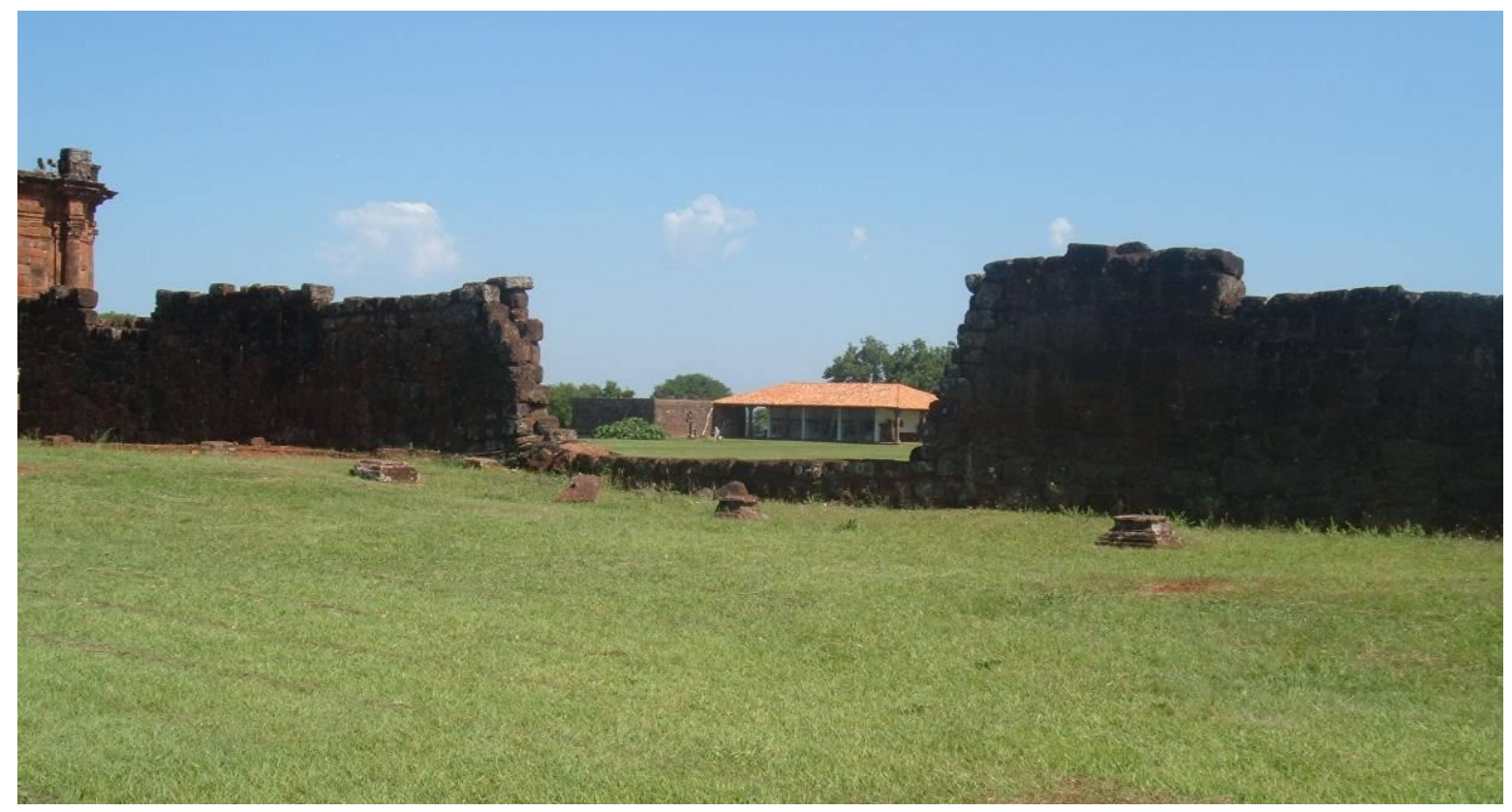

Figura 27. Através do antigo acesso ao colégio, ruído, tem-se a escala da praça, dada pelo conjunto moderno.

A planta de todos esses povos obedecia a um padrão uniforme preestabelecido. Os quarteirões, com as colunas dos alpendres em fila e bem alinhados, se arrumavam como regimentos em uma praça. Tudo se distribuía e ordenava com uma disciplina quase militar. Os jesuítas revelaram-se, nessas Missões, urbanistas notáveis, e a obra deles, tanto pelo espírito de organização como pela força e pelo fôlego, faz lembrar a dos romanos nos confins do império. Apesar do atual desmantelo, ainda se advinha, nos menores fragmentos, uma seiva, um vigor, um “impulso”, digamos assim, que os torna, estejam onde estiverem, inconfundiveis. - O traçado se desenvolveria em torno de uma praça quadrangular, medindo aproximadamente $130 \mathrm{~m}$ de lado. O lado que olhava o Norte era limitado por muros e construções da Igreja, do Colégio e pelo cemitério; os outros três lados pelas casas dos indígenas, dispostas em anfiteatro e separadas por nove ruas que partiam da praça. ... Dominando o conjunto elevava-se a magnífica igreja, toda de pedra e precedida de rico pórtico. - tudo revestido - À sua direita - grifo meu - ficavam as casas do colégio, que se dispunha em volta de dois grandes pátios. Essas construções eram dotadas de duplas varandas, exterior e interior, construídas com pilares de pedra lavrada. Do lado esquerdo - grifo meu - da igreja, o cemitério, cercado por paredes altas... ao meio do 
cemitério, de certo, uma grande cruz se levantaria, como nas outras Missões. Pelo lado dos fundos, ao longo do colégio, da igreja e do cemitério, devia ficar a quinta dos Padres, murada de pedra e barro, com jardim, pomar e horta.

Integrando o primeiro conjunto, no primeiro pátio contíguo à igreja, à leste, localizava-se o claustro, que englobava a residência dos padres e, em alguns casos, alguma sala de aula... - o colégio. O claustro tinha acesso para a igreja, para a praça e para o pátio das oficinas ou artífices... . A residência dos padres em São Miguel era composta por uma série de cômodos que se comunicavam internamente entre si, pavimentados em ladrilhos cerâmicos... . Existia um cômodo destinado ao refeitório e sob ele, um porão onde provavelmente se localizava a adega... . Atrás da residência dos padres,... - ao longo de todo o principal, ao Sul -... existia um segundo alpendre, elevado em relação à quinta. ${ }^{9}$ Fig. 28 a 29

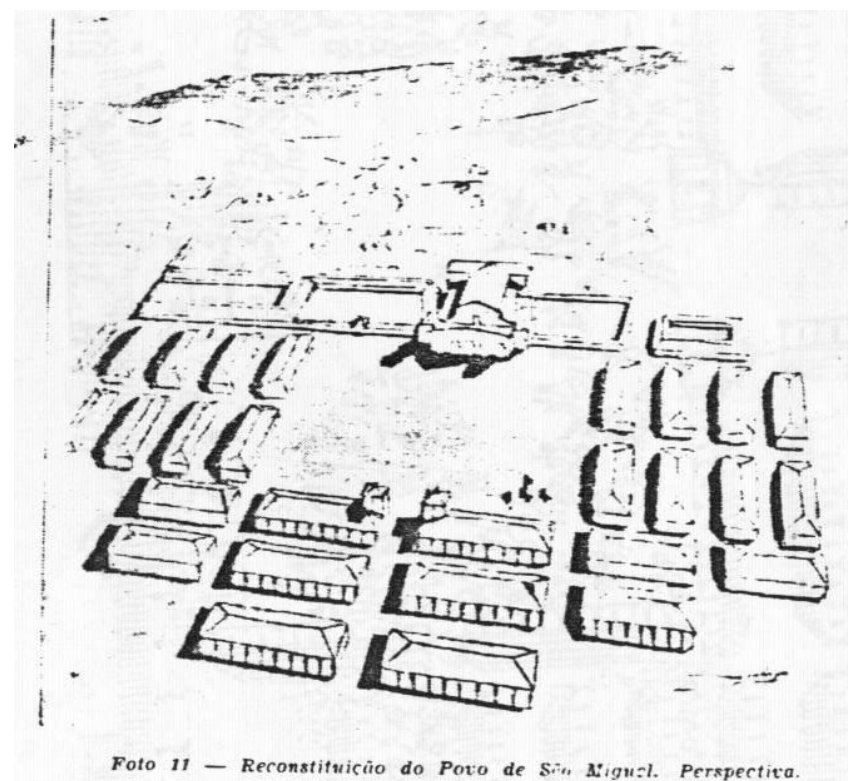

Figura 28. Ilustração interpretativa de como teria sido o conjunto da redução.

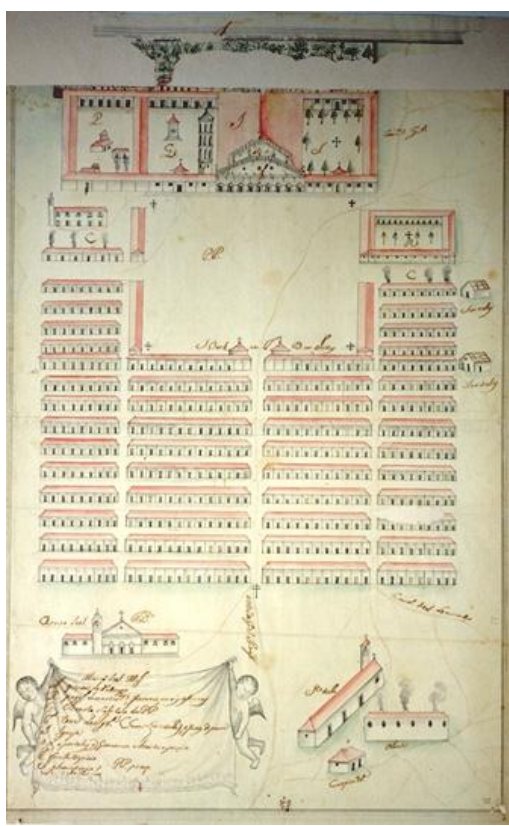

Figura 29. Risco de São Miguel. Biblioteca Nacional Rio de Janeiro.

A limpeza do terreno, em S. Miguel, deve limitar-se apenas ao mato existente, as árvores de porte deverão ser preservadas; também não vejo inconveniente em que depois de reconstituído o contorno da quinta, seja ela utilizada, como o tem sido até agora, para plantações de vária natureza.

\footnotetext{
${ }^{9}$ CUSTÓDIO, L. A. B. A Redução de São Miguel Arcanjo. Porto Alegre: Faculdade de Arquitetura da Universidade Federal do Rio Grande do Sul, Dissertação de Mestrado, 2002.
} 
O levantamento que será reproduzido em escala conveniente (...) deverá abranger todo o conjunto, inclusive a quinta, deixando-se à mostra o topo das fundações onde não existirem outros vestígios e fechando-se, a seguir, todo o perímetro com "cerca viva" de tunas ou qualquer outra planta característica da região e que melhor se preste para esse fim.

Nas reduções, a praça era o espaço público e aberto, onde se realizavam atividades cívicas, culturais, esportivas e militares. Fig. 30 Apresentava-se geralmente cercada por edificações com galerias cobertas que permitiam que se circulasse por toda a povoação ao abrigo do sol e da chuva (15), que, como adiantou Mayerhofer, era um quadrado de $130 \mathrm{~m}$ de lado. A praça é a extensão gestual do Barroco, as imagens votivas se movem nas procissões - suas vestes são sempre representadas como se estivesse ventando - , as pessoas se deslocam ao vento, construções e imagens tem conotação de volátil. A música é fundamental para o Barroco. Os guaranis são povos extremamente musicais...

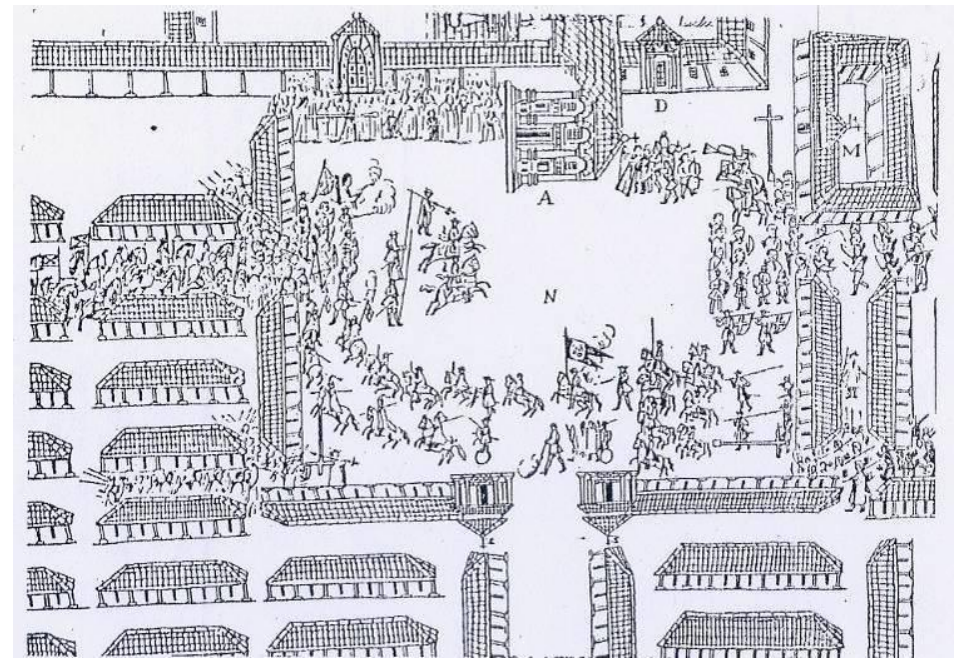

Figura 30. Ilustração mostrando o uso festivo/militar da praça.

Por que telhado de 4 águas? Responde Comas: - Porque era assim, repare nas gravuras de época. É um espanholismo, as Missões tinham base espanhola e não portuguesa...” (c.d.m.) Como Lucio, mesmo, já vinha alertando, os ladrilheiros.

Poderia ter sido em 2 águas, mas essa hipótese causaria a visualização completa da empena final, do último compartimento, o que daria peso excessivo ao conjunto, além de criar uma situação complicada no encontro com a casa do zelador - outra empena? Nesse caso, os oitões poderiam simular continuidade, como que lembrando a extensão maior da casa dos índios, mas o resultado dessa mera simulação acarretaria em mal maior, a perda da leveza conferida pelos espigões das 4 águas, mesmo com a já citada estranheza dos consolos nos cantos. 
Poderia, ainda, ter sido laje. Lucio Costa, trabalhando nos projetos do Ministério, que já continha terraço-jardim, não teria o menor receio em propor uma laje, Lucas Mayerhofer se refere a execução de lajes no local, criando patamares de travamento na torre. Trata-se, portanto, de uma decisão precisa: reconstituir o alpendrado reafirmado pelo peristilo.

\section{O "SIMPLES ABRIGO"}

O "museu” deve ser um simples abrigo para as peças que, todas de regular tamanho, muito lucrarão vistas assim em contato direto com os demais vestígios; $e$ como a casa do zelador precisa ficar no recinto mesmo das ruínas, é natural que os dois sejam tratados conjuntamente, ocupando a construção, de preferência, um dos extremos da antiga praça para servir de ponto de referência e dar um idéia melhor das suas dimensões. Conviria mesmo, aproveitando-se o material das próprias ruínas e os esplêndidos consolos de madeira do antigo colégio de S. Luís, reconstituir algumas travées do antigo passeio alpendrado que se desenvolvia ao longo das casas. Sugiro, dentro desse critério duas soluções que submeto à vossa apreciação:

\section{$1^{a}$ a construção de um grande alpendrado com os pilares internos} substituídos por panos de parede caiados de branco para fazer "fundo" às peças expostas e tudo diretamente ligado à casa do zelador que seria murada, a fim de isolar as atividades domésticas da vista dos visitantes;

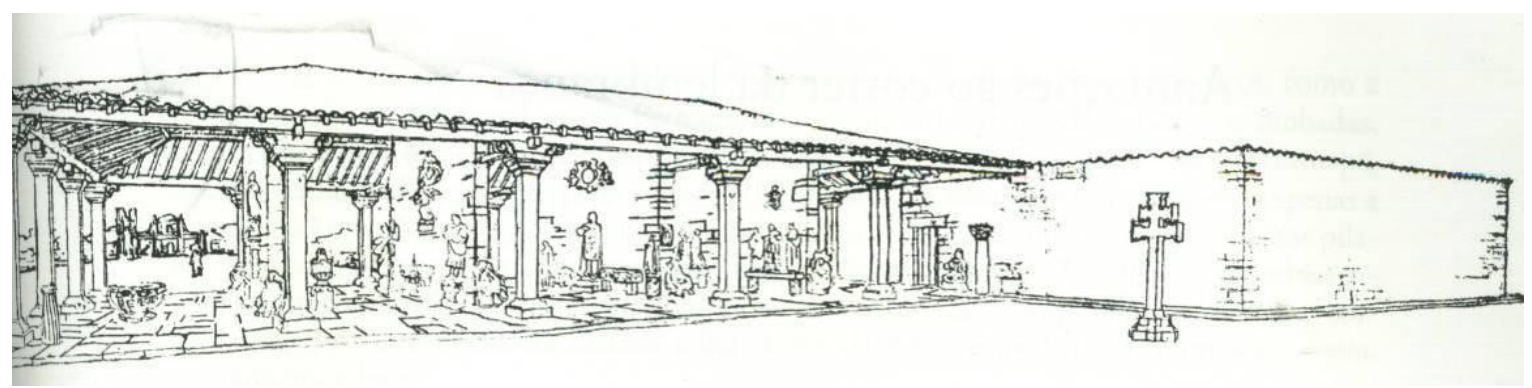

Figura 31. As ruínas, ao fundo, enquadradas pelo peristilo dos alpendres. Note-se a casa do zelador em posição invertida em relação ao que foi executado. 


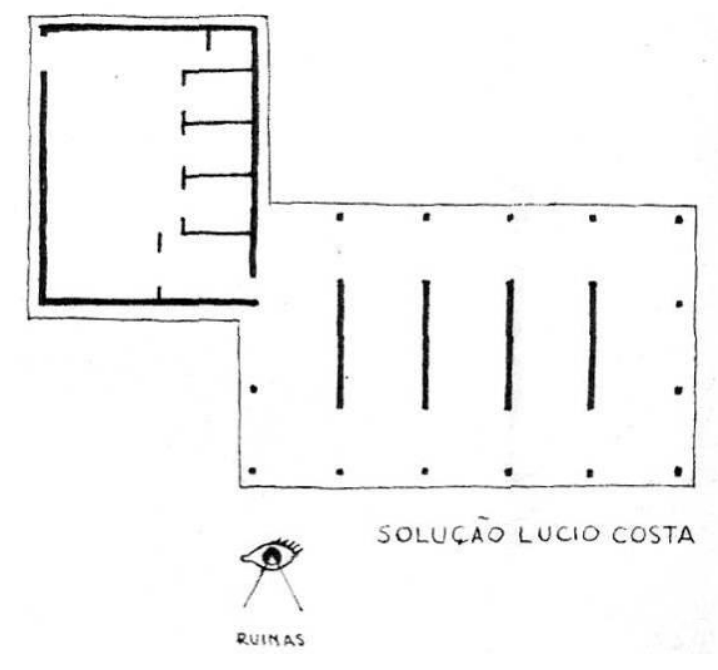

Figura 32. A casa do zelador na mesma posição da perspectiva da figura 31 .

$2^{a}$ o aproveitamento para abrigo das peças dos colaterais da própria igreja, fazendo-se para tanto uma cobertura simples de telha vã, telha antiga ou fabricada de acordo, não devendo empregar as modernas telhas de canal cujo tamanho e aspecto destoariam do resto; os fragmentos e imagens seriam então arrumados ao longo das paredes e junto aos pilares da nave. A casa do zelador continuaria no extremo da praça, mas a reconstituição do antigo alpendrado - necessária, a meu ver, para se ajuizar do valor do conjunto ficaria reduzida às proporções de um pórtico de quatro pilares. Fig 33 e 34

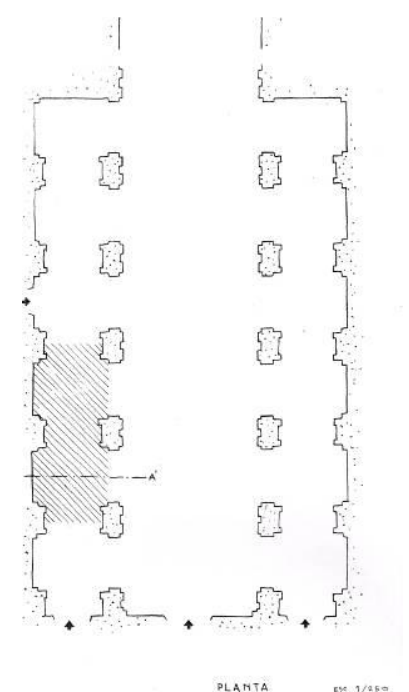

Figura 33. Proposta 2.

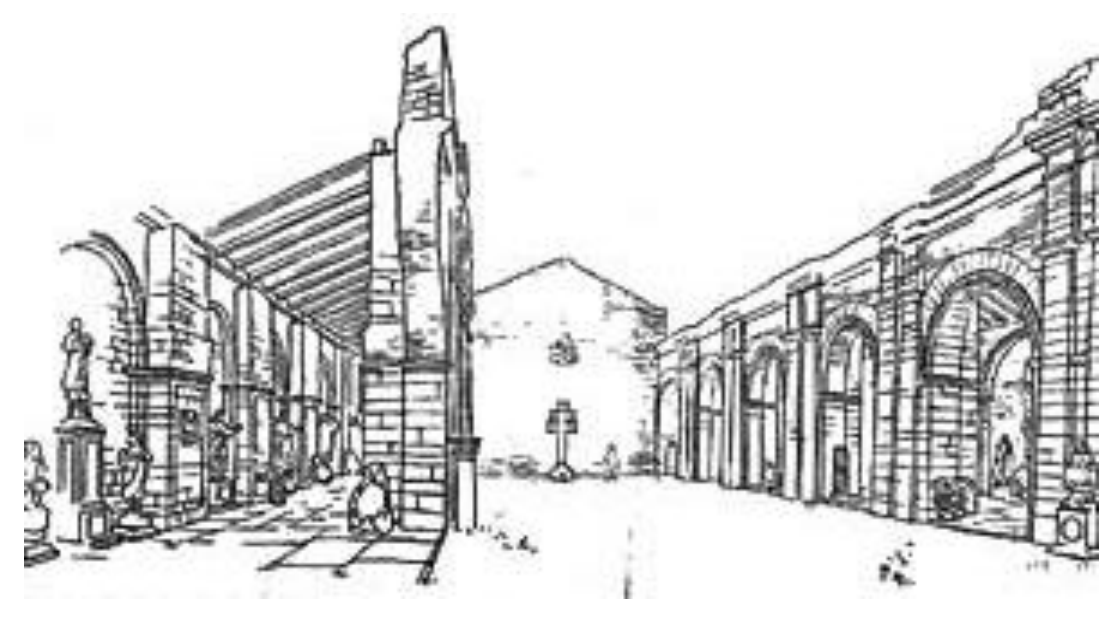

Figura 34. Proposta 2 utilização das naves laterais como museu.

A ressalva contida no final da frase da $2^{\mathrm{a}}$ proposta -... ficaria reduzida às proporções de um pórtico de quatro pilares - parecem ter influenciado Rodrigo Mello 
Franco de Andrade: Tendo se preferido a primeira das soluções alvitradas pelo arquiteto Lucio Costa, para a localização e edificação do museu, as medidas recomendadas com o objetivo de desobstruir a área e levantar a planta do antigo povo de São Miguel Arcanjo, bem como de consolidar os remanescentes da igreja e os restos das demais construções $(\ldots)^{10}$

O museógrafo Lucio Costa também aventa, antevê, expor as peças recolhidas contra um "fundo" branco, na $1^{\text {a }}$ hipótese, coisa que seria impossível de se realizar na $2^{\text {a }}$, ele mesmo, encantado com o aparelhamento da cantaria das ruínas, tinha se mostrado constrangido com a descoberta de que tudo em São Miguel Arcanjo era revestido.

O museólogo Lucio Costa apresenta também a sua proposta didática para seu museu:

Aliás, para que os visitantes, geralmente pouco ou mal informados "compreendam" melhor a significação das ruínas, sintam que já houve vida dentro delas e se possível, também "vejam”, como o Sr. Augusto Meyer, "aquela porção de índios se juntando de manhãzinha na igreja”, parece-me indispensável a organização de uma série de esquemas e mapas, além da planta de S. Miguel, acompanhados de legendas que expliquem de maneira resumida, porém clara e precisa, a história em verdade extraordinária das Missões, e como eram as casas, a organização dos trabalhos nas estâncias e oficinas, as escolas de ler e de música, as festas e os lazeres, a vida social das comunidades, em suma. Com datas e nomes, mas tudo disposto de forma atraente e objetiva, tendo-se sempre em vista o alcance popular. O alpendrado anexo à casa do zelador poderia então servir, também para esse fim.

Aqui ele retoma um pouco o alpendrado da casa do caseiro, deixando a ambivalência das propostas, ex aequo, nas mãos de Rodrigo.

Decidido, então pela proposta da construção do museu, e não pela adaptação deste nas ruínas, surge então nova surpresa: ao reparar no magnífico desenho de perspectiva da $1^{\mathrm{a}}$ proposta, que enquadra a igreja "dentro", no plano de projeção, da área contida pelo alpendrado, curiosamente, a casa do zelador está ao contrário - invertida para o ângulo Noroeste do museu - do que foi realizado, como mostram as figuras 32 e 33, já apresentadas. Encontra-se nos arquivos Noronha Santos, a seguinte seqüência de desenhos:

\footnotetext{
${ }^{10}$ ANDRADE, RODRIGO M. F., Museus regionais no Brasil: uma experiência in: “Rodrigo e o SPHAN" Rio de Janeiro: MinC, SPHAN/Pró-Memória, 1987
} 


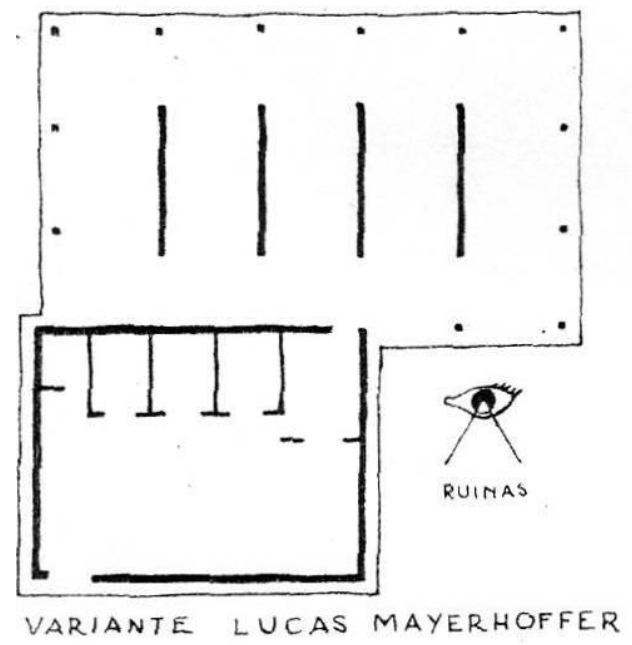

Figura 35. A hipótese Lucas é, sem dúvida, a pior.

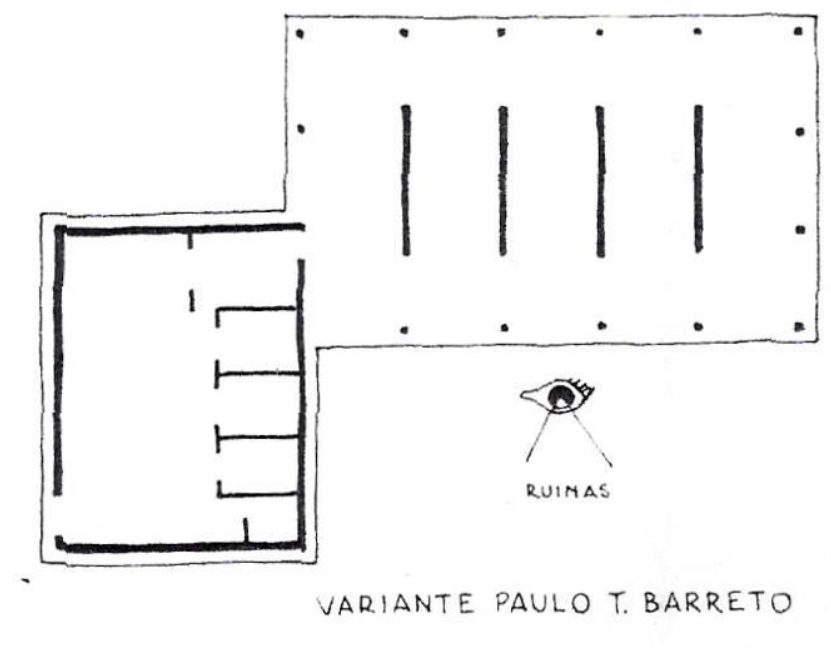

Figura 36. A posição definitiva do L.

Como os desenhos são "re-passados", apresentados em linguagem uniforme, não dá para afirmar nada sobre sua veracidade ou autenticidade. O certo é que para Lucio Costa, o "pontapé inicial" estava dado e, visivelmente, para ele, naquela conjuntura, tanto fazia - e o Correio Aéreo Nacional que ajudasse... Caso a hipótese apresentada na sequiência dos desenhos seja verdadeira, mais uma vez, Lucas Mayerhofer acertou! Inverteu a implantação da casa do zelador para Sudoeste do museu, constituindo uma esquina. $\mathrm{Na}$ verdade, as Reduções Jesuíticas não tinham esquinas, os quarteirões eram quarteirões-ilhas, aquela quina era livre, aberta, como demonstram as gravuras de época e o próprio Lucio Costa descreve. Mas ao reconstituir um "canto", reforça-se a visualização da escala urbana que existiu, do tamanho da empreitada jesuítica, do que fora aquela epopéia, do que foi a Redução de São Miguel Arcanjo.

A neutralidade da construção amurada da casa do zelador, prevista no projeto por Lucio, já continha ou permitia esse novo arranjo, sua opacidade leva a onipresença ou inexistência, instantaneamente, conforme se queira. Por mais estranho que possa parecer, algo pesado se dilui - a casa do zelador, amurada - e algo leve e flutuante marca presença - o museu. A superfície neutra da cantaria que fecha o quadrilátero do zelador, superfície "natural", funciona como fundo infinito, quase não existe, as trivialidades rotineiras, domésticas, que o muro contém, estão resguardadas dos olhos dos visitantes, como Lucio previu. $\mathrm{O}$ fato de ser uma casa, no sentido corriqueiro, doméstico, por assim dizer, e estar justaposta a um museu não ofende, "a verdade não vexa..." 
Assim descreve Comas:

A casa do zelador é (...) uma sucessão de peças retangulares, comunicadas por um alpendre, à maneira das casas da região. A sala na ponta se expande numa pérgula que abriga o poço. O pátio retangular com o poço se limita com muros de pedra, o alpendre e a pérgula em esquadro.(...) A parede de pedra que fecha a casa do zelador tem a altura dos pilares, escondendo a cobertura em meia água. Casa do zelador e pavilhão se dispõem em esquadro, trecho da parede de pedra substituindo dois dos pilares do lado menor do alpendrado a oeste.

E segue com uma comparação precisa: o pavilhão é a cabana enquanto a casa do zelador é a gruta. ${ }^{11}$ Poderíamos continuar, relacionando a casa do zelador com a fortificação e o alpendrado com os anexos comuns às antigas fortificações militares, agregadas a estes por motivos de segurança, em primeiro lugar, e comércio, também em primeiro lugar.

Do ponto de vista construtivo, Comas descreveu muito bem o fato de que a parede de pedra esconde a cobertura da casa do zelador, com a adoção de uma altura idêntica aos pilares, e assim como numa fortificação, guardada em impluvium, mas o detalhe da passagem do telhado de 4 águas para a meia-água sempre foi instigante, uma vez que nenhuma imagem apresentava isso com clareza. $\mathrm{Na}$ falta de desenhos técnicos disponíveis, de fotografias que apresentassem essa passagem, foi necessário tomar novas fotos, acima de uma escada, para, enfim, verificar como foi tão bem realizado o conjunto.

\footnotetext{
${ }^{11}$ COMAS, C. E. Simples abrigo, límpida ruína, modernidade real: o museu das Missões de Lucio Costa. in: $1^{\circ}$ SEMINÁRIO DOCOMOMO SUL, Porto Alegre: PROPAR / UFRGS, 2006.
} 

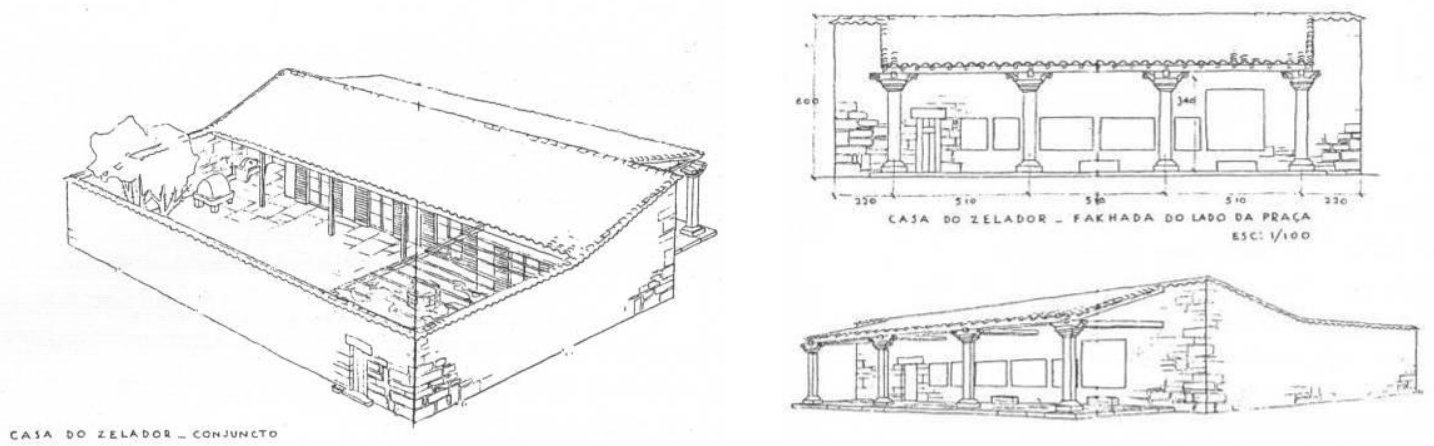

Figura 37. Casa do Zelador na hipótese 2 teria alpendrado próprio e o museu ocuparia uma das naves laterais da igreja.

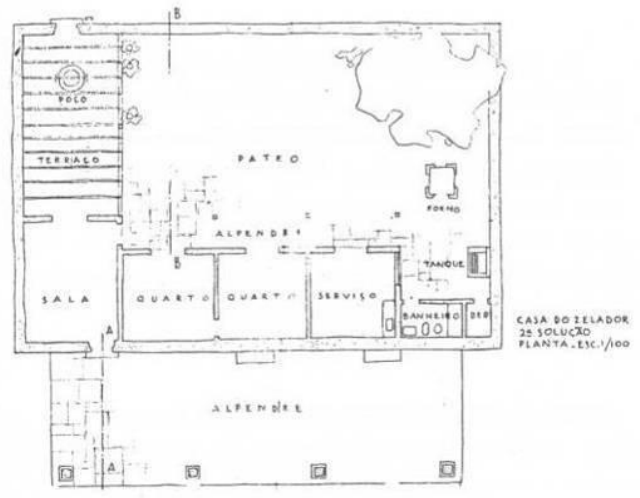

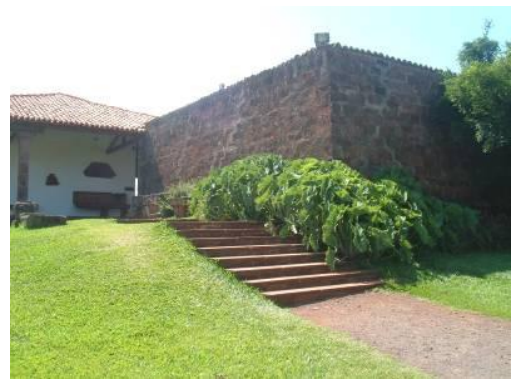

Figura 38. Junção da parede de pedras com o Museu.

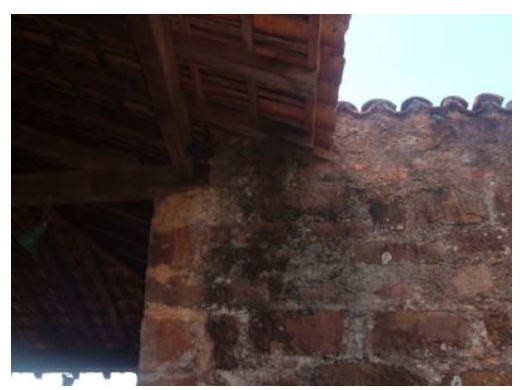

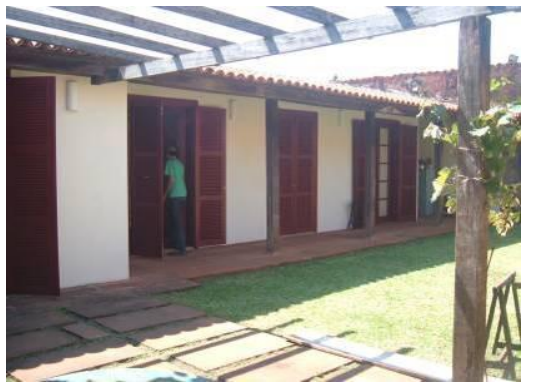

Figura 39. Pérgula que prolonga a sala do zelador até o poço.

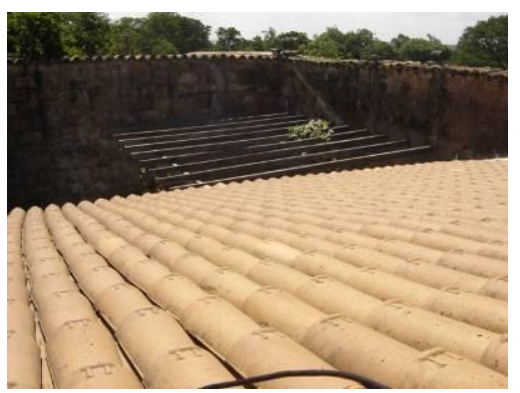

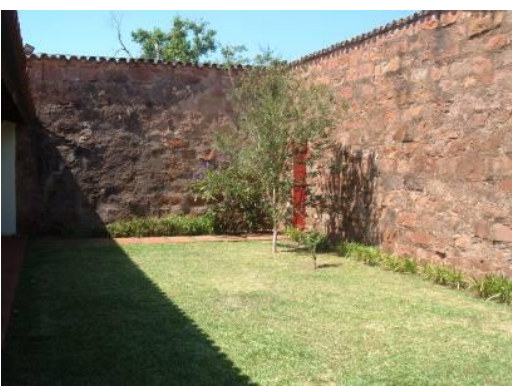

Figura 40. Pátio da casa do zelador, resguardada pelo muro de pedras.

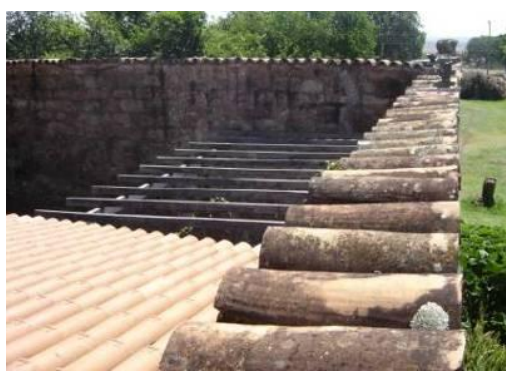



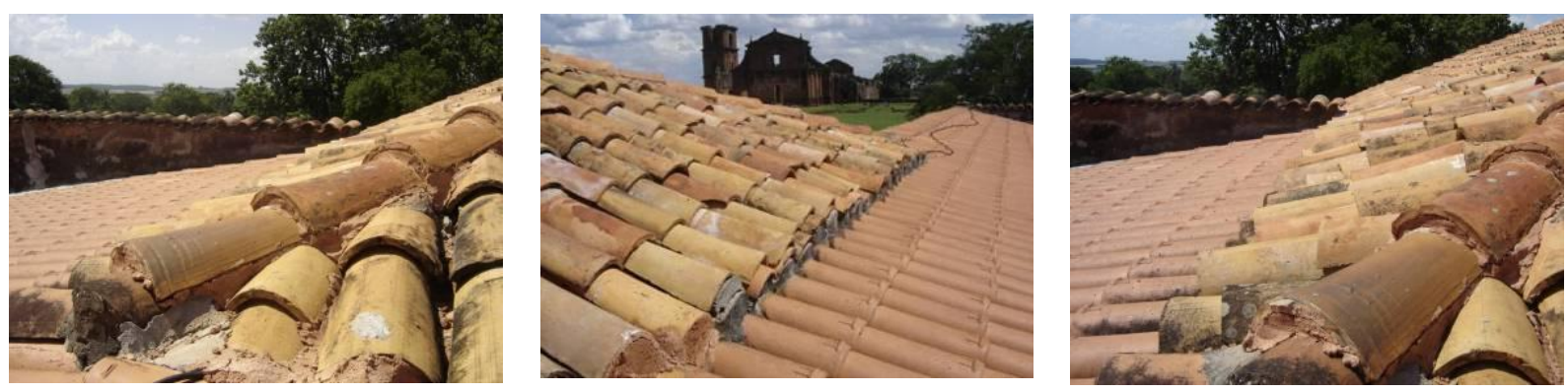

Figura 41. Várias imagens da junção do muro de pedras com telhado do alpendre do museu e das junções do telhado do museu com o telhado da casa do zelador. Vê-se que o telhado da casa foi refeito rescentemente. Mas o detalhe é de uma água contínua da tacaniça de uma das faces do museu.

E não é possível não ocorrer a lembrança do Pavilhão de Barcelona, de Mies van der Rohe, de 1929. Fig.42 A relação de transparências e continuidade do espaço, reflexões da luz, translucidez e opacidades, que o simples abrigo proporciona remetem, sem dúvidas, um ao outro. Como comentou Carrilho:

Desse modo, o sentido da transparência desta arquitetura não se limita às superfícies envidraçadas que protegem o acervo de imagens. Alíás, em sua concepção original não estava previsto fechamento de vidro. Este sentido não é, tampouco, constituído apenas de uma pretendida integração visual. A presença simultânea dos vários elementos que compõem o acervo arqueológico e artístico e o continuum visual decorrente da idéia de um “simples abrigo" geram uma superposição de sucessivos planos, nos quais já comparecem, justapostas, as imagens, peças de cantaria, a igreja e as ruínas.

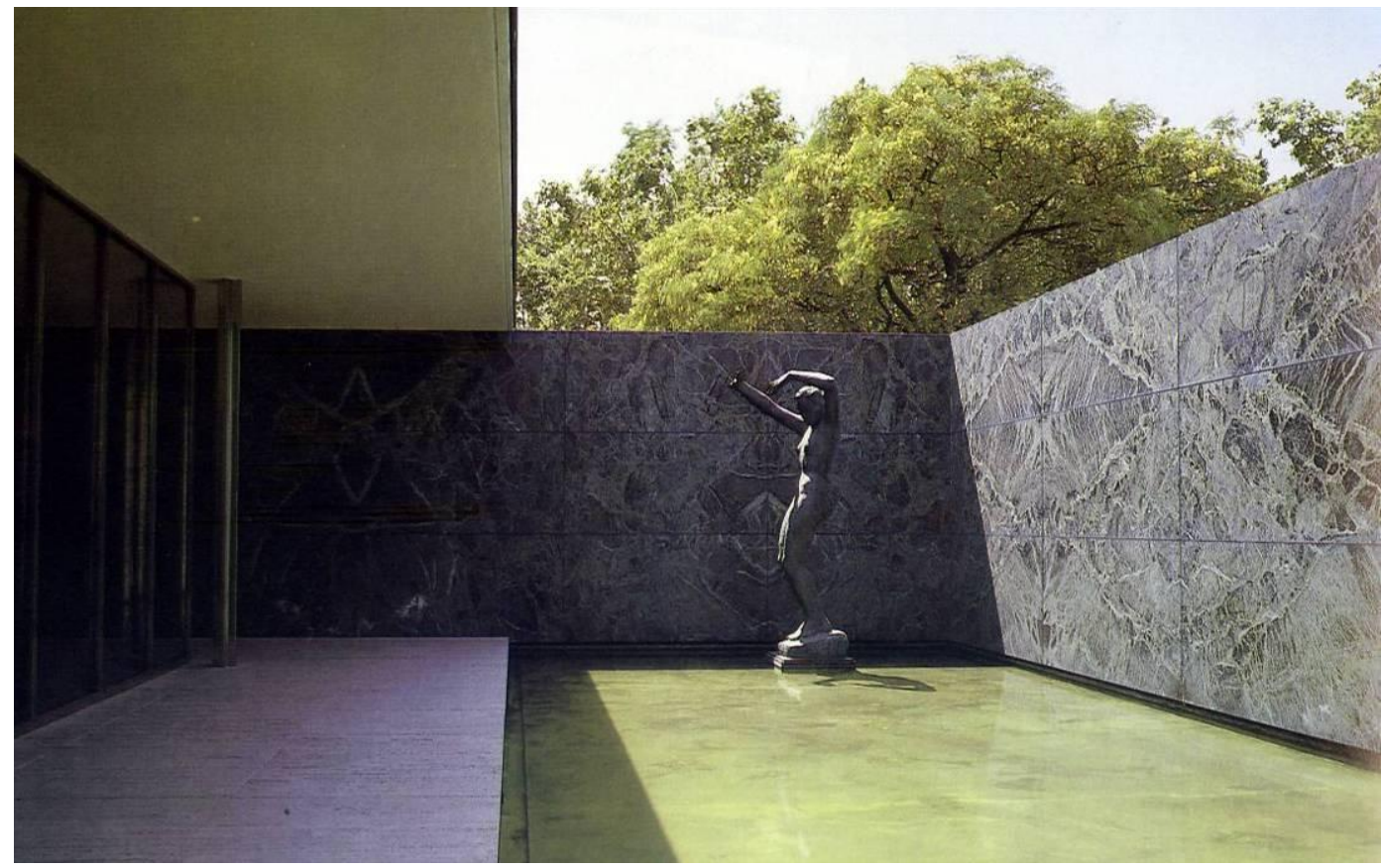

Figura 42. Pavilhão Barcelona. Mies Van Der Rohe. 
Da mesma forma, a transparência não termina no pano de vidro, nem no limite do alpendre, mas se estende além do edifício. A condição de simples abrigo significa a continuidade visual entre as peças sob a sombra e os restos expostos ao ar-livre. A distribuição de elementos escultóricos de cantaria em volta do edifício do museu intensifica e expande a percepção de planos superpostos. A integração visual prossegue através das ruínas, nas quais o espaço arquitetônico se dissolve sob a luz. A condição de ruína expõe a matéria constitutiva do edifício antes oculta sob o revestimento e revela a textura, a cor, a habilidade do artífice e o refinamento do artesanato. Até mesmo os resíduos de revestimento fazem parte desta evocação, uma vez que são vestígios do que foi o edifício e a natureza de sua arquitetura. ${ }^{12}$

Carrilho tem razão, as peças esparramadas ao redor do conjunto também dão uma sensação de despojos, de rastros, espalhadas como que perdidas, extendem o museu para um fora infinito.

Retomando, no mesmo sentido, o enfoque de Comas:

A transparência do pavilhão é capital nesse processo. Fator constitutivo da porosidade referida, ela se manifesta a norte-sul de modo tanto imediato (por um vazio) quanto mediato (por uma vidraça) e inclui, previsto no projeto o enquadramento que seleciona, recorta, aproxima e integra, a obra nova absorvendo a antiga de repente. No lugar de paredes de acesso às celas, os panos de vidro remetem a uma subtração e substituição de compartimentação opaca.(... $)^{13}$

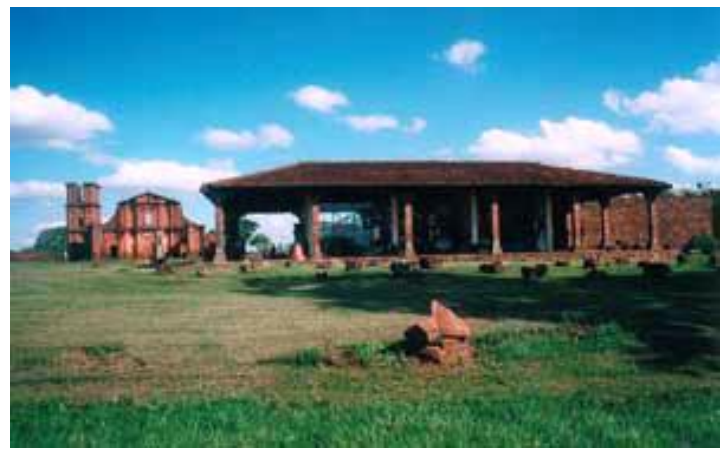

Figura 43.

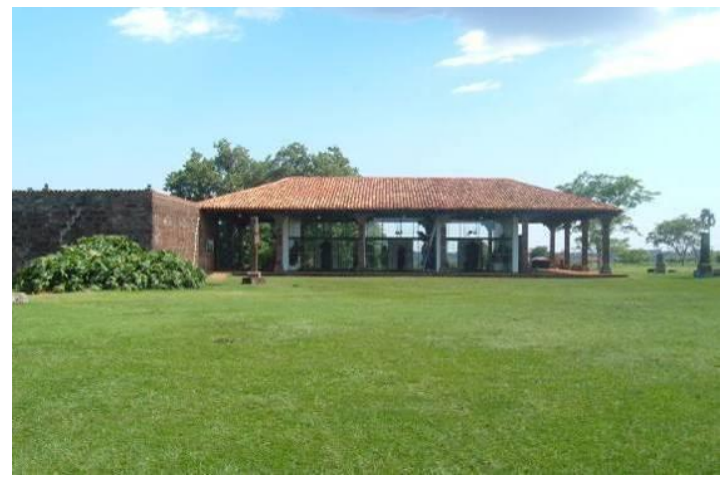

Figura 44.

\footnotetext{
${ }^{12}$ CARRILHO, M. J. A Transparência do Museu das Missões. in: $1^{\circ}$ SEMINÁRIO DOCOMOMO SUL, Porto Alegre: PROPAR / UFRGS, 2006

${ }^{13}$ COMAS, C. E. Simples abrigo, límpida ruína, modernidade real: o museu das Missões de Lucio Costa. in: $1^{\circ}$ SEMINÁRIO DOCOMOMO SUL, Porto Alegre: PROPAR / UFRGS, 2006.
} 


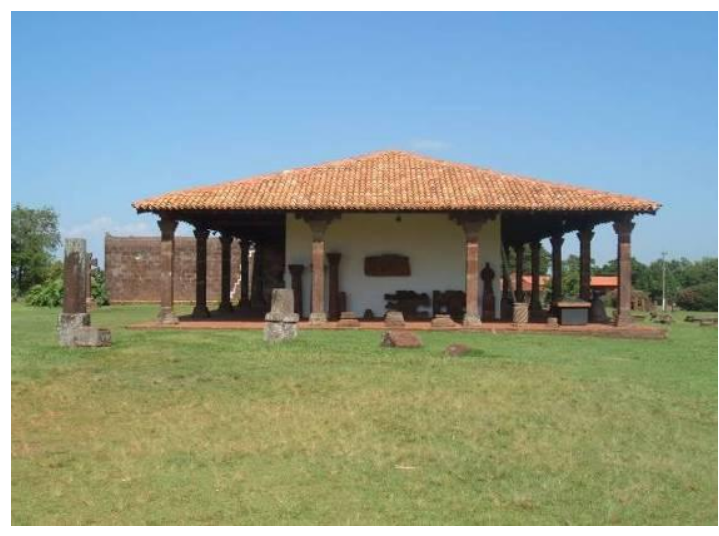

Figura 45.

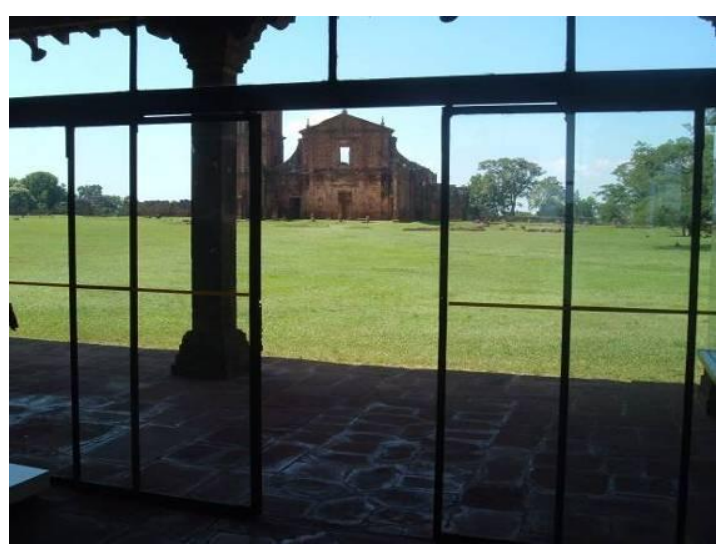

Figura 46.

\section{A CONSTRUÇÃo}

A implantação estratégica do conjunto, museu e casa do zelador, reconstitui a escala da praça, a proporção existente no antigo conjunto urbano, cheio de indiozinhos brincando. Sua implantação em "L", anexando a casa do zelador do museu, demarca, em relação à posição da catedral, o tamanho da antiga praça central do povoado, revelando a origem e o significado "urbano" do projeto do edifício. ${ }^{14}$ A posição Noroeste, em relação à fachada da catedral, dessa implantação também é algo notável: surge uma diagonal na praça, ligando a torre única do lado esquerdo e o conjunto novo do lado direita, equilibrando pesos numa abstrata e imaginária simetria. Caso o conjunto fosse implantado no lado Nordeste, a "indicação" do quadrilátero da praça seria dissolvida, é como se a torre única funcionasse como pivô, ponta seca de um compasso, uma espécie de âncora.

\footnotetext{
${ }^{14}$ WISNIK, G. Plástica e anonimato: modernidade e tradição em Lucio Costa e Mário de Andrade. Scielo. São Paulo: Novo Estudos / CEBRAP, n. 79, nov. 2007. Disponível em: <http://www.scielo.br/scielo.php?pid= S0101-33002007000300009\& script=sci_arttext $>$. Acesso em: 28 jul. 2009.
} 


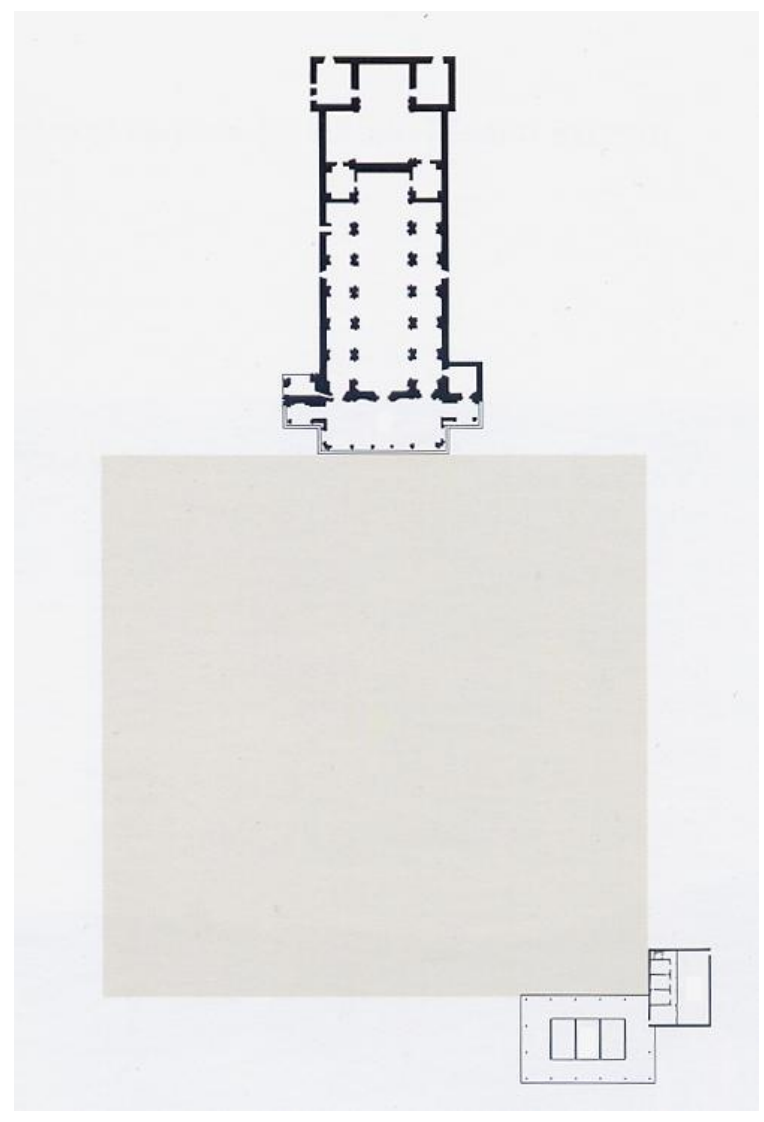

Figura 47.

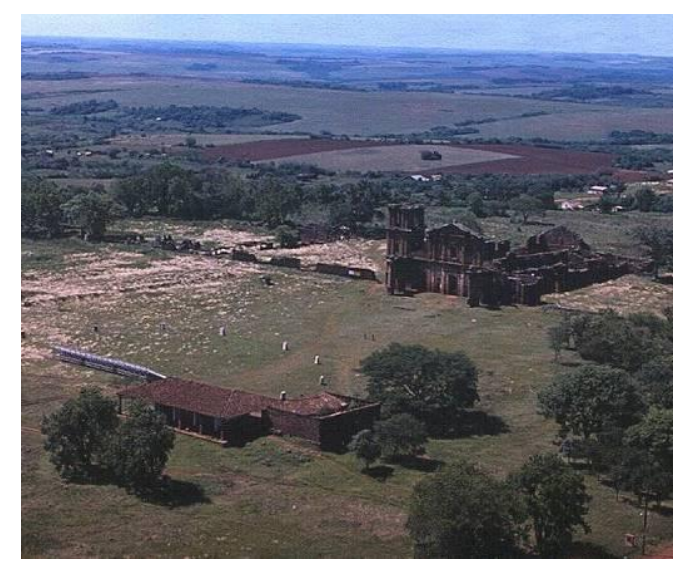

Figura 48.

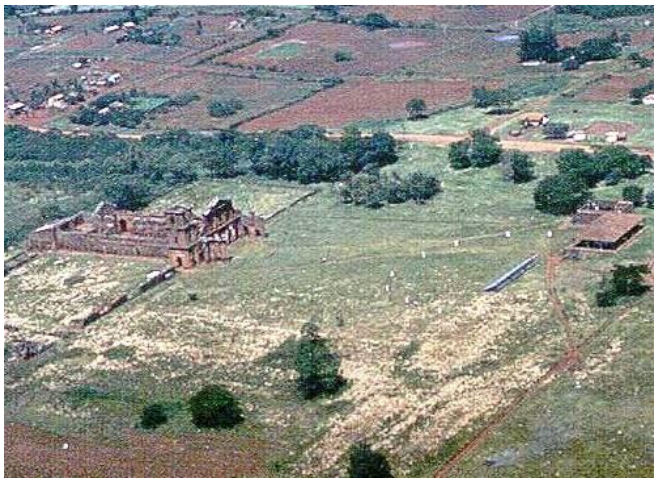

Figura 49.

Lucas Mayerhofer assim descreve as obras:

O Museu das Missões foi projetado pelo engenheiro arquiteto Lucio Costa. Tinha-se em vista uma construção simples, destinada a servir de abrigo às peças recolhidas das diversas regiões missioneiras e que ao mesmo tempo, representasse a reconstituição de alguns elementos do antigo passeio alpendrado que se desenvolvia ao longo das casas dos indígenas.

Está situado no ângulo NO da praça de São Miguel e consta de três secções ou compartimentos, limitados em dois dos seus lados por paredes paralelas, abrindo-se nos outros dois para um largo alpendre que faz a volta do edifício. É coberto por um telhado de quatro águas, cujo madeiramento se apóia nas empenas das quatro paredes paralelas e nos pilares das varandas. 


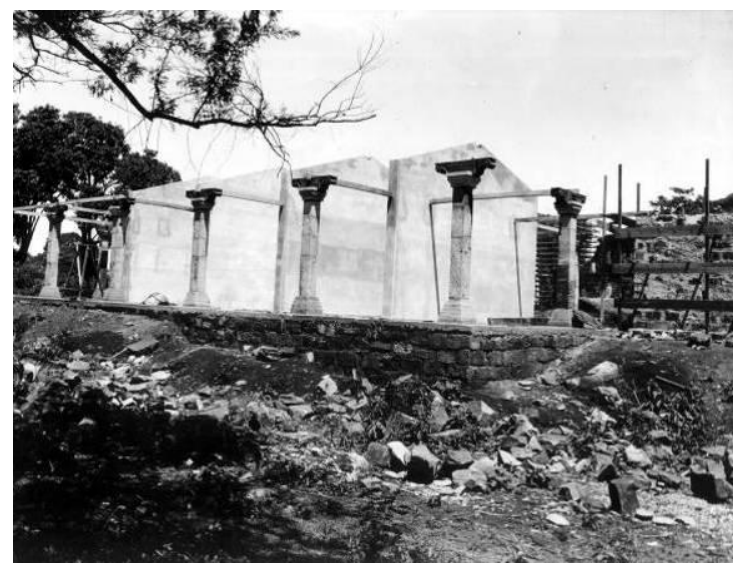

Figura 50. O museu em obras.

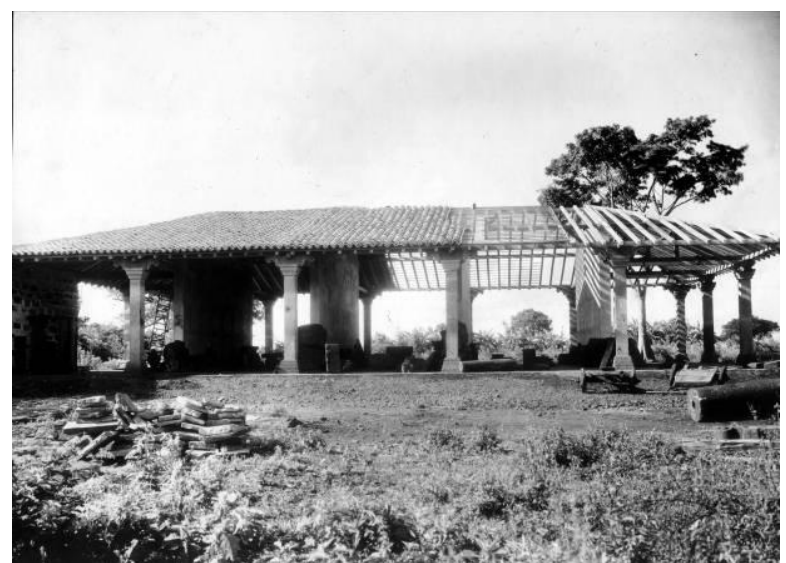

Figura 51.

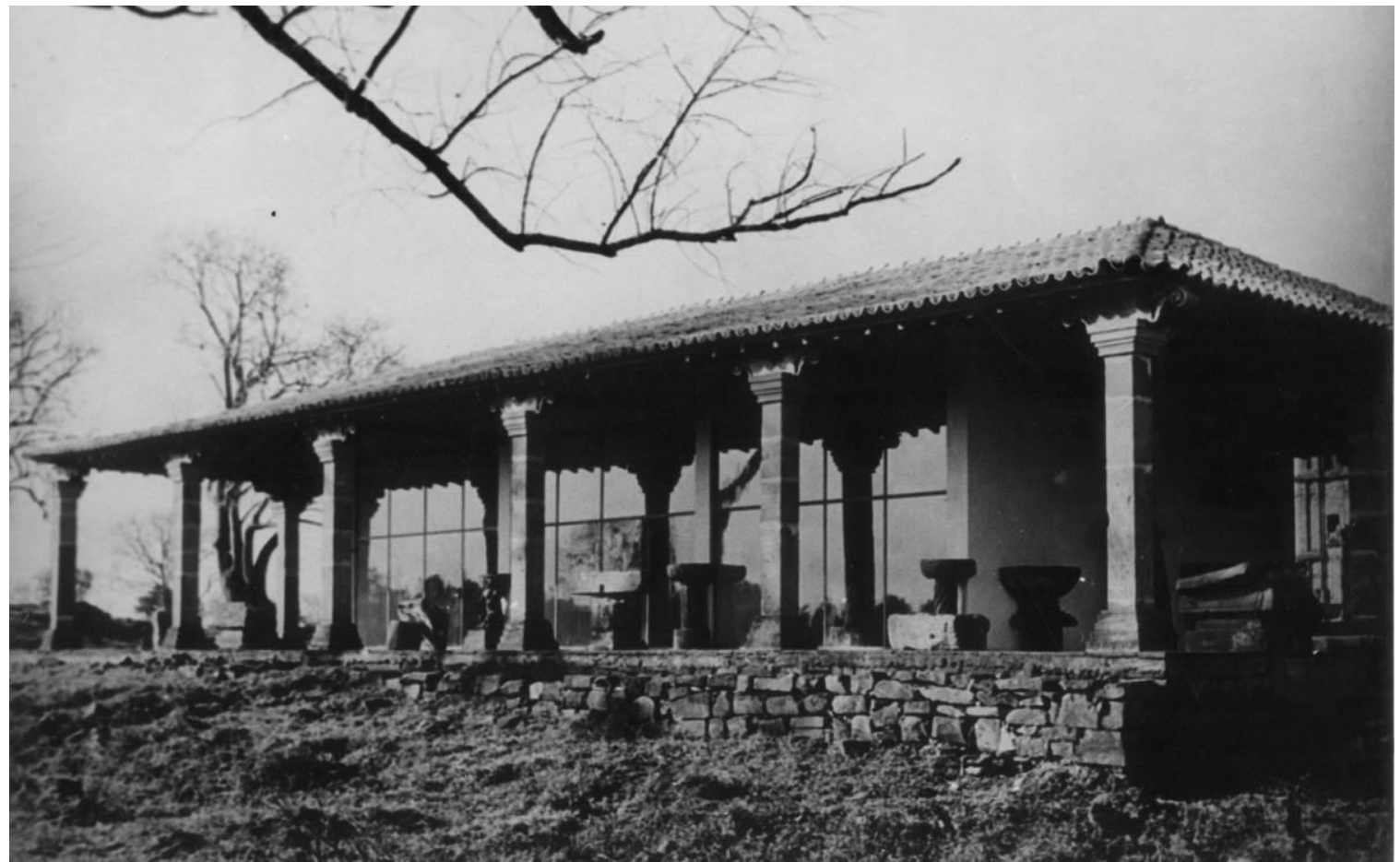

Figura 52.

Anexo ao museu, foi prevista a residência do zelador, constando de vários compartimentos, abrigados dentro dos muros de um pátio. (...)

As quatro paredes do museu, bem como o muro da casa do zelador, foram construídas de alvenaria de pedra; as paredes desta última de alvenaria da tijolo. As paredes do museu e da casa do zelador foram revestidas e caiadas, ficando sem revestimento o muro da casa. 


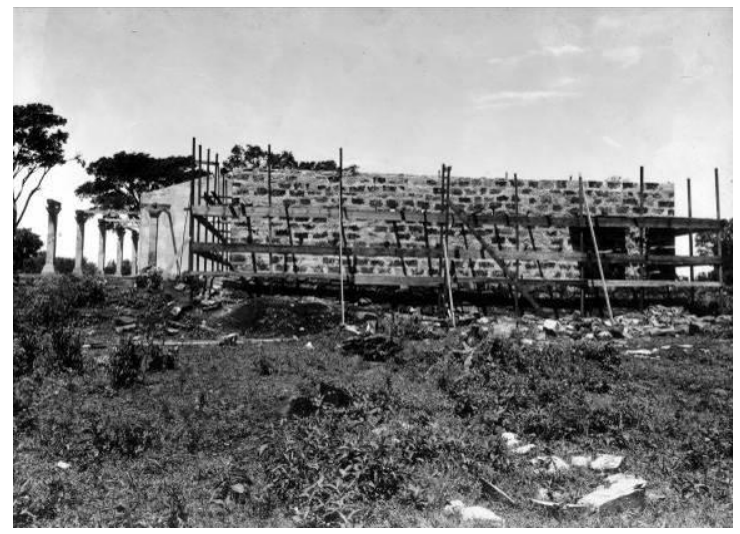

Figura 53.

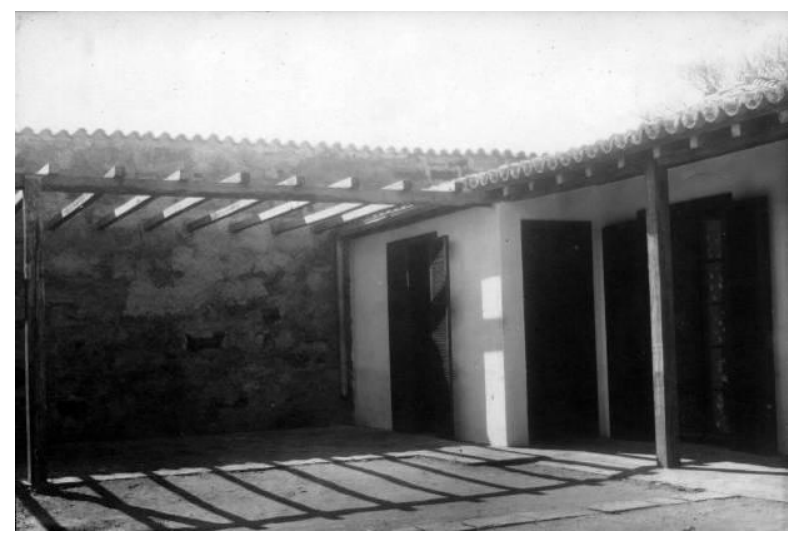

Figura 54.

$O$ autor do projeto aconselhara o aproveitamento de colunas monolíticas e de consolos de madeira que pertenceram ao Colégio do Povo de São Luiz. Dessas colunas encontramos apenas uma completa, e cinco bases. Em São Miguel deparamos, porém com bases em grande quantidade e alguns capteis; aproveitamos essas bases e capteis para o museu, e construímos os pilares com pedras das ruínas, em várias secções. Dos consolos do Colégio de São Luiz, em pequeno número e de tamanhos diferentes, conseguimos aproveitar um, e mandamos fazer todos os outros, de madeira de lei.

Repare-se na estranheza dos consolos quando nos cantos do telhado de 4 águas, eles são os mesmos consolos quando em linha contínua do beiral. Provavelmente não se encontrou nenhuma peça de canto de espigão.

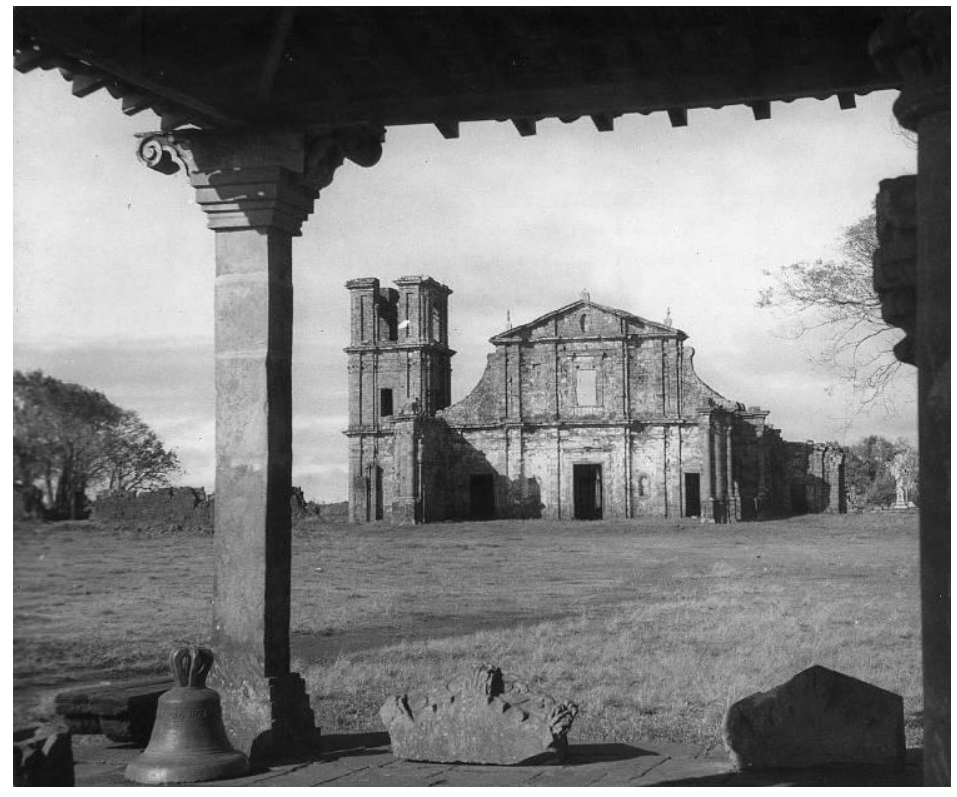

Figura 55 .

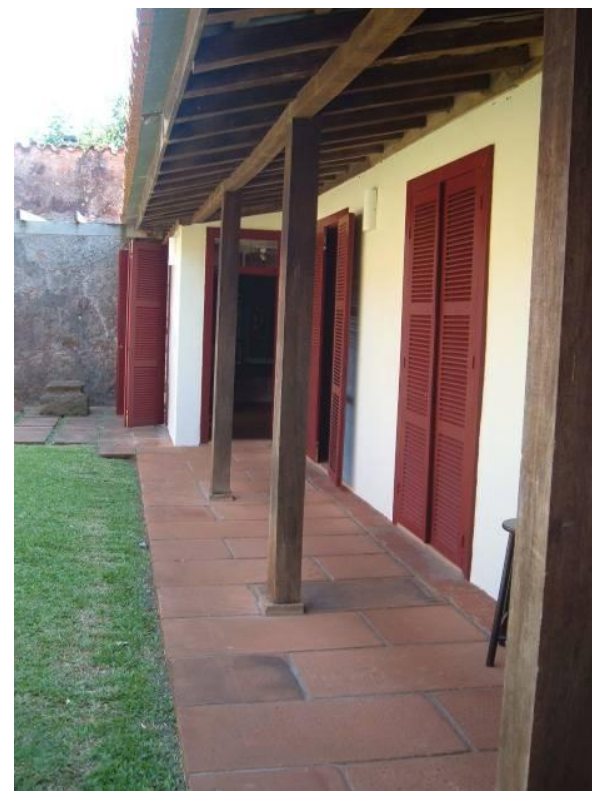

Figura 56. 
No madeiramento dos telhados, e nos forros, soalhos e esquadrias da casa do zelador, foram empregadas as melhores madeiras da região: louro, cabiúna, ipê.

Para o piso do museu não conseguimos nas ruínas quantidade suficiente de lajes de pedra. Com as que recebemos das ruínas do Povo de São João e com as de São Miguel só pudemos cobri 1/6 da área. Completamos o piso com lajes que fomos buscar a 18 quilômetros, na mesma pedreira que fora explorada pelos jesuítas.

Novamente Mayerhofer agiu bem, utilizou as pedras "usadas", retiradas das ruínas para formar "tapetes" centrais aos 3 compartimentos do museu, prezando seu formato e assentamento e completou em volta dos "tapetes" com as pedras "novas", mantidas com formato irregular e assentadas como opus incertus, deixando então bem marcada a diferença.

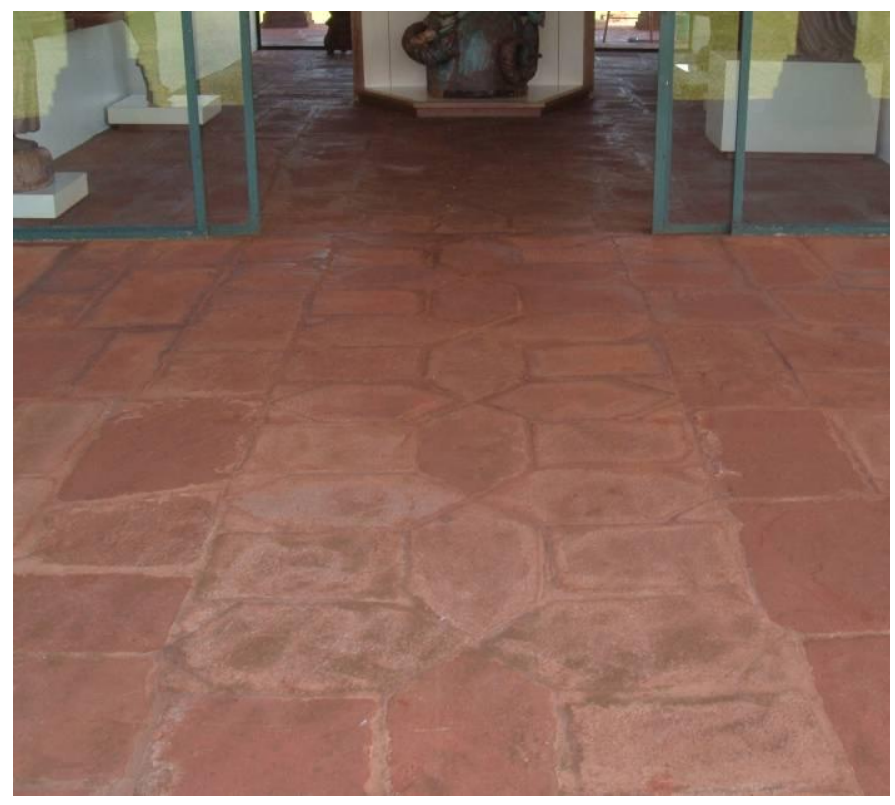

Figura 57.

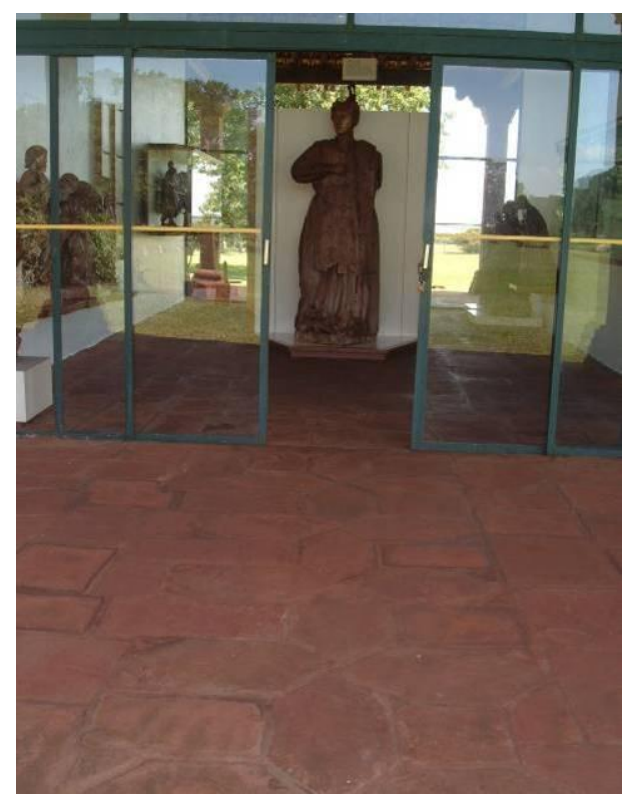

Figura 58.

Como disse Carrilho, acima, não estava prevista a colocação das esquadrias com vidros como fechamento dos topos dos compartimentos. Também em Comas:

$O$ aumento do número de imagens recolhidas durante a construção e a reconsideração das suas condições de abrigo leva a fechar os três compartimentos do museu com grandes vidraças, que não alcançam a altura da cobertura e incluem partes fixas $e$ portes de correr. Os perfis metálicos utilizados para os caixilhos proporcionam a máxima transparência e máximo contraste com a alvenaria, a madeira e a pedra. 
Por algum tempo suspeitamos que o projeto previa os caixilhos e que com a insipiente indústria de vidros no Brasil - nesse período não se fabricava vidros planos no país, só vidros para embalagens e copos rudimentares - eles teriam demorado a chegar até São Miguel, dificuldades de transporte inclusive, nessa hipótese. Só depois da investigação acerca dos "tapetes" de Mayerhofer é que nos deparamos com o detalhe do trilho guia sob o caminho da porta de correr, que demonstra não só a instalação posterior, como a não previsão da sua instalação.

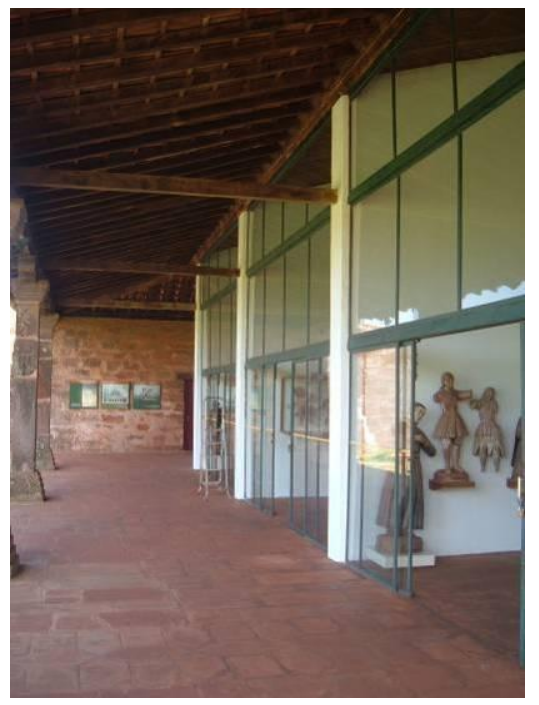

Figura 59.

E trabalho se completa:

A colocação das grandes peças - fragmentos de Arquitetura e Escultura, de pedra -, algumas pesando três toneladas, exigiu alicerces especiais, que foram construídos sob o piso de lajes.

Do lado externo e também sobre alicerce conveniente, colocamos a cruz de dois braços que se trasladara de Santo Ângelo.

Não foi, entretanto apenas para a reconstituição do alpendrado destinado ao museu que procuramos reunir o maior número possível de elementos originais. Terminada a construção, e por determinação do Serviço do Patrimônio Histórico e Artístico Nacional, procedemos a buscas em toda a região dos Sete Povos, afim de recolher ao museu os elementos de Arquitetura e peças de Escultura porventura subsistentes.

Graças à intervenção de S. Excia. Revma. D. Hermeto José Pinheiro, Bispo de Uruguaiana, conseguimos obter as melhores peças que se encontravam nas igrejas de Santo Ângelo, São Lourenço e São Luiz.

Grande foi o número de imagens encontradas em poder de particulares, os quais acederam patrioticamente na sua entrega, por solicitação nossa. 
As imagens e fragmentos esculpidos recolhidos ao Museu das Missões representam um patrimônio artístico de grande valor.

Como vimos, o Seu João Hugo Machado era o zelador das ruínas e passou a habitar a casa do zelador, junto ao museu. Foi sucedido pelo seu filho, até que, com a instalação do escritório técnico do Iphan, a casa ficou desabitada. Consta, como vimos, que Seu Hugo tinha uma carta do próprio Presidente Getúlio Vargas autorizando-o a confiscar as peças requisitadas e que, para encontrá-las, ele se fazia passar por um mero devoto, atrás de orações a determinados santos, usando desse artifício para descobrir onde as peças se encontravam. Ficou totalmente imbuído do "cargo", por assim dizer. Consta também que Seu Hugo "arrastava" as esculturas para fora, a pedido de turistas que se desejavam fotografar ao lado das peças, o que lhe rendeu uma dura carta do Ministro Capanema proibindo que o fizesse.

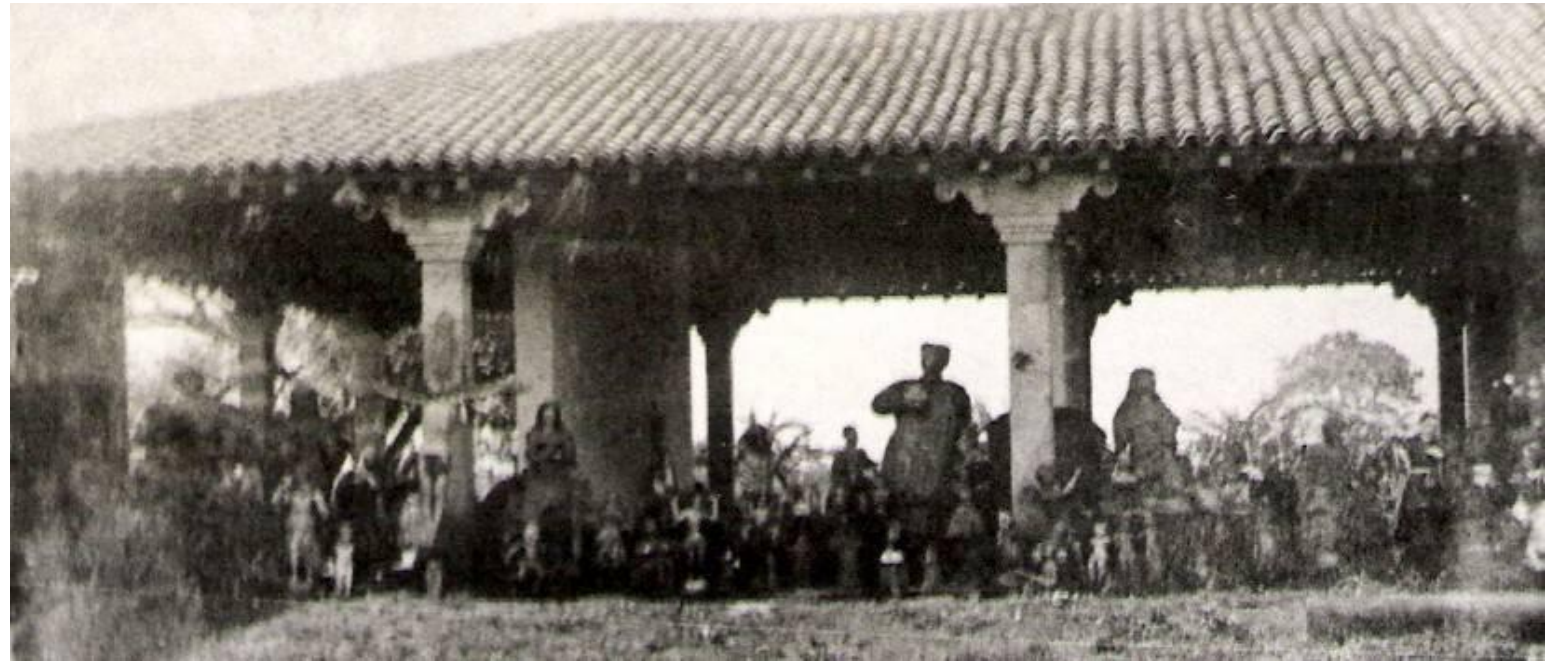

Figura 60.

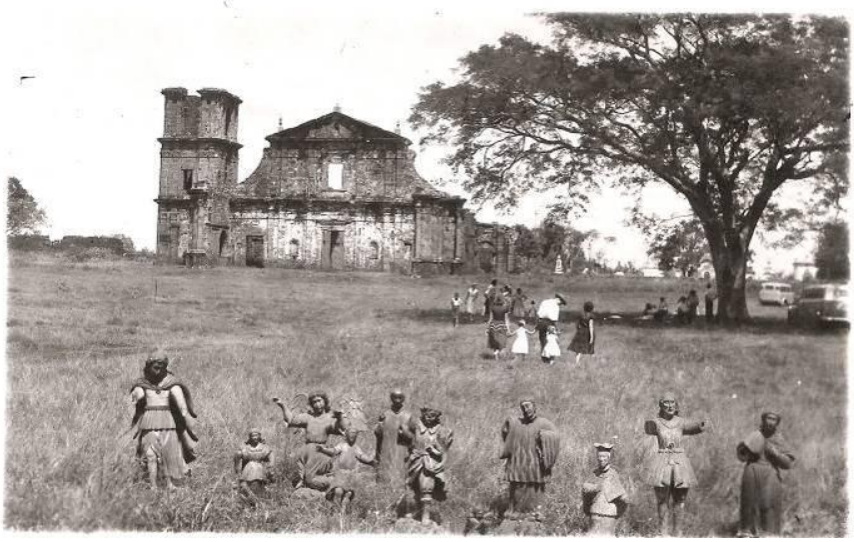

Figura 61.

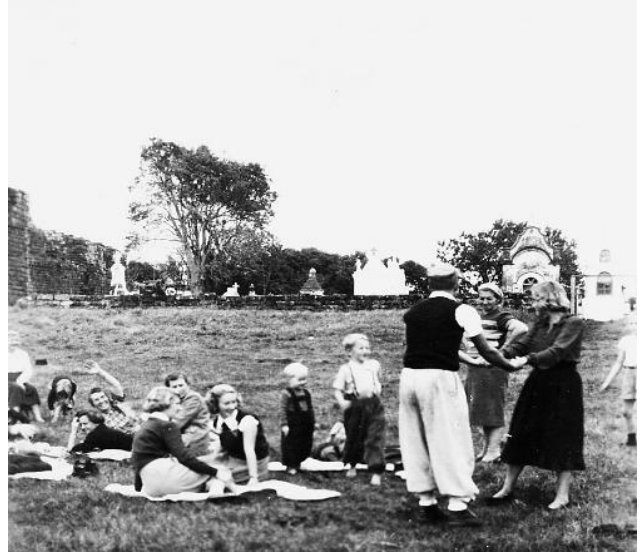

Figura 62.

Uma visita ao Pavilhão Lucio Costa, tal como é chamado hoje em dia o Museu das Missões, o pequeno abrigo, revela-se fundamental para a re-afirmação de uma sensação antes só percebida na visão de fotografias. O Museu é absolutamente justo, ajustado 
que está a todas as circunstancias aqui descritas, urbana, paisagística, arquitetônica e histórica.

Arrancou elogios desde a publicação de "BRAZIL BUILDS", de 1943, elogios que se estendem ao SPHAN, uma entidade absolutamente pioneira em trabalhos de preservação de patrimônio nas Américas. Conforme vimos, o acertado dessa empreitada se deve também a uma somatória de acontecimentos fortuitos e seqüenciais, graças à participação de profissionais empenhados, voluntariosos e imbuídos da grande importância do trabalho que estavam realizando.

Diversamente da atitude predominante na época, que possivelmente teria destinado todo o acervo a algum museu nacional consagrado, o arquiteto percebeu a importância de relacionar as obras de arte com o local em que foram produzidas, de forma a permitir ao visitante, em face da forte impressão que elas causam, reconstituir, na imaginação,o que possa ter sido a vida nesses "povos". 15

O acertado dessa empreitada vai ainda mais além:

Em qualquer das propostas, Lucio sugere uma anastilose dos blocos residenciais de São Miguel, a recomposição de partes existentes das ruínas, porém desmembradas ou deslocadas de sua posição original. Trata-se de estratégia que a Carta de Atenas considera obra feliz na lida com ruínas e é a alternativa aconselhada pela terceira recomendação da Carta Italiana, no caso de monumentos antigos longínquos de nossos usos e de nossa civilização. ${ }^{16}$

Foi uma saga, empreendimento inédito, pioneiro de nossa arquitetura moderna, assim como foi uma grande epopéia a história da República Jesuítica dos Guaranis. Poucas obras tocam tão profundamente assim, aos olhos não desavisados. Impressiona pelo vasto conteúdo, que está para além das peças juntadas sob o simples - pequeno - abrigo, emociona, transcende a sensação da materialidade de se sentir em São Miguel, sob seu sol escaldante, sua luz intensa, a linha do horizonte se esvaindo de e em ar, em todas as direções, o mito perdido do paraíso na terra, o lugar feliz...

Para um museu à primeira vista tão modesto, é um bocado de história. Nas suas formas há, definitivamente, mais do que o olho encontra. ${ }^{17}$

Um elegantíssimo desbravador, que carrega para as novas terras desbravadas a cultura de seu trajeto.

\footnotetext{
${ }^{15}$ GOODWIN, P. L. Brazil Builds: Architecture new and old 1652-1942. New York: The Museum of Modern Art, 1943.

${ }^{16}$ COMAS, C. E. Simples abrigo, límpida ruína, modernidade real: o museu das Missões de Lucio Costa. in: $1^{\circ}$ SEMINÁRIO DOCOMOMO SUL, Porto Alegre: PROPAR / UFRGS, 2006.

${ }^{17}$ COMAS, C. E. Simples abrigo, límpida ruína, modernidade real: o museu das Missões de Lucio Costa. in: $1^{\circ}$ SEMINÁRIO DOCOMOMO SUL, Porto Alegre: PROPAR / UFRGS, 2006.
} 


\section{SESC - Fábrica da Pompéia}

\section{(...) Todavia o que me encantou foi a elegante e precursora}

estrutura de concreto. Lembrando cordialmente o pioneiro Hennebique, pensei logo no dever de conservar a obra.

Foi assim o primeiro encontro com aquela arquitetura que me causou tantas histórias, sendo conseqüência natural ter sido um trabalho apaixonante.

Na segunda vez que lá estive, um sábado, o ambiente era outro: não mais a elegante e solitária estrutura Hennebiqueana, mas um público alegre de crianças, mães, pais, anciãos passava de um pavilhão a outro. Crianças corriam, jovens jogavam futebol debaixo da chuva que caia dos telhados rachados, rindo, com os chutes da bola na água. As mães preparavam churrasquinhos e sanduíches na entrada da Rua Clélia; um teatrinho de bonecos funcionava perto da mesma, cheio de crianças. Pensei: isso tudo deve continuar assim, com toda esta alegria.(...) ${ }^{1}$

Assim Lina abre seu texto explicativo dos trabalhos no SESC Fábrica da Pompéia, escrito depois que seu trabalho lá tinha sido bruscamente interrompido - foi um texto escrito para divulgação na imprensa em geral, já que foi bastante procurada para entrevistas, na época. E em apenas quatro parágrafos, cita a estrutura hennebiqueana por duas vezes. Embora o público de um modo geral tenha se encantado pela utilização daqueles galpões, com a intensa luz natural provinda, originalmente apenas dos sheds, mas aumentada em intensidade por Lina, que transformou a água curta do telhado em fonte de luz também, utilizando telhas de vidro, e também pelo confortável espaço existente, que vem de um vão de 14 metros, vencido pelas elegantes tesouras em madeira, Lina estava se referindo à estrutura de concreto, que sustenta essas tesouras; E é essa estrutura que ela chama de elegante - pela importância, e, à época, solitária - pelo abandono.

Somente a um arquiteto com a consistência de formação técnica de Lina, o perfeito entendimento daquilo que se estava vistoriando não passaria despercebido. Pelo contrário, é dali que se afere o valor intrínseco ao objeto mesmo, seja para uma avaliação puramente técnica, seja para a análise filológica e vinculada à valoração de patrimônios.

O engenheiro francês François Hennebique foi um dos pioneiros do cálculo em concreto armado, tendo patenteado seu sistema na Bélgica e realizado inúmeras obras de infra-estrutura, destacadamente pontes. Com seu sistema, abriu também uma construtora, que executou obras em diversas partes do mundo. Concorreu no campo tecnológico com o engenheiro suíço Robert Maillart - com quem havia realizado obras em conjunto - e com seu compatriota, o engenheiro Eugène Freyssinet, este mais bem sucedido técnica e empresarialmente, pois sua patente em concreto

\footnotetext{
${ }^{1}$ BARDI, L. B. Lina Bo Bardi. Marcelo Carvalho Ferraz org. São Paulo: Instituto Lina Bo e P. M. Bardi, p. $220,1993$.
} 
protendido, ainda é de uso corrente até hoje e, até por isso mesmo, é o engenheiro mais conhecido dos três. ${ }^{2}$

As idéias de Hennebique no desenvolvimento da história do cálculo em concreto armado diferenciam-se das de seus pares, propondo um sistema de travamento com peças mais delgadas, mas que, separadas entre si a distâncias precisas, forneciam os engastes suficientes, seja para maior esbelteza dos pilares, considerando-se uma mesma carga - as travas encurtam as distâncias verticais onde os pilares ficariam soltos - seja para o enrijecimento do conjunto todo. (fig. 1 a 5)

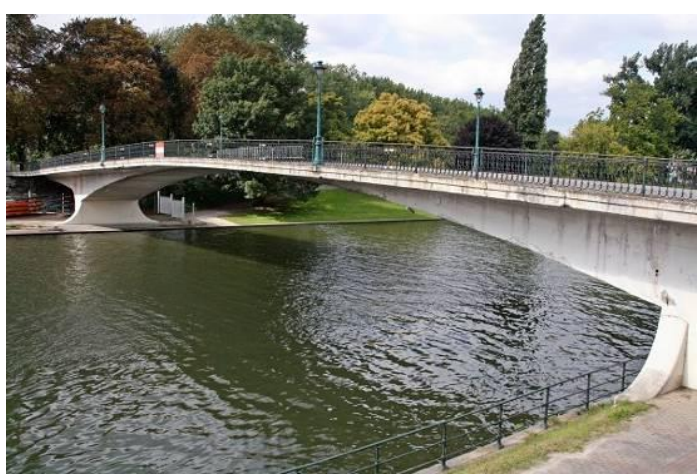

Figura 1. Mativa Footbridge. Liège. 1905.

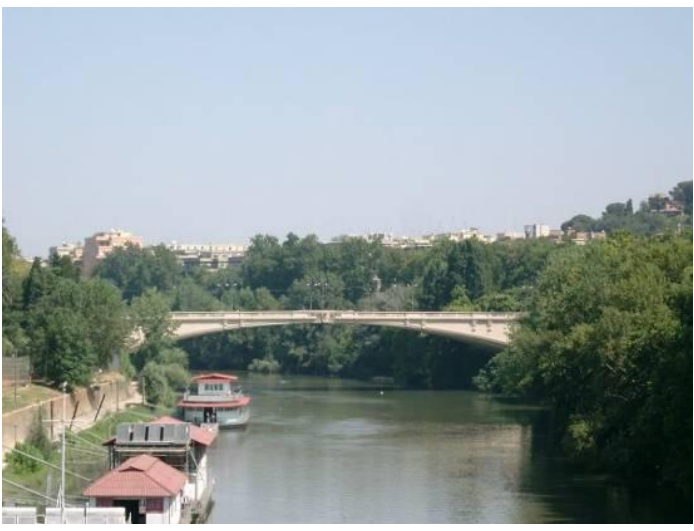

Figura 3. Ponte Del Risurgimiento. Roma. 19101911.

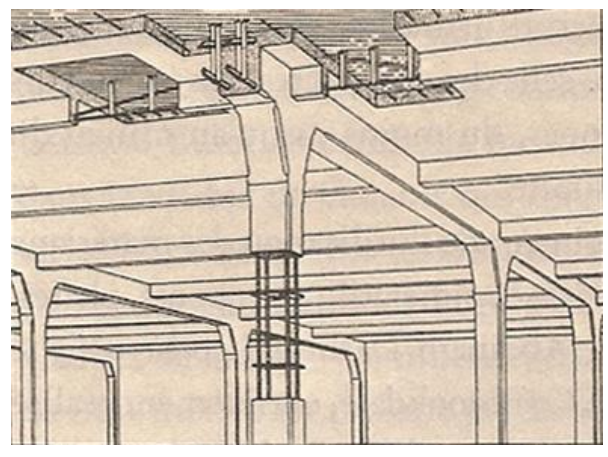

Figura 5. Esquema de uma estrutura proposta por Hennebique: note-se a importância dada aos estribos.

\footnotetext{
${ }^{2}$ DESWARTE, S.; LEMOINE, B. L'architecture ET lês ingénieurs, deux siècles de construction. Paris: Groupe Moniteur, p. 32, 54 e 57, 1997.
} 
Como sempre exigia Lina em suas obras que contavam com construções já existentes, de valor patrimonial ou não, foi realizado um laudo pericial das condições estruturais da velha fábrica, que concluiu estar em perfeito estado, como ela sempre referia. Para o laudo foram extraídos mecanicamente corpos de prova da estrutura em concreto e deu-se a primeira surpresa: a armadura em aço dos pilares tinha como principal posição e bitolas a dos estribos, sendo a armadura longitudinal tratada como secundária. A segunda surpresa foi que, quando se abriram as valas de inspeção das fundações, não se encontrou nenhum baldrame que unisse os pilares abaixo do piso acabado, demonstrando que o conjunto funcionava através do travamento duplo de cima, formando um porticado.

O parecer resultante, comprovando o perfeito estado da estrutura, foi realizado pela empresa Figueiredo Ferraz, cujo engenheiro fundador, José Carlos de Figueiredo Ferraz, tinha sido o responsável pelo cálculo do MASP - Lina trabalhou também com Pier Luigi Nervi, no projeto Taba Guayanazes, mas a tradição dela sempre trabalhar com grandes engenheiros continua. Porém Lina sempre continuou contando com seu corpo técnico, principalmente com o Engenheiro Roberto Carvalho Rochlitz. Foi também essa empresa que realizou os demais cálculos estruturais para todo o conjunto do SESC, sejam as intervenções nos galpões existentes, seja para o conjunto novo. Os engenheiros da Figueiredo Ferraz comprovaram que se tratava de um método diferenciado de cálculo de armadura, muito provavelmente o método hennebiqueano. Como se pode comprovar nas imagens que se seguem, a estrutura da velha fábrica realmente não passaria em branco por Lina.

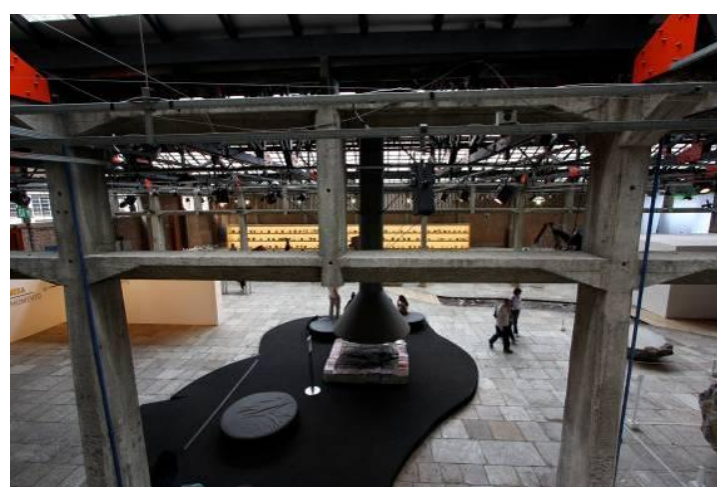

Figura 6. Estrutura de concreto armado em detalhe.

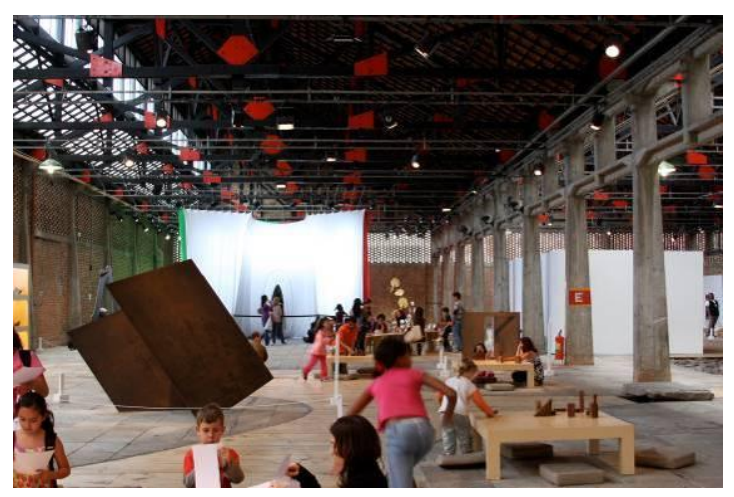

Figura 7. Sequência da estrutura de concreto armado, porticada por cima. 


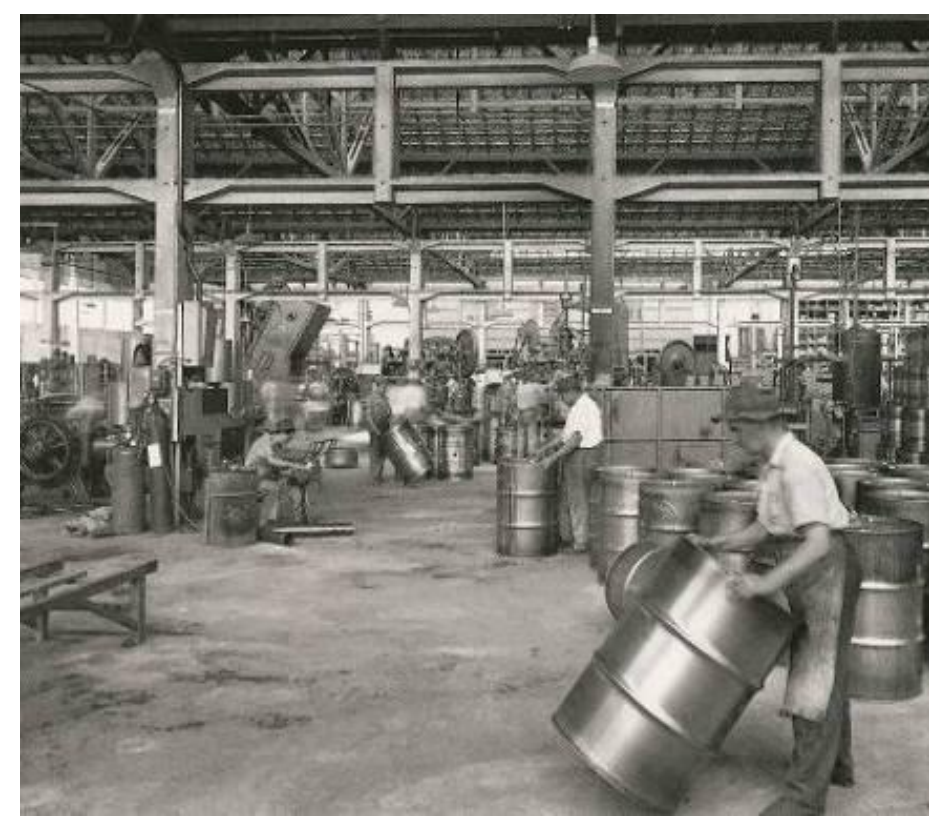

Figura 8. Antiga fábrica de tambores e sua elegante estrutura hennebiqueana. (anos 40)

Esse parecer foi fundamental para o desenvolvimento de alguns itens de projeto, com grande interferência da intervenção nova sobre o existente, como particularmente nas galerias laterais do Teatro, que parecem agarradas ao antigo corpo daquele galpão. Sua estrutura, cujo corte é em forma de "C", conta com reforços junto aos pilares que lhes conferem a aparência de contrafortes - ou gigantes. As fundações novas também foram feitas solidarizando as cargas da estrutura já existente com as novas provindas das galerias.

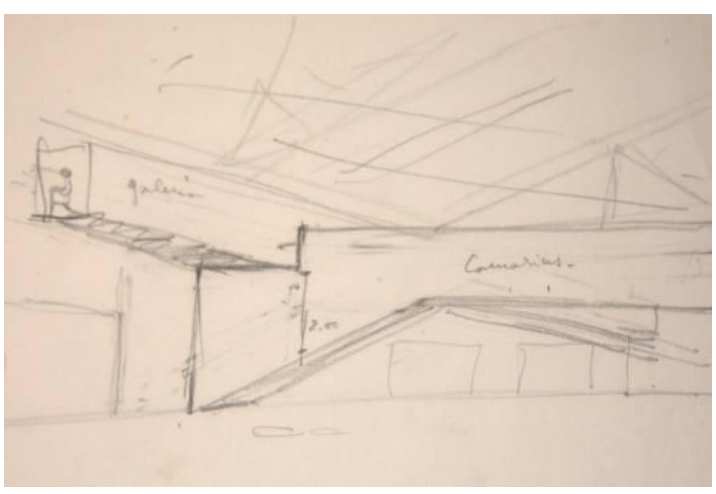

Figura 9. Croqui de Lina para o Foyer do Teatro.

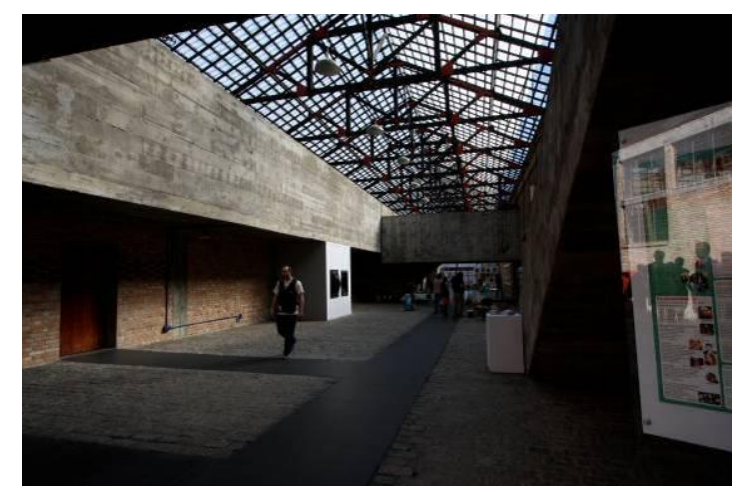

Figura 10. Foyer do Teatro e acesso às Galerias. Contraluz, que mascara o vermelho dos reforços, que permite ver melhor as tesouras, sem as novas interferências. 


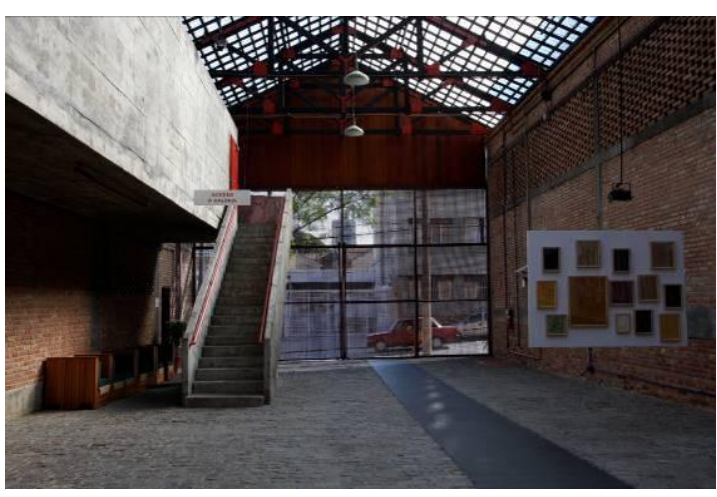

Figura 11. Detalhe do acesso às Galerias. Ao fundo a Rua Barão de Bananal, que aparece bem através da treliça pela larga exposição da foto.

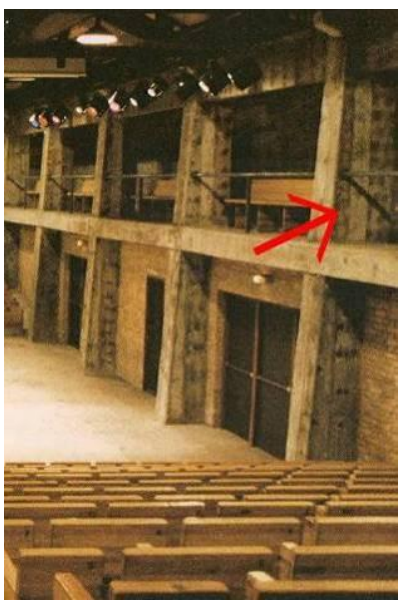

Figura 13. Vista dos pilares do Teatro: em tom mais claro, o pilar original, e os reforços, mais escuros e com a forma marcada no concreto, inclusive os nós da madeira de forma.

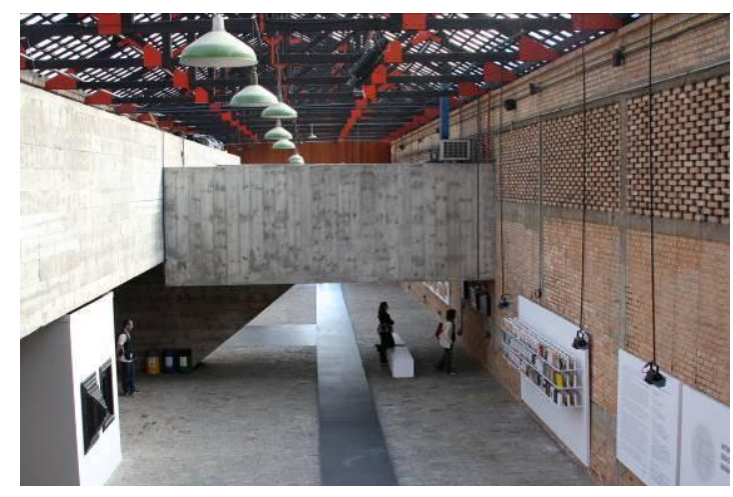

Figura 12. Vista do Foyer. Galerias e Camarins. O atual reforço das tesouras, pelos nós, ficou excessivo, parecendo uma decoração.

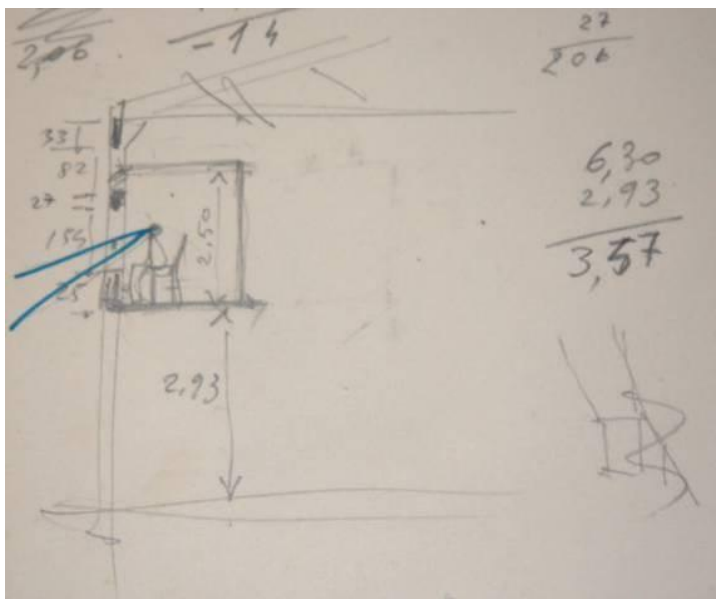

Figura 14. Croqui da Galeria do Teatro, em forma de "C", engastada na antiga estrutura existente.

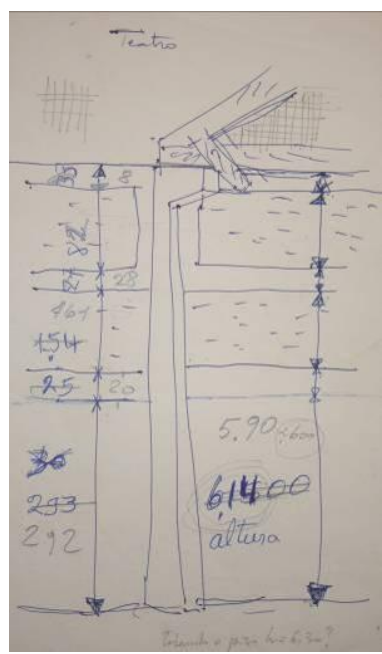

Todos os croquis de trabalho de Lina apresentam inúmeros cálculos e contas para o perfeito ajuste do projeto. Referem-se às escadas, pésdireitos, ângulos de visibilidade, e demais cuidados técnicos.

A estrutura em madeira das tesouras, com seus 14 metros de luz, também estavam na grande maioria em bom estado, e sua elegância provém da sábia diferenciação das bitolas: peças comprimidas e peças tracionadas são nitidamente diferenciadas, com seções adequadas aos diferentes esforços, uma a uma, peça por peça. Naquele período essas estruturas eram realizadas, em geral, sem cálculo, por 
carpinteiros práticos, porém extremamente conhecedores do ofício. Em São Paulo, os bons carpinteiros telhadistas eram imigrados, em geral alemães, mas tem-se notícia de um grupo de russos, parentes entre si, possivelmente pai e filhos.

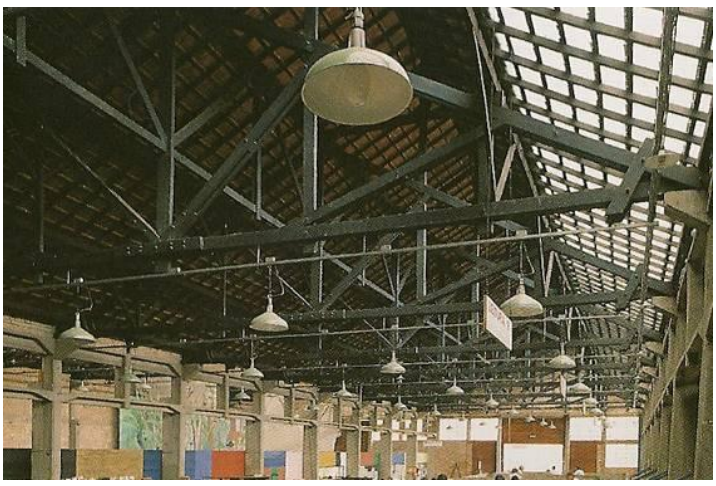

Figura 16. Tesouras de madeira, com as barras tracionadas bem diferenciadas das comprimidas muito elegantes, sem o reforço excessivamente presente de hoje em dia.

Algumas tesouras do Teatro apresentavam flambagem nas peças comprimidas, principalmente as pernas, problema que se agravaria com o aumento de carga que passaria a vir do tratamento acústico e do forro a se instalar. Lina apresentou uma solução bastante simples, justapondo e solidarizando através de parafusos peças metálicas novas, paralelas ao sentido longitudinal da peça flambada. E mandou pintar essas peças novas de vermelho vivo, acentuando sua presença contra os conjuntos das tesouras, escurecidos com extrato de nogueira. Tal solução foi reutilizada no conjunto Cozinha/Restaurante, quando da instalação do tratamento acústico.

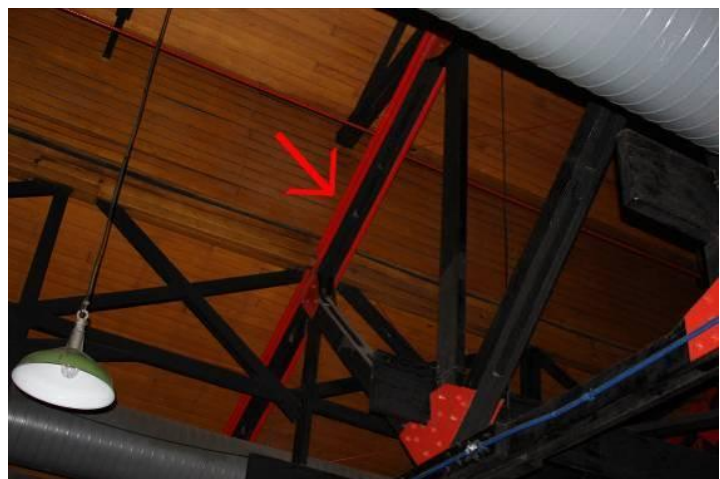

Figura 17. Tesoura do Teatro SESC Pompéia: a seta indica a intervenção de Lina, pintadas de vermelho, nas barras comprimidas; o reforço dos nós, também vermelhos, é recente.

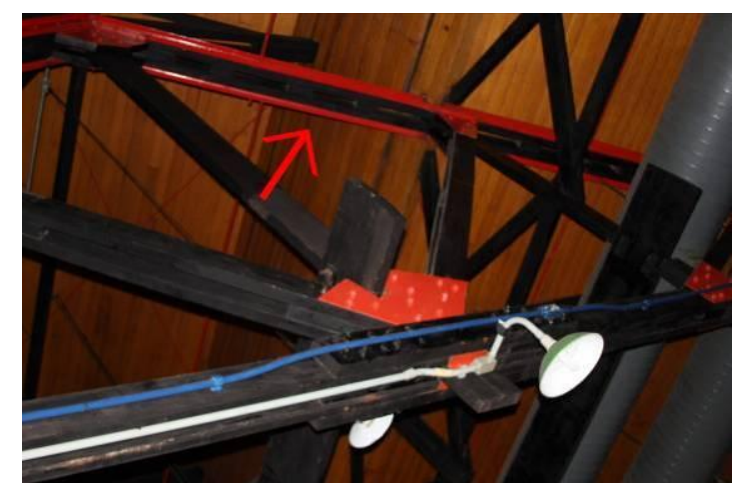

Figura 18. Tesoura do Teatro SESC Pompéia: idem.

Recentemente foram realizados reforços em todas as tesouras, criando enrijecimento nos nós da treliça, cujo resultado não é bom, tira a suavidade com que se viam essas articulações e que, agora, deixaram de ser articuladas. Além disso, com a reprodução dessa interferência, pintadas também em vermelho, em todas as tesouras há um ruído, como se tivessem enfeitadas. O que era exceção - interferências localizadas nas peças flambadas, e por serem raras, pintadas de vermelho -, quando viram regra e se generalizam - reforços em todos os nós das tesouras - perde o sentido de se fazer o destaque da pintura vermelha. Nesse caso melhor seria fazer o reforço em 
aço deixando-o oxidar-se naturalmente, como o aço cortain, por exemplo, ou no mínimo escurecido com pintura grafite, para ficar próximo do extrato de nogueira com que foi escurecida a própria tesoura.

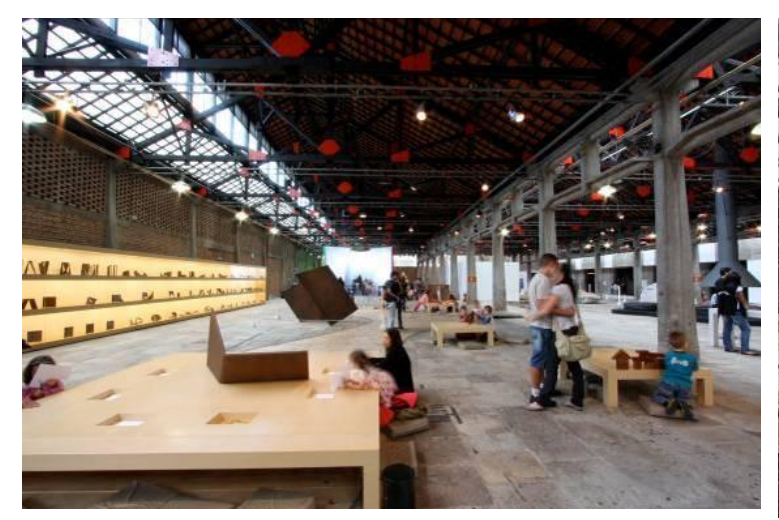

Figura 19. Os reforços das tesouras pelos seus nós. Pintados de vermelho, como parecia de bom alvitre, é excessivamente presente, ficaram salpicados, como uma decoração.

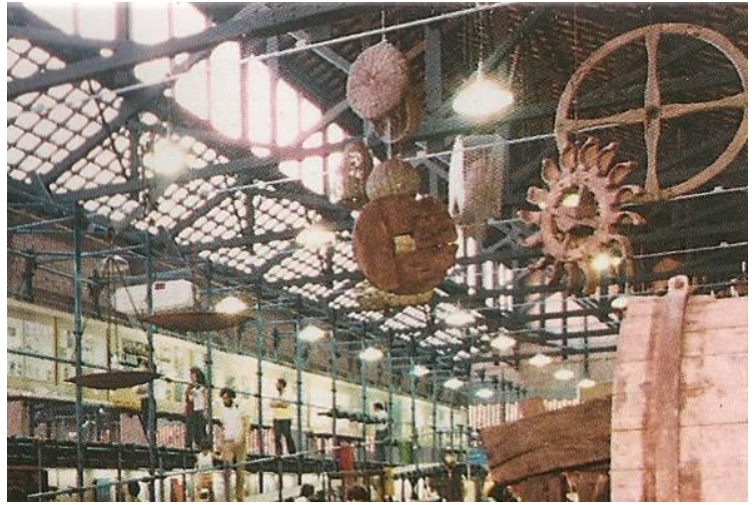

Figura 20. A primeira Exposição feita por Lina no SESC foi Design no Brasil. As pesadas rodas d'água ficaram penduradas por mais de 6 meses: prova de carga efetiva da segurança das tesouras.

Lina reforça o sentido de que a estrutura é o mais importante:

Ninguém transformou nada. Encontramos uma fábrica com uma estrutura belíssima, arquitetonicamente importante, original, ninguém mexeu... (...) ${ }^{3}$ (grifo nosso)

A elegância de um conjunto provém de duas fontes distintas, agindo paralelamente: a culta do concreto armado hennebiqueano, e a prática - usando aqui a expressão aceita no meio técnico, como de gente habilitada - nas tesouras, resultando no conjunto de uma estrutura belíssima. Belíssima é palavra aqui usada como reforço da idéia de que a estrutura era muito importante, pois como vimos era palavra proibida: deveríamos usar sempre gracioso, com o italianismo incluso.

\section{ONDE E O QUE}

Desde os primeiros desenhos aquarelados de Lina se nota a decisão já tomada para a ocupação desses galpões: o conjunto Cozinha/Restaurante e o Teatro já constam exatamente nos lugares onde estão hoje. O galpão onde se estabeleceu o Teatro é o único de todo o conjunto sem shed: originalmente já era com lanternim, e isso pode ter sido fator determinante para a escolha.

\footnotetext{
${ }^{3}$ Idem. p 220.
} 


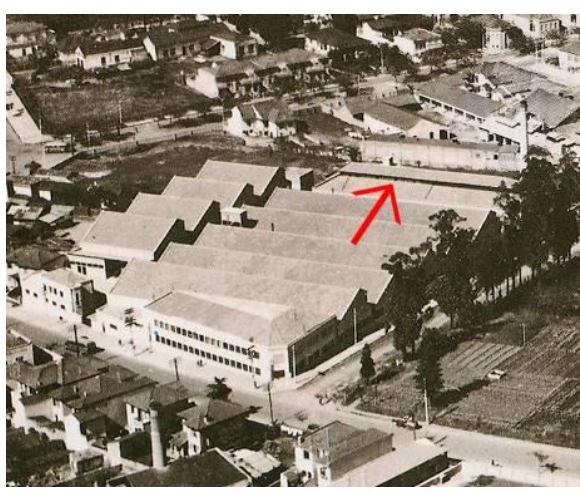

Figura 21. Vista do conjunto na década de 40. Teatro: único galpão com lanternim.

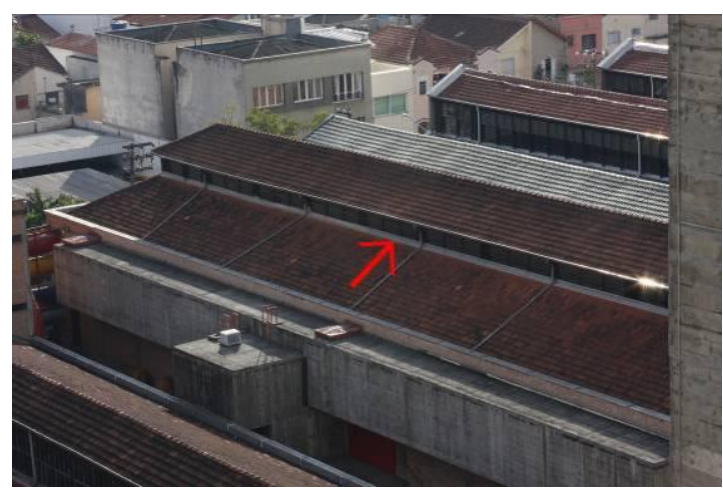

Figura 22. Detalhe da cobertura com lanternim do galpão, em foto atual.

A grande relevância que Lina dava para o Restaurante - de dia, pois de noite seria uma Chopperia, um “Wunder-Bar" - aponta para uma posição privilegiada, importante em relação aos demais: essa seqüência de galpões que se transformaram no Restaurante era isolada das outras seqüências, apesar disso se encontrar mascarado pelos inúmeros acréscimos e puxados executados ao longo do tempo de funcionamento da fábrica.

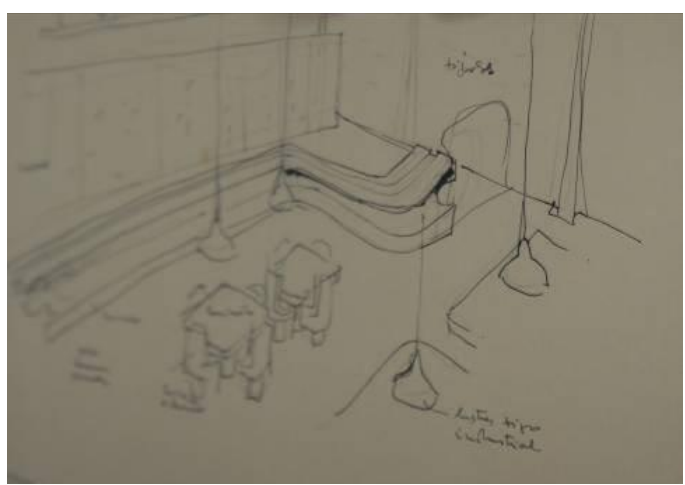

Figura 23. Estudo para o Restaurante.

Essas aquarelas demonstram a existência de algumas dúvidas em relação à ocupação dos outros galpões, a Área de Convivência já intuída, mas onde se vê uma série de mezaninos que ocupariam - em corte e não em planta - toda essa série. As demais funções são, naquele momento, apenas aventadas como possibilidades ou alternativas, principalmente na parca área disponível para novas construções (o que viria a ser o Bloco Esportivo), com anotações que explicitam o fato de que eram idéias, de que eram provisórias. Mas, como vimos anteriormente, Lina sempre foi contra o esporte competitivo, daí ser contra o centro se chamar Cultural e Desportivo. 


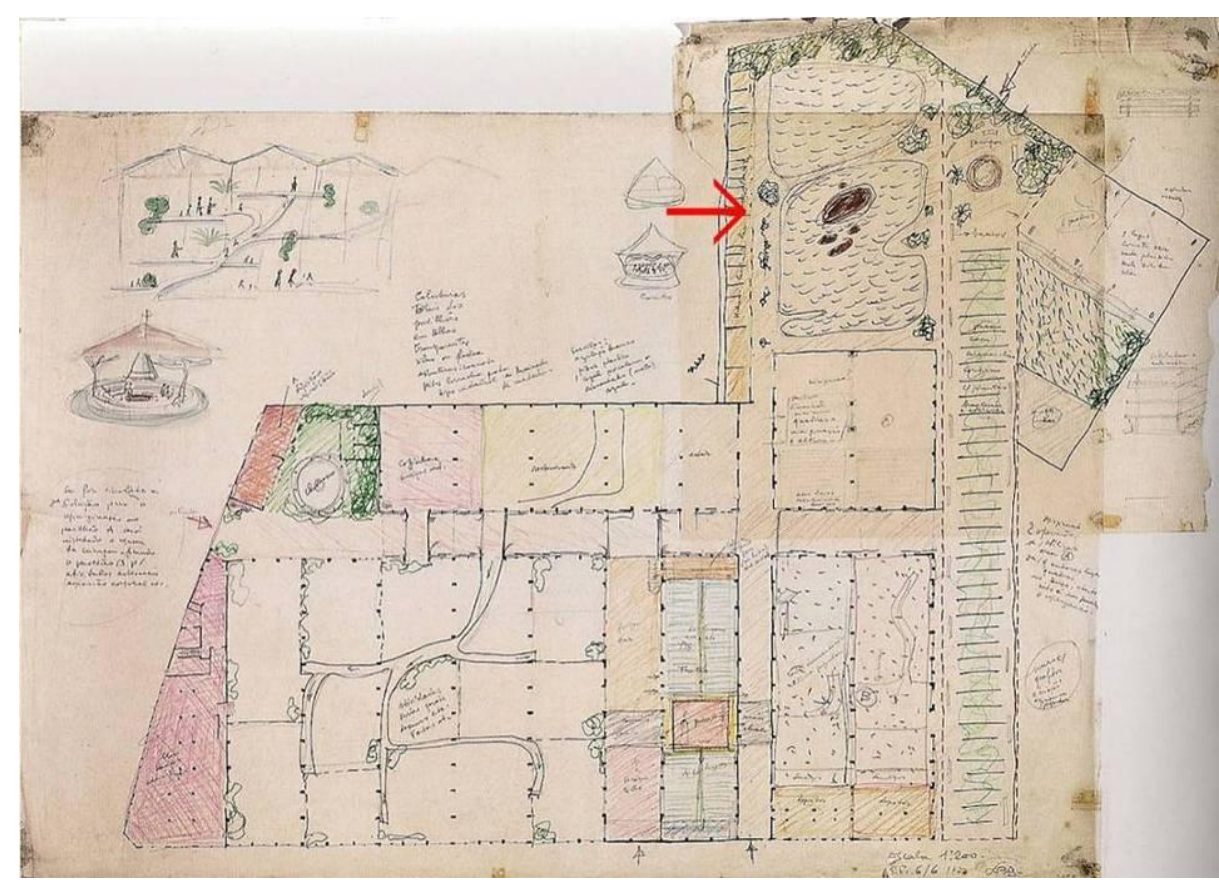

Figura 24. Croqui de Implantação do SESC Pompéia. Detalhe (seta vermelha) para a área esportiva, com outra conformação que não a definitiva. Restaurante e Teatro já estão nas posições em que vão ser realmente ficar.

Ela delineou uma torre com quadras, mais ou menos como a que foi feita, mas cujo embasamento era maior e saliente. Da saliência se esparramava uma espécie de área de lazer com água, não exatamente uma piscina, seguramente uma série de piscinas de recreação, sem caráter competitivo.

Sobre isso, era bastante categórica, e por mais que possa causar surpresa, conhecia bem o assunto. Conversando sobre Capoeira, ela dizia: - Conheço muito. O importante é a Angola, de Pastinha. A Regional foi por um lado atlético, que não interessa nada...- E citava de memória o nome de vários grandes capoeiristas: Pastinha, Traíra, Didi, Cabelo-bom (com seu italianismo: Cabelosbom), Waldemar, a "lenda" do BesouroPreto,... Afirmava que tinha conhecido a todos pessoalmente, e muito bem.

Quando de sua proposição para mais uma das grandes exposições para o SESC - Fábrica da Pompéia, a exposição do Futebol, dizia que o grande homenageado e que deveria ser relembrado sempre era Garrincha, o símbolo maior do futebol brasileiro, o homem que brincava ao invés de querer ganhar, o índio Garrincha. Conhecia também - e bem - o Boxe e citava sempre Primo Carnera, o maior pesopesado italiano de todos os tempos. Para mim dizia: - Você é bom de encaixe! Depois de dar uma bronca pesada, italianíssima. Encaixe é do jargão específico dos boxeadores, se referindo a quem agüenta as pancadas. Lina não era pessoa por fora dos assuntos que tratava, e não se faz idéia de como ela absorvia tanta informação diferenciada no seu conteúdo.

Quando roubaram, para derreter, a Copa Jules Rimet, ficou ofendida, dizia que tinham roubado um dos maiores símbolos nacionais. Sempre 
ostentou, no alto do armário do hall da Casa de Vidro, um frasco de bebida, vagabundos o frasco e a bebida, que reproduzia a Taça.

Por isso, as quadras têm uma pintura lúdica, não respeitando as normas de cores das associações internacionais das diversas modalidades esportivas para quadras - vôlei, basquete, handebol, e futebol de salão. As cores formam conjuntos que se associam às estações do ano, um mote para formular os conjuntos, grupamentos, enquanto tal: paletas.
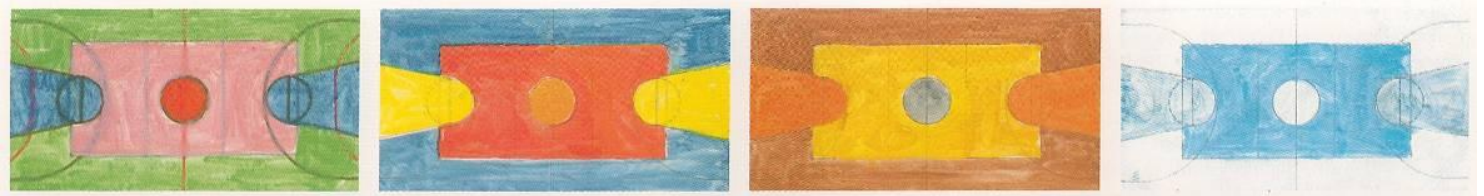

Figura 25. Projeto das quadras: Primavera, Verão, Outono, Inverno.

Por fim, a piscina foi incorporada ao corpo da torre, que passou a ficar totalmente a prumo, realçando o sólido prisma desse prédio, e se cancelou a saliência do embasamento, aventada nos primeiros estudos. Logo, nos estudos subsequientes de Lina, essa configuração a prumo já passa a ser a adotada, seguindo assim até o seu detalhamento para as obras. A piscina também, não tendo finalidades desportivas ou competitivas, pode se amoldar à geometria do prisma, adotando-se inclusive uma profundidade adequada apenas para o lazer e hidroginástica.

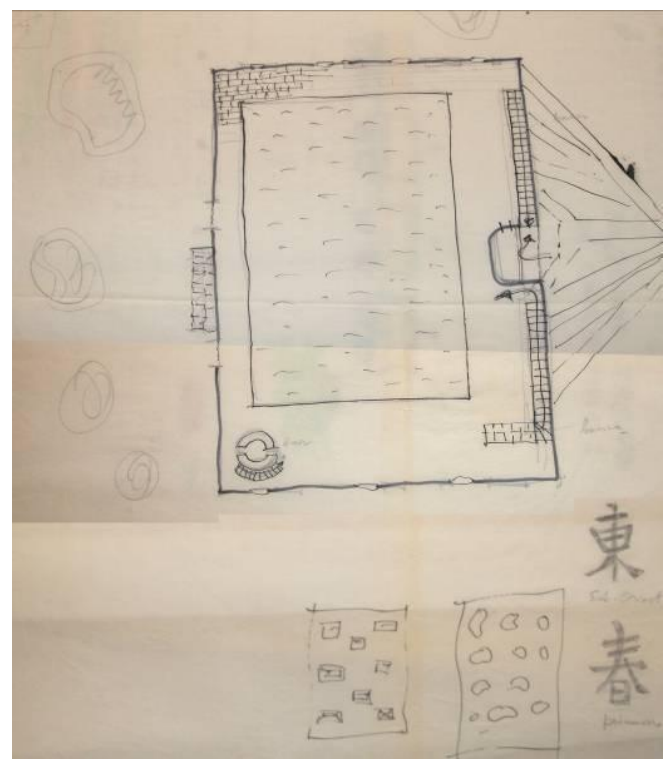

Figura 26. Estudo para a piscina, já com a configuração definitiva, contida nos limites do prisma do edifício.

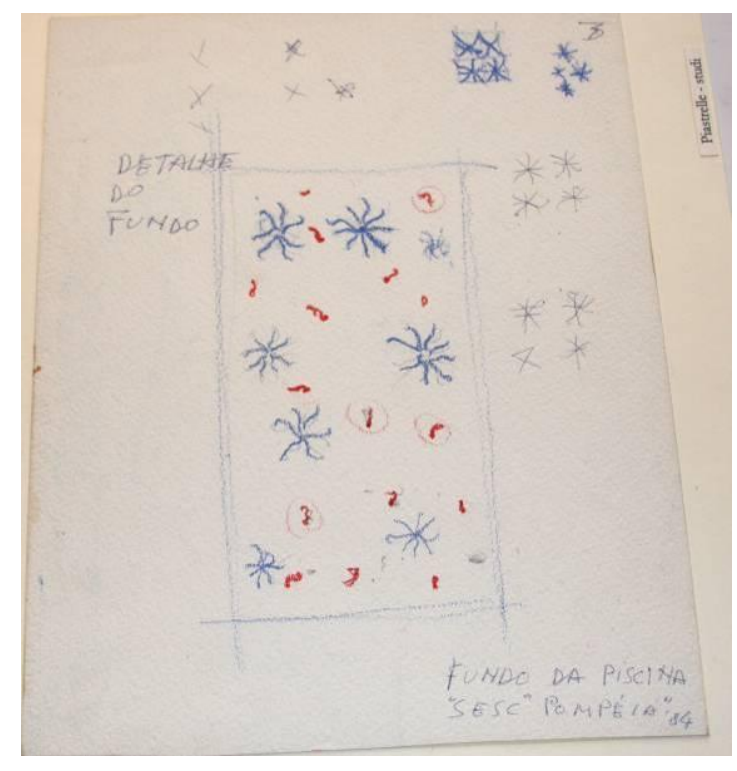

Figura 27. Estudo para o desenho do fundo da piscina, detalhado depois por R. Gershman. 


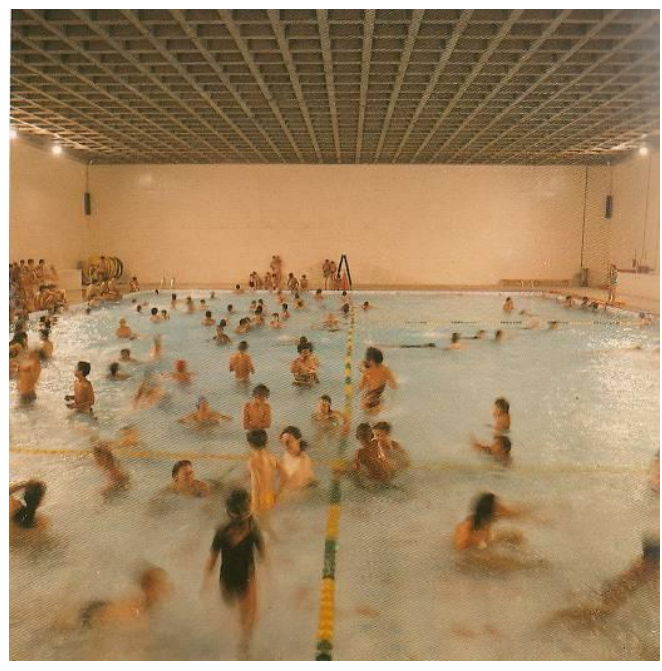

Figura 28. Vista da piscina com seu uso recreativo e não para treinamentos de competição.

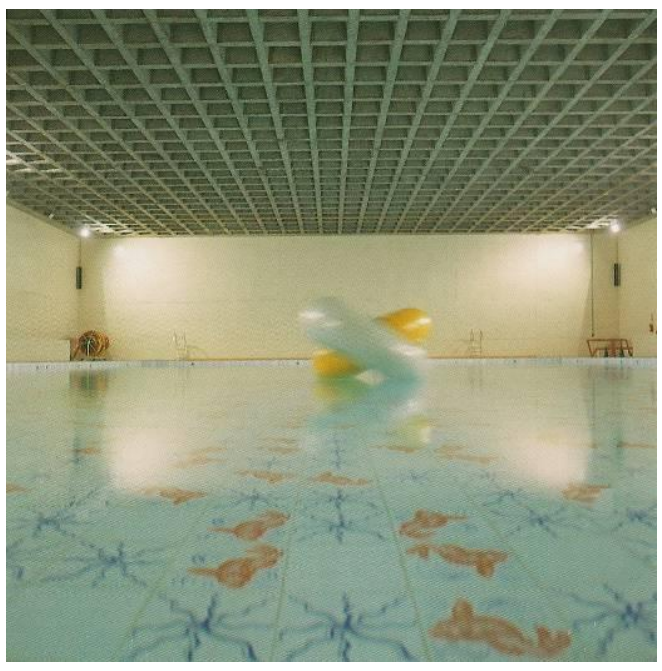

Figura 29. Vista da piscina. Detalhe para o desenho do fundo, de R. Gershman.

Mas Lina retoma a forma do embasamento saliente, à milanesa, na base da Torre de Serviços. Esse ressalto saliente na base do prédio consta desde as primeiras vezes em que os desenhos mostram também a Torre das Quadras já em forma de prisma regular. O ressalto é artificial, a estrutura muda de direção vertical, de prumo, numa transição muito complexa para a descarga dos esforços verticais nas paredes portantes, resolvida pelos engenheiros da Figueiredo Ferraz. Lina ainda acentua o peso dessa imagem, colocando o edifício sobre uma base saliente, mais larga ainda do que a transição do embasamento.

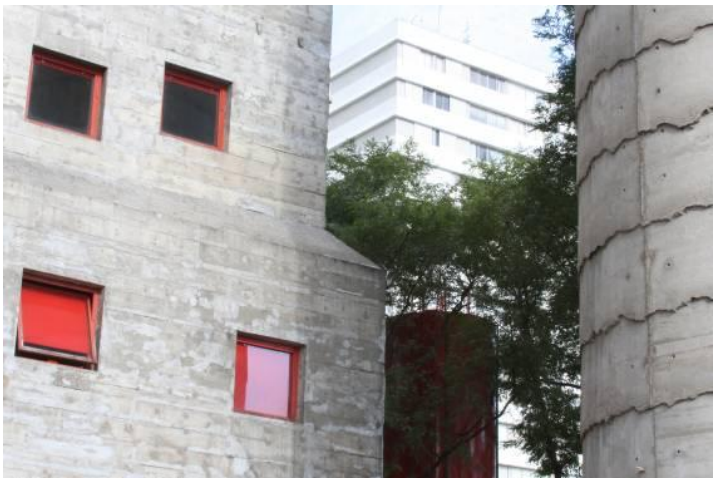

Figura 30. O ressalto artificial da Torre de Serviços é uma complexa transição dos esforços verticais, ao longo das paredes portantes.

Figura 31. Ressalto da Torre de Serviços, previsto desde os primeiros desenhos, após a definição do prisma regular do Prédio das Quadras. Nos desenhos ainda não consta o sóculo. $\mathrm{O}$ conjunto remete à organização clássica de fuste, plinto,e sóculo.

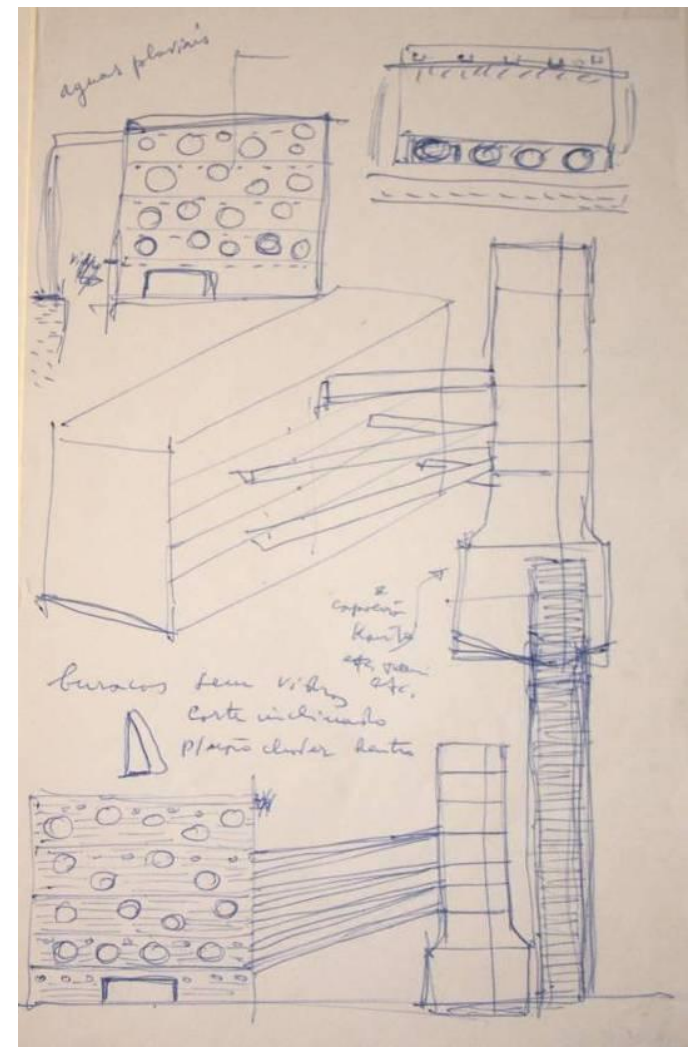


Pode-se referenciar essa sequiência, na clássica conformação de fuste, plinto e sóculo - ou soco; além de comportar a citação dos fortes militares, ao peso visual que eles transmitem, com suas paredes alamborada - paredes inclinadas -, com uma veemência surpreendente, como um crescenti musical, carregando progressivamente em intensidade sonora. Retomaremos a discussão sobre a importância dos fortes militares, dada tanto por Lina quanto por Lucio, para aprofundar mais esse dado importante.

Da rua central não sobra a menor dúvida quanto a suas determinações: o primeiro desenho já mostra que sua liberação integral se impunha, desimpedindo-a dos puxados executados posteriormente, liberando-a como rua mesmo, eixo urbano, e mantendo-se apenas as marquises que interligam a série de galpões que viriam a ser o Restaurante - lado esquerdo - com a outra série da Área de Convivência - lado direito, do desenho, e o conjunto de Oficinas ao de Manutenção - este foi transformado agora em mais uma área de exposições.

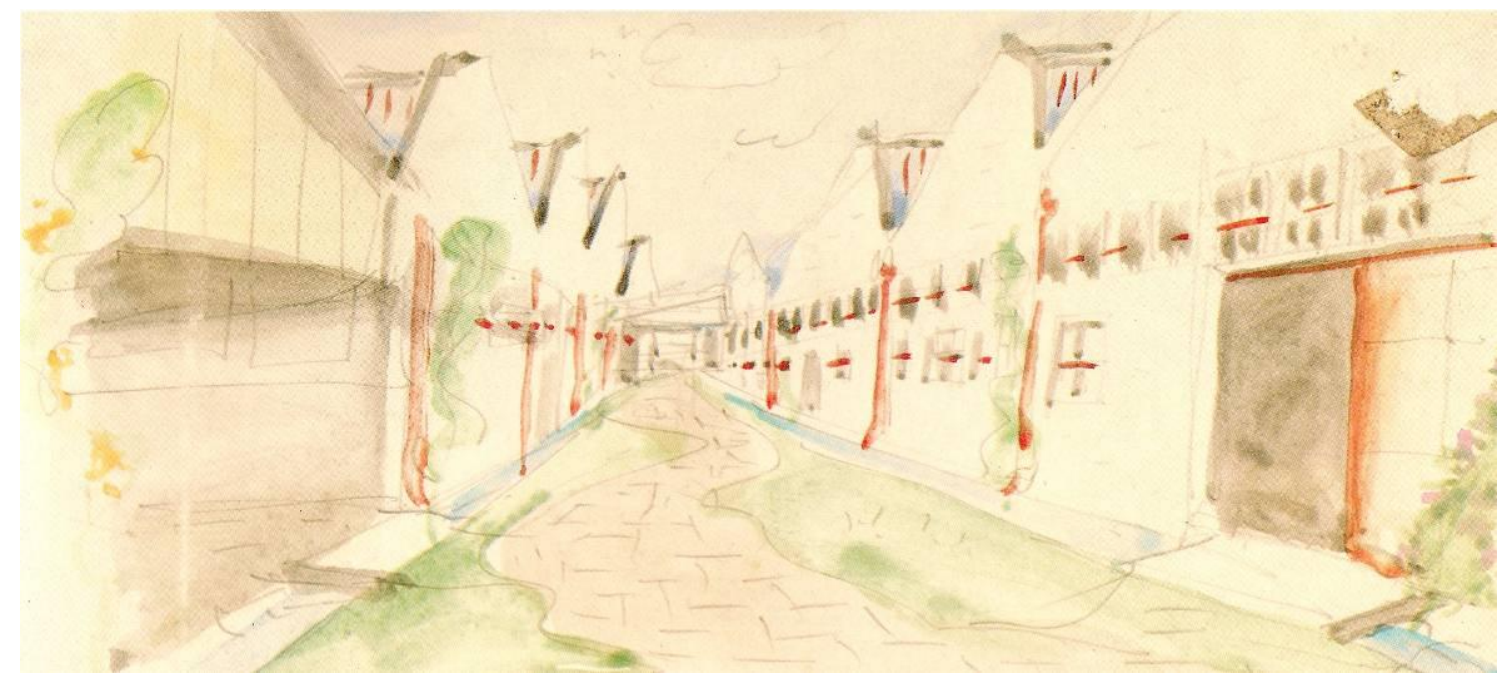

Figura 32. Primeira aquarela da rua central SESC Pompéia - 1976. Várias especificações que vão ser efetivamente usadas nas obras já aparecem aqui. 


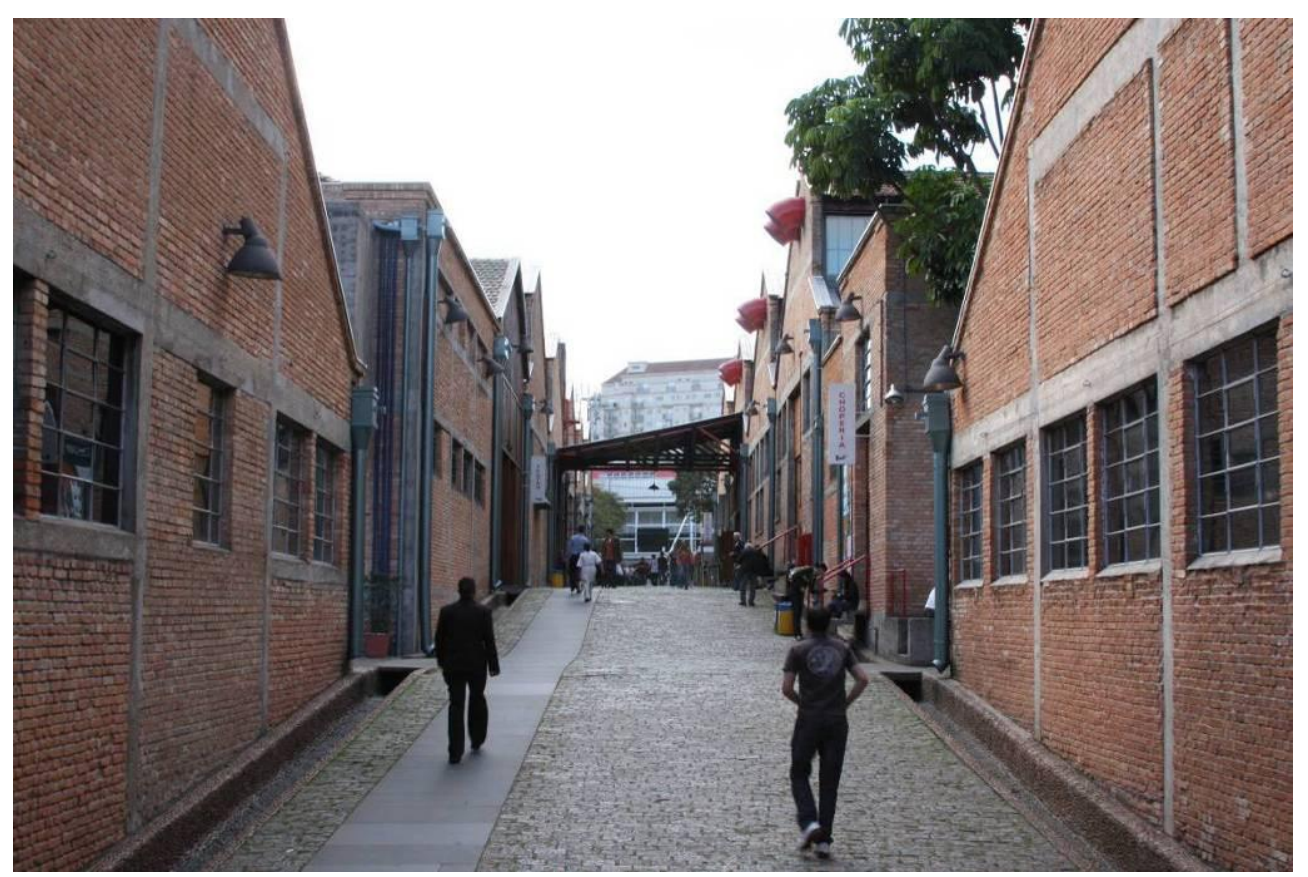

Figura 33. Rua central SESC Pompéia.
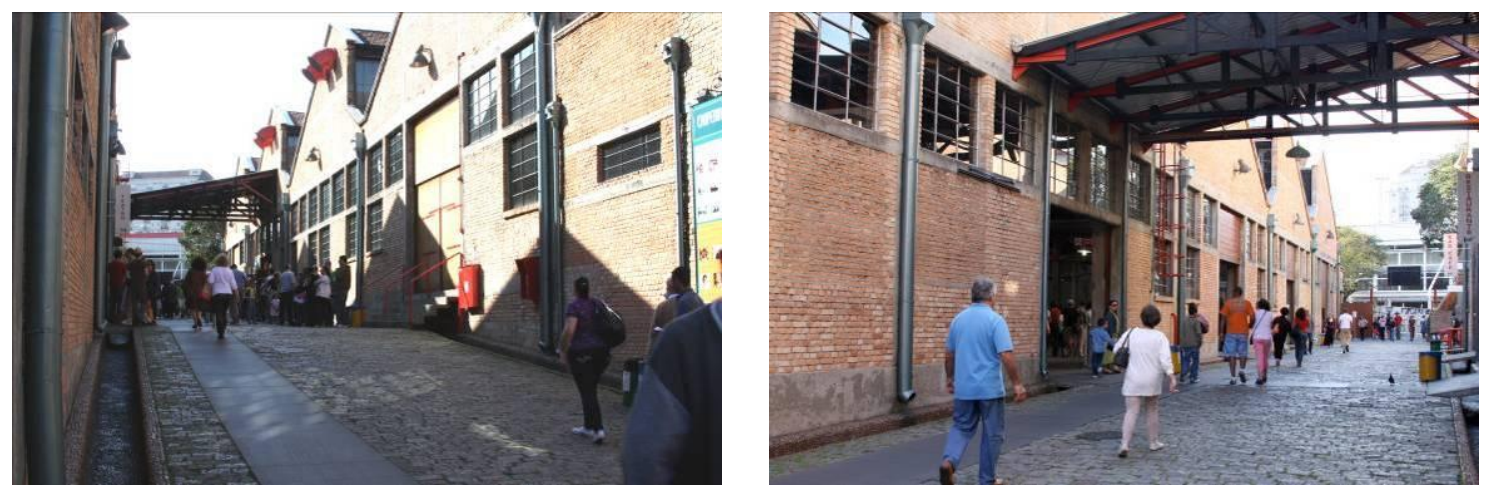

Figura 34. Rua central SESC Pompéia.

Figura 35. Rua central SESC Pompéia.

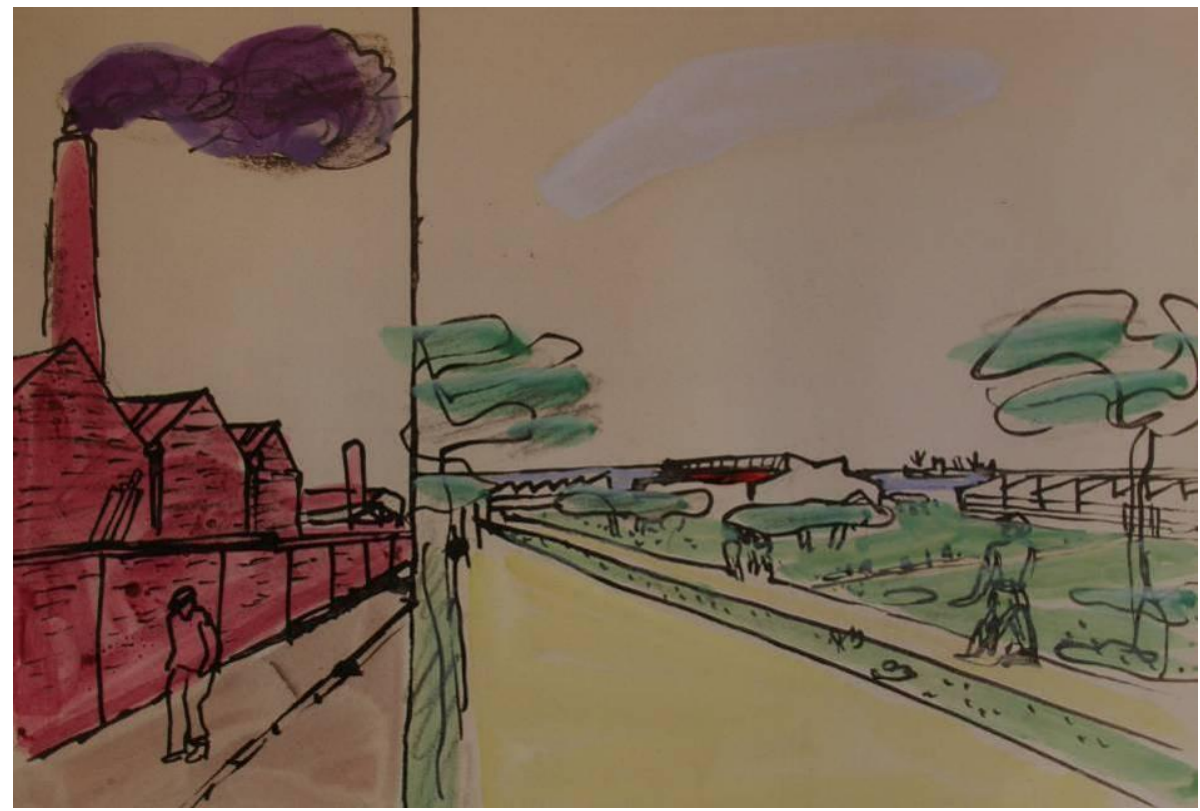

Figura 36. Desenho de Le Corbusier. A fábrica triste de então versus sua proposta de uma fábrica verde, c. 1944 
A primeira aquarela que mostra a rua central especifica também vários encaminhamentos a se seguir para o projeto definitivo, tais como as descidas de águas pluviais dos telhados até as canaletas a céu aberto que as direcionam para o Córrego das Águas Pretas; a textura do piso de pedras - sinuoso, talvez -, que, com assentamento correto, deixa nascer o matinho no vão entre elas, recurso já utilizado por Lina em outros projetos, extremamente visível no MASP, onde o mato nasce e dá um certo ar de abandono, sentimental e importante quando da sua proposição. Abandono infeliz nos dias de hoje, mas como dizia Lina, essa é uma outra história...

As canaletas foram detalhadas com rigor e o detalhe submetido a testes na própria obra. Quando de sua execução, os técnicos do SESC diziam que as crianças iriam cair nelas, mas Lina insistiu em mantê-las a céu aberto mesmo. $\mathrm{O}$ resultado é que as crianças não caem nelas, ao contrário brincam nelas, brincam com elas.

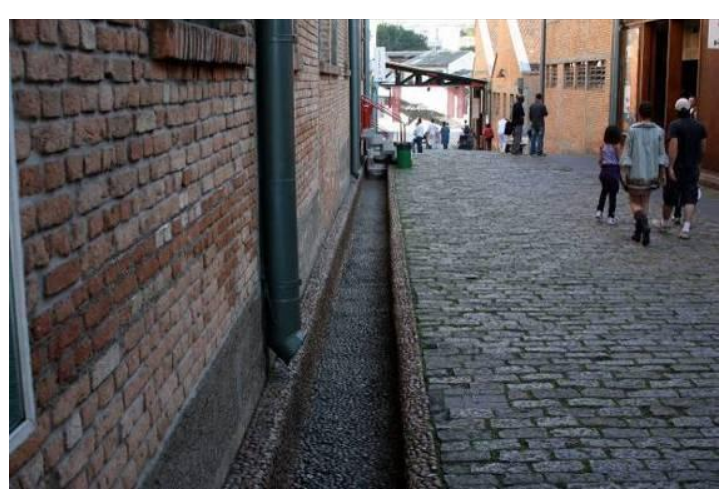

Figura 37. Canaletas de água pluvial SESC Pompéia.

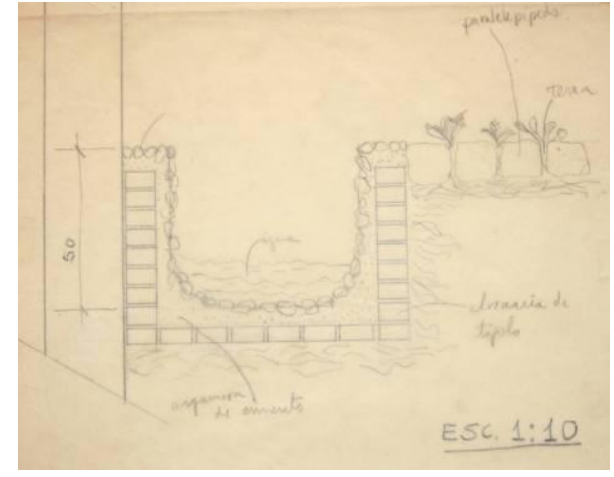

Figura 38. Croqui da canaleta de água pluvial. Note-se a especificação do rejunte de terra dos paralelepípedos.

Para o galpão das Oficinas, Lina fez vários desenhos, testando diversas versões para o labirinto. A definitiva vai se delineando mais enxuta e concisa que as primeiras. Logo em seguida começam a aparecer detalhes precisos, já em desenho técnico, feito por ela mesma. Menos divulgados, seus desenhos técnicos são também muito importantes para que não se tenha de Lina a visão de que ela teria feito tudo apenas com desenhos livres e aquarelas. Pelo contrário, sabendo desenhar muito bem e fazer aquarelas, os desenhos para arquitetura apresentados assim são fruto de quem também dominava muito bem a linguagem técnica, a nanquim, com canetas Graphos sobre papel vegetal, ou a lápis sobre papel manteiga. 


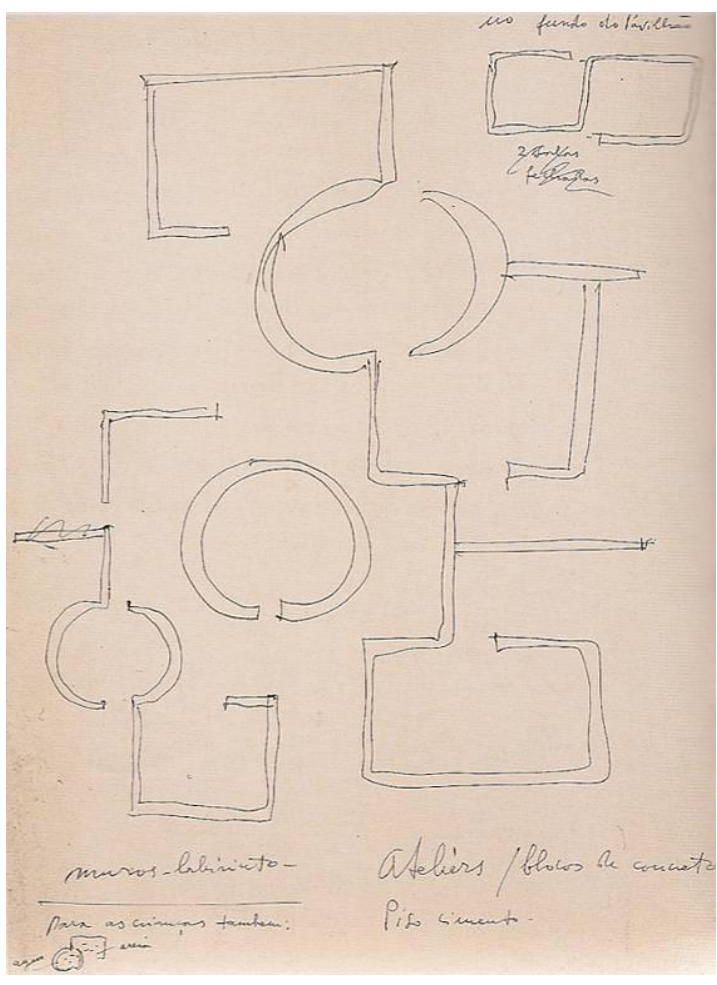

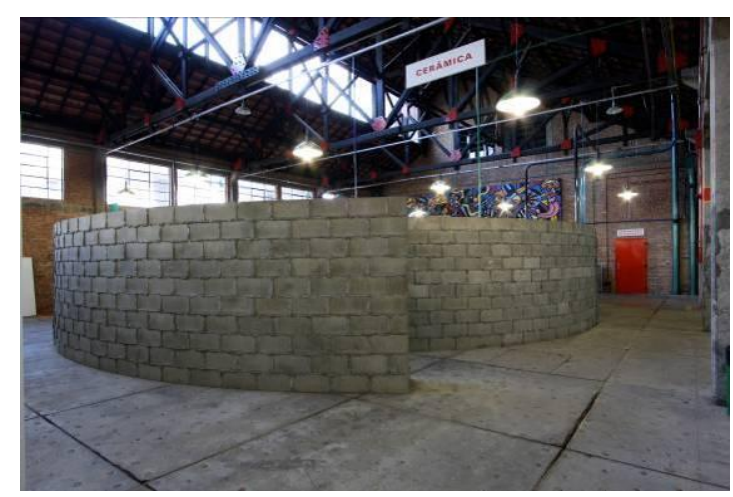

Figura 40. Oficinas de cerâmica, uma das oficinas do galpão.

Figura 39. Estudo para o Galpão das Oficinas.

Mesmo quando já não fazia mais ela mesma os desenhos técnicos, estavam sempre lá os estojos antigos ainda de madeira: o conjunto de canetas Graphos, o normógrafo Leroy, o grande compasso Kern, o belíssimo cintél, com as barras também de madeira, os grandes esquadros, os escalímetros de madeira, sempre cuidadosamente guardados nos seus respectivos estojos - um deles em polegadas -, ao nosso lado, à disposição, em cada lugar - casinha - em que nos instalamos para trabalho. Lina sempre se referiu ao fato de desenhar bem desenho técnico, sabendo usar o desenho livre para ser aproveitado disso como item técnico: - Desenhem aí uma mão apontando. Uma mão mal-feita, com seis dedos! Se eu mesma desenhar vai ficar bemfeita, aí não serve... (c.d.m.)

Há um engano na afirmação de que ela desenha apenas $o$ necessário para a burocracia. E de que é (...) no decorrer da obra que aparecem os detalhes, geralmente são apenas esboçados ou representados em aquarelas e colagens, sendo realizados diretamente no canteiro. ${ }^{4}$ Mesmo quando já não fazia mais ela mesma os desenhos técnicos, a exigência de que fizéssemos, e direito, inclusive em relação à posição dos desenhos dentro das pranchas e neles a correta posição das cotas, porque tudo era conferido por ela, era muito grande.

Sua presença e decisões tomadas no decorrer da obra, sim, foram fatos, e decisivos em muitos aspectos que essas obras assumiram. Mas isso ocorre sempre, por mais detalhado que seja um projeto, a presença do arquiteto junto às obras sempre trará fatos enriquecedores ao próprio projeto. Essa era a postura defendida por ela, e o projeto - as obras - para as rampas de acesso ao Outeiro da Glória, de Lucio,

\footnotetext{
${ }^{4}$ Oliveira, O. F. Lina Bo Bardi: Sutis Substâncias da Arquitetura. São Paulo: RG / GG, p. 33, 2006.
} 
comprovam totalmente suas razões: ele acompanhou diretamente, in loco, o tempo todo da execução ajustadíssima de seu projeto.

Os pilares dos mezaninos de leitura da Biblioteca são marcados por cortes feitos com serra-circular elétrica portátil. Como a serra é grande e pesada, o gesto para a feitura dos cortes, com as tábuas das formas já no local e o operário em pé, o gesto sai largo, aberto, violento, como uma machadada. Foram feitos in loco, com Lina ao lado, incentivando.

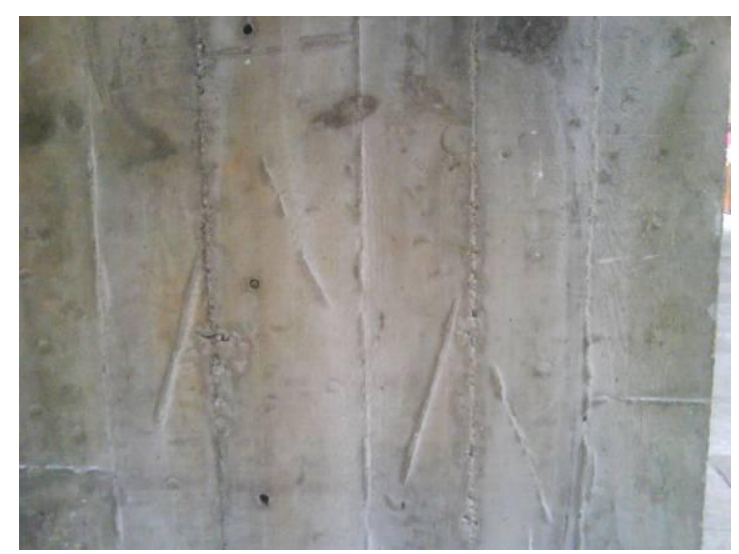

Figura 41. Marcas de serra circular elétrica-manual nos pilares dos mezaninos da biblioteca.

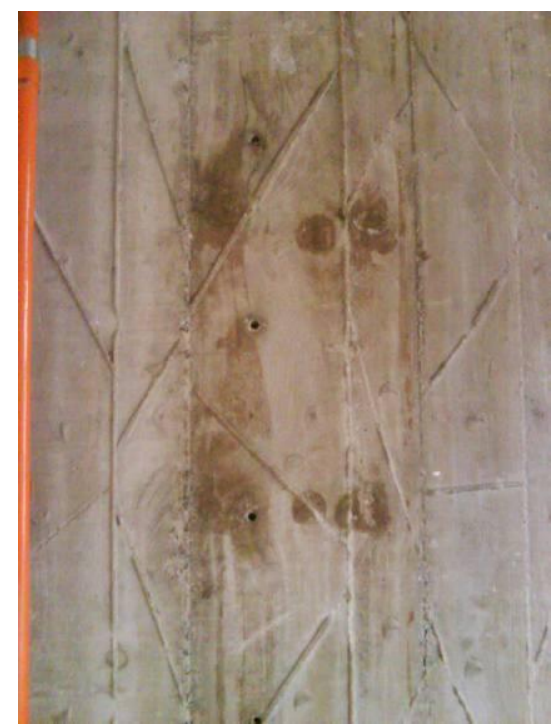

Figura 42. Idem. Nota-se as marcas dos nós das tábuas de forma.

Para que o pilar do totem de sinalização da entrada - quase igual ao do MASP -, feito em concreto, ficasse parecendo uma pedra esculpida, Lina ordenou que se aplicasse jato de areia. Para executar essa tarefa, foi necessário montar uma tenda de lona, para que o jato não se espalhasse pelo SESC inteiro. A areia, depois de usada é recolhida para o reaproveitamento, mas durante a aplicação é perigoso fazê-lo sem proteção, tanto pelo efeito intensamente abrasivo, quanto pela possibilidade de inspirar suas partículas. Quando se baixou a lona, diante da satisfação de todos os presentes com o resultado, retirando-se, como que apressada, Lina disse: Falei que dava certo. 


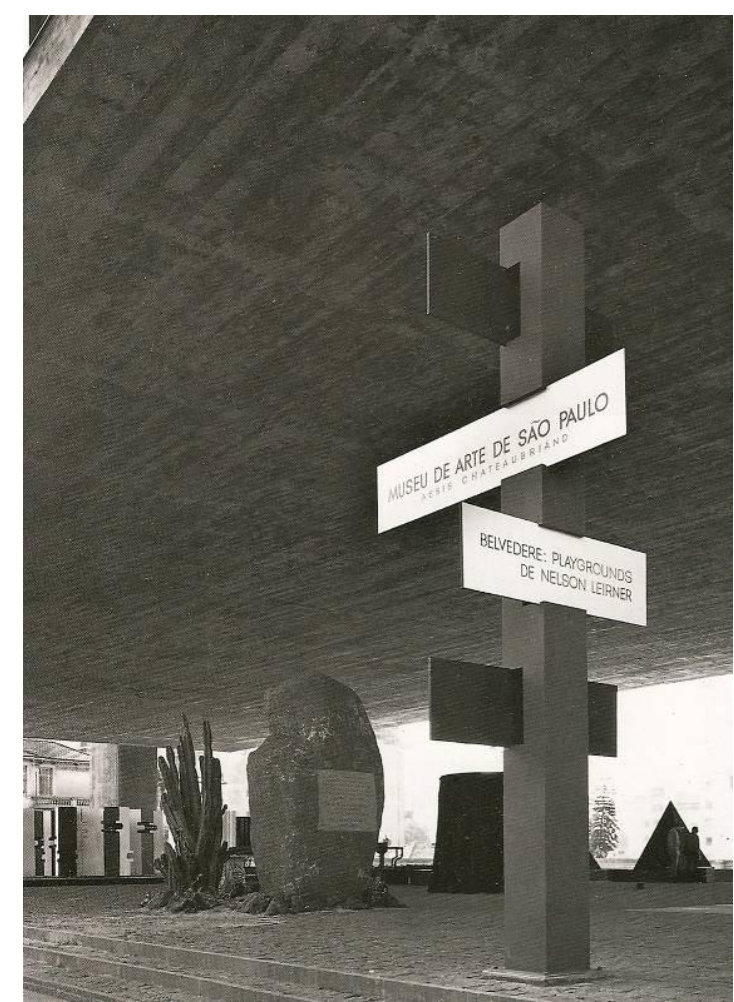

Figura 43. Totem de sinalização do MASP. No segundo plano a pedra Chateaubriand com as inscrições da inauguração, junto aos cactos (anos $60)$.

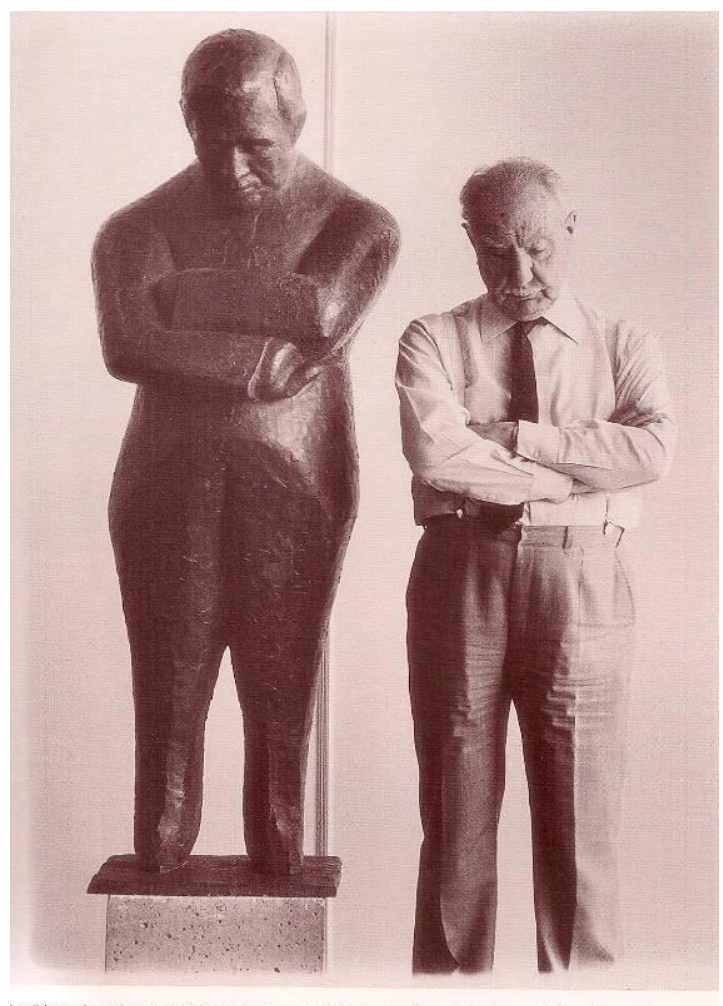

Lardi junto à estátua de Chateaubriand, do autoria do escultor polonés Augusto Zamoisky (1893-1969).

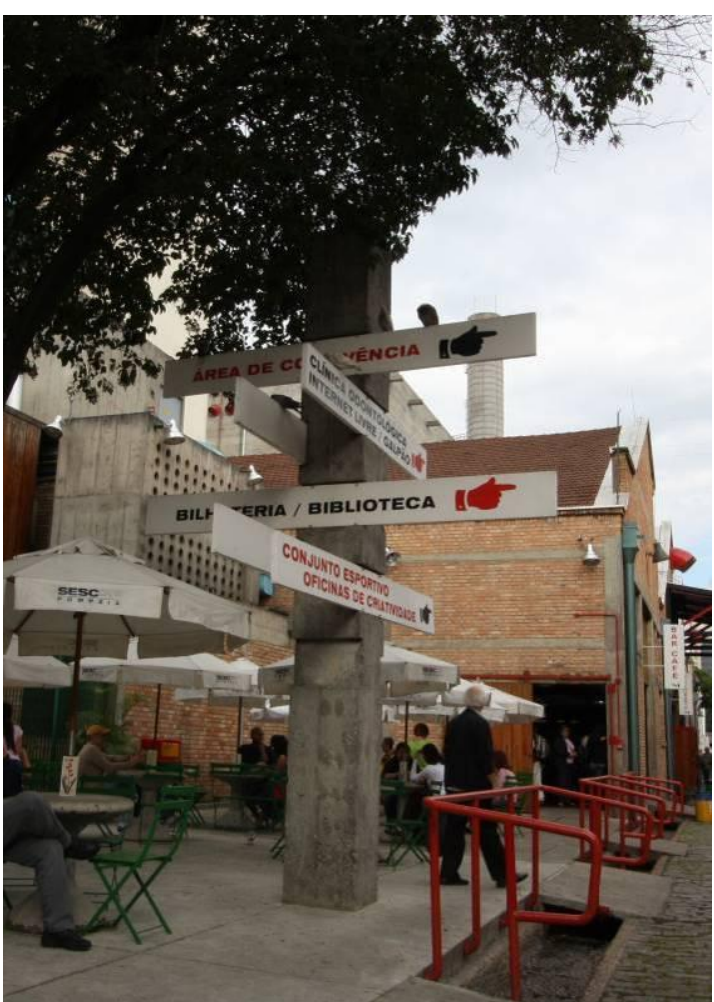

Figura 44. Totem de sinalização do SESC, em concreto, mais próximo da aparência de pedra esculpida, de aparência mais pesada que o do MASP (1981).

Figura 45. Bardi junto à estátua de Chateaubriand, de autoria do escultor polonês Augusto Zamoisky. A pedra da placa de inauguração do MASP, feita por Lina, é o perfil da clássica posição em que Chateaubriand parava para pensar, imitada pelo Professor na fotografia. A pedra foi uma homenagem póstuma de Lina. 


\section{BURACOS}

Para os buracos - as janelas - do Bloco Esportivo, foram feitos os moldes do vão em EPS - isopor - em escala 1:1, in loco. O complicador era o fato de que cada buraco, na face externa do prédio, tem, ao longo de todo o perímetro, posição na vertical abaixo do que a posição na sua face interna, formando, em toda a volta superior, uma pingadeira, e, em toda a volta inferior, na posição de peitoril, um caimento para fora. O funcionamento do sistema peitoril-lumeeira é evidente, e toda essa sabedoria construtiva provém das construções das antigas fortificações, não encaixilhadas, dos fortes militares: Lina chamou sua obra de cidadela da liberdade.

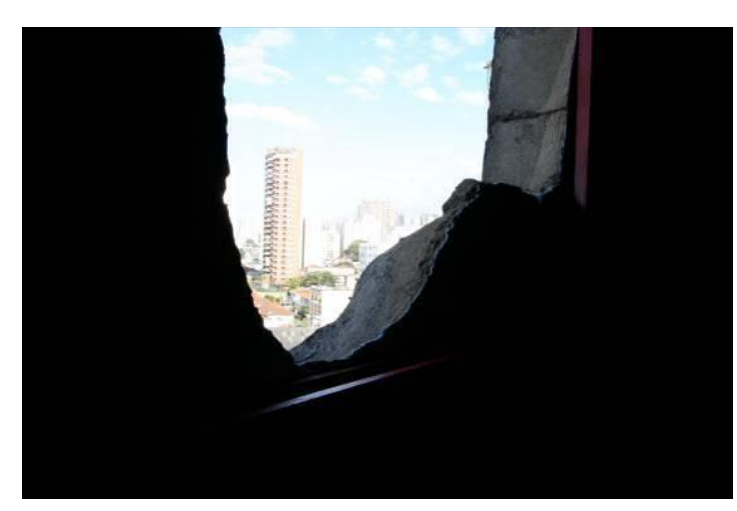

Figura 46. Buraco - detalhe do peitoril.

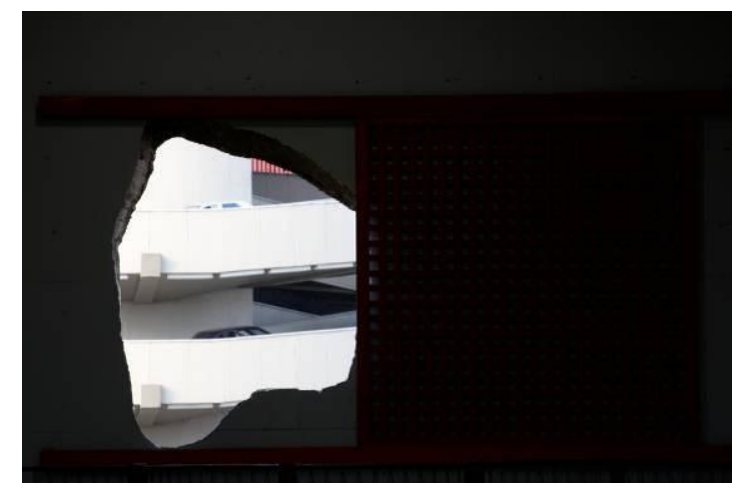

Figura 47. Buraco - o perímetro tem a face externa reversa em relação à interna.

Os buracos são interrupções na estrutura portante, fragilizam o trecho vazio que criam, e sobrecarregam os trechos adjacentes: as faces verticais do prédio deveriam ser entendidas como um plano portante, e não como uma grelha ou reticulado vertical. Ou, menos ainda, como pilares autônomos. Já citamos Lucio se referir aos buracos numa superfície portante, em sua palestra nos anos 70.

Para aquele uso, esportivo, o rombo na parede estrutural de concreto tem amplo sentido: não se pode obter janelas contínuas horizontais sem subdividir o quinhão de carga do grande vão para pilares pré-estabelecidos, o que não é o caso de paredes portantes contínuas; os pesos dos pavimentos, de grande carga, la folla saltando - carga de multidão saltando, como acontece nos estádios de futebol -, sem apoios intermediários, descarregando toda essa carga, do grande vão - 30x40 metros - diretamente para o perímetro, Lina então propôs as paredes portantes, como na arquitetura Românica, apoios contínuos, sem a famosa estrutura independente da vedação. Essa colocação de Le Corbusier leva, inevitavelmente, às fachadas livres e caixilhos horizontais, que continuam seu postulado.

\section{Lina foi por esse caminho natural:}


Tenho pelo ar-condicionado o mesmo horror que tenho pelos carpetes. Assim, surgiram os "buracos" pré-históricos das cavernas, sem vidros, sem nada. Os "buracos" permitem uma ventilação cruzada permanente. ${ }^{5}$

Os buracos são fechados no plano interno, sobrepondo painéis de treliça, de correr, ao vão propriamente dito, e, afora o grande tamanho e o fato de correr por dentro do ambiente das quadras, idênticos em tudo aos que foram substituídos na Casa de Vidro. No vídeo que acompanhou o catálogo Lina Bo Bardi, André Vainer compara os buracos com as bocas das cavernas, como algo ancestral, arquetípico, no ser humano, reconstituído ali. ${ }^{6}$

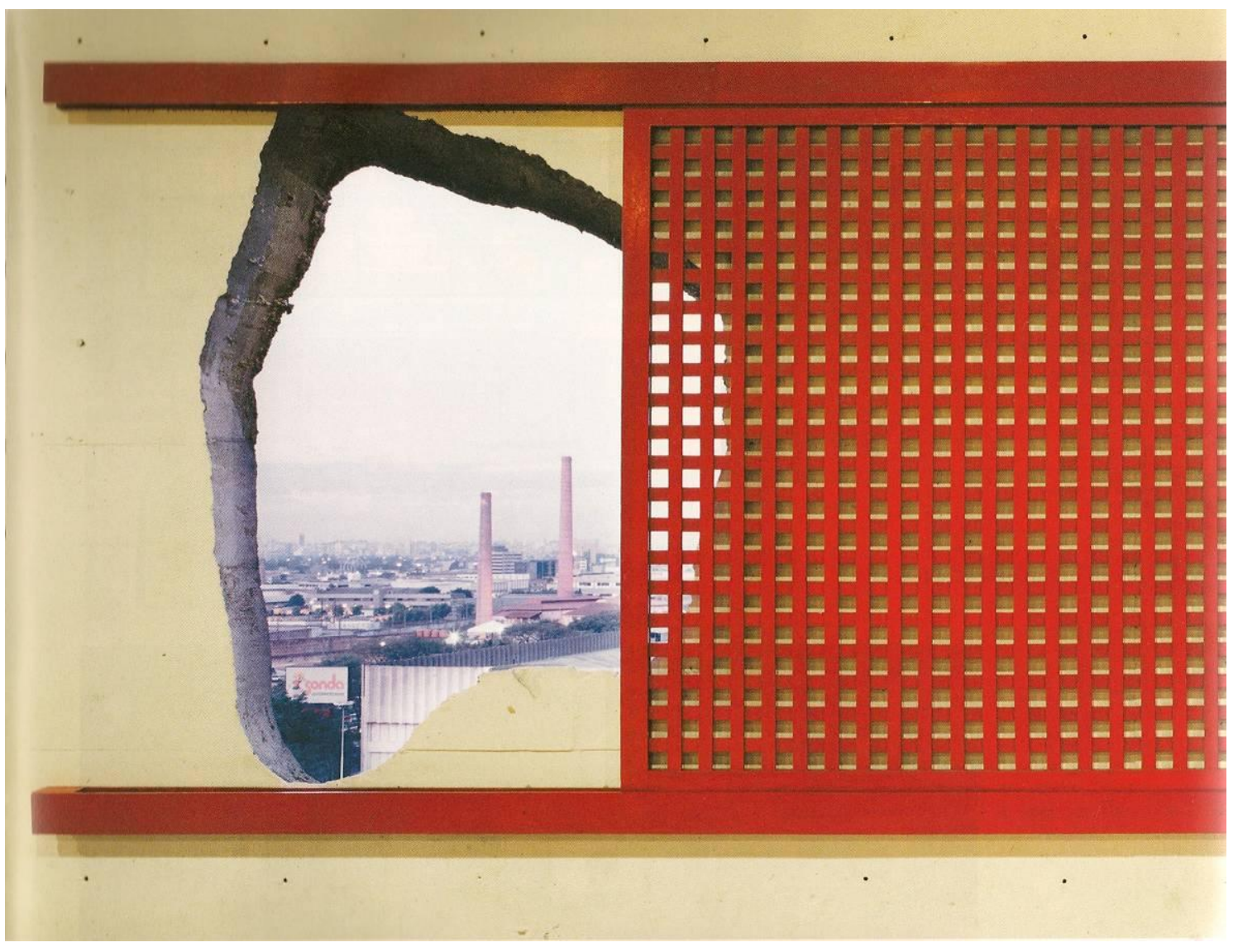

Figura 48. Buraco com o painel móvel de treliça, sobreposto à face interna, e não requadrando o vão.

\footnotetext{
${ }^{5}$ BARDI, L. B. Lina Bo Bardi. Marcelo Carvalho Ferraz org. São Paulo: Instituto Lina Bo e P. M. Bardi, p. 231, 1993.

${ }^{6}$ LINA Bo Bardi. Isa G. Ferraz e Aurélio Michiles. São Paulo: Instituto Lina Bo e P. M. Bardi, 1993. VHS.
} 


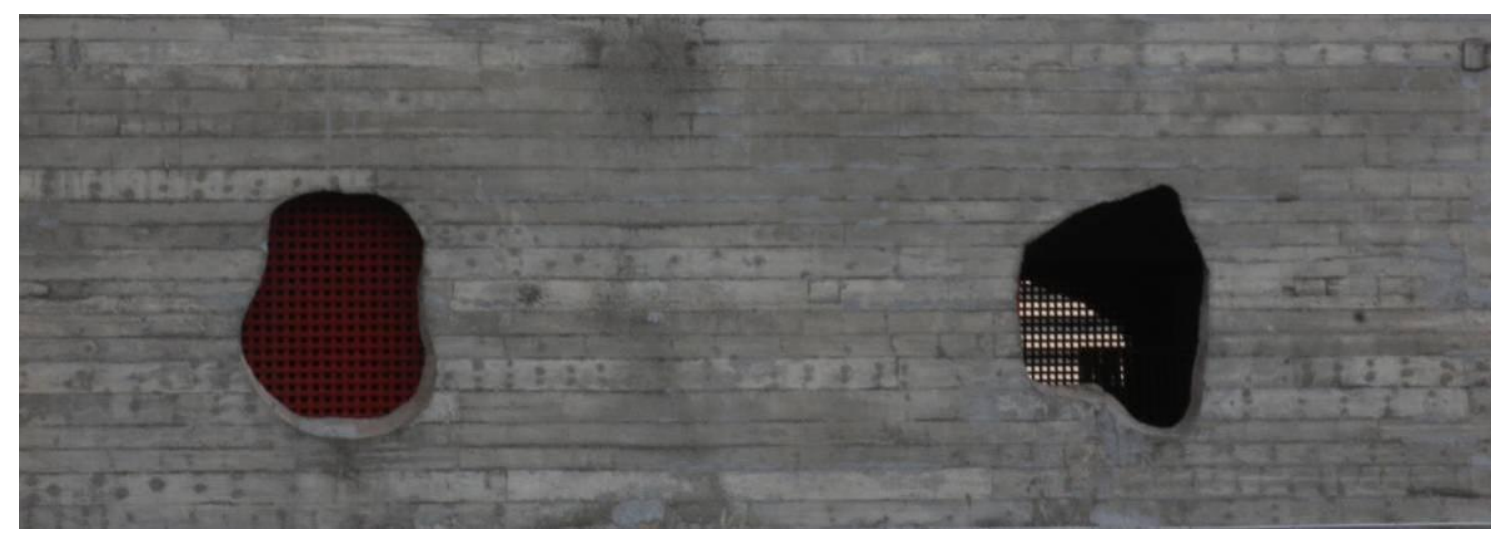

Figura 49. Buracos. Detalhes dos painéis de muxarabi, fechado e aberto. Através desse último se vê o buraco da fachada oposta.

Para esse vão de 30x40 metros, Lina previu uma dupla grelha, formando uma colméia, com eixos de 1 metro e 20 centímetros, no lacunário. Desde seus primeiros desenhos técnicos a especificação de que a altura estrutural seria de 1 metro, aparece com constância. A empresa de engenharia Figueiredo Ferraz, que como vimos, foi a responsável por toda a parte estrutural do empreendimento, procedeu aos cálculos da laje em colméia utilizando um centro de processamento de dados computadorizado, uma das poucas empresas que dispunham disso no país.

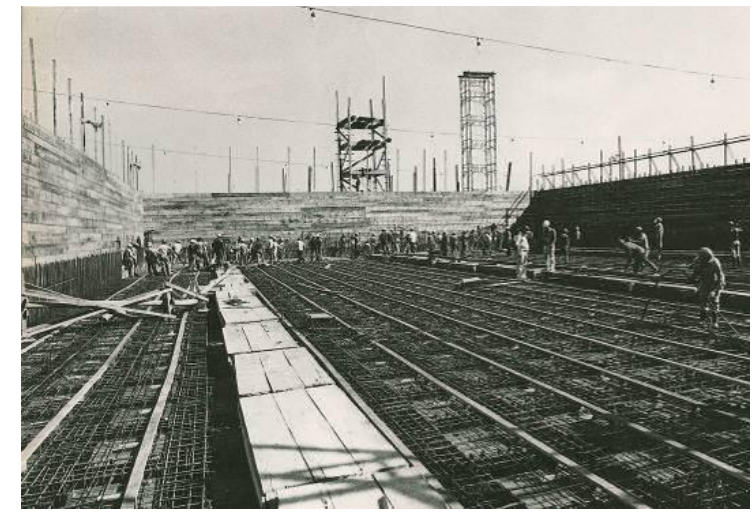

Figura 50. Concretagem de uma das lajes. As paredes desse pavimento ainda estão enformadas com as tábuas na horizontal e as formas das aberturas, feitas em EPS presas em seu interior.

$\mathrm{O}$ resultado foi apresentado e o jovem engenheiro que havia operado o computador - era uma sala inteira cheia de equipamentos que lembram uma sala cheia de geladeiras, o que equivalia ao que hoje é algo que se transporta no bolso apresentou um dado incontestável: a altura estrutural deveria ser 1 metro e 20 centímetros - que multiplicados pelas seis lajes que compõem o prédio, modificaria o volume total em 1 metro e 20 centímetros, inaceitáveis para quem tinha estudado tanto, tecnicamente, a composição dos três volumes do Bloco Novo.

Na reunião da manhã seguinte - a anterior tinha sido interrompida pela revolta com que ela tinha recebido a tal incontestável notícia, ela bradou: - Me chamem Rochlitz, quero falar com Roberto Rochlitz! Na outra manhã, veio o elegante engenheiro, seu assistente na obra do MASP, um gentleman, como ela dizia, apesar do 
desconforto daquele então jovem engenheiro que havia varado a noite, procedendo ao cálculo computadorizado.

O cálculo saído do computador era uma pilha imensa de papel dobrado com as bordas perfuradas, matriciais das impressoras da época. O jovem engenheiro, magoado, apresentou, desdobrando aquela imensidão os pontos que ele assinalara em vermelho cujos esforços não passavam - os itens assinalam trechos da estruturas onde os esforços são maiores que a capacidade resistente - e o rapaz os apresentou no meio daquela enormidade de papéis. Rochlitz, com a elegância de sempre, começou a inquirir o rapaz sobre com quais parâmetros ele tinha iniciado os procedimentos, ao o que ele respondeu, calmo, como quem diz sistematicamente procedimentos óbvios: a malha do vão de 30 metros por baixo, a malha do vão de 40 por cima, os recobrimentos das camisas de protensão somados aos próprios diâmetros, etc, etc. Rochlitz, então, argüiu que poderia ser recalculado considerando que o cruzamento das malhas fosse uma trama - um tecido, como dizia Lina - e não uma trama sobreposta, e, após uma ligeira contestação, decidiu-se reprocessar: uma noite inteira para as geladeiras realizarem o cálculo.

Ao final dessa história, na manhã seguinte - outra reunião -, um tanto constrangido, o jovem engenheiro apresenta uma nova pilha imensa de papel da impressora matricial: - Passava! Com 1 metro passa, sim!

As passarelas que unem os dois prédios do Bloco Esportivo, poelziguianas - ou expressionistas, como já preferiram em outros estudos -, também possuem dados estruturais importantes, e que tem passado despercebidos ao olhar menos avisado: os peitoris não são vigas, quando até poderiam ser, mas não o são, propositadamente. $\mathrm{O}$ que estrutura as passarelas são as lajes de piso e os peitoris não se unem aos seus pontos de chegadas, os desvãos estão lá, abertos até hoje, por muita insistência de Lina. As lajes de piso são na verdade caixões-perdidos - Lina também proibia a expressão: eram vigas longitudinais! E pronto. - e terminam nas paredes portantes com apoio Guerber. Portanto as passarelas não são ligações estruturais entre os dois edifícios, o que travaria um ao outro, as passarelas são articulações.

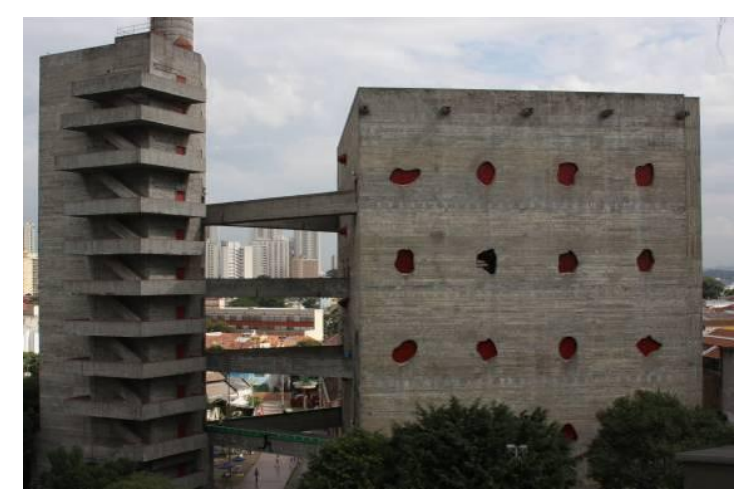

Figura 51. Bloco esportivo e sua união pelas passarelas.

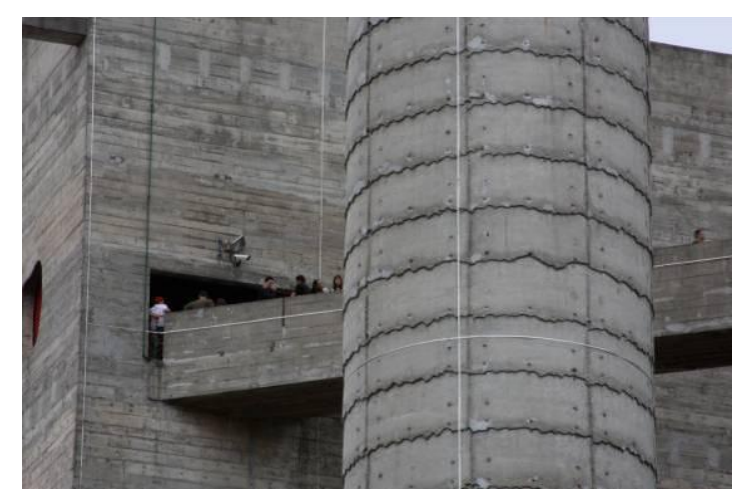

Figura 52. Bloco esportivo: detalhe do vão, na chegada em Guerber da passarela. 


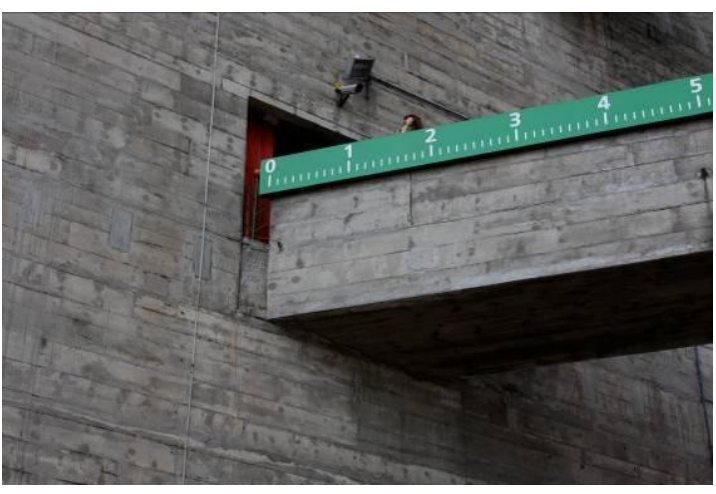

Figura 53. Bloco Esportivo: passarela e seu desvão.

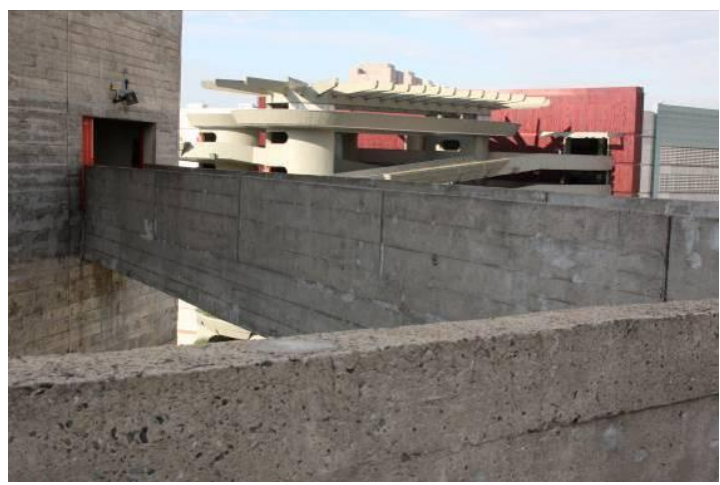

Figura 55. Bloco Esportivo: as aberturas de chegada das passarelas também são buracos, só que regulares, contra as superfícies dos edifícios.

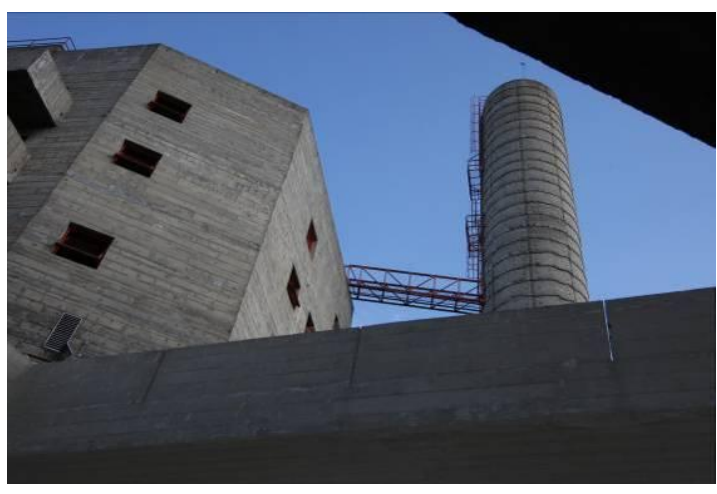

Figura 54. Bloco Esportivo: os recortes para acomodação no guarda-corpo da passarela demonstram que ele não é viga-peitoril. Nessa imagem, com a luz passante, isso fica melhor demonstrado. (não são juntas de dilatação!)

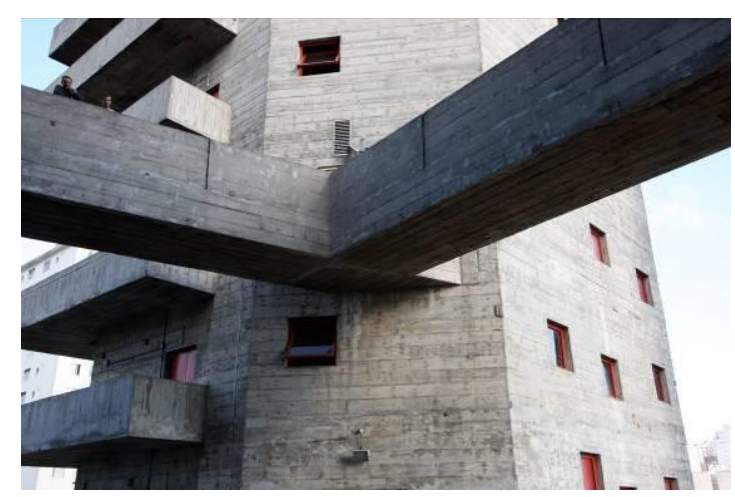

Figura 56. Passarela como articulação entre os dois prédios do Bloco Esportivo: encaixe Guerber e guarda corpo com recortes de acomodação.

Se as vigas-peitoris unissem um prédio ao outro, haveria um enrijecimento indesejável do sistema estrutural planejado, absurdo como concepção. As alternativas já se vislumbram, assim que se entende seu funcionamento: os peitoris poderiam ter sido leves, como guarda-corpos metálicos, envidraçados até a cintura, o envidraçado poderia encurvar por cima para formar um tubo e virar post-modern. A postura moderna, a modernidade dos fortes militares que é a visibilidade dominante pretendida, não o permite. A carga expressionista dessa visibilidade vem da intransigência moderna. É preciso que as passarelas sejam tão pesadas quanto possam para parecerem invasivas dos vãos das portas nas superfícies dos edifícios, que são também buracos, desta vez com formas regulares. Já estavam fazendo tubos leves e transparentes, como passarelas e acessos, no Beaubourg, enquanto Lina estava fazendo o SESC e ela não o desconhecia. Ela não queria que as passarelas fossem leves, elas tinham mesmo que mostrar peso: densas, indigestas, agressoras.

Alguns membros da diretoria do SESC, assim que a unidade se inaugurou, quiseram cobrir as passarelas que interligam os blocos de vestiários e serviços com o bloco esportivo. Lina respondia prontamente, e indignada: - Mas não 
são esportistas??? Não são praticantes de esportes? Que tal uma pequena chuvinha na garoa de São Paulo? Não faz mal nenhum... (c.d.m.)

Por isso se entende também que não há junção entre o peitoril maciço das passarelas com as faces dos dois edifícios que elas interligam, deixando sempre um desvão entre face do peitoril e face do edifício: sobra sempre um vão entre um elemento e outro, que Lina sempre relutou em fechar com grades. As superfícies das fachadas são os elementos portantes - e importantes - de todo o conjunto, como vimos, e dissolvê-los, prolongando, emendando, esticando, unindo em todas as direções, é roubar sua força intrínseca e verdadeira. Por extensão do mesmo raciocínio, as marcas das tábuas de formas para concretagem são horizontais em ambos os casos - fachadas e peitoril -, constituindo uma textura listada que reforça a idéia da interrupção.

Edson Mahfuz nota como Lina trata a questão da estrutura, do seguinte modo:

\section{O prazer derivado da resolução da estrutura fica claro com a} variedade de escadas e rampas não convencionais presente em vários projetos. Outro desdobramento dessa preocupação com a técnica é o estabelecimento de contrastes entre elementos rústicos, geralmente estruturais, mostrados sem disfarces, e outros de execução refinada, como portas, janelas, bancos e mesas (SESC) e escadas (Casa do Benin). A presença marcante da estrutura na construção formal de sua arquitetura, assim como o papel desempenhado pelos materiais e pelos detalhes arquitetônicos, indica que a forma nunca era pensada de modo independente da sua materialização. ${ }^{7}$

Com a pressão do corpo técnico do SESC para se vedar o desvão entre o peitoril das passarelas e os interiores dos edifícios, Lina propôs uma flor de mandacaru, meio incompreensível para os técnicos, meio adorada por essa leitura de que, para Lina, tudo era flor. O desvão denuncia o raciocínio estrutural, mas não era aceito, assim, sem nada a proteger os usuários do SESC. O desvão não podia ser fechado por uma grade qualquer, corriqueira, infeliz.

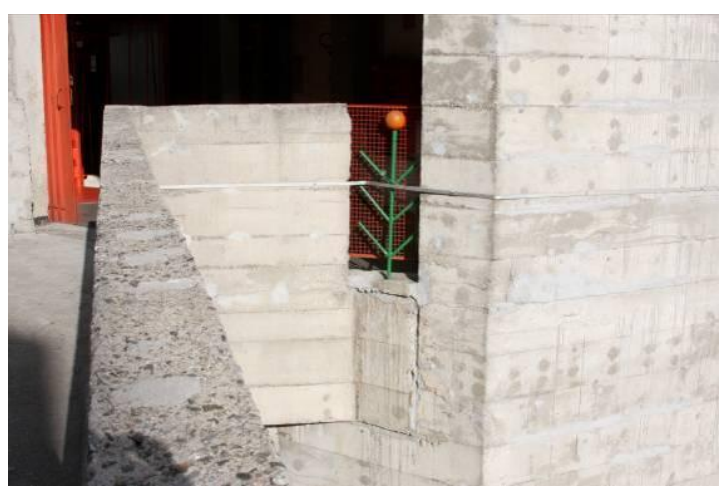

Figura 57. Flor de mandacaru e a grade colocada depois. Vê-se nitidamente o encaixe Guerber. Sem comentários sobre a fita de pára-raios.

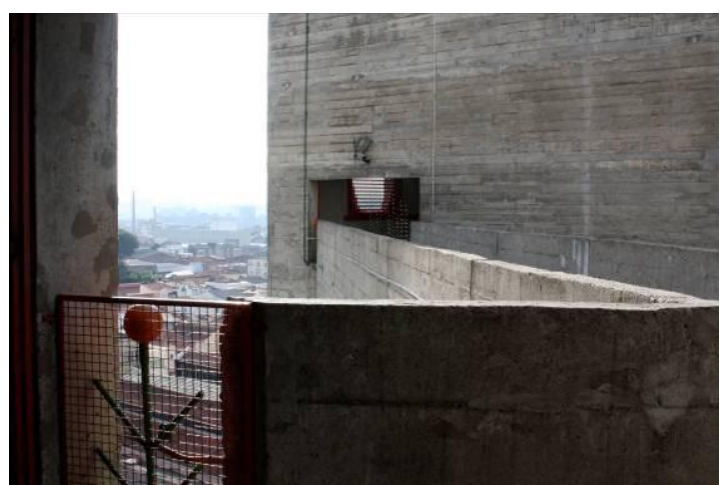

Figura 58. Desvão, flor de mandacaru, já com a grade. No outro extremo, a outra flor, ao fundo, o Pico do Jaraguá.

\footnotetext{
${ }^{7}$ MAHFUZ, Edson C. Traços de uma arquitetura consistente. Arquitextos 016, setembro de 2001. Disponível em: 〈http://www.vitruvius.com.br/minhacidade/mc224/mc224.asp >. Acesso em: 28 jul. 2009.
} 


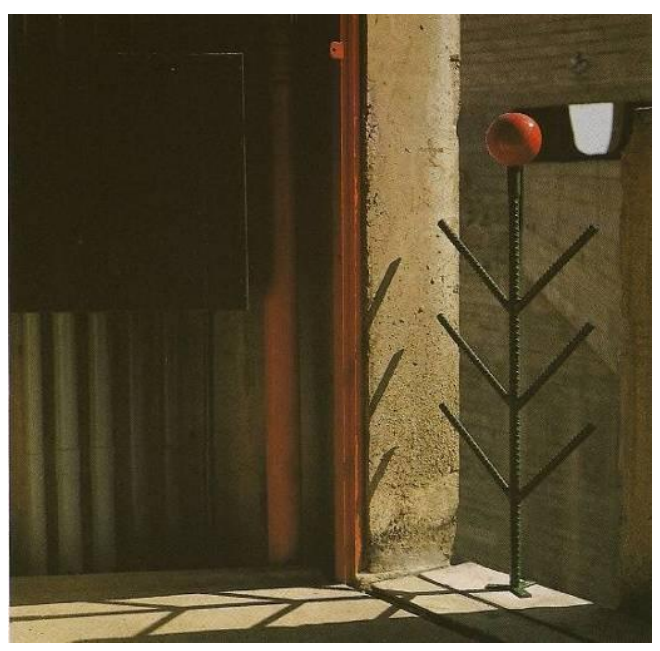

Figura 59. Desvão e flor de mandacaru.

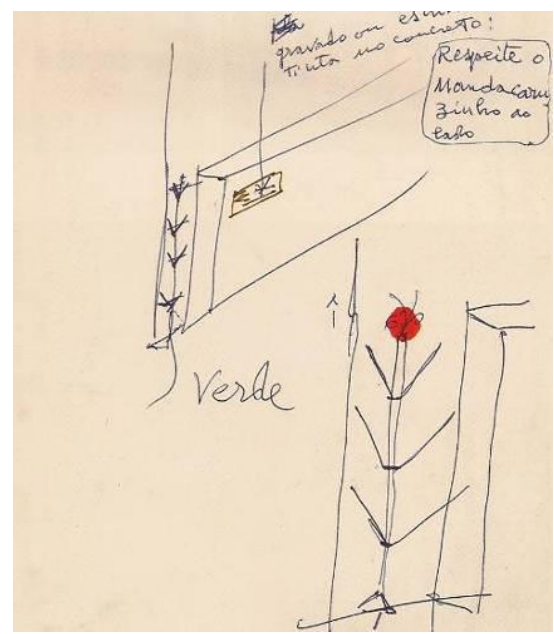

Figura 60. Croqui da flor de mandacaru. Lina deixou bem claro: "Gravado com escrito em tinta no concreto: Respeite o Mandacaruzinho ao lado"

Se o Sertão do Nordeste importa, mas ninguém vê; se a flor de mandacaru ninguém vê como flor - do ponto de vista botânico é -; se o desvão é o que mostra a verdade - estrutural, como vimos -, mas, ninguém vê; eis o projeto de fechamento para o desvão, que me exigem, teria pensado ela. Não é uma livre e criativa associação de idéias. A carga de intenções é mais pé-no-chão, mais dura como ela mesma se dizia ser. Lina acabou aceitando a colocação de uma grade afastada, por trás da flor de mandacaru, o que não invalida sua luta como um todo, no SESC-Pompéia.

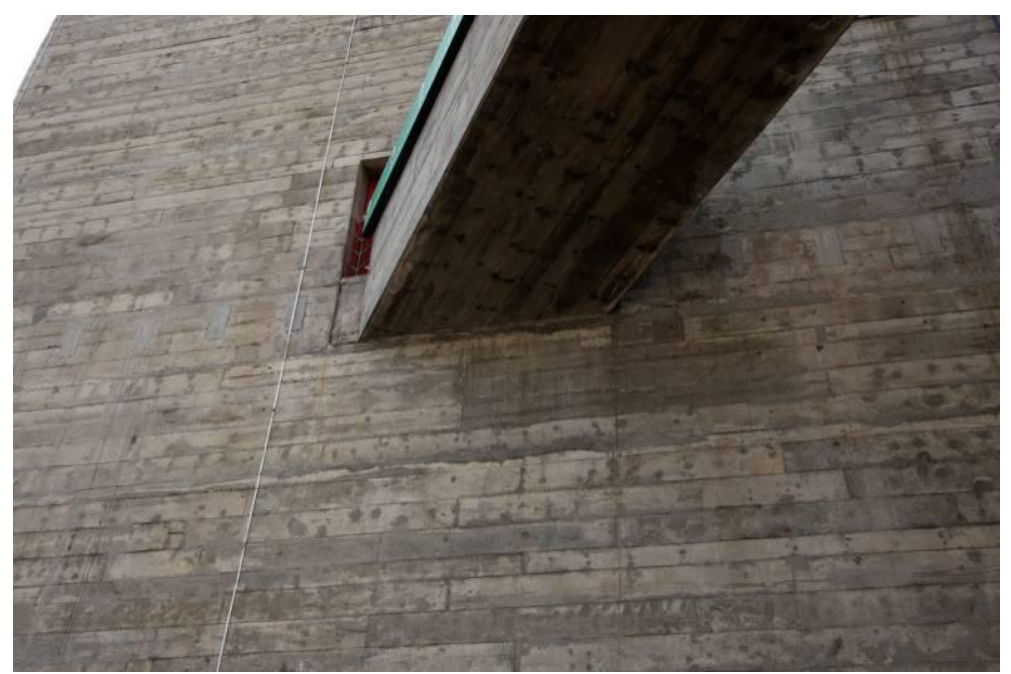

Figura 61. A passarela chega em um buraco também, só que regular, escavado contra a grande superfície fechada, do mesmo modo que são escavados os buracos amebóides das fachadas concorrentes. (Lina abominava que se usasse a expressão parede cega.) 


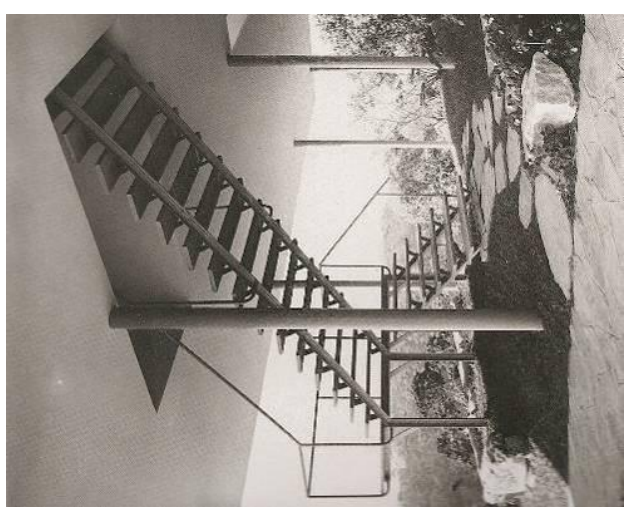

Figura 62. Escada do acesso principal da Casa de Vidro. (imagem invertida)

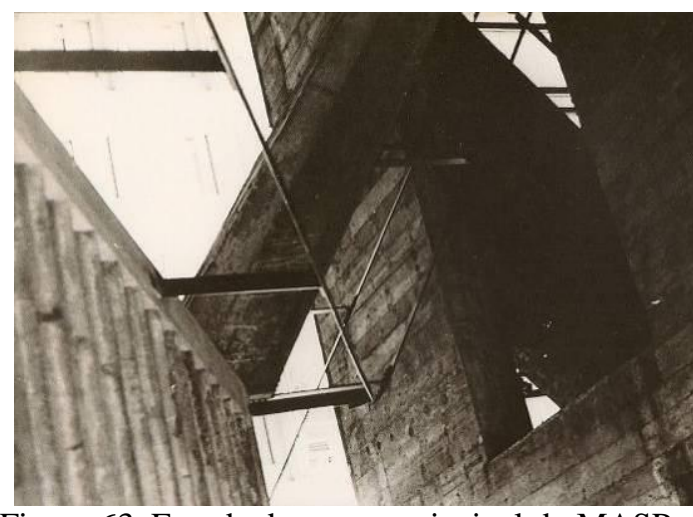

Figura 63. Escada do acesso principal do MASP (hoje, infelizmente, em desuso - imagem invertida)

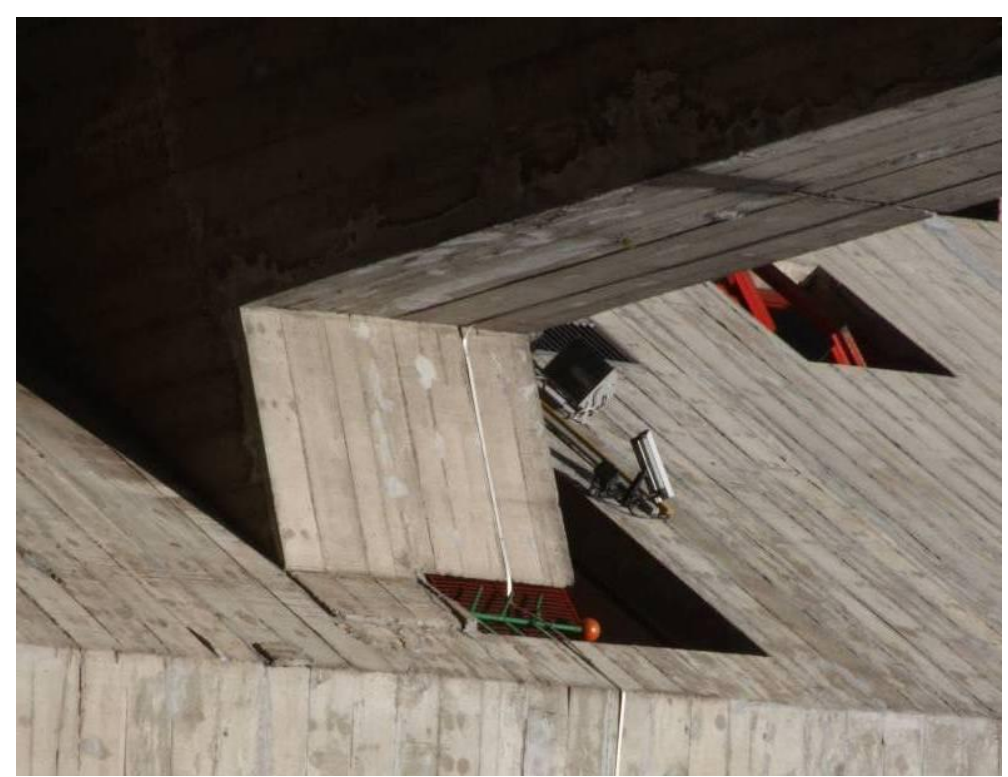

Figura 64. Passarela, chegada ao buraco, com o encaixe Guerber. (imagem invertida)

Consta da legenda das imagens imediatamente acima o fato de estarem invertidas - giradas, exceto a primeira delas - em relação à sua posição horizontal-vertical correta. Esse giro proposital, que poderia ser até aleatório, das outras três, realça alguns aspectos importantes a serem lembrados aqui.

Não é nenhuma referência ao grande desenhista Escher ${ }^{8}$. As imagens giradas querem reforçar o fato de que os buracos existem nas superfícies, e as superfícies são mais presentes - e duras - porque existem buracos. E a situação se reafirma: quanto mais a intenção de que sejam buracos mesmos, mais duro o tratamento da superfície. Nos estudos da lingüística, de que Zevi foi um dos teóricos proeminentes, isso é analisado como o discurso - ou retórica- da própria arquitetura. Amiga de Zevi, evidentemente Lina não desconhecia nenhum pormenor de sua teoria. ${ }^{9}$ Mesmo amiga

\footnotetext{
${ }^{8}$ O holandês Maurits Cornelis Escher,foi um grande artista gráfico do século XX; seus truques ilusionistas com a perspectiva não são da ordem dos assuntos de arquitetura.

${ }^{9}$ ZEVI, B. Saber ver arquitetura. São Paulo: Martins Fontes, 1978. Lina e Zevi foram colegas de escola durante o curso de Arquitetura em Roma.
} 
dele, ficou muito zangada com o fato dele ter falado mal de Brasília em um Congresso Internacional, no qual Maria Elisa esteve presente.

$\mathrm{Na}$ Casa de Vidro e no MASP, suas escadas principais também são invasivas contra o plano do teto. O acesso só é possível pelos rombos abertos nas superfícies horizontais de suas respectivas lajes, coberturas dos vãos livres - forçoso seria dizer pilotis, no caso do MASP - e pisos de suas áreas úteis, no andar acima.

Rombo - ou buraco - para assim parecer, depende da reafirmação da existência dominante da superfície para que, esta sim, pareça arrombada - ou esburacada. Sophia Telles já havia trilhado esse caminho, discorrido sobre esta questão lingüística, quando de seu texto sobre o Parque Guinle. ${ }^{10}$

Do mesmo modo, o espelho d'água na Convivência era um imperativo de ordem técnica: com o acréscimo de luz advinda do aumento de superfícies translúcidas, levado a cabo pela instalação de telhas de vidro na água menor, Lina sabia que provocaria um aumento considerável do calor interno do ambiente. Vegetação e/ou água circulante seriam dois caminhos naturais de conquistar um conforto ambiental sem lançar mão de meios eletro-mecânicos e ar-condicionado. $\mathrm{O}$ primeiro consultor técnico de conforto foi o arquiteto Luiz Chichierchio, que trabalhou dentro desses parâmetros. Para criar condições de baixar a temperatura do interior, a sugestão dele era criar circulação de água e, se possível, agregar vegetação constantemente irrigada, portanto opções perfeitamente ajustadas às formulações que já tinham partido dela.

Batizar o espelho d'água de Rio São Francisco é exatamente o mesmo processo reiterado - mas que aconteceu, cronologicamente, invertido a essa narração - pelo qual Lina queria fazer ver a paulistas, quem ela era, o que tinha feito, e que, para ela, São Paulo era o maior responsável pelo golpe de 64. Conforme ela fazia questão de que as pessoas lembrassem: $O$ Rio São Francisco é o mais importante rio sociológico do Brasil. Atravessa 7 Estados do Nordeste! E rio sociológico é uma expressão impressionante, lembra tanto a condição eternamente mutável, em que cada partícula de água, a cada segundo, já não é mais a mesma, já não está mais ali, tantas vezes relembrada na literatura; lembra a condição sociológica do povo brasileiro no Nordeste.

\footnotetext{
${ }^{10}$ TELLES, S. S. Lucio Costa: Monumentalidade e Intimismo, Revista Novos Estudos, São Paulo: CEBRAP, n.25, 1989.
} 


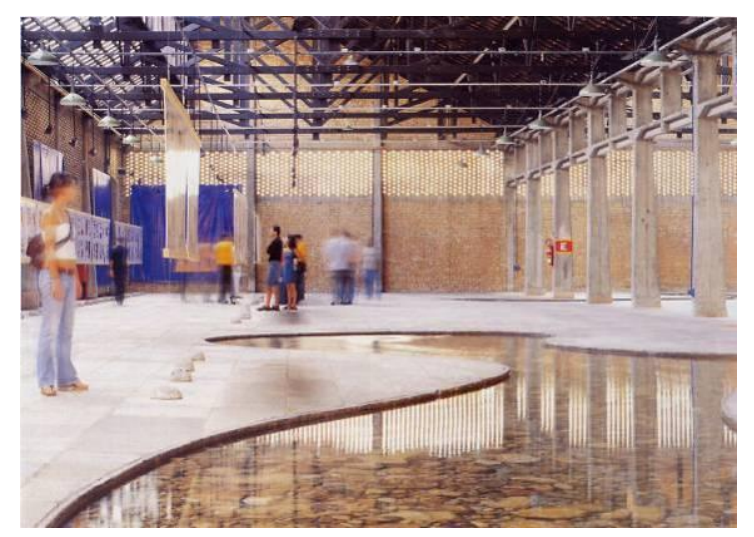

Figura 65. Centro de Lazer. Rio São Francisco.

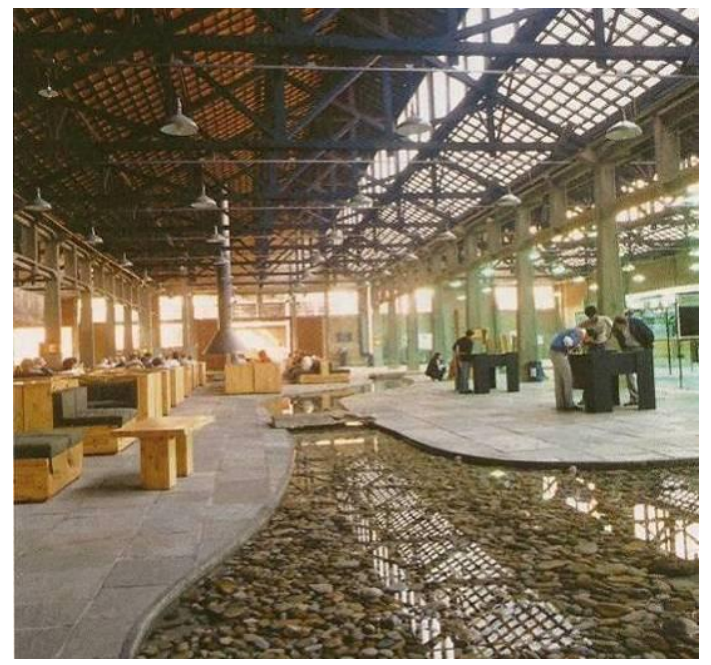

Figura 67. Estar, Rio São Francisco, ao fundo a lareira. As tesouras são elegantes, na imagem ainda sem os reforços nos seus nós.

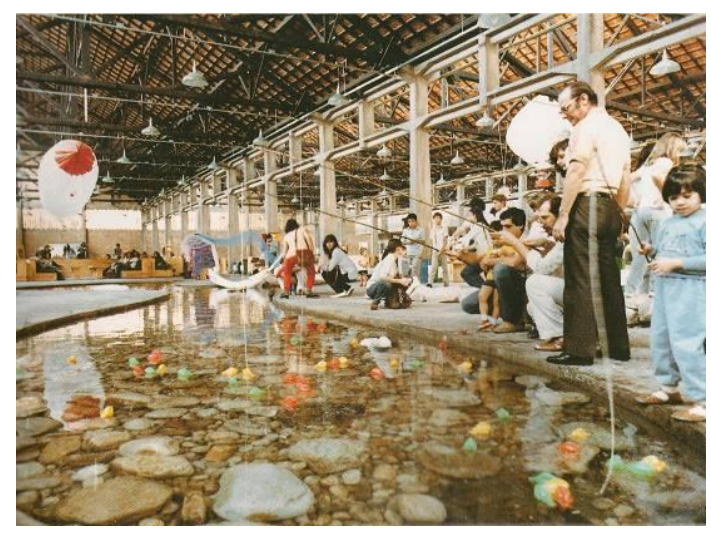

Figura 66. Centro de Lazer. Rio São Francisco.

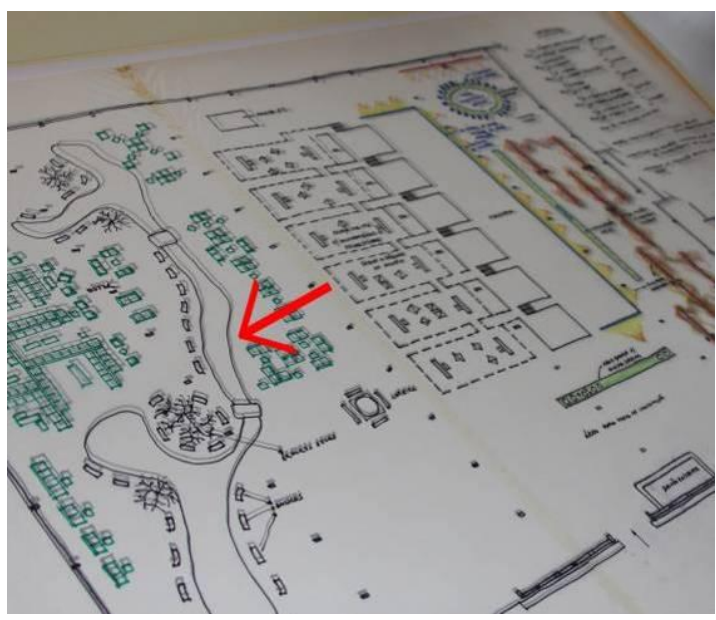

Figura 68. Desenho para a Área de Convivência, incluindo o lay-out do mobiliário. Detalhe do Rio São Francisco.

A lareira na área de Convivência, também está lá porque provém da mesma fonte de intenções, mais que inspirações, que querem ser metafóricas dessa sua experiência brasileira. $\mathrm{Na}$ Casa de Vidro, sua casa, a lareira ficava permanentemente acesa, mesmo nos dias de calor: - Os índios têm fogo dentro de casa o tempo todo, todos os dias, mesmo no calor da Amazônia, ou no Mato Grosso! -, dizia.

São Paulo faz frio, e o fogo é agregador: bastou a grande lareira lá instalada e, ao seu lado, uma pilha de lenha, para que, no primeiro inverno, assim que o Bloco Antigo do SESC foi inaugurado - pouco mais de 1 ano antes do Bloco Novo - os freqüentadores assumissem a função de acender e manter viva a fogueira, avivando-a civilizadamente, os demais usuários se agrupando em volta.

A base da lareira é pesada, em todos os sentidos.

Verdadeiramente, é de granito maciço, o conjunto composto com oito pedaços que se encaixam, como um quebra-cabeças, o todo recompondo um prisma único, como se fosse uma grande e única peça, ali depositada. Tecnicamente, os pedaços facilitaram o transporte e sua colocação no local. Os encaixes, a seco, sem rejunte, permitem a função 
de juntas de dilatação. $\mathrm{O}$ intrincado desses encaixes é que oferecem a visão de um corpo único.

Há um italianismo na proposição do encaixe dessas pedras, essa técnica não é comum no Brasil, embora tenha sido próxima quando os grandes mestres de cantaria portugueses atuaram na Colônia, nas grandes edificações, Fortes, Igrejas e em alguma, mais escassa, construção civil de gente de posses, mas tornada cada vez mais rara entre nós. As rampas de acesso ao Outeiro da Glória são de uma execução tão primorosa e requintada quanto essa, que também dependeu da qualidade e empenho da mão de obra ainda sabedora da técnica, do como-fazer, know-how, savoir-faire, que nunca deveria se perder, tanto nos intentos de Lina quanto de Lucio.

Ao mesmo tempo em que parece despropositado tamanho esforço para uma mera base de lareira, surge mais uma lição da técnica e da vontade de demonstrar que, mesmo nos dias que corriam, era possível propor e encontrar mão de obra disposta, no Brasil, a entender e executar, aprender ou re-aprender, como se fazia algo que tivesse significado, ou que ainda faça sentido. Para qualquer um que a use: quem acendeu a lareira e quem pode aconchegar-se, compreende também um mundo maior, uma lembrança do Brasil, o que inclui os índios, por exemplo, ou, simplesmente, quem está ao lado.

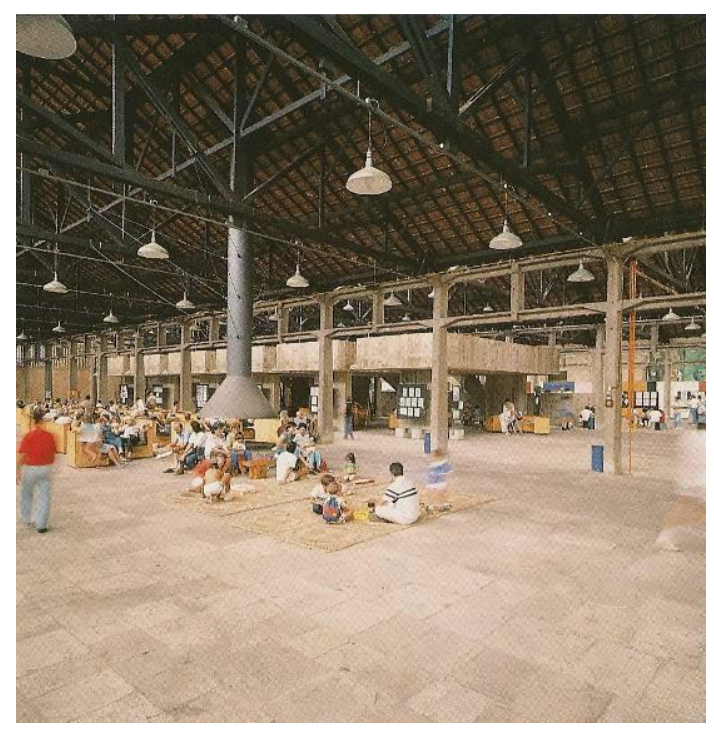

Figura 69. Lareira. Centro de Lazer.

Figura 70. Lareira. Centro de Lazer.

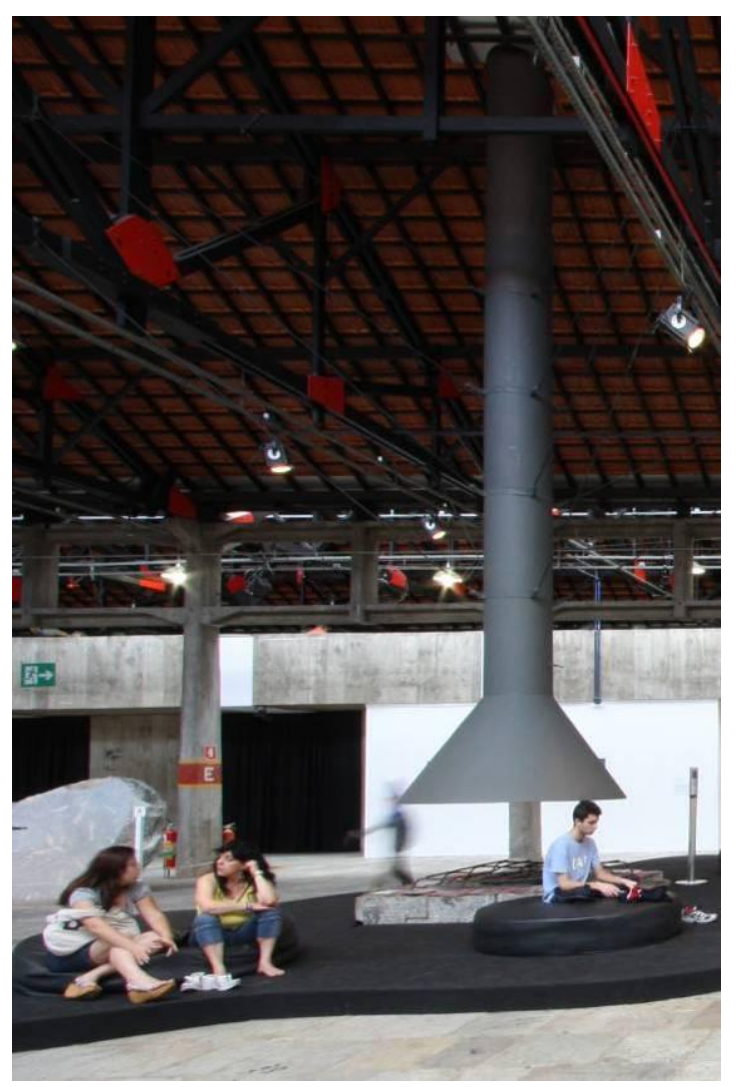




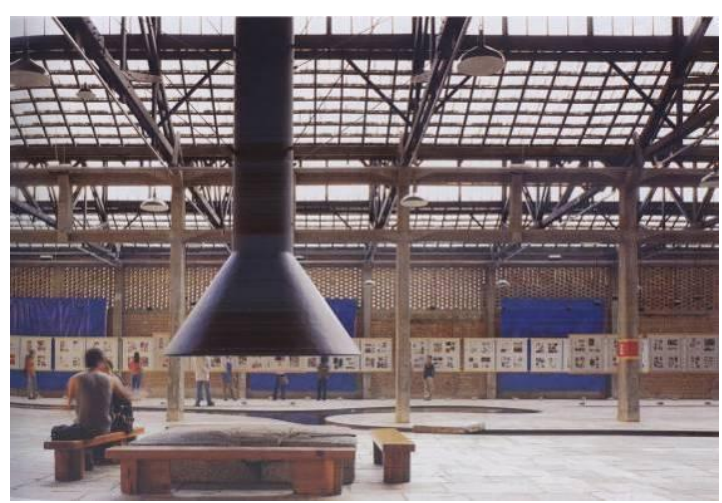

Figura 71. Lareira. Centro de Lazer.

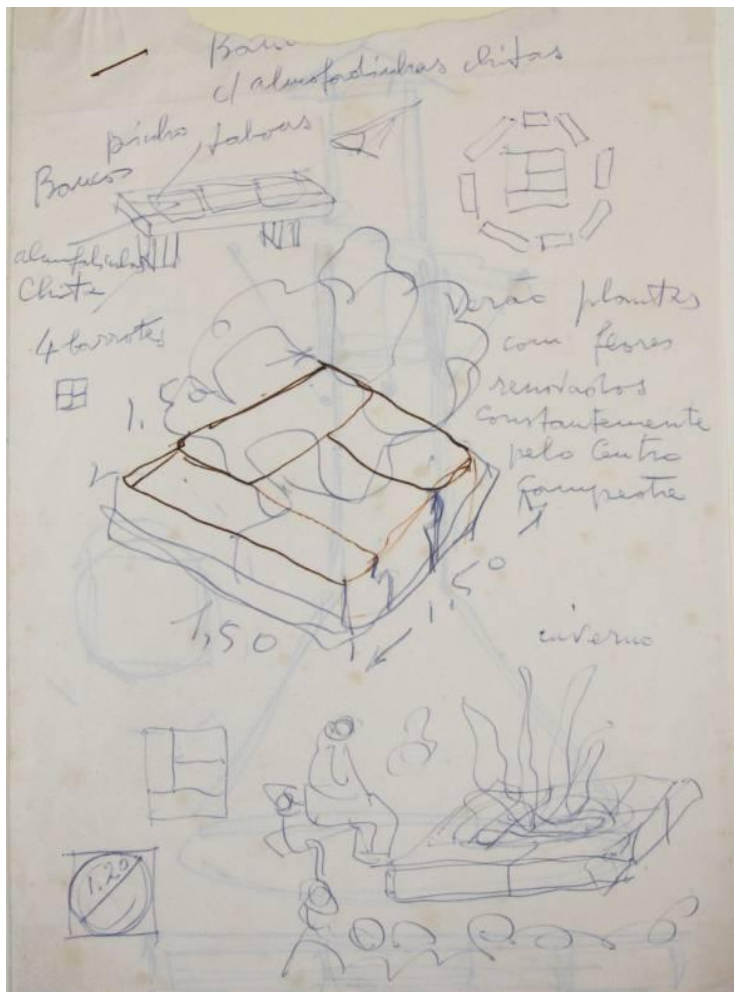

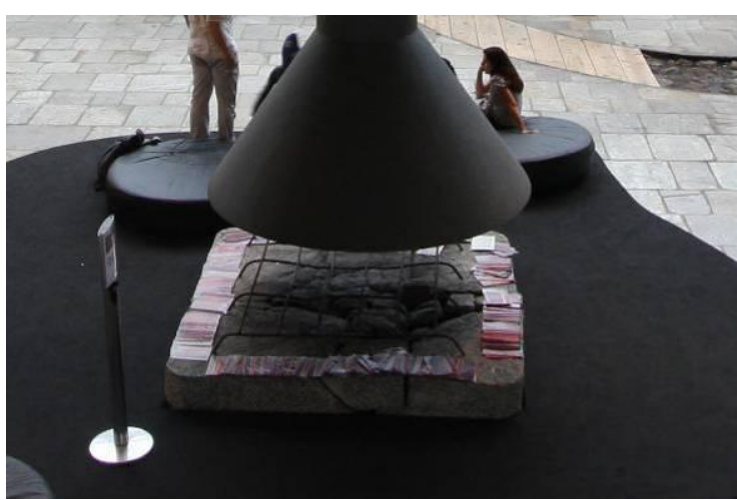

Figura 72. Lareira. Centro de Lazer.

Figura 73. Desenho do encaixe das pedras da base da lareira.

O piso da área de Convivência, em pedra Goiás - também chamada luminária, por seus pontos brilhantes - ou algumas vezes chamada de Pirenópolis, lugar de sua extração em Goiás -, tem o assentamento muito utilizado pelos modernos, a partir de lições do medievo, com as juntas alinhadas em uma direção, e desalinhadas na outra, porém, regradas na modulação 3, 4 e 5, desalinhadas em cada fileira. Le Corbusier utilizou essa regra, Lucio também, e, aí, Lina também. O MASP, nos pisos do Hall Cívico - assim chamados os níveis abaixo do Belvedere da Paulista também era assim, infelizmente hoje substituído por um granito vulgar, de supermercado, com um assentamento tão vulgar quanto. 


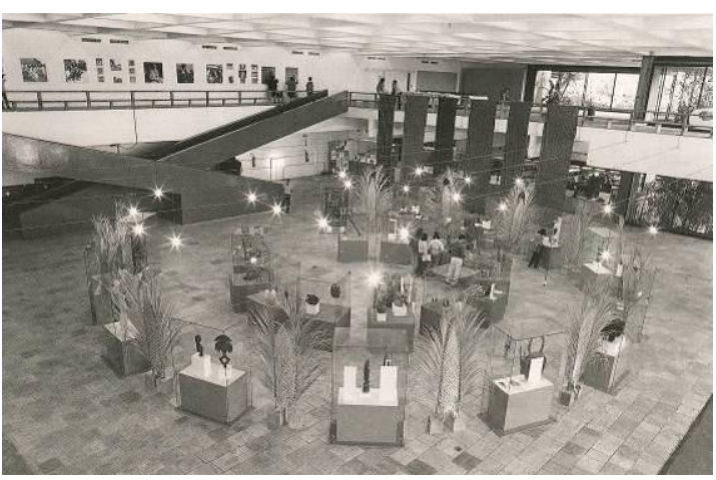

Figura 74. Piso do Hall Cívico do MASP em pedras Goiás. 1968

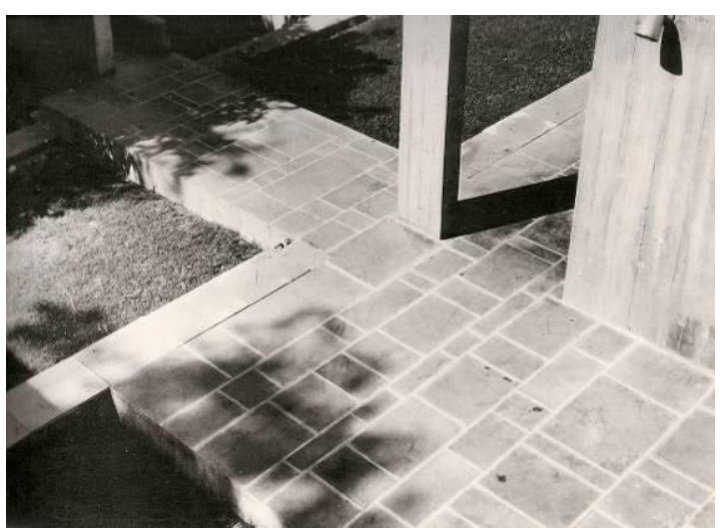

Figura 76. Piso da área externa da Villa Sarabhai, Ahmedabad. Le Corbusier, 1951-1956.

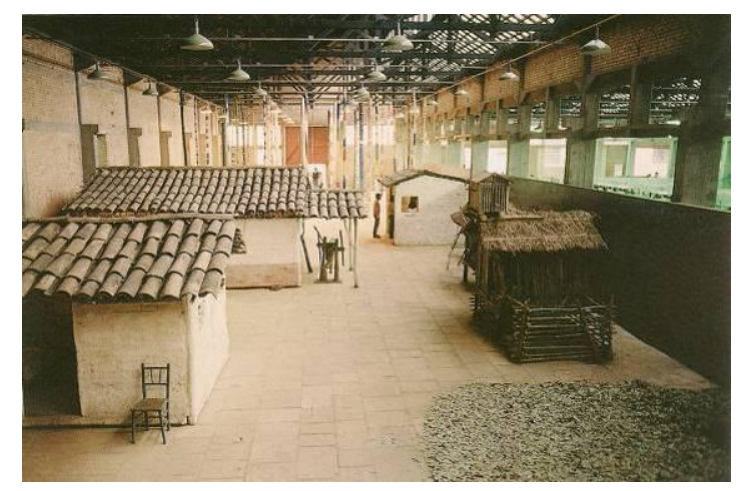

Figura 75. Piso do SESC Pompéia, em toda a área de Convivência, Biblioteca e Exposições, em pedras Goiás. 1981

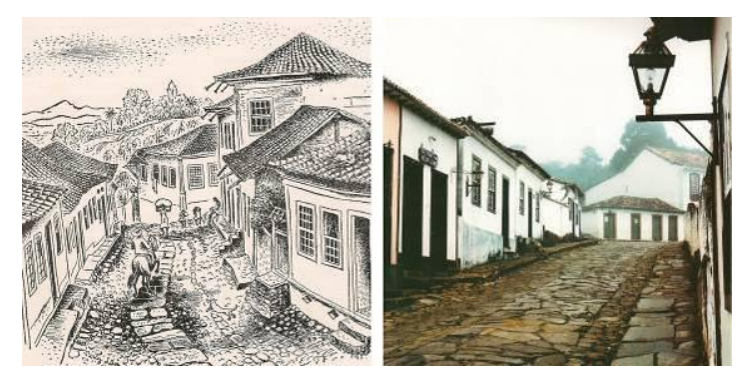

Figura 77. Desenho de Percy Lau de uma paisagem de Diamantina e foto de Tiradentes, de Mario Espinosa.

Para Monlevade, no item ruas, Lucio especifica:

As ruas pedidas deveriam conservar, tanto quanto possível, aquela feição despretensiosa peculiar às estradas - fazendo-se, em vez de calçadas, simples caminhos de placas de concreto fundidas no lugar e com juntas de gramas para se evitarem as trincas futuras: atualização das velhas capistranas. ${ }^{11}$ - desnecessário fazer novos grifos, além dos determinados por Lucio.

Lina dizia, a respeito desses pontos brilhantes que ficam piscando na pedra Goiás:

- Que outro país tem jóias que se pode por no piso, hem? Tem lugares nesse país que corre pedras preciosas nas enxurradas, a molecada sai correndo atrás...(c.d.m.)

Figuras de linguagem à parte, ela estava se referindo à sua tentativa de desenvolver projetos de jóias utilizando-se das pedras semi-preciosas brasileiras, tão apreciadas fora do Brasil, mas que aqui não se dá o merecido valor, pois corre até nas enxurradas. Seu famoso colar de águas-marinhas, - entre outros ,

\footnotetext{
${ }^{11}$ COSTA, L. Sobre Arquitetura. Alberto Xavier org. Porto Alegre: Centro de Estudantes Universitários de Arquitetura, p. 54, 1962. Idem: revisão fac-símile com comentários de Lucio Costa. Porto Alegre: Editora UniRitter, 2007.
} 
infelizmente roubados -, era um exemplo dessa tentativa. Lina sempre se referia também ao fato de que os cristais gigantes, que conheceu na Chapada Diamantina, Bahia, estarem com seus exemplares mais importantes expostos em acervos de museus da Europa. Ela já pensava isso quando especificou esse piso, pedra Goiás, para o MASP, mas os novos diretores não perceberam a sutileza da denúncia, que passou ao largo de sua compreensão e recentemente substituíram por granito polido, que resultou numa espessa vulgaridade.

Retomando: os paralelepípedos, que deixam os matinhos crescerem por entre as juntas de seu assentamento, foram utilizados tanto na rua central do SESC, como recobrem todo o belvedere do MASP. Lina disse:

Os paralelepípedos são um dos calçamentos mais sublimes da história da humanidade, documentos seculares de pedras cortadas e alisadas com as mãos, por homens, mulheres, crianças, documento de civilização. ${ }^{12}$ (grifo nosso)

Lina utiliza aqui a palavra sublime, que, assim como beleza, tem para ela significações muito específicas, que só poderiam ser usadas sob circunstâncias controladas. Ela pula da pedra, propriamente dita, o paralelepípedo, para a história da humanidade, e, aí sem dúvida, no sentido da Física, há sublimação, a mudança de estado sem passagens intermediárias. Não há o sentido Renascentista, de transformar os artistas plásticos em artistas maiores, pelo contrário, ela se dizia medievalista em relação às artes - também em relação à cosmologia cultural da Idade Média -, achava importante só até o Pré-Renascimento, Revolução Científica à parte.

Mas as imagens que brotam, dos diversos estudos que agora surgem sobre Lina, frutos de um revigorado interesse sobre suas obras, mas, mais precisamente sobre essa arquiteta - mulher -, que atuou com tanta desenvoltura e liberdade, num pais de terceiro-mundo - tão machista quanto a própria Itália -, são um tanto diáfanas, e, em alguns, chega-se mesmo a se referir à sua pouca obra realizada como sublime, palavra que entrou em voga no meio acadêmico atual, não se sabe bem por que, quando estamos tratando de arquitetura moderna.

Se sublime, adjetivo, está se reportando à novíssima categoria estabelecida no Renascimento, como um predicado - que era novo, para se tratar de um novo jeito de se ver a Arte - as artes plásticas, as manuais, tratadas como menores -, com o A Maiúsculo, como eles propuseram, é preciso dimensionar o quanto ainda serve sua adoção hoje em dia. Se é a utilização desse adjetivo que se está tentando estabelecer em relação à Lina, é preciso sempre lembrar o tanto de medieval a que Lina estava querendo se reportar, e demonstrar, no sentido exatamente contrário ao do Renascimento, em tudo o que queria fazer. Se se recorre a essa expressão como verbo, que é passar - pular - de um estado ao outro sem o estado intermediário - pular de sólido a gasoso sem passar pelo líquido -, é o que Lina menos, e, jamais, quis ser, preferia demonstrar uma possível realidade. O que não impede que haja nas atitudes de Lina um imenso carinho, que permeou cada ato de seu fazer como profissional, o tempo

\footnotetext{
${ }^{12}$ Idem. p 220.
} 
todo e em cada ato. Assim como há, sem dúvida, um grande carinho e atenção, por parte de todos os pesquisadores e pesquisadoras, ao analisar, assim, com essa abordagem, a sua obra.

Mas, há razão uma razão para que tudo isso tenha acontecido, o SESC - Fábrica da Pompéia foi um fato extraordinário, fundamental, para que se retomasse a arquitetura como assunto de interesse generalizado, e que um houvesse um novo animo de se retomar a crítica; escrevemos, certa vez:

Logo no início da década, em 1981, inaugura-se em, São Paulo, uma obra que causou um certo efeito revigorante: o Centro de Lazer - Fábrica da Pompéia - SESC. A curiosidade dos estudantes, a polêmica entre os arquitetos e um raríssimo acompanhamento por parte da grande imprensa - fato extremamente raro -, que quase nunca abordava o assunto arquitetura, tornaram esse projeto um espécie de estopim de discussões que virão logo a seguir. Seria o SESC-Pompéia "modernista, mas não funcionalista”? Seria "brutalista-minimalista”? Seria "post-modern”? "Contextualista"? 13

O fato de ter havido confusão sobre a obra ser isso ou aquilo, ser ou não ser pós-moderna, o fato de que a década de 70 tenha sido acabrunhada, o Brasil triste, com a ditadura no comando, a arquitetura mundial em uma situação de impasse, onde só propostas vinculadas ao grande capital tinham algum destaque, o fato de a Era Miterrand ter colocado arquitetura de novo num plano de discussões sobre cultura, no sentido amplo da expressão, o fato de Lina ser mulher, tudo isso transformou o SESC num polarizador de atenções, com opiniões as mais diversas mas sempre, desta vez, bem vindas.

Em 1986, Marlene Acayaba disse:

SESC Pompéia, um soco no estômago. (...) Do diálogo entre a antiga fábrica e o novo edifício nasce o espaço da multidão: da criança à terceira idade. ${ }^{14} 20$ anos depois, em Oliveira: $\grave{E}$ um grito, um soco no estômago, uma terapia intensiva contra um estado de coisas que está aí de fato, é palpável e precisa ser transformado. $^{15}$

Voltamos ao soco, expressão já utilizada por Flavio Motta, com visto anteriormente. Também em Comas:

\section{Brava e sabiamente, Lina proclama que "terribilità" é tão} inerente à cidade e tão relevante para a mesma quanto "bellezza", apaziguamento tão importante quanto provocação, que urbanidade requer tanto o colírio quanto o soco na cara. Doce ou chocante, seu imaginário vem de um fundo eclético, compreendendo

\footnotetext{
${ }^{13}$ SUZUKI, M. Década de 1980. in: Montezuma, R. org. Arquitetura Brasil 500 anos - vol. 2. Recife: Universidade Federal de Pernambuco, p 185, 2008.

${ }_{14}^{14}$ ACAYABA, M. SESC Pompéia, um soco no estômago. São Paulo: Projeto n.92, 1986.

${ }^{15}$ Oliveira, O. F. Lina Bo Bardi: Sutis Substâncias da Arquitetura. São Paulo: RG / GG, p. 16, 2006.
} 
tanto fontes disciplinares quanto fontes fora do território convencional da arquitetura. ${ }^{16}$ (grifo nosso)

Todos os pormenores do projeto do SESC foram testados na obra, executando-se amostras ou protótipos no local, em um para um, na escala real, seja de acabamentos, componentes ou peças de mobiliário, e até mesmo cores das tintas. A presença do atelier de Lina no próprio canteiro, a presença dela ali, todos os dias, acompanhando todos os testes até a aprovação final, junto aos operários, foi determinante para a perfeita execução das obras e o feliz resultado final demonstra a importância dessa presença.

Foi o engenheiro Toshio Ueno quem resolveu, brilhantemente, o projeto das formas para a torre da caixa d'água, testado em dois lances da forma trepante, para protótipo e aprovação de Lina, da execução definitiva, no próprio canteiro, ao lado de onde hoje se encontra a torre.

Essa técnica, trepante , ao contrário da sua concorrente, deslizante, requer dois jogos completos da forma, com a altura de lançamento de concreto de 1 metro, aproximadamente - no SESC, foi de 1 metro e 20 centímetros. Na medida em que uma das formas está concretada e em processo de cura, monta-se o segundo jogo e se procede à concretagem deste para, em 24 horas, desmontar o anterior e já remontá-lo sobre o antecessor, tendo-se então um rendimento de 1 metro e 20 centímetros a cada 12 horas. No sistema deslizante, a forma única se desloca para cima constantemente, através de macacos hidráulicos, e a cada movimento ascendente se procede à concretagem, de maneira contínua. Concorrem em rendimento, tempo de execução e custo.

Nesse caso, o engenheiro Ueno resolveu a textura requerida por Lina para a superfície exterior da caixa d'água, fazendo cada um dos dois conjuntos de formas ligeiramente telescópico, em forma de seção de cone. Com isso, a parte inferior de uma forma era maior que a parte superior da outra, deixando um vão. No vazio desse vão, a cada concretagem e remontagem de formas, era colocada uma grande quantidade de estopa, que o próprio peso do concreto empurrava para baixo, derramando e criando o efeito de um rendilhado, conforme ela queria.

\footnotetext{
${ }^{16}$ COMAS, C. E. Três variações sobre a domesticidade e a transparência no pós-guerra. Arquitexto 8, p. 11. 2006.
} 


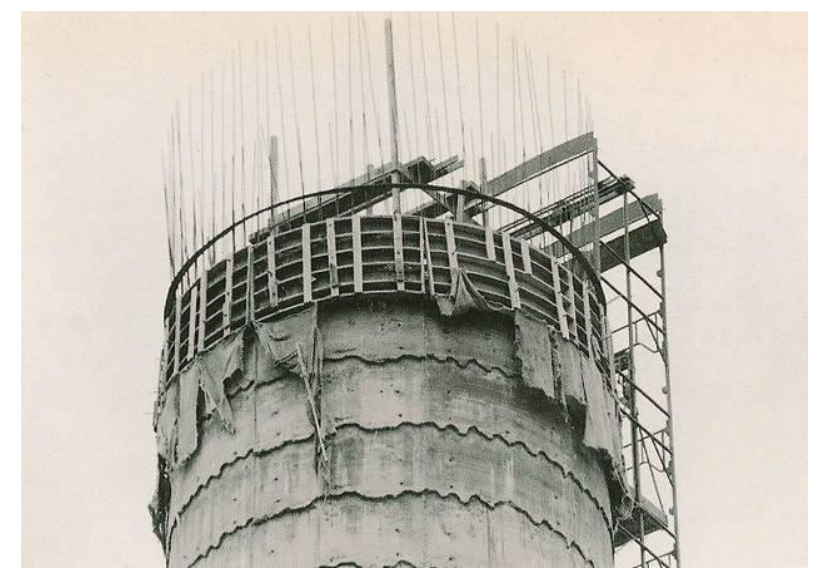

Figura 78. Caixa d'água em construção, com formas detalhadas pelo engenheiro Toshio Ueno.

Lina sempre agia assim. Fora assim no MASP e no Unhão, e por um bom período, assistindo a essas obras alternadamente e viajando constantemente para a supervisão. Não queria ter escritório, no sentido convencional do termo, e mantinha uma postura medieval em relação à profissão, permanecendo sempre que podia nos canteiros de obras, no atelier-casinha. Não queria secretária ou office-boys, dizia: - O telefone, atendo eu mesma!

Essa presença no canteiro também foi fundamental para o refinamento da alocação correta das diversas funções em seus lugares definitivos, tal como estão lá. Há um processo constante de releitura de cada lugar e detalhe que só a presença permite. Isso foi o que aconteceu também com Lucio, nas rampas de acesso ao Outeiro da Glória, obra na qual só a atuação do arquiteto, diretamente no canteiro, como já vimos, permitiu tão apurada acomodação dos caminhos àquela complicada topografia.

A experiência de leitura de um conjunto urbano e arquitetônico importante, com o intuito de transformá-lo em algo novo, com um programa novo, enfim, com um sentido novo, Lina já tinha passado e testado no seu projeto para o Solar do Unhão. Lá com carga mais densa de preocupações, por se tratar de um bem tombado, como se verá no capítulo específico daquele projeto. Mas aqui, no caso do SESC, que não era tombado em nenhuma instância, similarmente àquele projeto, a série de decisões tomadas sob a ótica do arquiteto, de seu projeto - intenção - arquitetônico, tem que ser ressaltadas.

A começar de: o que fica e o que sai - demolindo, mesmo, quando preciso - em nome de uma leitura da urbanidade do conjunto resultante da intenção, quer dizer, do projeto. Para continuar, onde colocar, alocar, implantar o que e quais, das novas funções. Continuando, ainda, quais as condições técnicas e conhecimentos arquitetônicos se dispõem para isso? Nesse caso essas condições reúnem conhecimentos de arte, filologia, história da técnica e conhecimento técnico construtivo. E, ainda, que meios sócio-político-econômicos estão aliados ao empreendimento para que ele se formule a contento. Por último, para que fazer tudo isso? E não necessariamente nessa ordem, em qualquer ordem ou, preferencialmente, de uma forma simultânea. 


\section{VOCAÇÃO}

Lucio considerava isso uma Vocação:

O problema da recuperação e restauração de monumentos, tratese de uma casa seiscentista como as de São Paulo ou das ruínas da igreja de São Miguel, no Rio Grande do Sul, é extremamente complexo.

Primeiro, porque depende de técnicos qualificados, cuja formação é demorada e difícil, pois requer além do tirocínio de obras e de familiaridade com os processos construtivos antigos, sensibilidade artística, conhecimentos históricos, acuidade investigadora, capacidade de organização, iniciativa e comando; e ainda, finalmente, desprendimento.

Segundo, porque implica em providências igualmente demoradas, como o inventário histórico-artístico do que existia na região, o estudo da documentação recolhida, o tombamento daquilo que deve ser preservado, a eleição do que mereça restauro prioritário, a apropriação de verbas para esse fim, a escolha de técnicos, o estudo preliminar na base de investigação histórica e das pesquisas in loco, a documentação e o registro das fases da obra. E, por fim, a manutenção e o destino do bem recuperado. ${ }^{17}$

Para Lina, a falta de resposta para qualquer uma dessas questões era razão definitiva para não se arriscar em um novo trabalho, no qual não se vislumbrasse seu encaminhamento futuro. Foi esse o caso da já citada recusa para o trabalho no Forte de São Pedro, em Salvador.

Em alguns casos ela mesma tentava suprir a deficiência de uma resposta ou outra, usando meios que só sua própria condição permitia: o apoio do Professor e da estrutura do MASP, sua grande gama de contatos tanto no Brasil quanto no exterior, mas principalmente seu conhecimento. Dessa maneira, tentava fazer com que qualquer projeto seu, inclusive os pequenos projetos, mantivesse a necessária dimensão maior, a larga abrangência ideal do trabalho da Arquiteto com A Maiúsculo.

Assim, uma casa não é casinha ou casona, como enunciou Le Corbusier ${ }^{18}$, uma cadeira não é só uma cadeira, um garfo não é um mero e frugal

\footnotetext{
${ }^{17}$ COSTA, L. Registro de uma vivência. São Paulo: Empresa das Artes, 1995.

18 (...) No ano passado, escrevi um livro dedicado a esse tema: Uma casa-Um palácio, ao qual dei um subtítulo: "em busca de uma unidade arquitetônica". (...) Desenhei a cabana do selvagem, o templo primitivo, a casa do camponês e disse: estes organismos, criados com a autenticidade que a natureza mesma infunde em suas obras - sua economia, sua pureza, sua intensidade -, são aqueles que, num dia de sol e de clarividência, tornaram-se palácios. Mostrei a casa do pescador, construída com uma verdade aguda, indiscutível; meus olhos, um dia mergulhados na arquitetura, no fato arquitetônico eterno, descobriram-na subitamente. "Esta casa", disse a mim mesmo, "é um palácio". LE CORBUSIER. $7^{a}$ Conferência: outubro de 1929. in: LE CORBUSIER. Precisões: sobre um estado presente da arquitetura e do urbanismo. São Paulo: Cosac \& Naify, p. 159 e 161, 2004.
} 
instrumento para se almoçar, e o resquício de uma última peça de louça de Macau ${ }^{19}$, em uma casa, não é uma mera peça de porcelana de um enxoval qualquer, a se perder. São lições de comportamento e de existência. E são dados indispensáveis para o rol de conhecimento necessário para o correto desempenho das obrigações civis da atividade profissional de todo arquiteto, como mestre-de-vida. Tudo, todas as coisas, têm um plano dimensional que não está nas coisas em si, mas sim numa esfera maior, que deve orientar cada instante do exercício dessa profissão.

\section{(...) o fato de ser o homem o constante protagonista "físico" de} que denominamos a "aventura arquitetônica" é uma aventura "útil" ao homem, cessando de ser Arquitetura no momento em que deixa de ser "útil". E assim acontece com a cadeira sobre a qual sentamos, com a colher que usamos para comer e o copo para beber, com uma folha de papel em que escrevemos ou uma embalagem a ser aberta e destruída: esta real e intima participação do home com as coisas "arquitetadas" é a essência da Arquitetura. (... $)^{20}$

Arquitetura como algo maior, grandiosa e totalizante, que ensina a viver, é inerente à postura moderna: a partir da modernidade o próprio Homem - o ser humano - já não seria mais o mesmo; a modernidade seria inevitável, não seria necessário muito esforço para, um dia, a sociedade como um todo compreendê-la, pois ela mesma estaria transformada, seria natural.

Por isso, não podemos concordar com Olívia, quando diz que sua obra extrapola os limites da arquitetura para atingir outros domínios disciplinares tal como o das artes, da filosofia, da antropologia, da literatura, ou da psicanálise ${ }^{21}$, pois, para essa geração de modernos, arquitetura já era tudo isso mesmo, ou até muito mais, como vimos, seu objetivo era a criação de um novo homem.

A insistente discussão sobre a dicotomia entre público-privado, tão presente a partir da década de 80, no meio intelectual e acadêmico - a discussão de um modo mais difuso é muito mais antiga -, fica, diante disso, pouco relevante, pois nada de nada deveria ser privado. Para os modernos, a atitude no projeto é que é, e sempre deveria ser, o tempo todo, pública. Para os arquitetos - e projetos - dignos desse título, tudo era sempre público, coletivo na sua instancia maior. Isso não é uma postura dela, Lina, é a postura dos modernos. O Movimento Moderno pregava essa necessidade de se ensinar o Homem a ser um outro Homem, e o arquiteto seria o intransigente operador dessa transformação.

\section{Lina sempre repetia: - Niemeyer tomou um caminho próprio,} individual, e foi por ai... - dito e soando como uma crítica, acompanhado por um gesto, relando as palmas das mãos, em seguida esticando um dos braços, como quem indica alguém que parte, vai embora. Dizia isso como quem diz: ao contrário de nós,

\footnotetext{
${ }^{19}$ É uma referência ao jeito carinhoso com que Lucio descreve a vida familiar em COSTA, L. Registro de uma vivência. São Paulo: Empresa das Artes, p. 16, 1995.

${ }^{20}$ BARDI, L. B. Contribuição propedêutica ao ensino da teoria da arquitetura. São Paulo: Instituto Lina Bo e P M Bardi, p. 43, 2002.

${ }^{21}$ OLIVEIRA, O. Lina Bo Bardi: Sutis Substâncias da Arquitetura. São Paulo: RG / GG, p.15, 2006.
} 
modernos, que optamos por um caminho coletivo, para romper com a arte acadêmica, da individualidade. E acrescentava: - Sou comunista, não acredito em Deus. Mas esse Niemeyer é abençoado por Deus! - ressalvando sua importância no contexto da moderna arquitetura do Brasil que ela sempre defendeu, e, sempre que podia, defendia diretamente Niemeyer das críticas superficiais que sempre ocorriam, reincidentemente.

Como disse Lucio, o moderno, que via no passado uma prospecção para o futuro:

De todas as artes é, todavia, a arquitetura - em razão do sentido eminentemente utilitário e social que ela tem - a única que, mesmo naqueles períodos de afrouxamento, não se pode permitir - senão de forma muito particular - impulsos individualísticos. Personalidade, em tal matéria, se não é propriamente um defeito, deixa, em todo caso, de ser uma recomendação. Preenchidas as exigências de ordem social, técnica e plástica a que, necessariamente, se tem de cingir, as oportunidades de evasão se apresentam bastante restritas; e se, em determinadas épocas, certos arquitetos de gênio revelam-se aos contemporâneos desconcertantemente originais (Brunellesco no começo do século XV, atualmente, Le Corbusier), isto apenas significa que neles se concentram em um dado instante preciso - cristalizando-se de maneira clara e definitiva em suas obras - as possibilidades, até então sem rumo, de uma nova arquitetura. Daí não se infere que, tendo apenas talento, se possa repetir a façanha: a tarefa destes, como a nossa - que não temos nem um nem outro - limita-se em adaptála às imposições de uma realidade que sempre se transforma - respeitando, porém a trilha que a mediunidade dos precursores revelou. ${ }^{22}$ (grifo d.a.)

Lucio sempre demonstrou muita discrição em relação a pessoas ou posições que tivessem pontos de vista abertamente ideológicos, seguros de convicções. Acreditou na razão e na técnica como solução irrevogável de problemas que se apresentavam como sendo ideológicos, sem abdicar da revolta pessoal contra situações execráveis, que contestou com veemência, publicamente, e em nome de todos, em nome de uma cidadania universal, como demonstrou no carinho de um roteiro para um filme de Charlie Chaplin.

Sua crença na sua razão e na técnica, fez com que ele até mesmo escrevesse carta pessoal endereçada ao Presidente dos Estados Unidos da América do Norte, discorrendo sobre os graves acontecimentos que se apresentavam na Guerra Fria. Seu comportamento lembra Chaplin, no dizer de Eiseinstein, o Garoto, e lembra a ele próprio, na tentativa de que Chaplin lesse, insistentemente, seu roteiro.

\footnotetext{
${ }^{22}$ COSTA, L. Razões da nova Arquitetura. in: COSTA, L. Sobre Arquitetura. Alberto Xavier org. Porto Alegre: Centro de Estudantes Universitários de Arquitetura, 1962. Idem: revisão fac-símile com comentários de Lucio Costa. Porto Alegre: Editora UniRitter, 2007. Na edição fac-símile comentada, Lucio corrige 1930, data do texto para 33 ou 35 e mais adiante consta um 1933! A respeito do trecho aqui reproduzido ele exclama: Só que os "talentosos", agora, desembestaram! Comentários provavelmente feitos em 1962, data em que Lucio recebeu o livro cinza das mãos de Xavier. Note-se também a inclusão de Le Corbusier como desconcertantemente original, que indica realmente a correção de datas. No Registro de uma vivência consta a data 1934.
} 
Nos anos 20, os arquitetos da vanguarda socialista levaram ao extremo os objetivos dessa missão, a transformação científica e inevitável da sociedade. ${ }^{23}$ Mesmo Le Corbusier, em 1923, em Vers une Architecture, com o capítulo Arquitetura ou revolução, estava, dentro do movimento moderno, querendo dizer a mesma coisa que os demais, que a Arquitetura seria o elemento transformador, mais lógico, mais elementar, menos dolorido que as Revoluções. É compreensível, dentro do espírito da época, mas a frase foi sempre utilizada como reacionária, motivo para considerar Le Corbusier um contra-revolucionário, etc. ${ }^{24}$ A confusão existe, ele realmente não era comunista, apesar de que a Igreja não queria consagrar Ronchamp, projeto de um comunista, assim como não queria consagrar São Francisco na Pampulha, obra de um comunista assumido, Niemeyer.

\begin{tabular}{|c|c|c|}
\hline 01. & Deitar-se. & $22: 00$ \\
\hline 02. & Oito horas de sono. Acordar. & $06: 00$ \\
\hline 03. & Ginástica, 5’. & $06: 05$ \\
\hline 04. & Asseio, $10^{\prime}$. & 06.15 \\
\hline 05. & Ducha (facultativa), 5 '. & $06: 20$ \\
\hline 06. & Vestir-se, $5^{\prime}$. & $06: 25$ \\
\hline 07. & Ir ao refeitório, $3^{\prime}$. & $06: 28$ \\
\hline 08. & Café da manhã, $15^{\prime}$. & $06: 43$ \\
\hline 09. & Ir aos vestiários, $2^{\prime}$. & $06: 45$ \\
\hline 10. & Indumentária (exterior), 5'. & $06: 50$ \\
\hline 11. & Ir à mina, 10'. & 07:00 \\
\hline 12. & Trabalho na mina, 8 horas. & $15: 00$ \\
\hline 13. & Ir à comuna, 10'. & $15: 10$ \\
\hline 14. & Trocar roupas, 7 . & $15: 17$ \\
\hline 15. & Lavar as mãos, 8 '. & $15: 25$ \\
\hline 16. & Jantar, 30' & $15: 55$ \\
\hline 17. & $\begin{array}{l}\text { Ir à sala de descanso para uso de } \\
\text { um tempo morto de uma hora, } 3 \text {. }\end{array}$ & $15: 58$ \\
\hline 18. & $\begin{array}{l}\text { Tempo morto de uma hora. } \\
\text { Os que quiserem, podem } \\
\text { dormir, nesse caso devem ir aos } \\
\text { dormitórios. }\end{array}$ & $16: 58$ \\
\hline 19. & Asseio e troca de roupas, $10^{\prime}$. & $17: 08$ \\
\hline 20. & Ir ao refeitório, $2^{\prime}$. & $17: 10$ \\
\hline 21. & Chá, 15'. & $17: 25$ \\
\hline 22. & $\begin{array}{l}\text { Ir ao clube. Distrações culturais. } \\
\text { Desenvolvimento cultural. } \\
\text { Ginástica. Talvez um banho } \\
\text { ou nadar numa piscina. É a } \\
\text { própria vida que, nesse caso, } \\
\text { ditará o emprego do tempo e que } \\
\text { estabelecerá o plano. Previsão de } \\
4 \text { horas. }\end{array}$ & $21: 25$ \\
\hline 23. & $\begin{array}{l}\text { Ir ao refeitório, cear e ir ao } \\
\text { dormitório, } 25 \text {. }\end{array}$ & $21: 50$ \\
\hline 24. & $\begin{array}{l}\text { Preparação para dormir (pode-se } \\
\text { tomar uma ducha), } 10^{\prime} \text {. }\end{array}$ & $22: 00$ \\
\hline
\end{tabular}

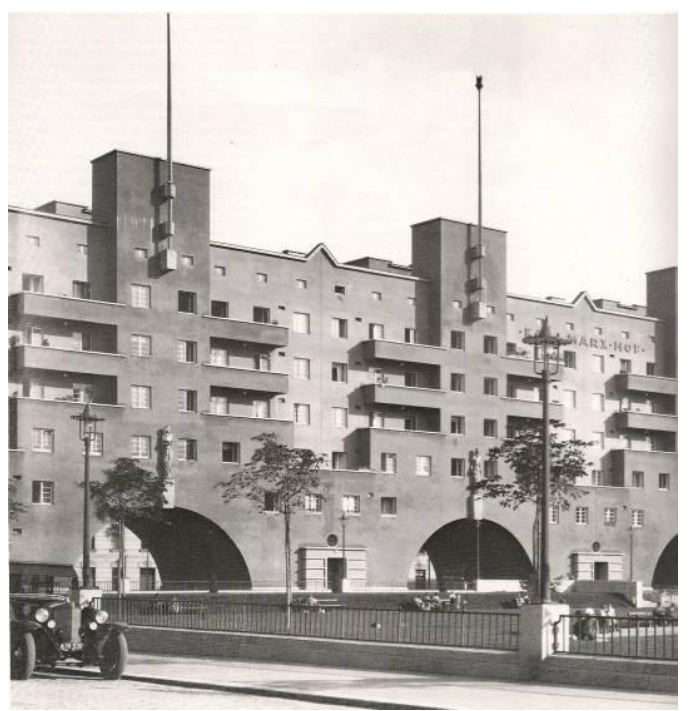

Figura 80. Karl Ehn, Karl Marx Hof, Vienna, 1927.

Figura 79. "O modo de vida socialista é ordenado de tal modo que corresponda à própria vontade do proletário, mesmo que ele ainda não a conheça. Pela consciência da necessidade, realiza-se a liberdade do homem, que entende ser sua a autodeterminação. ${ }^{25}$

\footnotetext{
${ }^{23}$ Ver em: AZEVEDO, R. M. de. Metrópole: abstração. São Paulo: Perspectiva, p. 76-77, 2006, quando o planejamento discutia não só a imposição da divisão espacial urbana, o tamanho das habitações, mas discutiam inclusive os horários das diversas atividades, que deveriam ser cronometrados. Ver também em: KOPP, A. Arquitectura y urbanismo soviéticos de los años veinte. Barcelona: Lúmen, 1974.

${ }^{24}$ Por ocasião do I CIAM, realizado em La Sarraz, em julho de 1928, já se explicitava a distância que o separava da "ala alemã", especialmente nas questões referentes ao papel social do arquiteto, aos problemas estéticos e éticos, às idéias políticas e às modalidades de ação política e de relação com o Estado-MARTINS, C. A. F. Uma leitura crítica : Posfacio. in: LE CORBUSIER. Precisões: sobre um estado presente da arquitetura e do urbanismo. São Paulo: Cosac \& Naify, 2004.

${ }^{25}$ AZEVEDO, R. M. de. Metrópole: abstração. São Paulo: Perspectiva, p. 76-77, 2006.
} 
Dentro da sua razão e na sua técnica, Le Corbusier disse:

É uma questão de construção que está na chave do equilíbrio rompido hoje: arquitetura ou revolução. $\mathrm{E}$, mais adiante: A época moderna está diante deles, brilhante e radiosa... do outro lado da barricada. (...) Essas pessoas reivindicam também os direitos à maquina de morar que seja simplesmente humana.(...) Mas se as modalidades de propriedade mudassem, e elas mudam (lei Ribot para o operário, construção de edifícios de aluguel em propriedade de andar, etc. ou todas as outras iniciativas privadas ou de Estado, mais ousadas, que pudessem intervir) poderíamos construir, estaríamos entusiasmados em construir e evitaríamos a revolução.(...) Houve revolução nos modos de construir. (...) Arquitetura ou revolução. Podemos evitar a revolução. (grifo d.a.) ${ }^{26}$

Lina dizia: - Era um reacionário de primeira... Mas vá escrever bem assim lá diante!Moderno... Panfletário!(c.d.m.)

A acusação de comunista, também foi utilizada para acusar e desqualificar os modernos brasileiros, inclusive e talvez principalmente Lucio, como reagiu Archimedes Memória, em carta endereçada diretamente a Getúlio Vargas, quando se consolidou a não-execução de seu projeto para o MÊS, apesar de vitorioso no concurso:

O que acabamos de narrar tem, no presente momento, gravidade não pequena, em se sabendo que esse arquiteto é sócio do arquiteto Gregori Warchavchik, judeu russo de atitudes suspeitas... Não ignora o Sr ministro da Educação as atividades do arquiteto Lucio Costa, pois pessoalmente já mencionamos a S. Excia. Vários nomes dos filiados ostensivos à corrente modernista que tem como centro o Club de Arte Moderna, célula comunista cujos principais objetivos são a agitação no meio artístico e a anulação de valores reais que não comungam no seu credo. Esses elementos deletérios se desenvolvem justamente à sombra do Ministério da Educação, onde têm como patrono e intransigente defensor o Sr. Carlos Drummond de Andrade, chefe de gabinete do ministro. Expondo aos olhos de V. Excia. esses fatos, esperamos que V.Excia., defendendo o Tesouro Nacional e a honorabilidade de vosso governo do país, alente a arte nacional que ora atravessa uma crise dolorosíssima, próxima do desfalecimento. ${ }^{27}$

Lina dizia que por ter sobrevivido à Grande Guerra, debaixo dos bombardeios aliados, possuía uma dureza para lidar com as dificuldades da vida - batia os nós dos dedos na mesa de pedra a sua frente para acentuar o que estava dizendo. Dava grande importância ao fato de Stalin ter criado a Frente Russa ${ }^{28}$, que isso tinha representado o alívio para quem estava sob a opressão do Nazi-facismo, no front ocidental. Dizia também que, no sentido da revolta coletiva, era maoísta. Admiradora

\footnotetext{
${ }^{26}$ LE CORBUSIER. Por uma arquitetura. São Paulo: Perspectiva, p. 190, 197, 201, 203 e 205, 1973.

${ }^{27}$ CAVALCANTI, L. Moderno e brasileiro: a história de uma nova linguagem na arquitetura. Rio de Janeiro: Ed. Jorge Zahar, 2006.

${ }^{28}$ Lina tinha sobre uma das mesas de centro da Casa de Vidro, junto à bela foto de Che Guevara fumando um charuto, a foto da reunião secreta num navio, com Churchil, Roosevelt e Stalin, que selou a frente russa.
} 
das idéias de Che, e seu manual para a guerrilha na selva, que para ela era uma aula de arquitetura, em acordo com suas idéias do mínimo de meios.

\section{A idéia inicial de recuperação do dito Conjunto foi a de}

'Arquitetura Pobre', isto é, não no sentido de indigência, mas no sentido artesanal que exprime Comunicação e Dignidade máxima através dos menores e humildes meios. ${ }^{29}$

Para ela, o importante seria conquistar a liberdade do homem e a felicidade das crianças. Era antifeminista, no sentido beauvoiriano, de que o movimento feminista tinha acarretado maiores perdas do que benefícios para a vida pessoal das mulheres, e isso com uma referência explicita ao universo feminino e a questão da felicidade pessoal, com exceção do reconhecimento da importância dos movimentos feministas revolucionários, como o de Rosa de Luxemburgo, por exemplo.

Quando da inauguração do SESC - Fabrica da Pompéia, a personalidade principal foi o próprio Presidente da República Gal. João Baptista Figueiredo, figura estranha e, ao que parece, para amigos e inimigos figura realmente estranha. Por exemplo, quando de uma ida a Florianópolis os estudantes cercaram a comitiva presidencial e apuparam o General, que rompeu a barreira dos seguranças e partiu correndo para cima da multidão, bradando - Minha mãe não está na pauta!... Só para se comparar caracteres e personalidades, quando então Presidente da República José Sarney foi ao Rio de Janeiro tomar posse na cadeira imortal da Academia Brasileira de Letras, a comitiva presidencial, mais uma vez, foi apupada pela multidão, que chegou a atirar pedras no ônibus da comitiva; o Presidente Sarney, então, moveu um processo para enquadrar os manifestantes na Lei de Segurança Nacional, instrumento espúrio e criado exatamente para o exercício do poder durante a ditadura. Isso mostra o contraste de personalidades, coisa que Lina analisava muito bem, atenta que era aos rumos sócio-políticos do país.

Quando finalmente se aproximou do Presidente Figueiredo, Lina disse o seguinte: - Sr. Presidente, é preciso convocar os arquitetos para resolver o problema da habitação popular! Os arquitetos! - Parece que o Presidente respondeu: É, vou pensar no assunto. - presente: Marcelo Carvalho Ferraz - depois, Lina contava repetidamente esse acontecimento.

Bem antes, quando de uma visita de conselheiros da Regional do SESC, na verdade os que determinavam os pagamentos para o andamento da obra do SESC - Fábrica da Pompéia foram fazer uma última vistoria antes da inauguração oficial, na qual estaria presente o Presidente, foi dito por Membros do Conselho: - $A$ obra está muito atrasada, não vai dar tempo. Faltam ainda os revestimentos, os carpetes no piso... Não se conformavam com os tijolos aparentes, alguns desgastados pelo tempo, outros demonstrando antigas interferências ou aberturas que foram posteriormente fechadas, ao longo da existência da fábrica de tambores, cujas marcas Lina fez questão de deixar, e, em menor número as obturações feitas para as obras da Recuperação, substituindo tijolos já em grau de decomposição.

\footnotetext{
${ }^{29}$ BARDI, L. B. Lina Bo Bardi. Marcelo Carvalho Ferraz org. São Paulo: Instituto Lina Bo e P. M. Bardi, p. 220, 1993.
} 


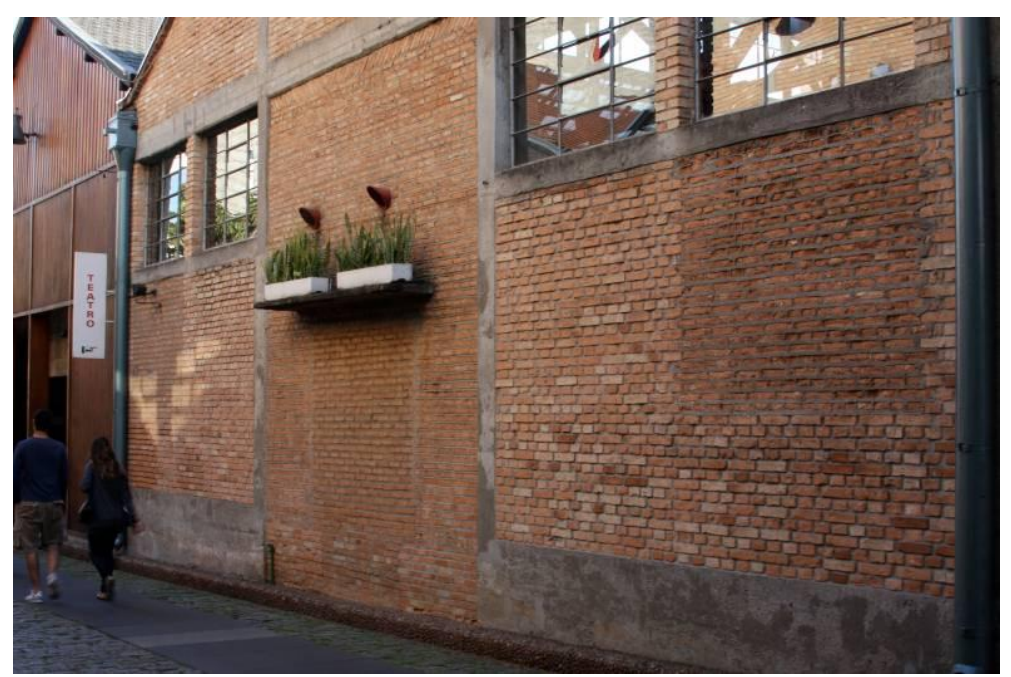

Figura 81. Os tijolos “claros” são obturações novas, sacando-se o antigo, em decomposição. Mas permaneceram as manchas da existência de portas ou janelas, do tempo da antiga fábrica.

Nesse momento o Diretor Regional já não era mais José Papa Júnior, que era o Diretor quando da proposta do Conselheiro Renato Requixa para que o SESC convocasse Lina para o parecer sobre a preservação do conjunto, em detrimento de outro projeto, de autoria do arquiteto Julio Neves, que propunha a demolição integral e a construção de um bloco totalmente novo, vertical, de mais uma unidade do SESC aos moldes usuais de então, como o Dr.Vila Nova, por exemplo. Seria mais uma torre com todas as atividades, sobre um embasamento saliente - loja e sobreloja -, com as atividades de maior concentração de público, tal como a unidade Dr. Vila Nova.

Por intervenção de Requixa é que se conseguiu primeiro o parecer de Lina, antes que se consumasse a demolição da velha fábrica. Mas tudo foi mudando, caiu o Diretor, e junto com ele o Conselheiro, as atividades de Lina que eram sucesso absoluto de público e mídia, eram provocativas demais, seja pelo seu conteúdo, seja pelo próprio sucesso, para os que Diretores e Conselheiros assumiram no lugar daqueles. Mandaram Lina embora, antes mesmo da inauguração oficial do Bloco Novo, o conjunto esportivo.

Depois que Lina foi mandada embora do SESC, passou muito tempo lamentando, execrando o acontecido, além da dificuldade de abrir frentes novas, animar-se a partir para novos trabalhos. Certo dia dissemos, para tentar animá-la: - Lina, você ganhou, você balançou a estrutura do SESC, uma instituição que no fundo no fundo é patronal, dos homens do poder, e você balançou. Não tem como eles voltarem atrás, criou um fato novo que eles não podem apagar... Ela interrompeu, categoricamente: - Cale a boca! Você não sabe o que são dez anos na vida de uma pessoa! - (c.d.m.) presente também Marcelo Carvalho Ferraz. E mandou a gente embora, dispensando do trabalho - falta de trabalho - daquela tarde. E compreendemos também que ela tinha dito, mais precisamente: na vida de uma mulher!

Mesmo nesse período de falta de trabalho continuávamos nos reunindo todas as tardes, na Casa de Vidro do Morumbi, discutíamos as dificuldades com as possíveis frentes novas, mas discutíamos também música, teatro, cinema, o que 
estava acontecendo com a arquitetura, etc., mas basicamente sob uma ótica bastante ácida. Lina continuou, a partir da perda do trabalho no SESC, trabalhando com bastante dificuldade, tanto física como psicologicamente. Pensava em pedir o tombamento do conjunto para defendê-lo de possíveis estragos, ou então dizia a alternativa: vamos publicar um livro, depois deixamos cair... (c.d.m.)

A dificuldade para novos trabalhos tem muito a ver com a mudança de contingência com que se apresentavam para Lina. Nada dos planos de pretensiosa grandeza, onde a tentativa de se re-configurar o Brasil existiram. Nada da possibilidade de se criar uma nova civilização, a partir da cultura Nordestina, como tinha sido a intenção. A partir do fim do trabalho do SESC, tudo parecia menor.

Mesmo que pequena, a organização comunitária de um bairro pobre, na periferia de Uberlândia, organizada por Frei Egydio e outros frades franciscanos, tinha grande interesse para ela, que se empenhou em fazer a igrejinha, mas outros casos, que para nós, pareciam promissores, não lhe despertavam maiores entusiasmos.

Por caminhos diferentes, dentro da postura moderna, que comporta as diferentes abordagens, Lina e Lucio chegam num mesmo ponto: o Brasil poderia ser diferente, ou, no Brasil deveria sempre acontecer diferente. O Brasil não será jamais um país medíocre. ${ }^{30}$

Para ela, o fato de ter sobrevivido a Grande Guerra, era o equivalente a ser, necessariamente, dura consigo mesma, exigente e intransigente, que também tem a ver com as primeiras proposições da transformação do homem moderno, militar, sem deixar de lado a compreensão maternal das questões da infância, do crescimento tranqüilo, do bem-estar humano.

Lucio tem uma postura bem diferente: declara, em alguns momentos, sua preguiça, seus motivos sentimentais inadiáveis, aceita fatos como naturais, etc. Uma certa dose de irresponsabilidade é necessária.

\footnotetext{
${ }^{30}$ COSTA, L. Com a palavra, Lucio Costa. Rio de Janeiro: Aeroplano Editora, p. 159, 2001.
} 


\section{OUTEIRO DA GLÓRIA}

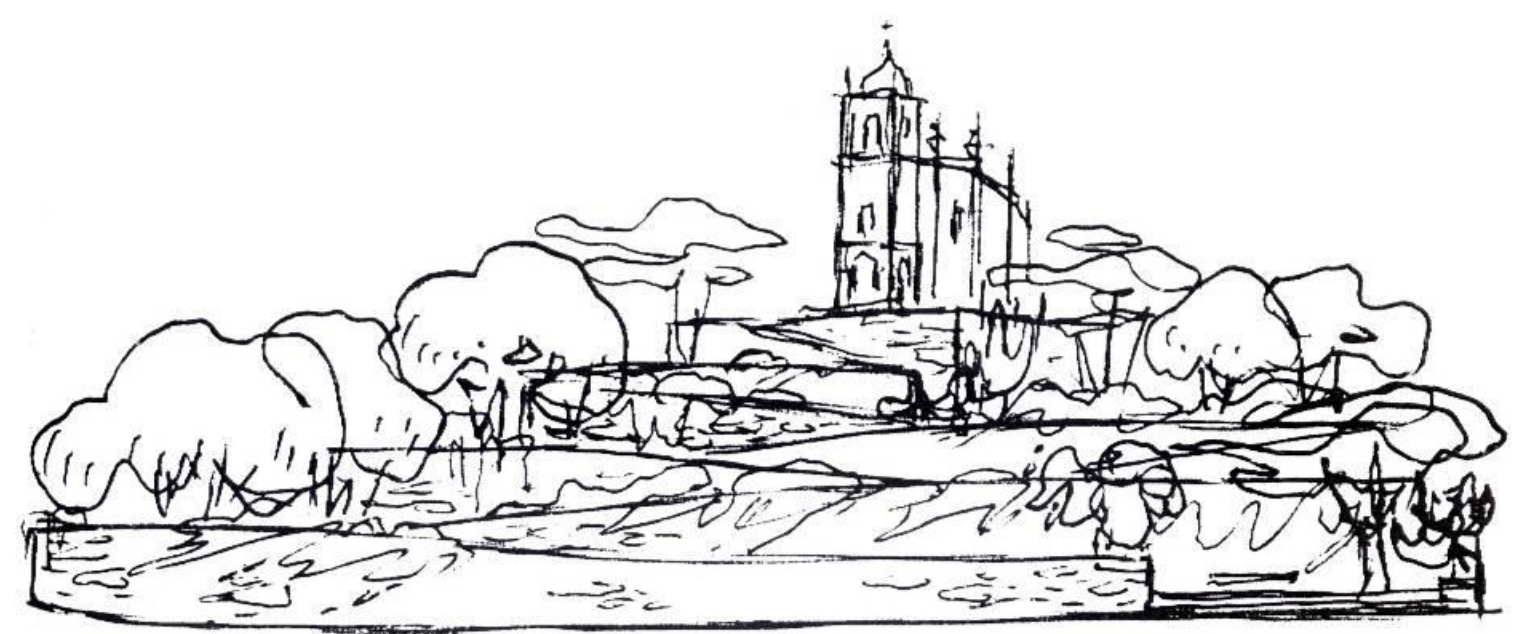

O Aterro do Flamengo

$\mathrm{O}$ aterro do Flamengo, atual Parque do Flamengo, era para ser um plano basicamente viário. O traçado original de Affonso Eduardo Reidy, de 1961, com a linha de encontro com o mar sinuosa, recebe uma nova geografia com a participação de Roberto Burle-Marx. A sinuosidade se manifesta horizontal e verticalmente, com morrotes artificiais e desníveis que separam o sistema viário dos usuários do parque, que conta com os belos e impressionantes $1.200 .000 \mathrm{~m}$. quadrados de áreas verdes ${ }^{1}$.

Antes da realização do aterro, o mar chegava ao bairro do Flamengo, no já sinuoso alinhamento da Avenida Beira-Mar, com um cais de porto na reentrância aos pés da colina da Igreja Nossa Senhora da Glória. Essa reentrância é repetida, longe, exatamente onde se encontra a atual Marina, objeto de discussões em torno de sua ampliação, e que agora já foi aprovada. Mas a reentrância da Marina é feita por Reidy, exatamente como Lucio recomendou.

${ }^{1}$ MOTTA, F. L. Roberto Burle Marx e a nova visão da paisagem. São Paulo: Nobel, p. 19-21, 1984. 


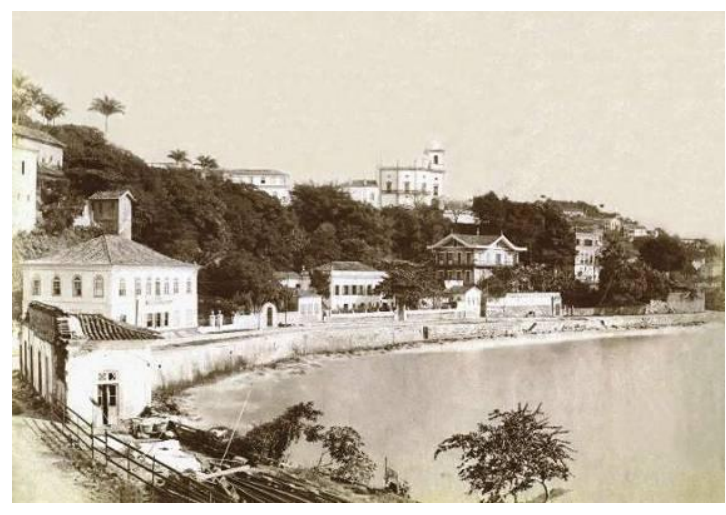

Figura 1. Flamengo e o Outeiro da Glória ao fundo.

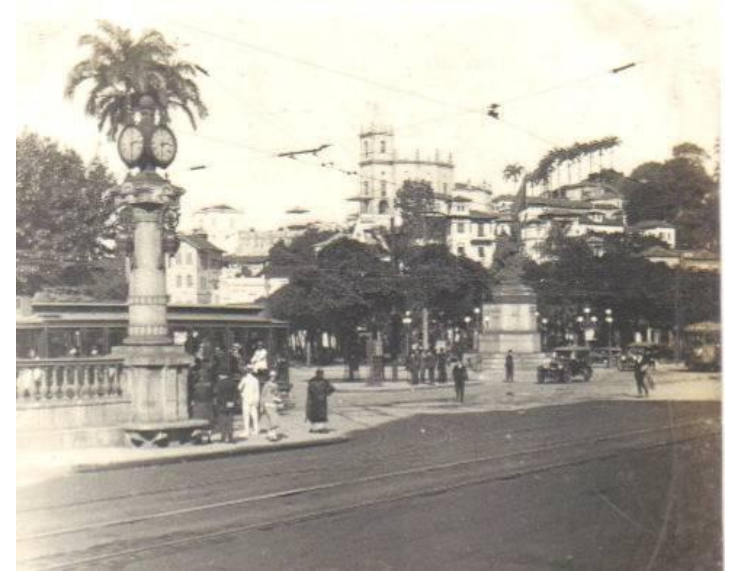

Figura 3. Esplanada, Largo e Outeiro da Glória ao fundo.

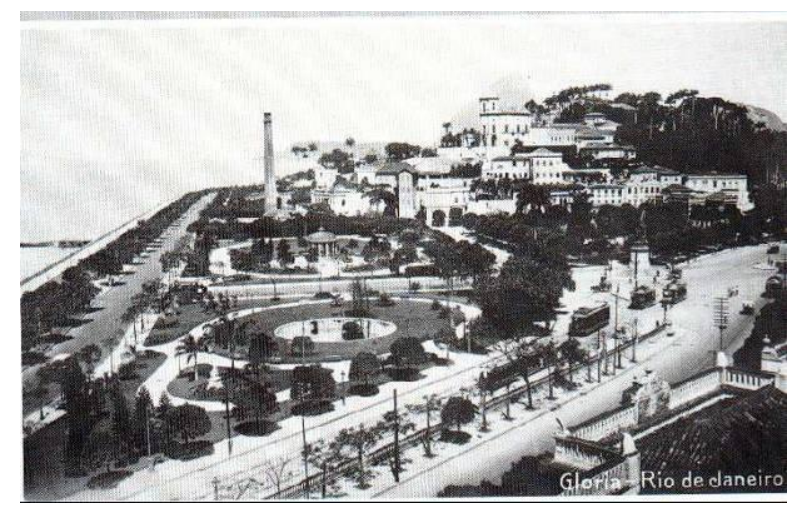

Figura 2. Esplanada, Largo e Outeiro da Glória ao fundo.

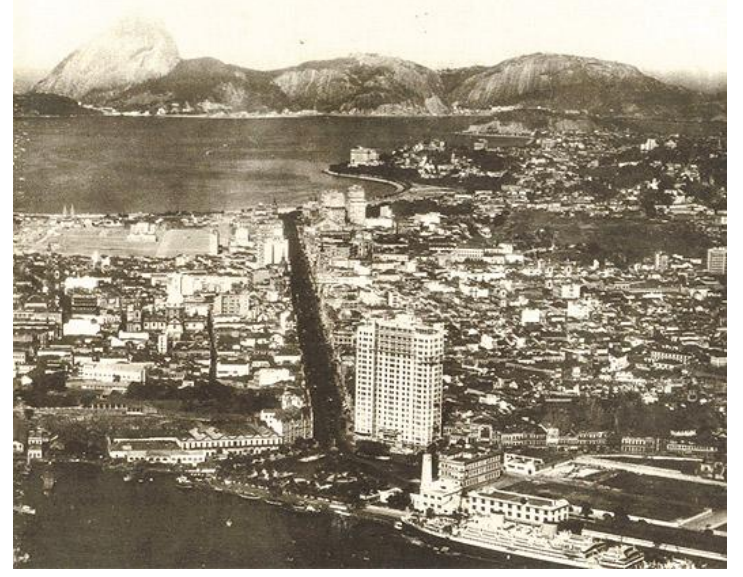

Figura 4. Centro do Rio de Janeiro entre 1929 e 1944. Vê-se o Outeiro bem no centro da imagem. ${ }^{2}$

Larga iconografia apresenta o sky-line do Rio de Janeiro com a colina no plano logo a seguir da linha do quebra-mar.

${ }^{2}$ COURT, A. (década 2000) Rio de Janeiro entre 1922 e 1944 - "não existe o Morro do Castelo, arrasado em 1922. O edifício "A NOITE”, construído em 1929 já está pronto. A Av. Presidente Vargas construída em 1944 ainda não parece." Fotografia de autor desconhecido, fornecida por Felipe Machado. Disponível em: <http://www.almacarioca.com.br >. Acesso em: 05 jun. 2007. 


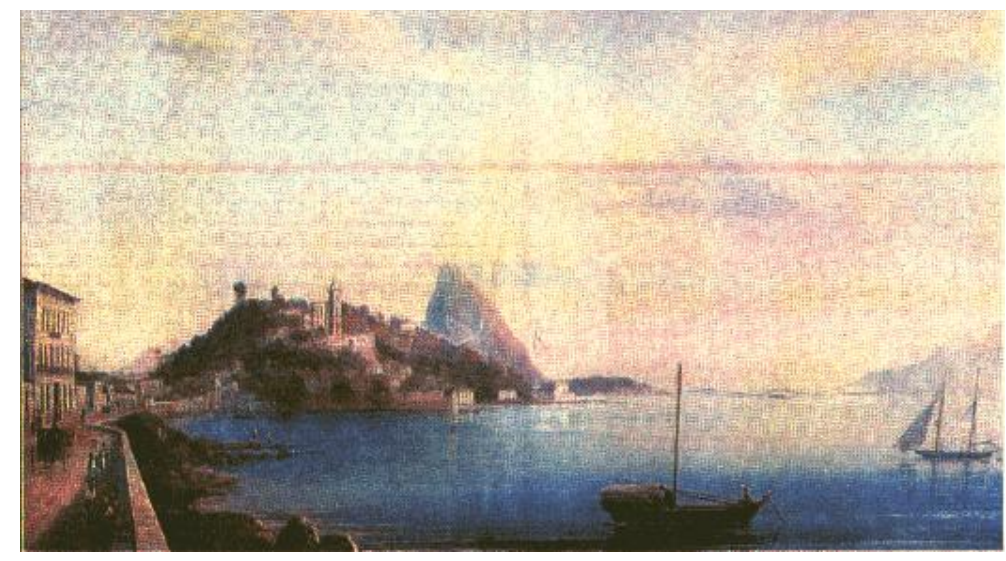

Figura 5. O Outeiro da Glória.

A demolição do antigo cais do Flamengo é o ensejo para que o arquiteto Lucio Costa, diretor da Divisão de Estudos e Tombamentos do então chamado Diretoria do Patrimônio Histórico e Artístico Nacional - DPHAN ${ }^{3}$, volte a dirigir-se a seu superior imediato, Rodrigo Melo Franco de Andrade para a construção das rampas e a liberação da vista da Igreja Nossa Senhora da Glória desde o aterro e da Praça Paris.

Pouca gente sabe que está caminhando sobre um grande e belíssimo projeto de arquitetura, em toda a sua abrangência: a pequena intervenção urbanística direta e indiretamente associada à grande intervenção - as rampas como proposta seguida ao aterro, a relação da intervenção com o patrimônio histórico - o acesso à Igreja, o restauro de monumento tombado - a Igreja propriamente dita, o paisagismo do macro ao micro - todo o entorno da Glória e o aterro e a vegetação composta com o construído, arrimos, muretas, escadas, caminhos, etc.

Advém daí, da quantidade de itens de uma boa arquitetura juntos em uma obra tão singela tornam qualquer comentário crítico extremamente árduo, a exigüidade de usos ou intenções que não as intrínsecas não permitem desvios retóricos: são rampas. São rampas de acesso ao Outeiro da Glória.

Curiosamente a palavra outeiro nesse caso funciona com toda sua própria ambivalência: é em, primeira acepção, colina ou morro, em segunda, trovas de louvor, de Glória. ${ }^{4}$

\footnotetext{
3. COSTA, L. José Pessôa org. Documentos de trabalho. Rio de Janeiro: IPHAN, 1999. (p. 11, nota do organizador): Serviço do Patrimônio Histórico e Artístico Nacional SPHAN, de 1937 a 1946; Diretoria do Patrimônio Histórico e Artístico Nacional DPHAN, de 1946 a 1970; Instituto do Patrimônio Histórico e Artístico Nacional IPHAN, de 1970 a 1979; Secretaria do Patrimônio Histórico e Artístico Nacional SPHAN de 1979 a 1990; Instituto Brasileiro do Patrimônio Cultural IBPC, de 1990 a 1994; Instituto do Patrimônio Histórico e Artístico Nacional IPHAN, desde 1994.

${ }^{4}$ Verbete do Dicionário Aurélio: Outeiro. S. $m$. 1. V. colina. 2. Festa que se realizava no pátio dos conventos, e por ocasião da qual os poetas glosavam motes dados pelas freiras.
} 


\title{
Igreja Nossa Senhora do Outeiro da Glória
}

\author{
A setecentista Igreja de Nossa Senhora da Glória do Outeiro foi
} definitivamente tombada em 04 de maio de 1938, pelo Serviço do Patrimônio Histórico e Artístico Nacional - SPHAN, com evidente participação de Lucio Costa. Trata-se de uma construção pequena, o próprio Lucio às vezes se refere a ela como capela. Mas a batalha pela liberação da encosta e a criação dos acessos foi longa, arrastou-se de 1943 a 1965, quando então foram realizadas. Assim ele narra:

A Igreja do Outeiro da Glória é uma das obras primas da arquitetura portuguesa na colônia. Foi um milagre a sua recuperação feita pelo SPHAN - de fato, a capela estava totalmente desmoralizada, tanto interna como externamente, quando Rodrigo M. F. de Andrade, por insistência minha, empenhou o Patrimônio na elaboração de um programa de recuperação total da igreja, criando também o acesso ao outeiro, cuja perspectiva ficou muito valorizada com a criação da praça Paris pelo plano Agache. ${ }^{5}$ Foram anos e anos de luta e só com muita persistência e a dedicação total do Rodrigo foi possível conseguir vencer as dificuldades de toda ordem que se interpunham.

Na parte externa a obra mais importante foi a retirada de uma varanda que em meados do século passado tinham construído ligando as janelas umas às outras por fora - essa grade chocava muito porque cortava a prumada dos cunhais da igreja.

O interior havia sido completamente desfigurado: o sopedâneo de pedra da capela-mor, do início de setecentos, estava quebrado - felizmente encontramos fragmentos e foi possível recompô-lo, com a colaboração de Paulo Barreto ${ }^{6}$; o estado irrecuperável em que se encontrava o piso original levou à opção de fazê-lo em campas, na forma tradicional, apenas sem numerá-las, o que ficaria artificioso. A beleza que hoje se vê da estrutura de cantaria contrastando com a caiação, os azulejos e a madeira dos retábulos estava toda encoberta por uma pintura uniforme, as paredes forradas de tabuletas comemorativas de episódios; a camada de tinta que cobria a apurada talha de todos os retábulos era tão espessa que impediu o restauro da pintura primitiva - deliberou-se então deixá-los na madeira, restituindo o dourado apenas em certos elementos, como os resplendores $^{* 3}$. E o resultado final ficou perfeito. ${ }^{7}$

\footnotetext{
${ }^{5}$ Plano Agache: Urbanista francês Donat Alfred Agache, contratado pela Prefeitura para promover o embelezamento da cidade, na década de 20.

${ }^{6}$ Paulo Thedim Barreto, engenheiro que também havia trabalhado com Lucio Costa no Museu das Missões Jesuíticas dos Guaranis de São Miguel.

${ }^{7}$ COSTA, L. Registro de uma vivência. São Paulo: Empresa das Artes, p. 411, 1995.
} 


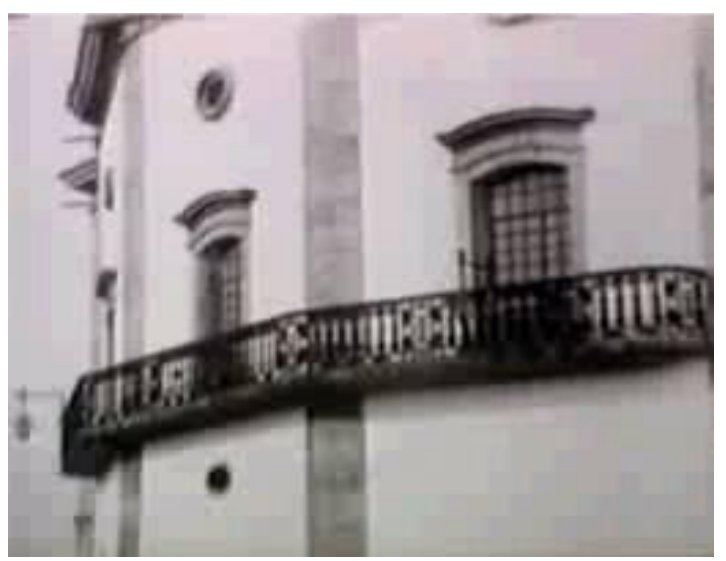

Figura 6. O Outeiro da Glória. Sacada que, embora antiga, destruía a percepção da verticalidade dos cunhais e da comodulação estrutural da igreja.

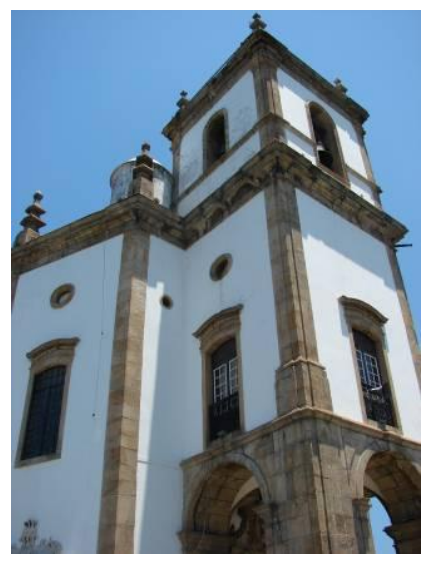

Figura 7. À direita os cunhais, livres da sacada, em toda sua verticalidade acentuada pela terminação com coruchéus.

Essa obra do barroco português dos setecentos, embora pequena como uma capela, é rica em detalhes construtivos e inovadora como concepção de planta. O volume é tripartido: a entrada coberta é a base da torre única do campanário; o corpo central é octogonal assimétrico,e a cabeça, também octogonal, menor em dimensões encontra o corpo sem o transepto. Contido no octógono menor, está o altar, solto em ambos os lados, afastamento que permite a passagem para a sacristia, atrás do altar, exatamente no trecho do encontro entre as duas octogonais. De ambos os lados, a partir do encontro, surgem inesperados corredores, como que embutidos na parede do hexágono maior, uma concepção totalmente diferente das naves laterais comumente encontradas em outras igrejas.Também no ponto de encontro das octogonais encontram-se portas externas, que permitem acesso direto à sacristia, criando um nó perfeito de circulação horizontal, além de que as portas estão em locais totalmente adequados, semi-escondidas, em relação às fachadas laterais.

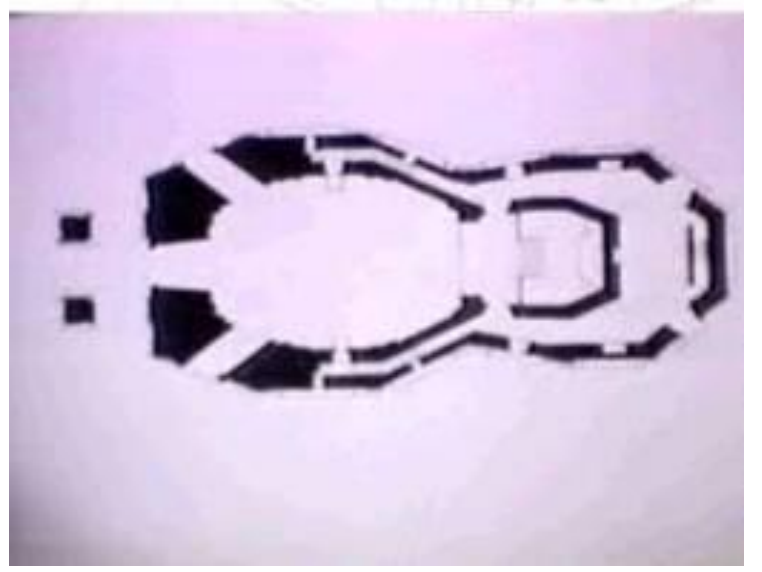

7igura 8. Planta da Igreja de Nossa Senhora do Outeiro.

As paredes inclinadas em forma de casco de navio, os ângulos internos do hexágono e o altar solto conferem grande dramaticidade ao interior da igreja, que apesar 
da data já distante do restauro encontra-se ainda hoje em perfeitas condições. Pode-se observar os tirantes de travamento, instalados no restauro, e que impedem que as paredes inclinadas continuem se desaprumando até perderem estabilidade, fato que vinha ocorrendo anteriormente.

A volumetria resultante guarda vaga semelhança com a Igreja Nossa Senhora do Ó, de Sabará, Minas Gerais.

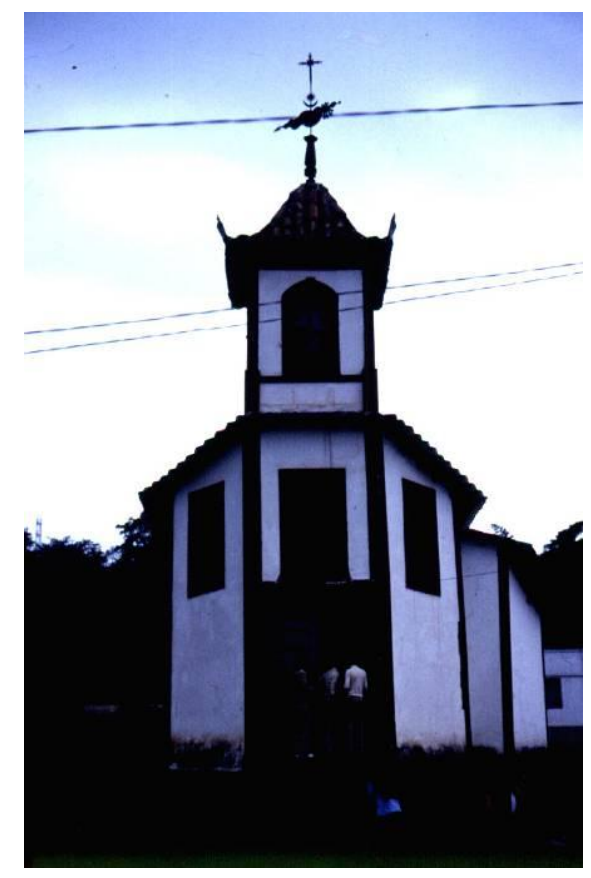

Figura 9. Igreja Nossa Senhora do Ó, Sabará, MG.

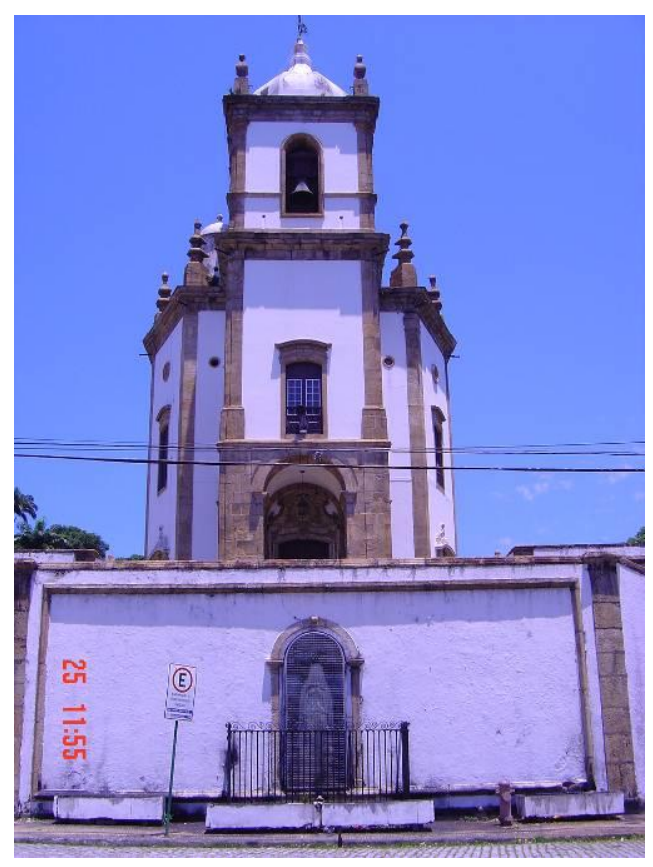

Figura 10. À direita Igreja de Nossa Senhora do Outeiro.

A varanda que unia as janelas, removida por determinação de Lucio Costa, cortava a prumada dos vários cunhais dos ângulos externos dos octógonos, prumada que desde o Renascimento em diante é sempre uma marca vertical que culmina sempre em um arremate superior, o acropódio ${ }^{* 5}$ para estátuas, ou os coruchéus *6 "caprichosos e dramáticos" $" 8$ encontrados nesse caso.

$\mathrm{O}$ adro dessa igreja também foi objeto de restauro principalmente com a eliminação de puxados e a reconstituição integral do piso de lajes de pedras grandes, de grande efeito visual de força, peso e vigor. O adro reforça a posição geográfica privilegiada do Outeiro, descortinando toda a Bahia da Guanabara, ligeiramente à esquerda o Aeroporto Santos Dumont, quase em frente o Museu de Arte Moderna, com toda a exuberância da vegetação no aterro do Flamengo, bem à direita o Pão de Açúcar.

\footnotetext{
${ }^{8}$ Documentário com o próprio Lucio Costa subindo as rampas do Outeiro e narrando. REZNIK, J. (dec. 90). Ladeira da Igreja da Glória. Acervo: vídeo. Disponível em: 〈http://www.casadeluciocosta.org>. Acesso: 22 mai. 2007.
} 

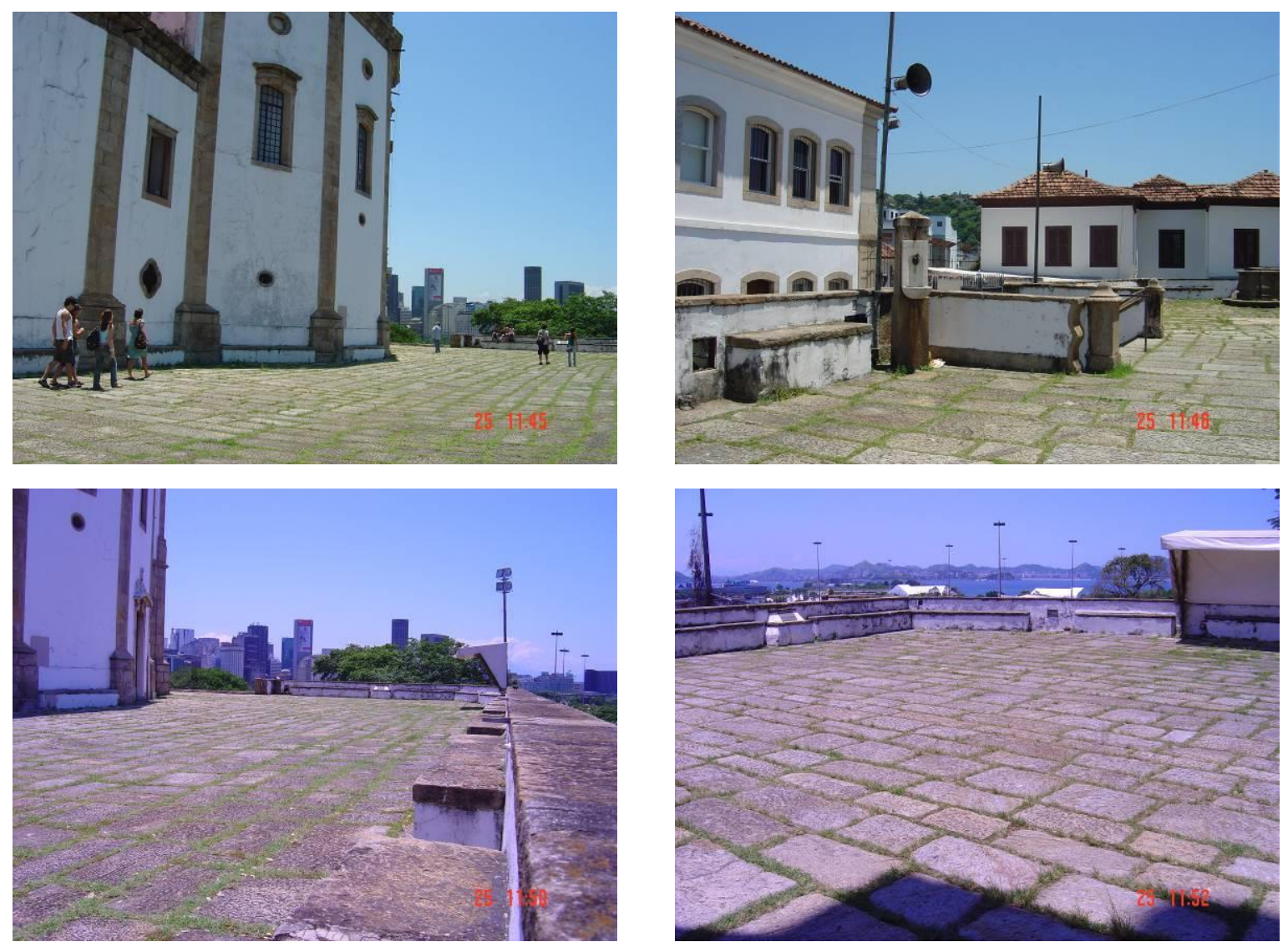

Figuras 11. Adro restaurado da Igreja..

$\mathrm{Na}$ parte posterior da Igreja, prolongamento do adro, Lucio cria uma ambientação para adequar a existência dela em relação à direção onde há proximidade da urbanização, lado oposto do que descortina a Bahia da Guanabara, onde o outeiro já tinha ocupação efetiva.

E para se chegar até esse lugar, agora, há, agora, um suave e tranqüilo percurso.

\section{Em defesa do Patrimônio Ambiental}

Em 26 de Julho de 1943, Lucio Costa, usando suas atribuições de Diretor do DPHAN, escreve o parecer acerca do destino a ser dado às encostas do Outeiro. Começa aí a sua longa e persistente batalha em defesa de sua desobstrução:

A questão de que trata o presente processo vem ao encontro de um dos problemas paisagísticos mais importantes da cidade, problema que precisa ser encarado agora de frente, porquanto, perdida a oportunidade atual, correrá o risco de ficar definitivamente sem solução: quero referir-me à incorporação de uma parte das encostas 
leste e norte do Outeiro da Glória, no conjunto dos jardins que lhe ficam ao pé, para servir como fundo de cenário, com a sua encantadora igrejinha setecentista, à bela perspectiva de parques que, partindo do Passeio Público e da Praça Paris, se espraia pela Esplanada da Glória até os jardins do largo do mesmo nome onde topa com o outeiro (fig. 1). Aliás, a importância do problema avulta quando se considera que a municipalidade ainda pretende vantajosamente ampliar essa área de parques com o aterro proveniente das obras de desmonte do Morro de Santo Antônio. ${ }^{9}$

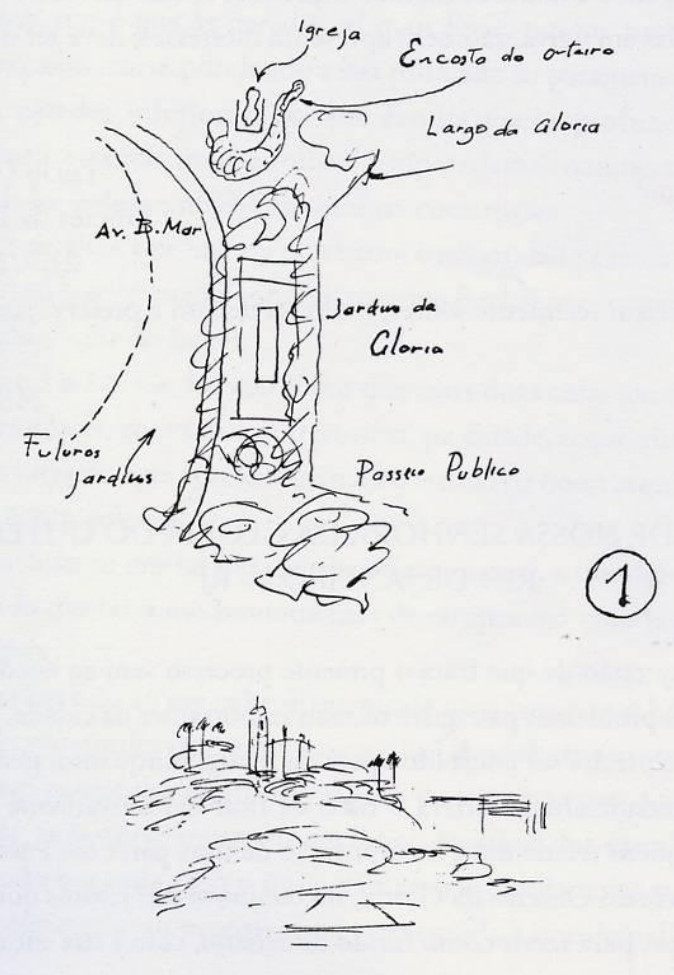

Figura 12. Desenho de Lucio Costa constante de seu relatório de 1943. (Figura 1 constante do próprio texto de Lucio)

Já em 1943 estavam em processo os estudos para mais um desmonte de morro no Rio de Janeiro. Primeiro, o do Castelo, em 1922, com cujas terras se promoveu o aterro que resultou na área pista de pouso de aviões, onde depois se construiu o aeroporto Santos Dumont, dos Irmãos Roberto, de 1944. Do Morro do Castelo resultou também uma área plana, onde hoje se encontra a Esplanada do Castelo, ou, mais comum e simplesmente chamado Castelo.

Ele continua:

Examinada sob esse aspecto, a idéia da abertura de uma clareira verde em frente à igreja só deve ser encarada com simpatia, pois representaria afinal, antes do mais, o primeiro passo no sentido da desobstrução daquela orla do outeiro.

9. COSTA, L. José Pessôa org. Documentos de trabalho. Rio de Janeiro: IPHAN, p 47-48, 1998. 
Entretanto o projeto, em boa hora submetido pelo senhor prefeito à apreciação do SPHAN, prevê a construção precisamente na faixa compreendida entre o Largo da Glória e a ladeira de acesso ao adro da igreja, de uma cortina de prédios de apartamentos, sendo três deles com sete pavimentos, um com oito e o último, finalmente, com dez, o que não somente viria agravar incrivelmente o aspecto atual, já de si condenável, como ainda comprometer qualquer possibilidade futura de solução para o caso. De fato, mesmo dos pontos de vista mais favoráveis, isto é, mais distantes quando o observador não se achasse rigorosamente em frente à projetada clareira, a igreja emergiria acima das cumeeiras e das casas de máquinas e caixas d'água dos referidos prédios de modo bastante grotesco e com a graça altiva de sua silhueta prejudicada pela proximidade da grande massa dos dez pavimentos do edifício mais alto (fig. 2). E à medida que as pessoas se fossem aproximando, ela iria aos poucos afundando, até submergir por detrás das construções (fig. 3), miseen-scène de certo pouco recomendável para servir de fundo à bela perspectiva que se descortina da praia e dos jardins. Uma visita ao Largo da Glória convencerá imediatamente da absoluta inconveniência de se permitirem edificações novas naquela faixa da encosta, e de como, pelo contrário, se impõe a demolição dos velhos prédios ali existentes, afim de que a orla valorizada do outeiro, conforme já ficou dito, se incorpore definitivamente aos jardins (fig. 4) ${ }^{10}$

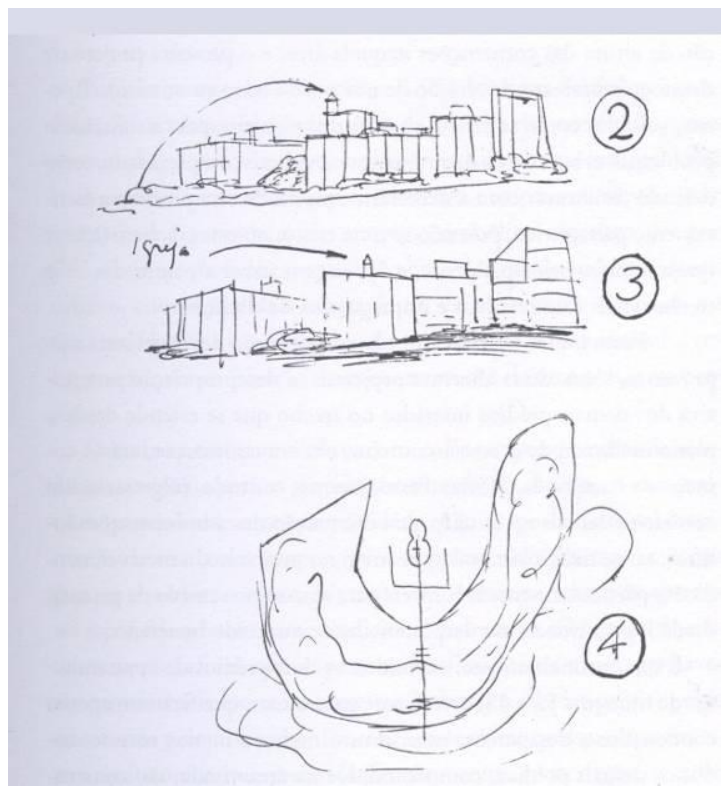

Figura 13. Desenho de Lucio Costa constante de seu relatório de 1943. (Figuras 2, 3 e 4 constantes do próprio texto de Lucio)

É visível que sua luta obstinada começa, mesmo antes de se determinar o destino das terras adquiridas no desmonte do Morro de Santo Antônio para algum aterro no Flamengo, e mesmo antes de se verificar, da remoção do antigo cais, a sobra de pedras magníficas em dimensões e que se tornariam em algum entulho e inclui todos esses itens no rol de suas preocupações.

${ }^{10}$ COSTA, L., José Pessôa org. Documentos de trabalho. Rio de Janeiro: IPHAN, p. 47- 48, 1998. 
Sua sensibilidade e sua visão urbanística é tridimensional, não se restringe às plantas e mapas coloridos, demonstra quadro a quadro com seus desenhos, como um filme assistido em câmera lenta ou na mouviola de montagem cinematográfica, o que estava querendo demonstrar, e nesse caso, combater.

A situação descrita conta-nos também como os poderes, Prefeitura Municipal e SPHAN se relacionavam nessa época, mas mais ainda, o empenho pessoal de um funcionário de alto escalão dos quadros do SPHAN na demonstração de que motivos públicos antecedem interesses diretos em ganhos especulativos com as mudanças imobiliárias já pressentidas naquele sítio, quando da implementação do aterro.

Conseqüentemente, no que se refere aos interesses da cidade o que vale dizer aos interesses da própria prefeitura, o objetivo em vista só poderá ser precisamente esse, e é evidente que o fundo do pensamento tanto do senhor prefeito como do secretário geral de obras e dos demais técnicos seus colaboradores é, de fato, no sentido de beneficiar, tanto quanto possível, a igreja (bastariam para comprová-lo, as medidas, anteriormente tomadas, visando à limitação da altura das construções naquela área, e o presente projeto de desafogo a pretexto da criação de um novo acesso ao outeiro). Apenas, voltados como se acham os referidos técnicos, para a solução de problemas urbanísticos de muito maior vulto e complexidade, terão deixado de encarar com a necessária amplitude este problema estritamente paisagístico, pois não se trata tanto, no caso, de beneficiar a igreja, como, principalmente, a "paisagem urbana", num dos seus trechos mais característicos e impregnados de tradição. ${ }^{11}$

É impressionante a atualidade do texto. Preocupações dessa ordem só começaram a surgir e fazer parte da rotina do planejamento urbanístico no Brasil muito recentemente. Falar claramente em paisagem urbana deve ter sido algo tão inusitado como expressão técnica que deve ser por isso que ele utilizou aspas. Cita, de passagem, que o caso não é exclusivo da igreja para reforçar os demais aspectos, até porque a igreja já tombada determinava a área protegida do entorno, fato então já sabido e compreendido pelos diversos interessados. As "medidas anteriormente tomadas", com toda certeza se referem a essa famosa legislação, formulada por essa equipe formadora do SPHAN, da qual ele fazia parte, de proteção também ao entorno de bens tombados.

\section{Diretrizes de Projeto Urbanístico}

Em seu parecer, de 1943, Lucio Costa já faz constar inúmeras diretrizes, algumas diretamente relacionadas ao outeiro, mas várias indicações de como proceder com o aterro que adviria do desmonte do Morro de Santo Antônio, quase todas elas

${ }^{11}$ COSTA, L., José Pessôa org. Documentos de trabalho. Rio de Janeiro: IPHAN, p. 50, 1998. 
obedecidas à risca por Reidy e Burle-Marx. Até então, Lucio está agindo como quem estabelece um programa arquitetônico para que se transforme em um contrato: ele está agindo do lado do contratante, fornecendo as diretrizes.

O que parecia mais fácil, se inverteu: Burle-Marx, que já estava ali, no Aterro, faz um projeto que Lucio recusa de imediato; ao contrário daquele paisagismo que foi desenvolvido para o aterro, Burle-Marx faz, para a encosta do outeiro um paisagismo geométrico, paisagismo construído, desgarrado do morro. Lucio demonstra, nesse caso, duas coisas importantes: por um lado, a franqueza de dizer para o amigo que o projeto estava recusado, colocando-se na postura de comitente, e, por outro, o de que, a longa batalha para estabelecer o programa a se implantar ali - uma subida de morro, e só isso - estava desenhado em sua cabeça - assim como o sol que teria que apanhar para levar a cabo sua idéia.

Ele já sabia o que queria contratar, mas os candidatos não acertavam $o$ alvo, na mosca. Para as encostas do outeiro:

... excluídos os dois prédios de apartamentos de números 52 e 48, com frente para o mar, que ficariam apenas condenados a desaparecer num futuro mais ou menos remoto, todos os demais prédios, compreendidos na área visada, são construções relativamente antigas, o que permitiria a desapropriação em condições normais, isto é de acordo com o valor real dos imóveis, desde que se proibisse, em tempo, a construção ali de edifícios maiores. (...) Por isso mesmo, há toda conveniência de serem, desde logo, consideradas as obras de desobstrução da encosta do outeiro, as quais constituem, como vimos, complemento paisagístico indispensável às obras do aterro, como fase preliminar desse empreendimento maior que assim teria, também ele, começo “simbólico”, começo que por si só já representaria obra capital do ponto de vista do embelezamento urbano, compreendida a expressão no seu sentido mais natural, ou seja, mais legítimo, pois implicaria, em verdade, numa autêntica recuperação. A recuperação do pequeno trecho de uma paisagem perdida. ${ }^{12}$

${ }^{12}$ COSTA, L., José Pessôa org. Documentos de trabalho. Rio de Janeiro: IPHAN, p. 50-51, 1998. 


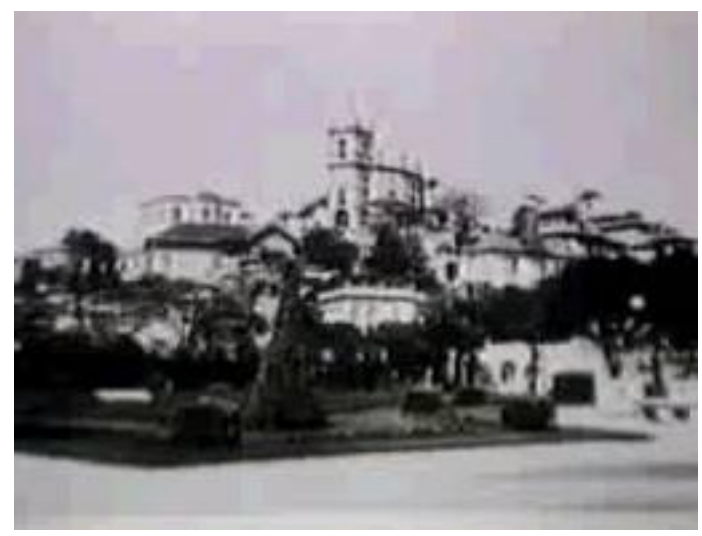

Figura 14. Vista do casario que ocupava toda a encosta. A Prefeitura do Rio de Janeiro avaliava a possibilidade de permitir edifícios altos, que Lucio Costa vetou.

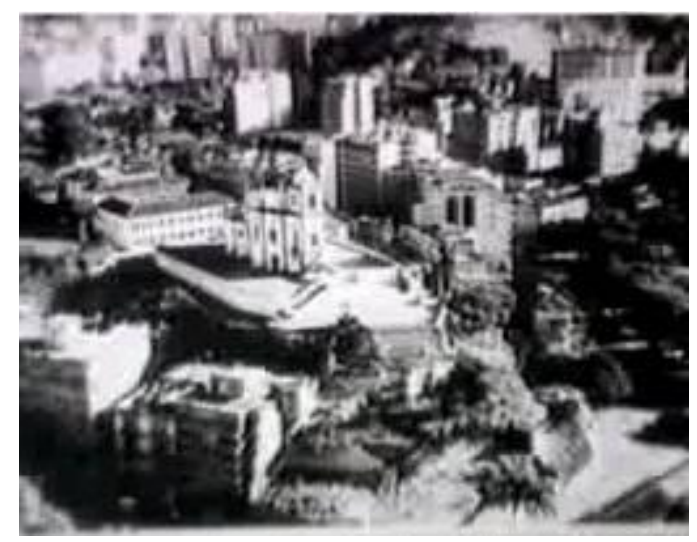

Figura 15. Idem.

Estrategicamente, Lucio Costa propunha maior velocidade nessa obra do que seria possível para as obras do desmonte do morro e o aterro, e tornaria esse fato o começo simbólico da outra. O desmonte do Morro de Santo Antônio, embora já planejado, passava por dificuldades de execução:

... de todos os empreendimentos projetados pela atual administração municipal, empenhada em grandes obras de remodelação urbana, apenas um não pode ter início, em virtude da situação mundial que impossibilitou a importação de aparelhagem especial requerida: o desmonte do Morro de Santo Antônio. Esse desmonte, porém, ter-se-á de fazer, segundo o plano da prefeitura que assegura a preservação do Aqueduto da Carioca e do Convento de Santo Antônio, ter-se-á que fazer também o aterro da Enseada da Glória, afim de recompor a deformação resultante das obras do aterro do aeroporto, mantendo-se sempre acentuada a linha curva do cais. ${ }^{13}$

A dificuldade da importação de equipamentos para o desmonte se deu por ser exatamente um período de grande recrudescimento da Segunda Guerra Mundial. Mas, visivelmente, Lucio Costa considerava a feitura dessa obra um fato consumado, alertando, porém, para alguns itens importantes: a preservação do Aqueduto e do Convento, enquanto patrimônio histórico e arquitetônico e para que o aterro quebrasse a dureza do desenho resultante do aterro anterior, feito para a construção do Aeroporto Santos Dumont, além de se redesenhar na nova linha de orla, a reentrância que dava no cais do Flamengo. Exigências que ele faz imperativamente, como demonstra a conjugação de verbo que ele adotou para essas especificações.

Anuncia também as diretrizes para a encosta, ainda sem considerar que seria seu próprio projeto, como um alerta para qualquer outro arquiteto:

\footnotetext{
${ }^{13}$ COSTA, L., José Pessôa org. Documentos de trabalho. Rio de Janeiro: IPHAN, p. 51, 1998.
} 
Quanto ao tratamento da encosta e das rampas e escadas de acesso ao outeiro na parte a ser inicialmente aberta, deve-se evitar qualquer propósito de monumentalidade, não só porque um tal tratamento destoaria das proporções e singeleza aldeã da capela, como porque equivaleria à introdução de um elemento novo e de aparato no aspecto despretensioso e tradicional da encosta arborizada do outeiro, aquilo, afinal, que importa reconstituir, tanto assim que haveria conveniência em se manterem as rampas e escadas parcialmente encobertas pelo arvoredo. Deve-se ainda evitar qualquer tratamento arquitetônico que pretenda simular, numa contrafação, o estilo antigo autêntico da igreja, tais como volutas ${ }^{* 7}$, coruchéus, etc., ou motivos complementares maiores de intenção "decorativa", como por exemplo, pérgulas ou fontes no chamado "estilo colonial", pois que a beleza da paisagem e a pureza da arquitetura da igreja dispensam semelhantes acessórios, sempre grotescos, mormente na vizinhança de monumentos antigos. ${ }^{14}$

As precauções são grandes: não fugir da singeleza, não enfeitar, não simular. Faz parte do vocabulário de Lucio Costa o respeito, que contém o bucólico, como de uma encosta simplesmente arborizada, mas que renega qualquer aproximação do pitoresco e imitações falsificadoras. São posturas claramente aceitas por todos os que atuam em patrimônio histórico e arquitetônico até os dias de hoje, em todo o mundo, e que demonstra sua total atualidade e conhecimento em relação às discussões sobre restauração entre os arquitetos e especialistas, que ocorriam naquele período.

Como foi dito, dentro desse enorme rol de preocupações, estava incluído o destino a ser dado às pedras do antigo cais do Flamengo. Então ele conclui assim o seu relatório:

...para os degraus e patamares das escadas, seria aconselhável o aproveitamento dessas magníficas pedras das velhas calçadas da cidade, calçadas que vêm sendo sistematicamente destruídas sem ao menos se levar em conta a utilização alhures de tão valioso material e isto apenas porque, devido às dimensões das pedras e respectivos tardozes $^{* 8}$, são pesadas demais para serem carregadas e descarregadas nos caminhões. Seria o caso, talvez, de a prefeitura repor em circulação algumas das antigas "aranhas", carroças de rodas enormes, apropriadas para essa natureza de transportes e que ainda há pouco mais de vinte anos estavam em serviço ativo. A época, aliás, é propícia pois, devido à escassez de gasolina, já ninguém mais se espanta com esse gênero de "aparições". ${ }^{15}$

\footnotetext{
${ }^{14}$ COSTA, L., José Pessôa org. Documentos de trabalho. Rio de Janeiro: IPHAN, p. 52, 1998.

${ }^{15}$ COSTA, L., José Pessôa org. Documentos de trabalho. Rio de Janeiro: IPHAN, p. 52, 1998.
} 


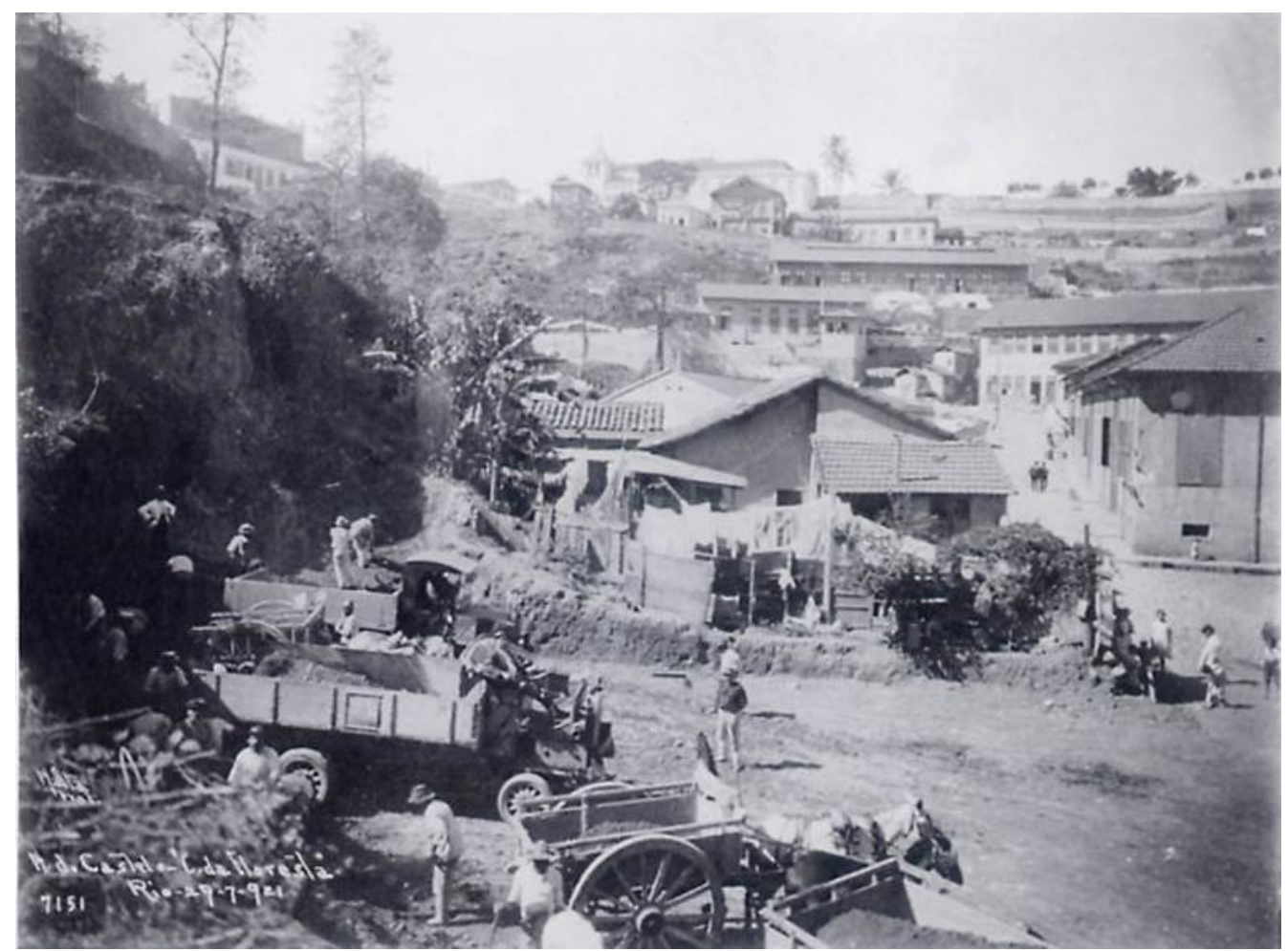

Figura 16. Desmonte do Morro do Castelo, 1921. No primeiro plano, provavelmente, a "aranha" de que falou Lucio.

Lucio Costa salvou uma quantidade enorme dessas grandes pedras empenhando-se pessoalmente para fossem reutilizadas na pavimentação da área central do Rio de Janeiro, em várias ruas. Foi também o que fez quando finalmente a obra do outeiro se realizou, realmente aproveitando as pedras do Cais do Flamengo, conforme havia preconizado no relatório, muitos anos antes, como diretriz imperativa para qualquer desavisado.

Mas fica evidente também sua estratégia de tornar essa obra viável de imediato e, conforme dissemos, mesmo a despeito do atraso por tempo indeterminado do desmonte do Morro de Santo Antônio, ou seja, tentando desvincular a exeqüibilidade de uma e outra.

Preocupou-se inclusive com o transporte das pesadas pedras outeiro acima, e sugere a utilização das "aranhas" para resolver o problema, numa clara proposição de realização imediata dessa obra, que, no final, depois de muita luta e muito tempo passado, quando, enfim, realiza-se também o Aterro do Flamengo, acaba sendo magnificamente realizada.

E, por ele mesmo. 


\section{Projeto e Obra}

Esse é um dos típicos casos em que é simplesmente impossível a realização de uma obra, a partir de um projeto executivo feito no escritório, que, depois de enviado ao canteiro, torna-se o sistema de códigos que deve ser seguido e obtém-se o produto desejado. É absolutamente necessário que o arquiteto fique presente no canteiro o tempo todo, tanto tempo que acaba sendo mais eficiente partir de croquis orientativos e passar a se tomar decisões de projeto diretamente in loco.

São situações em que o grau de precisão desejável no desenho técnico não corresponde aos dados realmente disponíveis no local, mesmo se partindo de um bom levantamento topográfico. A realidade se apresenta como uma superfície topológica, e as 2 dimensões do desenho topográfico não conseguem transmiti-la.

Além disso, no caso do Outeiro da Glória, a remoção de um antigo casario implantado na encosta ocorre mais ou menos em tempo simultâneo ao início das obras, remanescendo da demolição 3 platôs que foram incorporados ao projeto, de maneira quase contínua: surge o platô, uma vez removido o entulho, o platô vira patamar, plano de descanso, da subida, e assim sucessivamente, decidido ali, no local e na hora.

Para a criação do acesso impunha-se, antes de mais nada, remover o casario que havia na frente bloqueando a perspectiva vista da Praça Paris - obra dificílima, só levada a cabo à custa de muita tenacidade e empenho. ${ }^{16}$ É como Lucio Costa narra no documentário de José Reznik: "foi um trabalho enorme debaixo do sol..."17

Outra circunstância importante foi o desmonte do cais do Flamengo com a criação do aterro - pareceu muito conveniente utilizar uma parte das pedras da amurada para agenciar o caminhamento. Daí esse risco que dei para o acesso, procurando o percurso natural de rampas e escadas e incorporando os platôs resultante das demolições. Foi um trabalho enorme, debaixo de sol, fazer esses caminhos; tivemos a sorte de ter à nossa disposição um mestre muito capaz, que trabalhava para o Gianelli ${ }^{18}$, e a minha tarefa foi acompanhar esse mestre na escolha e colocação das pedras do antigo cais procurando aproveitá-as em seu tamanho natural (sic) ${ }^{19}$ e fazer a implantação, de acordo com o risco, em função desse material precioso. E ainda os muros de alvenaria de pedra, tão bem entrosados que parecem antigos, tudo isso só foi conseguido por causa da minha continuada presença junto ao mestre e aos pedreiros. ${ }^{20}$

\footnotetext{
${ }^{16}$ COSTA, L. Registro de uma vivência. São Paulo: Empresa das Artes, p. 411, 1995.

${ }^{17}$ LADEIRA da Igreja da Glória. Direção: José Reznik. Direção de Fotografia: Mário Carneiro. Disponível em: <http://www.casadeluciocosta.org.>. Acesso em: 22 mai. 2007.

${ }^{18}$ Emilio Gianelli, colaborador de Lúcio Costa nesse projeto, era quem conhecia o Mestre de Obras cujo nome se perdeu.

${ }^{19}$ Quer dizer, as pedras nos tamanhos encontrados após a demolição do cais.

${ }^{20}$ COSTA, L. Registro de uma vivência. São Paulo: Empresa das Artes, p. 411, 1995.
} 
No documentário de Reznik, ele acrescenta: “... um mestre acostumado com obras pesadas, trabalhava em marmoraria, estava acostumado com transferência de monumentos..." para descrever esse mestre que, então, estava acostumado a lidar com o manuseio de peças grandes e pesadas. E quanto aos muros, ele diz: ... tão bem entrosados que parecem estar aí a séculos, não parece coisa recente, que tem sempre coisa que se trai.... $^{21}$

A luta que começara com um relatório, na repartição do SPHAN, para se consumar é realizada, ainda, sob trabalho árduo, diretamente no canteiro.

\section{Caminho Suave ${ }^{22}$}

Os acessos em aclive até as igrejas e palácios são recorrências em toda história da Arquitetura. Inicialmente, por motivos estratégicos, militares e religiosos - veja-se como exemplo o Parthenon, na Grécia clássica -, esse tipo de implantação acaba por aumentar a própria carga simbólica do monumento por procurar sítio privilegiado na geografia: outeiro. Acrescida de torres, ornamentos no alto dos acropódios, coroamentos, etc. etc., tem toda sua monumentalidade claramente explicitada.

Alguns exemplos de acessos em aclive, cujas escadas não estão diretamente acopladas ao edifício e sim apresentadas como elemento à parte, como elemento urbano que se compõe com o edifício mas que não constitui sua escadaria são relembrados com constância, por sua significativa importância na história da arquitetura e por sua beleza.

A escadaria de acesso à Praça do Campidoglio, de Michelangelo, talvez seja o maior exemplo, mas, seguramente, a relação de similaridade do projeto de Lucio Costa se dá mais com o Barroco da Santuário de Bom Jesus do Monte, em Braga, em Portugal e com a Igreja do Nosso Senhor Bom Jesus dos Matosinhos, de Aleijadinho em Congonhas do Campo, Minas Gerais, e talvez, também, no Barroco Italiano, com a escadaria da Praça da Espanha, em Roma. A de Braga e a de Congonhas do Campo, sim, guardam enorme relação de similaridade entre si, porém a brasileira tem a simplicidade caipira de Aleijadinho, enquanto a de Portugal tem todo o requinte dado por André Soares.

\footnotetext{
${ }^{21}$ LADEIRA da Igreja da Glória. Direção: José Reznik. Direção de Fotografia: Mário Carneiro. Disponível em: <http://www.casadeluciocosta.org.>. Acesso em: 22 mai. 2007.

${ }^{22}$ Nome de uma antiga cartilha para alfabetização - com a qual fui alfabetizado.
} 


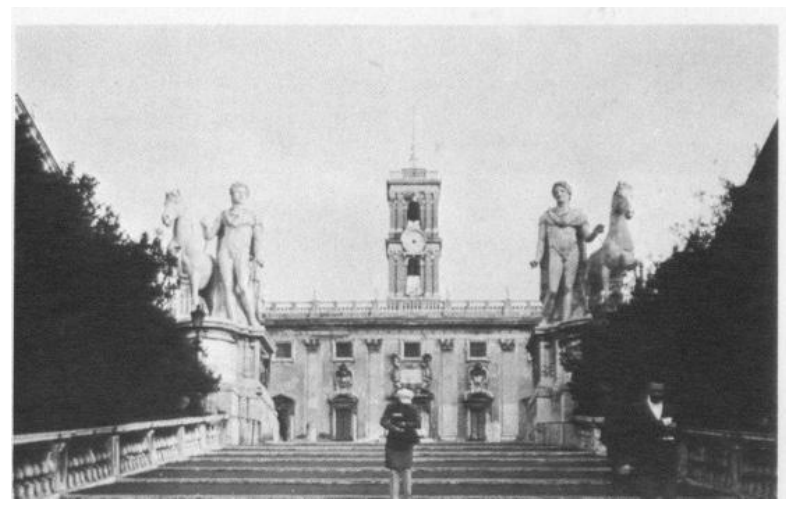

Figura 17. Escadaria de acesso à Praça do Campidoglio, de Michelangelo, Roma, Itália.

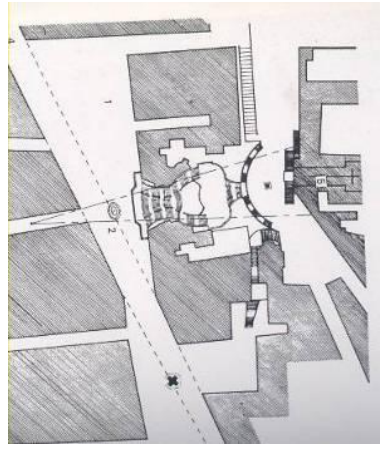

Figura 19. Praça da Espanha, de Alessandro Specchi e Francesco de Santis, Roma, Itália.

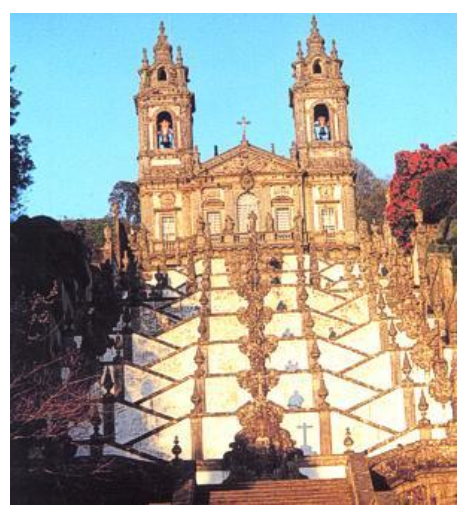

Figura 18. Escadaria de acesso à Igreja Bom Jesus do Monte, de André Soares, Braga, Portugal.

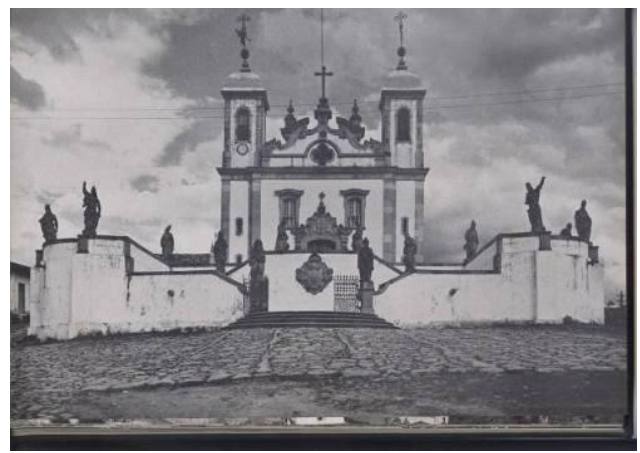

Figura 20. Igreja do Nosso Senhor Bom Jesus dos Matosinhos, de Aleijadinho, Congonhas do Campo, Brasil. - SMITH, G. E. K., in Brazil Builds.

Os trajetos zigue-zagueados, intercalados por patamares, transformam o percurso num evento diverso da subida linear e direta até o monumento: é como se na sinuosidade do trajeto barroco houvesse um tempo para reflexões outras, que não o olhar, o pensamento e o gesto de galgar a escada, todos voltados para um único objetivo. É como se a menor distância entre dois pontos não fosse uma reta inclinada no declive da escada, e sim uma senóide no plano suavizado da inclinação. 


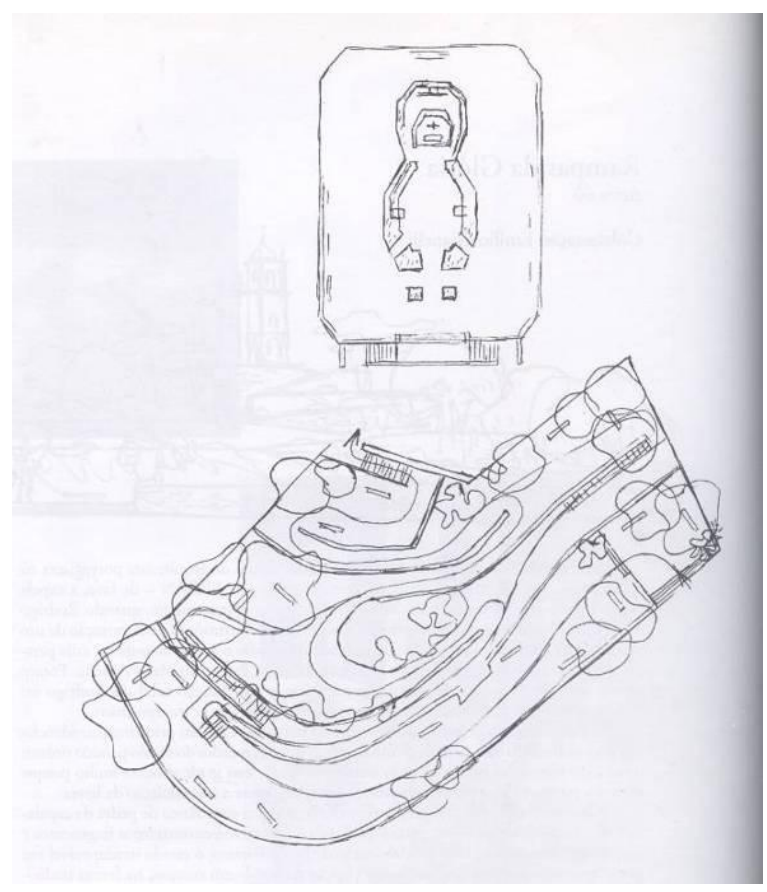

Figura 21. Desenho de Lucio Costa demonstrando a implantação e o trajeto sinuoso previsto.

Profundo conhecedor de história da Arquitetura, Lucio Costa com certeza conhecia muito bem os monumentos aqui citados e que haja certa similaridade entre eles e o seu, mas é apenas isso, uma relação de similaridade, sem qualquer citação ou referência direta.

O projeto de Lucio Costa opta pela suavização da subida do morro, utilizando o trajeto sinuoso, adotando o caminho do boi $^{23}$, bailando em zigue-zague pelo terreno e oferecendo pontos de parada nos platôs das antigas casas, transformados em pequenas praças arborizadas.

O fato dos muros de pedra já parecerem antigos é mais uma postura moderna do projeto novo que se relaciona com patrimônio histórico. Eles parecem antigos porque parecem que sempre estiveram ali e como sempre estiveram ali não causam mais incômodos, deixam de ser interferência a mais, o fato de que sempre estiveram ali é como se não existissem. Não se trai, como ele mesmo disse. Não finge ser o que não é, não é um a mais que atrapalhe. Não ornamenta, mas é de enorme força ornamental em si mesmo, pelo excelente trabalho de cantaria do mestre cujo nome já não se sabe mais.

\footnotetext{
${ }^{23}$ Expressão popular para os caminhos em diagonal das curvas de nível, tornando a subida da encosta de um morro mais suave.
} 

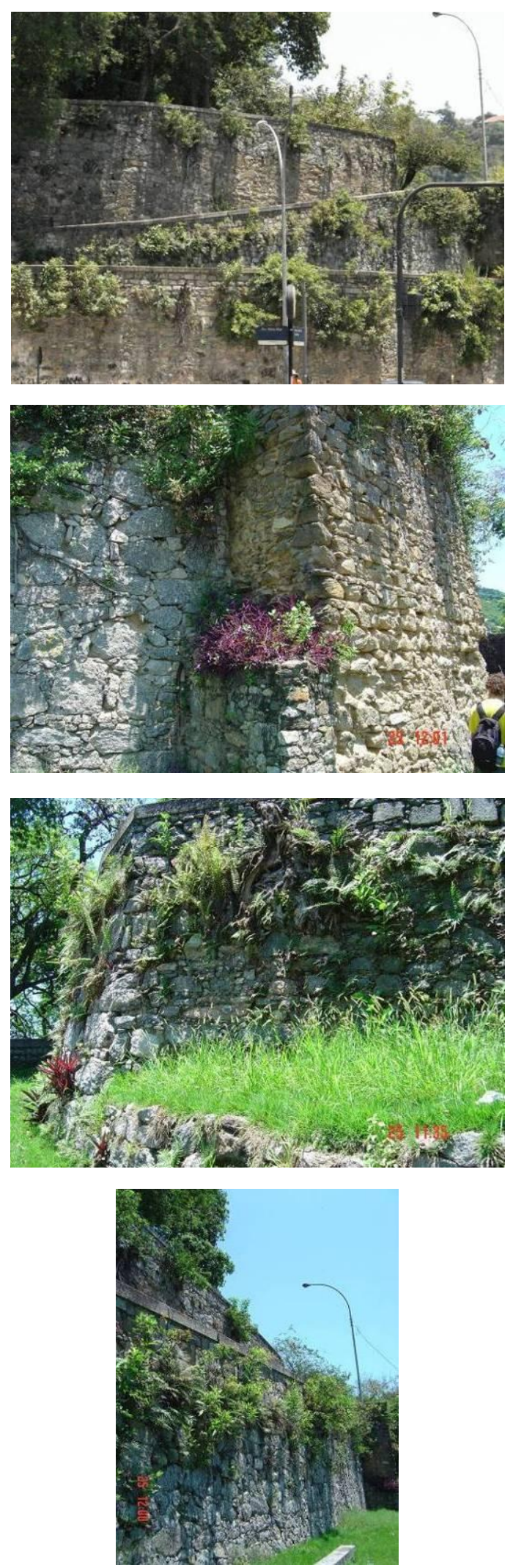
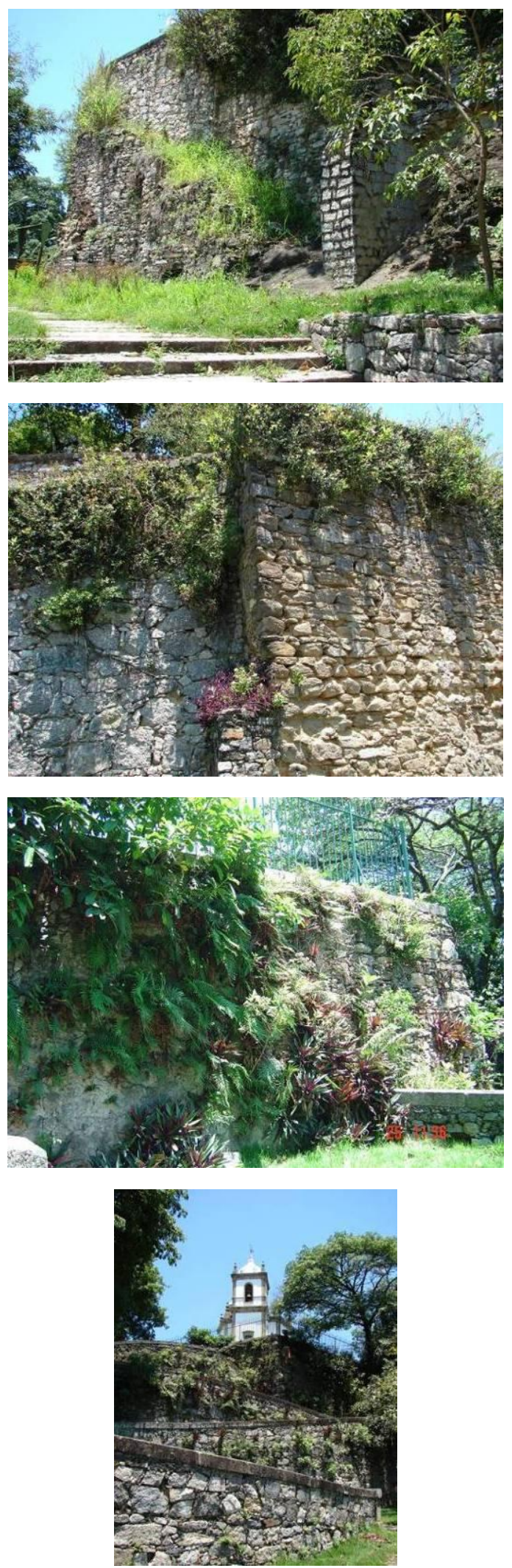

Figuras 22. Os arrimos de cantaria de pedras com a exuberante vegetação engastada nele. Nota-se nas terceira e quarta foto, a justaposição entre um arrimo velho existente e o novo. 
Com a vegetação que gruda e salta dele, essa força ornamental aumenta

mais ainda.

Vegetação indesejada naqueles projetos históricos, aqui imposta e determinada pelo projeto, porque Lucio Costa jamais deixou de inserir em seus projetos as diretrizes e especificações de paisagismo, fato já prenunciado no relatório de 43 . E a vegetação, no Rio de Janeiro ganha logo vigor e viço, encorpa, participa do todo com presença marcante. Como ele previa, acaba por ser um espaço urbano que dá continuidade ao espaço conquistado pelo aterro do Flamengo e seu paisagismo, feito por Roberto Burle-Marx.
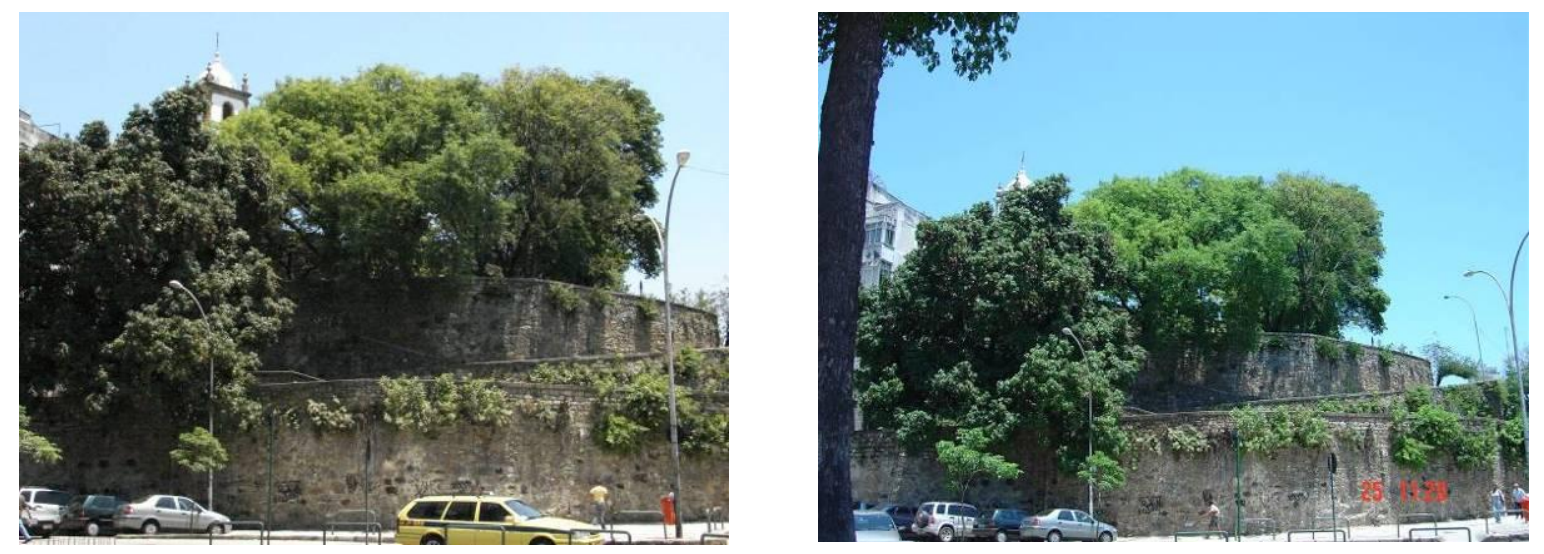

Figuras 23. Vistas da encosta com os muros e a vegetação, a partir do Aterro do Flamento.

Todos os demais elementos aparecem com a mesma afirmativa suavidade. $\mathrm{O}$ arremate do muro, quando surge como peitoril, é feito com paralelepípedos na longitudinal e largura que oferece uma pequena pingadeira para cada lado, no sentido transversal, convexos na face superior, tem excelente feitio, que demonstra a alta qualidade da mão de obra para esse tipo de serviço especializado. Os bancos têm a mesma linguagem e qualidade de acabamento, com participação ativa na linguagem curvilínea do paisagismo. Os pisos dos caminhos, à japonesa, com intervalos entre as pedras de piso que deixam faixas da grama entre elas, a alternância dos tamanhos, ora grande e larga, ora comprida e estreita, intercaladas, o intervalo entre estas pedras de piso e os muros de pedra deixando os elementos soltos, compõem a visão de um projeto de paisagismo totalmente contemporâneo. 

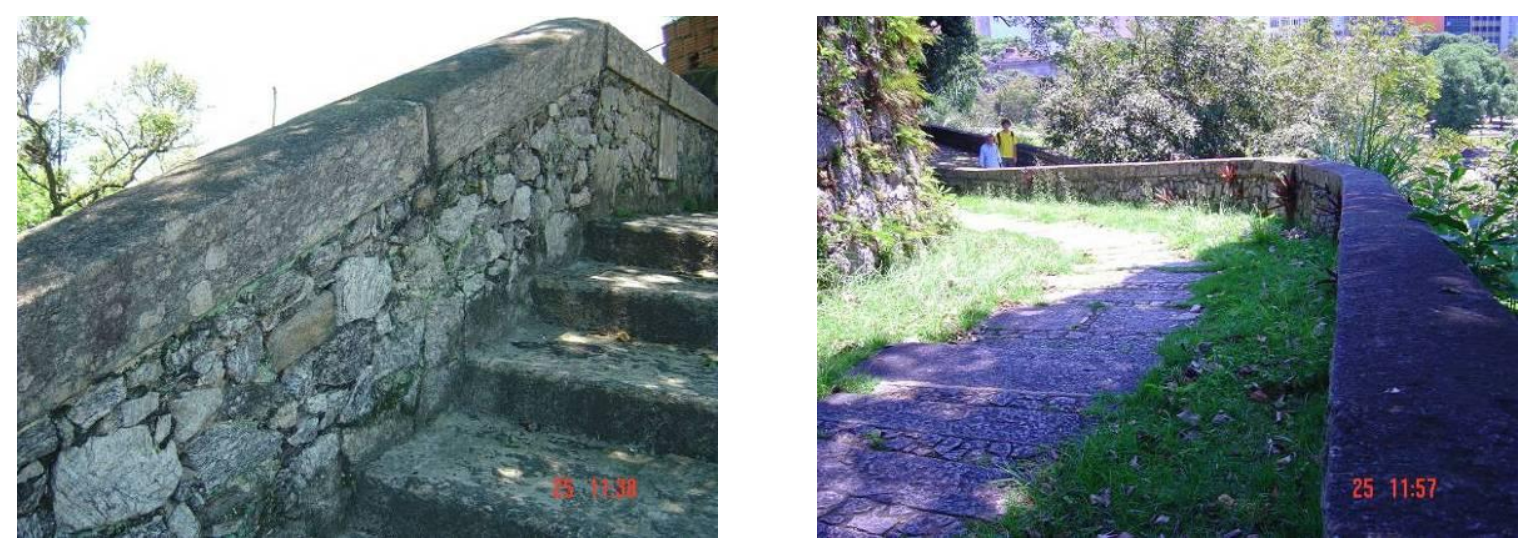

Figuras 24. O arrimo surge do outro lado como peitoril. Vê-se o acabamento superior do peitoril, com pingadeiras, de excelente execução.
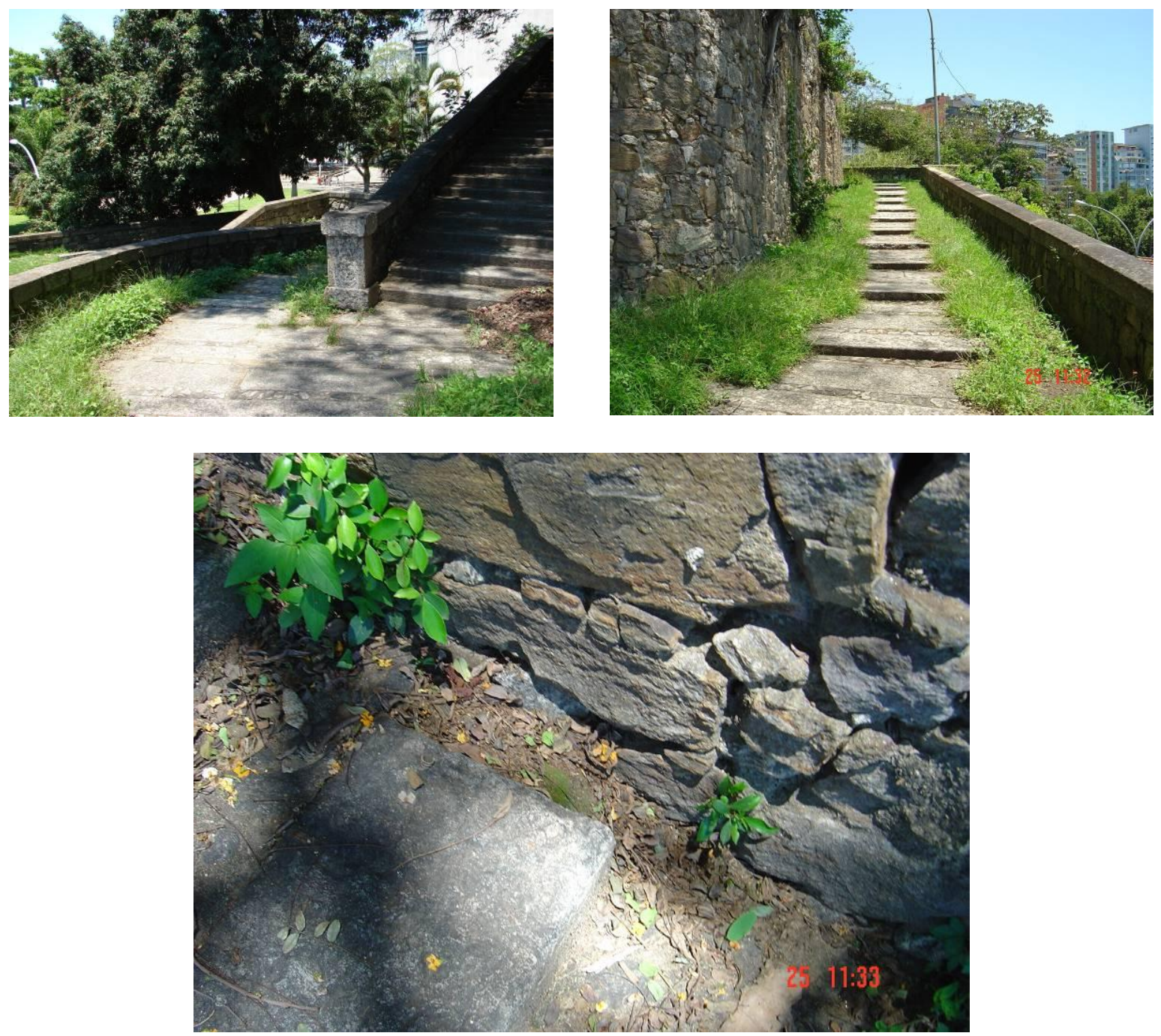

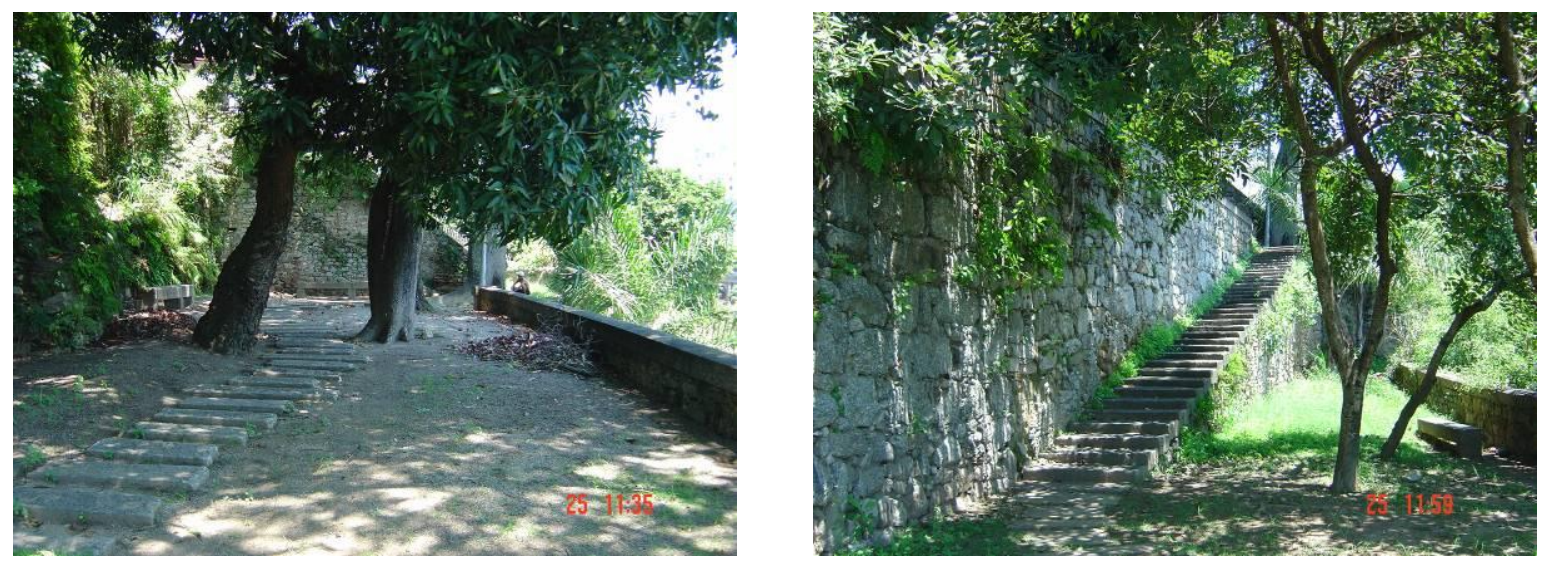

Figuras 25. (inclusive p. anterior) Imagens das rampas, escadas e praças de descanso criadas nos antigos platôs das casas demolidas; os pisos dispostos "à japonesa", e na figura do centro à esquerda detalhe do piso sem encostar no muro.

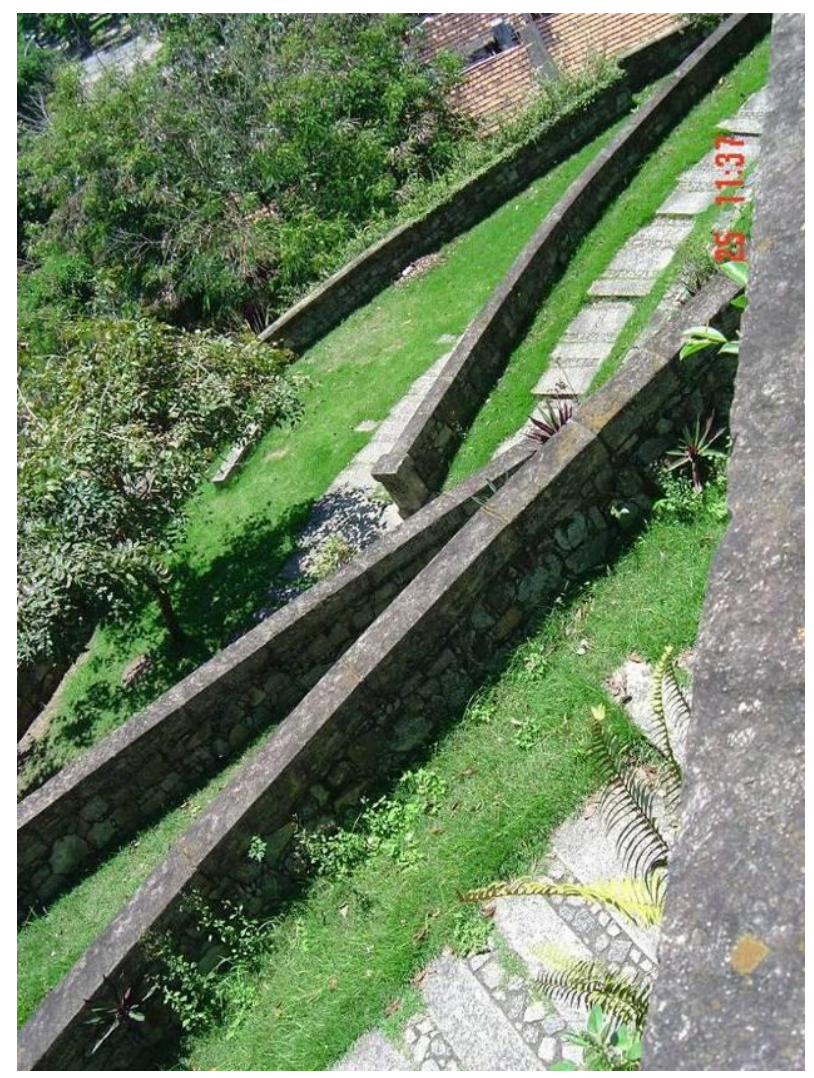

Figura 26. A beleza do projeto de paisagismo contemporâneo, compondo os diversos elementos, muros, passeios, vegetação, demonstrada em toda a sua forma dinâmica. 

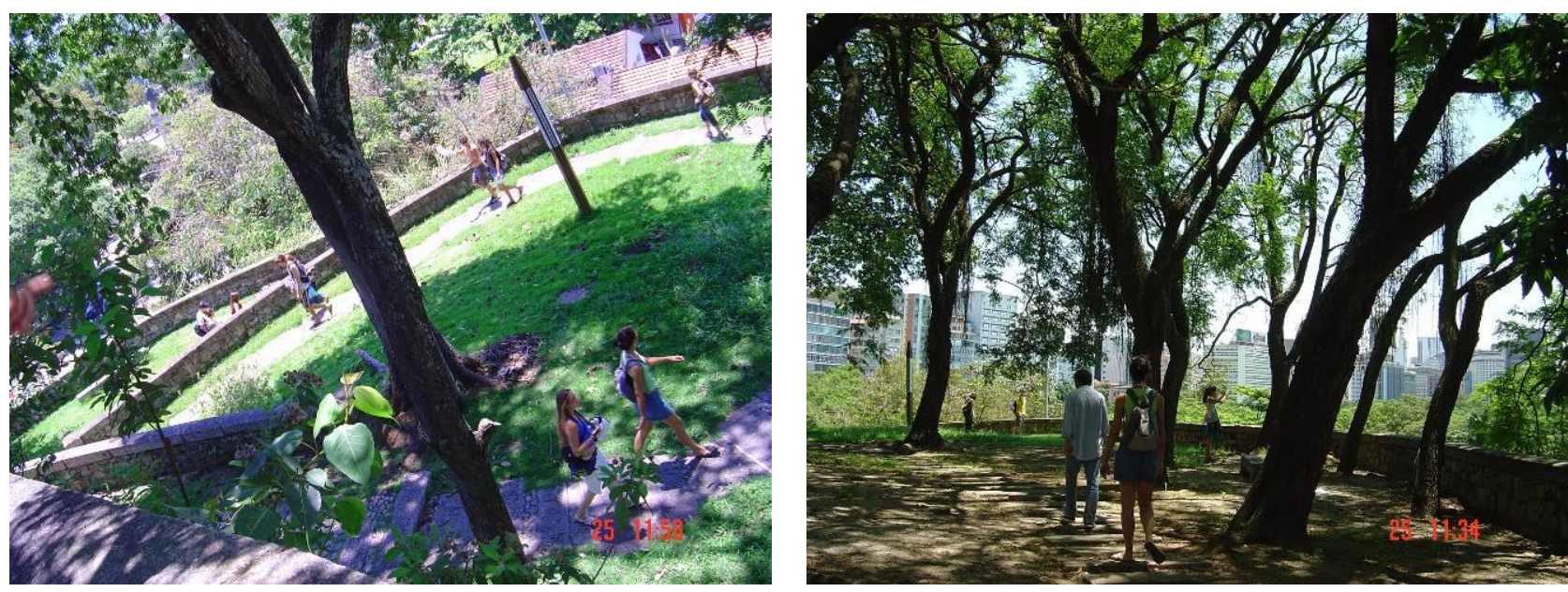

Figuras 27. Vê-se o bailado em zigue-zague das pessoas caminhando ao longo do percurso.

Ele conclui:

Com platôs, gramados, bancos - bem espaçados, como sugeria o projeto - e a escolha da vegetação apropriada, a capela, além de recuperar toda a sua integridade e limpidez original, ganhou um acesso condigno. ${ }^{24}$

E, para completar, o que arremata o que é um projeto técnico executado in loco perfeito, o passo do pedestre nas rampas e escadas é perfeito, é possível subir o desnível equivalente a 8 andares de altura suavemente, sem perder o fôlego, a não ser pela emoção de se passear por um grande e belo projeto de arquitetura, com todos os seus aspectos e abrangência.

${ }^{24}$ COSTA, L. Registro de uma vivência. São Paulo: Empresa das Artes, p. 412, 1995. 


\section{PARQUE GUINLE}

\section{A chácara originalmente de propriedade do Conde Sebastião}

Pinho, foi adquirida pelo Dr. Eduardo Guinle para nela ser construída sua residência. Na entrada do Parque Guinle, no fim da Rua Gago Coutinho, encontra-se um antigo portão, que era a antiga entrada da propriedade. Atualmente desativado, esse portão é, pode-se dizer, "uma escultura arquitetônica", tendo em vista a beleza do desenho da serralheria de suas folhas, sustentadas por duas colunas laterais de granito, e as duas esculturas, junto a elas, representando esfinges, sobre as quais estão sentados, displicentemente, dois anjinhos de bronze - informação constante da placa turística - ver imagem abaixo.
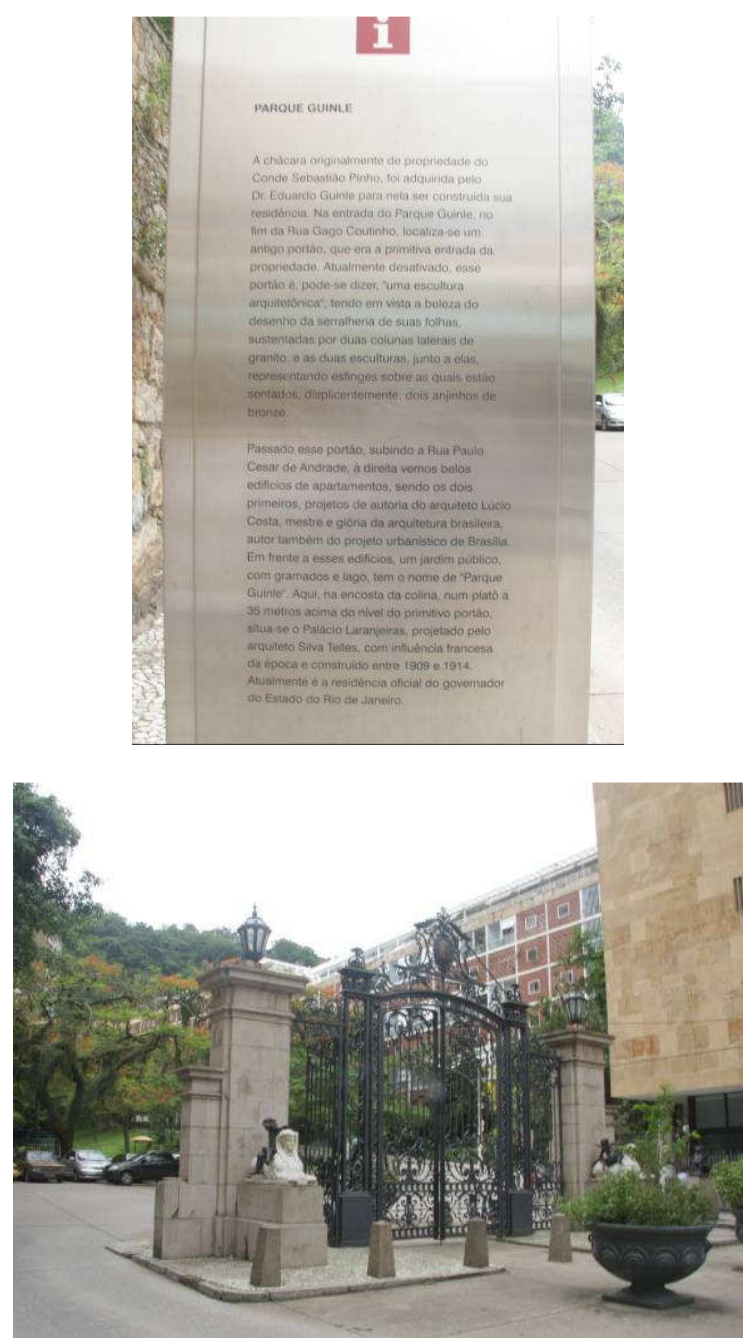

Figura 2. Portão de entrada da chácara.
Figura 1. Inscrição da placa de informações turísticas da Prefeitura do Rio de Janeiro, postada na calçada à esquerda do portão.

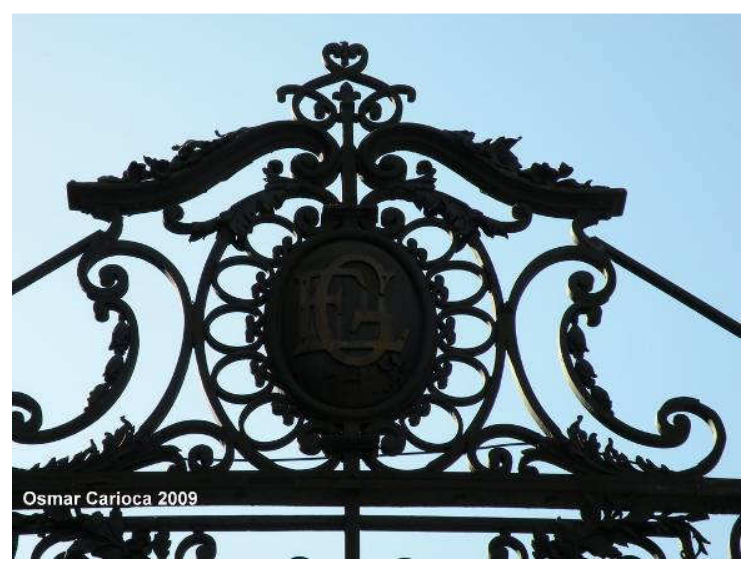

Figura 3. Iniciais EG no portão de entrada da chácara.

No alto do portão, o brasão contém as iniciais EG, sobrepostas, indicando a iniciativa de fabricação do portão de entrada da chácara por parte de Eduardo Guinle. Também foi dele a iniciativa de construir a mansão como um palácio afrancesado 
que mistura o estilo Luiz XV, Luiz XVI e o chamado estilo Império - além de citações do Cassino de Monte Carlo -, como sua residência. Foi construído entre 1909 e 1912, com projeto e supervisão do arquiteto Armando Carlos da Silva Telles, que provavelmente é o autor do portão também.

Como vimos, Lucio já tinha mudado um Portal de lugar, o da Academia Imperial de Belas Artes, e reclamado de palmeiras-imperiais justapostas a uma fazenda colonial, Colubandê. Neste caso, manteve um portão, inutilizando-o, com toda a clareza na intenção.

O edifício continuou na família até 1947 e era chamado de Palacete Eduardo Guinle. Nesta data foi vendido para a União, no governo do Presidente Eurico Gaspar Dutra, com a intenção de ser a hospedagem de visitantes ilustres à, então, capital do país. Após o suicídio do Presidente Getúlio Vargas, no Palácio do Catete, então residência oficial da Presidência, seu sucessor Juscelino Kubitschek, passou a usar o Palácio das Laranjeiras para nele residir e despachar, até 1960, quando passou a despachar direto da nova capital, Brasília. O Palácio das Laranjeiras continuou sendo a residência oficial dos presidentes no Rio de Janeiro e ainda recebia hóspedes ilustres. Em 1974 foi doado pelo Governo Federal para o recém criado Estado do Rio de Janeiro resultado da fusão entre os antigos Estados do Rio de Janeiro e da Guanabara.

Foi a partir de 47 que passou a ser chamado e se popularizou como Palácio das Laranjeiras, sem a menor relação com o homônimo palácio em Portugal, e com relação tênue com o bairro carioca de mesmo nome, porque seu principal acesso é por dentro do Parque, a partir do Cosme Velho, e não pelo antigo Bairro das Laranjeiras. Há essa confusão no próprio site do governo carioca: o bairro é mais antigo do que a mansão, mas, popularmente se diz que o bairro se formou em torno do Palácio. O mesmo ocorre com populares entrevistados no entorno do Museu Paulista, o Museu do Ipiranga, entrevistas nas quais declaram que foi a residência de D. Pedro, sem saber qual deles, o Primeiro ou o Segundo, e que o bairro se formou em torno do "palácio", depois da declaração de Independência.

O que não é citado em nenhuma informação disponível nos sites oficiais é que se trata daquelas construções que chamamos de Castelos, tal como em Chantilly, onde ocorreu um dos casamentos do craque Ronaldo, Chateau, castelos rurais, várias vezes reformados ao longo de suas histórias, adaptando e adotando, por sobreposição, novos estilos, e que mantém grande admiração leiga, alimentando as versões mediáticas dos novos contos de fadas.

A referência arquitetônica mais explícita é, sem dúvida, o Cassino de Monte Carlo, mas é preciso observar alguns detalhes importantes: a eliminação de uma das torres da fachada, em relação ao modelo original, e o conseqüente aumento da assimetria, com acento que se intensifica em direção ao pináculo principal, confere ao conjunto um dinamismo estudado, garantindo a essa obra eclética interesse muito particular. 
A implantação, no limite do espigão proeminente na chácara, ponta de espigão que se volta para a cidade, traz ao conjunto o caráter áulico, de palácio (ou castelo mesmo). E a assimetria de torres, com a proeminência do pináculo na borda do espigão tem a dramaticidade requerida para por aquelas intenções, de glamour e, por que não, esnobismo. Como Lucio disse, Eduardo Guinle era visionário e gastador - talvez, até mesmo ao ponto de ter sido freqüentador do Cassino de Monte Carlo. ${ }^{1}$

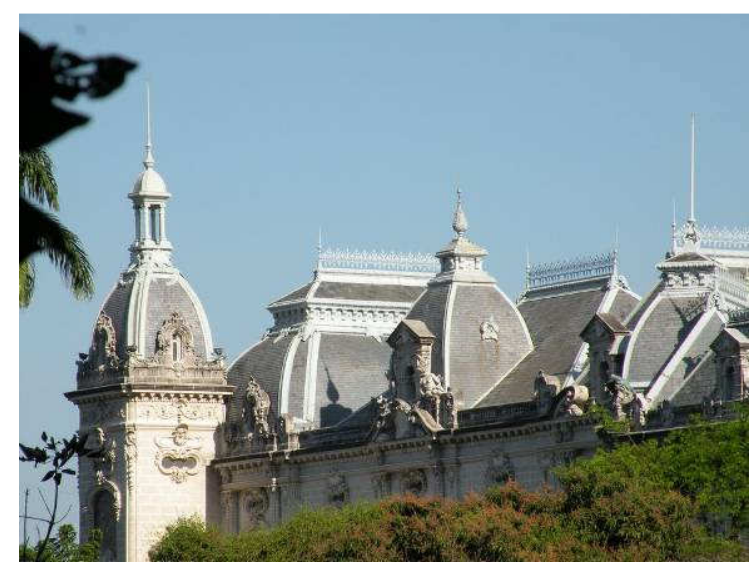

Figura 5. Torres do Palácio das Laranjeiras. A assimetria é intensificada com uma só torre principal, com o pináculo mais alto.

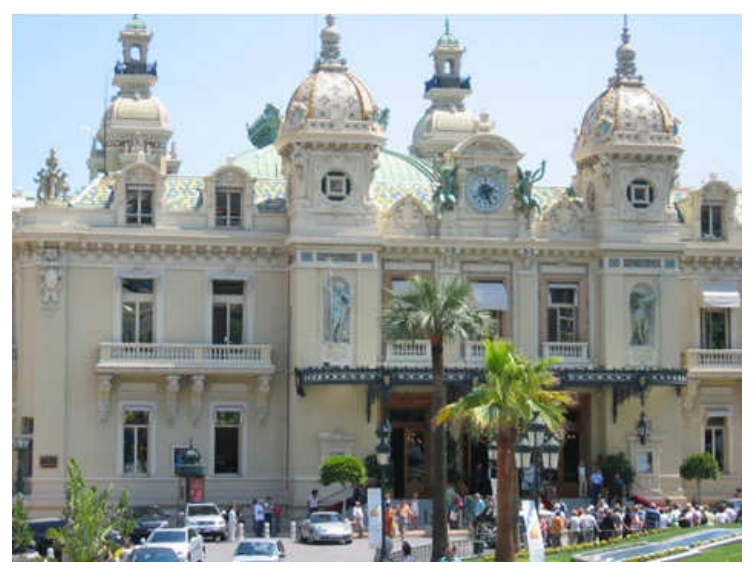

Figura 6. Cassino Monte Carlo, Charles Garnier, 1863. Principado de Mônaco.

Inevitável é voltar ao exemplo do Museu do Ipiranga: sua

implantação é colocada como uma barra transversal, rigorosamente ortogonal, à linha de talvegue, como um fecho. E o exemplo aqui é ao contrário, um explica o outro. No Palacete E. G. acentua-se a assimetria barroca sobre a ponta do espigão, e no Ipiranga a simetria se torna um fecho das encostas que, nesse caso, suaves, correm paralelas em direção ao edifício, com os jardins e espelhos d'água a acentuar o efeito neoclássico pretendido.

O projeto do Palacete organiza em três corpos nítidos e distintos as funções agrupando-as de maneira muito coerente: o corpo central, de frente para a ponta do espigão e para a vista e afastado da entrada, abriga a parte social e de cerimônias. A ala paralela ao Parque, com circulação de entrada e saída de veículos mais intensa é a parte de serviços, com a lógica de facilitar cargas e descargas, entrada e saída de empregados, etc. Na outra ala, voltada então para o lado menos movimentado e mais tranqüilo encontram-se os quartos, que abrigaram inúmeros hóspedes ilustres. Temos, portanto uma organização racional dentro de uma casca de um ecletismo até exagerado: mistura dos barrocos franceses Luís XV, Luís XVI e Estilo Império.

${ }^{1}$ COSTA, L. Parque Guinle - anos 40. in: COSTA, L. Registro de uma vivência. São Paulo: Empresa das Artes, p. 205, 1995. 


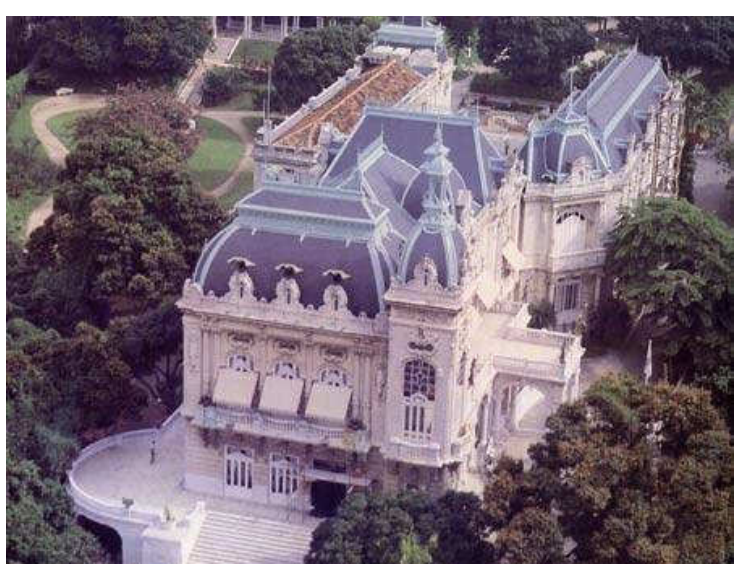

Figura 7. Palácio das Laranjeiras: dinâmica assimetria que aponta para o penhasco. Rio de Janeiro, de 1909.

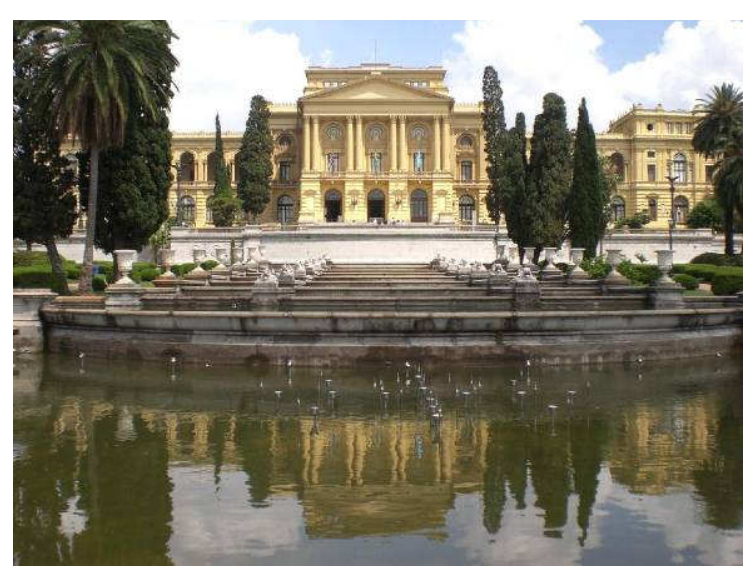

Figura 8. Museu do Ipiranga: simetria transversal ao talvegue, uma barra estática cenográfica. São Paulo de 1895 .

Acrescente-se ainda que, no Parque Guinle, o caminho sinuoso que leva à mansão é referência explícita a castelos: eles são, necessariamente, de difícil acesso. Pontes levadiças ou jogar tranças são permissões. Essa estrada vicinal da chácara, além de ser o único acesso de veículos ao Palacete, levava ao interior das poucas áreas ocupáveis do terreno, fato comum na topografia da cidade do Rio de Janeiro.

O ajardinamento inicial do acesso ao Palacete, contornando o lago artificial, foi feito pelo arquiteto francês Cochet, em 1916 - nos sites que tratam do Parque e no texto de Wisnik ${ }^{2}$ constam com essa grafia, em alguns dos sites como Gérard Cochet, não sendo portanto Couchet, sócio de Memória, herdeiros do escritório de Heitor de $\mathrm{Mello}^{3}$, arquitetos que atuaram na divulgação do neocolonial e do ecletismo vigentes, dados que carecem de informação mais precisa -, e é esse contorno que Lucio utiliza na sua proposta de implantação dos seis edifícios, a começar do fecho estabelecido pelo primeiro deles, o Nova Cintra, em relação à cidade, à Rua Gago Coutinho.

Sobre o paisagismo atual, duas versões são aventadas, ambas possíveis e que na verdade podem ser complementares, tendo-se somado: que Burle-Marx tenha dado retoques posteriores no desenho de Cochet, especificando novas espécies, etc., e a outra é que Lucio tenha feito todo o conjunto em definitivo. De qualquer modo, o paisagismo específico do entorno das edificações é de Lucio e se amolda perfeitamente ao desenho do paisagismo construído, da implantação que se amolda ao terreno, com a definição das variantes de cada prédio, especialmente como cada um deles chega ao solo.

A presença correta dos flamboyants afastados das áreas pavimentadas ou das edificações, pois essa espécie possui raízes agressivas, aparece como uma grande cobertura que sombreia e retém a umidade, tornando confortável e,

\footnotetext{
2 WISNIK, G. (org.). Lucio Costa. Coleção Espaços da Arte Brasileira. São Paulo: Cosac \& Naify, p. 87, 2001.

3 COSTA, L. Registro de uma vivência. São Paulo: Empresa das Artes, p. 165, 1995. 
principalmente agradável o passeio ou permanência sob suas copas. Quando florido e visto de cima, a partir dos apartamentos, parece um grande tapete de um entremeado das variantes amarelas, vermelhas e laranjas distribuídas pelo Parque. Antes de florir, os flamboyants lançam uma grande e curiosa vagem dura. A presença também numerosa de cássias reforça a hipótese da atuação de Lucio, pois como relatou Maria Elisa, era um espécime que ele admirava muito. As folhagens espessas e forrações, que não tem inflorescência e que sobrevivem mesmo na sombra, típicas das matas e florestas brasileiras - condição de sobrevivência absolutamente necessária quando usado sob pilotis,- são indícios claros de que quem atuou ali foi um - mais de um? - Paisagista Moderno e Brasileiro, constituindo esse remanso urbano.

A antiga estrada vicinal foi, com o loteamento da chácara, transformada em via pública, passando a se chamar Rua Paulo César de Andrade, ali permanecendo o portão como marco escultórico da entrada do conjunto, sem a função de fechar e abrir. Como já foi dito, desde o primeiro desenho de apresentação do conjunto, há relevância na presença do Palacete e da permanência do portão, já representado então numa ilha que divide as mãos de direção de entrada e saída de veículos no Parque. $\mathrm{O}$ portão, cercado por esfinges, a princípio misteriosas e perigosíssimas, tem os anjos brincalhões por cima; os leões alados, de sonho que o ladeiam, passaram a admirar o conjunto moderno, aumentando a quantidade de significados do portão inútil - enquanto tal.

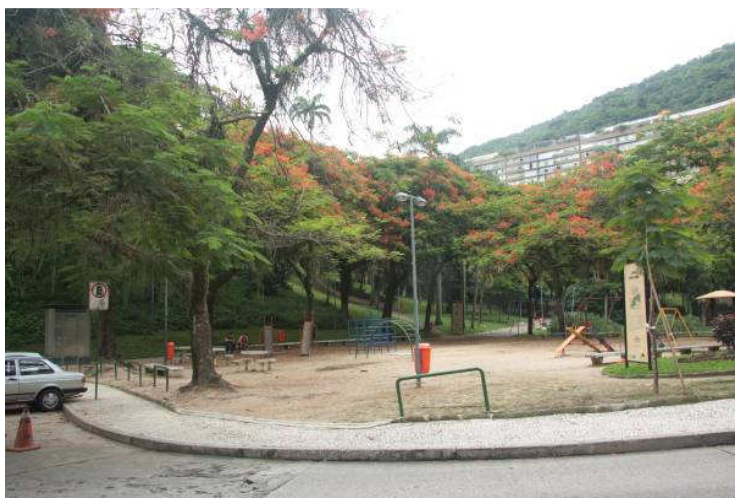

Figura 9. Entremeado de Flamboyants do Parque Guinle.

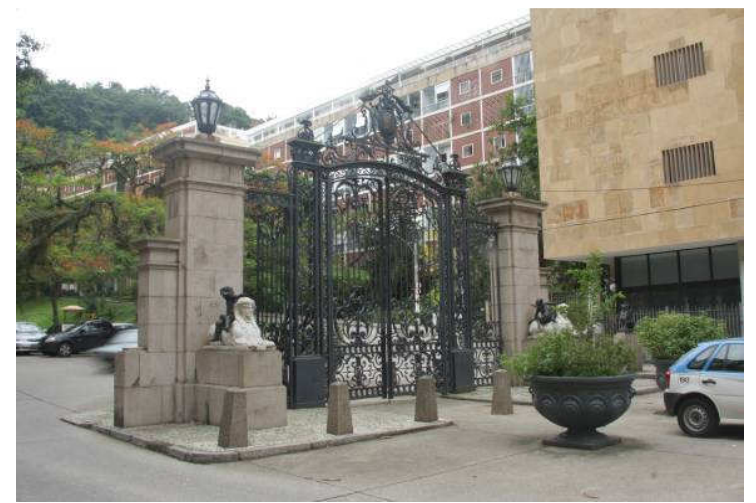

Figura 10. Portão de entrada do Parque Guinle, mantido por Lucio: não-portão. $\mathrm{O}$ fechamento do pilotis do Nova Cintra segue em vidro, como vem da fachada da Gago Coutinho. 


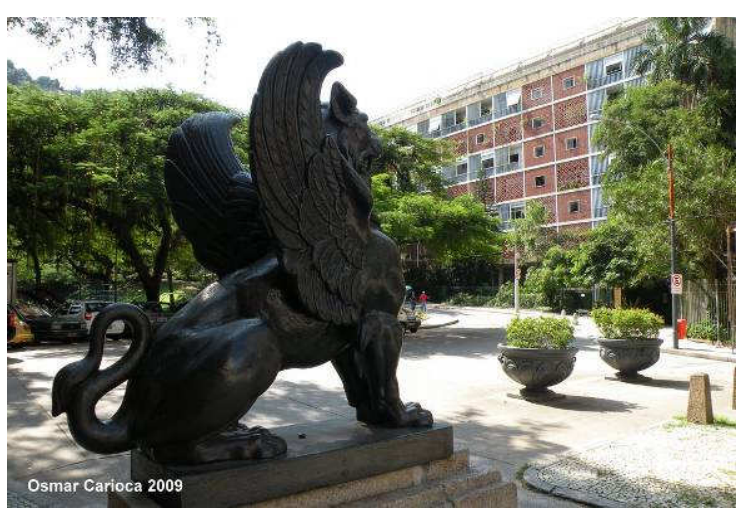

Figura 11. Leão alado de sonho admira a obra moderna.

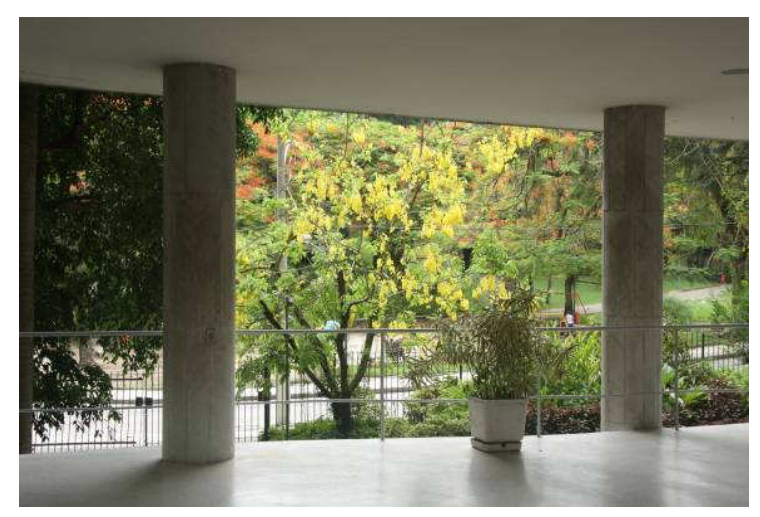

Figura 12 Cássia florida, com os Flamboyants ao fundo.

Ao final da Rua Paulo César de Andrade fica a Rua General

Mariante, acesso ao Palacete propriamente dito, virando-se para a esquerda, segue-se pela crista do espigão, praticamente no mesmo nível da implantação do conjunto, que hoje é a residência oficial do Governador, e que, no momento não é mais aberto à visitação pública. Seguindo pela direita pela Rua General Mariante, que nesse trecho está por cima do Túnel Santa Bárbara, e passando para outras vias, bastante sinuosas, e por várias favelas, chega-se até o outro lado da montanha, onde está o bairro de Santa Tereza.

Os herdeiros de Eduardo Guinle, além de vender o Palacete, resolveram criar um empreendimento lucrativo, loteando a antiga chácara para oferecer moradias de classe alta, e pretendiam manter o estilo afrancesado para criar um conjunto coerente com o estilo da construção inicial.

Mas, como narra Lucio, o projeto foi parar em suas mãos, por intermédio de Armando Faria de Castro, então Lucio ele ponderou para o herdeiro César Guinle que a imitação em escala diminuída iria reproduzir a "casa grande e senzala", e que deveria ser feito um projeto que se adaptasse mais ao parque do que à mansão ${ }^{4}$.

Lucio foi contratado também, logo a seguir, exatamente por César Guinle, Dr. César, para o projeto e o acompanhamento das obras, do Park Hotel São Clemente, em Nova Friburgo, portanto as obras do Hotel e do Parque Guinle tiveram períodos concomitantes - Parque Guinle de 1943 a 1954 e Park Hotel em 1944 e 45 . O Hotel foi feito para hospedar eventuais compradores de terrenos num loteamento das áreas supérfluas do Parque São Clemente ${ }^{5}$.

\footnotetext{
4 COSTA, L. Registro de uma vivência. São Paulo: Empresa das Artes, p. 205, 1995.

5 COSTA, L. Registro de uma vivência. São Paulo: Empresa das Artes, p. 214, 1995. 204
} 


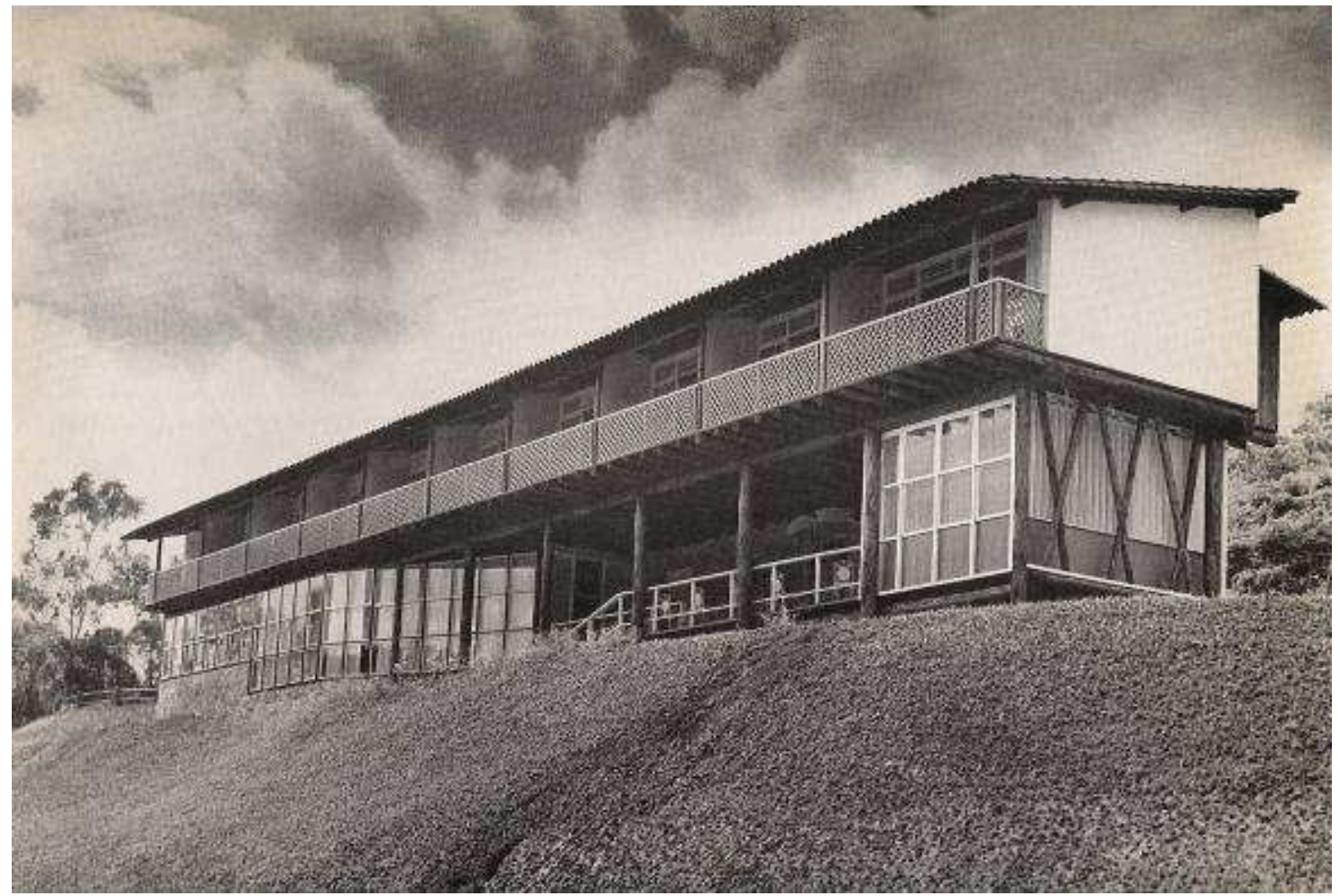

Figura 13. Park Hotel, 1944. Nova Friburgo, RJ.

A abertura dos túneis em direção a Copacabana, partindo de Botafogo, primeiro o Túnel Velho - Túnel Prefeito Alaor Prata -, em 1892, considerado o marco da fundação de Copacabana, em seguida a abertura do Túnel Engenheiro Marques Porto - ou Túnel Novo -, em 1906 e que tem seu tamanho dobrado, em 1949, com o Túnel Engenheiro Coelho Cintra - o engenheiro que construiu o Túnel Velho -, formando um binário de circulação sob o Morro da Babilônia, representam em três tempos, o início, o aumento de interesse e a consolidação da ocupação de Copacabana e da orla da Zona Sul do Rio de Janeiro. Seguiu-se a construção do Túnel do Pasmado, aumentando ainda mais a possibilidade de fluxo na direção Urca-Leme-Copacabana, com obras iniciadas em 1947 e concluídas em 1952, sob o Morro do Pasmado. 


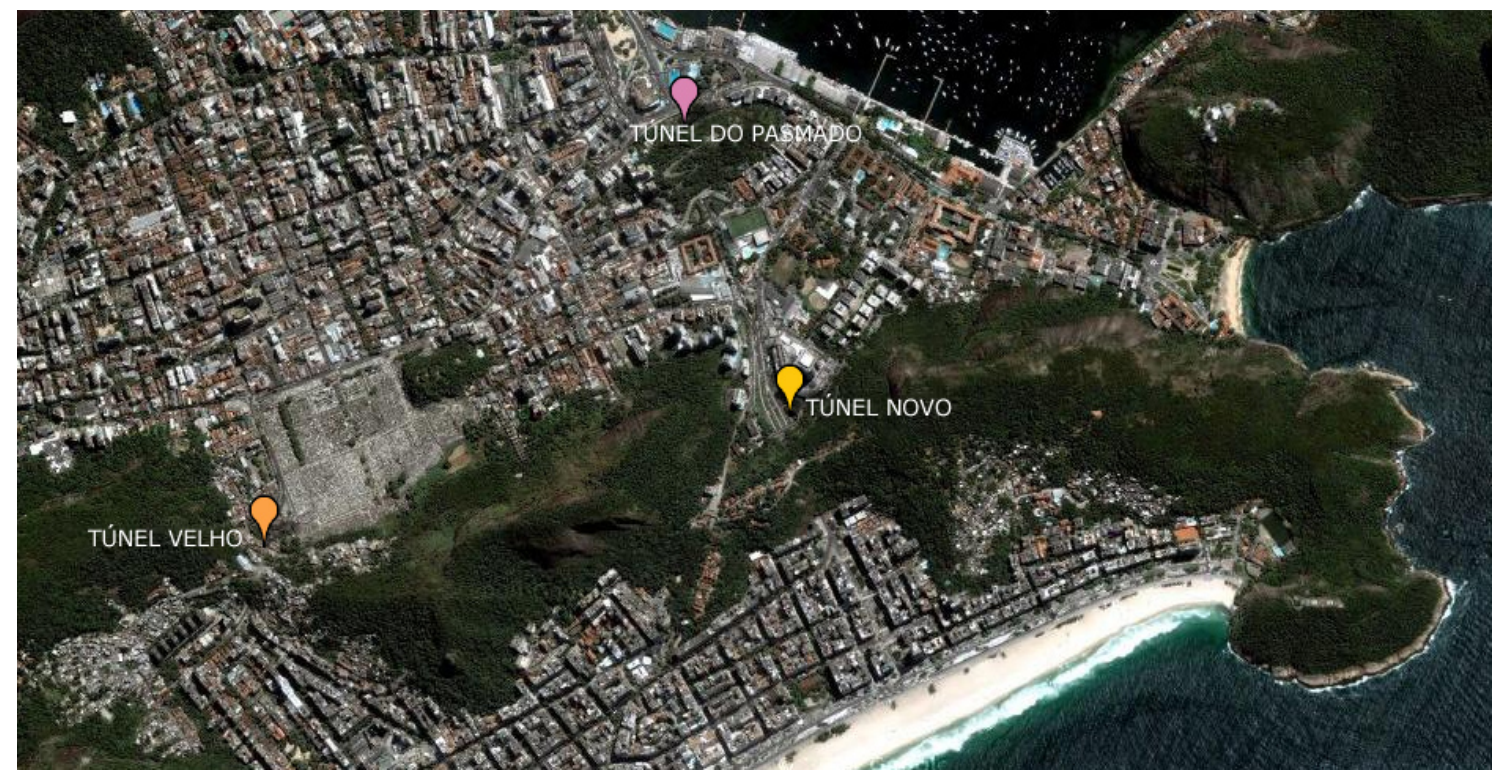

Figura 14. Imagem de satélite de localização dos túneis: Velho, Novo e do Pasmado. Fonte: Google Earth.

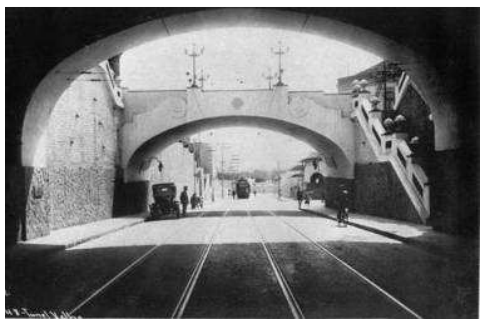

Figura 15. Túnel Velho (ou Prefeito Alaor Prata), de 1892.

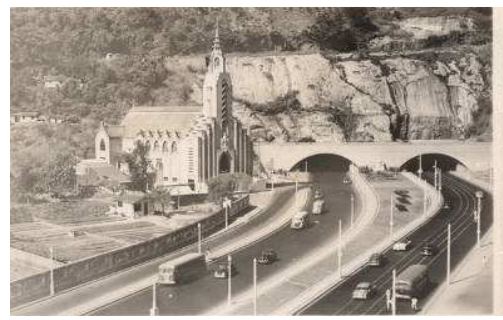

Figura 16. Túnel Novo de 1906 e duplicado em 1949.

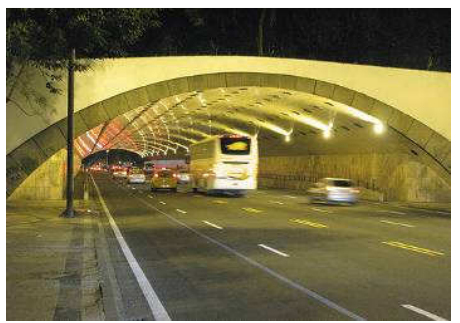

Figura 17. Túnel do Pasmado, de 1952.

Interesse despertado também pela mudança de costumes, pois somente a partir dos anos 20 os cariocas descobriram o nadar no mar, graças a imigrantes alemães que foram os primeiros a fazê-lo. Eles contribuíram também para que outros costumes fossem adotados definitivamente: refugiar-se na Serra durante o auge do verão e seu calor excessivo, a religião do chopp no final do expediente. E além disso fundaram o Flamengo, o clube. A proximidade da orla, tão indesejável até então, como já foi visto em capítulo anterior, começa aos poucos a desaparecer, apesar de que a vida rotineira do carioca até hoje se dê no interior desses bairros e morar de frente para o mar só passou a ter interesse e altíssimo valor imobiliário muito tempo depois: a Avenida Vieira Souto tem seu grande boom de especulação imobiliária para apartamentos de alto luxo durante a ditadura militar, particularmente na década de 70 .

Doutra parte, o afluxo sempre crescente dos antigos brasileiros e de brasileiros novos, de variada procedência do ultramar, bem como os hábitos salutares da vida ao ar livre, determinaram a expansão da cidade no sentido das praias da zona sul, então meio despovoadas, provocando assim, de forma desordenada, o surto 
acelerado das incorporações imobiliárias que se tornaria, dentro em pouco, febril, devido à desenfreada especulação ${ }^{6}$, afirma Lucio.

Junto com os túneis, a construção do Hotel Copacabana Palace é a representação inequívoca desse deslocamento das atenções e intenções. E é justamente iniciativa de mais um Guinle ${ }^{7}$, o empresário Octávio Guinle que, junto com Francisco Castro Silva, constrói o hotel, o único edifício alto de Copacabana, cercado apenas por casas, entre 1919 e 1923. O objetivo era inaugurar o hotel em 1922, para hospedar o grande número de visitantes esperados para a grande Exposição do Centenário da Independência do Brasil, um evento de dimensões internacionais a ser realizado na esplanada do Castelo, mas só se conseguiu terminar as obras um ano depois, por vicissitudes que incluiram até a maior ressaca que o Rio já conheceu.

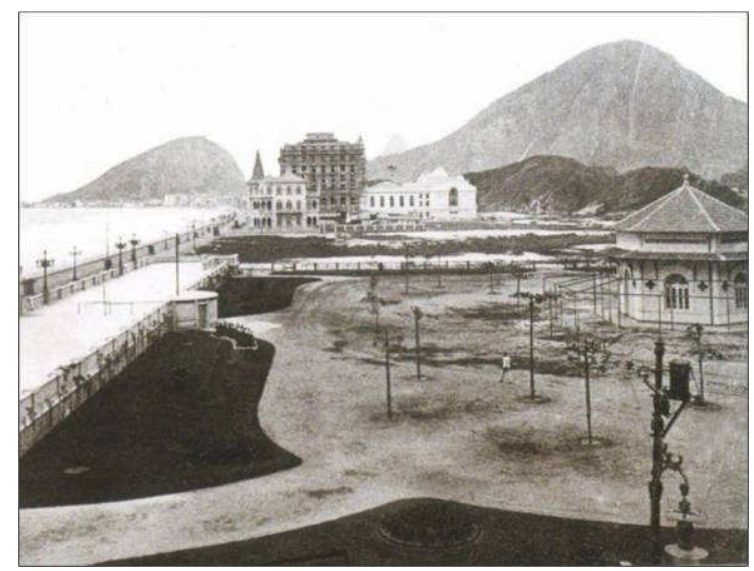

Figura 18. Praça do Lido, com o Copacabana Palace ainda em construção, em 1922. Vê-se Copacabana ainda vazia, e muitos lotes disponíveis.

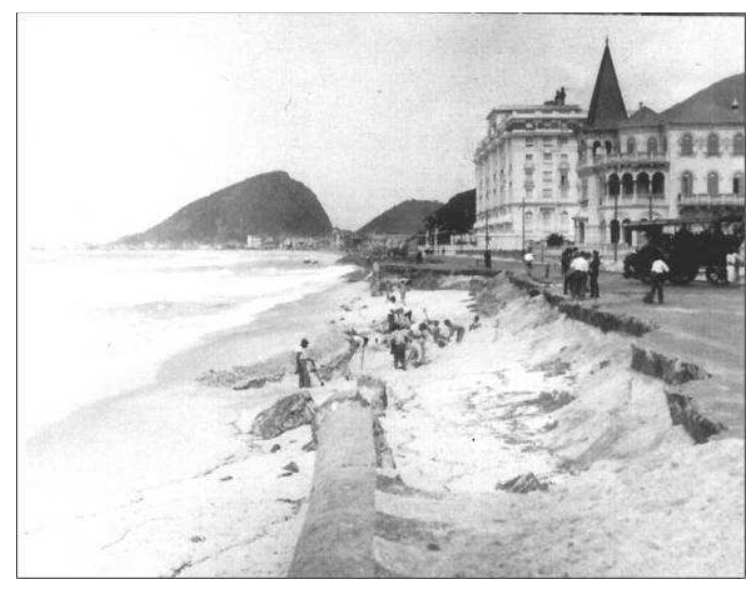

Figura 19. Av. Atlântica e Copacabana Palace inacabado - após a ressaca de 1922, um dos motivos dos atrasos nas obras.

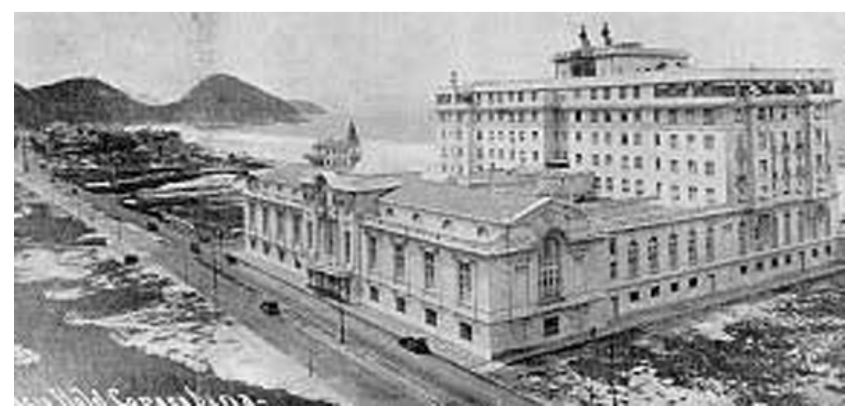

Figura 20. Copacabana Palace, já inaugurado. C.1925.

\footnotetext{
${ }^{6}$ COSTA, L. Registro de uma vivência. São Paulo: Empresa das Artes, p. 161, 1995.

${ }^{7}$ Sobre esse assunto ver: CATTAN, Roberto Correia de Mello A Família Guinle e a Arquitetura do Rio de Janeiro: Um capítulo do ecletismo carioca nas duas primeiras décadas do novecentos. Dissertação de mestrado. Rio de Janeiro: Pontifícia Universidade Católica do Rio de Janeiro, Departamento de História, 2003.
} 
Com maior possibilidade de acesso, grandes áreas passaram a ficar disponíveis para a construção de casas, competindo diretamente com a oferta de habitações em apartamentos no interior de edifícios altos, e nesse caso o comportamento não mudou: o costume das famílias ricas de morar em casas isoladas, herdado desde muitas gerações, criava grande reticência contra a opção de se morar em apartamentos. A combinação desses fatores acabou determinando a interrupção da execução dos outros três edifícios projetados por Lucio para o Parque Guinle.

Data de então, além da construção de casa minúsculas em lotes exíguos, os pseudo-bangalôs, a brusca aparição das casas de apartamentos - o antigo espantalho da habitação coletiva - solução já então corrente alhures, mas retardada aqui em virtude precisamente daquelas facilidades decorrentes da sobrevivência tardia da escravidão. ${ }^{8}$

\section{Edifício Nova Cintra}

O nome provém do Morro Nova Cintra, que está em frente um pouco mais adiante - à direita, olhando a partir da fachada do edifício -, na Rua das Laranjeiras. E o enorme morro em que o Parque está no sopé se chama Morro da Nova Cintra. Depois desse portuguesismo, os dois edifícios que foram construídos adotam anglicismos no nome: Caledônia e Bristol. Não se sabe quem batizou os edifícios e será quase impossível sabê-lo, mas não deixa de ser curioso - e brasileiríssimo - que tudo ocorra num ambiente que se iniciou afrancesado: ecletismo, ou melhor, ecumenismo de raça, cor, credo e país de origem ou inspiração: o arquiteto brasileiro Armando Carlos projeta o Palacete afrancesado e o francês Cochet projeta o jardim tropical.

O edifício Nova Cintra possui quatro eixos longitudinais, paralelos à Rua Gago Coutinho. Desta para dentro do Parque, temos um vão de, sempre aproximadamente, 4,5 m., seguidos de dois vãos de 3,5 metros, e balanços em ambas as direções de 1,25 m. Esses afastamentos de 1,25 colocam os pilares distantes das fachadas, liberando-as, no sentido corbusiano, e embora nesse caso não haja loggias - prenunciadas nas varandas dos fundos, presentes nos Bristol e Caledônia -, para os ambientes voltados para a Gago Coutinho, essa medida permite a continuidade de usos entre pilares e plano de fachadas.

No sentido transversal todos os eixos estão a $4 \mathrm{~m}$, também aproximadamente, constituindo a comodulação desse prédio. Lucio usa com extremo requinte essa comodulação: nos andares altos ele consegue sumir com a grande maioria de pilares, encaixando os diversos ambientes exatamente como sub-módulos dela, de tal maneira que só os pilares importantes fiquem solitários, independentes da vedação. Os

\footnotetext{
${ }^{8}$ COSTA, L. Registro de uma vivência. São Paulo: Empresa das Artes, p. 160, 1995. 208
} 
demais participam das divisões das diversas funções, num sofisticado domínio do principio da independência estrutural.

Na ponta do edifício que dá para a entrada do Parque esse requinte chega a ser surpreendente: a espessura da empena vista da fachada é artificial.

Internamente é ocupada por armários e os dois pilares centrais somem em meio a um ajuste do banheiro principal, o que não ocorre na ponta oposta. E há, ainda, uma quebra nessa lógica: no térreo, nesta mesma ponta ocorre a transição de quatro para três eixos, com os três pilares cilíndricos independentes do fechamento envidraçado e também soltos do plano vertical da empena, o que o aproxima da visualidade que haveria de ter os seguintes, Bristol e Caledônia. Nesta ponta encontra-se exatamente o imóvel comercial onde ocorre a declinação para dentro de seu caixilho de fechamento, no pilotis, que retomaremos a seguir.

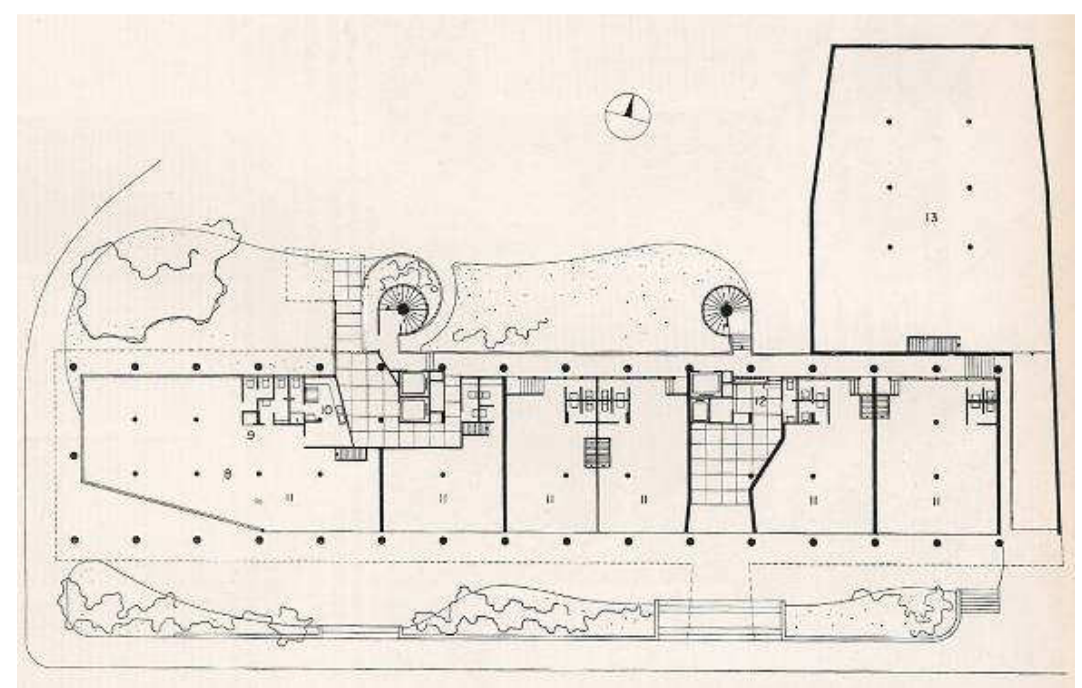

Figura 21. Térreo do Nova Cintra
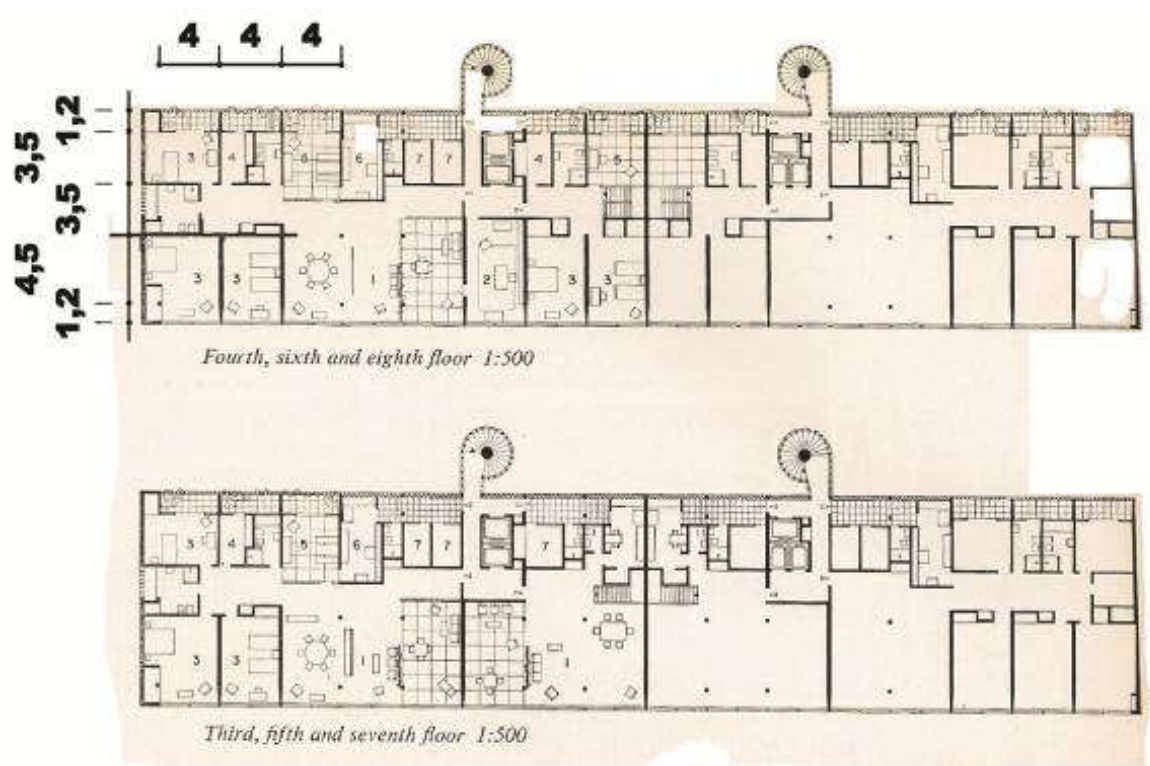

Figura 22. Acima $4^{\circ}$, $6^{\circ}$ e $8^{\circ}$ andares; abaixo $3^{\circ}, 5^{\circ}$ e $7^{\circ}$ andares. 
De qualquer modo, é certo que esse edifício de fecho do remanso tem particularidades que os outros dois construídos não precisaram ter: ele está paralelo à Rua Gago Coutinho, pré-existente e já consolidada como uso urbano, com transeuntes, trânsito de veículos - guardada a devida proporção da época -, seu comércio, seus moradores, etc. etc. Então o único dos três que tem o pilotis ocupado, com funções específicas e comercializáveis é este, o Nova Cintra.

Entretanto, parte da atenção de Lucio está destinada exatamente para esse pormenor: é a única implantação quase paralela às curvas de nível, ao quase plano - o declive é suave - da Rua Gago Coutinho e portanto o prisma está assentado paralelo a esse nível. Como dissemos é o único dos três, voltado para a área urbana préexistente, para a cidade. E Lucio resolve essa implantação adotando a cota de nível interna do prisma, sobrelevando o terreno até o limite do lote, de frente para a Gago Coutinho. Esse simples desnível, assim como a faixa ajardinada junto ao pequeno arrimo na testeira do lote, demarcava a área particular do condomínio em relação ao logradouro público. Hoje, e inevitavelmente, essa simpática relação desapareceu pela presença de uma grade que delimita agressivamente as duas situações. E o ditado zen diz: não lastimes o inevitável. (...)

Essa atenção de Lucio para com a cidade também é demonstrada pela marquise, que, ao contrário do trivial e usual, demarca a entrada das residências, quando as conhecidas marquises urbanas tinham surgido para proteger ou sombrear as lojas, os pontos comerciais: casas não tinham marquises. Talvez alguma remota lembrança da cobertura, toldo ou marquise de hotéis internacionais - apareceram muito no cinema na época e viraram renitentes, como longas línguas que vão até a borda da guia: até a entrega do Oscar tem esse elemento e lembram esse recurso, de uma língua lançada a diante, indo buscar possíveis embarques e desembarques. O público alvo do empreendimento não desconhecia essa imagem e informação.

Essa marquise se repete na fachada oposta, mas apenas no trecho em que, originalmente, era acessível por veículos, o que reforça essa idéia de marquiserecepção de embarques e desembarques. 


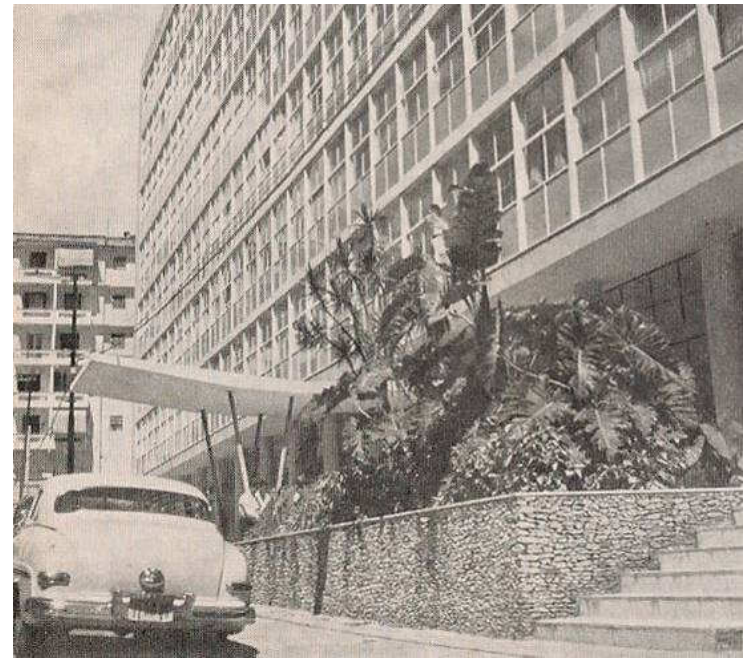

Figura 23. Edifício Nova Cintra, ainda sem a grade que existe hoje. Só o desnível demarcava o fora e o dentro. A marquise comercial é o recuo do caixilho das lojas e a residencial é o longo convite.

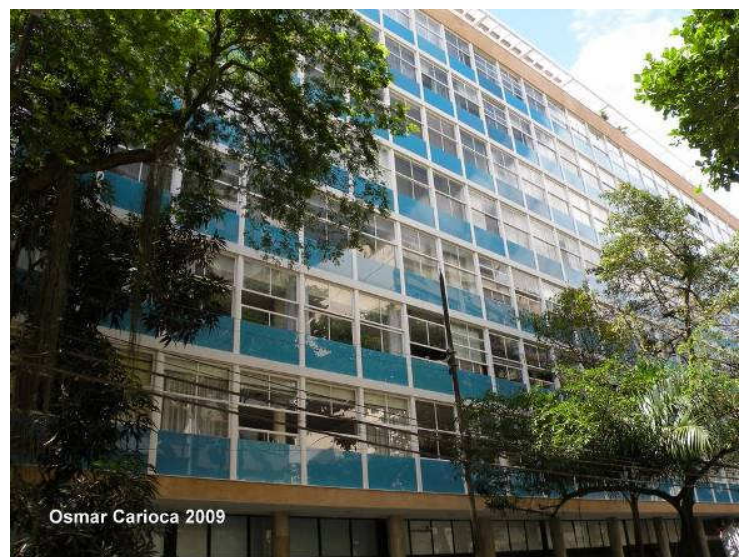

Figura 24. Idem, mas note-se a ausência do montante intermediário - que faz falta - no vidro azul do peitoril: com os vidros mais resistentes e coloridos na própria massa, só disponíveis anos mais tarde.

A derivação para dentro do caixilho de fechamento do térreo, exatamente no imóvel da ponta de entrada do Parque também é muito significativo: acentua o pilotis na medida em que demonstra que ele está liberado - a planta é livre, o caixilho é que mudou, mas são os pilares que se mostram cada vez mais sozinhos - o que aumenta o indício de varanda, o balanço vinha se anunciando como a marquise comercial - aquela usual - e nesse trecho vai aumentando, até que aponta, indica e induz ao percurso para dentro do Parque. Ao mesmo tempo em que libera ainda mais os pilares cilíndricos da fachada, guardam para si exatamente a passagem de três para quatro eixos de pilares, que ocorre só no Edifício Nova Cintra.

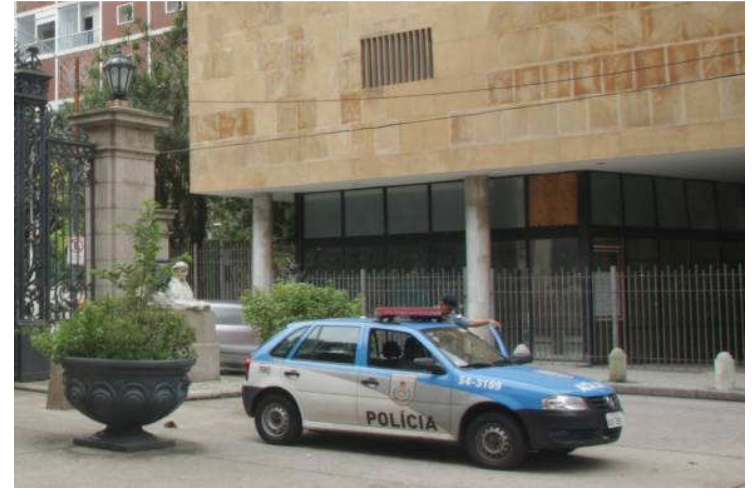

Figura 25. Pilotis Edifício Nova Cintra, trecho que prenuncia o remanso urbano.

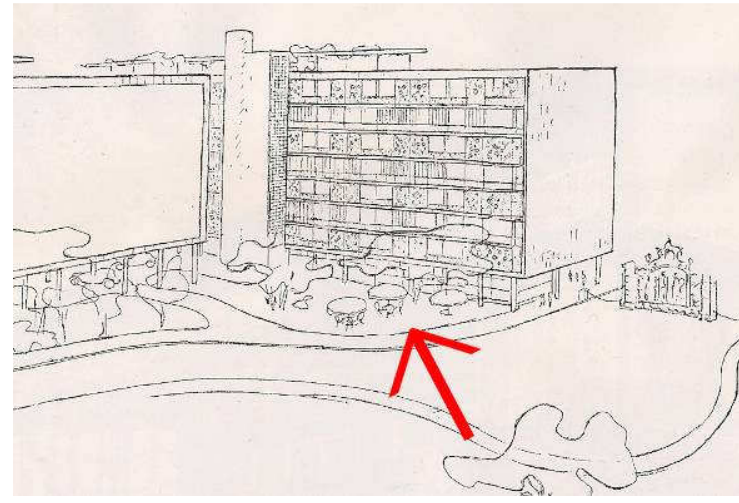

Figura 26. Mesinhas com guarda-sóis já previstos nos desenhos de Lucio Costa para esse trecho. 
Ao que parece, seu projeto tinha tudo preparado para que esse imóvel da ponta fosse um bar-café, bem ao jeito moderno que o Rio de Janeiro vinha conhecendo e adotando como costume, mas que ele desde a infância já tinha visto e muito pela Europa: cafés com mesinhas nas calçadas. Nos desenhos disponíveis desse térreo, todos os imóveis com fins comerciais tinham dois lavabos, modernidade de se poder contar com trabalhadores de ambos os sexos; entrentanto no imóvel da ponta, além de um banheiro de serviço, aparecem dois outros, seguramente de uso público, dada a disposição de suas peças de utilização - num desenho de racionalidade impecável. Além disso, é o único que possui uma área interna na qual seria possível instalar uma cozinha ou lugar de preparo como numa lanchonete.

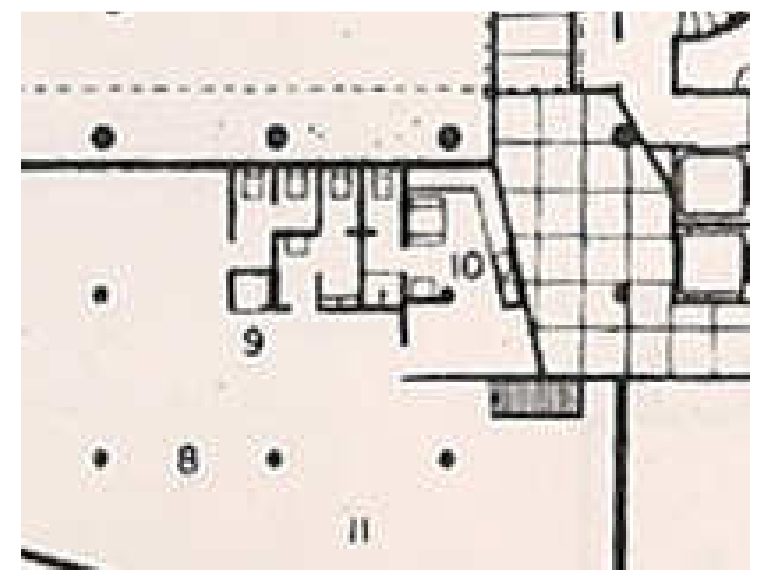

Figura 27. Detalhe da única copa/cozinha prevista no térreo do Nova Cintra; n. 10, no desenho original de Lucio.

Já constavam dos desenhos de Lucio, mesinhas com guarda-sóis na volta que a Rua Paulo César de Andrade faz ao desviar do não-portão e assumir-se como a antiga e tortuosa estrada vicinal. As mesinhas constam tanto da perspectiva vôo-depássaro, quanto da outra que mostra o canto formado entre o extremo do Edifício Caledônia e aproximadamente o meio do prisma do Bela Cintra. Acentua essa percepção o fato de que, nas plantas originais, não só o trecho da declinação do caixilho, afastandose da Gago Coutinho e apontando o portão, como todo o perímetro desse imóvel da ponta segue desenhado como caixilho, cuja transparência aumentaria a visualidade do Parque desde fora, e que permitiria $n$ aberturas conforme a conveniência desse bar-café.

Todas as unidades comerciais do térreo tinham essa relação frente$e$-fundo que consta da planta original, onde se percebe nitidamente que a área ocupável em nível é só no entorno daquele da ponta, onde Lucio espalhou mesinhas em seu desenho. O desnível aumenta na outra direção, obrigando a existência de escadas para vencê-lo.

A hipótese é a de que, possivelmente, proprietários dos imóveis residenciais, de cima, também tivessem imóveis comerciais no térreo, fato comum na nossa herança portuguesa, e que pode ser corroborada pelo fato de que os demais imóveis comerciais, além do desnível já citado, não serem tão franqueados assim, para o lado 
interno do Parque, com a empena do Caledônia, com o declive aumentando e a presença da garagem do próprio conjunto Nova Cintra fechando essa visão.

Bar-café na ponta, comércios com proprietários moradores - por hipótese - remetem à questão do estabelecimento do programa. Programas Arquitetônicos, assim, com maiúsculas, pois talvez esse seja um atributo importantíssimo das atividades dos arquitetos. Sobre isso voltaremos mais adiante, mas por ora, basta registrar a percepção de que no projeto do Nova Cintra se encontra esse rol de abordagens que todo projeto arquitetônico deve conter. Ou deveria. Infelizmente nem sempre ocorre. Pelo contrário, ora o comitente não o permite, ora os arquitetos se desobrigam.

Nos andares superiores do Nova Cintra, destinados a habitação, o projeto traz uma proposta até então inusitada: mescla, a partir de um mesmo principio estrutural, apartamentos em duplex e apartamentos em um mesmo nível. Pode-se considerar a construção do conjunto de edifícios do Parque Guinle (1943 a 1954) um acontecimento simultâneo à da Unité d' Habitation de Le Corbusier de Marselha (1948 a 1952), este com os apartamentos encaixados em forma de " $L$ " deitado, com pés-direitos duplos e mezaninos.
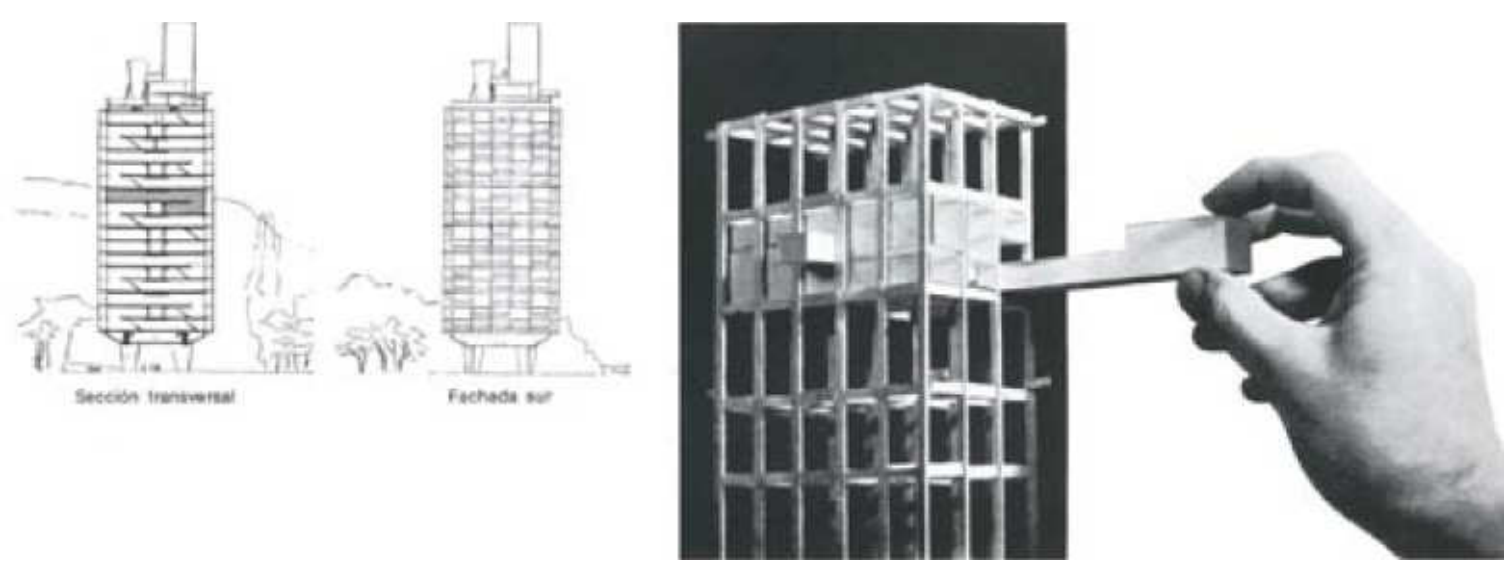

Figura 28. Unité d’ Habitation. Le Corbusier. Marselha. 1948 a 1952.

Corbusier já havia tentado árdua e insistentemente antes, desenhando vários complexos de habitação em diferentes situações, sem nunca conseguir construí-los, mas seguramente Lucio os conhecia:

Esse remanso urbano, construído por iniciativa de Cesar Guinle, foi a primeira experiência de um conjunto residencial de apartamentos destinados à alta burguesia, e também onde primeiro se aplicou, de forma sistemática, depois de tantas tentativas frustradas, o partido deixar o térreo vazado, os pilotis de Le Corbusier, que se tornariam de uso corrente na cidade ${ }^{9}$.

\footnotetext{
9 COSTA, L. Registro de uma vivência. São Paulo: Empresa das Artes, p. 205, 1995.
} 
Sobre o projeto específico das habitações e o estabelecimento de uma tipologia habitacional, ele conta:

(...) Mas houve ali outra particularidade que passou despercebida aos próprios usuários, ou seja, o propósito de fazer reviver, nas plantas de apartamento, uma característica da casa brasileira tradicional: as duas varandas, a social e a caseira - dois espaços, um à frente, para receber, outro aos fundos, ligado à sala de jantar, aos quartos e ao serviço.

(...) Foi a essência deste esquema tradicional que se pretendeu reviver nos apartamentos do Parque Guinle: uma espécie de jardim de inverno, contíguo à sala de estar e um cômodo sem destino específico, ligado aos quartos e ao serviço; um mais formal e outro mais à vontade, correspondendo assim à varanda caseira ${ }^{10}$.

Baseia-se ele em seu pleno conhecimento da história da habitação no Brasil, do qual faz um pequeno resumo:

(...) No século XVII o esquema se apura: a capela ocupa um dos compartimentos extremos, contíguos à varanda da frente, servindo o outro de camarinha para hospedagem dos forasteiros que assim não participavam da intimidade da casa. Os exemplos de taipa de pilão, que o Patrimônio (SPHAN) salvou em São Paulo, onde o clima é justamente mais frio, são preciosos testemunhos dessa fase.

No transcurso do século XVIII a varanda dos fundos passa a ser sala de jantar, envidraçadas ou não, conforme a região $(. . .)^{11}$

Lucio está descrevendo as varandas re-entrantes típicas da arquitetura bandeirista, e não saliente, como o alpendrado, expressão que se utilizou para descrever o tipo de construção das habitações dos índios nas Missões, e que utilizou no seu projeto para o Museu. E se contrapõe também à varanda saliente do tipo balcão, já usual para a constituição de varandas em edifícios em altura, que lembram gavetas abertas de um arquivo.

Invertendo as expressões, o seu colega de SPHAN em São Paulo, Luís Saia assim descreve:

(...) A planta se desenvolve segundo um esquema bem preciso: uma faixa social, fronteira, contém a capela e o quarto de hóspedes e, no meio, o alpendre; atrás dessa faixa e em correspondência com as divisões dela, em torno da sala central os quartos se dispõe lateralmente. Às vezes, no fundo, comparece um agenciamento de serviço, dando acesso ao pavimento superior. Nos exemplares mais tardios, este compartimento se transforma em alpendre. $(. . .)^{12}$

10 COSTA, L. Registro de uma vivência. São Paulo: Empresa das Artes, p. 212, 1995.

11 COSTA, L. Registro de uma vivência. São Paulo: Empresa das Artes, p. 212, 1995.

12 SAIA, L. Morada paulista. São Paulo: Perspectiva, p. 130 e 131, 1972.

214 
O uso das expressões realmente varia, no Brasil, de região para região, e a variação é tamanha que acabaram por virar sinônimos. Mas segundo os verbetes do dicionário Aurélio, em primeiro lugar alpendre significa: 1. Cobertura saliente, de uma água, de ordinário à entrada de um prédio, apoiada, de um lado, na parede deste, e de outro, em esteios, pilares ou colunas; (...) 3. Bras. V. varanda e varanda significa: 1. Balcão, sacada. 2. Terraço e 9. Bras., Amaz., MA e S Sala de Jantar. Só para facilitar, os resumos do dicionário, item 9 desse verbete são: Bras de português do Brasil, não consta em Portugal; Amaz., comumente usado na região Amazônica, Maranhão, e S de região Sul do Brasil, ou seja, há um longo hiato regional, mas a ocorrência é generalizada.

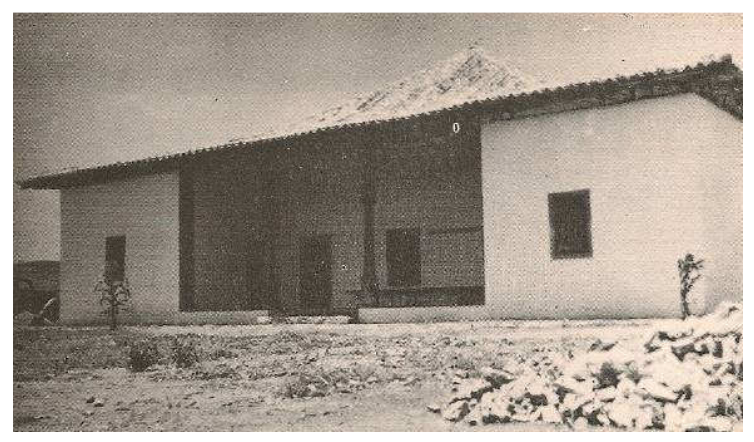

Figura 29. Varanda - ou alpendre - re-entrante em relação ao volume do conjunto, no Sítio do Padre Inácio, obra prima bandeirista.

Agora, visitando apartamentos a que, gentilmente, moradores atuais nos permitiram acesso, o que se encontra é fruto de uma sequência de modificações e reformas, em tal encadeamento que nem sequer eles sabem mais o que foi a planta original e sua disposição, ou à sua disposição: planta livre. E há grande dificuldade de se contatar melhor fonte, vai ser necessário um trabalho de pesquisa mais longo para se descobrir o projeto executivo, a começar por, até mesmo, onde ele está.

Fruto e desfruto da idéia corbusiana, da planta livre e da estrutura independente da vedação, os sucessivos moradores reformaram a vontade, com grande liberdade e direito para fazê-lo. Mas não se conformam com as colunas soltas, e nas reformas, na maior parte delas, mal feitas enquanto projetos de interior, de design, transparece o pressuposto de se tentar sumir com elas. 


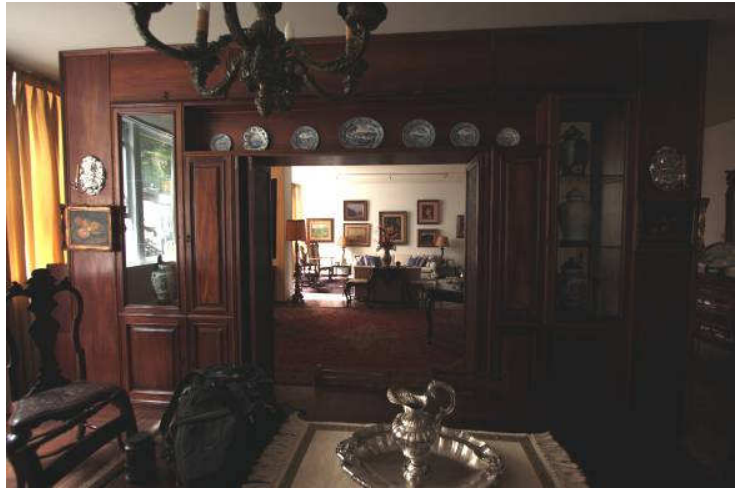

Figura 30. Interior de um dos apartamentos visitados. O propósito de se sumir com os pilares soltos ainda persiste.

Mas o poder que emana dessa concepção, a força advinda dessas fachadas, o privilégio das vistas a partir de algo indefinido... janelas no combogó, varandas - ou alpendres - re-entrantes, às quais, tanto quanto aos demais ambientes voltados para as fachadas do poente, se acrescenta a distância utilizável entre pilar e fechamento da loggia, impediram que mais malfeitorias ${ }^{13}$ pudessem ser feitas com o conjunto, ainda assim tão poderoso.

A sala de estar, sempre generosa, e sua justaposição à varanda social, na maior parte dos casos já definitivamente anexada, somada ao inteligente agenciamento da entrada principal, que resguarda a visão direta do hall para dentro, as dimensões dos vestíbulos dos quartos, que são tais que não configuram um mero corredor, e sim um espaço de articulação, tudo isso ainda está lá.

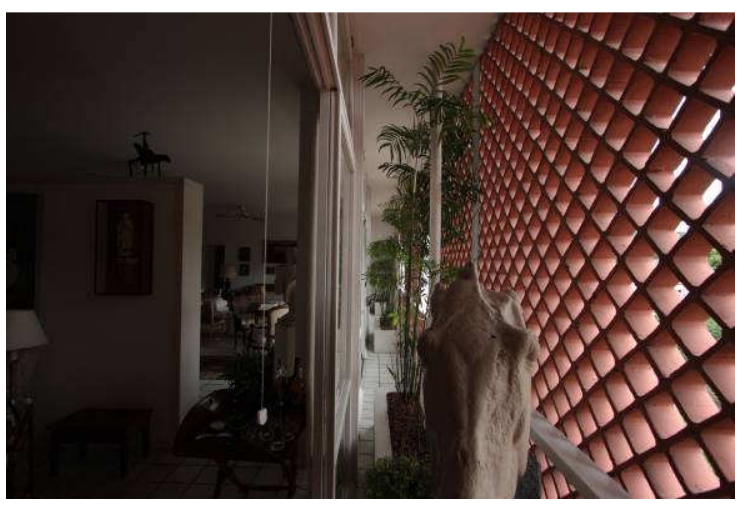

Figura 31. A loggia contínua: cerca de 1,2 m. entre pilar e face externa do prédio.

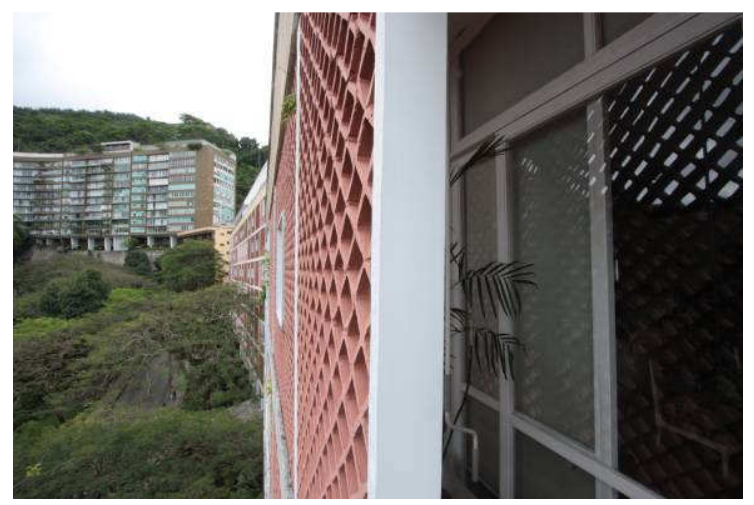

Figura 32. Vista da janela de caixilho ausente no combogó da loggia.

\footnotetext{
${ }^{13}$ Relato de Maria Elisa sobre a postura de Jorge Hue, que, morador do Parque disse que muitas malfeitorias têm acontecido, empreendidas pelos moradores por falta de compreensão...
} 


\section{EDIFÍCIOS BRISTOL E CALEDÔNIA}

Assim como o Parque Guinle e a Unité d'Habitation podem ser considerados acontecimentos simultâneos, o Edifício Louveira, de Vilanova Artigas, de 1946, pode ser considerado sincrônico com o projeto do Parque.

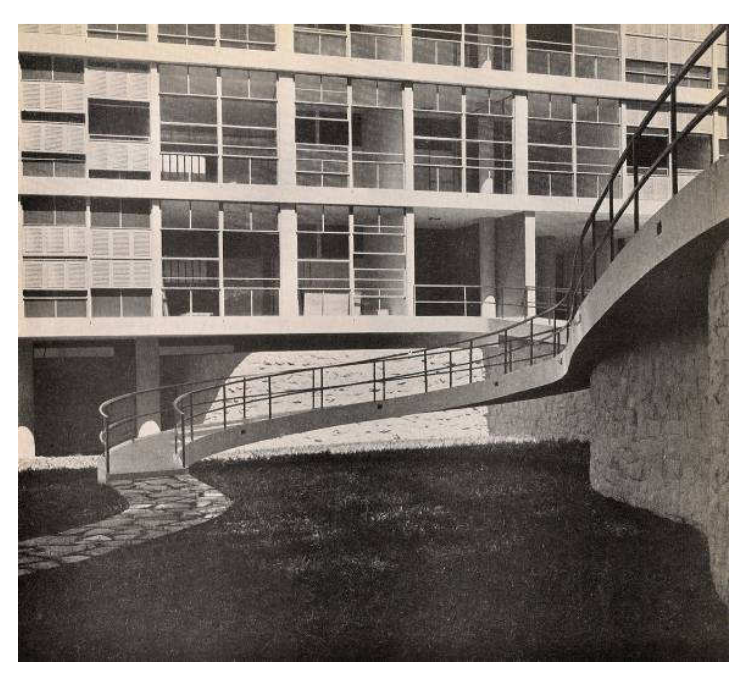

Figura 33. Edifício Louveira. Vilanova Artigas. São Paulo. 1946.

Luís Saia era colega de SPHAN de Lucio e muito próximo inclusive por ideologia - de Artigas. Assim o Edifício Louveira também tem as varandas re-entrantes da, já citada, Morada Paulista. Também estabelece a relação da varanda social para um lado e varanda de serviços para o outro. Como no Parque, no Louveira a comodulação estabelecida é de três eixos longitudinais - vimos a exceção do Nova Cintra, quatro eixos que mudam na ponta -, nesse caso espaçados a 4,5 metros que posicionam os pilares, e, no sentido transversal a cada 3,5 metros. Têm proporções volumétricas parecidas. Enfim, as sincronias são muitas.

No Bristol e no Caledônia, a comodulação é de aproximadamente 4 metros nos eixos transversais por seis metros nos longitudinais, ambas as direções são acrescidas de balanços, dos mesmos 1,25 metros. Mas trazem um fato novo: do pilotis para baixo, já que ambos têm subsolo, os pilares do eixo central não são mais cilíndricos, são ovalados, são oblongos em planta, o que torna plausível a hipótese de que talvez o quinhão de carga dirigido para o centro tenha sido, propositalmente, sobrecarregado como o oblongo tem o eixo maior na direção das fachadas e o eixo menor na mesma espessura dos cilíndricos, não se nota a diferença, olhando de fora; do pilotis para cima, eles retomam a condição de cilíndricos, e, ao contrário do Nova Cintra, aparecem, passam a constar como os importantes, não dissolvidos na malha de vedações das diversas funções das residências.

Quantas variações, quantos jeitos possíveis, quantas surpresas de caso a caso vai se descobrindo, mesmo com os apartamentos já reformados. Acontece o 
mesmo no Louveira: também com a grande maioria das moradias já reformadas, a força que vem do conjunto estabelecido não se perdeu, e continua lá como uma demonstração de que, com essa qualidade, por mais que sejam deturpadas as proposições originais, sobrevive a leitura daquela possibilidade ainda válida - expressão utilizada em inúmeras situações, tanto por Lina quanto por Lucio, a que retornaremos mais adiante, inclusive sobre trejeitos e rabiscos.

O Louveira, na verdade, é um conjunto de dois edifícios paralelos em suas longitudinais, interligados por uma passarela comum, que a partir de uma rampa mais ou menos central ou pela escada - que ostenta um pilar que cai exatamente no seu meio - do edifício mais à esquina com a Rua Piauí, que ascende primeiro a um alpendre sob pilotis e então daí se alcança a passarela. As implantações do Parque e do Louveira são absolutamente diferentes, por motivos óbvios, mas perfeitas nos dois casos. O Louveira aumenta a existência do pequeno e acanhado remanso urbano dado pela Praça Vilaboim, por seu respiro entre os edifícios paralelos, ampliando e arejando a própria Praça: o Conjunto é que ajuda a Praça. Mas é uma pequena praça urbana, sufocada por edifícios altíssimos nas demais direções; mesmo quando não era assim e os edifícios do entorno não existiam ainda, a escala é muito diferente do Parque - e da absoluta e lindamente brutal presença do Morro da Nova Cintra -, tal que Lucio propôs que os edifícios se ajustassem a ele.

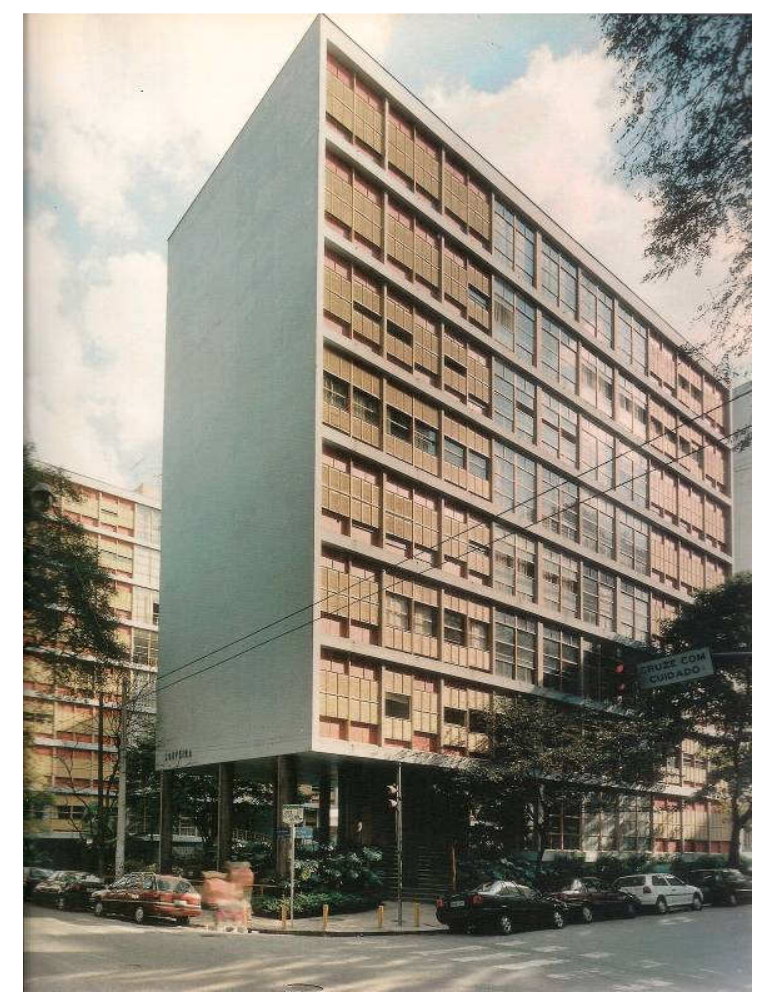

Figura 34. Edifício Louveira. Vilanova Artigas. São Paulo. 1946.

No Louveira, com a Praça pouco importante, tratou-se de orientar as duas fachadas com os ambientes de permanência prolongada - salas e quartos - para 218 
Nordeste, paralelos à Rua Piauí, de modo que, não só os blocos são paralelos entre si, mas colocados exatamente na mesma posição, sem espelhar. Já a determinante vista para o Parque obrigou Lucio a adaptar estes ambientes para o poente - lado do Parque - a despeito da insolação e do calor inclementes do Rio de Janeiro, o que lhe forneceu o ensejo de projetar a famosa e magnífica fachada.

Há um primor no uso do declive natural do terreno no Louveira, com destaque para o fato de que, ao mesmo tempo em que a já citada rampa sobe, com inclinação contrária ao declive original do terreno, este é tratado de modo a acomodar as garagens, com a altura necessária garantida pela sobre-elevação dos térreos; como a demonstrar o sistema estrutural - e denunciar outros mais - o vazio isola a residência do zelador, acessada por uma ponte dependente de apenas uma das linhas longitudinais de pilares e a face dessa ponte voltada para dentro do conjunto é fechada por um combogó de elementos vazados cerâmicos similares ao do Parque. O vazio deixa dois pilares soltos ao longo de dois pés-direitos e na diagonal oposta, na esquina da Rua Piauí com a Praça, os três primeiros pilares ficam soltos - na rua - por pé-direito e meio, equilibrando a percepção do pilotis em qualquer direção que se olhe, independente da relação frente-efundo - com o duplo sentido, sempre presente em seus projetos.

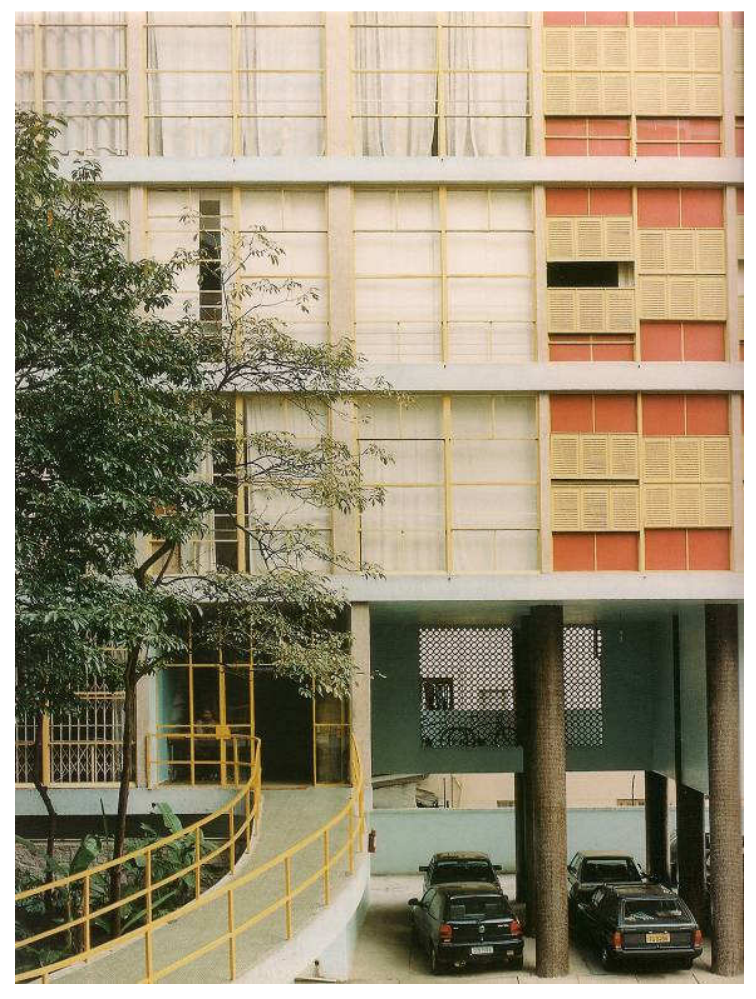

Figura 35. Edifício Louveira: ponte que leva à casa do zelador, com o combogó voltado para o pédireito duplo, e os pilares soltos, a plena altura. Vilanova Artigas. São Paulo. 1946.

Há um primor no uso do declive natural do terreno no Parque Guinle. Do cuidadoso tratamento programático e encaixe do projeto no declive no Nova Cintra já falamos, mas esse precisava do térreo-pilotis ocupável e comercializável. 
Nos térreos do Caledônia e do Bristol, estabelecem-se profícuos diálogos entre perfil do terreno e pilotis, ora entremeados por platôs artificiais curvilíneos, sustentados por arrimos de pedra, ora térreos artificiais criados por lajes intermediárias de perfis sinuosos. E também se resolve nesse entremeio o já então absolutamente necessário acesso de automóveis.

No Bristol, na ponta em direção ao Nova Cintra, a laje sinuosa que toma cerca de metade do pilotis constitui um mezanino que rememora o Pavilhão do Brasil na Feira Mundial de Nova York, em 1939, que, também com perfil sinuoso, ora trespassa pilares, ora escapa deles e busca apoio em um arrimo de pedras, ora só os tangencia, como um jogo, gingado de capoeira. Poderíamos dizer o mesmo da Casa do Baile, no jogo estabelecido entre para onde vai a marquise, para onde vai a mureta de proteção, para onde vai a borda do lago, para onde vai o espelho d'água. Jogo de capoeira angola, mas também a Dança de Matisse (1910); a ginga brasileira ou o tango, a liberdade da arte moderna, ou bossa ou jazz. (?)

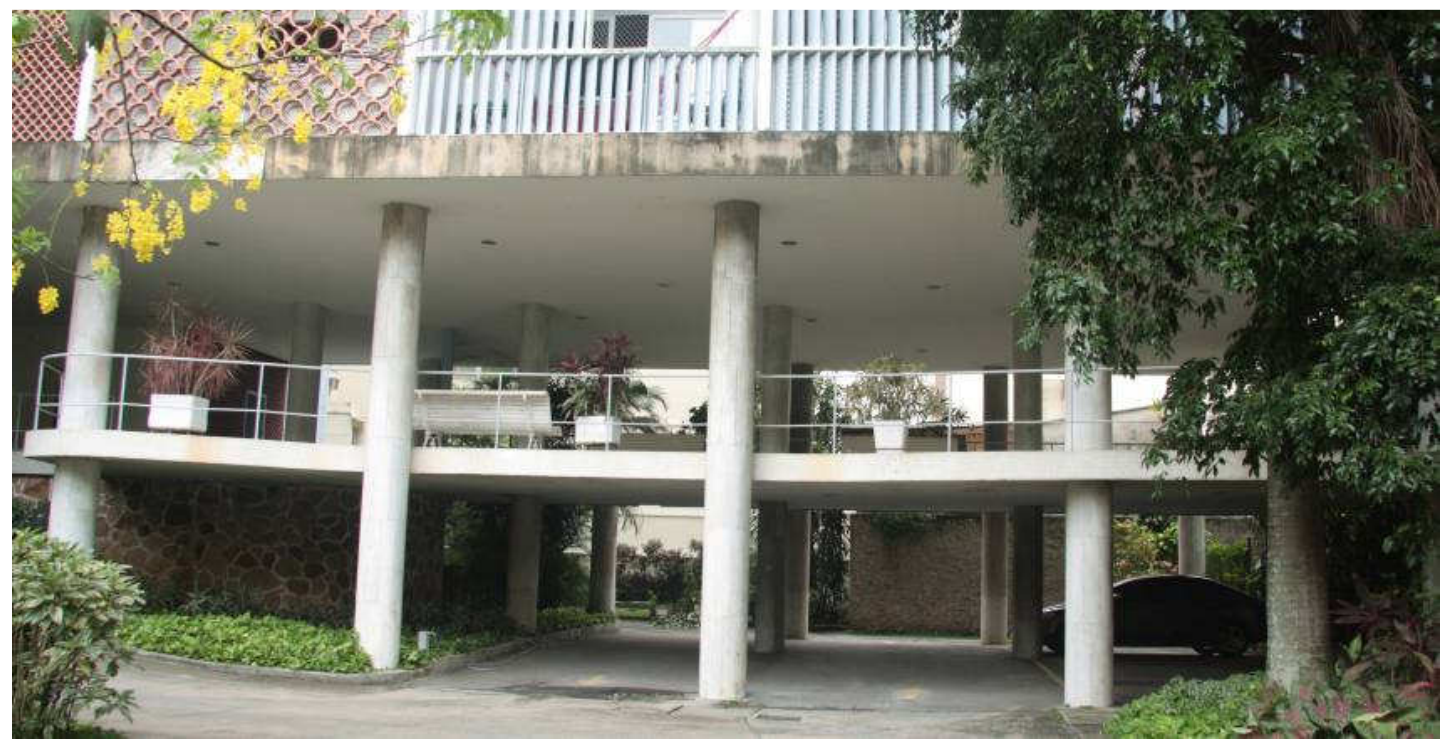

Figura 36. O mezanino do pilotis do Bristol, ora foge, ora tangencia, ora envolve os pilares.

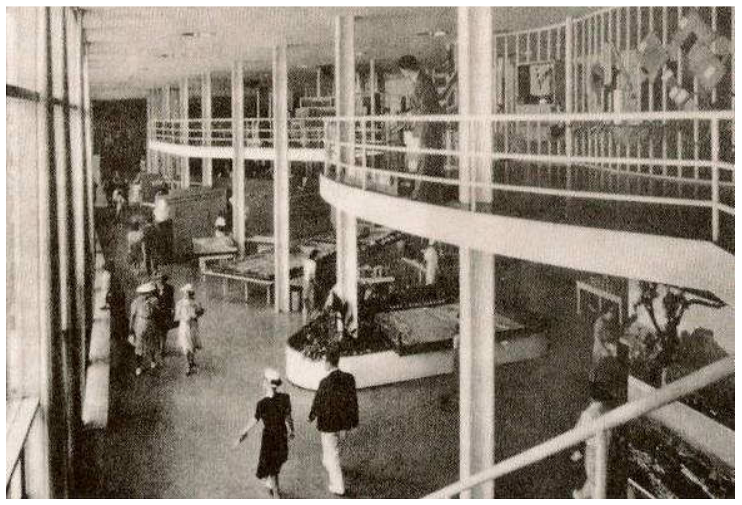

Figura 37. Pavilhão do Brasil, na Feira Internacional de Nova York, de 1939: vista do salão de exposições e do mezanino sinuoso.

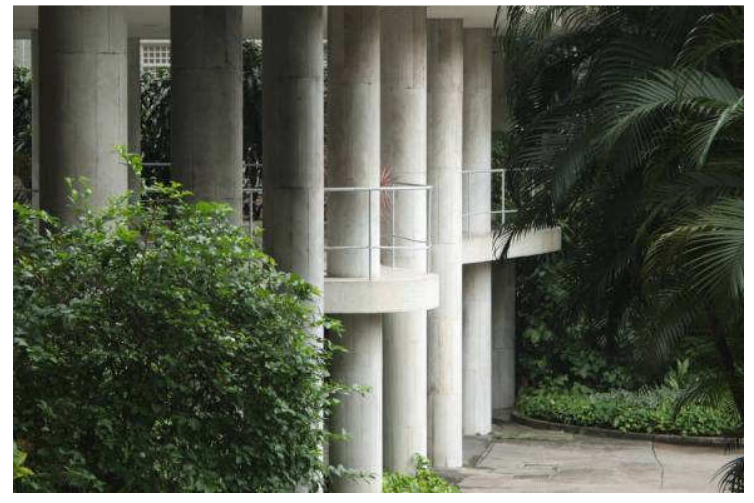

Figura 38. Mezanino sinuoso do Bristol. 
Sob esse mezanino, qual ponte, encontra-se a entrada de veículos para as garagens, situadas na fachada leste, a posterior em relação ao Parque. Sobre ele é possível sentir perfeitamente a sensação de se estar em uma sala de estar, fechada apenas por um levíssimo guarda corpo-metálico.

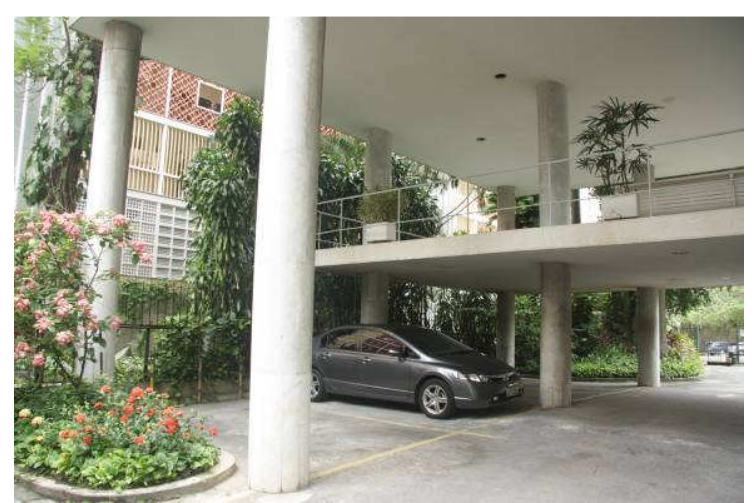

Figura 39. Mezanino, como uma ponte sobre o acesso às garagens.

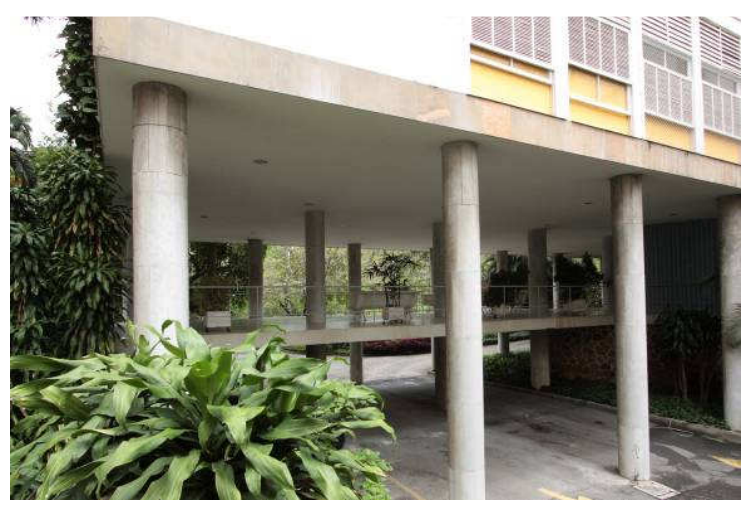

Figura 40. Mezanino, o acesso às garagens e, ao fundo da imagem, o Parque.

Ajuda a configurar essa sensação a presença de um biombo - feito dos mesmos elementos, lâminas, de que é feito o brise-soleil utilizado nas fachadas que se voltam ao poente. Esse biombo delimita a área de uma espécie de ante-sala, da qual, por uma porta colocada num combogó - com o mesmo elemento vazado usado naquelas fachadas - adentra-se à área de serviços e escadas. É o único, trecho fechado desse pilotis, mas fechado por uma vedação anulada pelos azulejos, desenhados por Lucio, com um padrão, dentro de um plano combinatório, como em situações já vistas em capítulo anterior. 


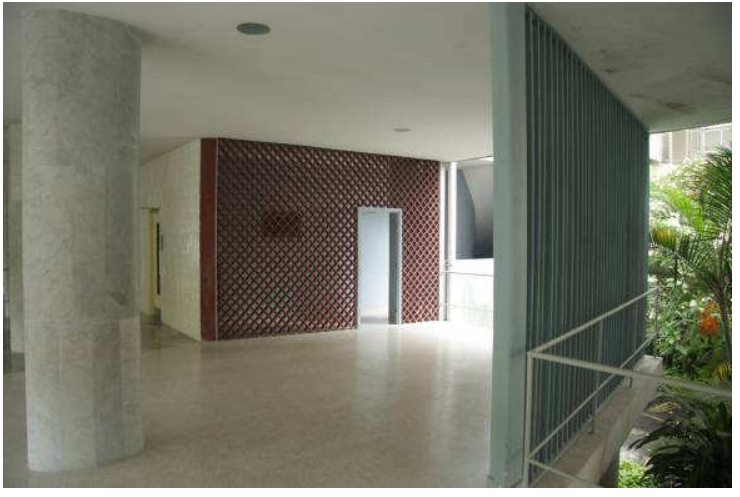

Figura 41. Conformação dos espaços e funções no mezanino do pilotis do Bristol: ante-sala da sala de estar aberta para os jardins.

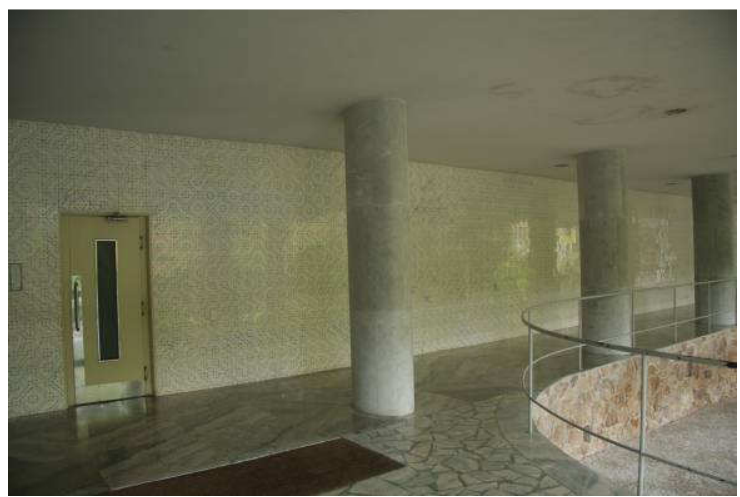

Figura 43. O longo prisma fechado do Bristol: Lucio anula a vedação com os azulejos, ressaltando os pilares.

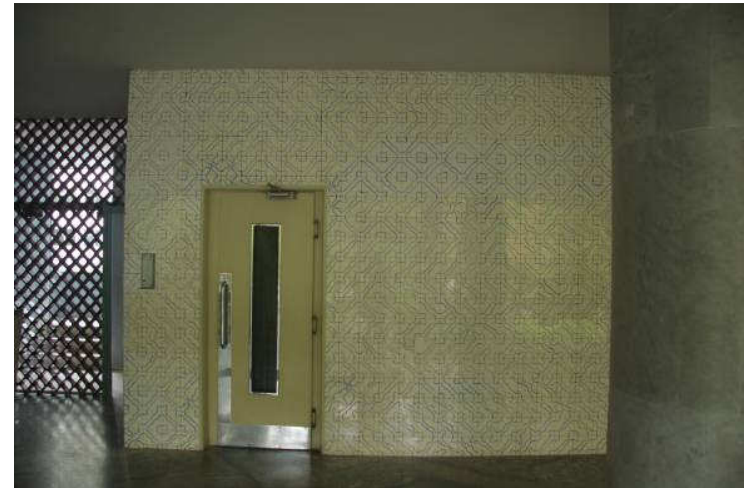

Figura 42. Chegada do elevador no térreomezanino. Vedação revestida em azulejos.

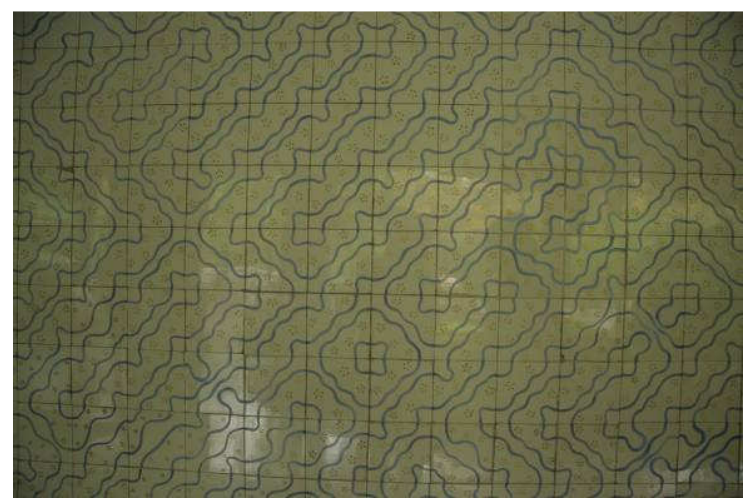

Figura 44. Padrão de assentamento dos azulejos, produzidos a partir de desenho original - inclusive as cores - por Lucio.

De fora, a visão da laje que conforma o mezanino parece uma lâmina que corta o pé-direito duplo desse trecho, a meia altura dos pilares, dos quais alguns passam livres em toda a altura dupla e outros são amarrados pela laje

Ajuda a aumentar essa sensação o teto ser em laje de caixão perdido - Maison Dom-ino, de Le Corbusier, como demonstra o professor Comas -, e que isso permite, assim como no conjunto Louveira, obter uma superfície lisa, branca e neutra, neutralidade acentuada pelas luminárias embutidas e não em plafons salientes como verrugas, sensação que se repetirá de maneira idêntica no Caledônia, onde os níveis artificiais de piso atingem o ponto de pé-direito mais baixo, muito próximo do teto. 


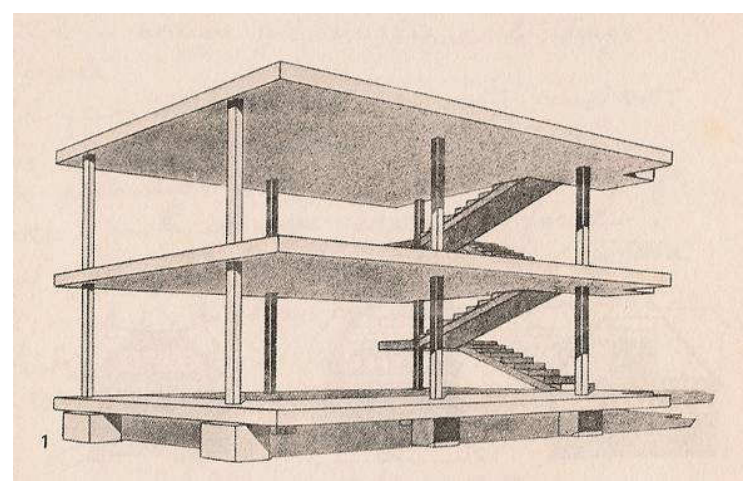

Figura 45. Maison Dom-ino: a relação de pilares com lajes é do tipo cogumelo, sem vigas, o que configura os tetos planos e sem saliências; as lajes cogumelo podem ser maciças ou em caixão perdido. Proposta genérica e abrangente de Le Corbusier, 1914. Vêem-se os balanços em todas as direções, o que deixa a visão das horizontais dominantes em relação às linhas verticais sensação acentuada por Le Corbusier, no desenho, pela marcação das sobras nos pilares.

A cerca de pouco mais de dois terços do prisma, na direção oposta ao até agora descrito, o nível desse mezanino se transforma no próprio térreo, coincidindo com o nível alcançado pela rua, em seu aclive, e onde se encontra o portão - que antes não existia - de pedestres, que transitam assim em um percurso plano. Mas antes, ambígua e desconcertante, a meio nível encontra-se a magnífica escada em leque, solta estruturalmente e solta como proposição: sem a grade - posterior - tanto fazia ao percurso na ascendente ou na descendente do terreno, os percursos eram fluídos, permeáveis, dinâmicos.

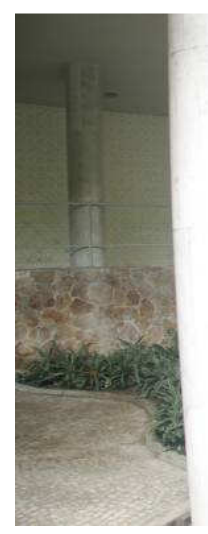

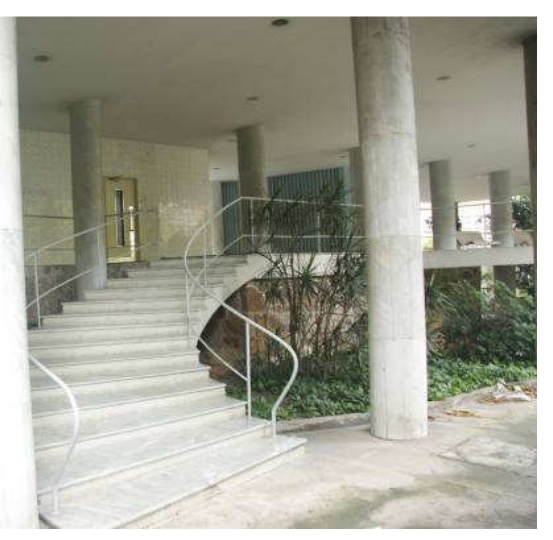

Figura 46. Escada em leque, implantada a meio nível em relação à declividade da rua e o mezanino - que passa a ser térreo no outro extremo; a escada começa no degrau convite, enquanto o guarda-corpo metálico faz a curvabengala, aumentando o convite. A escada foge da malha estrutural do conjunto.

No Caledônia não há o longo corpo que fecha o pilotis, os elevadores caem a seco no térreo-pilotis. Como o desnível do terreno se acentua nesse trecho, o acesso de veículos se dá logo de cara, no intervalo entre ele e o Bristol. Isto se deve ao fato de que o Bristol se encontra mais junto à divisa da propriedade, ao limite da antiga chácara, restando então pouco espaço para a manobra dos veículos para acessarem as garagens em uma espécie de subsolo criado, já que o nível do térreo é construído artificialmente. O Bristol tem uma ligeira derivação que lhe confere a folga de espaço necessária para a manobra de veículos, mas o Caledônia não tem essa possibilidade. 


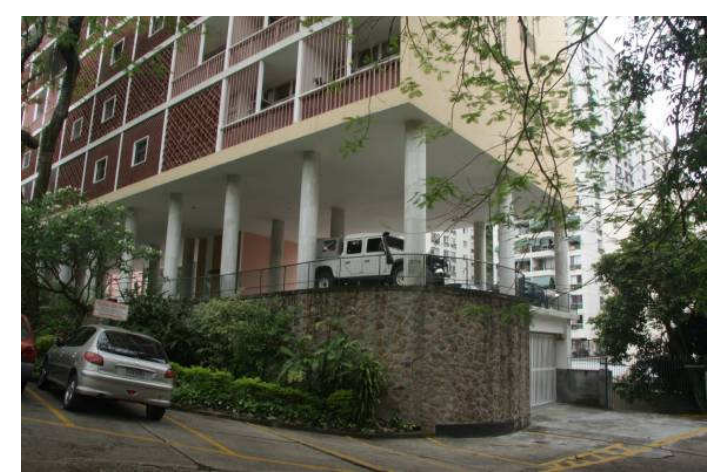

Figura 45. Entrada do estacionamento do Caledônia; é o edifício mais próximo do limite de vizinhança de todo o conjunto, com a manobra de veículos mais restrita. As garagens ocupam o subsolo e a cantaria é, em parte arrimo, em parte vedo do sub-solo.

Nesse trecho então, o pilotis é avantajado, com pé-direito e meio de altura e parece cair em uma base pesada, que é o arrimo de pedras. O arrimo, em parte funciona como arrimo mesmo, em parte constitui essa visualidade pesada, mas é o fecho de parte das garagens. Esse recurso foi utilizado pelos Robertos no edifício que fizeram a cavaleira do Parque, como veremos mais adiante.

Mas, de novo, é no ponto onde o térreo artificial cruza com a rua em aclive, e exatamente aí, se dá a entrada de pedestres. No Caledônia ainda não há cerca ou portão, é o único dos três executados que se mantém aberto, liberado em seu limite de propriedade e área pública, tal qual o projeto original e que os anteriores também eram. Se, para quem entra nesse nível, para a direita é um platô, para a esquerda surge um duplo caminho curvilíneo: por fora, em terreno plano porque arrimado, contornar o edifício até a parte posterior, de serviços, um nível abaixo, ou através de uma rampa subir meio nível e chegar a uma nova sala de estar, bem diferente do Bristol.

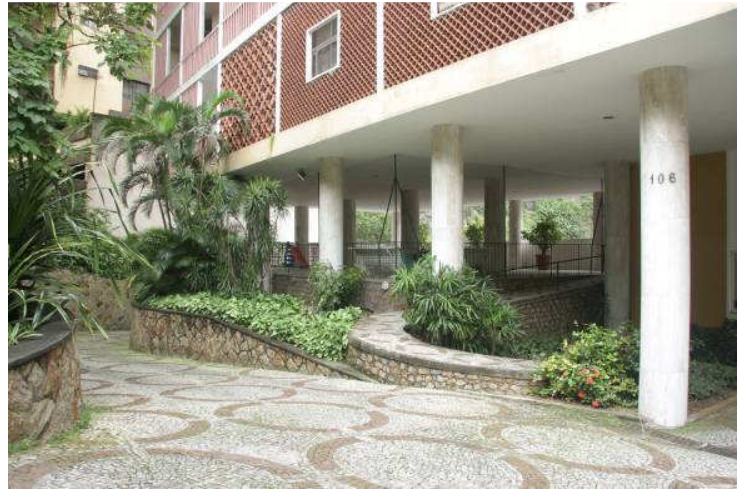

Figura 48. Quando o desnível da rua encontra o nível térreo do Caledônia as circulações se bifurcam. Neste caso, sem mezanino, a sala de estar se aconchega no arrimo - crescente nessa direção - e no pé direito mais baixo, Domin-O.

Essa sala é mais resguardada - talvez mais aconchegante, pelo pédireito propositadamente mais baixo, em relação à sala do Bristol. Seu platô, sobrelevado sobre arrimos de pedra, tem o nível empatado com o ponto mais alto atingido pela subida da rua, nessa ponta do prisma, fato que lhe tira qualquer aspecto de retraído. Mais próxima do teto liso e neutro. Repete a sensação descrita acima, como originária da concepção Dom-ino. 
O próprio Lucio declarou que aí está o laboratório de onde surgiu a Superquadra de Brasília, como já vimos, embora isso sempre tenha sido relacionado com a escala dos prédios. Mas o laboratório mostra também toda a maestria com que o chão, ora natural, ora artificial, é tratado, tal como em outra escala, gigantesca, o solo de Brasília foi trabalhado. É dessa mesma ordem de sabedoria o projeto e execução das rampas de acesso ao Outeiro da Glória.

Continuando a subir pela Rua Paulo César de Andrade, surgem decepções que se vão se acumulando, e avultam: o prédio seguinte ao Caledônia, encalacrado entre o Caledônia e o paredão criado pelos Robertos é, realmente de uma espessa vulgaridade - e deveríamos ter todo o direito de acrescentar aqui vários pontos de exclamação. Além disso, o edifício que encima o conjunto, feito pelos Robertos, ignora totalmente a proposição de Lucio de uma ocupação parcimoniosa e suave da subida do morro: pelo contrário, estabelece uma cota de térreo na junção das Ruas Paulo César de Andrade com a General Mariante e, estabelecido esse platô como uma espécie de pilotis, criam um edifício contínuo, único, alongado porém muito alto - provavelmente por conta dos comitentes e da procura por apartamentos de alto luxo, nesse lugar de vista privilegiada como tantas outras que ocorrem no Rio de Janeiro.

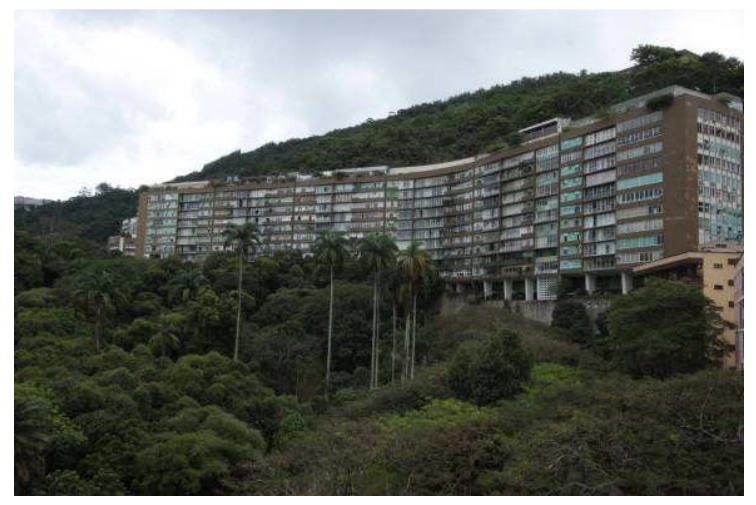

Figura 49. Edifício Parque Guinle, dos Irmãos Roberto, Anos 60.

Para estabelecer o térreo, os Robertos lançaram mão de um artifício já empregado por Lucio ali mesmo, mas dessa vez em uma escala agigantada: o arrimo é parcial, em parte funciona como arrimo mesmo, em parte constitui - somente - essa visualidade pesada, mas é o fecho de parte das garagens, e, nesse caso, acesso a algumas áreas de serviço. Sobra, assim, para a paisagem urbana vista a partir do Parque, um paredão agressivo, que retira toda a sutileza e suavidade de implantação aventada por Lucio.

O conjunto que o prédio conforma, lá em cima, não tem nenhuma graça ou maior interesse. Afora o fato de que, para quem mora lá, os apartamentos serem realmente confortáveis, luxuosos, e que desfrutam de tão maravilhosa vista - até mesmo para a parte de trás, para o Morro da Nova Cintra , não têm mais nada em particular. 
Resta-nos saber, que na bela vista que têm está inclusa os três prédios - e as idéias - que Lucio conseguiu executar.

De lá, de cima do prédio projetado pelos Robertos, se observa um fato, ainda não esclarecido: nas perspectivas originais de Lucio as coberturas de todos os seis edifícios teriam volumes soltos, aos moldes de Villa Savoye ou dos realizados no MESP: volumes relativos a caixas d'água, maquinaria dos elevadores, etc., que, como vimos, eram parte da preocupação constante de Lucio: o mau remate das coberturas que proliferavam nos edifícios altos que estavam surgindo.

Constituiriam assim um terraço- jardim, aos moldes corbusianos.

Mas o que está realizado ocupa muito mais do que o previsto nos desenhos originais: exigências dos comitentes, ocupações posteriores, mudança do projeto ao longo das obras, etc., etc. Tudo isso permanece sem que, no momento, tenhamos indícios mais precisos do que, e como, isso se sucedeu.

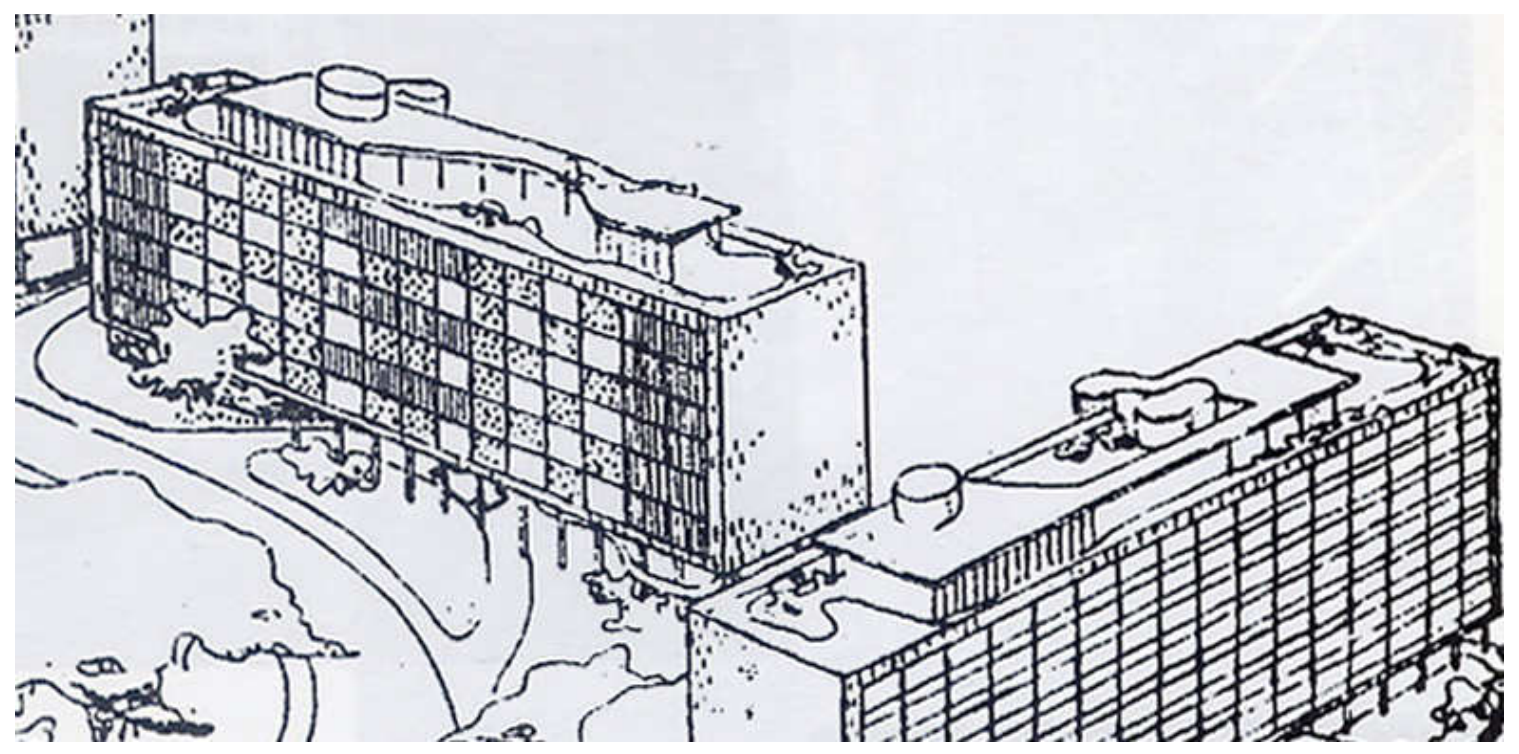

Figura 50. Como deveriam ter sido os áticos segundo o desenho original.

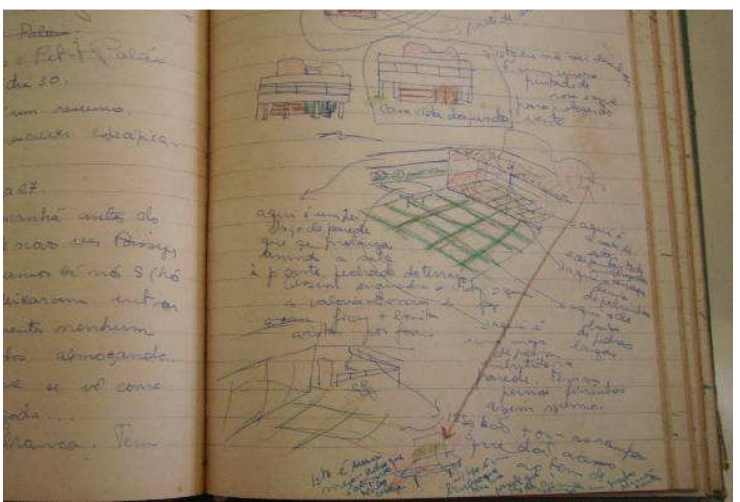

Figura 51. Ático da Villa Savoye, desenhado por Maria Elisa, aos 13 anos de idade.

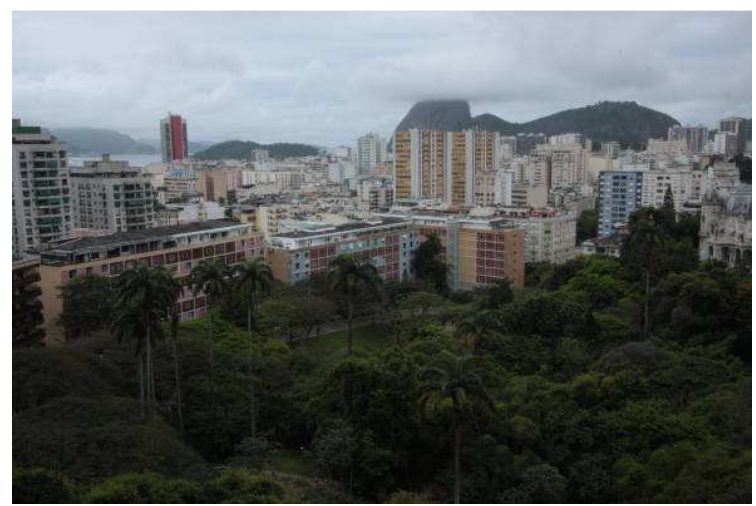

Figura 52. Terraço-ocupável dos edifícios, como foi executado. 
Independente de se historiar o sucedido, o que se vê é uma ocupação do terraço maior do que a idéia inicial. Ainda assim essa ocupação é recuada dos planos de fachada, sem interferir ou distorcer do prisma do corpo principal de cada um dos edifícios. E Lucio, em algum momento, neste período não determinado, utiliza um recurso precioso: a cobertura das habitações do terraço é recuada de todo o perímetro estabelecido pelo prisma, mas uma pérgola avança em balanço na direção das fachadas longitudinais, com a viga de borda alinhada ao seu plano vertical, no mesmo prumo. $\mathrm{O}$ resultado, surpreendente, é que isso reforça a presença do próprio prisma e do plano dessas fachadas, e não o contrário.

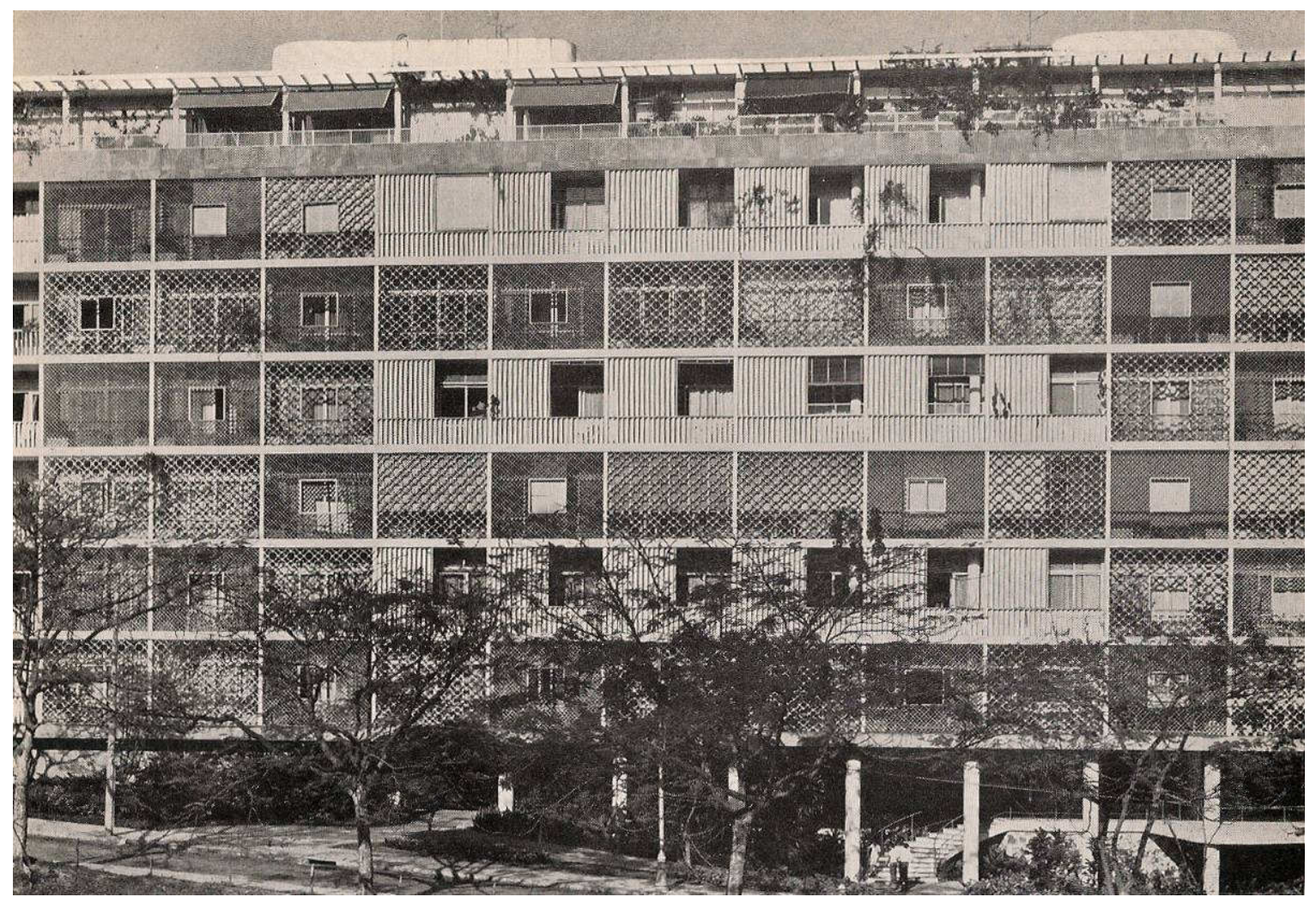

Figura 53. Foto histórica do livro de Henrique Mindlin: o pergolado do coroamento do ático tem a viga de borda a prumo com o plano da fachada.

\section{ESCADAS E CORES}

Na volta de uma viagem, anos depois, passando por ali um belo dia, tomo um susto: com a melhor das intenções e grande dispêndio, haviam trocado os "meus" vidros pintados por vidros azuis de verdade, só que, dessa vez, de um intenso azul shocking ${ }^{14}$.

\footnotetext{
${ }^{14}$ COSTA, L. Registro de uma vivência. São Paulo: Empresa das Artes, p. 205, 1995.
} 
De fato, o azul dos vidros que estão lá desde então até hoje não provém da paleta de Lucio. E os que ele tinha usado eram vidros pintados, enquanto esses são coloridos na massa, pertencem à matéria do próprio vidro, como se usa hoje, mas não existiam lisos - somente os martelados e os canelados - quando da execução do Nova Cintra. Mas na fachada oposta, bem como nas fachadas do Bristol e do Caledônia estão lá, mantidas como o original, as cores especificadas por Lucio: rosa, azul e vermelho óxido de ferro, de tons mais delicados, abaixo do tom médio, central. Ligeiramente pastel, o azul é levemente acinzentado, que foge do celeste puro e, como disse Maria Elisa: ele sempre disse que o azul "dele” partia do cobalto, e não do celeste - cerúleo. São suaves e não shocking, como ele disse.

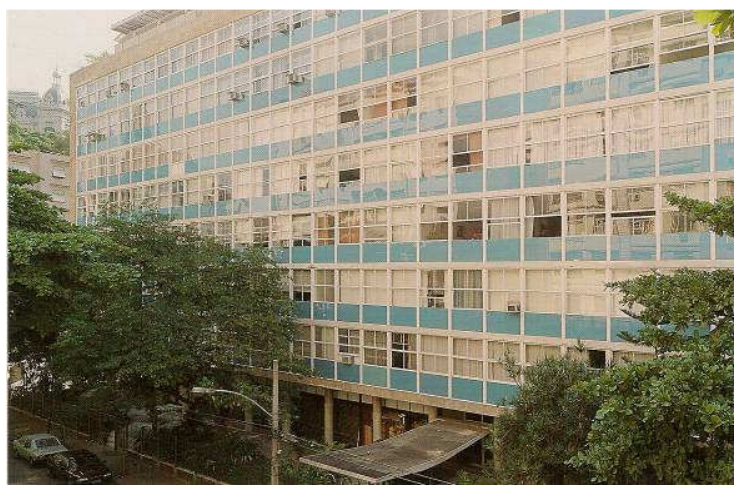

Figura 53. Fachada do Edifício Nova Cintra, com os peitoris das janelas em azul shocking, enquanto o original era o azul pálido da paleta característica de Lucio. Se comparada com a imagem 20, desse capítulo, vê-se também a retirada do montante intermediário de sustentação de cada um dos requadros desse peitoril. Vidros temperados esses, coloridos na massa - são mais resistentes, dispensando a sub-divisão com a melhor das intenções e enorme dispêndio.

Os volumes salientes das escadas do Bristol e do Caledônia, em duplas para cada prédio, são fechados em alvenaria e pintados, Bristol de azul e Caledônia de rosa, cores que na fachada oposta se apresentam nos brises verticais, os elementos vazados na cor natural da cerâmica de que são feitos; todos os demais elementos em ambas as fachadas são brancos. Os brises da fachada do verso do Nova Cintra são azuis como os peitoris em vidro do outro lado, só que no azul original. Mas nele o fechamento da dupla de escadas, também salientes em relação ao corpo do prédio são fechadas em vidros lisos jateados. 


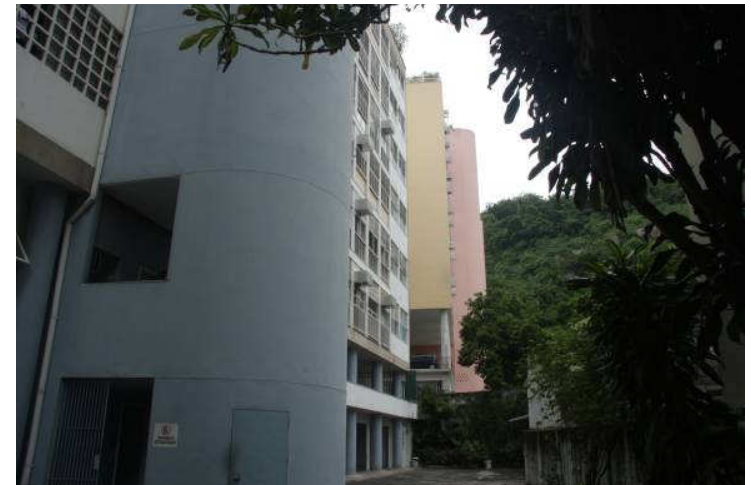

Figura 54. Volumes azul e rosa, dos volumes salientes das escadas do Bristol e Caledônia, respectivamente.

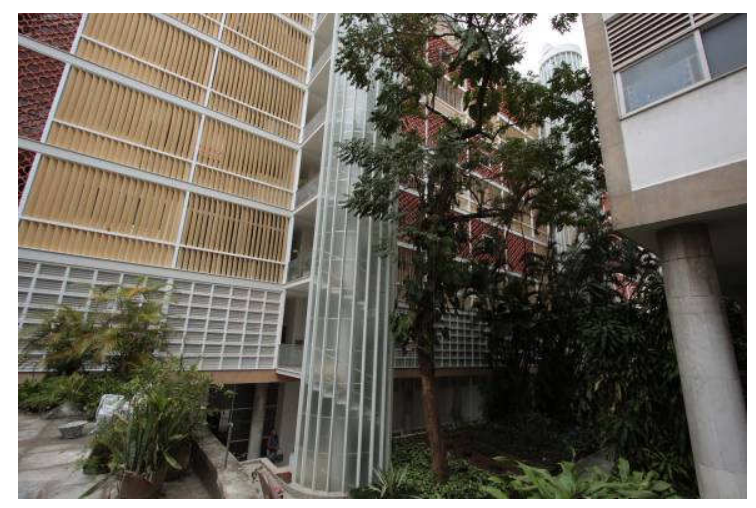

Figura 55. Fechamento das escadas em vidro jateado do Nova Cintra. O fechamento para no patamar, soltando a pequena ponte que conecta a escada ao edifício.
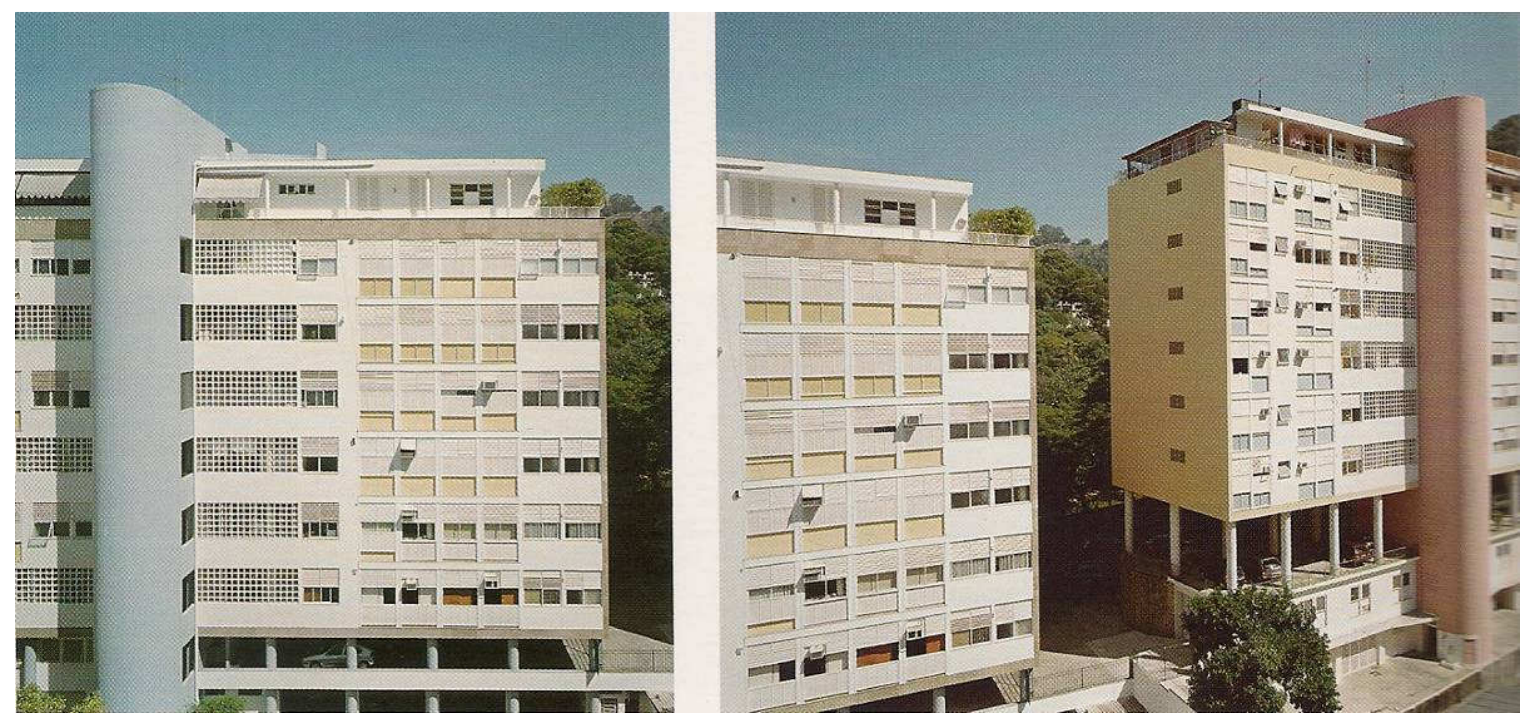

Figura 56. O azul-Bristol e o rosa-Caledônia, mantidos segundo a paleta de Lucio.

A que se deve a diferença? Talvez a explicação esteja no grande dispêndio, que Lucio referiu para a troca dos seus vidros. As duas escadas do Nova Cintra são as únicas visíveis a partir do Parque, o Bristol e o Caledônia têm as fachadas com as escadas voltadas para o limite do lote, inclusive na curvatura, se aproximam dessa vizinhança, sobre a qual não se teria o menor controle. Como realmente aconteceu, um punhado de prédios, alguns bem altos, se acumulou nessa direção, e a vista não tem nenhum interesse, restando, importante, a vista para o Parque. É possível que, sendo assim, não se devesse ter maiores dispêndios, pois a escada envidraçada é mais cara do que fechada em alvenaria; já vimos as dificuldades que o país tinha para dispor de vidros de grande tamanho. Bastaram os volumes coloridos.

Esses volumes fechados têm que ultrapassar o térreo-pilotis, pois vão desde o sub-solo garagem até o andar mais alto, o que não ocorre no Nova Cintra. Todos eles, fechados em vidros ou em alvenaria colorida, têm um ponto em comum: o 
fechamento falha exatamente no patamar de chegada em cada andar, quando então o patamar se transforma em uma pequena ponte, aberta para o lado. Esse escape é o respiro, uma pausa para a vista e, nos fechados em alvenaria, de onde provém a iluminação dos degraus da escada.

\section{FACHADAS AO POENTE}

Apesar de já termos trilhado, em primeira instância, desde a epígrafe deste trabalho, dada a sua importância, as questões relativas às fachadas do Caledônia e do Bristol, que, voltadas para o Parque, tem orientação desfavorável quanto ao conforto térmico e à luminosidade intensa do Rio de Janeiro, retomamos o assunto para mais algumas colocações: é claro que a diferença de luminosidade interior versus exterior torna o combogó assim usado pelos arquitetos modernos do Brasil o herdeiro direto dos muxarabis coloniais só que com a função acrescida de brise-soleil, e Lucio faz a demonstração disso oferecendo, à vista de qualquer um, as variantes e possibilidades, porque, na essência continuam diferentes, como descreveu Sophia Telles ${ }^{15}$.

Mas o uso desse recurso que foi, num primeiro instante, empregado com sabedoria, tanto que dispensavam parcimônias, ao contrário, transformou-se numa referência, usada com fartura: no livro Brazil Builds, Goodwin, ao se referir ao castelo d'água projetado por Luiz Nunes em Olinda, diz assim:

Apenas uma parte desta bela torre é usada como depósito d'agua. Os longos muros são de combogé ou concreto perfurado. O terraço inferior servirá para nele se realizarem bailes e festivais ${ }^{16}$. (grifo nosso)

E, no Brazil Buids - mais ainda no Modern Architecture in Brazil -, seguem-se inúmeros outros exemplos do emprego do elemento vazado, todos eles com uma característica importante: seguem a doutrina corbusiana de que as estruturas devem ser independentes das vedações e que, por isso mesmo, as fachadas devem ser livres e as janelas em extensão. Com a fachada livre, ao invés de janelas em extensão porque não têla toda em muxarabi, de piso a teto e em toda a extensão? Tal se dá no castelo d'água de Luiz Nunes, onde o curtain-wall seria absurdo: nem dinheiro, nem tecnologia para fazer uma cortina de vidro, os andares de cima se resumindo a um tanque, etc., etc. Parece tão lógico como o emprego simples de vitreaux para os brise-soleil da Obra do Berço, já citada aqui. Os arquitetos modernos se desdobrando para superar as dificuldades com proposições ricas a despeito dos parcos recursos.

15 TELLES, S. S. Lucio Costa: Monumentalidade e intimismo, Revista Novos Estudos. São Paulo: CEBRAP, n.25, p. 85 e 86, 1989.

16 GOODWIN, P. L. Brazil Builds: Architecture new and old 1652-1942. New York: The Museum of Modern Art, p. 158, 1943. 


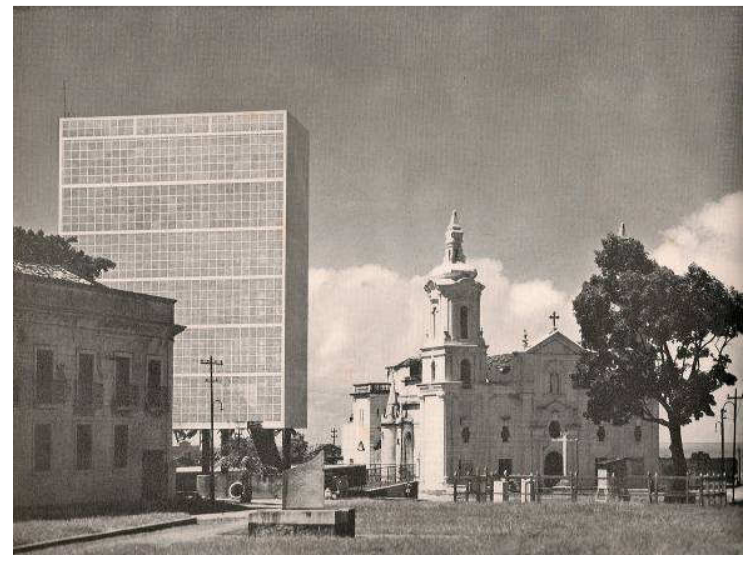

Figura 57. Castelo d'agua. Luiz Nunes. Olinda. 1936. Intervenção moderna em sítio histórico.

Mas não é só isso. A disseminação da linguagem moderna não se deu por igual e nem no mesmo nível, e acabaram surgindo os casos de obras muito ruins a maior parte dos casos - onde o elemento vazado, cerâmico ou de concreto, começou a ser empregado de maneira vulgar, requadrado dentro da própria malha estrutural, como se estivesse com curativos de esparadrapo recruzados e eles fossem a sobra, o intervalo da estrutura, a gaze que ficou para fora da cruz de esparadrapos.

No exemplo de Nunes, dominam as horizontais da borda da laje em balanço em relação ao eixo estrutural, recuado: fachada livre. O travamento vertical dos elementos vazados tem que ser feito interno ao rejunte entre eles, com barras esticadas como num instrumento de cordas, modulados pelas dimensões dos elementos, da mesma maneira que um caixilho e seus montantes verticais. No entanto, o vento turbilhonado porém passante pelo combogó, perde empuxo se comparado a quando ele bate de encontro a uma superfície em curtain-wall, o efeito vela-de-navio é bem diferente nos dois casos.

Esta lá, no Parque Guinle, um exemplo elucidador: a modulação estrutural não bate com a modulação das travas verticais dos requadros do combogó, são defasadas, fato que pode até mesmo ter determinado a dimensão exata dos balanços do prisma, em seus extremos longitudinais. A somatória de panos requadrados ultrapassa a somatória de eixos estruturais transversais, mas ambos se reencontram na delimitação do quanto há de balanço, para cada lado, das empenas de fecho, o topo do prisma. Isso "desmodula" a estrutura com as "cordas-de-violão" - aspas, aqui, inevitáveis -, que só vão se reencontrar nos extremos da famosa fachada, nas empenas, que ficam assim em balanço. Balanço que comodula as diversas partes componentes, de novo. Balanço necessário, pois se se alinhasse os últimos pilares com a empena, o prejuízo plástico seria enorme; então seria muito melhor modular - e não comodular - e daí descer, de vez, as empenas dos topos até o chão, à paulista - mas que ainda não tinha sido formulada assim, vide os topos do conjunto Louveira. Essa formulação da empena inteiriça, desde o chão fica clara na imagem do edifício Jaraguá, muito posterior à época que relatamos: 1984, de Paulo Mendes da Rocha, arquiteto que consolida de vez o diferenciado jeito paulista de fazer. 


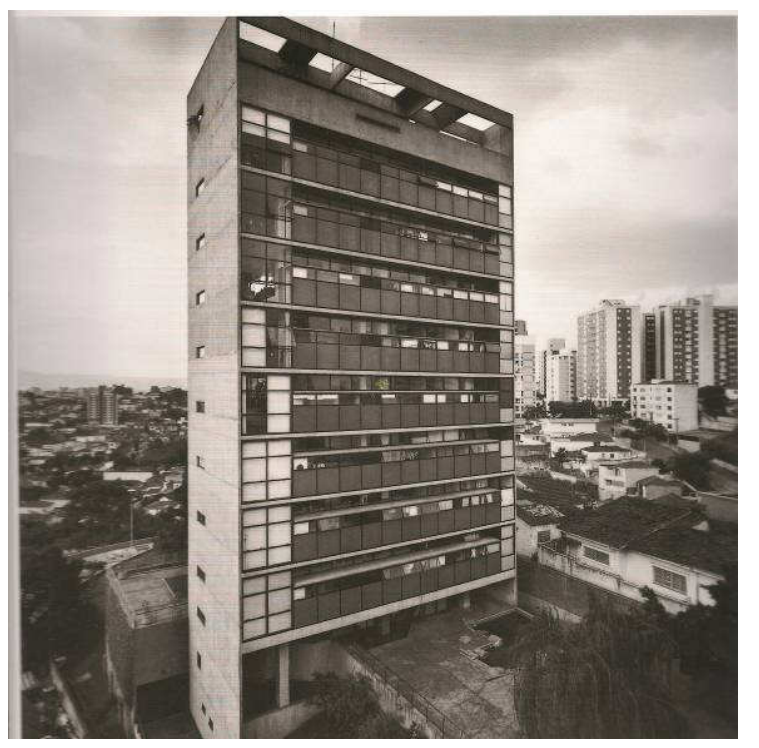

Figura 59. Empena contínua, desde o chão - Paulo Mendes da Rocha, Edifício Jaraguá, 1984.
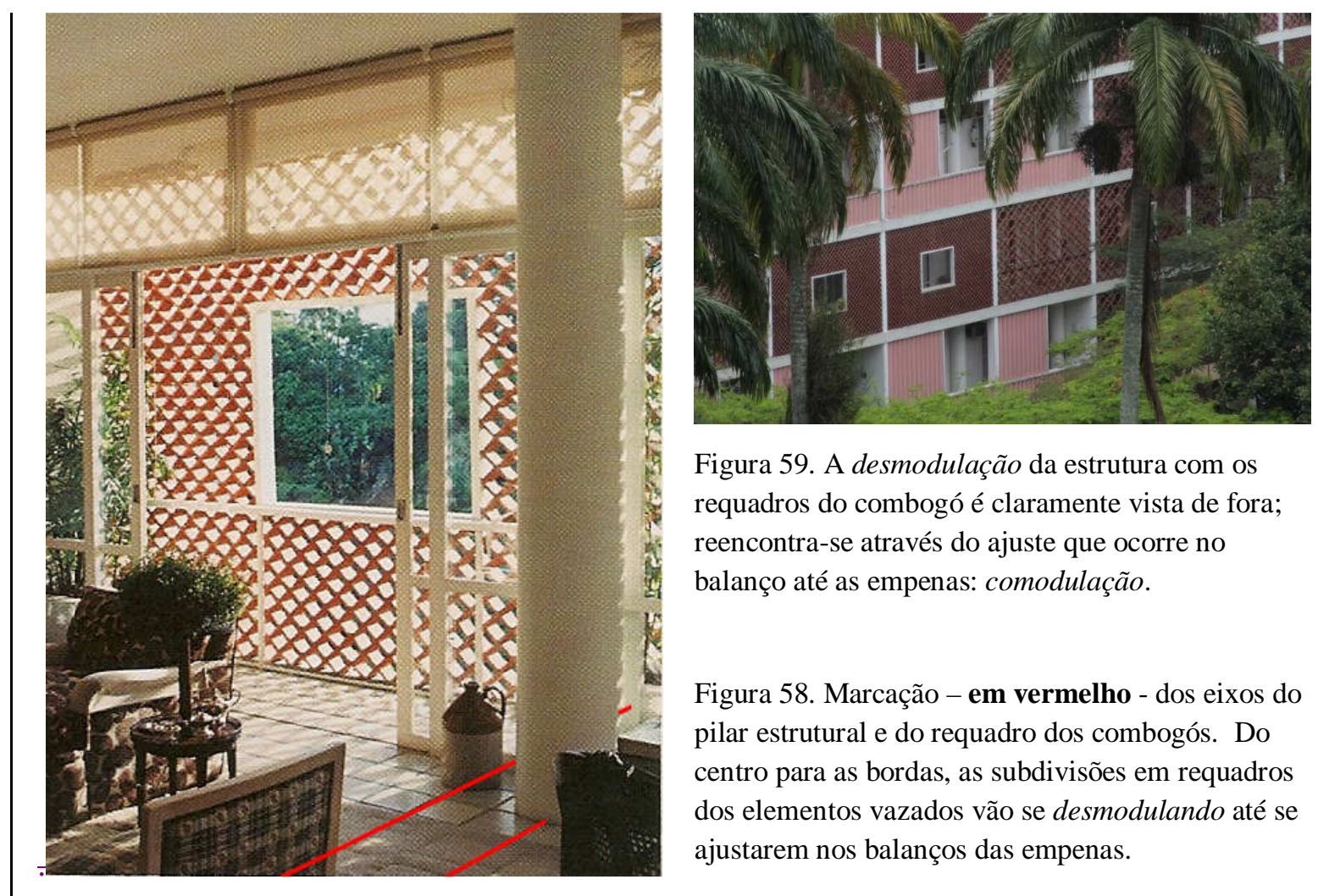

Figura 59. A desmodulação da estrutura com os requadros do combogó é claramente vista de fora; reencontra-se através do ajuste que ocorre no balanço até as empenas: comodulação.

Figura 58. Marcação - em vermelho - dos eixos do pilar estrutural e do requadro dos combogós. Do centro para as bordas, as subdivisões em requadros dos elementos vazados vão se desmodulando até se ajustarem nos balanços das empenas.

Panos requadrados, mas que soam quadrados, mesmo que exatamente, matematicamente, não o sejam. A correção de perspectiva era plenamente conhecida de Lucio: são quadrados, aparecem à vista como uma grande malha justaposta de quadrados, na qual se abrem novos quadrados: quando é brise-soleil, o vão que sobra avarandando é um quadrado; quando tem janela ausente, a janela é um vão quadrado; quando o vão é inteiro em combogó, com qualquer das opções de elemento vazado, esse vão é quadrado. E em todas as situações os elementos vazados estão inteiros, são módulos do quadrado maior. Quadrados re-quadrados com leveza estrutural, sutileza de situações 
possíveis, consideração pela vida e comportamento das pessoas por detrás daquele muxarabi sempre misterioso - para isso que eram feitos. Mas no Parque Guinle o muxarabi tem janelas sem gelosias ${ }^{17}$...

E os requadros são sutis, delgados e esbeltos - no sentido estrutural -, não têm as dimensões que seriam exigidas, compatíveis com as necessidades, que ocorrem no plano do eixo estrutural propriamente dito. E, aí, fica óbvio, na horizontal e na vertical têm a mesma dimensão aparente, requadros de quadrados. Então, por excelência de exatidão, não há recortes ou quebras nos diferentes modelos de elementos vazados, todos eles são assentados por inteiro, seja na vertical, seja na horizontal, seja quando interrompidos pelo desvão da janela ausente.

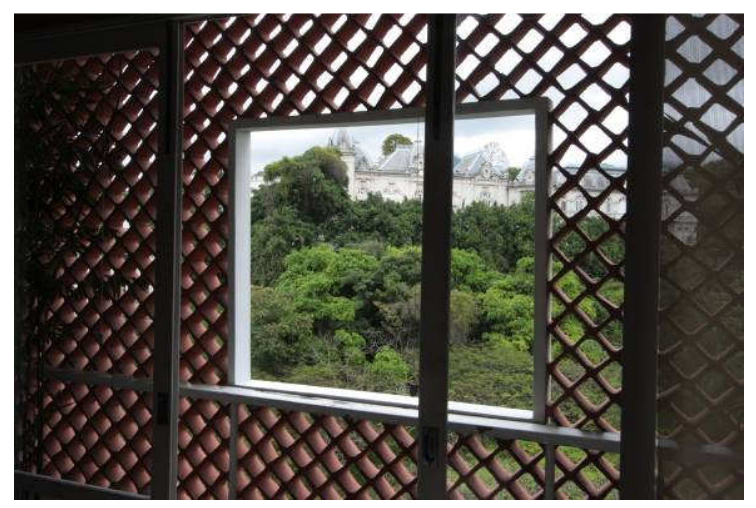

Figura 60. Janela do caixilho ausente, com vista para o Palacete.

Maria Elisa, certa vez, contou: Não foi com meu pai, foi com Charlotte Perriand. Eu estava sem saber como fechar o vão grande do meu apartamento que dá para o pátio (Lucio tinha pensado em uma coisa que suspendesse e que nunca foi feita, alguns anos a chuva entrava). O vão é retangular deitado. Ela olhou, olhou e me disse "Tu gardes le carré" +ou - "segure" (ou preserve) o quadrado. Aí, fizemos a portona (quadrada), que originariamente abria, hoje não mais, e uma portinha cheia, estreita, no canto, que por sugestão do Jayme Zettel, pintamos de branco. - Invertendo, poderíamos dizer: ache-o, ache o quadrado!

Na mesma linha de leitura, podemos comparar duas obras do arquiteto Rino Levi. Na primeira delas, o edifício Sedes Sapientiae, de 1940-42, os combogós requadrados não sustentam o valor de superfície, esse plano se perde nas linhas marcadas dos requadros. Já no edifício Plavinil-Elclor, de 1961-64, com os requadros apenas nas espessuras de sustentação do combogó e alinhados no mesmo plano, plano que é acentuado pela quina aberta no encontro das fachadas, o combogó aparece com maior vigor. Rino Levi repete aqui a proposição de janela de caixilho ausente tal como Lucio; porém o emprego de um único elemento vazado para todo o conjunto, variando sua

\footnotetext{
17 Chico Buarque: Flor da idade, 1975. Música que contém a citação do poema Quadrilha, de Carlos Drummond de Andrade.
} 
posição em pé e deitado, além do fato de serem módulos retangulares tanto para os requadros quanto para as janelas, não tem a mesma graça que os do Parque Guinle.

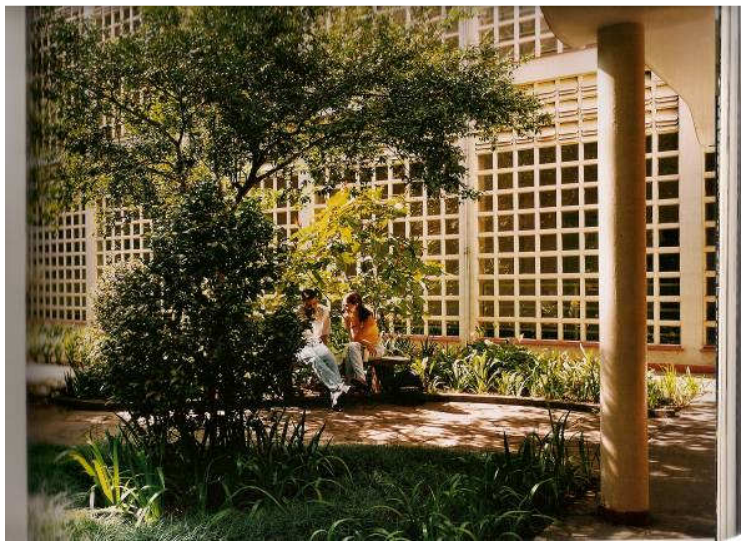

Figura 61. Sedes Sapientiae. Rino Levi. 1940/1942.

Figura 62. Edifício Pavinil-Elclor. Rino Levi. $1961 / 1964$.

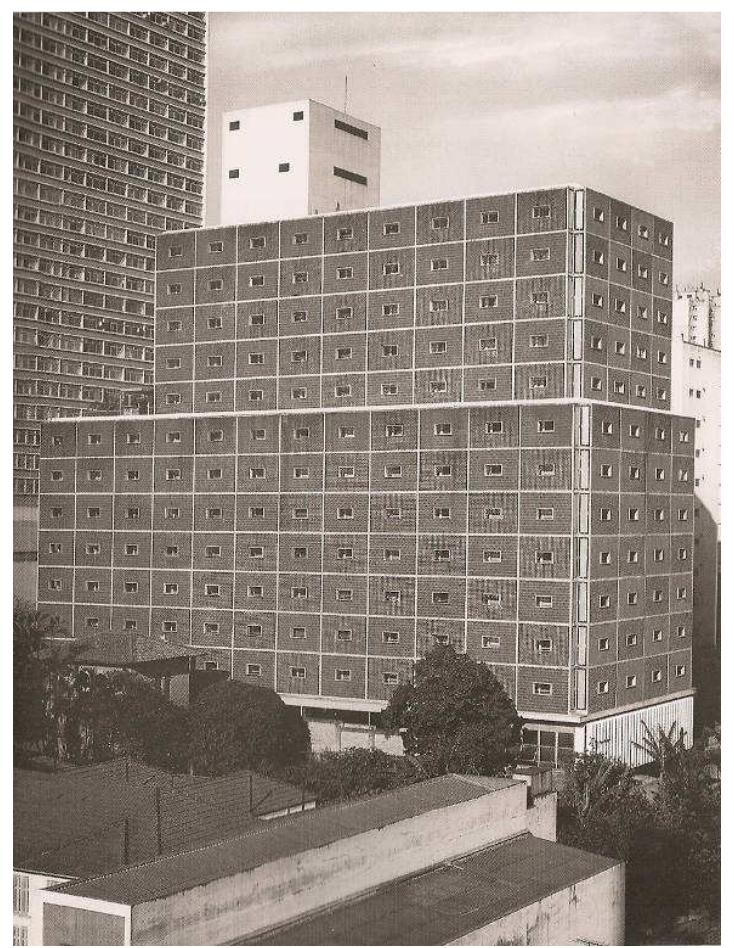

Infelizmente esse combogó não sobreviveu ao ambiente agressivo da poluição de São Paulo. Rino usou com maestria os combogós em projetos residenciais, inclusive na horizontal, como pérgolas. A arquitetura moderna brasileira utilizou combogós e muxarabis de muitas maneiras, como planos inclinados, como planos soltos do volume, às vezes independentes e soltos do corpo da edificação, etc. etc. Assim como outros arquitetos utilizaram também a janela de caixilho ausente, como Reidy, em 195052 no Pedregulho, Rio de Janeiro, Lygia Fernandes, em 1953, em Maceió e Helio Uchôa, em 1959, em Brasília, para acrescentar mais três bons exemplares. 


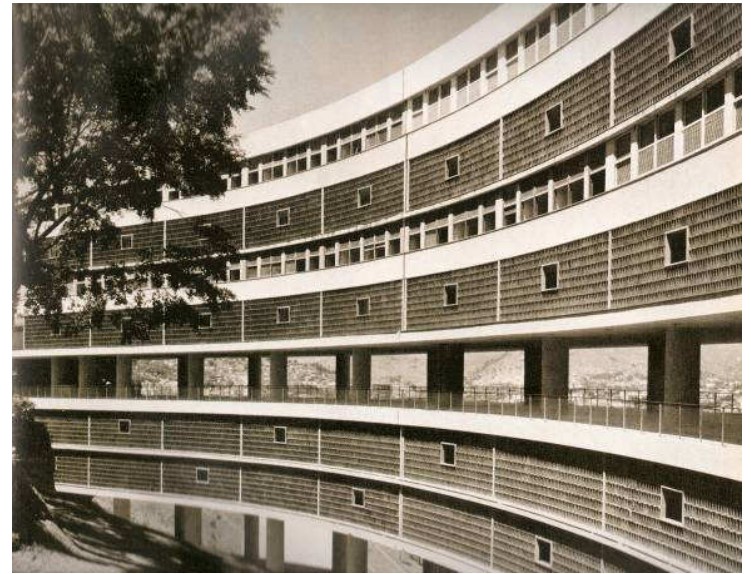

Figura 63. Conjunto Pedregulho. Rio de Janeiro. Affonso Eduardo Reidy. 1950/1952.
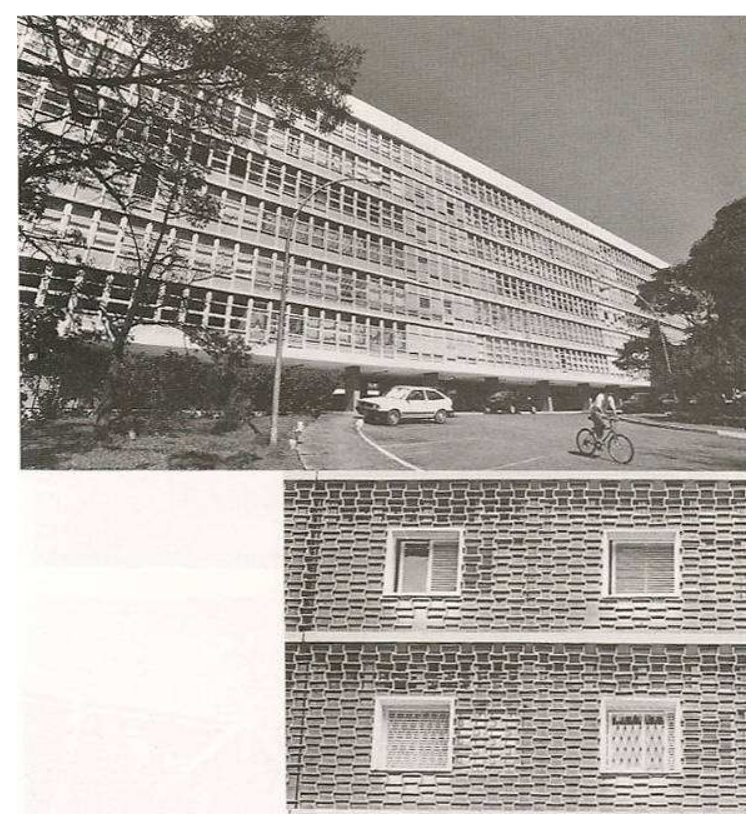

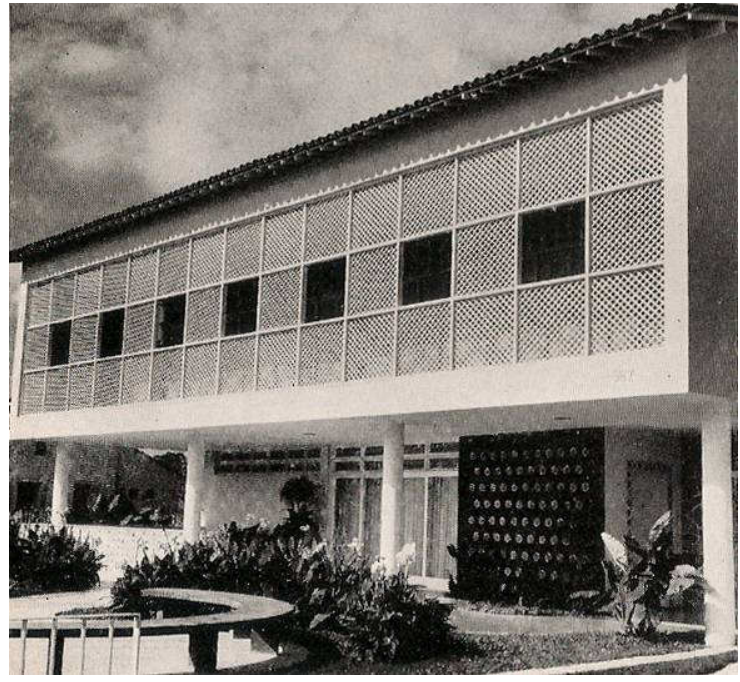

Figura 64. Residência. Maceió. Lygia Fernandes. 1953.

Figura 65. Edifício residencial. Brasília. Hélio Uchôa. 1959.

Como foi dito, o uso generalizado, na disseminação da linguagem moderna da arquitetura, acabou desgastando a visualidade do emprego de certos materiais. Os combogós, por exemplo, usados como as antigas janelas, como simples substituição delas, enquadradas dentro do plano de vedação de alvenaria, em pequenos vãos nas fachadas de prédios onde o ambiente interior corresponde à lavanderia, ficam amesquinhados. Queimaram ofilme, como se diz coloquialmente. O uso incorreto de materiais, assim como a mediocridade da repetição de fórmulas, queimam o International Style.

Pena os Guinle estarem tão afoitos em fazer dinheiro rápido e tantos empreendimentos, tenham parado aí. Pois o relacionamento com $D r$. César, pela descrição que Lucio faz da proximidade de ambos, durante as obras do Park Hotel, 
deveria ser excelente. Mas os corretores não souberam vender a idéia-morar em um moderno edifício, mas com todos os elementos do bem-morar do aconchego da conhecida e vivenciada casa brasileira - e assim a oportunidade de recuperar esse partido ainda válido, e restabelecer o vínculo, se perdeu ${ }^{18}$.

$\mathrm{O}$ vínculo, ativo, sutil, às vezes inesperado entre modernidade e tradição, entre erudito e popular continuarão a ser luta, estudos e realizações de Lucio - e também de Lina - por toda a vida. Mas, pensamos, não fora a necessidade de fazer dinheiro rápido, com um pouco mais de competência dos corretores e muito mais abertura cultural dos compradores, poderíamos ter mais três edifícios, mais três implantações com variantes sutis e elaboradas, mais usos diferenciadas de estruturas, além daqueles que ficaram demonstradas nos três que foram executados, cada um com sua personalidade, tal qual filhos, cada uma com a sua e o seu jeito. Mais lições do imenso repertório de Lucio.

18 COSTA, L. Registro de uma vivência. São Paulo: Empresa das Artes, p. 212 e 214, 1995. 


\section{SOLAR DO UNHÃO}

La escalera.

Levemente, con un roce, nos conduce hacia arriba, nos levanta gererosamente, nos hace girar entre estas cuatro columnas. !Se trata de um acontecimiento!

Al ascender y descender, nos sentimos como grandes señores enobrecidas. Provoca algo en nosotros, como si uno...? cómo se dice? Como si uno fuese conducido. Ella no dicta el camino... sino que apenas estimula y conduce con elegancia. (obs. d.a.)

Sólo revela cómo se puede ir de un nível a otro. No es una escalera, es una especie de milagro. Cómo nos eleva de un nível al otro. La construcción, con maderas de Brasil, tan grandes; los peldaños son de una única pieza, dos piezas.

En esta escalera no tengo miedo. $* 1$

Hoy, temprano, vimos una escalera de hormigón diferente, *2 también un sueño absoluto. He conocido tres escaleras. Ella debe haber construido más... tres escaleras de las diez más hermosas de la arquitectura moderna en el mundo. !Increible!

!Simplemente, miren! Miren como asciende despacio, *3 como una colina y allí, en el centro, va girando hacia arriba. Uno puede ir más despacio o más deprisa.

Aldo van Eyck.*4

*1 Se refiere al hecho de que esta escalera no tiene pasamanos.

*2 Se refiere a la escalera del teatro Gregório de Mattos.

*3 Habla al mismo tiempo que se acerca a la parte central de la

escalera.

*4 Transcripción del video Tarde de uma noite depois de uma caminhada en que el arquitecto Aldo van Eyck visita y comenta la obra de Lina Bo Bardi. Toenke Berkelbach (direc.) Jenny Borger y Linda Lodeizen (produc.).1

\footnotetext{
${ }^{1}$ OLIVEIRA, O. F. Lina Bo Bardi: obra construída. Barcelona: Editorial Gustavo Gili, 2G n. 23/24, p. 80, 2003.
} 
Trata-se do documentário Ga-naar Bahia, had Lina hem gezegd «Vá para a Bahia, Lina disse a ele» - Aldo van Eyck, ideação e narração, e Direção Toenke Berkelbach. Produção TV VPRO. Holanda, 1996.

Segundo Aldo van Eyck, seu primeiro encontro com Lina se deu em 1968, por meio do amigo dela, o arquiteto Joaquim Guedes. Aldo então, proveniente de Buenos Aires, estava interessado em favelas ou projetos de habitação popular, como tem acontecido até hoje com muitos arquitetos holandeses que vem ao Brasil. ${ }^{2}$ Parece que para eles, holandeses, e, principalmente nos anos recentes, o tema favela é algo imantado, polariza quase totalmente suas intenções de vinda até aqui - claro, o tema é da maior importância para nós, mas o que chama a atenção é a persistência com que ele reincide a várias gerações deles.

A data precisada por van Eyck, 1968, também contém detalhes importantes. Ele, chocado com a violência e a truculência do ditador Videla, veio ao Brasil como se aqui as coisas estivessem muito diferentes, mas foi a partir daí que a ditadura daqui recrudesceu, e também a partir daí é que Lina passa a realmente ter problemas, em 1969. Lina teve confrontos políticos desde 1964, o que motivou sua saída da Bahia, e eles vão se acirrando até que, em 69, se vê obrigada a sair do Brasil.

Outras observações são reveladoras, a partir dessa entrevista: enquanto a Argentina teve uma trajetória extremamente voltada para sua própria europeização - e sempre apostou nela -, o que Lina via no Brasil era a possibilidade dele não ser da civilização ocidental, tamanha a presença e influências de outras origens na sua composição étnica e em sua cultura, e Lina apostava nessa hipótese.

Para ela, poder dizer isso para qualquer outra pessoa de origem européia - como ela - era uma vitória, saia ganhando logo de cara, com algo que podia demonstrar: -Vá para a Bahia! Mesmo que ela já aventasse a possibilidade de nunca mais poder pisar lá, depois do que já tinha acontecido, como se verá adiante. Depois disso, ela passa a dizer, para as pessoas próximas, que a Bahia, para ela, era um caso encerrado! Ainda assim continuava a tentar demonstrar as diferenças do Brasil dela e recomendar aos estrangeiros que olhassem a Bahia, a partir das referências - importantes e bem embasadas - que ela dava.

Então Aldo van Eyck veio da Argentina para Brasil em 1968, mas vê as escadas (três) só em 1996 e não tinha esquecido o - Vá para a Bahia! -, que Lina tinha-lhe exclamado, e fez esse vídeo-poema, no qual também citou as outras duas escadas, projetos dela, das quais uma é - la escalera del teatro Gregório de Mattos. - a outra não consta da entrevista.

$\mathrm{O}$ arquiteto holandês Paul Meurs descreve assim as circunstâncias em que Aldo van Eyck retornou ao Brasil, por intermédio dele, e como dessa vez aconteceu a Bahia:

\footnotetext{
${ }^{2}$ Entrevista de Aldo van Eyck realizada por Anete Araújo e Olivia Fernandes. (ver Anexo III) 238
} 
PM: Uma matéria que eu havia escrito sobre a Lina Bo Bardi resultou na ida da mostra sobre o trabalho dela no MASP para a Holanda, tendo sido recebida pela Universidade de Delft e inaugurada por um arquiteto holandês, Aldo van Eyck [1918-1999], que havia certa vez visitado a Lina, há 30 anos atrás, e que por sinal é um arquiteto muito parecido com ela. A TV holandesa ficou então interessada e eu consegui, junto com o Instituto Bardi, fazer um contato para levar o arquiteto Aldo van Eyck ao Brasil, para visitar Salvador e São Paulo, para que se fizesse um documentário, que foi exibido na $3^{a}$ Bienal Internacional de Arquitetura em 1997, e acho que também na TV Cultura. Nesse documentário, ele comenta sobre o contato inicial dele com a obra de Lina. Ele estava com o Guedes visitando o MASP e ficara impactado com o vão livre do MASP, e depois foi almoçar na casa da Lina [Ver o artigo "A Casa de Vidro de Lina Bo Bardi", de Dick van Gameren, publicado em "Brazilie" e traduzido no $n^{o} 3$ de Arquitextos] e levou outro susto, pois foi quando percebeu que ela era a arquiteta que havia projetado o MASP. Há uma cena de seis minutos, na escada no Solar do Unhão, na Bahia, que parece que ele está fazendo amor com a escada, é fantástica sua análise. Na matéria que ele escreveu, ele ressalta a questão da exposição dos quadros em cavaletes de vidro no MASP, que ele considera um grande gesto do museu, que é como expor os quadros ao ar livre. Isso para ele é uma coisa única, todos os museus do mundo estão errados. O MASP seria o único que mostra os quadros na dimensão correta, pois você pode ter contato com vários quadros ao mesmo tempo. ${ }^{3}$

Van Eyck se refere às madeiras brasileiras: peças inteiras, enormes, no máximo duas delas para os patamares maiores do giro do passo da escada, a maioria delas em peças únicas - em peroba; volta-se aos quatro pilares externos, à escada cuatro columnas - que são os pilares da modulação original do Solar, aproximadamente 4.15 x $4.75 \mathrm{~m}$. - No es una escalera, es una especie de milagro! E ele usou a palavra: milagre...Talvez ele pudesse ter completado: naturalmente! - que daria na mesma, para nossas caseiras discussões.

Não cita o pilar central, em pau d'arco - como muitas regiões chamam o Ipê, e sim os degraus, estes em Ipê-amarelo. O pilar central provavelmente é originário de outra região que não a Mata Atlântica da Bahia, dado sua grande altura, e segundo Lina, veio da Amazônia - e demorou para chegar a Salvador -, mas o fato é de difícil comprovação, pelo menos por enquanto - somente um técnico muito especializado poderia fazer essa verificação.

\footnotetext{
${ }^{3}$ Entrevista de Paul Meurs a Heitor Frúgoli Jr e Marcos Cartum. Disponível em: < http://www.vitruvius. com.br/entrevista/meurs/meurs 4.asp>. 2000.
} 


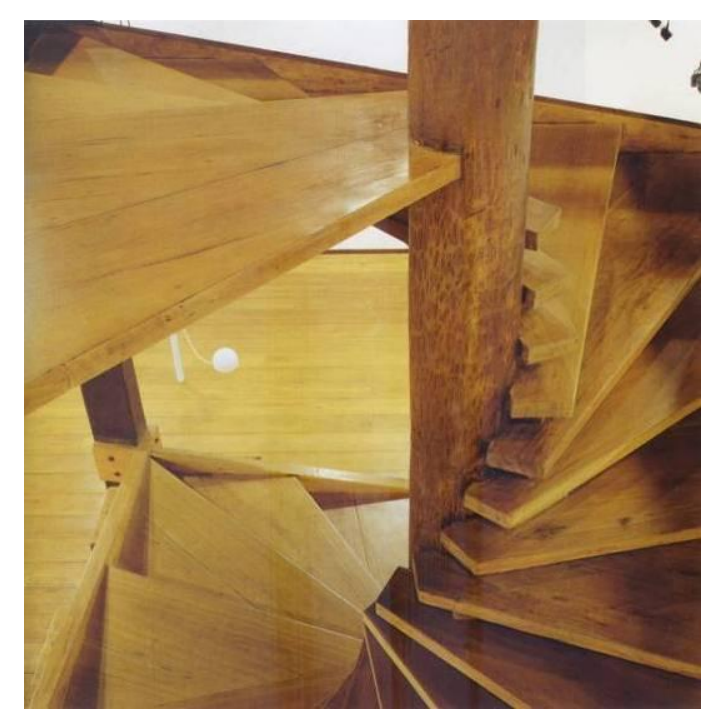

Figura 1. Direção tangente dos degraus em relação ao grande pilar central.

A escada é quase um sonho de tão surpreendente, mas o é de fato: visceral - bucho, fato (como se diz na Bahia)-. Merece as descrições poéticas de Aldo van Eyck. Mesmo os que já a conheciam por fotografias, surpreendem-se com suas reais dimensões, tão grandes.

Com quase todas as pessoas com quem conversamos que tiveram a experiência de encontrá-la, lá no Unhão, as expressões ficam nessa ordem de sentimento. Um acontecimento, um evento, um poema-material, mas matérico demais, na medida em que um poema não poderia sê-lo, talvez uma escultura, sim, como Calder, por exemplo instável e estável, móbiles e stabiles -, quando se chega perto de suas grandes - em qualquer sentido do termo - esculturas. Ele, Alexander Calder que havia feito uma grande exposição, em 1959, no Museu de Arte de São Paulo, e conhecido Lina e o Professor na Casa de Vidro.

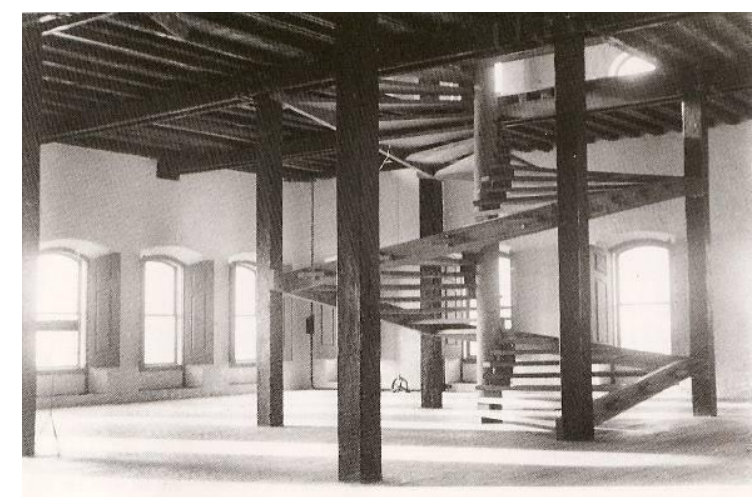

Figura 2. A escada em foto do período imediatamente após sua montagem

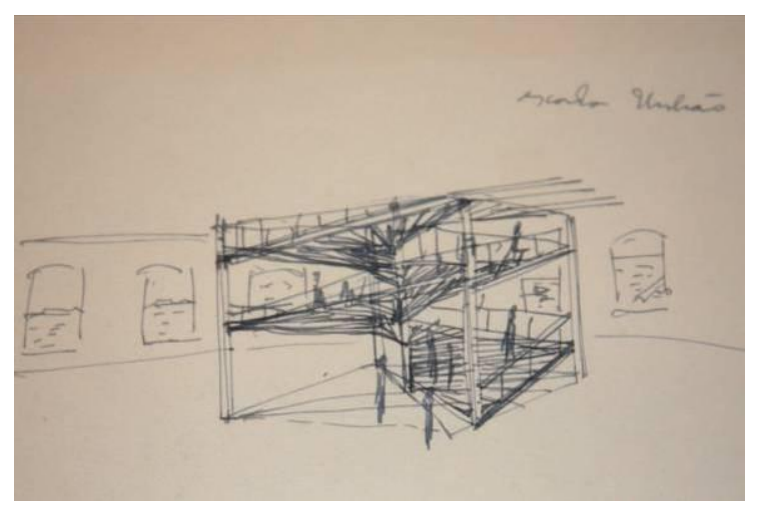

Figura 3. Desenho de Lina para a escada 


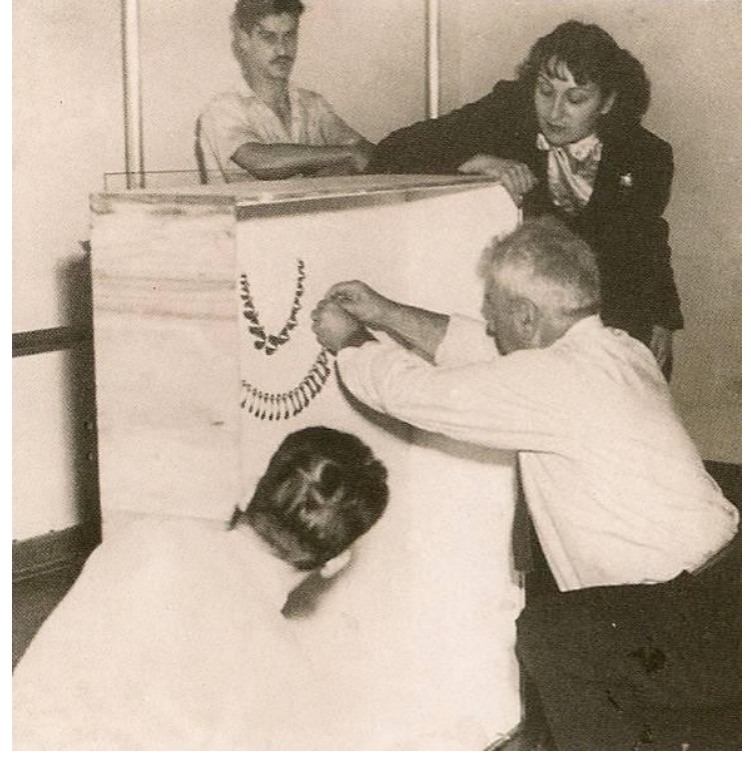

Figura 4. Lina observa Calder, quando da montagem de sua exposição no MASP, ainda no prédio dos Diários - Rua 7 de Abril - 1949

Esconsa na implantação - assimétrica dentro do volume do Solar -, a escada realiza a difícil proeza da parte que transforma o todo. Algo indizível, como Le Corbusier se referiu aos espaços, expressão que Lúcio tanto admirou ${ }^{4}$, ali é peça indizível, componente de um espaço pré-existente da real, porém indizível, Bahia, e do, até então, para Lina, quase-indizível Brasil.

Lina ressaltava o uso do encaixe do tipo "carros-de-boi", para o apoio dos degraus; Aldo para os quatro pilares externos. Os encaixes são de cunha-eespiga, já presentes em instrumentos muito antigos, como as bancas - bancadas - de marceneiro, que possuem o mesmo tipo de encaixe, a seco, e por isso, talvez, Lina gostasse tanto. O a seco é o procurado dado moderno que ela buscava sempre - e via exemplos disso desde o Japão ancestral, como já foi dito aqui.

Lina utilizou esse encaixe de cunha-e-espiga em diversas ocasiões desde 1948, em cadeiras feitas no Studio de Arte Palma, em parceria com Giancarlo Palanti: nos apoios das vigas de piso junto aos pilares da Casa Cirell, de 1958, e na poltrona que projetou para o auditório MASP, que não foi utilizada, mas cuja concepção não teria estofado, assim como as polêmicas poltronas do Teatro do SESC - Fábrica da Pompéia, e que deve datar de época próxima a 1968, já que a poltrona existente no auditório foi comprada às pressas, para a inauguração da nova Sede.

\footnotetext{
4 (...) daquilo que chamava, com seu dom inato da palavra exata, o "espace indicible”. (...) COSTA, L. Ronchamp. in: COSTA, L.. Registro de uma vivência. São Paulo: Empresa das Artes, p. 574, 1995.
} 


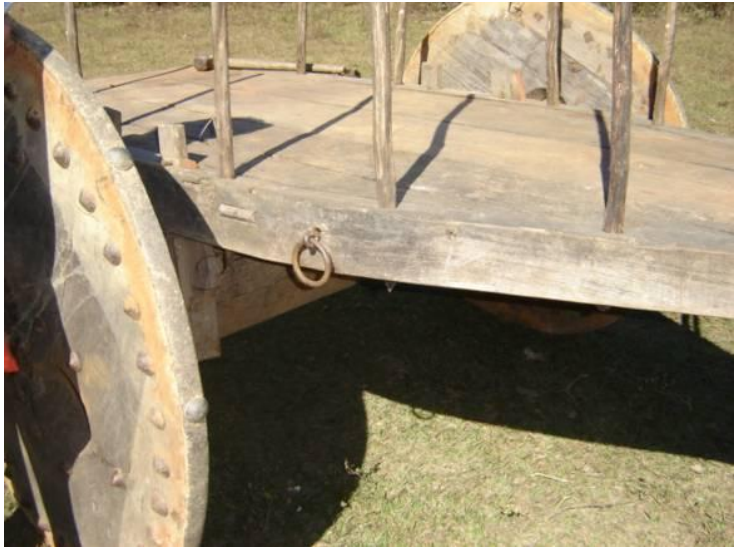

Figura 5. Carro de boi, ainda de uso corrente no interior do Brasil.

Figura 6. Eixo do carro de boi, terminando em espiga que é atravessada pela cunha.

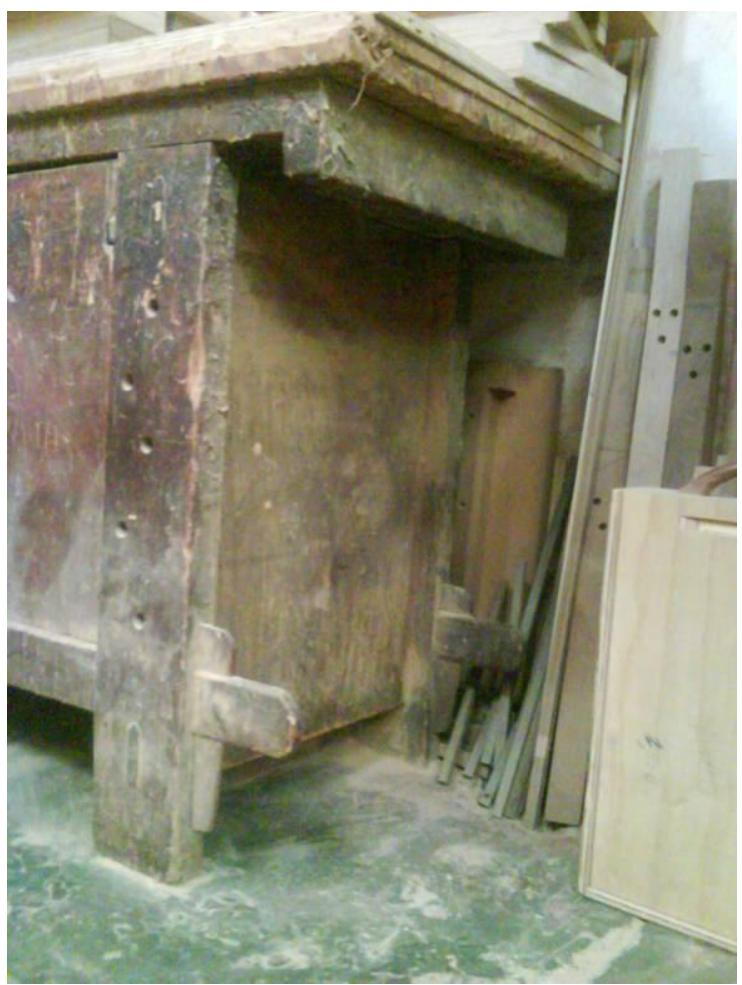

Figura 7. Encaixe espiga e cunha em bancada de marceneiro.
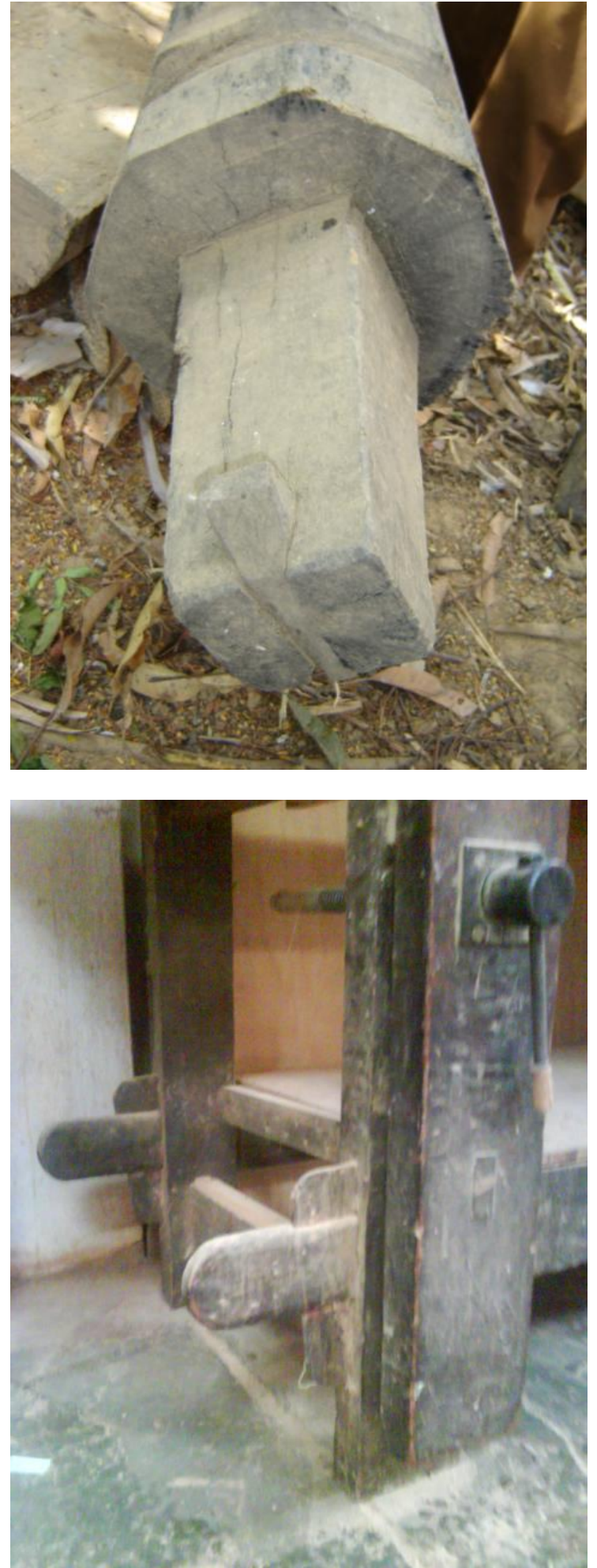

Figura 8. Idem 


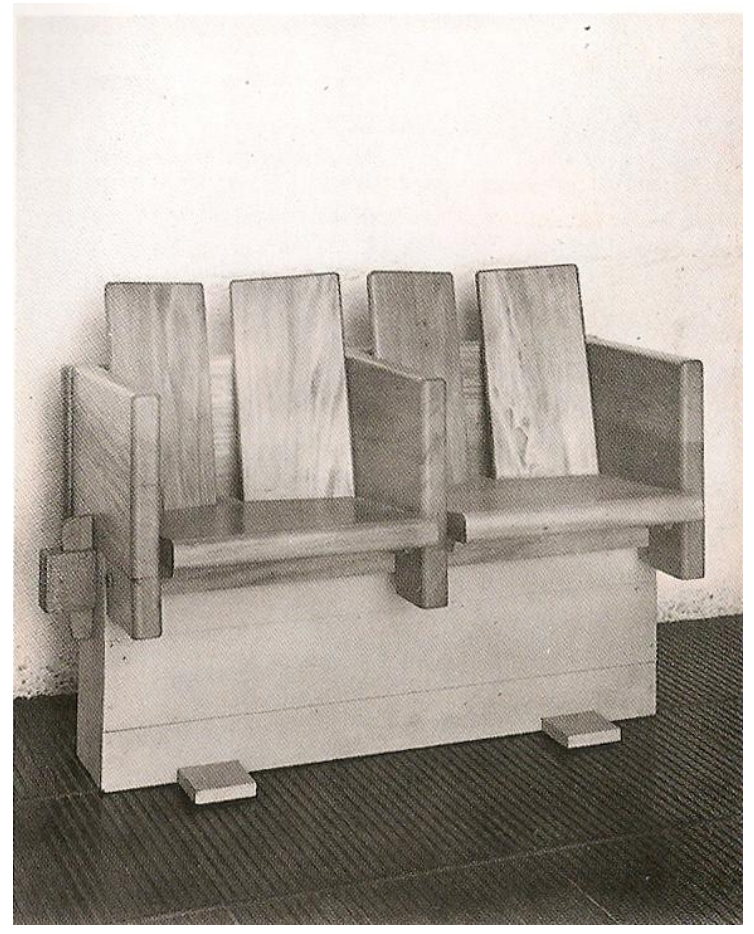

Figura 9. Protótipo das poltronas para o auditório do MASP - na Sede definitiva. A base seria de concreto. Note-se a terminação da viga em espiga, a cunha travando o conjunto

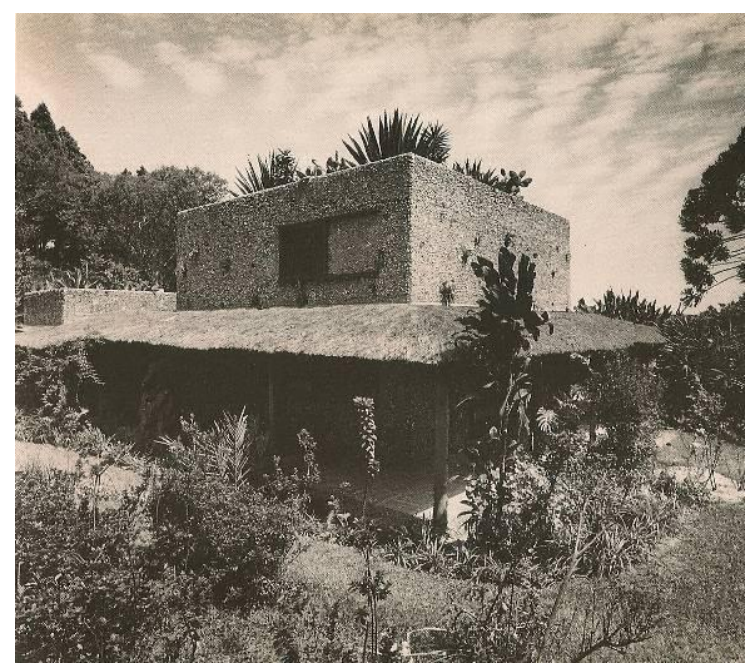

Figura 11. Casa Cirrel, 1958. Varandas com pilares em madeira e vigas de sustentação do tabuado suspenso encaixados com cunha-espiga, conforme detalhe ao lado.
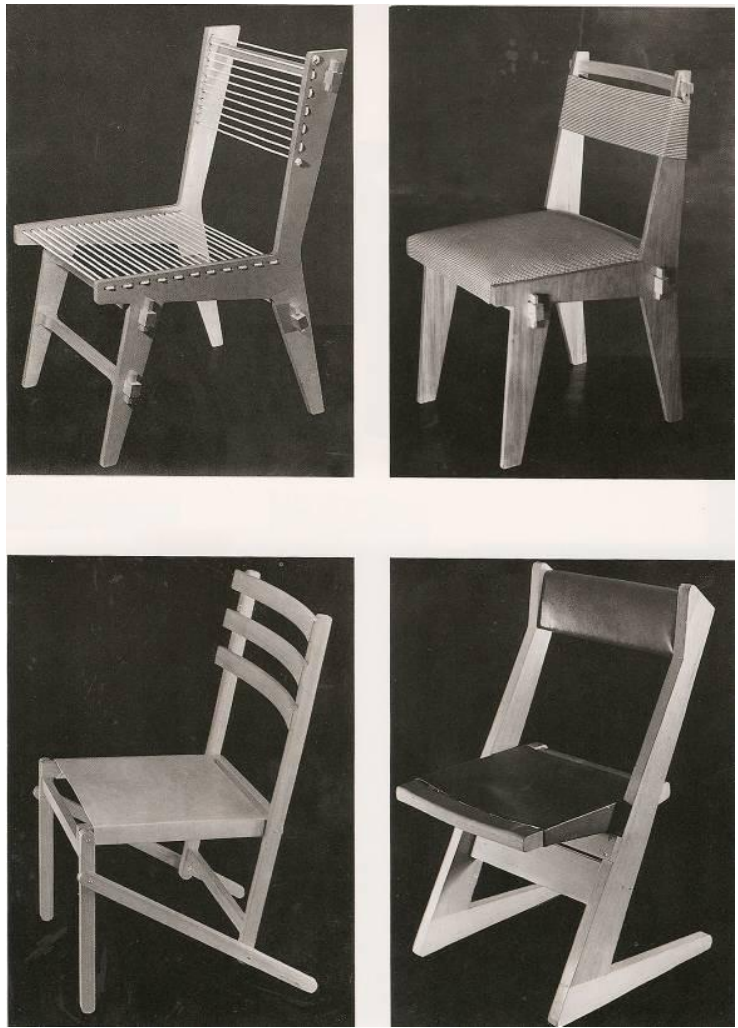

Figura 10. Cadeiras do Studio de Arte Palma: as duas imagens de cima mostram a utilização do sistema cunha-espiga.

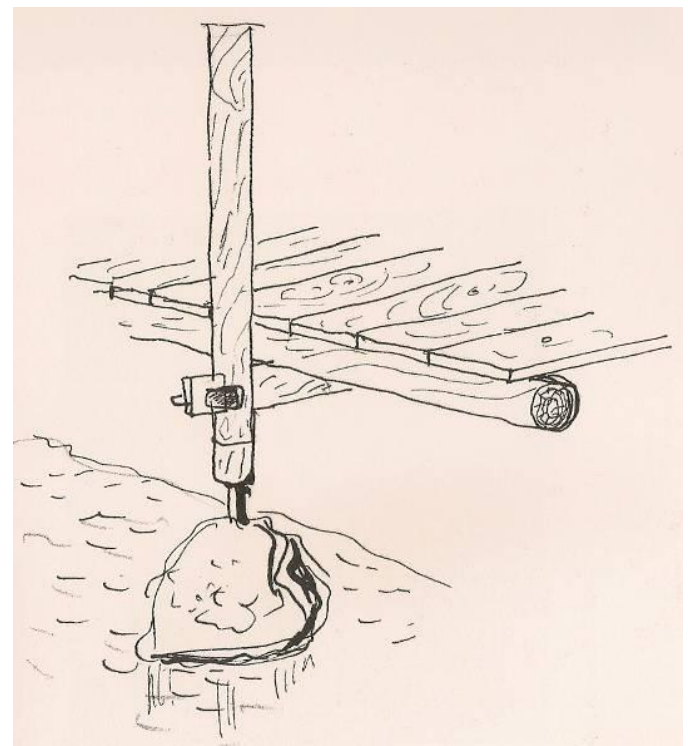

Figura 12. Desenho com detalhe para o apoio dos pilares sobre blocos maciços de pedra bruta $-\grave{a}$ japonesa, - e da chegada das vigas nos pilares. 
Comas assim descreve:

Desenhado por Lina, o mobiliário é deliberadamente

desconfortável, porque a vanguarda preza o sofrimento e despreza o prazer, $e$ deliberadamente pesada, maciça, para ficar no lugar e criar lugar. Enquanto ela foi a diretora artística do centro, exposições memoráveis intensificaram o excitamento visual. Em última instância, contudo, animar o ambiente era uma tarefa deixada para os usuários, e eles não a recusaram. ${ }^{5}$

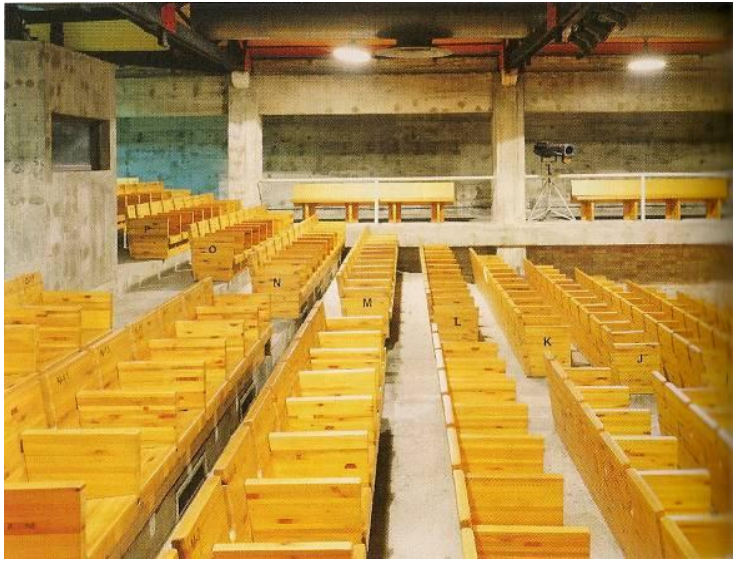

Figura 13. Poltronas do Teatro do SESC - Fábrica da Pompéia

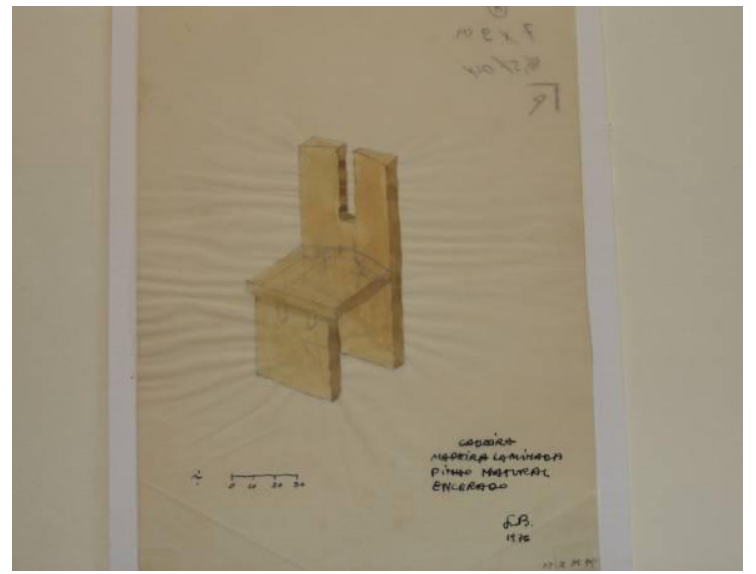

Figura 14. Cadeira para o Restaurante do SESC Fábrica da Pompéia

Falando sobre a escada, Lina então chama a atenção para fora, desloca nosso olhar para o famoso encaixe. Aldo pegou essa linha, olhou para os quatro pilares, os de fora. Mas o que nos chama mais a atenção é o espaçador central, a peça que dá o vão entre pisos, exatamente o que galga os degraus para terem sempre o mesmo espelho, justaposto ao pilar central.

Neste pilar, poste enorme, inconcebível de tão retilíneo para algo natural - o tronco de uma árvore de uma altura inimaginável sendo tão direito -, ocorre o espaçador, peça que alivia o tronco de ser machucado pela série interminável de encaixes necessários, caso o detalhe não fosse esse. Se cada um dos pisos tivesse que ser incrustado diretamente nele, resultaria bastante prejudicado, enquanto, na verdade, as pranchas de piso são passantes - e é isso que dá a visualização de uma série de planos retos que simplesmente tocam o pilar central, porque na verdade são dependentes dele de modo indireto.

\footnotetext{
${ }^{5}$ COMAS, C. E. Três variações sobre a domesticidade e a transparência no pós-guerra. Arquitexto 8 , 2006. Disponível em: < http://www.ufrgs.br/propar/publicacoes/ ARQtextos/PDFs revista 8/8 Carlos\%20Eduardo\%20Comas.pdf $>$. Acessado em: 26 jun. 2009. 


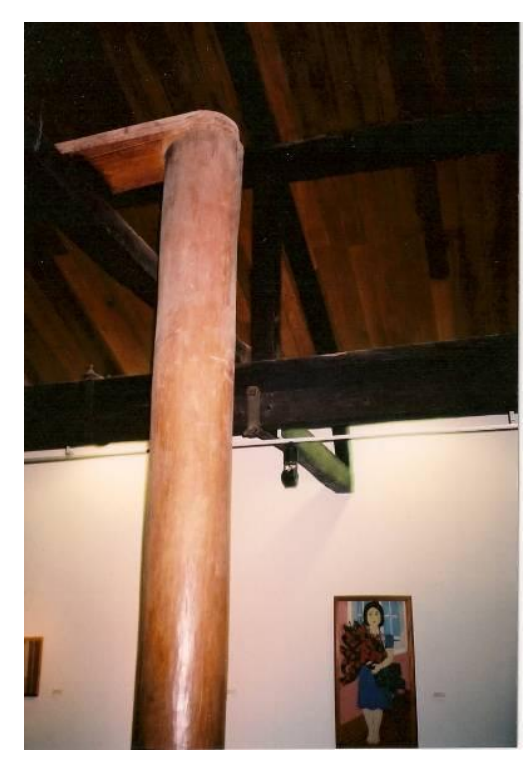

Figura 15. Detalhe do pilar central, escada do Solar do Unhão. A peça no topo do pilar é simplesmente uma prateleira que Lina usou na Exposição Nordeste, onde deveria ter ficado, para sempre, a imagem do Caboclo. O pilar é solto do ponto de vista estrutural em seu trecho de cima.

O espaçador central é um grosso tarugo da mesma madeira do piso - ipê-amarelo -, tal que sua altura, somada à forte espessura do pranchão do degrau, resulte exatamente a requerida para o espelho constante. As fibras desse tarugo estão paralelas à tangente do pilar, ou seja, o tarugo está na posição mais resistente possível a se exigir de uma peça de madeira: seja nessa direção, horizontal, essa que é tangente ao pilar, seja na vertical, comprimido entre dois pisos, os degraus. Nessa posição, tem o sentido da mediatriz do ângulo formado entre os dois pisos, o de cima e o de baixo, ficando então na bissetriz formada pela mediana dos ângulos desses degraus. 


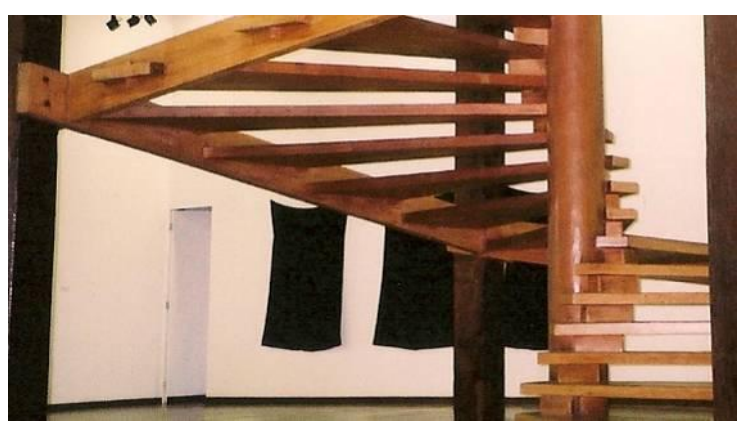

Figura 16. O sistema concebido preserva a integridade do pilar central, através do tarugo espaçador. Ao mesmo tempo os próprios degraus travam o pilar na estrutura pré-existente, através das vigas inclinadas das bordas.

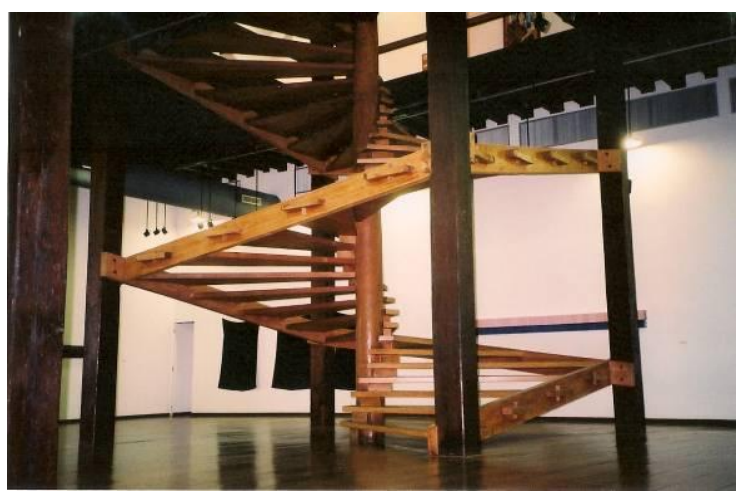

Figura 17. Se comparada à Fig. 2, a escada parece estar num espaço qualquer, e não no Solar. Depois da saída de Lina, adotou-se o costume de se emparedar as janelas do Solar para as exposições, fato que infelizmente passou a ser adotado também no MASP, que além disso deixou de usar os cavaletes de vidro.

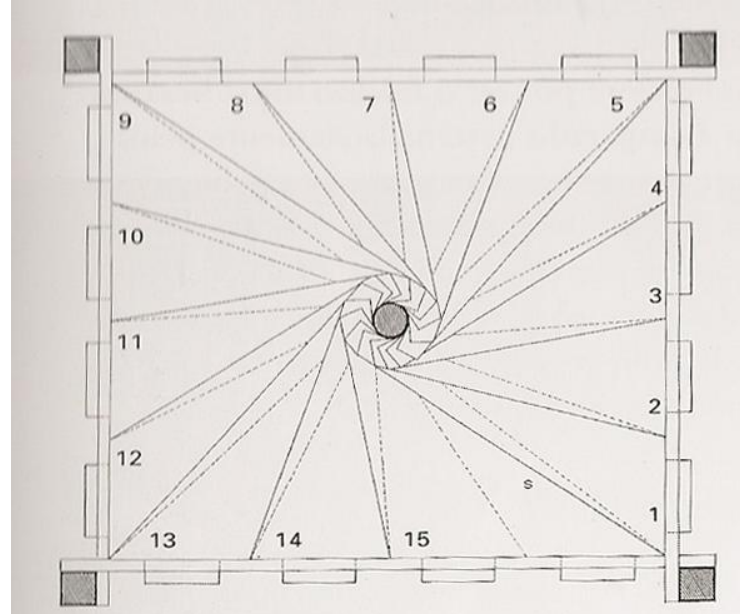

PLANTA DA ESCADA

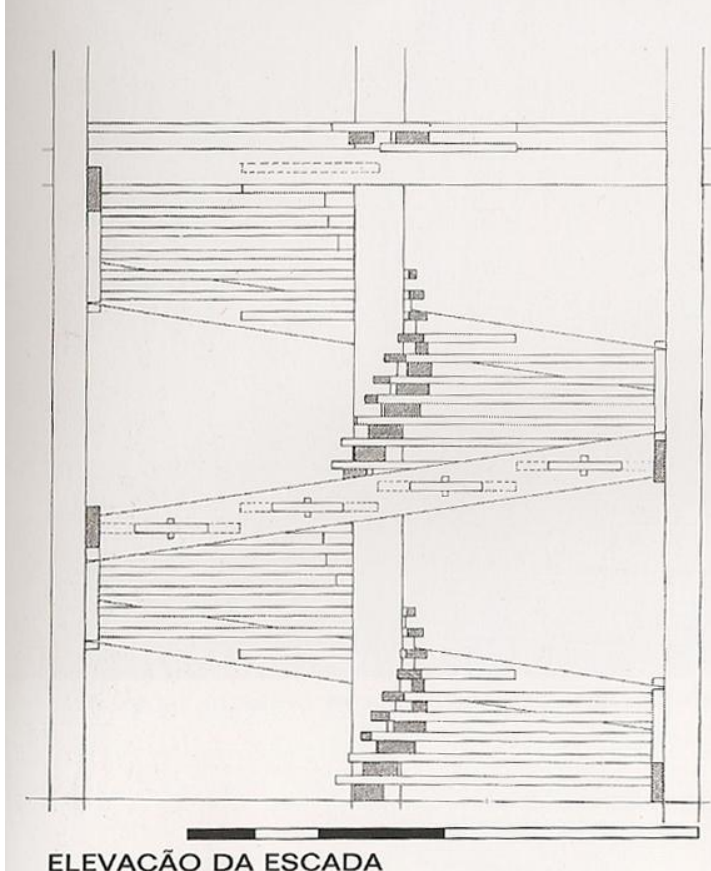

Figura 18. Desenho executivo da escada, com a clara demonstração dos topos das peças de madeira.

Isso tudo permite um jogo de montagem na obra que é de novo surpreendente: a grande - e pesada para o manuseio - prancha de cada degrau, que como observou van Eyck, às vezes é composta, com mais de uma prancha, pode primeiro ser deslocada para a espiga, entrar na envasadura das vigas inclinadas laterais - aquelas, entre os quatro pilares do módulo original - para depois se apoiar no tarugo, e assim sucessivamente, como se a própria escada fosse seu andaime. Com o jogo armado, todo o conjunto passa a funcionar: o pilar central, esbelto, não sofre o efeito da flambagem, pois possui travas horizontais quase que contínuas, que são os próprios vigorosos degraus que seguem até as vigas inclinadas das bordas; estas vigas estão travando em diagonal os quatro pilares existentes do edifício e essas diagonais conferem rigidez ao conjunto. 
Quando a equação se fecha, um matemático fica feliz com a beleza da fórmula assim como uma frase musical é algo que se completa em forma de música.

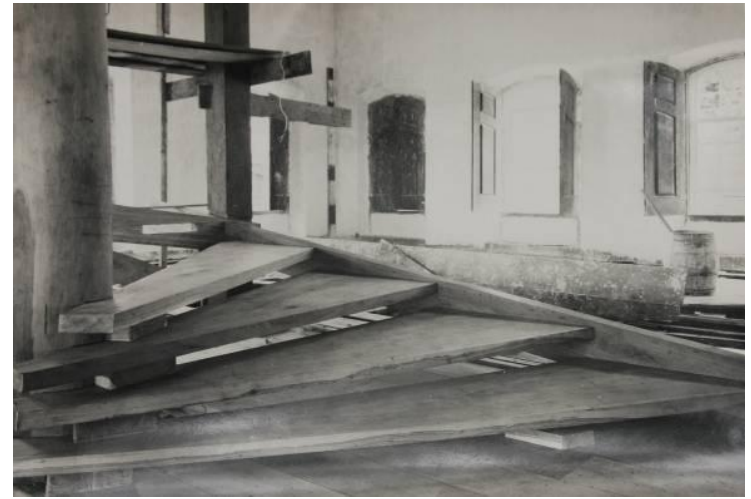

Figura 19. A montagem da escada: andaime de si mesma.

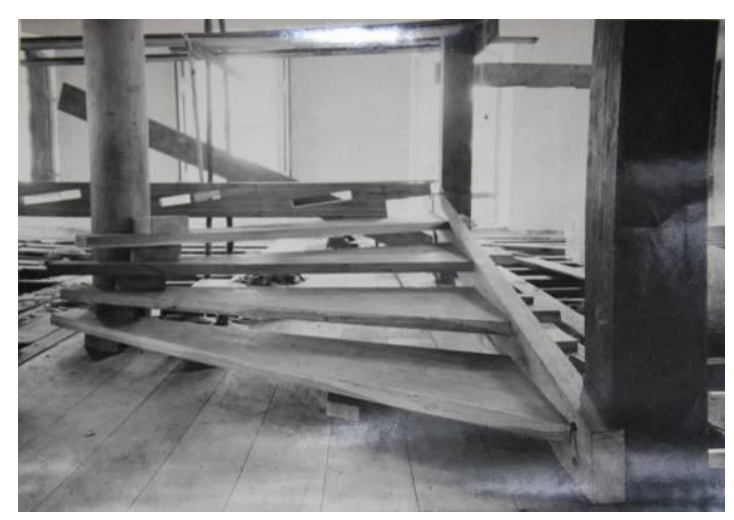

Figura 20. A montagem, de tão simplificada, dispensa andaimes auxiliares.

Os desenhos do projeto executivo dessa escada não deixam dúvida: a textura, usual em desenhos técnicos para expressar os topos aparentes em madeira, indica claramente as exatas posições em que tais peças deveriam ser usadas, de tal modo que não há mestre-artesão que tenha executado tal procedimento sem a determinação imposta pelo projeto arquitetônico, o que afasta qualquer hipótese nesse sentido, como se pudesse ter ocorrido algo experimental, exceto o fato de que Lina sempre exigiu protótipos, testes executados in loco, mas previamente planejados.

Lina, quando se referia à escadaria monumental da Biblioteca Medicea- Laurenziana, de Michelangelo, falava com emoção muito forte, perceptível. E completava: - Escada não é uma coisa de subir e descer, é muito importante... (c.d.m.) O Professor apresentava uma imagem dessa escada da Biblioteca - escultura, obra de arte em seu posfácio ao Introdução à arquitetura de Benévolo, lançada no Brasil em 1972. ${ }^{6}$

${ }^{6}$ BENEVOLO, Leonardo. Introdução à arquitetura. Posfacio de Pietro Maria Bardi. São Paulo: Mestre Jou, 1972. 


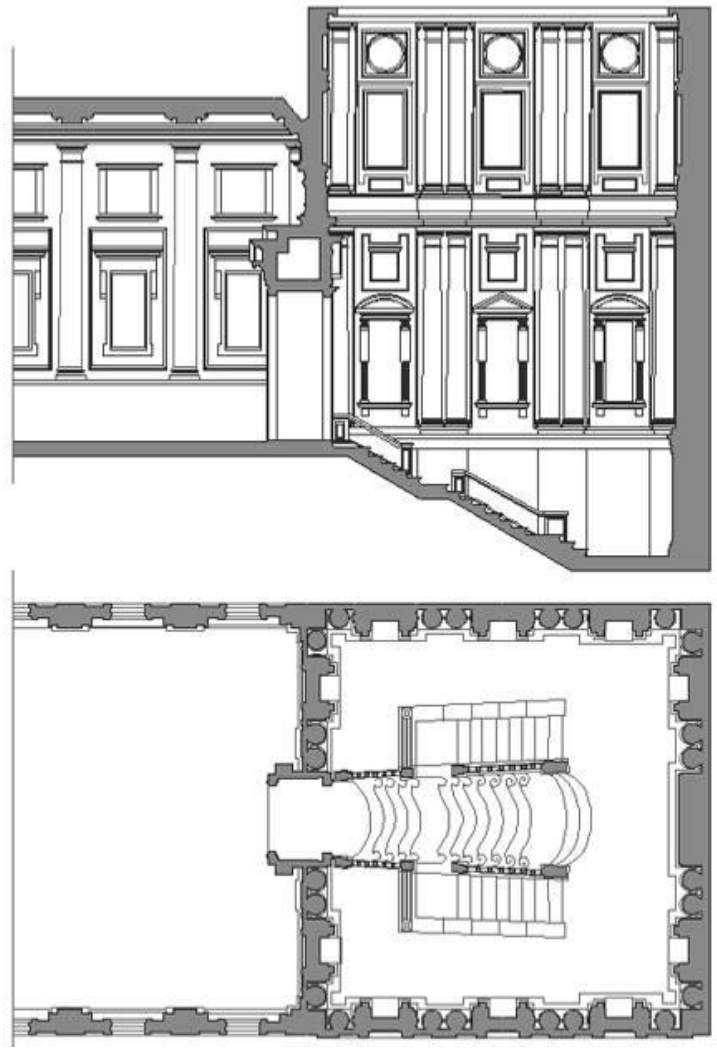

Figura 21. Planta e corte do vestíbulo da Biblioteca Medicea-Laurenziana.

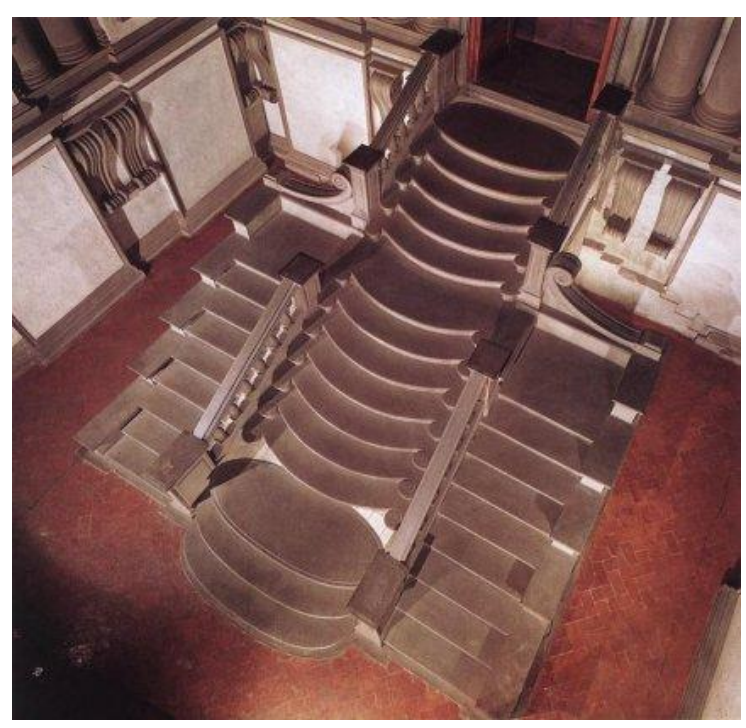

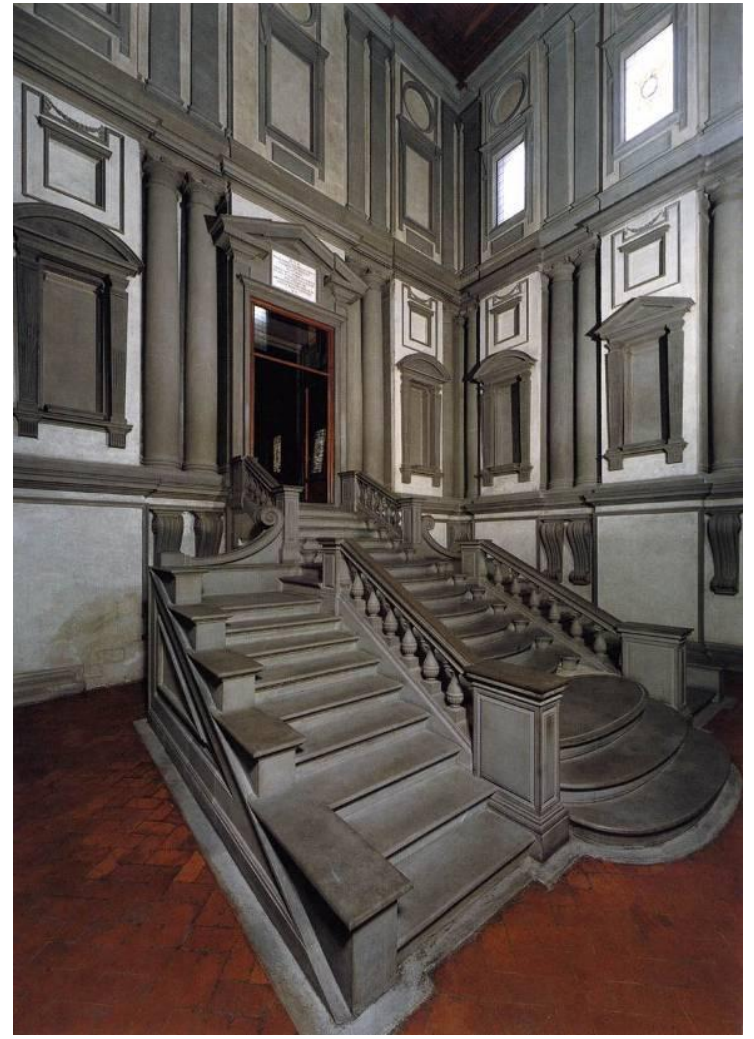

Figura 22. Vestíbulo e escada da Biblioteca Medicea- Laurenziana, de Michelangelo, em Florença.

Figura 23. Idem

E ela escreveu assim: As escadas sempre fascinaram o homem. As grandes escadarias das cidades, as escadas dos tronos, dos templos... são um elemento fascinante, e eu sempre fui, como arquiteto, fascinada pelas idéias de uma escada.

Nunca tomei uma escada como um elemento prático, para subir de um nível a outro nível. No Unhão, por exemplo, tem uma escada que é remarcável (sic) 
na Bahia. É uma coisa bem dentro do que eu disse agora. ${ }^{7}$ Ela estava apresentando o projeto da escada do Teatro Gregório de Mattos, outra que foi citada por Aldo.

Serapião, muito recentemente, nos fez rememorar: (...) no clássico Dicionário da arquitetura brasileira, de Eduardo Corona e Carlos Lemos, antes de ser definida pela função de "proporcionar a circulação vertical entre dois ou mais pisos de diferentes níveis", a escada é apresentada como "elemento de composição arquitetônica”. (...) ${ }^{8}$

A já comentada posição assimétrica da escada, dentro do quadrilátero da planta do Solar não só cria uma tensão na percepção sinestésica de quem entra, é também o dado modernizante imposto pelo projeto, uma vez que deveria acontecer uma escada centralizada, que nos ocorreria puxada, de maneira recorrente, lá do fundo da memória de qualquer outro edifício - memória que qualquer um tem - sobre edifícios daquela idade - vetusto assim. Entrar pelo centro - a porta principal é rigorosamente central - de um velho edifício, ali, passando por uma pequena ponte azulejada nas faces internas dos peitoris -, cria a expectativa de uma escada em frente, nesse eixo central. Mas a posição dessa escada faz nosso olhar se deslocar para a direita do salão, já destituído de vestíbulos e de outras divisões que seguramente existiram ali.

No andar de cima também, as divisões - tabiques, pau-a-pique ou quaisquer outros que sejam - em qualquer das posições em que estiveram, ao longo das várias ocupações que o conjunto possuiu e sofreu, foram demolidos, ficando como o de baixo, um salão que ocupa integralmente toda a planta, até as quatro faces do perímetro interno do Solar. Com isso, os dois salões, do térreo e do primeiro andar, passam a ter um lado mais curto - à direita de quem entra - e outro mais amplo, na direção oposta, permitindo assim melhor organização dos novos usos pretendidos, exposições, reuniões, peças de teatro, festas, por exemplo. Tudo gira por conta dessa escada e sua estudada posição.

A imagem que mostra a escada encontrada por Lina, registrada quando se fez o cadastro de imagens e levantamentos, antes do início das obras de restauro, não tem data de origem precisa, resultado provável de alguma das várias reformas ali ocorridas. Apresenta uma escada em "L", o primeiro lance passando tangente a um pilar original do primeiro eixo paralelo à fachada da entrada; a virada no patamar apoiada em um pilar secundário - que também apóia a ponta do assoalho do primeiro pavimento no trecho interrompido para a abertura de chegada da escada nesse nível - e o lance de cima do "L" apoiado em vigas metálicas inclinadas.

\footnotetext{
${ }^{7}$ BARDI, L. B. Lina Bo Bardi. FERRAZ, M. C.. org.. São Paulo: Instituto Lina Bo e P. M. Bardi, P. 278, 1993.

${ }^{8}$ CARDOSO, P.. Arquitetura pelas escadas. Posfácio de SERAPIÃO, F. citando: CORONA, E., LEMOS, C. Dicionário da Arquitetura Brasileira. São Paulo: Edart, 1972 - São Paulo: Estação Liberdade, 2009.
} 


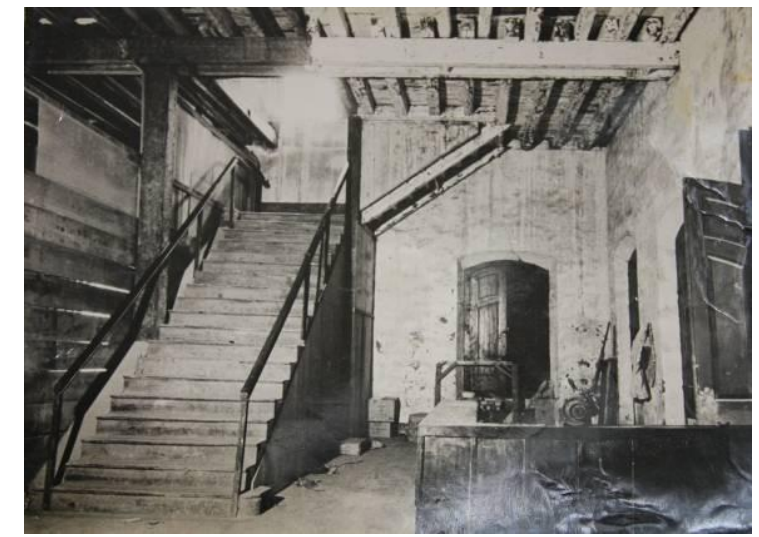

Figura 24. Escada existente no Solar do Unhão tal como Lina encontrou, e demoliu.

A posição dessa antiga escada em relação à porta de entrada visível na foto - indica a possibilidade de ter existido uma segunda escada, espelhada a essa, que contemplasse a esperada e usual simetria de que falávamos, formando uma dupla com a monumentalidade esperada, por especulação e hipótese. Restou essa única imagem e salvo novos dados não nos é possível outras afirmações sobre isso. Mas ela informa um pouco mais: os tabiques e subdivisões do Solar, originais ou não, aparecem aí, e foram demolidos para a liberação total dos salões - térreo e primeiro pavimento.

No MASP, obra que em grande parte foi concomitante com o restauro do Solar do Unhão, ocorre o mesmo desvio de olhar, de modo parecido com o que ocorre com a escada. No conjunto suspenso, chama a atenção o travessão superior Lina chama -, como se o conjunto pilares-travessões pendurassem todo o conjunto, o que não é verdade: a viga superior suporta exclusivamente a cobertura da Pinacoteca, que é um salão inteiramente livre, até todo o perímetro. A viga principal do conjunto corre dentro do primeiro andar, suportando ao mesmo tempo, o piso da pinacoteca e o desse primeiro andar, neste caso, pendurando-o. Sob essas vigas principais - uma dupla, paralela - ocorrem os corredores de acesso às diversas salas administrativas do MASP, sem que ninguém as veja, exceto no saguão e no ponto de chegada da escada monumental, em "L". No entanto há olhos que não vêem!' Muita gente pensa que a laje de baixo está pendurada pelos caixilhos, mas isso, já vimos, era mais dificuldade do que auxílio.

\footnotetext{
${ }^{9}$ LE CORBUSIER. Por uma arquitetura. São Paulo. Perspectiva, p. 67, 1973. (...) Nossa época fixa a cada dia seu estilo. Ele está aí sob nossos olhos. Olhos que não vêem. E também em: LE CORBUSIER.

Precisões. São Paulo. Cosac \& Naify, p 222, 2004. Você abre os olhos? Está treinado para abrir os olhos? Sabe abrir os olhos, abre-os frequentemente, sempre, bem? O que você observa quando anda pela cidade? (...) 


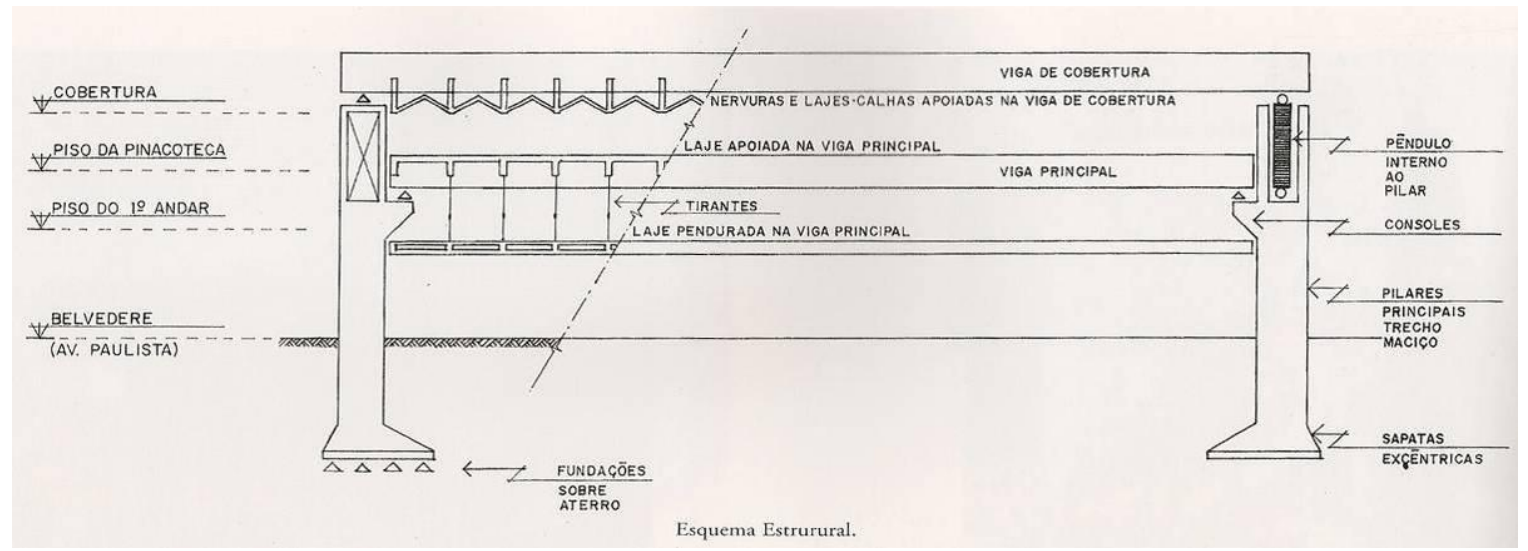

Figura 25. Corte esquemático do sistema estrutural do MASP.

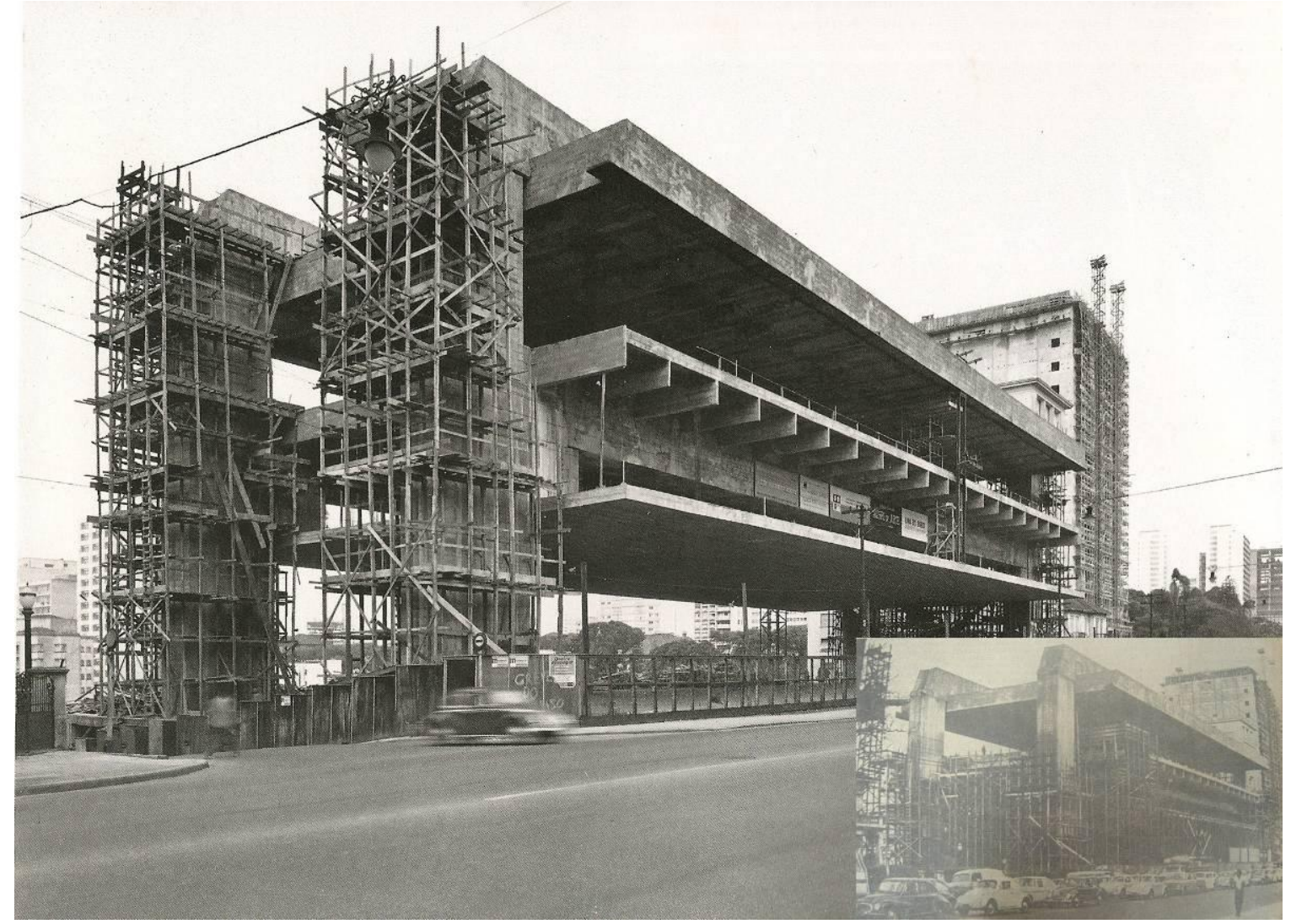

Figura 26. O MASP em obras. Sem os caixilhos, vê-se perfeitamente a dupla principal de vigas, no interior do prédio. 


\section{JANELAS VERMELHAS}

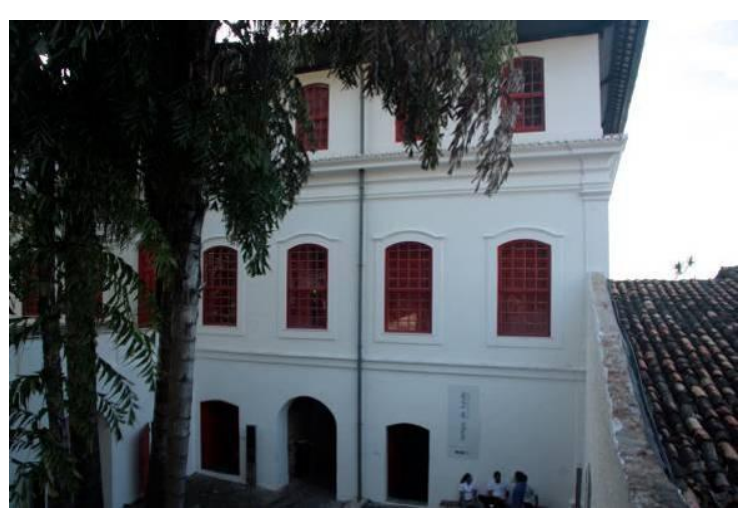

Figura 27. Guilhotinas por fora, escuros por dentro.

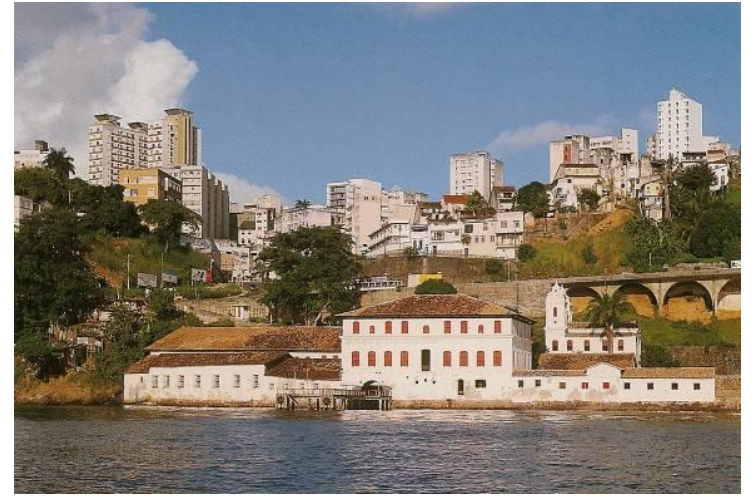

Figura 28. Vista do conjunto a partir do mar.

O Solar manteve o nome do primeiro morador fixo Pedro Unhão Castelo Branco - constando em algumas informações como desembargador e também provedor da Santa Casa de Misericórdia no ano de $1693 .{ }^{10}$ Segundo Coelho Filho, até então, o que poderia ser a cidade, estaria muito ligada à Fortaleza do Salvador, portanto parece que o período de ocupação desse trapiche, como a princípio chamou Lina, tem indícios convincentes. ${ }^{11}$

Consta também que a propriedade foi vendida 10 anos depois, 1700, para José Pires de Carvalho e Albuquerque - o velho -, que ali estabeleceu morgado para Salvador Pires de Carvalho e Albuquerque, primogênito, passando por um período de bonanças, ainda com o comércio de açucar. A primeira referência documentada à existencia da igreja, então devotada a Nossa Senhora da Conceição, data de 1740, por ocasião do batizado de uma de suas netas, o que é mais uma demonstração da punjança financeira desse período. Além da casa-grande e da igreja, uma série de outras construções se aglomeravam pelo sítio, como galpões vinculados às atividades econômicas, a senzala, o extenso cais com o guindaste, o pier, etc. ${ }^{12}$

\footnotetext{
${ }^{10}$ PIRES, F. T. F.; GOMES, G. Antigos engenhos de açúcar no Brasil. Rio de Janeiro: Editora Nova Fronteira, p. 136, 1994.

${ }^{11}$ COELHO FILHO, L. W. A fortaleza do Salvador na Baía de Todos os Santos. Salvador: Secretaria da Cultura e Turismo, 2004.

${ }^{12}$ PIRES, F. T. F.; GOMES, G. Antigos engenhos de açúcar no Brasil. Rio de Janeiro: Editora Nova Fronteira, p. 136, 1994. 
O s1t10 $f$ menoionado desde fins do s6oulo XVI, oonhooldo por " R Rboira de Gabriel Soarea " O oroniata da " Hotiola / do Mrasil ", seu primoiro dono, que o logou ao losteiro de São Bento: " E terra que tonho valsde no caninho da vila $V_{2}$ 1ha, de bande do mar...".

O estabelooimento aparece durante o s6culo XVII, tornan do-no conhooido por "Quints do Unhão", nomo do sou propr1ot đ́rio àquela 6poos, O desembargador da relagão da lahis, PQ dro Unhâ̄o de Caate10 Branco, oelobrisado através das af́tirm de Grogorilo de Katos.

Na primoira motade do setecentos passe a propriodade para Jose P1res de Carvalho o Albuquerque, fidalgo da Gasa Roal o Pamiliar do Santo offolo, que al fixou residênois of ing tituiu un morgado dos seus bena, no qual fol bem sucedido por seu primogênito, Aleaide- Wir da Mahis, Salvador P1rea de Car valho o Albuquerque, sucodido por oua vez pelo segundo José PIres do Carvalho o Albuquerque, seu filho, Cap1täo-llor de la hia, que inioia a faae induatrial na propriednde, protondendo " obter privilibgio de descascar arroz num ongenho do figua - bestas, que pretendia construir om sue quinta do Unhão à /

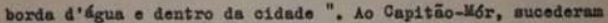
no dominio da propriedade, neu sobrinho o genro, de 1 gual no mo, Secretário do Batado o Ouerra do Braeil, que dronou o plin tano exiatente na encosta e fes oncanar as aguas "... de un $\underline{6}$ tho dela de que o povo se servia", (vilhena).

Ao iniolar-ae o oitocentos, aeu dono 6 O Cel. Antônio dos quill P1res de Carvalho o Albuquerquo, também Secrotário do Ri

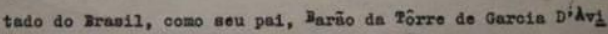
1a,

primeiro de afrio doe titulares braelleiroe,

Wudando rea1dêne1a para o Crusoiro de São Yrano1sco, alı gou a Quinta ao suigo Auguato Froderioo do llouron, titular in f1rma louron \& C1a, 1nduatris de rap6, que permaneceu, auced1 de por Borrel a C1a., at6 1926. Antea, em 1917, mudou de dono, vendids que fol ao Dr, Clemente Finto de Oliveire Mendes, que por sua vez, a vendeu, em 1928, ao negociante Valeriano / Porfirio de Sousa.

Tranaformado en trapiche de inflambiveis da Standard 011 , aob a denominação de Trapicho Sta. Iuzia, aerve, durante a II Guerra Xundial, como albergue de nfufragos de navios torpedeados o posteriormente, quartel de IV Companhila de husileiroe Hava10, Io aṕa guerra, volte a abrigar atividades induatriats, com o funoionamento de fóbrios de aubprodutos de cacau da firme Joanes Induatrial. Retirando-ee essa para ause novas instalaçōes, voltou a đepboit to de merondorias divereas, sobrotudo 1netioldes, sl6a de fobrica de móve1s, de colohöea, torrofa-

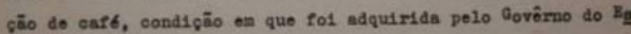
tado o donde so whe.

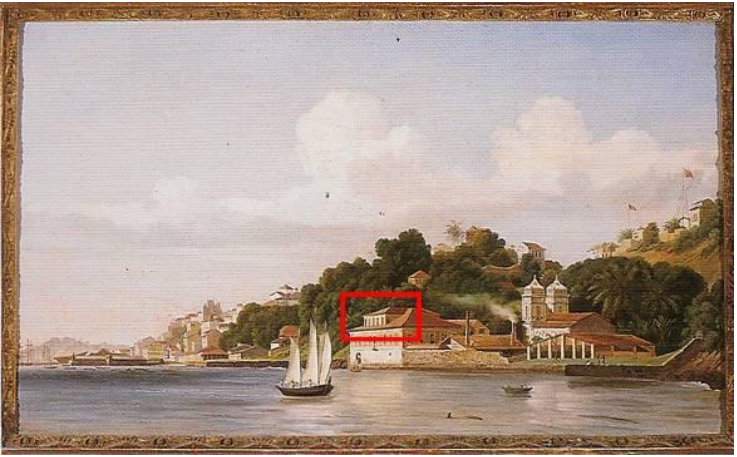

Figura 30. Paisagem da Bahia, com vistas para o Conjunto do Unhão - Pintura a óleo - autor desconhecido - atribuída ao Século XVIII

Figura 29. Documentação levantada por Lina para o início das obras de recuperação do Conjunto do Unhão - "O estabelecimento aparece durante o século XVII, tornado-se conhecido por "Quinta do Unhão", nome do seu proprietário àquela época, o desembargador da relação da Bahia, Pedro Unhão de Castelo Branco, celebrisado através das sátiras de Gregório de Matos." (sic)

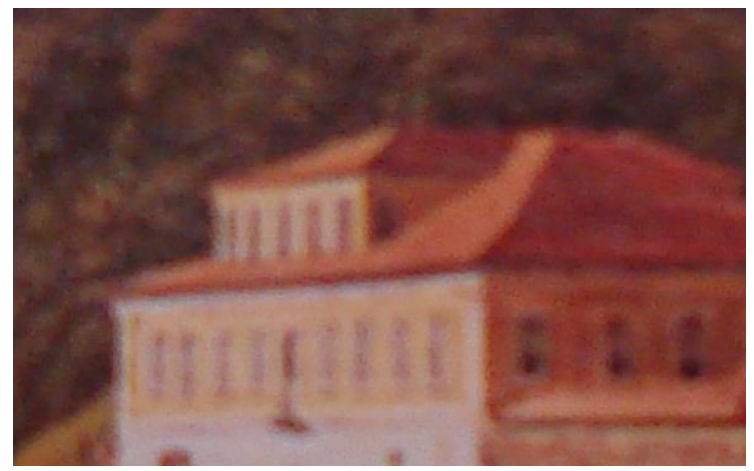

Figura 31. Detalhe da cafua do Solar, na ampliação de trecho da pintura ao lado. 
A pintura registrada como do Século XVIII, mostra o conjunto com seus anexos, muito próximo do que foi preservado por Lina, indicando que as demolições realizadas por ela foram de puxados e outras construções sem importância relativa - isso é sempre arbitrado, nesse caso por Lina, mas com muito fundamento técnico para fazê-lo.

Observando ainda essa pintura, nota-se que o andar superior é representado como uma cafua - sótão -, que ocupa parcialmente a projeção correspondente ao térreo e seu subsolo na mesma projeção, saliente na água principal, afastado das tacaniças. Então, se na pintura houve verossimilhança, a Casa Grande passou por ampliações chegando ao atual primeiro pavimento. Nota-se também a chaminé fumegante, conotação de seu período áureo.

Lina sempre afirmou que os azulejos eram obra dos holandeses, quando estiveram pela Bahia, período muito pequeno, se comparado ao que dominaram Pernambuco. Mas, ao que consta, período suficiente para que fizessem vários diques, dos quais só restou o Dique de Tororó.

Realmente o empreendimento holandês do período, na América do Sul, foi excepcionalmente rico em obras de infraestrutura, benfeitorias e construçõesem relação a todo o período de colonização, inclusive em demais regiões do planeta onde os holandeses estiveram. Mas só um estudo filológico muito profundo - será uma cena de caça? Será São Jorge contra o Dragão ${ }^{13}$ ? - conseguiria provar a origem flamenga desse revestimento que sobrou na ponte do Solar - há sugestões de que muito mais áreas eram revestidas assim, mas já não estavam mais lá muito antes de Lina entrar nessa história, como comprovam imagens antigas. Na maior parte das demais informações disponíveis, os azulejos - bem como o chafariz - são de procedência portuguesa.

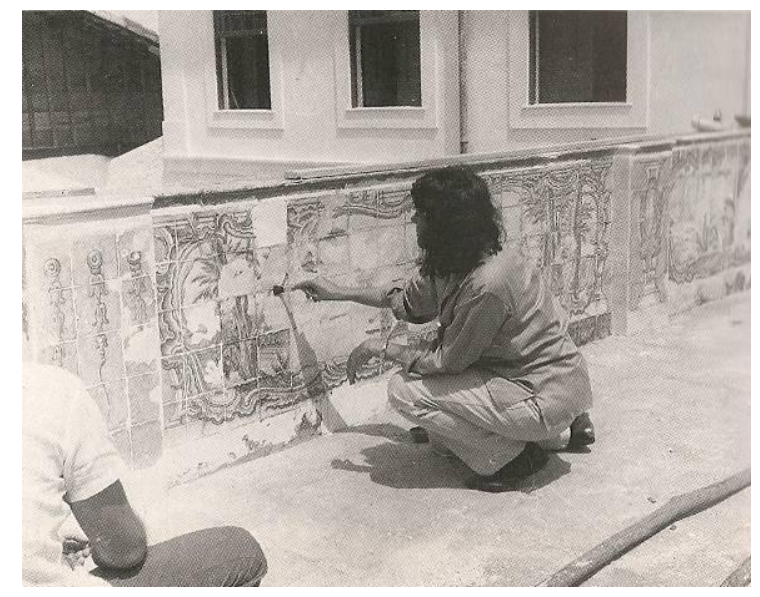

Figura 32. Lina demonstra aos operários os procedimentos na recuperação dos azulejos na ponte de acesso ao Solar.

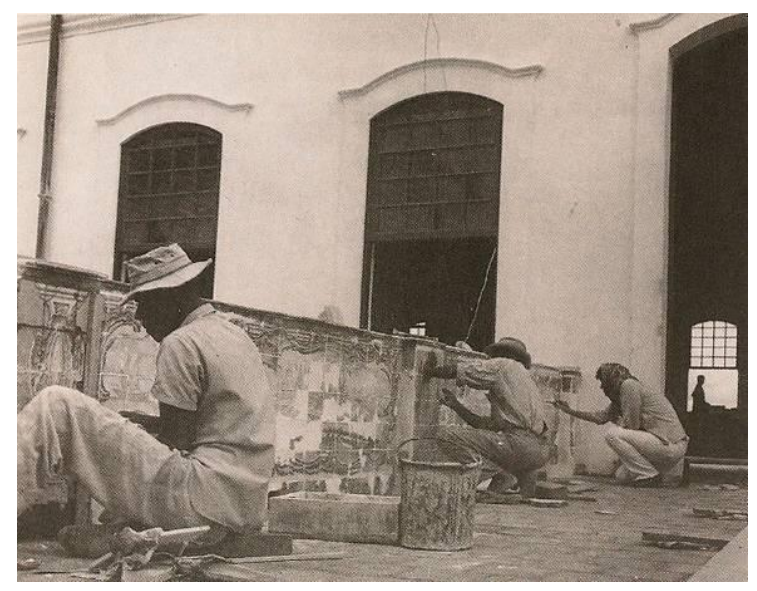

Figura 33. Idem, Lina está ao fundo, junto à porta principal do Solar.

\footnotetext{
${ }^{13}$ BARDI, L. B. Lina Bo Bardi. Marcelo Carvalho Ferraz (org.). São Paulo: Instituto Lina Bo e P. M. Bardi, p. $156,1993$.
} 


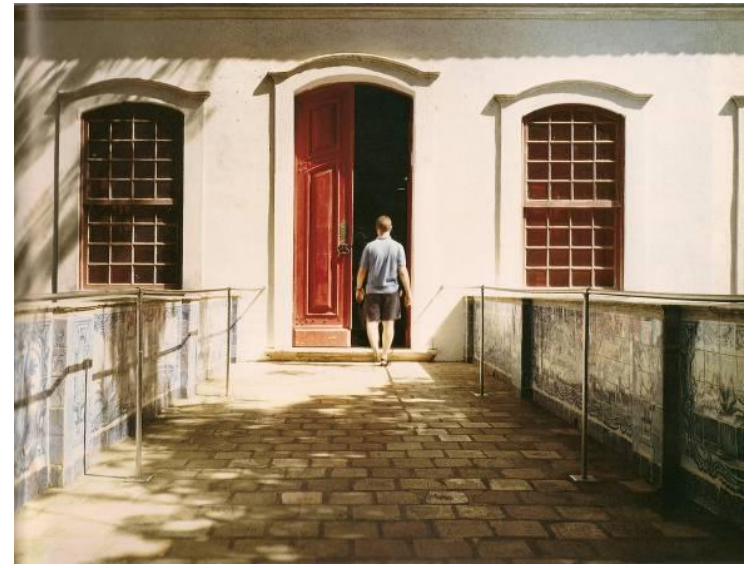

Figura 34. A ponte com os guarda-corpos revestidos de azulejos.

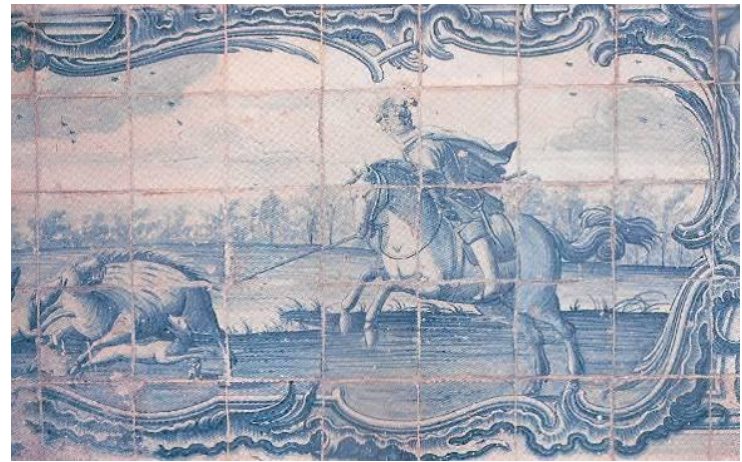

Figura 35. Uma das cenas apresentadas nos painéis de azulejos. São Jorge?

O engenho do Solar do Unhão teve período áureo em meados do século XVIII. Nesta época, a casa-grande recebeu painéis de azulejo português, um chafariz, e a capela foi reedificada para homenagear Nossa Senhora da Conceição. Mas com o declínio da economia açucareira, o Solar foi arrendado, período em que passou por um processo de desgaste. Nas instalações do engenho de açúcar funcionou uma fábrica de rapé, entre os anos de 1816 a 1926, e trapiche, em 1928. O solar serviu ainda de depósito de mercadorias destinadas ao porto e, mais tarde, foi transformado em quartel para os fuzileiros navais que serviram na Segunda Guerra Mundial. ${ }^{14}$ (grifos nossos)

De qualquer modo, quando Lina foi iniciar o restauro, o conjunto estava invadido, tranformado em moradias encortiçadas, o que inclui a capela, utilizada como pensão. ${ }^{15}$

\footnotetext{
${ }^{14}$ Disponível em http://ibahia.globo.com/salvador/solar.asp

${ }^{15}$ ZOLLINGER, C. B. O Trapiche à beira da baía: a restauração do Unhão por Lina Bo Bardi. Porto Alegre: Anais do $7^{\circ}$ DOCOMOMO BRASIL, p. 16, 2007. Quando lemos a declaração de Lina de que «pensou logo em recuperar o Conjunto do Unhão para a definitiva instalação do Museu de Arte Moderna e de um Museu de Arte Popular podemos perceber que o projeto da instalação do Museu de Arte Popular e da restauração doUnhão começaram desde 1959 com o convite do governador para que ela dirigisse o museu. Além do fato de que o projeto de criação de um Museu de Arte Popular e da Universidade Popular, em complementação ao Museu de Arte Moderna, já existisse desde a fundação deste, o projeto de Lina era, desde o primeiro momento, instalá-los no Conjunto do Unhão, segundo seu próprio relato. Assim, não se pode pensar no restauro do Unhão sem entender o que era o projeto do Museu de Arte Popular, pois eles nascem juntos.
} 


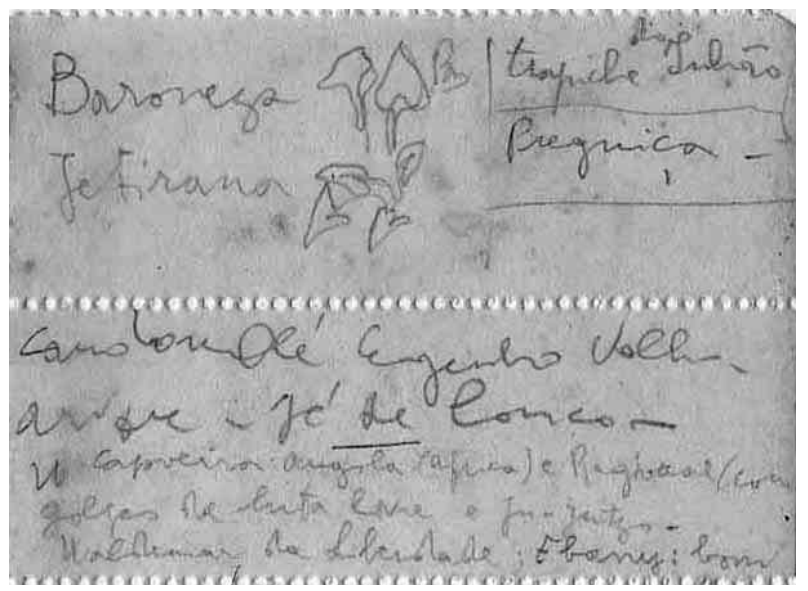

Figura 36. Páginas da caderneta de anotações de Lina: a colagem de informações anotadas indica que são os primeiros contatos de Lina com a Bahia.

Baroneza (sic)?

Jetirana: espécie vegetal ornamental (Ipomeia).

Se Jitirana pode ser o inseto tirana-bóia.

Trapiche do Inhão (sic)

Preguiça: o bicho.

Candomblé Engenho Velho: famoso terreiro em Salvador.

Árvore(?) - Pé de Louco (sic): árvore gameleira branca, pé de loco - ou ainda loko ou iroko.

Capoeira Angola (áfrica) e Regional (com golpes de luta livre e ju-jitzo.

Waldemar (famoso capoeirista) da liberdade (o bairro); (ininteligível): bom

No restauro do Conjunto do Unhão, Lina toma atitudes radicais toma os fatos por suas raízes - e com independência em relação a dados filológicos, que poderiam ser aferidos mais precisamente na época. A demolição da escada - ou das escadas, por hipótese - é a marca de sua vontade de transformar os espaços disponíveis em algo utilizável contemporaneamente. É sua idéia de Presente Histórico, que por sua vez tem base na proposição de Restauro Crítico, contrapondo-se - ou melhor, evoluindo - a de Restauro Científico que aprendera com o Mestre Giovannoni desde a sua graduação,.$^{16}$

Na nota IV de seu texto Tempos de Mistura, Comas, coloca: Os preceitos do restauro "filológico", defendida por Camillo Boito (1836-914) foram incorporadas à Carta de Atenas (1931) e à Carta Italiana del restauro (1932)e promovidos por Giovanni Giovannoni (1873-1947) como "restauro científico" . Giovannoni foi professor de Lina. ${ }^{17}$

Durante muito tempo consideramos que o Conjunto do Unhão não era tombado pelo SPHAN, e fora tombado depois da obra de Lina.

Em grande parte essa suspeita provinha do quão diferente era esse restauro de todos os demais que conhecíamos, tal o vigor das proposições nele contido. Em parte também porque Lina, na medida em que perdia os trabalhos - quase sempre pelos mesmos motivos: inconformidade das diretrizes político-ideológicas com os comitentes - procurava pedir o tombamento, como última tentativa de salvá-los: assim foi no MASP, tentativa de evitar que fosse cercado de prédios muito altos a sua volta, ou que sem o Professor, já em idade avançada, mexessem muito no prédio (sem o Professor tiraram o piso em pedras Goiás e assentaram um granito polido, chinfrim, e desativaram a

\footnotetext{
${ }^{16}$ GIOVANNONI, G. Questioni di architettura nella storia e nella vita: edilizia - estetica architettonica ristauri - ambiente dei monumenti. Roma: Società Editrice D'Arte Illustrata, 1925. Ver também em: BARDI, L. B. Contribuição Propedêutica ao ensino da Teoria da Arquitetura. São Paulo: Instituto Lina Bo e P. M. Bardi, p 51 e 52, 2002.

${ }^{17}$ COMAS, C. A. Três variações sobre a domesticidade e a transparência no pós-guerra. Arquitexto 8, 2006. 
escada principal, entre outros desatinos). Foi também assim no SESC, quando foi mandada embora pela diretoria, iniciou as tentativas de tombamento, hoje conquistado, junto ao CONDEPHAAT; e com a Casa de Vidro, ela e o Professor tomaram a iniciativa da solicitação, hoje também tombada pelo CONDEPHAAT e em processo junto ao IPHAN. No entanto, o Conjunto do Unhão era mesmo tombado, desde $1943 .{ }^{18}$

A escada principal do MASP, em "L", merece pausa para uma reflexão: Lina tinha feito vários outros estudos de escadas, sempre nessa posição assimétrica em relação ao volume, ocupando a ponta voltada para o bairro do Paraíso, juntamente com o elevador e a escada que desce para o Hall Cívico, que já apareciam mais definidos nos desenhos. A escada principal, não, foi objeto de vários estudos diferentes até que vão se definindo na direção da que foi edificada, já com as obras em andamento. Mas, sem se deter na análise das versões anteriores, e atentando na que foi construida, e está lá, desativada, observemos o seguinte: de todas as versões aventadas, é a que se encaixa mais perfeitamente na modulação transversal das nervuras - vigas tranversais -, da estrutura do edifício. Os lances perpendiculares à Avenida Paulista só se sobrepõem entre o que desce para o Hall Cívico e o que vai do primeiro pavimento para a Pinacoteca, ficando, portanto, um vácuo nessa prumada.

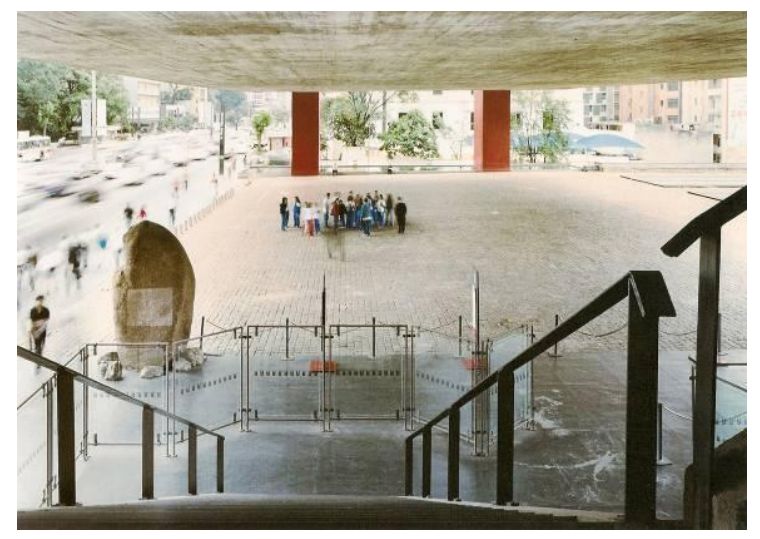

Figura 37. Vão do MASP -70m. O enorme sofito visto do patamar da escada principal.

A escada principal tem o primeiro lance que parte do próprio belvedere, paralelo à avenida, gira em 90 graus no patamar, giro apoiado em um pilar placa, da largura da escada inteira, e que está na exata posição da modulação das nervuras. O giro de 90 graus encaixa o segundo lance entre a segunda e terceira nervura, pega, obediente, a modulação, adentrando no vão, buraco escavado no sofito da grande laje do belvedere. O segundo lance está exatamente sobre a prumada da escada que vai para o Hall Cívico. O lance que interliga os andares já internos ao prisma suspenso foge dessa prumada, adentra por outro buraco escavado na laje do piso da Pinacoteca, entre a primeira e a segundo nervura. Nessa disposição, os diversos lances constituem um

\footnotetext{
${ }^{18}$ De acordo com a publicação do IPHAN com título Bens móveis e imoveis inscritos nos livros do Tombo do Patrimônio Artístico Nacional (Brasília, 1982), o tombamento do conjunto do Unhão data de 16.09.1943, conforme processo n. 279-T, Livro Histórico, fls.37, e inscrição n.288-A, Livro de Belas Artes, fls.61.
} 
percurso com variações de trajetos possíveis, não constituindo uma racional prumada de circulação vertical.

Na fragilidade das críticas - veladas, algumas apócrifas, outras não - dos arquitetos paulistas, grande parte delas divulgada pelos integrantes da Escola Paulista e da FAU-USP, diante de obra de tal monta, o MASP na Paulista, a escada foi $\underline{o}$ alvo: diziam que eram inadmissíveis escadas em " $\mathbf{L}$ ", dentro dos princípios da arquitetura moderna, que isso era um erro grosseiro, etc. Omitiam, assim, as belas escadas em " $\mathbf{L}$ " de Mies e de Aalto - que conheciam, sem dúvida.

O primeiro patamar oferecia um último vislumbre da vegetação do Parque do Trianon, do vale da Avenida 9 de Julho e dos arranha-céus da Paulista, logo antes de girar e projetar-se para penetrar a laje crua. A pedra comemorativa e o poste de informações tomavam o lugar da árvore que crescia, os pilares substituíam os tubos, mas ainda conspiravam contra a horizontalidade dominante com o corpo humano em movimento. Metal preto e vidro temperado junto à pele eram um alívio bem-vindo depois de tanto paralelepípedo e concreto aparente ${ }^{19}$, descreva Comas.

No entanto, era no trajeto ao contrário, descendo pela escada do MASP, que acontecia o encanto. O usual para qualquer um era ter visto e se surpreendido com o grande vão, em seguida subir pelo elevador, visitar o maravilhoso acervo, mas quando se retornava - como era comum então, não se esperar o elevador para isso tomar a escada em rota de descida. Quase todos os visitantes paravam no patamar, pois como a mudança de direção para o lance de baixo obriga a virar para a posição paralela à Avenida Paulista, a meia altura - 3,50 metros de altura - deparavam-se com o imenso sofito. Abriam bolsas e sacolas, novamente, para se retirar dali suas máquinas fotográficas e registrar o acontecimento. Dramático - teatral - como queria Lina, como se um viajante que se vai desse uma última olhada de adeus do convés de um navio. Ficávamos observando isso acontecer, confirmar o efeito; hoje, com a escada desativada não se vê mais a cena. Basta reativá-la. Pela descrição da pressa com que Aldo van Eyck esteve no Brasil, em 1968, em companhida de Joaquim Guedes, esse detalhe passou-lhe desapercebido, embora a escada da Casa de Vidro tenha sido contemplada em seus comentários.

Mas voltando à questão de que tratávamos, dos primeiros tombamentos de obras modernas feitas pelo atual IPHAN: a Capela de São Francisco, na Pampulha, tombada em 1947, emergencialmente pois a igreja católica queria demolí-la. O Catetinho, em Brasília, foi tombado em 1959. A Catedral de Brasília em 1967, por motivos semelhantes aos da Capela da Pampulha. O Plano Piloto de Brasília, como um todo, em 1990, mas desde 1987 considerado Patrimônio da Humanidade. O MASP teve

\footnotetext{
${ }^{19}$ COMAS, C. E. Três variações sobre a domesticidade e a transparência no pós-guerra. Arquitexto 8, 2006. Disponível em: <http://www.ufrgs.br/propar/publicacoes/ARQtextos/PDFs_revista_8/ 8_Carlos\%20Eduardo\%20Comas.pdf>. Acessado em: 26 jun. 2009.
} 
seu acervo tombado em 1969 e o edifício é tombado pelo CONDEPHAAT, em 1982, e só em 2003, pelo IPHAN.

Invariavelmente os motivos dos tombamentos foram defensivos contra malfeitorias contemporâneas, incluindo dois equívocos de Niemeyer, em Brasília, o primeiro deles Lucio conseguiu mudar de lugar, do segundo Maria Elisa acompanhada de inúmeras outras manifestações - conseguiu que ele desistisse. (ver Anexo IV)

Lina dizia que tinha tido uma autorização especial de Rodrigo, Rodrigo Mello Franco de Andrade, o diretor-fundador do ISPHAN, e sempre repetiu isso como um dado de, que sem interferência superior, o restauro do Conjunto do Unhão não se consumaria. O fato é que logo de início as obras foram embargadas pela Assistencia Técnica da Região - o escritório técnico do SPHAN, à época -, que alegou, ao que parece, a falta de documentos e desenhos sobre o que estava sendo feito.

As obras são reiniciadas depois que chegou a esse escritório um bilhete de Lucio, conforme depoimento do arquiteto Lula:

Quanto ao bilhetinho de L. C. o que posso te dizer é que o vi entre os documentos relativos ao Solar do Unhão, arquivados pelo IPHAN, quando fui atrás de alguma informação que pudesse me ajudar na definição das intervenções que fiz no local visando, melhor adequá-lo às necessidades do MAM-BA, no início de 1993.

Na mesma documentação encontrava-se um breve texto (umas 2 / 3 páginas) datilografado e assinado por Lina, em que ela justificava a intervenção, dizendo tratar-se de um "restauro crítico", muito embora não chegasse, a meu ver, naquela altura, a realmente fundamentar a sua argumentação.

Tratava-se de um papelzinho manuscrito a lápis - possivelmente do início dos anos 60 - em que Lúcio se posicionava pela suspensão do embargo do IPHAN à obra de "restauração" do solar segundo projeto de Lina.

Lúcio não entrava no mérito de avaliar o projeto arquitetônico em si, e apenas focava seus argumentos na importância e ganho social da proposta ao dar ao monumento um uso digno e aberto à sociedade baiana. Afinal, o solar havia sido tombado muitos anos antes, mas até então estava mutilado por vários usos indevidos que o colocavam em franco processo de degradação e consequente risco de desaparecimento.

Em seu pequeno texto, Lúcio também reconhecia Lina como uma arquiteta talentosa, sem contudo se delongar muito neste aspecto.

Não poderia lhe dizer quem mais teria tido acesso a tal bilhetinho depois disso.

Infelizmente, na época, não tive a preocupação em fotocopiá-lo acreditando que estaria "a salvo" por estar arquivado - embora solto - junto a 
documentação relativa ao Unhão, existente na sede do IPHAN aqui em Salvador. ${ }^{20}$ (grifo nosso)

E, assim, com o bilhete de Lucio, a obra continuou: era então um cortiço invadido, um pardieiro, já inteiramente degradado, e, por isso mesmo triste. Caiou tudo de branco. Janelas ensolaradas, todas vermelhas. Não importa se as alvenarias foram brancas e as janelas, provavelmente, azul-real, apelidado de azul-colonial, pintou todas as esquadrias - portas e janelas de vermelho vivo, vermelho-bombeiro, como ela dizia.

Num dado Presente Histórico não há tempo a se perder que justifique a perda do tempo real, diante da visível, inegável, necessidade de mudar pela raiz o problema enfrentado, criar a importância do ganho social.

Sabedora de que o patrimônio brasileiro era uma invenção dos modernos e que estava nas mãos dos modernos, tendo conhecido desde logo o livro Brazil Builds, com o respaldo de seu conhecimento provindo da sua formação na Itália, consciente de que a história do Brasil era muito recente, comparada à vetustez de lá, para Lina caiu como um prato cheio o trabalho de recuperação do Conjunto do Solar do Unhão.

De qualquer modo, importante é que o projeto foi aprovado por uma atitude não ortodoxa do corpo técnico do Patrimônio - quer dizer: Lucio -, ao contrário da postura extremamente rígida e restritiva com que se comportam hoje em dia todos os novos especialistas que atuam nesse campo. É estarrecedor que, ao mesmo tempo em que é bem vinda a expansão da vontade de se conservar bens patrimoniais, por grande parte da população, leiga em geral, exista um retrocesso em relação ao que os inventores do Patrimônio tinham conquistado. Essa nova classe dos especialistas se posta como sabedores de um conhecimento que só eles detêm, e usam isso de uma maneira "conservadora" para avaliar ou aprovar projetos de intervenções novas em edifícios antigos. Perto do que os modernos já haviam conquistado, é uma política retrógrada e arquitetonicamente equivocada. Já vimos isso quanto à gritaria para a remontagem do pavilhão Monroe e a crítica a Lucio. Que, por sua vez, já antevia esse panorama:

\section{(...) Se na generalidade dos casos, a especialização dependia} apenas do deliberado propósito de futuro aperfeiçoamento no rumo escolhido, valendo então o sentido amplo da formação inicial como preventivo contra os riscos latentes da burrice especializada a que se pode eventualmente conduzir a fragmentação cada vez. maior dos vários setores do conhecimento profissional, - com referência à arquitetura o caso era diferente, pois que se tratava e trata de outra coisa. ${ }^{21}$ (grifos dele)

Isso assinala a postura com que Lina propõe e impõe para sua obra: fazer com que o velho Conjunto fique moderno. Poderíamos interpretar assim:

\footnotetext{
${ }^{20}$ Depoimento do arquiteto Luiz Antonio Fernandes Cardoso, Lula (UFBA - Universidade Federal da Bahia e IPAC), por E-mail, em 11 de janeiro de 2010.

${ }^{21}$ COSTA, L. -Arquitetura brasileira - Rio de Janeiro: Serviço de Documentação - Os cadernos de cultura - Ministério de Educação e Saúde - 1952 
- que o velho conjunto continue velho, mesmo restaurado, e não o cenário de algo que pareça velho;

- que o velho conjunto funcione nos dias que correm, e para funcionar necessita de atividades, vida nova, gente. E a proposta para estabelecer seu programa depende do arquiteto;

- que as marcas das intervenções novas fiquem mesmo marcadas, nítidas e contrastadas, tal que fiquem possíveis de ser percebidas por qualquer um, erudito ou leigo no assunto, em qualquer tempo. Que o novo seja muito importante, visível e claro, feita por quem sabe, o melhor arquiteto;

$\mathrm{O}$ item do meio é fundamental para que o anterior e o posterior existam: sem vida, mesmo que seja cenário, inexoravelmente, voltará a entrar em estado de ruína. Sem vida, não vale a pena fazer uma interferência importante. O último item é o mais difícil, ocorrer a conjunção de uma situação importante de restauro ser conduzida por um arquiteto especial, preparado tecnicamente, com conhecimento da história e para um trabalho desse tipo, com o talento e a vocação, de que falava Lucio, já aqui citado.

Do ponto de vista histórico - ou filológico para uma análise mais pormenorizada - há um detalhe importante a se registrar: as construções mais antigas têm os caixilhos - que são esquadrias que seguram, contém, vidros - pelo lado de fora, e escuros pelo lado de dentro. $O$ fato é que as esquadrias, sem caixilhos pois ainda não se dispunha dos vidros à época, já estavam lá. É com o advento e a disseminação do uso de vidros que se passa a instalar caixilhos.

Como os escuros abrem para dentro com grande varredura - o trajeto dela ao longo do movimento de abrir -, não havia como instalar as esquadrias ali, e só restava a solução de colocá-las pelo lado de fora. Nessa época era simbolo de status já possuir janelas - em geral guilhotinas - ostentando os vidros. Centros históricos inteiros ainda demonstram essa sobreposição posterior dos caixilhos, como pode ser visto no Pelourinho, em Ouro Preto, Mariana, e demais sítios onde se encontram edifícios com essa datação aproximada.

Nos Solares, devido aos grandes tamanhos das janelas, e consequente peso, as guilhotinas eram de difícil manuseio, mas a máquina de morar brasileira $^{22}$, os escravos, como Lucio detectou, resolviam o problema de abrir ou fechá-las - ou abanar o sinhô, ventiladores, em dias de muita estiagem. A guilhotina, por sua vez, resolve dois problemas: não sendo em folhas de abrir, não ficam batendo ao vento, com o risco de se quebrar os vidros caros; dispensa as ferragens, bastando as taramelas borboletas - para mantê-la no ponto de parada, quando abertas.

Só em momento posterior, segunda metade do século XVIII, com o item caixilho já constante do repertório coletivo - os preços se tornando mais acessíveis-, passa-se o escuro para o lado de fora e os vidros, mais frágeis, para o lado de dentro - ter

${ }^{22}$ COSTA, L. Depoimento de um arquiteto carioca - 1951 in Registro de uma vivência. São Paulo: Empresa das Artes, p. 160, 1995. 
vidraça ou telhado de vidro passa a ser expressão popular para designar quem é fragil na defesa contra alguma acusação. Nesta linha de evolução, os próprios escuros vão sendo substituidos pela rótulas - gelosias - e mais adiante pelas folhas com venezianas, com paletas - por fora dos caixilhos como ocorre até hoje.

Quando das restaurações propostas para o Centro Histórico Pelourinho - na década de 80, Lina propunha que todas as obras fossem pintadas à cal, e de branco. Dizia - Deixaram ficar nessa situação, eles moram em ruinas, em pardieiros, mas eles têm que morar lá, foram eles que salvaram aquilo, porque foi só assim que a especulação imobiliária se desinteressou... Mas tem que ser a cal, branco, que limpa, como a grande Engenharia Sanitária do século XVIII, início do XIX...Será tudo branco até se consertar, eu não vou fazer a aquarelinha das gravuras, essas gravuras são mentirosas, os pintores inventam umas cores para os quadros ficarem mais bonitinhos... (c.d.m.)

Ela tinha ficado furiosa com o retoque - não-restauro - executado no final da década de 70, chamava de Dona Flor ${ }^{23}$ - por conta do filme, que ela sabia, muito bem, mesmo sem ter assistido, para ela, puro folcklore apressado -, simplesmente arrumando verba para se re-pintar o Pelourinho, disfarçando a dura realidade que ocorria por trás daquelas fachada: - Quando esse pessoal se ajeitar, eles mesmos pintam, da cor que quizer, não vamos nós ficar escolhendo corzinha para cada casinha...Tudo branco e pronto!(c.d.m.)

Desde o Unhão, as reticências e, principalmente, contestações, como o embargo da obra por exemplo, que degeneraram em confrontamentos, foram grandes em relação ao seu trabalho e a essas proposições. As obras da restauração do Conjunto não foram fáceis de se levar a cabo: desde a escada nova assimétrica à pintura vermelha das janelas, foram alvos de críticas pesadas o tempo todo. E isso se repetiu, na volta dela para a Bahia, em meados dos anos 80 .

Hoje em dia, pouquíssimas pessoas - leigos ou não - lembram-se do prédio do MASP com os pilares e os travessões superiores em concreto aparente e sem a pintura vermelha que existe hoje, principalmente os mais jovens. Desde 1968 data da inauguração oficial, mas já dava para ver desde o período da desforma dos moldes - até 1989-1990, portanto durante vinte e um anos, eles foram na cor e natural do concreto.

\footnotetext{
${ }^{23}$ Dona Flor e seus dois maridos, Bruno Barreto. 1976. 


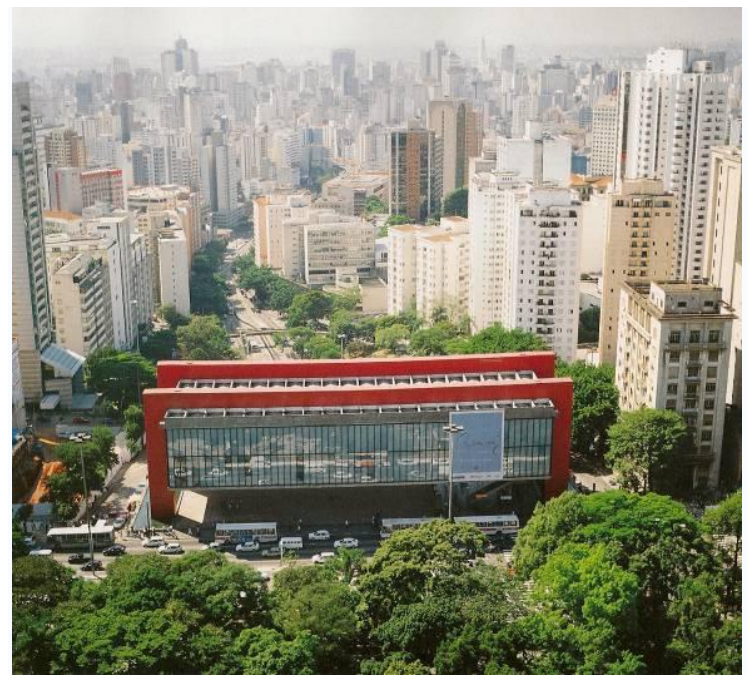

Figura 38. Desde 1990 o MASP ostenta pilares e travessões vermelhos, conforme o projeto original de Lina.

Era quase o final do mandato do então prefeito Jânio Quadros, em 1988, sua última, e como sempre malfadada, presença política entre nós, quando a Prefeitura, atendendo a solicitações do MASP - do Professor - resolve reformar o edifício. Como ele é de propriedade do Município, em comodato para o MASP, alguém decidiu por obras de manutenção no conjunto todo, sem nenhuma consulta à Lina e ao Professor. Como era fim de mandato desse prefeito, o máximo que conseguiram foram embrulhar o MASP naquelas telas, comuns de serem empregadas em obras de recuperação de fachadas, mas alí, absolutamente necessárias com o prédio a prumo sobre a calçada da Avenida Paulista. Não fizeram mais nada, até que na eleição seguinte se reiniciaram tratativas com a equipe da nova prefeita, Luiza Erundina.

O prédio ficou embrulhado por anos, e quando perguntavam o que Lina achava daquilo, ela dizia: Eu gostei tanto que pedia a Pietro, meu marido, diretor do museu, que deixasse o MASP embrulhado de azul para sempre. Ficou bonito como uma das grandes esculturas de Christo. ${ }^{24}$ Mas quando soube pela imprensa o valor com que tinham sido licitadas as obras, no tempo de Jânio, 2 milhões de dólares - à época, uma enormidade -, dizia: Não pode, é melhor demolir esse prédio. Com esse dinheiro todo faremos outro, muito melhor! Ou não? - com o som de $O$ no? (c.d.m.)

Com Luiza Erundina de Souza, Luiza Erundina, a primeira mulher prefeita da cidade de São Paulo, que, então, atendendo ao importante anseio de arquitetos e outros setores da sociedade, lutou pela revitalização do Centro de São Paulo, e iniciara contatos com Lina para restaurar o Palácio das Indústrias, foi possível reverter a licitação anterior e executar as obras de manutenção do MASP. ${ }^{25}$

\footnotetext{
${ }^{24}$ Christo Javacheff, escultor búlgaro. Notabilizou-se por esculturas embrulhos, inclusive embrulhar inteiro o edifício do Reichstag, em Berlim.

${ }^{25}$ Ver o estudo de ALEX MIYOSHI: Entre a origem e a degradação: a primeira reforma do edifício do Museu de Arte de São Paulo. IFCH/Unicamp. Ver também: "Para presente - embrulhado em plástico, o Masp ganha sua primeira reforma". Revista Veja SP. São Paulo, 10 de agosto de 1988, p. 110.; "Dias difíceis do museu empacotado". Revista Veja SP. São Paulo, 22 de fevereiro de 1989, p. 14-20.; "Museu ganha vigas e lajes vermelhas". Revista Projeto. São Paulo, n. 134, 1990.
} 
A flecha que o conjunto sofria estava sendo monitorada havia vários anos e, atingindo cerca de $14 \mathrm{~cm}$, tinha se estabilizado. O principal problema então era a cobertura da Pinacoteca, que apresentava muitos pontos de goteiras, tanto que estava inativa, desocupada, com todo o acervo principal recolhido. Foi feita uma nova e esmerada impermeabilização, mas que não resolveu o problema em alguns pontos, exatamente na junção entre a laje e as vigas, os travessões superiores. Como sempre: Chamem Roberto Rochlitz! (c.d.m.) E Roberto teve uma intuição incrível: aventou a possibilidade de que as vigas estivessem cheias d'água. As vigas são feitas em forma de tubos, ocas, e esse vazio é interrompido, de tanto em tanto, por septos. Se realmente estivesse cheia d'água, teriam que ser esvaziados todos os tanques em que tinham se constituídos os vazios, entre septos. Estudadas as posições dos cabos de protensão, para que não fossem prejudicados, foram feitos furos nas vigas, de baixo para cima, entre os cabos. Jorrou água por dez dias consecutivos, e a flecha voltou um pouco. Roberto tinha razão.

Mas restou um problema, - para nós um problemão -: como falar com Lina sobre impermeabilizar as vigas inteiras, se os produtos disponíveis para tal são, ou pretos, com os produtos de base asfáltica, ou cinzas, de um tom mediano, pobre, ou brancos, mas um branco sujo. Munidos de alguma coragem comunicamos a ela, em sua casa, o que sucedera, mas para nossa surpresa sorriu irônica e disse: - Impermeabilizem e pintem de vermelho, por cima! Sempre foi assim! (c.d.m.) E saiu da sala enquanto, um tanto atônitos pela inutilidade da adrenalina, achamos que ela estava confundindo com o Museu de São Vicente, o qual, em todos os desenhos que tínhamos visto e que foram publicados, tinham os pórticos vermelhos. Mas ela voltou à sala, trazendo um desenho do MASP - da década de 60 - com os pórticos - e os olhos - vermelhos. Disse: - Não me deixaram... Lembrem-se, era 68... (c.d.m.) Ano a partir do qual a barra da ditadura pesou de vez, o ano em que Aldo visitara Lina, no qual ouvira dela - Vá para a Bahia!

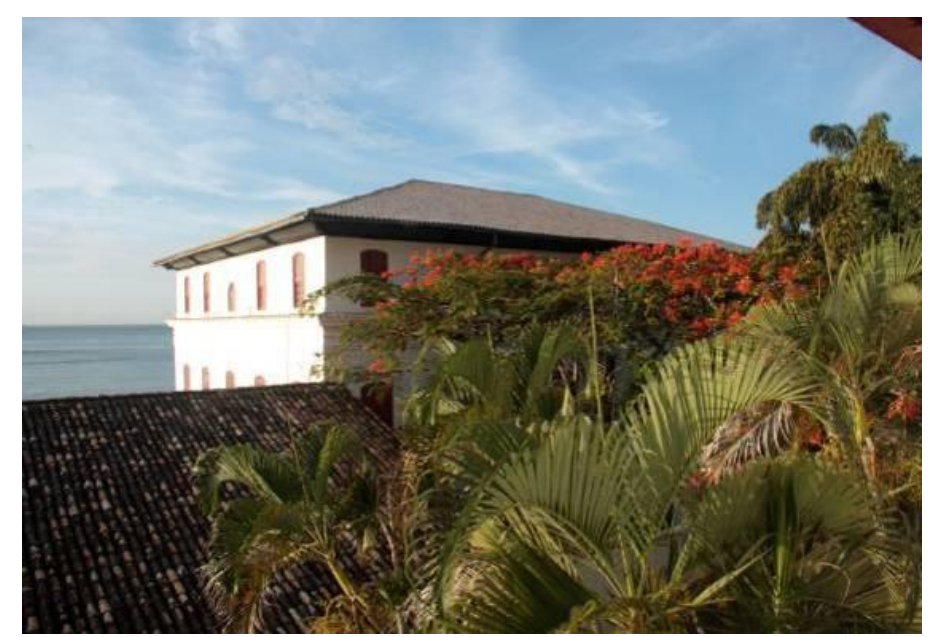

Figura 39. Janelas vermelhas sobre superfícies brancas, ao por do sol da Bahia de Todos os Santos. 


\section{TEMPOS DE GROSSURA}

Já falamos aqui da importância que tanto Lina quanto Lucio davam para o fazer do dia a dia dos trabalhadores manuais - o fazer com as mãos que até o Renascimento tinha relegado como ofício das artes-menores - de todas as origens, que mesclados aqui, deixaram uma herança especial no que havia de mais singelo e pobre. Explicaram muito bem o que entendiam por essa palavra: o contrário do pseudo-requinte das casas ricas.

Com toda atenção, provavelmente acentuada pelo curto período de permanência prevista, Lucio já observa em seu Relatório de 1937, a competente manualidade dos Guaranis, na feitura elaborada dos ornamentos exigidos a eles - e que o fizessem como cópia. E em vários outros momentos ele retoma ao tema de como faziam, esses ou aqueles mestres de obra portugueses, - o velho "portuga" - por exemplo. ${ }^{26}$

Já desde Precisões, Le Corbusier, também - e incrivelmente, para tão curto período que passou na América do Sul - registra as qualidades arquitetônicas inerentes aos fundos - e rejeita as fachadas enfeitadas - das casas construídas por empreiteiros italianos em Buenos Aires:

\section{(...) "Têm uma planta padrão, um jogo de belas formas sob a luz} argentina, um jogo de formas muito belas, muito puras. Observem! Meçam o escândalo que são estes cottages ingleses com seus tetos de telhas, inutilizáveis, com quartos nas mansardas, impondo despesas anuais de manutenção. Os senhores fizeram nascer naturalmente o teto-terraço na Argentina. (... $)^{27}$

No mesmo Precisões, antes ainda, diz: - Desenhei a cabana do selvagem, o templo primitivo, a casa do camponês, e disse: estes organismos, criados com a autenticidade que a natureza mesma infunde em suas obras - sua economia, sua pureza, sua intensidade -, são aqueles que, num dia de sol e de clarividência, toraram-se palácios. Mostrei a casa do pescador, construída com uma verdade aguda, indiscutível; meus olhos, um dia mergulhados na arquitetura, no fato arquitetônico eterno, descobriram-na subitamente. "Esta casa", disse a mim mesmo "é um palácio". 28

Para os modernos o olhar tem que ser carregado de informações prévias, mesmo o desconhecido ou o surpreendente têm que passar pelo intransigente estado de julgamento, não é nunca desprevenido. Com visão de antropólogos, enxergar com atenção o comportamento - os costumes, a cultura dos povos - e agir com e sobre este, alavancá-lo e transformá-lo. Para o intelectual europeu, impregnado do verdadeiro

\footnotetext{
${ }^{26}$ COSTA, L. Documentação necessária - 1938, in Registro de uma vivência. São Paulo: Empresa das Artes, p. 462, 1995.

${ }^{27}$ LE CORBUSIER. Precisões: sobre um estado presente da arquitetura e do urbanismo. São Paulo: Cosac \& Naify, p. 222, 2004.

${ }^{28}$ LE CORBUSIER. Precisões: sobre um estado presente da arquitetura e do urbanismo. São Paulo: Cosac \& Naify, p. 161, 2004.
} 
sentido do Romântico, que, como vimos, abriu as brechas para o Moderno, esse olhar era, no mínimo, interessado, e isso não escapava ao rol de assuntos tratados nos CIAMs.
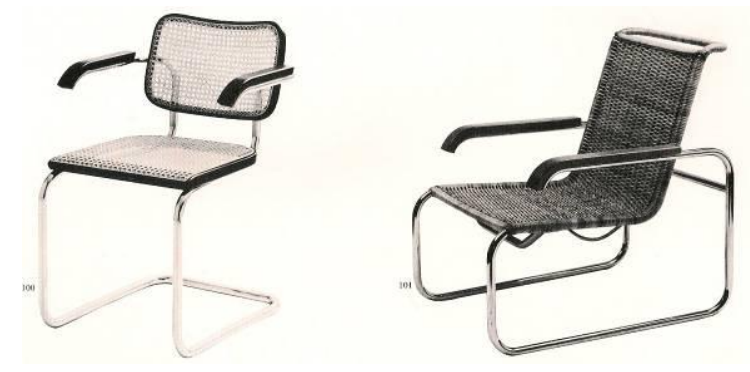

Figura 40. Cadeiras de Marcel Breuer, (1928). O aço inox passa a ser o símbolo da alta industrialização, em substituição ao ferro fundido, que foi o da Revolução Industrial. Mas nessas famosas cadeiras, Breuer utiliza a palhinha e o entramado de fibras - artesanais - como a marca da manualidade do homem.

Com duas obras de grande importância e simultâneas - UNHÃO E MASP - mais o respaldo advindo do Professor - e de Chateaubriand - e, num primeiro momento, do governador da Bahia, Juracy Magalhães, Lina arrojou-se a um projeto extremamente ambicioso: projetar um Brasil. Poderíamos pensar em outro, mas era esse outro Brasil que para ela era real, já existia, estava ali na frente, bastava abrir os olhos que ainda não vêem. ${ }^{29}$ Mas, segundo ela: Não foi um programa ambicioso, era apenas um caminho. ${ }^{30}$ (grifo nosso)

Com esse projeto, Lina tentou aproximar suas pesquisas sobre a produção popular aos trabalhos da recém fundada SUDENE e de seu superintendente, Celso Furtado, no que nunca chegou a ser uma efetiva ligação de colaboração.

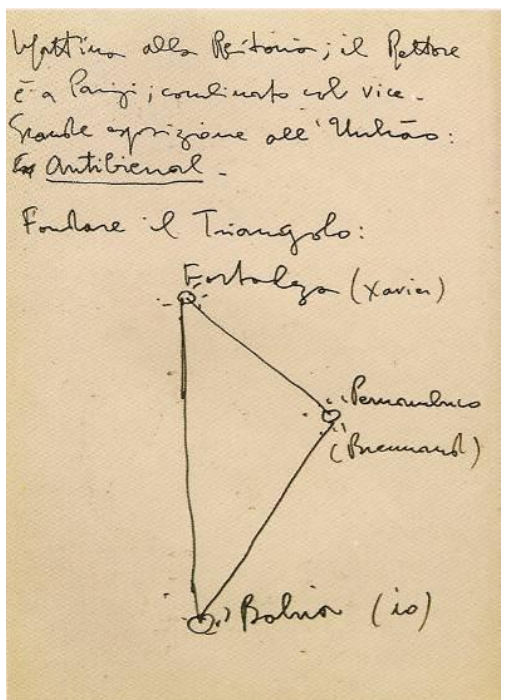

Figura 41. Croquis de Lina para a organização geográfica de seu projeto para o Nordeste - em Fortaleza, Lívio Xavier; em Pernambuco: Francisco

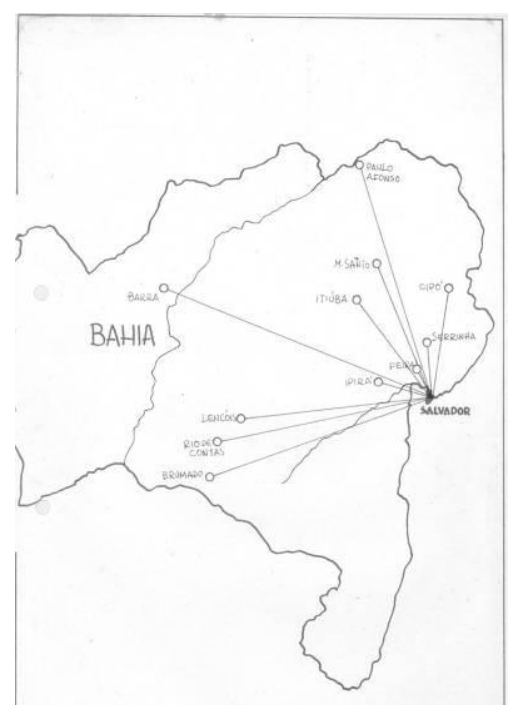

Figura 42. Mapa de desenvolvimento dos trabalhos técnicos na Bahia. Ver anexo V.

\footnotetext{
${ }^{29}$ E suas obras simultâneas, foram também simultâneas à construção de Brasília, que ela defendeu sempre, inclusive brigou com Zevi quando este se pronunciou de maneira desairosa contra Brasília em um congresso internacional: - Você não sabe, se não fosse Brasília, isso aqui seria a republiqueta das bananas... O crítico de arquitetura Bruno Zevi tinha sido seu colega de classe, nos tempos de Roma.

${ }^{30}$ BARDI, L. B. Cinco anos entre os brancos (1967) in Lina Bo Bardi. Marcelo Carvalho Ferraz (org.). São Paulo: Instituto Lina Bo e P. M. Bardi, p. 161, 1993. 
Um resumo do que representava esse projeto é, conforme suas palavras: (...) Pensei no conjunto do Unhão, cuja construção datava do século XVI, que Martim Gonçalves em 1958 quando pensava em instalar nele uma dependência da Escola de Teatro. Consegui do Governo do Estado a desapropriação e a verba necessária à restauração, e oito meses depois, março de 1963, o conjunto estava praticamente pronto; nele iriam funcionar o Museu de Arte Popular e as Oficinas do Unhão, centro de documentação de arte popular (não folklore) e centro de estudos técnicos visando a passagem dum pré-artesanato primitivo à industria, no quadro do desenvolvimento do pais.(...) O Museu de Arte Popular do Unhão pertencia ao Museu de Arte Moderna da Bahia e tinha como programa o levantamento do artesanato (pré-artesanato) popular de todo o país.

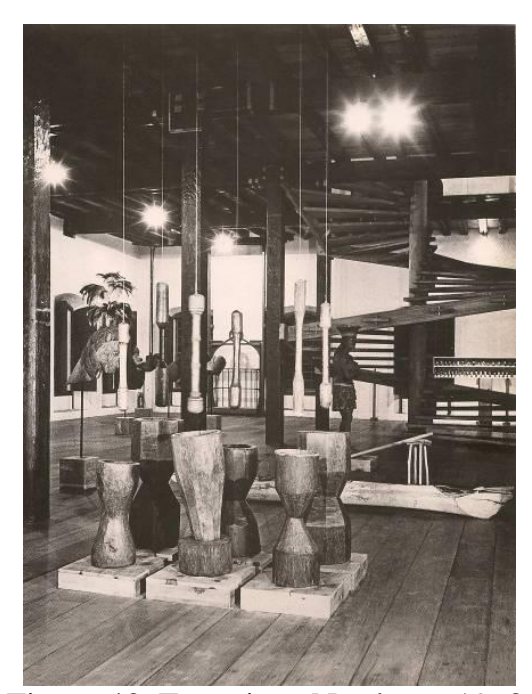

Figura 43. Exposição Nordeste, 1963.

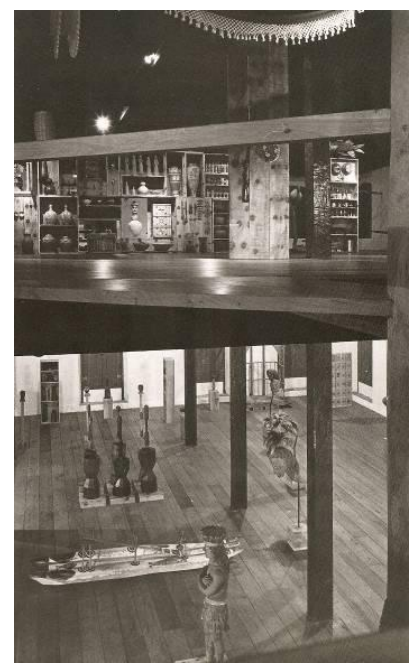

Figura 44. Idem

Não cabe aqui entrar nos detalhes, seja da transferência do MAMB do foyer do Teatro Castro Alves para o Conjunto do Unhão, nem do fim dessa experiência de Lina, com o golpe militar de 64, já bastante estudados e objeto de muitas pesquisas entre nós - e que avultam pelo interesse que tem despertado -, conforme constante nas referências.

Apesar dessas vicissitudes, Lina não abandonou o caminho, pelo contrário, continuou a lutar por ele: sua presença enquanto programadora cultural no SESC - Fábrica da Pompéia, de 1982 a 1986, foi a reafirmação de sua postura, assim como os trabalhos realizados no Centro Histórico de Salvador, na segunda metade da década de 80 , trilharam no mesmo sentido.

Sua visão sobre o pré-artesanato tem muito do sentido de se demonstrar a inteligência e a capacidade criativa para superar dificuldades, de forma tal que dessa demonstração pudesse nascer um caminho próprio, brasileiro, para o país se 
desenvolver. É com esse sentido que Lina contestava as proposições da indústria contemporânea onde a obsolescência dos produtos estava sendo substituída pelo descartável, no consumismo de inutilidades e supérfluos como gadgets, a hipocrisia intelectual contida nas expressões kitsch e folklore.

É nesse sentido, do elogio à inteligência, que Flavio Motta disse:

A lâmpada, na lamparina, não interessava ao consumidor da "lamparina" como lâmpada. Está ali como reservatório de vidro. Perdeu sua significação de lâmpada. Os consumidores de lâmpada não sabiam o que fazer com ela e deitaram-na fora. O produtor que não sabia o que fazer com um a lâmpada enquanto significando lâmpada, soube criar uma nova significação para ela. E pretendia que seu trabalho - a lamparina - fosse valorizado, respeitado, usado e consumido - pelo menos como resultado de sua atividade em organizar um pequeno universo de peças, aliadas às exigências gerais da vida, num ambiente de pobreza, mas, mesmo assim, com a indispensável criatividade. Isso não consagra uma estética do lixo, uma estética da pobreza, muito a gosto do "terceiro-mundismo". Mostra tão somente que a área de ocupação de uma determinada maneira de organizar a distribuição, a produção e o consumo nem sempre atinge toda a população. E isso afirma a capacidade humana do apesar de. Não justifica a pobreza, a incapacidade ou impossibilidade de trabalho socialmente necessário. ${ }^{31}$ (grifo nosso)

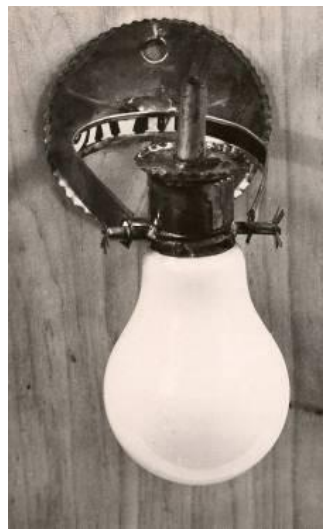

Figura 45. Fifó, candeeiro, lamparina. Feito com lâmpada queimada e latas velhas. Esse exemplar é de múltiplo uso: de parede ou de mesa

O excesso, o consumismo, o descartável, o lixo, tudo agora passa a ser intensamente debatido e questionado, assim como as preocupações com o clima e com a sobrevivência do planeta como um todo; reciclar passa a fazer parte da rotina de mais e mais pessoas, embora se consolem com o discurso - superficial - do slogan do sustentável. Mas é impressionante a atualidade do pensamento dos intelectuais aqui citados, antecipando com proposições efetivas as preocupações com ecologia.

Uma das possibilidades contidas no projeto de Lina é que se desenvolvesse uma linguagem de design - que talvez nem passasse pela mesma trajetória

\footnotetext{
${ }^{31}$ MOTTA, F. Textos informes. São Paulo: FAU-USP, p. 3, 1973. 
do industrial design - partindo de uma matéria mais bruta, menos lapidada, e que daí surgisse algo totalmente diferente. Foi dessa matéria bruta que veio o lampejo da arquitetura moderna brasileira: Diamantina, como vimos. Não foi Barroca, de Aleijadinho, mas foi também: tanto que a crítica - a pró e a contra - apontou o barroquismo. Não é independente, aprendeu direto na fonte - Le Corbusier -, é, portanto, internacional.

A possibilidade de utilizar essa matéria pura - ainda em estado bruto, sem lapidações - como dado moderno ocorreu a muitos e vive sendo tentada, inclusive a idéia de se integrar designers formados nas escolas com os artesãos práticos, para o desenvolvimento de um trabalho em comum. Mas quase sempre sem sucesso, o resultado é de nível abaixo do esperado, além de, como dizia Lina, estragar os artesões. Descaminham. Para isso, a presença de alguém como ela, que direcionasse a visão das equipes para o como fazer, sensível e tecnicamente, sempre se fez necessária.

Assim como o despontar da moderna arquitetura brasileira não é barroca, mas é também, o barco que Amir Klink construiu não é uma jangada, mas é sim. Como ele relatou:

(...) Eu não parava de pensar na genialidade das jangadas cearenses de piúba ${ }^{32}$, infelizmente já extinta. Duvido que um engenheiro da NASA, usando os mesmos materiais, sem usar uma só peça de metal, lograsse construir um barco para orçar, como aquelas jangadas, até quarenta graus de contravento. Sem usar leme, que elas de fato não têm, ou metal, nem na âncora. Imensos mastros de pedaços de gororoba emendados com linha e mais resistentes que um moderno de fibra. Estranho mesmo esse mundo das modernidades tecnológicas, onde se emburrece tão rapidamente. Onde tão rapidamente se perde a sabedoria do simples.

E ele continua, na legenda das ilustrações:

A morte da jangada de piúba e a passagem para a de tábuas deram origem a uma embarcação igualmente revolucionária em desenho. A atual jangada cearense usa com maestria conceitos que projetistas modernos têm dificuldade da aplicar: estabilidade de forma, mastreação autoportante e flexível, perfil variável de velame... Dispensa portos e abrigos, encalha na praia, é simples e genial. Todos os dias cruza a arrebentação de um litoral difícil, numa navegação que a nenhum outro tipo de veleiro é permitida. ${ }^{33}$

Se Lina esteve quase - mas não totalmente - sozinha em sua proposta, o caminho apontado por ela existe, real, possível de ser detectado, como o barco que fez o - aí sim - absolutamente solitário viajante Klink, por exemplo.

Na exposição NORDESTE, que inaugurou o Museu de Arte Popular em 1963, Lina expôs, junto a inúmeros outros objetos do cotidiano do Nordeste, principalmente do Sertão, as redes penduradas muito altas e inacessíveis, para serem

\footnotetext{
${ }^{32}$ Piúba ou Timbaúba (Apeiba Tibourbou) da família das Tiliáceas.

${ }^{33}$ KLINK, A. Linha-d'água. São Paulo: Companhia das Letras, p. 69, 2006.
} 
olhadas de um ângulo improvável, ou para usar a expressão de Caetano, insuspeitadas. ${ }^{34}$ Apresentavam muito mais o trabalho manual de sua feitura, principalmente da trama de suas varandas, do que a imagem do costumeiro objeto visto no ângulo habitual.

Os demais objetos pobres eram apresentados de maneira também pobre, mas com fortíssima elegância expográfica - o que transforma o sentido de pobre para Lina -, perfeitamente amalgamada ao Solar do Unhão. Expor objetos do uso cotidiano assim, deslocados, ready-made's em museus e galerias foi uma proposição das Vanguardas.

No texto de abertura da mostra, Lina escreveu:

Esta exposição é uma acusação.

Acusação de um mundo que não quer renunciar à condição humana apesar do esquecimento e da indiferença. É uma acusação não-humilde, que contrapõe às degradadoras condições impostas pelos homens, um esforço desesperado de cultura. ${ }^{35}$

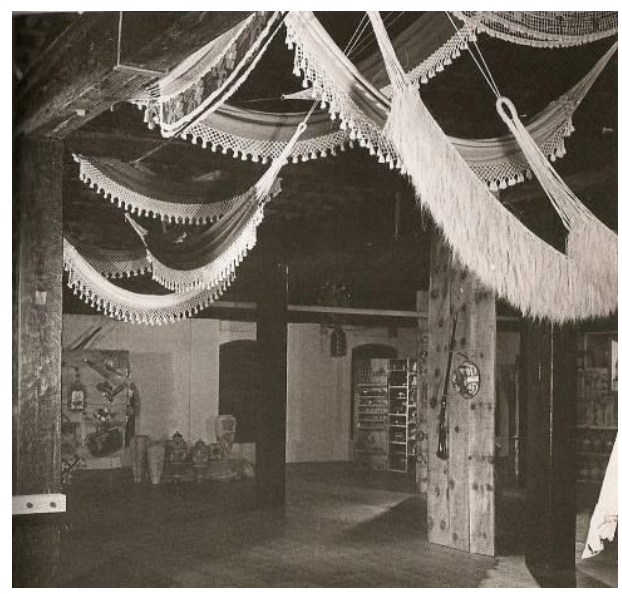

Figura 46. Exposição Nordestes, 1963

No stand do Brasil na XIII Trienal de Milão, 1964, Lucio toma a direção exatamente oposta:

Bastará apresentarmos ali um ambiente de estar "mobiliado" apenas com redes - cerca de 14 - e alguns violões dos mais singelos, ambiente este destinado a acolher o inevitável cansaço dos visitantes da exposição, e que, por sua indole, despertará fatalmente a curiosidade de todos. (...) À guisa de dossel, haverá um conjunto de faixas amarelas e brancas penduradas e, sobrepostas a elas, letras altas e verdes convidarão o visitante a repousar: RIPOSATEVI. (ver Anexo VI)

\footnotetext{
${ }^{34}$ CAETANO VELOSO: O estrangeiro, 1989.

${ }^{35}$ BARDI, L. B. Lina Bo Bardi. FERRAZ, M. org. São Paulo: Instituto Lina Bo e P. M. Bardi, p. 158, 1993. 

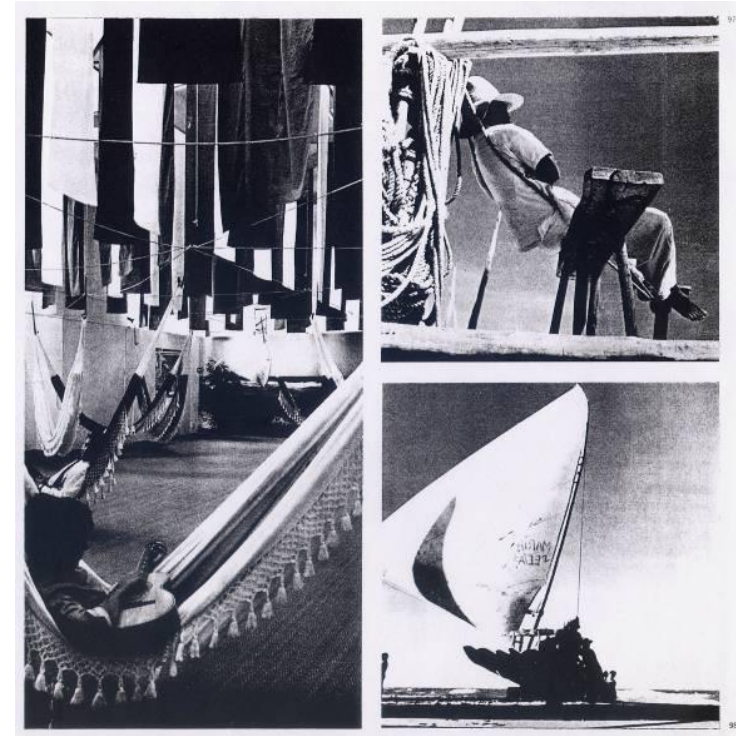

Figura 47. XIII Trienal de Milão, 1964. Página do catálogoVer Anexo V. Os painéis que foram expostos eram grandes ampliações de fotos de Marcel Gautherot: dentre eles, com imagens do jangadeiro e da jangada de piúba, citada por Klink. Mostrava também imagens de Brasília.

Ou seja, na Trienal, Lucio põe redes para serem usadas e não para serem vistas e insiste nisso - incentiva - com o letreiro de grande tamanho: é para usar descansar; e os violões para tocar. Poderíamos emendar essa proposição com outra colocação de Lucio:

Restez chez vous - Fiquem onde estão. A construção de Brasília no cerrado deserto, a mil quilometros do litoral, provocou, de início, um movimento geral de simpatia no estrangeiro, ainda mais que sua arquitetura despojada, elegante e inovadora, até mesmo algo insólita, surpreendia as pessoas.

Em seguida, começaram a "snobar" a cidade, acusada de ser uma oportunidade perdida porque - entre outras falhas - a população pobre estava mal alojada. Como se por uma simples transferência de capital o urbanismo pudesse resolver os vícios de uma realidade econômico-social secular. Como se o Brasil não fosse o Brasil $(\ldots)^{36}$

Riposatevi, relaxem, fiquem onde estão.

Numa carta de Lina a Celso Furtado, superintendente da SUDENE, na qual, sabedora de uma exposição a ser organizada no exterior pelo Itamaraty, colocase na posição da pessoa a ser indicada para tal evento - a data à mão, sobre a carta, indica 5 de abril 1964. Sua carta tem uma resposta lacônica de Celso Furtado, datada do mesmo 5 de abril. Não dá para saber se era a XIII Trienal de Milão, o evento a que se referia, cuja encomenda coube a Lucio; o que se sabe é que a parceria SUDENE - Museu de Arte Popular não funcionou. Além disso, já era '64! (ver Anexo VII).

Lina continuou tentando levar a exposição para fora do país, para a Galeria de Arte Moderna de Roma, em 1965. Mas ordens superiores impediram, mesmo

\footnotetext{
${ }^{36}$ COSTA, L.. Registro de uma vivência. São Paulo: Empresa das Artes, p. 314 e 315, 1995.
} 
com a exposição já em adiantada fase de montagem. Em protesto, Bruno Zevi publica no L' Espresso, de 14 de março de 1965 o artigo: L' arte dei poveri fa paura al generali. ${ }^{37}$

Então ela montou outra exposição, dessa vez chamada $\boldsymbol{A}$ mão do povo brasileiro, no MASP, em 1969, ano em que teve que interromper seus trabalhos no Brasil, por um bom tempo. Mas depois continuou lutando para demonstrar seu projeto de trabalho a partir da matéria bruta e singela - pobre -, que ainda percebia no Brasil e é com esse esforço que monta Repassos, 1975, com o trabalho artesanal em teares dos Confins de Minas Gerais. Expõe, junto com as tapeçarias e imagens de trabalho das tecelãs os produtos de tingimento, inclusive merda de vaca - estrume. ${ }^{38}$

Mas Lina já vinha adotando uma ligeira mudança de ponto de vista em relação à real possibilidade do país mudar. Ao contrário, a ditadura militar tinha alinhado muito mais ainda a posição do Brasil com os moldes ocidentais, predominantemente o modelo norte-americano, para conceber o nosso sistema como um todo:

Passaram-se 12 anos (1976, portanto, o texto foi publicado sem data), à nova geração a tarefa, embora as premissas sejam outras. O Brasil entrou, queira ou não queira, na era da industrialização.

E aquilo que era 'aproveitável' naqueles anos, hoje é a história.

Que a página seja virada, e que o esforço continue com a sinceridade que nos pusemos na pesquisa das forças básicas do País. ${ }^{39}$ (observação nossa)

E no texto publicado na Malasartes no início de 1976 - que indica sua feitura em 1975 - diz:

(...) O Brasil se industrializou, a nova realidade precisa ser aceita para ser estudada. A "volta" a corpos sociais extintos é impossível, a criação de centros artesanais, a volta a um artesanato como antídoto a uma industrialização estranha aos princípios culturais do país é errada. Porque o artesanato como corpo social nunca existiu no Brasil, o que existe é um pré-artesanato doméstico esparso, o que existiu foi uma imigração rala de artesãos ibéricos ou italianos e, no século XIX, manufaturas. Artesanato, nunca (existiu).

\section{(...) Precisa recomeçar saindo de uma nova realidade, mas uma} coisa está hoje bem clara e definida: os que se ocupam das necessidades de uma parcela

\footnotetext{
${ }^{37}$ BARDI, L. B. Tempos de grossura: o design no impasse. SUZUKI, M., org . São Paulo: Instituto Lina Bo e PM Bardi, p. 46 a 50, 1994.

${ }^{38}$ Os trabalhos reaparecem aos poucos, primeiro em cenografias para Teatro e Cinema, em 1970 e 1971. BARDI, L. B. Lina Bo Bardi. FERRAZ, M. org. São Paulo: Instituto Lina Bo e P. M. Bardi, p. 196 a 199, A mão do povo brasileiro, p. 192 a 195, Repassos, p. 200 e 2001, 1993.

${ }^{39}$ BARDI, L. B. Lina Bo Bardi. FERRAZ, M. org. São Paulo: Instituto Lina Bo e P. M. Bardi, p. 153, 1993. 
bem reduzida da sociedade, os autores da serena tomada de anotação dos fatos, os que não fazem escândalo, estão, com certeza, de outro lado. ${ }^{40}$ (observação nossa)

Ainda sobre a discussão do impasse do Industrial Design, e já no SESC - Fábrica da Pompéia, montou Design no Brasil, história e realidade em 1982, exposição inaugural desse conjunto. Em seguida Mil brinquedos para a criança brasileira, em 1982 - de fato uma exposição de brinquedos, e como na anterior, apresentada com a dicotomia artesanal (popular), de um lado, e industrial, de outro -, $\boldsymbol{O}$ "belo" $\boldsymbol{e}$ o direito ao feio, contra a discriminação contida na expressão "kitsch". ainda em 1982. Caipiras, capiaus: pau-a-pique, sempre com o distanciamento do "kitsch" e a demonstração de um universo real dentro da cultura brasileira viva, em 1984, às quais se deveriam seguir muitas outras, já pré-estudadas, com croquis iniciais de apresentação que Lina sempre fazia, todas no e para o SESC - Fábrica da Pompéia.

A última apresentada lá, Entreato para crianças, de 1985, uma brincadeira para despertar a curiosidade científica nas crianças, no campo da ecologia, da proteção dos animais e do meio ambiente, foi a que abalou de vez sua relação com a Diretoria do SESC. Logo depois do final da exposição, Lina foi mandada embora. ${ }^{41}$

\section{VOLTA À BAHIA}

Em 1986, sem trabalhos efetivos em andamento, abatida por ter sido tirada do SESC, Lina acaba se convencendo a aceitar o trabalho no Centro Histórico de Salvador por insistentes convites do Secretário de Assuntos Especias da Prefeitura Municipal, Roberto Pinho - articulado com o Prefeito Mario Kertéz e Marcelo Carvalho Ferraz - para que a página virasse, mas no sentido contrário: Back in Bahia. ${ }^{42}$

Apesar de seu pouco entusiasmo, alguns pontos lhe eram muito tentadores: poder trabalhar simultaneamente com patrimônio histórico e com o tema da habitação popular, para ela recuperar a Alma Popular da Cidade ${ }^{43}$, trabalhar em conjunto com Lelé - João Filgueiras Lima e alguns focos de cultura, da cultura popular não-ocidentais.

O trabalho também, mais uma vez para ela, não teve continuidade (...) Comigo é sempre assim. Eu sou jogada fora de todos os trabalhos dos quais

\footnotetext{
${ }^{40}$ BARDI L. B. Planejamento ambiental: “desenho” no impasse. Periódico: Malasartes, Rio de Janeiro, n.

2, dez./jan./fev. 1976

${ }^{41}$ BARDI, L. B. Lina Bo Bardi. FERRAZ, M. org. São Paulo: Instituto Lina Bo e P. M. Bardi, p. 236 a 249 , 1993.

${ }^{42}$ Gilberto Gil: Back in Bahia (música e letra), in Expresso 2222, 1972

${ }^{43}$ BARDI, L. B. Lina Bo Bardi. FERRAZ, M. org. São Paulo: Instituto Lina Bo e P. M. Bardi, p. 270, 1993.
} 
participo, depois que eles ficam prontos. Estou acostumada. (... $)^{44}-$, por várias razões, tão conhecidas e estudadas que não vale a pena repetir aqui.

Dos que foram realizados, o que mais a entusiasmou foi o Conjunto da Casa do Benin, tanto que ela foi à inauguração, não foi a nenhuma outra - o Conjunto da Ladeira da Misericórdia nem sequer chegou a ser ocupado como previsto, portanto não foi nem mesmo inaugurado - Aqui tudo parece que é ainda construção e já é ruína. ${ }^{45}$

Para a Casa do Benin a animação foi tal que o Professor também foi, acompanhado de diversos componentes dos quadros técnicos do MASP.

A proposta foi recriar o vínculo das culturas africanas presentes no Brasil - principalmente em Salvador - com as etnias presentes nos países do Golfo do Benin, de onde vieram os ascendentes de grande parte da população bahiana - objeto do grande e pormenorizado estudo de Pierre Verger, em seu Fluxo e refluxo do tráfico escravo $^{46}$. Como não havia relações diplomáticas estabelecidas entre o Brasil e o Benin, seria necessário que a Prefeitura se adiantasse à diplomacia federal e tomasse a iniciativa sozinha.

Outras Casas seriam feitas nesses moldes, sempre com o intuíto de se estabelecer os vínculos consanguíneos que se perderam, principalmente porque essas populações foram e continuam a ser as mais podres, com menor autonomia para fazê-lo por sua própria conta: assim seriam a Casa de Cuba, a Casa de Angola, a Casa da Nigéria, e muitas outras, que espalhadas pelo Centro Históricos, seriam pequenos polos balizadores da intervenção e geradores de novas atividades e renovado interesse por esses pontos. Deveriam ocorrer as recíprocas, casas de Salvador em todos os países, para que hovesse intercâmbio real, de pessoas, estudantes, etc.

O Conjunto da Casa do Benin é constituido por três imóveis contíguos, na ponta de baixo - a menor - do Pelourinho, em frente a chegada da Ladeira do Taboão, o que torna o imóvel da esquina bem visível, como na foto de Verger.

\footnotetext{
${ }^{44}$ BARDI, L. B. Aula de arquitetura. in Lina por escrito. Textos escolhidos de Lina Bo Bardi. Silvana Rubino e Marina Grinover (org.). São Paulo: Cosac \& Naify, p. 162 a 177m 2009.

${ }^{45}$ Caetano Veloso. Fora da ordem (música e letra) in Circuladô, 1991.

${ }^{46}$ VERGER, P. Fluxo e refluxo do tráfico de escravos entre o Golfo do Benin e a Baía de Todos os Santos, dos séculos XVII a XIX. São Paulo: Corrupio, 1987. 


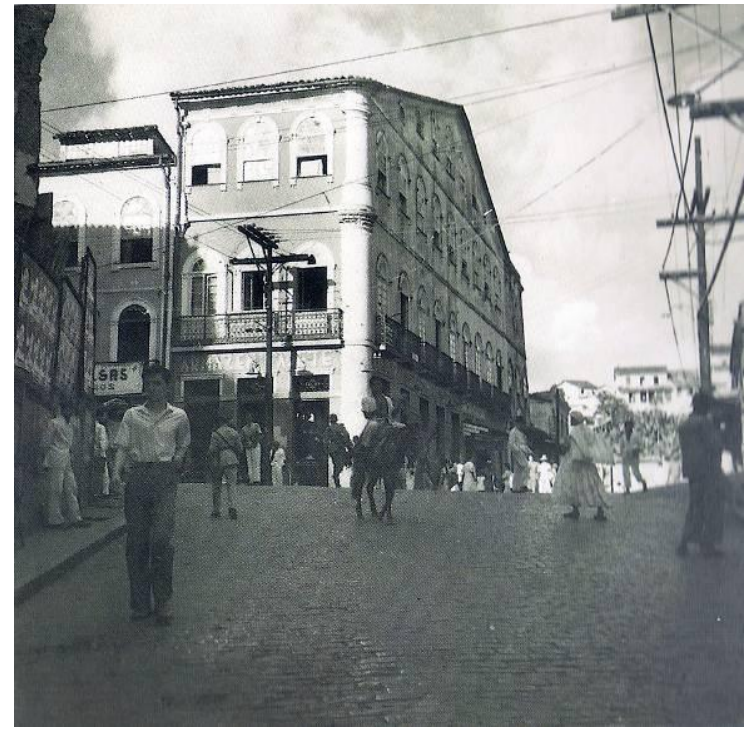

Figura 48. Pierre Verger: Subida da Ladeira do Taboão. Vista do imóvel da esquina que viria a ser a Casa do Benin. Anos 40.

Os imóveis se encontravam em situação ruinosa, mas em graus diferentes: o da esquina, já pertencente à Prefeitura, tivera iniciada uma obra de recuperação, após um incêndio, por parte de algum órgão municipal, quando Roberto Pinho mudou sua destinação para a Casa. O vizinho imediato a este estava em situação grave, a cobertura e os pavimentos já tinham desabado, levando consigo a fachada posterior; a principal sobrevivera razoavelmente - no com que roupa eu vou, com muito capricho para se mostrar a público, os antigos se esmeravam mais nas fachadas urbanas, mais bem construidas, com cunhais e os conjuntos umbrais-lumeeiras; também as paredes de baixo mais fortes do que as de cima, sucessivamente, o que explica a maior capacidade de sobrevivência dessa face em relação às demais. O terceiro imóvel era o em pior estado, até mesmo essa fachada da rua estava bastante degradada. Mas não se sabia o que era pior, a degradação geral ou o péssimo projeto - apesar da boa intenção - com que tinham iniciado as obras no primeiro imóvel.

O partido estrutural anterior estabelecia uma premissa: uma fileira de pilares próxima à parede dos fundos - da qual só tinha restado a do térreo, pelo motivo que vimos logo acima - permitiria com que vigas nascidas da forte parede da fachada principal, passassem pelos pilares e se lançassem em balanço, deixando integra a parede antiga e suportando, no prumo dela, a parede nova, empena fechada para a vizinhança. Mas essa ginástica para salvar uma parede histórica fez com que a estrutura em concreto ficasse pesada demais, as grossas colunas próximas uma das outras e do próprio muro.

Para piorar, numa imóvel tão fino num sentido e comprido no outro, tinham executado uma escada, em dois lances, exatamente no centro, o que fazia com que todos os ambientes, em todos os andares fossem partidos em dois.

Lina aproveitou-se do balanço e soltou a parede de vez, criando uma fresta irregular, fechada por uma tira de vidro que permite passar um rasgo de luz entre esse muro e a estrutura nova; os pilares, sem remédio, foram revestidos de palha: $A s$ colunas de concreto, "demais" para um espaço tão pequeno foram revestidas de palmas 
de coqueiro, trançadas a mão, conforme os trabalhos de folhas, taquaras e fibras dos Países Africanos. ${ }^{47}$

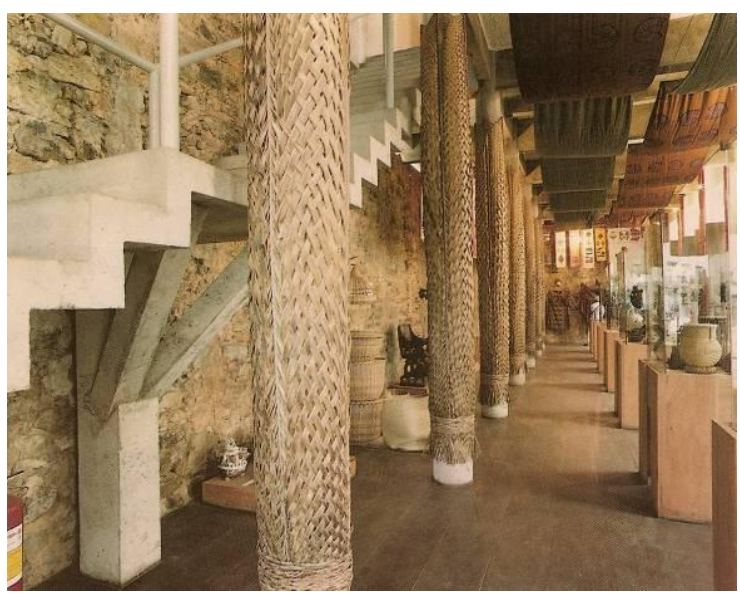

Figura 49. Ao longo do muro que sobreviveu Lina dispôs longitudinalmente a escada e amorteceu a presença excessiva dos pilares com palha trançada.

A escada no meio foi demolida e Lina projetou uma escada contínua, em linha, perpassando todos os andares, no pequeno vão entre os pilares e a parede, antecipando a adequação dos ambientes para os futuros usos de exposições, estudos e reuniões, conforme o estabelecido no programa. No ultimo andar há um giro para se chegar à escada metálica de acesso à cafua, destinada a alojamento de bolsistas beninienses em viajem ao Brasil.

$\mathrm{Na}$ véspera da inauguração, o Professor foi visitar os últimos preparativos e partiu com tudo para subir a escada. Partimos atrás, e o seguimos sempre, com medo que ele caísse, pois apesar de ser um sujeito muito forte, já estava com 87 anos. Quando chegou no último lance, depois de ter reparado em todos os andares, sem perder o fôlego, parou, girou-se para nós e, como sempre fazia, deu uma pequena batida na perna para em seguida levantar a mão espalmada, e disse: - Moderno... racional. (c.d.m.)

No térreo foi montada uma exposição de objetos de uso cotidiano trazidos diretamente do Benin por Arlete Soares, e Lina deu a ela o mesmo caráter das demais exposições relativas à manualidade com que o povo africano tem para a confecção dos seus objetos utilitários - inclusive os ritualísticos - numa relação direta com sua visão do pré-artesanato do Brasil.

\footnotetext{
${ }^{47}$ BARDI, L. B. Lina Bo Bardi. FERRAZ, M. org. São Paulo: Instituto Lina Bo e P. M. Bardi, p. 282, 1993. 


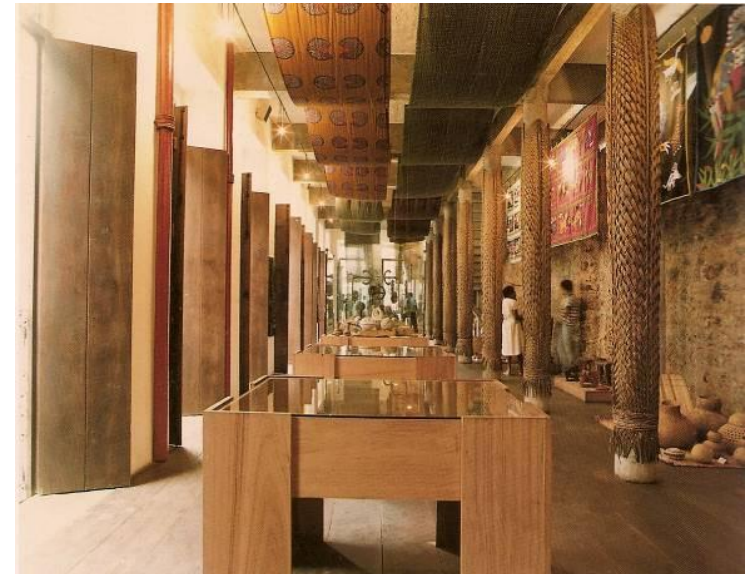

Figura 50. Exposição de objetos utilitários provenientes do Benin.

Seguiu-se a ela uma exposição no MASP, África Negra, com material proveniente do Benin, de colecionadores da Bahia e do Musée de l'Homme, de Paris. Nessa exposição, o vão entre as vitrines tinha tótens feitos de duas palmas de coqueiro trançadas meio a meio, sobre pedestais de concreto das exposições do próprio MASP. As palmas foram trançadas pelos mesmos artesãos da Bahia que embrulharam os pilares da Casa do Benin.

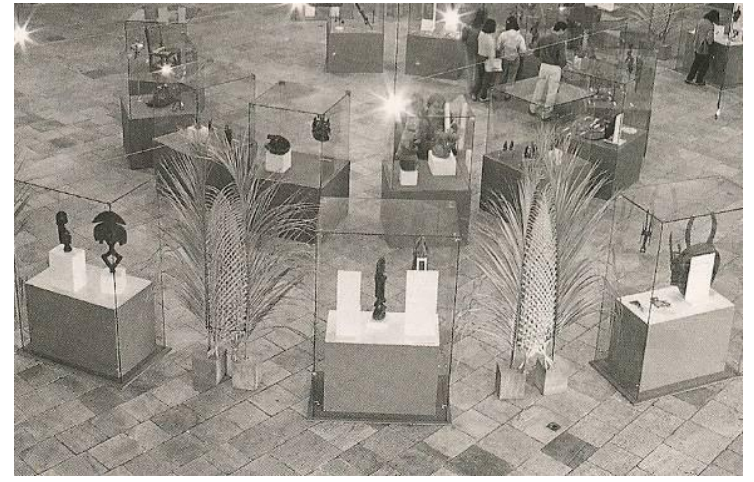

Figura 51. Os mesmos artesãos que fizeram a palha trançada das colunas fizeram também os biombos entre vitrines na Exposição África Negra.

E mais escadas: no ano anterior, 1986, tinha sido inaugurado a Fundação e Teatro Gregório de Mattos, num período em que Lina não esteve bem, portanto não foi. Para esse trabalho é que Lina projetou outra das escadas citadas por Aldo van Eick:

Aí projetamos uma escada. Bom, para mim pessoalmente, como arquiteto, arquitetura é estrutura. Quer dizer, a estrutura de um edifício é elevada ao nível de poesia, como parte da estética. (...) A idéia de uma viga inclinada me veio de uma grande estrutura que, desde estudante de arquitetura eu sempre admirei, que é a estrutura de Nervi, das escadas do Estádio Berta de Florença. Mas é muito diferente. Aqui, há um corpo central, que é um pilar, com uma viga que praticamente abraça o pilar, e desta viga saem, como espinhas de peixe, umas mãos-francesas. Em cima dessa estrutura fundamental, que é a parte portante da escada, se apóia, como um papel, um 
papelãozinho dobradinho (os dobradinhos seriam os degraus) a escada propriamente dita.

O desenho livre deste papel dobrado, forma, em baixo, um convite. Bom, convite eu gosto. Desde criançã sempre admirei os convites. Agora não se usa mais... ${ }^{48}$

Quando Lina apresentou seus desenhos para a escada, não dava para entender nem como seria a estrutura, muito menos a escada em si, até que, como não gostava de fazer, mostrou o livro de Nervi: Alí a viga vai ao contrário da escada, a nossa vai na mesma direção. (c.d.m.) Num lapso de tempo entendemos tudo.

E mais Rochlitz: assim que bateu o olho disse - Dá certinho! Como o conjunto da escada puxa - torce -, o pilar para o lado da maior assimetria, opinou: Basta estroncar a ponta do pilar contra a estrutura existente do prédio. Lina topou no ato, e essa escada, ao contrário da ponta solta do pilar da escada do Unhão, essa tem uma estronca na ponta do pilar: onde deveria ficar, para sempre, um vaso de 7 ervas.

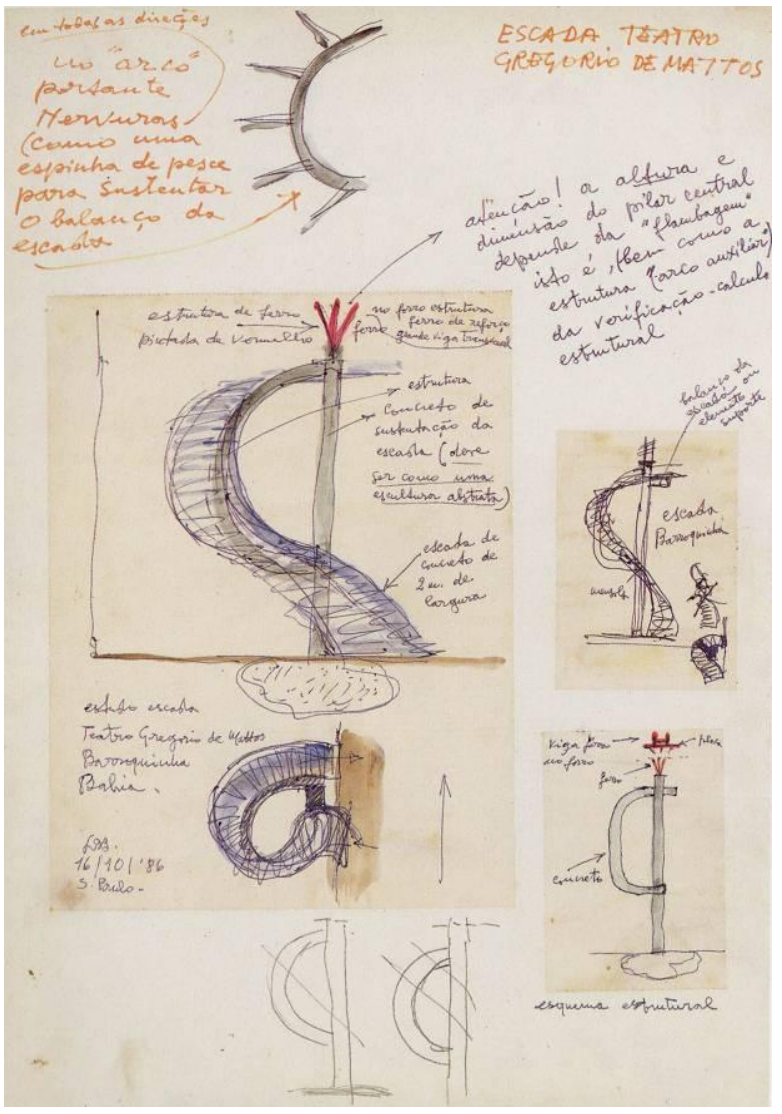

Figura 52. Desenho original de Lina para o Teatro Gregório de Mattos.

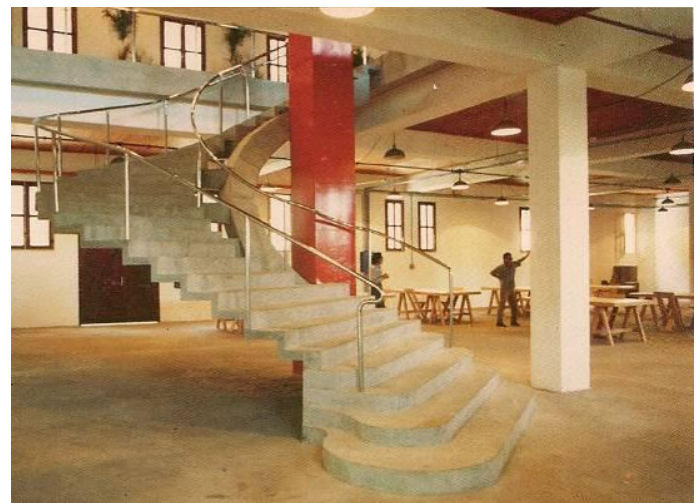

Figura 53. Escada tal como executada.

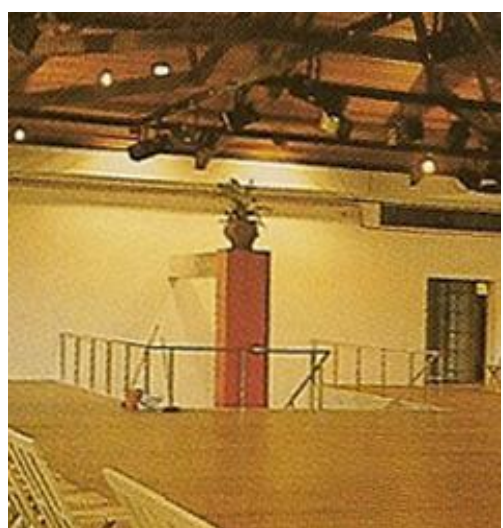

Figura 54. Ponta estroncada do pilar, com o vaso de 7 ervas em cima.

\footnotetext{
${ }^{48}$ BARDI, L. B. Lina Bo Bardi. FERRAZ, M. org. São Paulo: Instituto Lina Bo e P. M. Bardi, p. 278, 1993. 


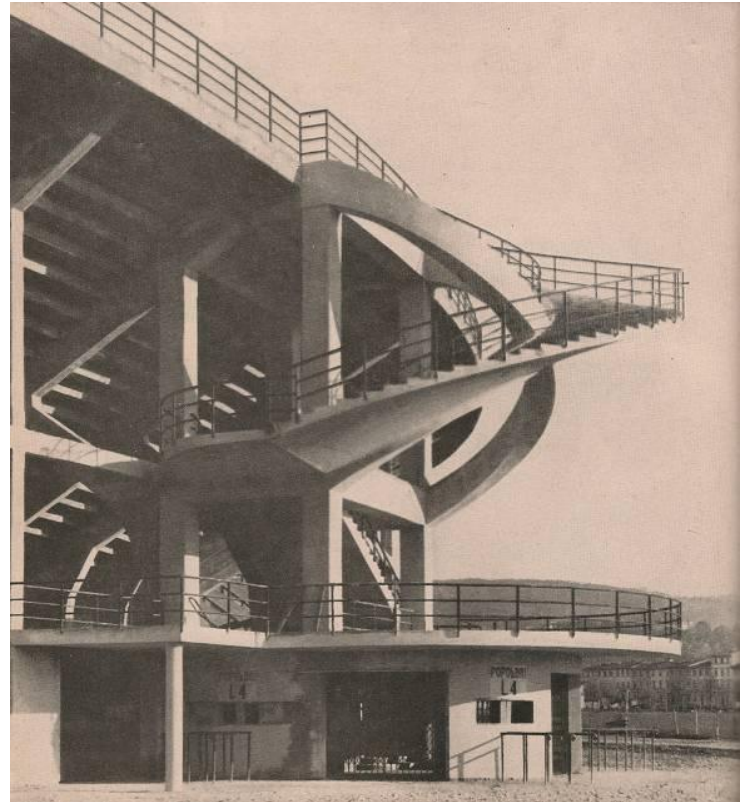

Figura 55. Imagem do livro de Nervi do Florence Stadium. Itália. 1932.

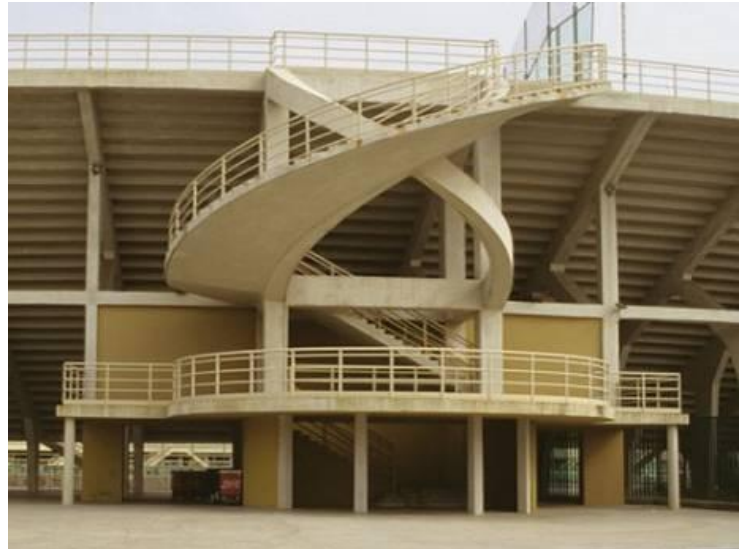

Figura 56. Foto do Florence Stadium. Itália. 1932.

Lina, como não estava muito bem, também não foi antes, nas últimas inspeções dessa obra. Quando voltamos de uma das inspeções finais, relatamos entusiasmados que tínhamos visto a forma do concreto da escada já com bom andamento, e que os carpinteiros tinham entendido muito bem como era, e que em mais alguns dias já seria concretada. Ela disse: Claro, lá tem carpinteiros que ainda sabem fazer até saveiros...(c.d.m.) 


\section{CONCLUSÃO:}

\section{OS BRASIS DE LINA E LUCIO}

Tanto Lina como Lucio tiveram uma visão particular do Brasil, marcada pela total ausência de complexo de inferioridade, ambos nascidos na Europa, ele brasileiro, nascido na França, ela nascida na Itália, brasileira por adoção - que para ela significou ser mais brasileira ainda -. Brasileiros da gema em suas atitudes, mas que, talvez por conter um estrangeirismo - estranhamento -, mantiveram o intransigente estado de julgamento, o tempo todo e em todas suas atitudes.

Esse complexo de inferioridade realmente existe; complexo de viralata e de "sim-sinhô!" é voz corrente na literatura - notabilizada de forma memorável por Nelson Rodrigues -, de jornalística até a acadêmica, que revela o sentimento corrente de admiração pelo que vem de fora, como superior, independente e acima de qualquer avaliação crítica. Mas quando vêm, caso venham, com origem nesse complexo não são críticas, aparecem como reação nacionalista equivocada. Ou importado é muito melhor e ponto final, ou a reação não leva a proposição de nada a fazer, que simplesmente denuncia um mal escondido despeito, que dá na mesma - ou é pior.

Pela efeméride de 2008, o que foi mais reportado é que jornais, livros e filmes retrataram a conquista da Copa do Mundo de Futebol, de 1958, na Suécia, como o fato sociológico que mais proporcionou auto-estima aos brasileiros. Nas matérias, relacionar o primeiro título de Campeão do Mundo com Brasília e à Bossa-Nova - e Juscelino, como o presidente-bossa-nova -, é a presença mais constante. Alguns mais sérios relacionam Juscelino ao intermezzo democrático no país.

Parece que agora o complexo vem diminuindo, mas tem que valer como lição e advertência ${ }^{1}$. Referir-se ao lá fora como $\mathbf{1}^{\mathbf{0}}$ Mundo, independente de critérios de discussão sobre condições econômicas, tecnológicas, etc., e que é expressão comum até hoje entre as pessoas de classe média que conseguem viajar para o exterior, mesmo que seja só até Miami, continua a ser um mau sintoma. Contribuir para a euforia de que no Brasil tudo é melhor, não ajuda - como diria Lina, não consola - nada.

Lina e Lucio sempre mantiveram uma visão totalmente distinta dessas, enxergando no povo um comportamento bastante diverso deste da classe média, que põe a perder o homem cordial, quem sabe por um homem politicamente correto - que se fosse real já seria muita melhoria.

Sérgio Buarque, nos anos 30 e 40, expôs sua visão muito peculiar sobre o homem brasileiro autêntico: (...) o homem cordial - expressão cunhada por Ribeiro Couto - a lhaneza no trato, a hospitalidade, a generosidade, mas também a inimizade e outras condutas similares, desde que nascidas do coração. A cordialidade não tem nada a ver, como se poderia supor, com boas maneiras, com a civilidade e a

\footnotetext{
${ }^{1}$ COSTA, L. Registro de uma vivência. São Paulo: Empresa das Artes, p. 169, 1995.
} 
polidez. As manifestações de cordialidade são expressões "de um fundo emotivo extremamente rico e transbordante". A civilidade, ao contrário, envolveria justamente controlar e esconder as emoções, graças à subordinação da conduta a regras que podem exprimir-se em mandamentos e sentenças. "Nossa forma ordinária de convívio social é, no fundo, justamente o contrário da polidez". (...) A cordialidade, pois, é tentativa de reconstrução fora do ambiente familiar, no plano societário, do mesmo tipo de sociabilidade da família patriarcal, de um tipo de sociabilidade dependente de laços comunitários. (.... ${ }^{2}$ (grifos nossos)

E é esse homem cordial que encanta Lina, desde seus primeiros momentos de vivência no Brasil:

Quando eu cheguei aqui no Brasil, fiquei atordoada. Era um pessoal desaforado, ordinário, maravilhoso... Reencontrei aqui as esperanças das noites de guerra. Estava feliz, e aqui não tinha ruínas. E, mais adiante, um povo cafajeste, elegante, que lugar que tem?... ${ }^{3}$

\section{Lucio diz:}

No Brasil, desde 1500 até o fim do século XIX, toda mão-de-obra era escrava.

Embora abolida a escravidão legal, a massa trabalhadora do campo e das cidades continuou a se considerar, ela própria, inferior à burguesia. Só depois de 1930, com a criação do Ministério do Trabalho, ela passou a ter consciência dos seus direitos e a reivindicá-los.

$$
\text { (...) }
$$

Apesar dos contrastes e das circunstâncias, o país, graças à força viva que o impele, está fadado a um grande destino porque não tem vocação para a "mediocridade".

\section{O Brasil não será jamais um país mediocre. ${ }^{4}$}

Esse vaticínio é muito vinculado à idéia de Sergio Buarque de Hollanda, porque agindo com o coração não haveria nunca lugar para meios-termos, para as situações medianas, de classe média, mediocridades; uma perda, para menos deveria ser muito menos do que merecíamos - famosa frase de Darcy Ribeiro, mas para outros assuntos e outros motivos, mas relevantes no mesmo sentido. - (c.d.m.), ou para mais, muito mais e melhor, como poderíamos.

No texto, Lucio continua:

\footnotetext{
2 SALLUM JR., B. Sérgio Buarque de Holanda: Raízes do Brasil. in: MOTA, L. D. org. Introdução ao Brasil: Um banquete no trópico. São Paulo: Editora SENAC, p. 251, 2004.

3 FERRAZ, I. G. e MICHILES, A. - LINA BO BARDI - documentário em VHS - Instituto Lina Bo e P. M. Bardi - São Paulo - 1993

${ }^{4}$ COSTA, L. Opção, recomendações e recado. In: Registro de uma vivência. São Paulo: Empresa das Artes, p. 382, 1995.
} 
Geográfica, histórica e socialmente o Brasil-inclusive por suas dimensões e por esse problema da escravidão da raça negra - corresponde, simetricamente no sul, aos Estados Unidos no norte, enquanto a Argentina, o Chile e o Uruguai corresponderiam ao Canadá, e os demais países de tradição pré-colombiana, ao México. ${ }^{5}$

E, segue, em outro texto:

O Novo Mundo já não é este lado do Atlântico, nem tampouco o outro lado do Pacífico.

O Novo Mundo já não está à esquerda nem à direita, mas acima de nós - precisamos elevar o espírito para alcançá-lo, pois já não é uma questão de espaço, porém de tempo, de evolução e de maturidade.

O Novo Mundo agora é a Nova Era, e cabe à inteligência retomar o comando. ${ }^{6}$ (o negrito é uma correção feita à mão pelo próprio Lucio, onde antes constava: em cima - obs nossa)

E faz as seguintes recomendações:

Assumir e respeitar o nosso lastro original - luso, afro, nativo.

Reconhecer a grande importância para o Brasil de hoje do aporte da imigração européia - mediterrânea e nórdica -, bem como a do oriente - próximo e distante.

Aceitar como legítima e fecunda a resultante desse entrosamento, mas reputar fundamental a absorção, nesse aporte, da nossa maneira peculiar, inconfundivel-brasileira-de ser.

Preservar e cultivar tais características diferenciadoras, originais.

Recusar subserviência, inclusive cultural, mas absorver e assimilar a inovação alheia. ${ }^{7}$ (primeiro e terceiro grifos nossos, segundo grifo de Lucio)

Absorver e assimilar a inovação alheia tem o grande antecedente de Oswald de Andrade e o movimento antropofágico. Não escapou nem a Le Corbusier, por mais rápida que tenham sido suas estadas no Brasil - ou em qualquer lugar para onde ia, nas suas buscas -, mas o fato surpreendente é que ele anotou:

(...) Os jovens de São Paulo expuseram-me sua tese: "Somos antropófagos". A antropofagia não era um costume glutão. Tratava-se do rito esotérico, de uma comunhão com as melhores forças. O repasto era parcimonioso, dele participavam cem ou quinhentas pessoas que iriam comer a carne do inimigo capturado. Esse guerreiro era valoroso; assimilavam-se suas virtudes, porém ele, por sua vez, havia

\footnotetext{
5 COSTA, L. Registro de uma vivência. São Paulo: Empresa das Artes, p. 382, 1995.

${ }^{6}$ COSTA, L. Registro de uma vivência. São Paulo: Empresa das Artes, p. 379, 1995. Publicado originalmente na revista MÓDULO N. 93, artigo de Arnaldo Carrilho.

7 COSTA, L. Com a palavra, Lucio Costa. COSTA, Maria Elisa, org. Rio de Janeiro: Aeroplano, p 158, 2000 .
} 
comido a carne dos próprios guerreiros da tribo. Assim ao comer sua carne, assimilavase a própria carne de seus ancestrais. ${ }^{8}$

O Movimento Antropofágico reinterpretava esse fato transportandoo para a questão cultural, onde então deveria ocorrer algo similar ao que faziam os antropófagos: tratava-se de mastigar e digerir a informação, e resultar plenamente alimentado da sua força. Por isso mesmo, certa vez, relacionamos isso com um chorinho:

Mistura e manda", é uma música, chorinho. O "choro" tem por peculiaridade ser interpretada por músicos que, em conjunto recebem o estranho nome de "Regional" apesar de ter nascido no Rio de Janeiro, capital do País de então. E, melhor, não chora nada. É um ritmo quase sempre acelerado (tanto que as letras, quando as têm, são difíceis de acompanhar ou apanhar), alegre (dito em português coloquial, não andamento, da linguagem musical), divertido e jocoso, cheio de breques e trejeitos. (...) Pixinguinha trocava partituras via correio com Duke Ellington. ${ }^{10}$ Pixinguinha não falava inglês, Sir Duke idem, não sabia nada de português: e se entenderam pelas pautas e notações musicais.

Mistura e manda, também é expressão popular corrente para designar o jeito brasileiro de comer, arroz com feijão e farinha, carne seca: mistura tudo e manda, e, quando dito, é sempre acompanhado do gesto de se levar um garfo à boca, mas um gesto feito brusco, desaforado. Mistura também é o que é mais caro - de preço e de sabor - durante a refeição: arroz, feijão e farinha a base, carne - boi, galinha, cabrito é a mistura - mesmo quando carnes "de-segunda": bucho, fato, como se diz na Bahia. Na música brasileira, misturar e mandar pra-dentro, mastigar, comer e engolir, sempre foram salutares: há influências de todos os tipos e procedências. Na arquitetura moderna brasileira isso também ocorreu, ou melhor, foi assim que foi nascendo, trazida ou colhida na fonte, não importa, como já observamos aqui.

Há uma síntese maravilhosa contida no nome de batismo, dado por Nelson Alves nesse chorinho. Comas nomeia de Tempos de Mistura o conjunto de textos que comentam obras, a partir de Lina, mas na verdade é uma análise do que se passou com a arquitetura nas duas décadas finais do século $\mathrm{XX}$, em relação ao status-quo brasileiro - também esse batismo entra em sincronia com o pensamento de que não há medo que valha perder o que é mais caro - de sabor, paladar: gôsto! Com a necessária grossura mantida na ordem do dia: manda...

Nesse aspecto, Lina, é incisiva, em juntar grossura e desaforo com liberdade e elegância, tirando as possíveis antinomias, ressaltando uma complementaridade:

\footnotetext{
${ }^{8}$ LE CORBUSIER. Precisões: sobre um estado presente da arquitetura e do urbanismo. São Paulo: Cosac \& Naify, p. 29, 2004.

${ }^{9}$ NELSON ALVES: Mistura e manda. in PAULO MOURA: Mistura e manda. Rio de Janeiro: Kuarup Discos, 1986

${ }^{10}$ MONTEZUMA, R. (org.). Arquitetura Brasil 500 anos - vol. 2. Recife: Universidade Federal de Pernambuco, 2008.
} 
O Ocidente está à beira de uma revisão total. Eu acho que o Brasil não faz parte do Ocidente. É África! Graças a Deus o Brasil está fora do Ocidente que, afinal, é pobre. O Ocidente depois da II Guerra Mundial está minguando. Tudo aquilo que era elegância, o refinamento, as coisas gostosas... sumiram. Isso não pode nem deve ser visto como uma grossura, mas sim como uma miséria moral. (grifo nosso - a "civilização ocidental", devido às perdas gerais de comportamento que, segundo ela, ocorreram na Europa, não lograram chegar à grossura, não atingiram necessária grossura, que no entanto já era endêmica no Brasil.) ${ }^{11}$

Lina sempre contava que nos primeiros navios que chegaram da Itália com imigrantes estouraram rebeliões, pois achavam que tinham sido trapaceados e enganados pelos agentes que os despacharam, e tinham sido mandados para a África e não para América: do navio, o que avistavam no porto de Santos, onde deveriam desembarcar, eram só pretos, todos, os estivadores... (c.d.m.)

\section{E em Progresso e Civilização:}

O que os homens conquistaram no decorrer dos tempos foi o progresso, a civilização sobreviveu ameaçada. (...) O que o Ocidente tem feito, rigorosamente, até hoje é (...) separar o Progresso da Civilização, o que não aconteceu no Oriente. (...) Quem atravessa as Américas rumo ao Extremo Oriente sente nos grandes horizontes, na calma da Natureza (aparente, é terra de terremotos), que a opção do Progresso do Ocidente não é necessariamente a única, outras opções poderiam ter sido feitas, com os mesmos resultados. A opção escolhida pelo Ocidente deu resultados potentes, mas o custo é enorme. A América do Norte é América e, num certo sentido não é Ocidente, chegou tarde demais. Apesar dos esforços que querem demonstrar o contrário, um dia o povo da América do Norte envidará para seu verdadeiro caminho.

Eram estas idéias que nos guiaram em fins de 50 e nos anos 60. Nesse sentido, foi nosso esforço, nosso caminho. ${ }^{12}$

Mas, especificamente, sobre o Brasil, ou, mais ainda, a sua poética "descoberta" do Brasil:

Como é o Brasil para o europeu que desembarca pela primeira vez no Rio de Janeiro? Do avião, o contraste entre as favelas e as construções modernas induz mais ao caos social que ao ressentimento burguês pelo arranha-céu padronizado, no lugar da casa de estilo. Do navio, a enseada de Copacabana e a baía com o Ministério da Educação e os outros edifícios que aparecem repentinamente, quase colados na floresta, da qual emana o odor que chega a bordo, sugerem um esforço humano que não deixa tempo para pensar se era melhor o arranha-céu ou a casinha folclórica portuguesa. ${ }^{13}$

\footnotetext{
${ }^{11}$ BARDI, L. B. Lina Bo Bardi. FERRAZ, M. C. org. São Paulo: Instituto Lina Bo e P M Bardi, p. 203, 1993.

12 BARDI, L. B. Lina Bo Bardi. FERRAZ, M. C. org. São Paulo: Instituto Lina Bo e P M Bardi, p. 209, 1993.

${ }^{13}$ BARDI, L. B. Lina Bo Bardi. FERRAZ, M. C. org. São Paulo: Instituto Lina Bo e P M Bardi, p. 12, 1993.
} 
Enquanto Lucio, por sua vez, descreve a sua "descoberta" do Brasil através de uma criança, de maneira também poética, mas não de alguém que estava recém saída de uma Guerra:

Só tomei conhecimento do Rio de Janeiro aos 14 anos de idade. É que nascido fora e trazido com poucos meses, meus pais retornaram em 1910 Inglaterra, França e Suiça - e lá ficamos até fins de 1916. Assim, a volta definitiva à cidade foi para mim uma revelação: as montanhas diferentes, a mata, o casario, o céu perto, o mar. Então vista de frente nas ressacas, antes do aterro, a "arrebentação", esse imemorial encontro da onda com a praia - era o espetáculo de prender em suspenso a respiração. A onda começava longe, sozinha, apenas insinuada, indecisa; aos poucos se definia, ia crescendo e sempre maior vinha vindo, como que tomando fôlego, até que, reluzente e coroada por uma crina de espuma, se dobrava e rebentava com estrondo numa explosão de brancura. Aí, célere, a água se derramava e espraiava lavando docemente a areia até se extinguir. ${ }^{14}$

Entretanto, o destino, roda das fortunas, quis que Lina viesse para

São Paulo:

1947. Chateaubriand convida Pietro para fundar e dirigir um Museu de Arte no Brasil: Rio ou São Paulo. Torci pelo Rio, mas o dinheiro estava em São Paulo. Disse a Pietro que queria ficar, que reencontrava aqui as esperanças das noites de guerra. Assim ficamos no Brasil. ${ }^{15}$

Assim relata o Professor:

Mas o Promotor (Assis Chateaubriand, n.a.) continuava com uma dúvida: onde sediar o Museu? As opções eram duas: ou Rio de Janeiro ou São Paulo. A indecisão permaneceu até confessar sua preferência pela terra que produzia a riqueza de então, o café. Acabamos paulistas. ${ }^{16}$ (grifo nosso)

O Professor relata o encontro com Chateaubriand da seguinte, e aproximada, maneira:

Embarcamos em 46 no navio Almirante Jaceguay, trazendo (ele e Lina), conosco as obras de arte.

Na Capital fomos recebidos por um velho amigo, Mário da Silva, jornalista brasileiro (...). Tive a sorte de, com sua ajuda, obter o salão nobre do edifício do Ministério de Educação e Saúde, onde pude apresentar as duas coleções que trouxera e cujos catálogos ele traduziu. (grifo nosso)

Foi ali que tive ocasião de encontrar Assis Chateaubriand, um dos primeiros visitantes, muito interessado nos quadros antigos, tendo adquirido quatro obras. Mario conhecia aquele visitante e me contou rapidamente sua vida (...)

${ }_{14}^{14}$ COSTA, L. Registro de uma vivência. São Paulo: Empresa das Artes, p. 371, 1995

15 BARDI, L..B. Lina Bo Bardi. FERRAZ, M. C. org. São Paulo: Instituto Lina Bo e P M Bardi, p. 12, 1993.

${ }^{16}$ BARDI, P. M. História do MASP. São Paulo: Instituto Quadrante, atual Instituto Lina Bo e P M Bardi, p. $11,1992$. 
recomendando 'stare attento'.(...) Durante nossa conversa, Chateaubriand me falou sobre sua intenção de criar um Museu no Brasil. ${ }^{17}$

Durante as comemorações de seus noventa anos, o Professor contou que logo no primeiro dia de encontro ocorreu o seguinte diálogo com Chateaubriand: Bardi - Me informaram que o senhor é um aventureiro. Chateaubriand - Sou sim. Bardi - Ah, bom! Porque eu também sou... (c.d.m.) Continuaram amigos, fazendo coisas do arco-da-velha, por toda vida.

Mesmo que nosso relato seja impreciso, demonstra o fato dele não ter o menor medo de polêmicas, que as arranjou muitas por aqui, assim como Chateaubriand. Também Lucio, e também Lina, como vimos, por motivos muito diferentes, mas que têm resultantes convergentes ${ }^{18}$ em demonstrar, o tempo todo, a importância e a necessária abrangência da Arquitetura, a atuação pública e intelectual pelas quais os arquitetos têm que perseverar e lutar, brigar, com carradas de razões ${ }^{19}$, quando for preciso.

De maneira idêntica, ou seja, por razões muito diferentes, foram impedidos de prosseguir a carreira de professores nas Universidades, mas continuaram, seguiram sendo professores o tempo todo, pois os arquitetos escrevem: registram memoriais para apresentar e elucidar a própria obra, manifestos para tomar posição ante outros arquitetos, para exaltar o depreciar arquiteturas de outros tempos.(...) Aquele que é talvez o mais importante arquiteto do século $X X$, Le Corbusier, escreveu cerca de cinquenta livros, argumentando que quando circunstâncias o impediam de projetar ele desenhava, escrevia, falava... de modo que suas proposições arquitetônicas não deixassem de ser veiculadas. ${ }^{20}$

Lina e Lucio deram palestras, escreveram muito, deixaram textos formadores - muito mais que informativos. Por muitas vezes tiveram que fazê-lo para reagir contra acusações e críticas improcedentes, e faziam-no com firme veemência de abalizadas autoridades nos assuntos de seu ofício: Arquitetura.

Se a crítica internacional, no primeiro instante, foi amplamente favorável a Brasília, num segundo momento foi acidamente crítica, em vários momentos de declarado desprezo. Houve um intensivo boicote contra a arquitetura moderna brasileira, e Lina afirmava isso a todo instante. Segundo Maria Elisa, a princípio eles acharam exótico - um passo para folklorizar, como dizia Lina - para depois criar as reticências. Enquanto algo exótico e distante, tudo ia bem, mas quando viram que era a sério, passaram a criticar. (c.d.m.) Segundo Lina, os países desenvolvidos tratavam o

\footnotetext{
${ }^{17}$ BARDI, P. M. História do MASP. São Paulo: Instituto Quadrante, atual Instituto Lina Bo e P M Bardi, p. 10, 1992.

${ }^{18}$ COSTA, L. Com a palavra, Lucio Costa. Maria Elisa Costa, org. . Rio de Janeiro: Aeroplano Editora, p. 23, 2001.

${ }^{19}$ LEONÍDIO, O. Carradas de razões: Lucio Costa e a arquitetura moderna brasileira. Rio de Janeiro/São Paulo: Ed. PUC-Rio, Loyola, 2007.

${ }^{20}$ RUBINO, S. A escrita de uma arquiteta. In GRINOVER, M., RUBINO, S. Lina por escrito - textos escolhidos de Lina Bo Bardi. São Paulo: Cosak \& Naify, p.20 e 21, 2009.
} 
Brasil como o cabritinho amarrado - e São Paulo, da ditadura, fazia o mesmo com o Nordeste.

Segundo sua teoria o cabritinho amarrado, muito jovem e surpreendentemente vigoroso naquele semi-árido do Nordeste, por inexperiência, quando via algo que atraísse, saia correndo. Como estava amarrado a um tronco, levava um tranco no pescoço e caía de costas. Até que de tanto tentar, e adquirindo mais experiência na vida parava de fazer isso. Além dessa teoria, havia a outra, a do caldo de feijão: crianças no Brasil são alimentadas com caldo de feijão, que contém ferro, importante na absorção dos demais alimentos. Parecem viçosas e fortes, a fome vem logo em seguida. Ela se referia a jovens músicos, poetas, artistas em geral, autores de uma brilhante obra, na estréia, e que depois somem, não continuam a carreira inicialmente promissora. Bela Criança $^{21}$ é seu alerta exatamente para essa situação.

O local da exposição, acima frisado, é importante, foi no salão nobre do Ministério! Teria sido assim o primeiro contato de Lina e Lucio? Porque Lina relata:

Recepção no IAB do Rio: Lucio Costa, Oscar Niemeyer, Rocha Miranda, os Roberto, Athos Bulcão, Burle-Marx e outros. No Cosme Velho, Portinari, o escultor Landucci, o Marcos Jaimovitch, "velhos amigos” do Oscar. Era a primeira vanguarda internacional do Brasil (a segunda seria Brasília). Deslumbramento pela simplicidade inteligente e capacidades pessoais. Deslumbramento por um país inimaginável que não tinha classe média, mas somente duas grandes aristocracias: a das Terras, do Café, da Cana, e ... o Povo. ${ }^{22}$ (grifo nosso)

Chegada ao Rio de Janeiro de navio, em outubro (1947?). Deslumbre. Para quem chegava pelo mar, o Ministério de Educação e Saúde avançava como um grande navio branco e azul contra o céu. Primeira mensagem de paz após o dilúvio da Segunda Guerra Mundial. Me senti num país inimaginável, onde tudo era possível. Me senti feliz, e no Rio não tinha ruínas. ${ }^{23}$ (dúvida nossa)

Ainda era possível ver o Ministério a partir da baía, de um navio. Ainda se vê, mas só o topo, o ático com as torres azuis, hoje num tom um pouco mais mortiço do que foi no original. Construíram muito mais prédios na frente, depois. Segundo contou Maria Elisa Costa, não encontraram mais as pastilhas com as cores originais, e para uma manutenção ou recuperação integral da superfície, sem remendos, adotou-se uma pastilha disponível no mercado, com a cor e o tom atual. (c.d.m.)

O navio Ministério, branco e azul, visto a partir de um navio não é uma metáfora qualquer, é uma citação explicita de Le Corbusier, cuja obra Lina conhecia bem, ele, que já nos anos 20, conclamava a todos para observarem os navios, o projeto dos navios:

\footnotetext{
${ }^{21}$ BARDI, L. B. Bela Criança. Texto publicado originalmente em São Paulo: Habitat, n. 2 p. 3 , 1951.

22 BARDI, L. B. Lina Bo Bardi. FERRAZ, M. C. org. São Paulo: Instituto Lina Bo e P M Bardi, p. 12, 1993.

${ }^{23}$ BARDI, L. B. Lina Bo Bardi. FERRAZ, M. C. org. São Paulo: Instituto Lina Bo e P M Bardi, p. 12, 1993.
} 
Prossigo no encaminhamento de minha idéia. Ela me conduz a realidades iminentes. Eis o corte de um navio intercalado entre os palácios da Concórdia, em Paris.

Desenho o navio ao contrário. Melhor ainda, gosto de visitá-lo de alto a baixo. Existem 2.000 a 2.500 pessoas nesse navio. É uma grande casa. ${ }^{24}$

A relação com navios segue na obra de ambos - vários outros arquitetos modernos também -, com várias re-aparições, explicitas ou não: "Brasília nasceu no mar"'- num navio. ${ }^{25}$

Lina dizia: o bom de cidade com porto é que a gente sempre sabe que pode dar o fora. E o Brasil é isso, meio estrangeiro em si mesmo, como um eterno "eu não sou daqui, marinheiro só...", do tradicional samba-de- roda bahiano, que Caetano Veloso recompôs, e que na voz incomum de Clementina de Jesus tem força magnífica.

Quando da realização do concurso para o Vale do Anhangabaú, Lina propôs a estrutura da via elevada em tubos náuticos, que se abriam em cima e em baixo como ocorre com a vegetação de mangue. Desde a inauguração do SESC Fábrica da Pompéia até a permanência dela na direção cultural daquela unidade, durante aqueles dois anos, funcionava, meio-dia em ponto, um apito de navio, aquele apito extremamente grave, baixo, das naves. Lina mandou substituir a sirene da antiga fábrica, em vez da sirene tradicional, um navio que parte soava na hora do almoço. Depois que ela saiu da direção, a nova direção mandou desligar o apito, mas o equipamento está lá até hoje, no teto do bloco esportivo.

Lina explica seu deslumbre com o Brasil por todos os lados e vieses: a novidade - o viço, a cultura popular, o povo e sua grossura, a arquitetura moderna executada, concluída, e, com destaque, a ausência de ruínas. Vale dizer, com um passado não tão longínquo, não tão carregado do peso de civilizações e culturas que, na Europa, se acumularam ao longo de milhares de anos e que, diante de um quadro de guerras e tristezas, na verdade, não se sabia mais o que fazer com aquilo tudo, como um pesado lastro a ser descarregado. Com um país que não tinha ruínas, país onde tudo estava ainda por fazer, e não refazer em razão dos bombardeios, sob os quais ela mesma ficou, no período em que permaneceu em Milão, seu entusiasmo foi, como ela dizia, instantâneo.

Lina citava Brazil Builds muitas e muitas vezes, em diversos textos publicados ou não, em declarações reiteradas, como o anúncio de uma coisa muito diferente, sui generis em relação a um mundo "conhecido", o ocidente culto, como a publicação que mudou tudo. Ela sempre se referia à surpreendente descoberta desse país, e do seu deslumbre. Também não dá para encontrar o possível original da publicação, o exemplar desse primeiro original contato, dentro do material pesquisável e disponível,

\footnotetext{
${ }^{24}$ LE CORBUSIER. Precisões: sobre um estado presente da arquitetura e do urbanismo. São Paulo: Cosac \& Naify, p. 72, 2004.

${ }^{25}$ FOLHA DE SÃO PAULO - Brasília nasceu no mar. Matéria de Mario César Carvalho. São Paulo: Caderno Mais, 11/02/ 2007.
} 
seja no MASP, seja no Instituto. Não vi esse exemplar em nenhum momento do nosso convívio. ${ }^{26}$

Documentação de antecedência: o livro do Museum of Modern Art, Brazil Builds, uma esperança real quase cotidiana, não metafísica, na simplicidade das soluções arquitetônicas, nos "halloos" humanos, coisas desconhecidas para uma geração que chegava de muito longe. Naquele tempo, no imediato pós-guerra, foi como um farol de luz a resplandecer num campo de morte... Era uma coisa maravilhosa. (... $)^{27}$

Lina quase nunca citava o livro de Mindlin como sendo uma referência importante, o Modern Architecture in Brazil, curiosamente o livro que incluiu a casa dela no rol do desenvolvimento da arquitetura brasileira após o Brazil Builds, como um dos artigos. ${ }^{28}$ Está certo que Lina não gostava de mostrar a ninguém livro nenhum, só muito raramente fazia isso. Mas as enormes pilhas de livros que se amontoavam ao lado da cadeira na sua posição preferida na Casa de Vidro, variavam conforme os livros que ela estava utilizando, e era usual que nós ou qualquer visitante que quisesse os folheasse, enquanto ela ia fazendo interessantes e interessados comentários sobre eles. Às vezes se referia a um ou outro, mas sem mostrar, sem por na mesa. Mas quando era muito importante mandava que alguém buscasse na sua biblioteca, imediatamente.

Citava a Aula Magna da Universidade de Caracas, de 1952, como impressionante, um silêncio (nunca usava a palavra bonita, mas aí o silêncio tem duplo sentido: para a Aula Magna, o espaço indizível, portanto faça-se silêncio, e para o bairro El Silencio, para ela a melhor experiência de habitação popular na América Latina); também citava Barragán como um poeta importante da arquitetura, mas não mostrava nem contava como tinha conhecido: ao que se sabe, não foi nem no México nem na Venezuela, nenhuma vez. Como não tínhamos livros, as publicações muito escassas por aqui, restava uma curiosidade imensa.

Uma pequena dica foi o livro, dos raros disponíveis entre nós, Nuevos Caminos de la Arquitectura Latinoamericana, publicado em 1969, encontrável no livreiro da FAU, um sujeito simpático, de ascendência basca, de nome, Merino, muito amistoso com os estudantes - o meu exemplar tem a assinatura e a data da compra: 1978, ano em que Marcelo C. Ferraz passou a trabalhar com Lina, ano em que se formou minha turma (eu atrasei dois anos e meio para formar). Nesse livro aprendemos pelo menos a olhar para os lados, a ver os países vizinhos! Do Brasil, o livro apresenta em destaque Brasília, a Pampulha, Pedregulho e como nova geração, o amigo de Lina, Joaquim Guedes. ${ }^{29}$

Voltando ao livro inaugural:

\footnotetext{
${ }^{26}$ GOODWIN, Philip L. Brazil Builds Architecture New And Old 1652-1942. New York: The Museum of Modern Art , 1943.

27 BARDI, L..B. Lina Bo Bardi. FERRAZ, M. C. org. São Paulo: Instituto Lina Bo e P M Bardi, p. 12, 1993.

${ }^{28}$ MINDLIN, Henrique E. Modern Architecture in Brazil. New York: Reinhold Publishing Corporatino, p. 42 e $43,1956$.

29 BULLRICH, F. Nuevos caminos de la Arquitectura Latinoamericana. Barcelona: Editora Blume, 1969.
} 
Rio de Janeiro, capital of Brazil, led the way. In 1936, I was asked, with Lucio Costa's enthusiastic group, to study anew the plans for the Education and Health Building and to make the first suggestions for the University City of Brazil. I brought the "sun-breaker" to the tropics, the building supported on posts, the wall of glass, the roof garden... War came!...Liberation of Paris, 1944; then I learned what they had built in Rio, and in Recife, and in Pampulha. And that a skyscraper of the new type existence, rational and smiling, fit to serve modern work. ${ }^{30}$

Notável que as pessoas que estudam e se manifestam sobre os textos de Lucio sobre o Ministério e, muito particularmente sobre o Depoimento de um Arquiteto Carioca se surpreendam com o fato de que Lucio Costa, um intelectual com admirável capacidade de escrever bem e de ser preciso, mesmo que sempre colocando, em seus textos, seus sentimentos, expondo-os, inclusive nos famosos redigidos à mão com que se comunicava oficialmente, tenha usado a palavra milagre para se referir ao fato de que o Ministério realmente foi construído e consolidado. É curioso intelectualmente que eles atribuam tão grande importância ao termo. Por exemplo, em Otília Arantes:

Isso parece contrariar sua afirmação a respeito da origem "milagrosa" dessa arquitetura, e da série de acasos que a fizeram surgir - o que muitas vezes é tomado ao pé da letra, como se ela tivesse brotado do chão nativo, espontaneamente, e que não tivesse havido um trabalho prévio. ${ }^{31}$

Bem, uma coisa foi o milagre, com o sentido descrito anteriormente, não-religioso, natural, dadas as circunstancias já relatadas, as enormes dificuldades, etc. e, com esse nome ou não. Mas houve, sim, o preparativo anterior, o que incluiu a enorme dúvida de Lucio sobre os destinos daquilo que se apresentava. Para ele, moderno ainda podia ser mais uma mera aventura estilística - ele já percebera que estilo não era mais a questão - que não se poderia ser tão efêmero - leviano - quanto o recém conhecido Art Nouveau tinha sido. Até com isso ele foi cuidadoso, manteve seus medos em dia. Mas a frase citada mistura o tal milagre, com uma coisa surgida do chão nativo, de outro trecho do discurso: o fato de ter surgido Oscar Soares, como ele gostava de usar, Oscar Niemeyer.

São coisas nitidamente separadas no texto de Lucio: sua singeleza a respeito de seu próprio papel, fundador e fundamental, dito com muita, e elegante, humildade: surge Oscar Soares que, nasceu, brotou, do chão nativo, a partir de seu convívio de pouco mais de um mês com Le Corbusier, e a primordial importância da vinda dele. Já está dito aí o trabalho prévio, e o que veio antes, literalmente, foi tão batalhado por ele, Lucio, que incluiu, entre outras coisas, até ter que se explicar para Getúlio Vargas, para conseguir com Le Corbusier viesse - segundo consta Getúlio, diante de tanta e tão obstinada insistência sorriu e disse - Pois então tragam o homem.

Entre outras batalhas estão: a anulação de um concurso - inclusive pagando os prêmios -, montar a equipe, contando com ex-participantes do concurso

\footnotetext{
${ }^{30}$ LE CORBUSIER. When the cathedrals were White: A journey to the country of timid people. New York: Reynal \& Hitchcock, p. 35, 1947.

31 ARANTES, O. B. F. In: O RISCO: Lucio Costa e a Utopia Moderna. Direção: Geraldo Motta Filho. Rio de Janeiro: Bang Bang Filmes, 2003. 1 DVD (76min.)
} 
anulado e suas diversas versões e interpretações do tema para com isso fazer nova proposta, refazer com Le Corbusier e de novo, refazer sobre a versão Niemeyer, modificar de novo em função do necessário aumento de área em função de mais demandas, agüentar as pesadas e insistentes críticas provenientes de vários lados: perdedores do concurso aliados aos defensores do Neocolonial, suspeitas políticas e acusações de comunismo infiltrado nos modernos, a demora e o custo das obras, etc. etc. Não foi pouco, foi tamanho o trabalho prévio dele, Lucio, que por fim e provavelmente exaurido com tão longa prévia, só podia achar que tínhamos - nós todos - conseguido por milagre, de tão inacreditável que fora essa luta. E que brotou do chão nativo, naturalmente, tendo bebido diretamente da fonte, Niemeyer: - ele (Corbusier) nos deixaria de quebra, sem quereralém dos planos para a Universidade, das aulas ao vivo e daquele risco fundamental -, uma dádiva: foi durante esse curto mas assíduo convívio de quatro semanas que o gênio incubado de Oscar Niemeyer aflorou. ${ }^{32}$ (observação nossa)

E ele reitera, com mais um:

Digam o que quiserem, Brasília é um milagre. Quando lá fui pela primeira vez, aquilo tudo era deserto a perder de vista. Havia apenas uma trilha vermelha e reta descendo do alto do cruzeiro até o Alvorada, que começava a aflorar das fundações, perdido na distância. Apenas o cerrado, o céu imenso, e uma idéia da minha cabeça. O céu continua, mas a idéia brotou do chão, como por encanto e a cidade agora se espraia e adensa. E pensar que tudo aquilo, apesar da maquinaria empregada, foi feito com as mãos - infra-estrutura, gramados, vias, viadutos, edificações, tudo à mão. Mãos brancas, mãos pardas, mãos dessa massa sofrida-mas não ressentida que é o baldrame dessa Nação. ${ }^{33}$

Em Martins, encontramos uma explicação mais ponderada:

É talvez, seu empenho em negar a naturalidade dessa

transformação que o leva a usar a expressão "milagre”, fadada a gerar não poucos malentendidos.(...) Assim, se a expressão "milagre” seria de difícil incorporação ao vocabulário do crítico suíço (Siegfried Giedion), ele não deixa de manifestar que o desenvolvimento da arquitetura moderna no Brasil parecia escapar aos esquemas usuais de interpretação.

\section{(...)}

Em outras palavras, isto significa que os esquemas de interpretação que temos manejado não têm se preocupado em investigar as afinidades entre a doutrina corbusiana e as convicções e inquietações prévias de Costa. Evitar a armadilha de buscar a data, os motivos e circunstâncias de "conversão" de Costa talvez nos permita deixar de lado os esquemas da naturalidade da "influência" assim como fugir do incômodo substrato religioso ("milagre”, "conversão”, "livro sagrado”, etc.) que mais nos enreda do que esclarece. ${ }^{34}$

\footnotetext{
32 COSTA, L. Relato pessoal 1975. In: Registro de uma vivência. São Paulo: Empresa das Artes, p. 136, 1995

${ }^{33}$ COSTA, L. Manchete n 1167, 31/08/74. In: Registro de uma vivência. Maria Elisa Costa (org.). São Paulo: Empresa das Artes, p. 323, 1995.

${ }^{34}$ MARTINS, C. A. F. Lucio Costa e Le Corbusier: Afinidades Eletivas. In: NOBRE, A. L.; KAMITA, J. M.; LEONÍDIO, O.; CONDURU, R. (org.). Um modo de ser moderno: Lucio Costa e a crítica contemporânea. São Paulo: Cosac \& Naify, p. 71, 72 e 75, 2004.
} 
Lúcio é mais específico ainda:

$O$ "milagre da moderna arquitetura brasileira" - (ilegível) - que se estendeu, na sua fase inicial, da vinda de Le Corbusier, em 36, ao pós-guerra - se constituiu, no dizer de Walter Gropius, numa surpresa para o mundo - (ilegível) renascido do pesadelo, tal como o foi a criatividade de Alvar Aalto, na Finlândia.

Esta segunda vinda dele ao Brasil não decorre de um conjunto de circunstancias favoráveis e da ação conjugada de várias pessoas interessadas, - ela foi obra exclusivamente minha. ${ }^{35}$ (grifo nosso)

Como disse Le Corbusier, em 1929:

Pelo amor de Deus, o que faremos com os catálogos de decoradores? A grande obra de arte emprega meios pobres. Mas aí está o jogo: a partir do nada, realizar um milagre! ${ }^{36}$ (grifo nosso)

Além de milagre, outra palavra entra na baila das discussões:

Divulgou-se muito a idéia de que a arquitetura brasileira tenha surgido como uma espécie de milagre e e isso se deve à própria frase do Lucio Costa. Mas o fato de o edifício do Ministério realizar tão integralmente os princípios da arquitetura moderna, que ainda não estavam realizados em nenhum outro lugar do mundo, está muito relacionado com o contexto histórico da Europa e dos Estados Unidos, empenhados na guerra. Então, eu acho que a questão de se louvar o pioneirismo, no caso, não é o ponto mais importante. (...) $)^{37}$ (grifo nosso)

Sim, o Brasil, por milagre e pioneirismo, realiza, então integralmente os princípios da arquitetura moderna fato que eles não tiveram condições, em guerra que estavam, de o realizar, naturalmente. Porém não é nada útil ficar a imaginar o que poderia ter acontecido com outro contexto histórico da Europa que não a guerra $e$ dos Estados Unidos, que não tinha a guerra em seu território. Não é possível supor o que aconteceria. Mas é sabida a rejeição contra Le Corbusier no ambiente norteamericano, coisa que não ocorreu aqui, embora essa história não tenha se encaminhado de maneira totalmente pacífica, entre os brasileiros e ele. Voltaremos a isso logo adiante.

Por outro lado, os princípios da arquitetura moderna, aqui citados referem-se à conjunção de princípios corbusianos. O trabalho de Frank Lloyd Wright na América do Norte, desde períodos anteriores já vinham se realizando, com outros princípios, mas tão abrangentes quanto, nas preocupações do fazer arquitetônico.Talvez até o pioneiro, no sentido de datas, mas isso não importa, assim como ficar discutindo a invenção do avião, na qual e de novo, brasileiros e franceses entram em conflito exatamente com americanos.

Levando-se em conta as dificuldades específicas para edificar aquela construção de grande porte, e, mesmo apesar dos atrasos, percalços e demoras - 10 anos - o prédio moderno, o primeiro prédio moderno de grande porte de uso público em todo o mundo, se realizou o Ministério. Foi um milagre, no sentido lato. Tudo indica que

\footnotetext{
${ }^{35}$ COSTA, L. Registro De Uma Vivência - Ministério - fac-simile de texto manuscrito datado de 87 (p 121)

${ }^{36}$ LE CORBUSIER. Precisões: sobre um estado presente da arquitetura e do urbanismo. São Paulo: Cosac \& Naify, p. 69, 2004.

37 WISNIK, G. (org.) O Risco: Lucio Costa e a utopia moderna. Rio de Janeiro: Bang Bang Filmes Produções Ldta, 2003.
} 
Lucio tenha usado dessa maneira, simples e direta, mais do que algo se possa descobrir em entrelinhas. Foi um milagre e ponto.

Lucio, em diversos textos também usa natural, não para se referir a algo encontrado na Natureza com $n$ maiúsculo, usa natural para se referir a algo que cabe, cabível, como uma pessoa que age com naturalidade, como normal, que ele também usou bastante para várias explicações que deu, ao longo de sua árdua atribuição de explicar tudo, ou quase tudo. Tanto que escreveu Art, manifestation normale de vie, em 1968. (grifo nosso)

Ele usa natural não como o inerente ao homem, dada uma certa circunstância, quase um da natureza humana, atributo descoberto no iluminismo, mas que não cabe no Oriente, cuja dicotomia entre humano e natural pertence a outra lógica e desconhece o que se sucedeu na ocidentalização do ocidente, a partir do século XVI, acentuado no século XVIII, quando fica em voga a natureza humana. Ele usa normal e natural como um atributo social, da sociedade como um todo, como um "do outro". Nada de sobre-natural. Usa como lógico. Certa vez, para proibir mais uma afronta contra Brasília, disse - Não pode, naturalmente.

$$
\text { É o próprio Costa, em seu "Depoimento de um arquiteto carioca", }
$$

de 1951, que adverte para os riscos da adesão à tese da "naturalidade" da transformação vivida pela arquitetura brasileira nos escassos vinte anos que mediavam a tentativa - rápida e atribulada - de renovação do ensino de arquitetura na ENBA e o momento de seu texto, quando "uma fração mínima da massa edificada" havia alcançado "o apuro arquitetônico necessário para sobressair em primeiro plano no mercado da reputação internacional", permitindo aos arquitetos brasileiros "encabeçar o período de renovação da arquitetura internacional". 38

Sim, é nesse mesmo tex to que Lucio disse que: o episódio vale com lição e advertência. Lição de otimismo e esperança (...). E advertência, pois parece insinuar que, quando o estado normal é a doença organizada, e o erro, lei -o afastamento da norma se impõe e a ilegalidade, apenas, é fecunda. ${ }^{39}$ (grifo nosso)

Sobre o episódio, Lucio conta que o entusiasmo dos jovens arquitetos - meninos - era tão grande, a partir da obra do MESP, que passaram a dar palestras e conceder entrevistas, inclusive estrangeiras, e de tão entusiasmados, esnobes, omitiam Le Corbusier. Por isso, a mesmo a advertência foi usada acima, da possível perda do complexo de vira-lata, se transformar em arrogância, ou como quando um tímido em um lapso e irrompe...

Lucio, ainda em Razões, diz assim:

Para comprová-lo, basta que se note a maneira pouco feliz com que os russos - apesar das experiências iniciais do "construtivismo" - dela se têm servido, o que atesta uma estranha incompreensão. Torna-se mesmo curioso observar que a Rússia - como as demais nações - também reage, presentemente, contra os princípios da nova arquitetura, procurando em Roma inspiração ás obras de caráter monumental com que

\footnotetext{
38 MARTINS, C. A. F. Le Corbusier e Lúcio Costa: Afinidades Eletivas. In: NOBRE, A. L.; KAMITA, J. M.; LEONÍDIO, O.; CONDURU, R. (org.). Um modo de ser moderno: Lucio Costa e a crítica contemporânea. São Paulo: Cosac \& Naify, p. 71, 2004.

39 COSTA, L. Registro de uma vivência. São Paulo: Empresa das Artes, p. 169, 1995.
} 
pretende "épater" turista beócios e camponeses recalcitrantes. Não passará este fato, possivelmente, de uma crise de fundo psicológico e de fácil explicação. Era, na verdade, industrialmente, esse país um dos menos preparados para embarcar na aventura comunista; não obstante, em menos de vinte anos de trabalho (esse texto é de 1934), o resultado já obtido - embora o padrão de vida ainda seja baixo, com relação ao de certos países capitalistas - surpreende os espíritos mais céticos. É, pois, natural que depois de tantos séculos de exploração sistemática e miséria, o otimismo transborde e se derrame em aparatosas manifestações exteriores, numa escolha nem sempre feliz de formas de expressão.

Essa falta de medida resultante de uma crise de crescimento $e$, portanto, temporária, é porém tão humana, tem um gosto tão forte de adolescência, que faz sorrir, porquanto repete - com acentuada malícia - a pequena tragédia do "novo rico" burguês, com a agravante de ser, desta vez, coletiva. ${ }^{40}$ (obs. em negrito nossa)

Mais adiante, 1968, ele mostra ainda sua enorme paciência em esperar acontecer naturalmente, normalmente:

Mas como reconhecer, diante das contradições do mundo atual, o caminho que nos levará, finalmente à idade industrial verdadeira? Para mim, a referência é muito simples: toda ação que tenda a se opor fundamentalmente ao bem estar e ao desenvolvimento intelectual e social das massas obreiras (desenvolvimento que se impõe em conseqüência da prodigiosa capacidade de produção da indústria moderna) ou mesmo simplesmente retardá-la deverá ser considerada nociva aos interesses da arte, já que contribuirá para o adiamento indevido do novo equilíbrio indispensável ao seu florescimento.

Todavia, é preciso reconhecer igualmente que este advento das massas, determinado pela intensificação da produção industrial, implicará necessariamente no aviltamento temporário do gosto artístico, pois da mesma forma que o novo-rico se compraz primeiro na ostentação do seu novo estado, o "novo-riquismo" coletivo deverá também passar pela mesma prova, antes que possa atravessar esta crise de crescimento inevitável e atingir a maturidade. ${ }^{41}$

E ele explica sua teoria e sua paciência:

Não se deve, contudo, desesperar. É justamente quando a perplexidade atinge seu clímax que, por efeito do que talvez se pudesse chamar Teoria das Resultantes Convergentes, novas perspectivas se abrem em meio à configuração intrincada e ilógica dos acontecimentos e tudo parece, de novo, fácil e claro (1977). A lei das Resultantes Convergentes há de encaminhar gradativamente o processo para o desejado equilíbrio, porquanto sendo o desenvolvimento científico e tecnológico, como é simples produto da natureza amestrada, não poderá ser - em última análise, por

\footnotetext{
${ }^{40}$ COSTA, L. Razões da Nova Arquitetura. In: Registro de uma vivência. São Paulo: Empresa das Artes, p.116, 1995.

${ }^{41}$ COSTA, L. Arte, manifestação norma de vida. in Registro de uma vivência. São Paulo: Empresa das Artes, p. 267, 1995.
} 
princípio e em termos coletivos - contra o homem (Museu de Ciência e Tecnologia, 1970). ${ }^{42}$ (obs. Maria Elisa, grifo nosso)

Há um contraste bastante forte com as idéias de Lina - embora não excludente nem conflitante, mas diferentes e, num certo sentido complementares com as de Lucio. Lina, grande admiradora do filósofo Antonio Gramsci ${ }^{43}$, já em 1957, afirmou:

A "produção em série", que deve-se hoje levar em consideração como base da arquitetura moderna, existe na própria Natureza, e intuitivamente, no trabalho popular. ${ }^{44}$

Essa é a legenda de várias imagens, 76 a 79, da extinta feira de Água dos Meninos, em Salvador, em seu Propedêutica. As imagens apresentam pilhas e pilhas de objetos de barros, travessas, tigelas e moringas, e uma com uma pilha de frutas tropicais misturadas, como a produção em série da Natureza. As fotos vieram da Bahia, pois consta na legenda: J. Medeiros, O. Tavares, A. Brill.

Para o Concurso da FAU-USP, o trabalho popular não era de maior interesse, não era o objeto do concurso, daí não constarem maiores informações a respeito, mas a data é significativa: Lina foi oficialmente convidada pelo arquiteto Diógenes Rebouças para ministrar um curso na Universidade Federal da Bahia em 58 e o texto é de 57.

A Casa Cirell é de 1958, e, assim como os dados acima, indicam que a atenção e aproximação de Lina com a Bahia já vinham ocorrendo com muita intensidade, anterior ao convite.

Lina e Lucio, entre outras preocupações internas ao fazer arquitetônico, e exatamente impregnados do antropológico olhar com intransigente estado de julgamento, estabeleciam programas arquitetônicos ou interferiam nos programas de necessidades que lhes eram fornecidos.

Lina determinava como as pessoas deveriam usar, se deslocar, se comportar, dramaticamente, dentro dos espaços que projetava, na relação entre móveis e objetos projetados para esse espaço e na relação desse conjunto com seus usuários, o SESC - Fábrica da Pompéia e o próprio MASP, são exemplos claros dessa aplicação. No MASP, ainda com os cavaletes de vidro soltos no grande salão, os visitantes ziguezagueavam entre os quadros numa dança, como ela dizia. Os museus emparedados transformam a visitação numa penosa romaria.

Mas o maior exemplo disso foi o processo de projeto para o Pavilhão do Brasil em Sevilha, em 1991, que a despeito de não ter recebido qualquer menção, deixa uma memorável história:

Lina tinha quebrado a perna em uma queda, estava de cama, e, lógico, de muito mau-humor, quando lançaram as bases para o concurso para fazer o Pavilhão: Sevilha sediou as comemorações dos 500 anos da chegada de Colombo às

\footnotetext{
${ }^{42}$ COSTA, L. Com a palavra Lucio Costa. Maria Elisa Costa, org. Rio de Janeiro: Aeroplano, p. 24 e 25, 2000.

${ }^{43}$ BARDI, L. B. Lina por escrito. Textos escolhidos de Lina Bo Bardi. Silvana Rubino e Marina Grinover org. São Paulo: Cosac \& Naify, P. 37, 2009.

${ }^{44}$ BARDI, L. B. Contribuição Propedêutica ao ensino da Teoria da Arquitetura. São Paulo: Instituto Lina Bo e P. M. Bardi, p. 28, 2002.
} 
Américas. Ela não queria fazer, dizia que não se interessava, que não gostava de entrar em concursos, etc. Como queríamos tirá-la daquela situação, insistíamos muito.

Diante da nossa insistência dizia: - Cadê o programa? Não tem programa, não faço... Dizíamos que tinha sim, e apresentávamos as normas do concurso, onde constava o usual programa de necessidades. Tentamos isso por várias vezes, assim que começávamos: um teatro, um restaurante, um salão de exposições, $\boldsymbol{n}$ banheiros, $\boldsymbol{n}$ vagas de estacionamento, etc. ela nos interrompia muito brava e dizia: - Isso não é programa, onde já se viu... Nunca vi isso em toda minha vida profissional...Não vou fazer nada!

Passavam-se os dias e o prazo para apresentação do concurso estava se esvaindo. Até que numa manhã, ela muito melhor e, dessa vez, sentada na sala, disse já temos o programa, vamos expor o Homem das Américas! Me chamem Niède Guidon...Não sabíamos, naqueles tempos, quem era o tal Homem das Américas, nem quem era Niede, ela brava com a ignorância explicou: - é a pesquisadora, antropóloga, da UNICAMP!

Niède Guidon veio ver Lina, explicou que em São Raimundo Nonato, no Piauí tinha descoberto um casal de humanos, com a datação aproximada de 10 mil anos, talvez os mais antigos vestígios humanos das Américas. Lina então disse: Você empresta esse homem?Ahn, o esqueleto? Com o sim de Niède, Lina entusiasmou-se e partimos para os trabalhos com tudo, ela "ditando": - Vamos fazer uma grande caixa, toda fechada. Fechada de mármore brasileiro, toda branca, brilhando no sol de Sevilha. Um esquife para o Homem das Américas. Vamos mostrar para os europeus... eles chegaram aqui destruindo tudo, matando todo mundo, eles vão ver só: estávamos aqui a muito mais tempo, ela se incluía. E foi formulando o programa, restaurante no térreo com o cardápio: as comidas dos índios, as comidas do Brasil pré-Descobertas. No teatro primeiro andar - espetáculos como ritual dos índios Pankararu, etc. etc.

Aí entendemos: para ela programa não era o usual programa de necessidades, ela estava buscando um conteúdo para dar forma, dentro da famosa relação forma e conteúdo, debatida desde a Bauhaus. A empatia do SESC - Fábrica da Pompéia provém da força dessa estudada relação. (c.d.m.)

Lúcio também estabelecia conteúdos, sempre, inclusive em seu urbanismo. Monlevade tem vários exemplos de extrapolação do programa - de necessidades - estabelecido no concurso, e ele inclusive desenha as cenas de comportamento dos usuários de seu projeto.

Mas em Brasília, essa extrapolação chega a detalhes impressionantes, os conteúdos de cada lugar e cada lugar com seus conteúdos têm porquês precisos e todos já com nome de batismo, e até endereços, por exemplo, N-Q3-L ap. 201. ${ }^{45}$ Ou ainda, já citada aqui: Praça dos Três Poderes, contribuição de Oscar Niemeyer para a praça que projetei - e batizei. ${ }^{46}$

E o espaço-forma indizível da Plataforma Rodoviária, de tantos

\section{conteúdos.}

\footnotetext{
${ }^{45}$ COSTA, L. Registro de uma vivência. São Paulo: Empresa das Artes, p. 294, 1995.

${ }^{46}$ COSTA, L. Registro de uma vivência. São Paulo: Empresa das Artes, p. 306, 1995.
} 
Lina e Lucio: lutaram muito, passaram por venturas, mas muitos mais dissabores que não foram poucos. Mas reagiam e prosseguiam. A inteligência das diferentes reações - no mais das vezes veementes - somadas ao sempre renovado ânimo de continuar no afazer do ofício é impressionante. Deixaram um legado maravilhoso, lições de Arquitetura, ditas, escritas, desenhadas e construídas.

- Herói é no que dói. ${ }^{47}$

${ }^{47}$ ROSA, G.. Primeiras Estórias. Rio de Janeiro: Nova Fronteira, 1988 (1ª ed. 1962). 


\section{PARTE III}





\section{ANEXO I}

\section{Lucio Costa - homenagem aos seus 90 anos de vida}

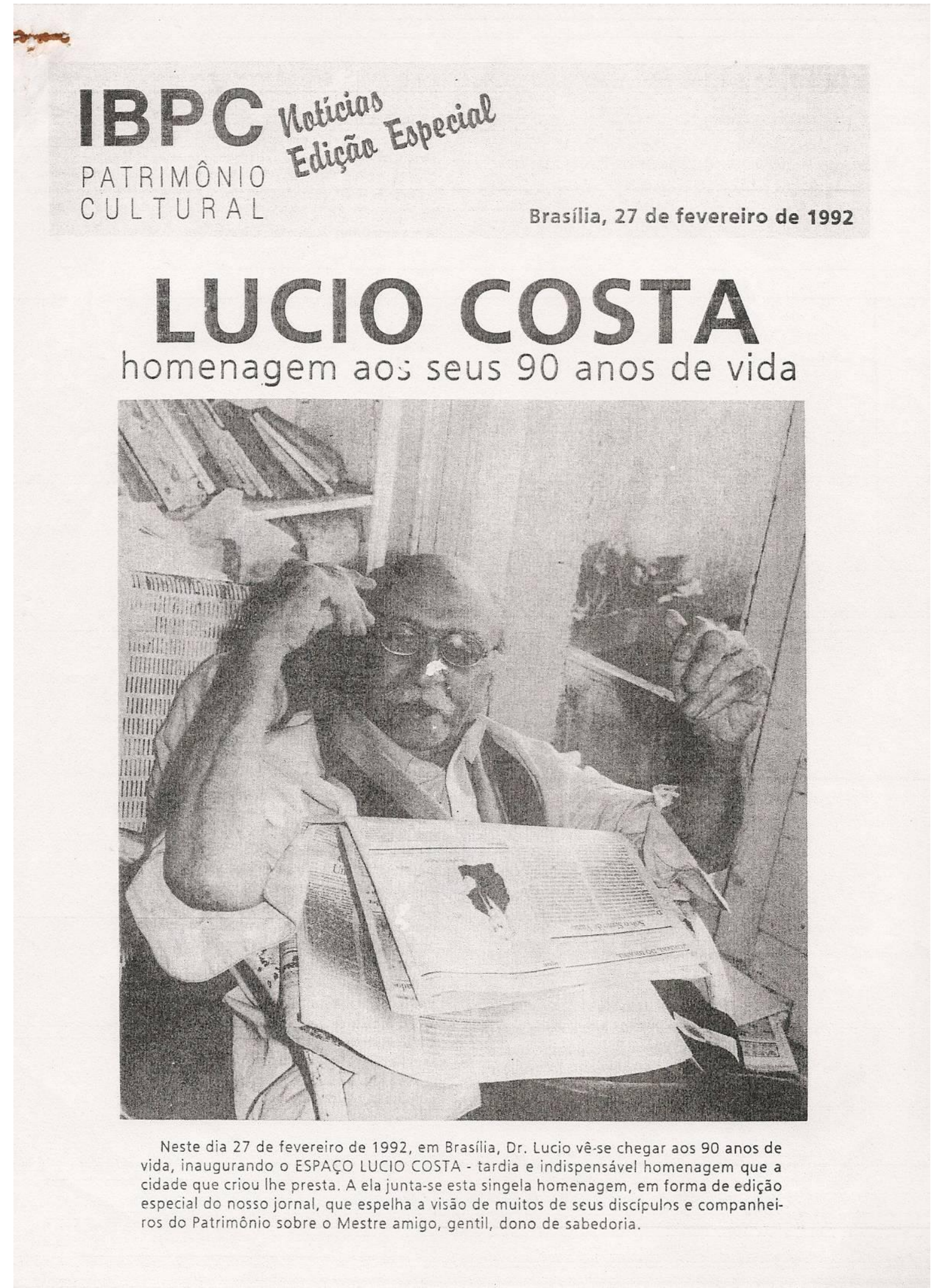




\section{Pro $: \rightarrow 0$ \\ ENTREVISTA}

Dr. Lucio recebeu em seu apartamento - que se - debruça sobre o mar do Leblon - o Diretor de Promoção do IBPC, Lauro Cavalcanti, e sua assistente, Cláudia Coutinho,e para eles discorreu sobre suas lembranças no Patrimônio.

Dr. Lucio, hoje eu queria conversar com o Senhor sobre Patrimônio..

- Foi a sua geração e mais especificamente - Senhor que começou a ter interesse sobre o passado brasileiro. Como começou esta preocupação?

Nós éramos formados para conhecer os estilos passados e aplicar estes conhecimentos aos programas contemporâneos. De acordo com o programa, recorria-se ao barroco, ao gótico, ao estilo francès Luiz XV, XVI; este era o critério chamado eclético, e houve também aquele movimento neocolonial. Já que era para imitar o passado, então vamos imitar o nosso passado e valorizáto. Começou mais em São Paulo com. o Ricardo Severo e Dubugras. Havia um clima meio decorativo, mas sempre muito equivocado. 0 nosso passado, como sabemos agora, estava cheio de coisas dignas de preservação, mas este neocolonial foi um equivoco, começou com um maneirismo e criou uma espécie de estilo falso chamado neocolonial, que não tinha nada a ver com o colonial. Isso correspondeu aos anos 20. Em outros países, aquelas pessoas que se diziam apaixonadas pelo passado, formavam um grupo e as pessoas inovadoras, modernas, outro grupo. No nosso caso, os membros interessados em modernizar, em São Paulo, em 22, foram a Minas, ao Norte, na busca do nosso passado. Foram todos eles, o Mário de Andrade, e todo o grupo. Isso ocorreu da mesma maneira nos anos 30, com o movimento relacionado com a construção do Ministério da Educação. De modo que aquele mesmo grupo que criou o Patrimônio em 1937 estava também interessado em atualizar a nossa abordagem artistica.

- Os interessados no neocolonial faziam viagens ao Brasil para colherem exemplos?

Sim, na época em que o José Mariano presidia a Sociedade Brasileira de Belas Artes, resolveram mandar três arquitetos para estudar Minas. Éramos Ângelo Bruhns, o Nireu Sampaio e eu. O Ângelo Bruhns foi para Mariana, o Nireu para Ouro Preto e eu para Diamantina. Eu era o mais novo, então, me mandaram para mais longe. Para Diamantina eram 36 horas de viagem de trem com baldeação em Corintho.
- Quanto tempo o Senhor ficou em Diamantina? O Senhor desenhava?

Eu fiquei mais ou menos um mês. Trouxe umas dez pranchas de levantamentos, Diamantina é uma cidade de pau a pique, pobre, em relação às outras, como Ouro Preto e Mariana, que tinham coisas de mais valor aparente para se documentar. Diamantina não, era um encanto de autenticidade, toda de pau a pique, não tinha nenhuma estrutura de alvenaria. Era uma cidade muito singela, no meio daquela área muito agreste, pedregosa, daquele interior, e dava a impressão de que deveria ser uma espécie de oásis de madeira e derrubaram a madeira toda para fazer a cidade. Só sobraram poucas árvores, predominando jabuticabeiras e roseiras na entrada das casas mais rurais. Era um ambiente singelo, puro. Isso foi a coisa que mais me tocou neste contato direto com o Brasil antigo. Foi também nos anos 20

Em 1926 quando viajei para Europa, tive um problema no pulmão e então me puseram num sanatório chamado Villa Igeia, fora do muro, saindo de Roma. Na entrada da cidade, tinha guardas controlando a mercadoria que entrava e a Villa Igeia era além. Um sanatório de bonitas freiras, onde eu tinha toda liberdade. Eu saía, ia a Roma passear. Mas como tinha que voltar a Paris, o médico que me atendeu, Dr. Passini,

recomendou-me consultar, no caminho, um outro especialista que, após a consulta, me disse: "Non c'è niente" e pediu-me para tomar certos cuidados mas não tinha nada sério. Quando voltei, fiquei com aquela coisa na cabeça, que tinha tido um problema. Como eu já gostava de Leleta e queria casar, achei bom fazer antes uma temporada no interior de Minas e um amigo nosso, Botafogo, que já tinha estado na Caraça e conhecia Dom Jeronymo, o superior do Caraça, escreveu uma carta de recomendação para eles me receberem. Passei lá mais de um mês. Tem aquela capela em estilo francês de meados do século XIX. Demoliram a Capela antiga, barroca, e que existe em gravuras, para construirem uma Capela em estilo gótico. Felizmente muito sóbrio, muito puro, com aquela agulha, o interior, sem ornatos, praticamente só arquitetura e ficou uma coisa bastante interessante.

Eu almoçava na mesa com os professores e a garotada toda em frente, os seminaristas, quer dizer. Nos intervalos eu ficava andando naquele adro enorme, bonito; em frente tinha uma escadaria antiga, barroca, onde a garotada ficava passeando nos intervalos das aulas. Era um ambiente muito bonito e agradável.

Fui a Sabará depois, onde fiquei bastante tempo, de modo que conheci de fato, de perto, aquela arquitetura.

$E$ isso foi sedimentando..

Em 1929 casei-me com Leleta e fui morar em Correias na casa que meu sogro tinha. Foi um 
ha. .s.

período de pobreza, praticamente miséria. Um dia - Rodrigo me telefonou dizendo que tinha sido criado o Ministério da Educação e Saúde e que ele era Chefe de Gabinete do Ministro. A preocupação deles no começo era a renovação. Rodrigo pedia-me para vir ao Rio, propondo-me ser diretor da Escola de Belas Artes. O consultor dele era Olínio Sá Pereira, engenheiro, professor da Politécnica, e me lembro de ter tido uma conversa longa com ele, eu querendo tirar o corpo fora, não topar porque senti que não tinha condiçōes. E ele alegava: "Mas se você justamente está criticando a orientação, você foi aluno, um bom aluno, os professores gostam de você, de modo que seria uma oportunidade". Aí eu tive que aceitar e foi uma experiência que durou menos de um ano. Foi uma experiência fracassada, embora muito bem recebida de inicio e com apoio total dos estudantes. Depois, o Rodrigo teve um desentendimento com o Chefe de Gabinete e demitiu-se e era ele meu apoio, pois tinha me indicado; a Congregação sentiu que eu não tinha mais o mesmo apoio. Logo depois mudou o próprio ministro e ai fracassou de fato. A Congregação da Escola me propôs uma cadeira nova, do meu agrado, que fosse criada para eu ficar numa situação regularizada, pois,

11 legalmente, para ser diretor era necessário que eu fosse professor da Escola. Mas como eu tinha entrado na Escola com o propósito de moralizar, teria sido uma coisa inadequada pretender participar da Congregação por este artificio, de modo que eu lamentei mas achei inviável. Assim continuou aquela crise e eu tive que deixar a direção da Escola.

Voltei para Correias e nessa época era procurado por uma clientela que queria coisas acadêmicas, de gente que tinha estado na Europa, naquelas cidades badaladas e queriam coisas de estilo francês, inglês e o neocolonial de quebra. Eram coisas que eu não conseguia mais fazer. Havia aquela intransigência, inteiramente compreensivel na época, mas teria sido uma coisa muito falsa.

Quero assinalar que a minha presença no Patrimônio foi muito irregular, porque eu só aceitei colaborar com Rodrigo de uma maneira pessoal, como consultor.

Durante muitos anos não tive nenhuma função regular.

- Mas o Senhor começou a colaborar desde - inicio, desde a fundação?

Sim, desde a fundação. Ele funcionou primeiro no edifício Rex.

- O Senhor participou da elaboração do anteprojeto do Patrimônio, feita por Mário de Andrade?

Não, a proposta foi feita baseada nas sugestões do Mário de Andrade, Manoel Bandeira, aquele grupo de intelectuais muito amigos do Carlos Drummond de Andrade.
- Uma vez estabelecido o anteprojeto de Mário de Andrade e depois de nomeado o Rodrigo, o Patrimônio começa a funcionar $\mathrm{com}$ um pequeno grupo de colaboradores. 0 Senhor fazia parte?

Não, não nessa época. Não sei se talvez politicamente näo fosse inidicado eu intervir diretamente no Patrimônio devido à questão da Escola, assim eu penso. O grupo era: Carlos Leão, Mário, Alcides da Rocha Miranda, Paulo Barreto.. Alguns anos mais tarde, ele quis que eu participasse a título de Consultor dele, pessoal, mas não tinha nenhuma função oficial dentro da instituição. Fiquei com esse caráter de colaborador dele durante alguns anos até que houve uma reforma e criaram a Divisão de Estudos de Tombamento. Rodrigo, então, disse-me que era preciso que eu participasse dessa renovação, oficialmente. Puseram-me como diretor desta Divisão de Estudos de Tombamento. Lá estavam também o Prudente de Morais Neto, o Luiz Jardim, o Beneditino D. Clemente Nigra e depois o Carlos Drummond. De modo que eu levei muitos anos na mesma sala onde era a biblioteca, junto com o Carlos. A minha mesa era junto à janela, a dele, junto à porta. Foi um convivio de anos. Eu ficava muito preocupado porque o Carlos vivia rasgando papéis, querendo colocar em ordem aquele arquivo e a minha tendência era poupar e eu ficava aflito com aquela desenvoltura com que ele rasgava papel. Ele ficava muito no telefone, com conversas e era bastante visitado, também. Foi um convívio muito agradável.

- Dr. Lucio, eu imagino uma geração de jovens que estavam redescobrindo o Brasil e procurando construir um Brasil novo. Então foi um trabalho de selecionar o que deveria ser tombado.

Era exatamente assim.

\section{Quais foram as primeiras diretrizes?}

A primeira diretriz era respeitar a legislação, que era muito restritiva. Para tombar, exigia-se muita qualidade e exemplares de raridade. Entre as peças valiosas daquele periodo, escolhia-se as que, de fato, eram mais significativas. A proposta era mais nesta direção. A experiência mostrou que esta guarda, esta garantia de preservação, não estava sendo coberta pela legislação porque a todo momento surgia a notícia de que iam demolir um prédio e coisas valiosas que deveriam ser preservadas, mas nāo tínhamos condiçōes de impedir. Havia outros exemplares representativos do mesmo gênero já tombados.E este foi o drama dessa grande fase do Patrimônio; não havia condições legais de preservar muita coisa. Tinhamos então que forçar, era o tombamento "in extremis". Corria o risco de uma coisa ser destruida e se essa coisa de fato era representativa do Patrimônio, então tombávamos para garantir, impedir essa perda. 
- Nessa primeira fase, era dada uma especial atenção à produção mais àntiga?

Sempre. A antigüidade era um ponto de referência, um dos pontos. Os exemplares mais valiosos eram as construçōes do séc. XVI e XVII e assim sucessivamente. Do século XVI, muito pouca coisa restou e o século XVIII foi mais denso de coisas a serem tombadas e finalmente o século XIX.

E nesta primeira fase era tombada mais a parte religiosa?

Sempre prevaleceu a parte religiosa porque 0 número de igrejas era enorme. Enquanto os anglo-saxões tinham aquela preocupação de criar riquezas, o mundo latino, de herança portuguesa e espanhola, concentrava-se na construção de conventos e igrejas. Havia uma desproporção enorme em relação à parte residencial e militar. Essa condição de que a igreja era fundamental na tradiçāo colonial, foi considerada pela crítica leiga uma espécie de desperdicio. Aquela riqueza, opulência na arquitetura religiosa, muito sóbria de fachada e que você entrava e era aquele esplendor. Mas havia um sentido social, muito profundo, nesta aparente contradição. A igreja, com aquele esplendor todo, estava aberta, pertencia a todos, qualquer pessoa do povo, por mais miserável que fosse, era só entrar e ficar lá. Havia também aquelas senhoras que se reuniam na igreja. Aquilo socialmente, tinha uma força enorme, era de uma significaçăo muito séria na formação das pessoas.

- Dr. Lucio, da mesma forma que para o estabelecimento da arquitetura moderna houve uma parceria com o trabalho de Le Corbusier, para a implantação do Patrimônio vocês entraram em contato com algum serviço de patrimônio, coin o francês, por exemplo?

Que eu saiba não. Este convivio só começou a ocorrer depois que o Patrimônio passou a ser considerado no estrangeiro como um organismo de interesse, sério, e isso foi uma coisa posterior. Não houve nenhuma procura nossa no sentido de nos apoiarrmos no já existente. Foi uma falha aliás e ocorreu, sim, o contrário.

- Sobre a especialidade que realmente dá - tom do nosso Patrimônio, isto é, a participação dos modernistas, o que poderiamos identificar como resultado disso?

Isso foi uma renovação porque o modo de encarar o Patrimônio foi bastante diferente. Nós éramos mais apegados à realidade, às coisas autênticas e não ao sentido de querer acompanhar a idéia daquele falso estilo que estava sendo criado na época, quando da Revolução de 30 . Estilo que era aquela coisa eclética, neocolonial, um desastre, no sentido da aplicação. O que era válido a ser preservado era o que servisse de apoio à nossa cultura, conhecer a fundo o passado, selecionar as coisas válidas, isso era uma coisa. Esta idéia de criar um estilo baseado em remanescentes de várias épocas, de arquitetura religiosa, misturada com arquitetura civil e fabricar umas casas chamadas de neocolonial é que foi um lastro equivocado. Aquele movimento do José Mariano. Ele, inteligente e culto, apaixonou-se pela idéia e dedicou-se a esta campanha que já existia em São Paulo, com o Ricardo Severo e outros. Só depois da sua criaçāo, é que o Patrimônio tomou pé, no sentido de zerar esta conotação artificiosa do movimento que deu origem ao neocolonial.

- E na questão da restauração mesmo, na liberdade da construção de coisas novas junto a antigas?

O Patrimônio marcou muito esta abordagem principalmente com o José de Souza Reis. 0 primeiro exemplo que o Patrimônio teve que enfrentar foi em Ouro Preto.

O Reis projetou uma coisa francamente atual, despojada e sem pretensōes de criar falsos modernismos. Ele fez uma estrutura simples mas contrastando violentamente com a redondeza, com a ambientação vizinha. Eu acho que foi uma inexperiência do Patrimônio, porque a experiência levou a distinguir os critérios, que não podem ser únicos na orientação da restauração. Acho que se o prédio é encravado entre um renque de casas antigas contínuas, por exemplo, numa rua, me parece que 0 critério deve ser fundamentalmente submetê-lo à vizinhança, de uma forma discreta, mas obedecendo àquela modulação, àquela maneira, porém sem cair na caricatura do pastiche. Em outros casos, quando há mais possibilidade, deve integrar-se na ambientação, com muito mais liberdade para fazer uma coisa contemporânea, como é o caso do Grande Hotel de Ouro Preto.

- 0 episódio do Grande Hotel é quase uma radicalização do movimento, no sentido de se afirmar como obra de arte?

Quando o Rodrigo me telefonou e disse que tinha confiado a Oscar Niemeyer a construção de um hotel em Ouro Preto, pensei: "Ah! meu Deus, você está comprando uma situação muito perigosa" ; fiquei apreensivo quanto às conseqüências.

O projeto inicial era francamente moderno contemporâneo e, naquelas dimensões e local, achei que era um pouco excessivo, seria de mau gosto tomar esta iniciativa. Foi então feita, pelo Zanini, uma maquete do projeto e se questionou 
a conveniência de fazer uma coisa tão radical. Foi projetada uma variante pelo próprio Oscar e o resultado foi uma coisa mais agradável

integrada, inclusive a parte de pintura.

- No Patrimônio, o Senhor viajaya muito?

Não, eu viajava relativamente pouco. Conheci mais a Bahia e Pernambuco, em escalas nas minhas viagens para a Europa, pelo Lloyd. 0 navio ia parando e ficando uma boa temporada em Salvador, Recife e foram meus períodos de maior demora lá. Fora disso, em Minas, naquela fase de que já lhe falei, sempre fazia pequenas viagens, mas nada demorado.

\section{E as Missões Jesuiticas?}

Foi exatamente a minha primeira tarefa no Patrimônio. Rodrigo me chamou e pediu-me para resolver alguns problemas na regiäo missioneira. Ele disse para ir lá, estudar e fazer uma proposta. Eu fui de hidroavião e encontrei-me com Augusto Meyer, um intelectual de primeira categoria que. chefiava a biblioteca de Porto Alegre e era representante do Patrimônio lá. De modo que foi agradável esta ida, apesar de ter sido uma viagem bastante penosa, de Porto Alegre até Santo Ângelo. Fiz o relatório e o projeto do museu que tem lá aproveitando o material que tinha espalhado pelo chão. Este projeto era baseado na casa dos índios da maneira que os jesuítas fizeram, avarandada com colunas de pedra e telhado cobrindo a galeria. Era uma sensação muito curiosa você andar no mato e encontrar fragmentos de cornijas e outros elementos. Inclusive havia duas casas construidas no século passado com o material das ruínas. Eu fiz até o levantamento.

- E o museu? O Senhor acompanhou a obra?

Não, eu não voltei lá não, só muito tempo depois.

Dr. Lúcio, quando começa a questão do entorno, do além do monumento?

Bom, isso foi uma decorrência fatal, não com esta palavra mas com vizinhança, ambientação, porém entorno diz melhor, é mais fiel. Sempre se levou em conta muito isso, mas estávamos presos à limitação da legislação, à excepcionalidade que ela exigia para dar validez ao tombamento. Engraçado é que não chegou a haver muita reação, muito protesto, das "vítimas" de um prédio tombado, querendo justificar, reclamar, alegando que o prédio não tinha tantas qualidades, tanto valor, para justificar o tombamento. Houve poucas reações.

- $E$ a extensão da questão do Patrimônio para as cidades históricas?

Isso foi uma iniciativa da própria indole do Rodrigo, pelo interesse histórico de alguma região, de algum prefeito, e outras por iniciativa do próprio Patrimônio. Em casos excepcionais, coisas muito puras sobreviveram desconhecidas. As primeiras casas de taipa que eu vi em Săo Paulo, como a casa do Padre Inácio, por exemplo, aquele partido paladino de ter uma "loggia", uma varanda e dois corpos cheios com uma janela cada um, me impressionaram e logo providenciei o tombamento de todos os remanescentes neste gênero que eram bem característicos.

- No Patrimônio o Senhor se envolvia com as obras?

O Renato Soeiro foi por grande tempo responsável pela Seção de Obras e eu às veze dava alguns pareceres.

- Como o Senhor fez a ligação entre os orincipios Corbusianos e a arquitetura de taipa? Quando isso começa a tomar importância?

Foi a bordo do navio, em 1927, quando voltava da Europa. Houve um epsiódio significativo para mostrar como eu era alienado. Numa dessas brincadeiras de jogo de forca, colocaram a primeira letra, que era um nome começado por " $L$ " ; eu fui indo, fui indo, e acabei enforcado. A palavra era Le Corbusier, veja como eu estava alienado, três anos antes da minha entrada para Escola.

Foi com a vinda de Le Corbusier, uma iniciativa dificil, exclusiva minha, que surgiu a personalidade do Oscar Niemeyer. Ele trabalhou mais de um ano no meu escritório sem revelar nenhuma qualidade excepicional. É muito. perigoso você orientar ou desorientar alguém dizendo que não tem vocação. Eu até sugeri ao Oscar para ir trabalhar num banco porque ele não parecia uma pessoa com vocação. Ele explodiu com o convivio daquele grupo que trabalhou com Le Corbusier.

Como o Senhor vê o Patrimônio hoje?

Não tem o espírito do Patrimônio da época do Rodrigo. Naquele periodo conheciamos mais nosso Patrimônio, nossos valores e havia mais paixão, mas eu espero que vocês consigam recuperar este espirito.

Dr. Lucio, muito obrigado. 


\section{RELATO PESSOAL}

Texto escrito por Dr. Lucio especialmente para o $n^{2} 40$ - edição de relançamento da revista Módulo, em 1975

O projeto do edifício-sede do Ministério da Educação data de 1936. A sua construção, iniciada no ano seguinte, foi lenta. Em 1944 já estava praticamente concluido, mas só foi inaugurado em 1945. Se considerarmos, portanto, como referência, a sua concepção, já tem mais de 50 anos, mas apesar da época não perdeu, nem perderá jamais a força e carga expressiva que lhe são inerentes.

É dificil ao arquiteto de hoje perceber a significação dessa obra e aquilatar o que ela representou de paixão, de esforço, de sacrifício.

Os novos conceitos arquitetônicos, formulados na década anterior, ainda não haviam sido assimilados pela opiniäo culta e popular e eram violentamente refutados. Mas para mim, que tinha dedicado o chômage de 32 a 35 ao estudo da obra teórica de Le Corbusier, o problema arquitetônico parecia então indissoluvelmente entranhado no problema social, porquanto oriundos da mesma fonte - a revolução industrial do século $\mathrm{XIX}$ - , e esse vinculo de origem conferia sentido ético à tarefa em que estávamos empenhados, exigindo-nos dedicação total, como se fôssemos, na nossa área, moralmente responsáveis pelo bom encaminhamento da meta comum.

Isto explica porque, tendo um projeto já pronto e aprovado, em vez de darmos logo início à obra como seria normal e faria qualquer arquiteto hoje em dia, resolvemos considerar o dito por não dito e recomeçar tudo da estaca zero. É que, apesar de se tratar de um belo projeto, tínhamos as nossas dúvidas e deliberamos submetê-lo ao veredito do mestre.

Esse projeto inical compunha-se de um bloco mais alto implantado na posição atual do edifício, já com a fachada sul envidraçada e quebra-sol na fachada norte, mas dispondo de pavimento térreo com saguão !igado ao auditório, construção esta solta do bloco principal ao qual se articulavam do lado oposto, ou seja, norte, duas alas de menor altura, sobre pilotis baixos, enquadrando a entrada com pórtico carroçável precedido por um espelho dágua e pela escultura de Celso Antônio intitulada "Homem em Pé" cujo modelo já estava pronto. Nas salas de trabalho dessas alas laterais, orientadas para leste, as janelas eram corridas, enquanto as galerias de acesso, voltadas para o poente, dispunham apenas, em cada tramo, de uma pequena janela quadrada, prevendo-se revestimento externo com granito rosa do Joá.

Mas não foi fácil conseguir a vinda de Le Corbusier, porquanto no ano anterior já aqui estivera Piacentini - o arquiteto de Mussolini contratado pelo governo para ajudá-lo no problema da implantação da Cidade Universitária (a escolha então oscilava entre a Praia Vermelha e a área existente aos fundos da Quinta da Boa Vista, onde se acha atualmente o Jardim Zoológico) - e o ministro (apanema não se sentia em condições de pleitear nova contratação. Mas tanto fiz que me levou ao Catete, e o Dr. Getúlio, entre divertido e perplexo diante de tamanha obstinação, acabou por aquiescer, como se cedesse ao capricho de um neto. Recorremos então ao Monteiro de Carvalho que conhecia pessoalmente Le Corbusier, ficando estabelecido que viria por quatro semanas para reexaminar o problema da Cidade Universitária, fazer uma série de conferências (realizadas no então Instituto Nacional de Música, sempre lotado) e, finalmente, para dar parecer sobre o projeto do Ministério.

Ele viajou pelo "Graf Zeppelin", que fazia em quatro a cinco dias a rota Atlântico sul, pousando em Santa Cruz. E fomos todos de madrugada esperá-lo em companhia de Hugo Gouthier, então do gabinete do ministro, chefiado por Carlos Drummond de Andrade.

Tinhamos escritório no Edifício Castelo, na av. Nilo Peçanha 151, onde ele se instalou, mantendo inicialmente certa reserva para conosco, pois ignorando as circunstâncias da sua convocação julgava-se convidado por iniciativa do próprio ministro, desejoso do seu parecer sobre a construção projetada.

Considerou, de saida, o terreno impróprio oorque estaria dentro em pouco cercado por prédios inexpressivos. Parecia-the, que 0 edificio deveria ficar voltado para o mar e o Pão de Açúcar, fixando-se na área correspondente, antes do segundo aterro, àquela onde hoje se encontra - MAM, e para ela elaborou, com extrema espontaneidade, o belo risco de um edifício de partido baixo e alongado que serviu depois de base ao projeto definitivo. "J'ai simplement ouvert les ailes de votre bâtiment", disse ele então num generoso understatement. Mas a troca do terreno já na posse do governo federal por outro de propriedade municipal implicaria em delongas, e não se efetivou. Ele ainda tentou adaptar a sua concepção ao terreno original, surgindo então um impasse, porque sendo. o lote mais estreito na desejada orientação sul não haveria como dispor, nessa orientação, a metragem total de piso requerida pelo programa, uma vez que então as autoridades da aeronáutica limitavam o gabarito a dez pavimentos. Teve assim que implantar o bloco no sentido norte-sul, com fachadas para leste e oeste, o que resultou numa composição algo contrafeita que não agradou nem a ele nem a nós. Contudo, apesar dessa frustação final, ele ainda nos deixaria de quebra, sem querer - além dos planos para a Universidade, das aulas ao vivo e daquele risco fundamental -, uma dádiva: foi durante este curto mas assíduo convivio de quatro semanas que o gênio incubado de Oscar Niemeyer aflorou.

Depois de sua partida nos atribuímos a tarefa 
de fazer novo projeto baseado na sua proposição inicial, ou seja, orientado mesmo para o sul e com a altura necessária, determinando desde logo a Emilio Baugart, engenheiro responsável pelo cálculo estrutural, a previsão de fundiçōes capazes de suportar a carga definitiva, isto porque eu, como bom carioca, entendia que, com o tempo, a coisa se resolveria. E assim de fato ocorreu.

Elaborado o projeto, enviamos um jogo de cópias acompanhado de fotografias da maquete à rua de Sèvres 35 e ele respondeu congratulando-se conosco: "Il est beau, votre projet".

Éramos todos ainda moços e inexperientes Oscar Niemeyer, Carlos Leão, Affonso Eduardo Reidy, Jorge Moreira, Ernani Vasconcelos; o mais velho e já vivido profissionalmente era eu. Entretanto agimos como donos da obra, construida sem a interferência de um empreiteiro geral, pela própria divisão divisão de obras do ministério, chefiada então por Souza Aguiar, e tivemos como técnico principal para as instalações Carlos Ströebel. Foi uma experiência difícil, tanto mais que a concepção arquitetônica do prédio era tida pela crítica e opinião pública como exótica, imprópria para a ambientação local, além de "absurda" por deixar o térreo em grande parte vazado. Aliás, o próprio Auguste Perret, de passagem aqui, menosprezou, na presença do ministro, o risco original de Le Corbusier, declarando que o edifício estaria dentro de pouco tempo sujo "devido à falta de cornijas" - mas apesar desse sombrio prognóstico as suas belas empenas continuam impecavelmente limpas.

Com o início da guerra os contatos eventuais se interromperam de todo, e Le Corbusier só teve notícias da obra concluida quando, terminado o pesadelo, revistas especializadas em todos os paises começaram a-divulgar, como revelação, a chamada nova arquitetura brasileira, despertando assim o interesse de arquitetos que aqui vinham unicamente para conhecer o Ministério, a $A B I$, a Pampulha, o Parque Guinle etc, enquanto daqui partiam grupos de estudantes em excursão pela Europa orientados por professores nem sempre suficientemente informados mas que faziam palestras sobre o assunto. E como tanto as revistas como os improvisados divulgadores omitissem pormenores da participação pessoal de Le Corbusier no caso, e os contatos diretos conosco não houvessem sido restabelecidos, ele passou a interpretar tais ocorrências como usurpação da parte que, de direito, lhe cabia, estado de espírito que o levou, numa espécie de revide, à défaillance de publicar como risco original seu para o edificio efetivamente executado um croquis calcado sobre aquela fotografia da maquete que lhe havíamos em tempo enviado junto com o projeto, desenho este feito sem convicção e sem data (ele sempre datava todo e qualquer risco que fizesse). Evidentemente a sua intenção fora simplesmente evidenciar o vínculo - melhor, a filiação - de uma coisa com a outra.

Esse risco figurou maliciosamente numa exposição havida em São Paulo, por volta dos anos 50, quando eu havia escrito aos organizadores da mostra alertando para o fato de se tratar de um falso testemunho que deveria ser substituido pelo risco original da edificação baixa e alongada à beira-mar que, este sim, serviu de base ao novo projeto.

Informado do que ocorria, escrevi-lhe então precisando os fatos e as circunstâncias e remetendo, inclusive, fotografia da inscrição gravada na própria parede do saguão do edifício e redigida por mim em substituição ao texto omisso que me fora submetido, pois já estava prevendo as possíveis consequências do caso. E a coisa assim se desfez, tanto mais que nos sucessivos encontros em Paris passou a me conhecer melhor e logo compreendeu que o empenho de todos nós fora unicamente contribuir para a consolidação da sua obra e fazer, tanto quanto possivel, na sua ausência, o que fosse do seu agrado. Assim, acatamos as suas recomendações no sentido do emprego de "azulejôs" nas vedaçōes térreas e do gnaiss nos enquadramentos e nas empenas, bem como a preferência assinalada no seu risco por outra escultura de Celso Antônio que não a escolhida por nós, - "Homem Sentado".

A propósito dessa figura monumental, de vários metros de altura, cabe aqui, num parêntese, o registro da cena trágica que presenciei no atelier improvisado no próprio canteiro de obras onde o escultor trabalhou vários anos a fio. Certa tarde o ministro - tal como Lourenço de Medici ou Julio II ele acompanhava amorosamente o trabalho dos seus artistas, mormente os de Portinari e do Celso -, pediu que mostrássemos a obra a Aníbal Machado. O escultor, que já havia recoberto a enorme massa de alto a baixo com panos umedecidos para a devida preservação do barro, determinou ao seu auxiliar que a descobrisse novamente, e na luz mortiça da tarde e de uma lâmpada que lhe avivava a forte modenatura, a estátua foi aos poucos surgindo; mas, quando a tarefa ia a meio, a possante figura com seu olhar parado foi-se inclinando lentamente para trás e desmoronou num estrondo.

Seja como for, porém, a verdade é que depois daquelas quatro semanas de 1936 não houve mais qualquer interferência de Le Corbusier, que só veio a conhecer o edifício já pronto poucos anos antes da sua morte, quando aqui retornou para projetar a embaixada da França em Brasília, projeto este lamentavelmente desfeito com a colaboração do próprio arquiteto do atelier da rua de Sèvres incumbido de levá-lo avante.

Esse belo edifício do Ministério é, conforme já 
tenho dito, um marco histórico e simbólico. Histórico, porque foi nele que se aplicou pela primeira vez, em escala monumental, a adequação da arquitetura à nova tecnologia construtiva do conreto armado, inclusive a fachada totalmente envidraçada, o pan de verre; as experiências anteriores haviam sido todas em edifícios de menor porte. Quando, com a sua estrutura já adiantada, fui com Oscar Niemeyer cuidar do pavilhão do Brasil na Feira Internacional de 1939, não havia em Nova York nenhum edifício com essas fachadas translúcidas que caracterizam atualmente a cidade, as agora chamadas "curtain walls" ou "murs rideaux". Vieram todos depois. É simbólico porque, num pais ainda social e tecnologicamente subdesenvolvido, foi construído com otimismo e fé no futuro, por arquitetos moços e inexperientes, enquanto o mundo se empenhava ern autoflagelação.

Assim, as marchas e contramarchas; os obstáculos, as contrariedades, tudo valeu a pena. Mesmo a difícil deliberação de me afastar quando senti que já perdia o poder de decisão e que, portanto, a minha presença tolhia os demais; tudo valeu a pena porque, assim, o grupo nắo traiu a confiança do extraordinário ministro e do nosso poeta maior que, na sua condição de eficiente moral tal, lhe chefiava o gabinete.

A minha última intervenção, já no final da obra e depois do ostracismo que me impusera, foi quanto à cor dos peitoris da fachada norte, que o Oscar pretendia azuis como as lâmpadas do quebra-sol. Juntos descemos pela avenida Graça Aranha, a fim de ajuizar à distância, e me pareceu melhor fazê-los cinza, conforme felizmente ficaram.

E com esta pequena e derradeira escolha, dei por encerrado essse capítulo da minha vida profissional.

Lucio Costa

\section{LUCIO COSTA E O PATRIMÔNIO}

Carta do Arq. Lucio Costa ao Diretor do SPHAN, Dr. Rodrigo M.F. de Andrade, sobre o projeto do Grande Hotel de Ouro Preto, elaborado pelo Arq. Oscar Niemeyer.

"Rodrigo.

$\mathrm{Na}$ qualidade de arquiteto incumbido pelo CIAM de organizar o grupo do Rio e na de técnico especialisra encarregado pelo SPHAN de estudar a nossa arquitetura antiga, devo informar a você, com referência à construção em Ouro Preto do hotel projetado pelo O.N.S. (Oscar Niemeyer Soares), o seguinte:

Sei, por experiência própria, que a reprodução do estilo das casas de Ouro Preto só é possivel, hoje em dia, à custa de muito artifício.

Admitindo-se que o caso especial dessa cidade justificasse, excepcionalmente, a adoção de tais processos, teríamos, depois de concluída a obra, ou uma imitação perfeita, e o turista desprevinido correria o risco de, à primeira vista, tomar por um dos principais monumentos da cidade uma contrafação, ou então, fracassada a tentativa, teríamos um arremedo 'neocolonial' sem nada de comum com o verdadeiro espírito das velhas construções.

Ora, o projeto do O.N.S. tem pelo menos duas coisas de comum com elas: beleza e verdade. Composto de maneira clara, direta, sem compromissos, resolve com uma técnica atualissima e da melhor forma possivel, um problema atual, como os construtores de Ouro Preto resolveram da melhor maneira então possivel, os seus próprios problemas. De excepcional pureza de linhas, e de muito equilíbrio plástico, é, na verdade, uma obra de arte e, como tal, não deverá estranhar a vizinhança de outras obras de arte, embora diferentes, porque a boa arquitetura de um determinado período vai sempre bem com a de qualquer período anterior - 0 que não combina com coisa nenhuma é a falta de arquitetura.

Da mesma forma que um bom ventilador e telefone sobre uma mesa seiscentista ou do século XVIII não podem constituir motivo de constrangimento para os que gostam verdadeiramente de coisas antigas - só o novorico procura escondê-los ou fabricá-los especialmente no mesmo estilo para não destoarem do ambiente; da mesma forma que automóvel de último modelo trafega pelas ladeiras da cidade-monumento sem causar dano visual a ninguém, concorrendo mesmo, talvez, para tornar a sensação de 'passado' ainda mais viva, assim, também, a construção de um hotel moderno, de boa arquitetura, em nada prejudicará Ouro Preto, nem mesmo sob o

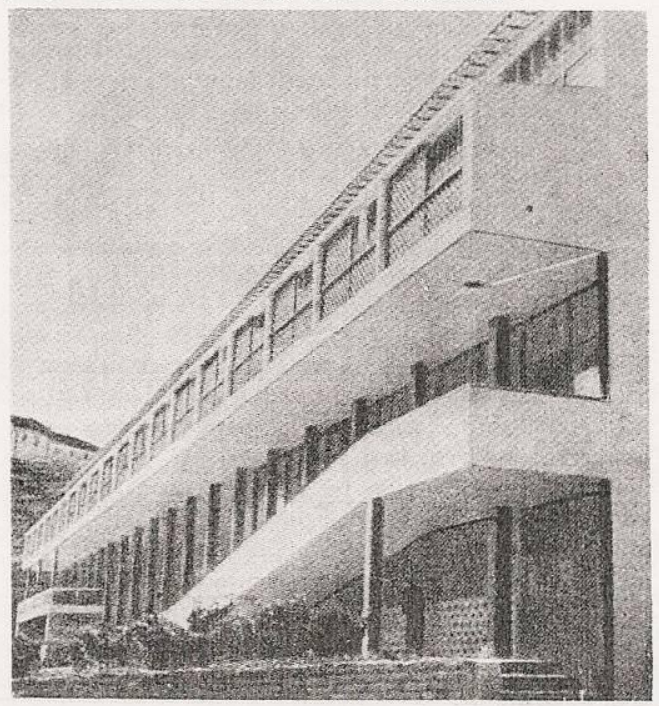


aspecto turistico-sentimental, porque, ao lado de uma estrutura como essa tão leve e nítida, tão moça, se é que posso dizer assim, os telhados veihos e despencando uns sobre os outros, os rendilhados belissimos das portadas de $S$. Francisco e do Carmo, a Casa dos Contos, pesadona, com punhais de pedra do Itacolomi tudo isso que faz parte desse pequeno passado para nós já tão espesso, como você falou, parecerá muito mais distante, ganhará mais um século, pelo menos, em vetustez. E as duas grandes sombras, cuja presença o Manuel sentiu tão bem, avultarão - iendárias, quase irreais.

E não constituirá um precedente perigoso possivel de ser imitado depois com má arquitetura - porquanto Ouro Preto é uma cidade já pronta e as construçōes novas que, uma ou outra vez lá se fizerem, serão obrigatoriamente controladas pelo SPHAN que terá mesmo de qualquer forma, mais cedo ou mais tarde, de proibir em Ouro Preto os fingimentos 'coloniais'.

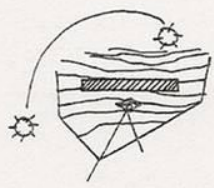

withen.
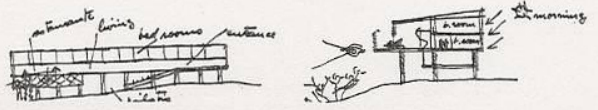

Quanto aos inúmeros exemplos de fora, Inglaterra e USA - principalmente USA, em que se tem adotado critério oposto, isto é, o de reproduzir um estilo 'apropriado' a tudo, até mesmo nos interruptores de luz elétrica - eles significam para mim bem pouca coisa. Conheço os 'grandes artistas' que orientam essas importantes organizaçōes culturais patrocinadas por senhoras da melhor sociedade, muito ricas extremamente sensiveis às belezas artísticas da Itália e da Espanha de outros tempos. Lá também as pessoas melhor informadas já não querem saber disso.

Agora na qualidade não só de arquiteto filiado ao CIAM e de técnico especialista do SPHAN, mais, ainda, de seu amigo, sinto-me na obrigação de dizer também o seguinte:

Diante da reação 'instantânea' - ao meu ver um tanto precipitada - daqueles justamente de quem fora lícito, por todos os títulos, esperar-se uma atitude mais acolhedora e comprensiva - pelo menos depois do exame refletido da questão - e o apoio moral à iniciativa, e por avaliar perfeitamente as conseqüência possíveis, senão mesmo prováveis, desse 'caso' em que, por falta de amparo, você poderá se ver na contigência de ter de sacrificar todo esse esforço de mais de dois anos de que sou testemunha, comprometendo. então, irremediavelmente o seu programa de realizaçōes no Serviço e não se fazendo, assim nem uma nem outra coisa, me pergunto se objetivo em vista justifica os riscos da experiência e corresponde verdadeiramente - para outros que não para nós, arquitetos - à importância do que está em jogo. E já que você, ontem, me comunicou haver solicitado do O.N.S. o estudo de uma variante que procurasse atender mais de perto às caracteristicas locais ouro-pretanas solicitação esta feita por você espontaneamente, sem, nem de leve, qualquer sugestão ou interferência minha - me pergunto também, e ainda aqui sem perder de vista nem o CIAM nem - SPHAN, se, em casos assim tão especiais, e dadas as semelhanças tantas vezes observadas entre a técnica moderna - metálica ou de concreto armado - e a tradicional, do "pau-a-pique", não seria possível se encontrar uma solução que, conservando integralmente o partido adotado e respeitando a verdade construtiva atual e os princípios da boa arquitetura, se ajustasse melhor ao quadro e, sem pretender de forma nenhuma reproduzir as velhas construções nem se confudir com elas, acentuasse menos ao vivo o contraste entre passado e presente, procurando, apesar do tamanho, aparecer o menos possivel, não contar, melhor ainda, não dizer nada (assim como certas pessoas grandes e gordas mas de cuja presença a gente acaba esquecendo), para que Ouro Preto continue à vontade, sozinho lá no seu canto, a reviver a própria história. L."

Obs: Na transcrição procedeu-se d̀ atualização da ortografia In revista do Patrimônio Histórico e Artístico NAcional, $n^{2}$ 22/1987. SPHAN em Ouro Preto - uma história de conceitos e critérios. Lia Motta.

\section{Plano de Trabalho para a Divisão de Estudos e Tombamentos da DPHAN}

O estudo e a consequente classificação do acervo histórico-monumental de interesse artístico que nos incumbe preservar baseia-se nos dados colhidos em duas fontes distintas de informaçōes.

De uma parte informações de natureza técnico-artistica, ou seja as constantes do inventário fotográfico, tanto quanto possível completo e acompanhado de plantas se for 0 caso, das obras e alfaias dignas de exame, bem como as decorrentes da observação direta dos principais monumentos e peças assim inventariados, observação esta enriquecida, ainda, pela experiência adquirida no trato mais íntimo e no manuseio diário de uma fração ponderável desse material, em consequência das obras de restauração, conservação e asseio empreendidas por todo o país. 
De outra parte informaçōes de natureza histórico-elucidativa que, em última análise, se resumem na compilação de dados, tanto quanto possivel precisos, sobre a história da construção desses monumentos e da execução dessas obras e alfaias, e sobre os artistas e artífices - mestres e oficiais - que os conceberam e construiram ou executaram, e ainda, finalmente, sobre as circunstâncias que tornaram possivel o seu feliz andamento ou as vicissitudes que dificultaram a sua realização, senão mesmo a impediram de chegar a bom termo.

Sem esse lastro seguro de informaçōes os estudos tentados serão sempre tateantes e de proveito precário, porque sujeitos a desmentidos mais ou menos prontos e chocantes ou mesmo à completa revisão e as obras de restauração empreendidas correrão sempre o risco de mutilar determinadas características originais ainda preservadas, devido a erros de interpretação, compremetendo-se assim, sem remédio, a integridade e autenticidade da obra primitiva, com evidente prejuizo da autoridade e da confiança que os empreendimentos da DPHAN devem inspirar e merecer.

A importância dessa tarefa fundamental é de tal ordem, que não me vexaria de recomendar a paralização quase completa das obras em andamento e o cancelamento dos novos serviços com exceção dos de proteção provisória aos forros pintados com tintas à base de água contra a ação das goteiras - a fim de que as verbas da dotação anual do DPHAN fossem integralmente aplicadas, durante dois ou três exereícios consecutivos, nessa empresa de colheita e compilação maciça de informações - fundamento sobre o qual deverão assentar todas as iniciativas da Repartição.

Ainda que se julguem tais medidas de caráter caráter extremo intempestivas e impraticáveis por motivos de ordem política ou administrativa, o fato é que providências de amplo alcance e urgentes se impõem, visando a enfrentar de modo decisivo tão flagrante lacuna, a fim de que, no menor prazo, a Divisão de Estudos e Tombamento possa dispor de material de trabalho adequado, pois, sem ele, não poderá realizar de maneira séria e sistematizada os estudos que the incumbem de interpretação, crítica e classificação das obras inventariadas, nem contribuir de forma criteriosa na elaboração do plano de obras de cada exercício, nem tampouco, ainda, proceder à seleção idônea dos monumentos 'ou das partes ou peças deles que, por seu excepcional valor, devam ser inscritos nos livros do Tombo respectivos.

Pois, na verdade, tanto no que se refere ao inventário de fotografias e de plantas, como no que diz respeito aos dados históricos elucidativos, a documentação existente é deficientíssima. No primeiro caso não é apenas o inventário de numerosas obras ainda por fazer que desalenta o eventual pesquisador, mas, principalmente, 0 registro na grande maioria dos casos incompleto e disparatado das obras inventariadas, o que falseia a sua interpretação tanto no geral como no particular e impossibilita qualquer juizo seguro de valor a respeito delas. No segundo caso, então, a omissão é, por assim dizer, total, porquanto - excetuados determinados monumentos de certas regiöes de Minas Gerais, onde já se coligiu documentação abundante e precisa, capaz de esclarecer e explicar em suas minúncia a execução da obra, e excetuando ainda, um ou outro monumento ou personalidade de outra regiāo, estudado isoladamente por algum pesquisador a serviço da repartição ou autônomo - no mais, näo existe praticamente documentação alguma.

Ora, a colheita desse material é tanto mais necessária e premente quanto sabemos que, devido ao estado ruinoso da maior parte dos monumentos e dos livros onde se contém a respectiva documentação - estado esse decorrente não só da ação natural do tempo, como da falta de recursos e do desleixo das pessoas ou autoridades responsáveis pela sua guarda - ambos se acham permanentemente ameaçados: os monumentos de destruição, mutilação ou desmantelo; os livros, de extravio ou deterioração.

Mas nem só da falta de material organizado para servir de base aos estudos se ressente esta Divisão, senão também da falta de pessoal técnico habilitado e possuído da necessária paixão pela tarefa especializada a empreender, capaz, em suma, de utilizar com proficiência e proveito o material compilado.

À vista do exposto, parecem-me recomendáveis as seguintes medidas de ordem geral, visando a aparelhar esta Divisão dos meios efetivos de tornar-se útil:

19) A criaçăo, tanto na Sede como nos diferentes distritos, de corpos de técnicos abrangendo as seguintes especializaçōes:

a) arquitetura e construção; b) pintura figurativo-ornamental e douramento; c) talha e escultura; d) mobiliário e obras de torno; e) prata e ourivesaria em geral; f) louça, porcelana e demais cerâmicas; g) vidros e cristais. Cada corpo desses deverá constituir-se de, pelo menos, um técnico em cada especialização, selecionado de preferência entre os artistas e críticos experimentados no ofício, ou entre colecionadores, antiquários ou conservadores de museus, e, na falta de pessoas já devidamente habilitadas, a escolha deverá recair sobre elementos dotados de cultura geral e conhecimentos afins à especialização e que, pela sua natural disposição se mostrem capazes de, em condições propícias e pelo esforço, tornarem-se, com o tempo, especialistas na matéria. A função desse pessoal será o estudo, interpretação, classificação e tombamento do material inventariado correspondente à respectiva 
especialização, bem como a recomendação das providências necessárias à sua defesa, restauro e boa conservação.

$\left.2^{2}\right)$ A criação na sede e em cada um dos distritos, de pequenas "equipes" incumbidas unicamente de batidas sistemáticas para colheita de material de inventário, não somente nas regiöes acessiveis, como também, principalmente, nas zonas de acesso dificilservidas por caminhos antigos, equipes constituidas de um fotógrafo e de um técnico habilitado - possivelmente a mesma pessoa - ambos com gosto por essa espécie de aventura que deverá ser levada a cabo sem pressa, com o espírito esportivo próprio dos caçadores e com o mesmo zelo e determinação de que dão mostra os viajantes catadores de antiguidades. Essa tarefa não poderá ficar na exclusiva dependência dos chefes de distritos, geralmente absorvidos por preocupações de natureza mais urgente e com tendência a adiar indefinidamente esse gênero de providências. As equipes deverão ter espírito de iniciativa e dispor de certa autonomia a fim de se garantir a eficiência e o bom êxito do empreendimento.

Além disso, cada distrito deverá possuir um aparelho "Leica", ou similar, completo, e contratar com fotógrafo competente um curso prático de fotografia com o propósito de fazer de cada um dos funcionários técnicos da repartição um fotógrafo habilitado, capaz de fazer a sua própria documentação nas viagens de reconhecimento, pesquisa ou inspeção.

$\left.3^{2}\right)$ A criação, na sede e nos distritos, de várias turmas de pesquisadores de dados histórico-elucidativos, para atuarem simultaneamente cada uma num setor delimitado, concentrando-se cada pesquisador em um determinado monumento com as obras de arte que encerra, a fim de esclarecer quando se construiu ou executaram, como se construiu ou executaram, e quem construiu ou executou: a) o edificio propriamente dito; b) as obras de talha e marcenaria; c) as obras de pintura e douramento; d) o mobiliário, prataria e demais alfaisas. A importância desse trabalho para os fins a que se propõe a DPHAN é capital e deve-se usar do maior critério na escolha do pessoal incumbido da tarefa. Contudo não é necessário, nem mesmo talvez aconselhável o recurso exclusivo a historiadores de profissão, uma vez que a curiosidade do oficio os conduz insensivelmente a pesquisas laterais demoradas e absorventes com prejuizo dos informes simples e precisos que interessam à repartição. Pode-se recorrer com proveito a estudantes universitários em período de férias e a intelectuais de várias categorias necessitados de amparo. O que importa é a circunspecção do investigador, uma vez que certos erros de interpretação, de cópia ou redução, poderão vir a causar sério transtorno ao especialista posteriormente incumbido do exame da matéria. Nesse sentido, seria conveniente o chefe do distrito fazer periodicamente o confronto do texto de alguns dos documentos transcritos por cada investigador. Seria ainda conveniente remeter a cada distrito uma súmula da documentação existente sobre determinados monumentos de Minas Gerias a fim de esclarecer a natureza do serviço a ser efetuado.

Paralelamente outras equipes de pesquisadores deverão da batida sistemática na preciosa documentação já publicada nas coleções das revistas dos institutos históricos, nos anuários e boletins de museus, bem como nos textos dos historiadores antigos e das numerosas crônicas conhecidas de viajantes, etc, assinalando toda e qualquer reeferência a edifícios, cidades, vilas, logradouros, fazendas, engenhos ou sítios porventura encontrada.

Quanto ao tombamento - se levarmos em conta que a indicação do monumento ou da peça de exceção pressupõe o conhecimento da totalidade das obras de sua categoria - deveria decorrer do estudo e da classificação sistemática do material inventariado, como conseqüência lógica de suas conclusöes, e só prescindir desse conhecimento prévio processando-se empiricamente a sua revelia, em casos de flagrante evidencia ou de procedimentos especiais ou de emergência, isto é comedida preventiva ou intervenção "in-extremis"

Contudo não é somente essa dependência de um inventário completo o que tem impedido o tombamento sistemático e dificultado o prosseguimento do tombamento empírico, mas a falta - melhor, a impossibilidade - de um critério seguro capaz de discernir entre tantas obras que seria desejável preservar, aquelas poucas que devem merecer o privilégio de tombamento. Isto porque, a grande maioria das obras de valor não apresenta-se consideradas no âmbito nacional aquelas qualidades de exeção reclamadas pela legislação atual para que a proteção do Estado se torne efetiva. São obras de excepicional significação regional, ou apenas local, que seria do maior interesse preservar, mas que não se enquadram nem no espírito nem na letra da lei, por que não apresentam características de "monumento nacional". E assim, o técnico incumbido da seleção se há de ver permanentemente angustiado e perplexo sem saber se deva cumprir rigorosamente a legislação vigente e deixar ao desabrigo de qualquer proteção obras valiosas, ou se torce a lei e salva o imóvel - que é o caso mais comum - com uma informação capciosa, invocando, por exemplo, o seu interesse excepcional para a história da arquitetura brasileira em determinado periodo, região ou categoria.

É imprescindivel, portanto, encontrar-se a fórmula jurídica capaz de estabelecer, dentro dos preceitos constitucionais, o vínculo necessário entre o governo federal e os governos estaduais e municipais, criando-se então três categorias de tombamento conforme o grau de interesse 
apresentado pelo monumento: nacional, regional ou estadual, e municipal, atribuindo-se uma parte do ônus que a medida acarreta aos governos do estado e do município interessados - ou atingidosconforme o espírito com que a medida venha a ser, por eles, recebida.

Só assim se poderá vencer o impasse que, de longa data, tanto embaraço e prejuizo vem causando à proteção da parte mais modesta . tantas vezes a mais significativa - do nosso patrimônio histórico-artístico.

Sem dúvida que, mesmo com a deficienncia ou ausência total de documentação apropriada, mesmo com a falta de pessoal técnico habilitado e com gosto pelo "métier", mesmo com a legislação que não corresponde à realidade da tarefa a cumprir, teria sido possivel a realização de vários estudos - ainda que de utilidade futura precária -, a classificação - ainda que não muito certa - de muitas obras e o tombamento - muito embora irregular - de numerosos monumentos. Teria bastado um pouco de esforço, alguma dedicação. Esforço e dedicação que, da minha parte, por motivo de saúde - inclinado como estou a preservar cada vez mais tempo para os cuidados e o prazer do convívio familiar - não me sinto com ânimo nem disposição de conceder.

$E$ aqui talvez caiba mais um esclarecimento de ordem pessoal. É que, quando aceitei prontamente em ocupar o cargo de diretor da Divisão de Estudos e Tombamento, interpretei o convite como uma decorrência natural da reestruturação do antigo SPHAN, uma vez que, dentre as várias atividades da repartição era essa que, pelo seu conteúdo, precisamente me competia, mas nunca pensei em alterar fundamentalmente a natureza das minhas funções junto à direção geral - isto é, nunca pensei em exercer, na prática, atividades de diretor autônomo, e sim, tão só, certas formalidades funcionais, bem como beneficiar-me do argumento dos vencimentos, melhor ajustados ao custo atual da vida pequeno-burguesa, prosseguindo no mais com a modalidade de cooperação que vinha prestando desde que fui induzido a contribuir, com a minha experiência do ofício - atividades da repartição, ainda nos tempos históricos do saudoso SPAHN, ou seja, com maior exatidão, funções de

assistente-conselheiro, de aplicação irregular, mas de confiança. Eis o motivo por que nunca me preocupei em dirigir a divisão, senão em acompanhar a orientação geral, de cuja responsabilidade, aliás, na medida daquelas funções limitadas, também participo.

De acordo com o plano acima sugerido, cumprirá, como tarefa de rotina, à Seção de Arte durante o próximo exercício, além das iniciativas da responsabilidade do respectivo diretor: a) proceder à revisão total do inventário fotográfico e de plantas, assinalando, pasta por pasta, as deficiências e lacunas da documentação existente, providenciando a sua pronta complementação, quando se trate de obra compreendida na jurisdição da sede, ou a comunicaçăo ao Chefe do respectivo distrito nos demais casos, com a indicação de uma escala de prioridades sujeita, porém, à revisão dos Chefes de distrito a fim de não causar atropelo ao serviço local; b) apresentar periodicamente à Diretoria Geral uma relação empírica de obras dignas de preservação e de eventual tombamento; c) prestar assistência e colaboração permanentes à Divisão de Conservaçãoo e Restauração; d) recomendar à mesma D.C.R. as obras aconselháveis, a fim de valorizar determinados aspectos e benefícios de um modo geral à boa apresentação dos monumentos; e) elaborar estudo de caráter geral sobre a casa brasileira durante a colônia e o império, baseado no esquema de classificação já aprovado pela Diretoria Geral; f) elaborar o esquema geral de classificação sistemática das obras de arquitetura religiosa; g) proceder a estudos avulsos destinados a uma classificação provisória sujeita a futura retificação; h) proceder a inventário de urgência visando ao registro dos últimos vestígios ainda existentes das obras e curiosidades cariocas e petropolitanas características de fins do século XIX e começo do século atual.

Da mesma forma cumprirá à Seção de História além dos trabalhos a serem planejados por iniciativa do respectivo diretor e dos estudos procedidos pelo único investigador regular de que a Seção dispõe - o registro sistemático da série infindável de lacunas de natureza

histórico-elucidativa e referentes á construção dos monumentos ou à execução das demais obras de arte inventariadas, para que sejam tomadas as providências cabíveis em cada caso e de acordo com a mesma escala de prioridades fixada pela Seção de Arte.

Rio, 1949

Lucio Costa

Obs: Na reprodução desta carta procedeu-se à atualização ortográfica.

\section{Relatório de Viagens à Europa em 1949}

O objetivo principal da excursão através das provincias portuguesas era o de procurar estabelecer um sistema fundamental onde fosse possivel apreender os vínculos naturais de filiação das várias fases e expressōes diferentes da arquitetura colonial brasileira com a arquitetura original da metrópole naqueles períodos e modalidades que thes correspondessem.

Tal objetivo não foi, porém, alcançado. Nem foi mesmo siquer possível coligir elementos básicos capazes de servirem de ponto de partida para 
uma futura tentativa de ordenação nesse sentido.

Esse aparente fracasso não se deve à rapidez da excursão considerada em relação à extensão das regiōes percorridas e à abundância do material a ser aproveitado, nem tampouco às vicissitudes ou embaraços ocasionais que tanto pertubam ou mesmo impedem, na prática, o bom êxito dos planos pre-estabelecidos, tais como, no caso, o mau tempo, o estado dos caminhos, os dias curtíssimos de inverno e, pior que tudo, o suplício de Tantalo das portas cerradas, com o problema tantas vezes insolúvel da cata das respectivas chaves; não foi mesmo devido, ainda, à falta de preparo prévio ou às naturais deficiências do observador; resultou, isto $\operatorname{sim}$, de uma circunstância imprevista: é que de fato, mais das vezes, não existem laços lógicos e coerentes de filiação capazes de serem codificados num sistema onde fosse possivel retroceder, em cada caso, às nascentes concretas ou virtuais da obra realizada por portugueses e brasileiros na colônia.

Não se conclua apressadamente do exposto que a nossa arquitetura independe da reinol. Uma tal presunção seria, além de primária, paradoxal e absurda, pois cada colono-aventureiro ou artífice, cada padre, cada militar ou administrador já trazia consigo, no aportar à terra, todo um passado de hábitos e experiências revelados, consciente ou inconsciente, através de determinados preceitos de gosto ou preferências formais, o que traduzia, na prática, por um determinado modo peculiar de fazer as coisas, ou seja um estilo, - o estilo da região de onde procediam. Era pois natural que -

independentemente das recomendaçōes oficiais em tal sentido, na construção da morada, da igreja, da casa da câmara ou do forte e, de um modo geral, no incipiente delineamento urbano, procurassem, na medida em que as novas condições do meio físico e social o permitissem, reconstruir, no conjunto e no pormenor, o quadro familiar.

Sucede porém que, na realidade, as coisas não se passaram de modo assim tão simples. Não somente porque, em tantos casos, esse quadro familiar já não seria mais apenas o da aldeia ou da vila provinciana, nem mesmo, talvez unicamente metropolitano, senão enriquecido de perspectivas e experiências anteriores - orientais e africanas, como também porque contribuições simultâneas procedentes de regiões diferentes combinavam-se, concorrendo, assim, para a criação de variantes e inovações de forma e de técnica que haveriam de parecer, mais tarde, aos olhos dos adventícios, peculiaridades de inspiração local. Se muitas dessas transposições, de tão variada procedência, não deixaram vestigios, outras vingaram, foram repetidas, perduraram, sobrevivendo mesmo quando nas terras de origem já caiam em desuso; ou então evoluiram ou se deformaram, seja atribuindo maior ênfase a determinados pormenores em detrimento de outros e criando assim valores plásticos diferentes dos que lhes haviam dado origem, seja despojando-se de umas tantas características fundamentais; outras, ainda, receberam verdadeiros enxertos ou transfusões de sangue, graças às idéias modernas trazidas pelas sucessivas levas de colonos e assim um "reaportuguesamento" imprevisto se operava na obra já aclimada, dando-lhe vida nova e rumo diferente. Finalmente a arte dos mestres $e$ oficiais-canteiros, pedreiros, taipeiros, carpinteiros, alvanéos -,instalados em determinado lugar, era também fator importante nos desvios ou na fixação do estilo ulterior da região, e as imposições do meio físico e social americano serviam como denominador comum nesse caprichoso processo de integração das velhas formas ao novo ambiente.

Daí a impossibilidade de refazer-se, na maioria dos casos, o caminho percorrido. Não que as obras perdessem a sua qualidade ou condição de obras portuguesas - a contribuição indigena e africana foi por demais frágil, nesse particular, para desnaturalizá-la - mas porque as filiaçōes possiveis ou prováveis são várias e se confundem num emaranhado de sugestões parciais de articulação extremamente difícil. Quando muito se pode reafirmar a predominância, ou quase exclusividade, das influências provindas dos distritos do centro e principalmente do norte, o que não esclarece, na verdade, grande coisa, dada a extensão da área que uma tal classificação abrange $e$ as expressões variadas de estilo que nela contêm.

Cabe pois concluir que a importância adquirida pelo desenvolvimento da arquitetura portuguesa na colônia foi de tal ordem e se processou de forma tão irregular e especial que suas manifestações não podem ser consideradas apenas como decorrências de determinados regionalismos metropolitanos, mas como um complexo em cujo todo intervieram variadas filiações e caprichosas interferências retificadoras ou desintegradoras, e que nas várias provincias brasileiras a arquitetura portuguesa

desenvolveu-se algumas vezes idêntica aos padrões metropolitanos, outras vezes diferente, da mesma forma como se desenvolveu igual ou diferenciada nas províncias do próprio reino, cada qual portuguesa à sua moda; e as nossas modas de o ser - pois, que houve várias - foram sempre brasileiras. Assim, portanto, mesmo quando o estilo é o mesmo, como ocorre no caso das igrejas do mosteiro de $S$. Bento e da Ordem Terceira de S. Francisco, no Rio de Janeiro, ou do Convento de S. Francisco e do antigo Colégio dos Jesuitas, na Bahia, os monumentos devem ser considerados originais, pois têm personalidade própria, embora concebidos e executados ao gosto e segundo os preceitos reinóis então 
correntes, e como tal são tão autênticos e legítimos como os de lá.

Por onde se vê, finalmente, que tanto é incorreta a atitude dos que estão sempre a pretender descobrir na arquitetura colonial brasileira a "cóoia" ou a "imitação" de modelos portugueses todas as vezes que aquela semelhança se torna mais viva, como a dos que atribuem a maior parte, senão todas as suas características, a imposições de ordem funcional ou mesológica. Pois que, de uma parte, os portugueses estavam aqui na própria casa e portanto, ao idealizarem e construírem a morada ou a capela à sua meneira, não estavam a copiar coisa alguma,senão a fazer muito naturalmente a única coisa que de fato lhes cabia, da mesma forma como ao falar português não arremedavam ninguém, - falvam a própria, lingua.

Enquanto, por outro lado, se nos paises europeus a fomação das várias modalidades de arquitetura regional se processou passo a passo, como decorrência lógica da função a que se destinavam e das imposições do meio físico e social, nos países americanos o processo foi inverso:os colonizadores trouxeram soluções já prontas que se tiveram de ajustar como roupa feita - ou, para ser-se mais verdadeiro, de "meia-confecção", como agora se diz -, ao corpo de nova terra.

Obs: Na reprodução desse relatório procedeu-se a atualização ortográfica.

\section{Reunião do MEC}

Texto escrito para uma exposição durante a Reunião do MEC com os Governadores para a defesa do Patrimônio Histórico e Artístico do País, em Brasília, abril de 1970.

O problema da recuperação e restauração de monumentos, trata-se de uma casa seiscentista como estas de São Paulo, ou das ruínas desta igreja de São Miguel, no Rio Grande do Sul, é extremamente complexo.

Primeiro, porque depende de técnicos qualificados cuja formação é demorada e difícil, pois requer, além de tirocínio de obras e de familiaridade com os problemas construtivos antigos, sensibilidade artística, conhecimentos históricos, acuidade investigadora, capacidade de organização, iniciativa e comando e, ainda, finalmente, desprendimento.

Segundo, porque implica em providências igualmente demoradas como o inventário histórico-artistico do que exista na regiāo, o estudo da documentação recolhida, o

tombamento daquilo que deva ser preservado, a eleição do que mereça restauro prioritário, a apropriação de verbas para esse fim, a escolha de técnicos, o estudo preliminar na base de investigação histórica e das pesquisas in loco, a documentação e o registro das fases da obra e, por fim, a manutenção e o destino do bem recuperado.

Apesar da deficiência dos meios, a Diretoria do Patrimônio Histórico e Artístico Nacional - obra da vida de Rodrigo M. F. de Andrade - tem procedido ao restauro de monumentos - talha, pintura, arquitetura - em todo o país; mas no acervo de cada região há obras significativas e valiosas cuja preservação escapa à alçada federal é pois chegado o momento de cada Estado criar seu próprio serviço de proteção vinculado à Universidade local, às municipalidades e à D.P.H.A.N., para que assim participe diretamente da obra penosa e benemérita de preservar os últimos testemunhos desse passado que é a raiz do que somos, - e seremos.

\section{Lucio Costa}

1970

\section{Lucio Costa, por Carlos Drummond de Andrade:}

\section{Lucio Costa e o Papel Mágico}

Um dia, Antônio Callado, então redator-chefe do Correio da Manhã, procurou-me para obter uma coisa impossível: um estudo de Lucio Costa sobre a evolução da arquitetura no Rio de Janeiro, na primeira metade deste século. O grande jornal hoje desaparecido ia comemorar 50 anos de existência e planejava uma série de edições especiais, que passassem em revista esse período de tempo, nas diferentes formas de atividade social. Para falar sobre arquitetura, ninguém melhor do que Lucio Costa. Mas Lucio era justamene o homem que fugia a todos os convites.

- Duvido que ele tope - respondi. Mas vou tentar.

Imprevistamente (Lucio é homem de imprevistos), topou sem relutância e até com prazer. Disse-me que estava precisamente refletindo nos últimos tempos sobre o que fez no Rio em matéria de construção civil, de 1990 para cá, e a encomenda vinha a calhar, estimulando-o. Seria um trabalho longo, a ser entregue em prazo curto, improrrogável. O resultado foi o magnífico estudo crítico estampado no Correio, em junho de 1951, e depois reproduzido num dos Cadernos de Cultura, do Serviço de Documentação do MEC, editados por Simeão Leal, sob o título Arquitetura Brasileira. Logo se tornou um clássico da bibliografia especializada. As agudas observações sobre estilos e confusão de estilos, neste tumultuado Rio de Janeiro, eram feitas pela primeira vez, num traço de escritor e não apenas 
de profissional, que faz do uma obra-prima, terminando pela sentida nota evocativa do velho Batista da Costã, diretor da Escola Nacional de Belas Artes.

Confesso que fiquei orgulhoso de haver obtido de Lucio o que parecia ao jornal coisa inatingivel. E foi tão fácil obtê-lo. Já conseguir que ele recebesse uma delegação de admiradores do Rio Grande do Sul, ou do Pará, ávidos de recolher dos lábios do Mestre a palavra iluminadora em vê-lo, era mais difícil. Ciente de que havia grupos numerosos à espreita, saía de mansinho, cabeça baixa, sem olhar para ninguém, forma infantil de não ser visto. Mas se o grupo, ou um importuno qualquer o pegava à traição ("Dr. Lucio! só uma palavrinha...") ele se rendia sem condições, com a gentileza perfeita de quem pratica as leis da civilidade. Arisco e gentil, rservado e cordial, capaz de colocar num apertado abraço silencioso toda a carga de emoção, assim eu via Lucio, nesses anos no SPHAN em que tive o privilégio de trabalhar a seu lado.

Dia "histórico" para mim foi aquele em que Lucio me apareceu, discreto como sempre, botando em minha mesa uma folha de papel rabiscada às pressas, com palavras e um esboço de desenho que aparentemente pouco significavam. Peguei da folha e tive entre os dedos nada menos do que a cidade de Brasilia, inexistente e completa, como um germe contém e resume a vida de um homem, uma árvore, uma civilizaçao. A primeira noção de uma cidade diferente de todas as outras até então imaginadas mostrava-se ali, nos traços rudimentais de uma cruz (ou um avião) plantada na terra ou alçando vôo. O plano-piloto de Lucio dizia bem pouco para um leigo habituado a ver cidades em funcionamento e não no papel, um papel nada luxuoso como o dos grandes escritórios de arquitetura. Falei em rabisco, e pulsava. Sem entender, eu sentia a vibração das formas implicitas naquela folha de papel que mudava a história do Governo do Brasil e, em certa escala, a vida dos brasileiros. Comovi-me. Lucio também devia estar comovido por ter achado a solução quase mágica para o problema de conceber uma Capital de Pais em termos absolutamente originais. Mas disfarçava?

Ou o seu pudor de aparecer era tão positivo que the permitia filtrar e decantar a emoção até 0 ponto de torná-la invisivel?

Parecia o mais vago dos homens; entretanto, em dada ocasião deu-me um conselho que não segui e que, se fosse observado atento, me pouparia uma decepção política. Na realidade, era e é um observador atento e sagaz do mundo e da vida brasileira em particular. Se tudo parece escapar-lhe, talvez o mais correto seja dizer que nada lhe escapa; se não dá mostras constantes dessa capacidade de observação e análise - uma análise quase sempre original, resultante do seu gosto, cultura e independência de espírito, e não de padrões estabelecidos de crítica - isto se deve à sua inclinação natural para a penumbra, o bastido, a ocultação de si mesmo. Lucio argumenta, julga, define-se mas desinteressa-se da ação prática que (e isto sucede com frequência) um detalhe das coisas the choque a sensibilidade, e ele investe contra a anomalia. No mais, que o deixem viver sossegado, reflexivo, quase uma sombra, na retaguarda dos que brilham e adoram brilhar com luz própria ou de empréstimo. Este nobre e humilde senhor não quer que $o$ aborreçam. Será que $o$ estou aborrecendo com estas lembranças do corredor onde trabalinávamos juntos e calados?

\section{Carlos Drummond de Andrade}

Reprodução de artigo publicado no Jornal do Brasil, de 03.03 .82

\section{Lucio Costa na Repartição}

Trabalhei cerca de 12 anos ao lado de Lucio Costa, num canto de sala do Ministério da Educação. Entre a divisão de madeira e uma fila de arquivos de aço, formou-se um corredor com duas mesas. Para chegar à dele, Lucio passava pela minha. Dirigia-me um "olá" quase silencioso $e$, vez por outra, dava um leve toque no meu ombro. Pouco nos faláva-mos, mas nos entendíamos bem. Lucio não tinha hora fixa de chegar e sair. Dizia-me mais um consultor de Rodrigo M. F. de Andrade, diretor do PHAN, do que um burocrata responsável pela Divisão de Estudos e Tombamentos.

Eu era seu subordinado, como chefe da seção de História, mas não sentia qualquer espécie de subordinação. Fomos bons camaradas, dentro da discrição natural dos temperamentos. Ao dirigir-me a palavra, sempre em voz baixa e tom extremamente delicado, deixava transparecer simpatia e compreensão, mas em geral preferia manter-se em silêncio - um silêncio que durava o tempo de permanência no corredor-que eu respeitava como se respeita o silêncio das igrejas. Não tinha nem de leve ar importante, e parecia mesmo querer se ocultar de todos e de tudo, até o nome de Lucio Costa. Tanto que assinava os seus pareceres com um esmaecido $L C$, saido do toco de um lápis que era todo seu equipamento de trabalho. Quando preferia não assinar nada, o que realmente dava no mesmo, pois todos os seus pronumciamentos, escritos com a mesma ponta de lápis, eram identificáveis à primeira vista. A letra não era das mais fáceis, mas de cunho elegante, e as idéias e opiniões de Lucio vinham iluminadas por um claro raciocínio e um original e livre ponto-de-vista.

Freqüentemente surpreendia, pois se esperava que ele tivesse esse ou aquele ponto-de-vista, que 
parecia ser o mais evidente e o mais afeiçoado à sua linha intelectual. Mas ele vinha com alguma coisa totalmente nova, fundamentada com rigor, que nos forçava a considerar aspectos imprevistos do problema. Às vezes chocava pela novidade da colocação; depois, ruminado o texto após mais de uma leitura, o que Lucio propunha era a solução magistral. Expressa em meia lauda que a datilógrafa convertia em papel submetido à consideração, sigilosamente, falsificava a assinatura de Mestre Lucio, já que com L C a lápis não era possivel subir o processo ao Conselho do PHAN ou ao Presidente da República, via Ministro.

Mas ele gostava de opinar também sobre temas avulsos, que aparecessem na imprensa ou fossem objeto de discussão nos meios intelectuais. Certa vez, por exemplo, ao sair, calado, deixou em minha mesa duas páginas de bloco pequeno com estas palavra:

"Importa distinguir, primeiro, o que se deve entender por hermetismo, a fim de evitar confusões.

Quando há significação poética, embora falte o sentido literal corrente, não cabe a designação, pois será hermética, quando muito, para os que não entendem de poesia, da mesma forma como a pintura de Picasso é hermética para quem não entende de arte, - para nós, ela se apresenta carregada de significaçāo plástica, ou seja, daquelas qualidades essenciais que a distinguem e caracterizam como obra de arte, acima e apesar do sentido objetivo formal corrente, ou anedótico.

Quando, além da falta do sentido literal, há também ausência de significação poética, aí, então, já não se trata mais de poesia, mas de anti-poesia, ou simples masturbação e, como tal, deve ser combatida".

Mais raramente, estando fora do País, lembrava-se de transmitir notícias especiais, como esta carta, sempre a lápis, enviada de Paris em 14.III.1952:

"De passagem por aqui, acabo de assistir, de 8 $1 / 2$ a meia-noite, numa sala quase vazia, ao filme do Marc Allegret sobre Gide. E me lembrei de você, quando, passeando no cais com Maria Elisa, vi aquela fotografia, - pois para um artista do seu feitio deve ser um verdadeiro deleite intelectual assistir a este documentário.

Todos os diálogos, ou melhor, monólogos, já que os demais figurantes servem apenas de pretexto para ele falar, são perfeitos. Desde o significativo episódio de infância ou o caso de Nouvelle Revue Française, até a experiência como jurado, a cena com as crianças e, finalmente, a lição de piano.

Também a visita ao apartamento vazio, acompanhada do comentário lido por ele, e as passagens em que aparecem outros escritores, como Valéry e um close-up ótimo do Saint-Exupéry.
E ainda o período da catapora social e as suas duas viagens ao Congo, que me interessaram particularmente por causa das curiosíssimas casas indigenas. Sem esquecer a principal parte, com a reprodução de retratos e ambientes da época, e ainda com Pierre Louys, a primeira viagem à África com o filho do Jean Paul Laurens, a doença e o casamento. Começa com o enterro, no campo, e termina com a leitura do discurso aos jovens alemães.

E quando sai, sentia certo remorso por me ter cabido a mim - que não concordo nem com as atitudes nem com as conclusões dele e não a você ou ao Rodrigo, o privilégio de assistir a tão comovente espetáculo.

Com o abraço do seu vizinho, sempre tão distante,Lucio"

Voltarei a falar sobre ele, um desses dias. Seus gloriosos e discretos 80 anos merecem comemoração, muito embora o Mestre, que a considera abominável, fuja a qualquer espécie de discurso, medalha e foguete.

\section{Carlos Drummond de Andrade}

Reprodução de artigo publicado no Jornal do Brasil, de 04.03.82 


\section{TESTEMUNHOS}

\section{Da Filha}

"Vó! Olha lá o Jornal Nacional!" Foi esta a exclamação da minha neta caçula, 3 anos, ao se deparar pela primeira vez com a Esplanada dos Ministérios - atestado inequivoco da força da identidade visual de Brasilia.

E me veio à lembrança um episódio acontecido quando os 19 anos da cidade coincidiram com os 40 de Roberto Carlos, e a comemoração foi conjunta! Show com direito à lua nascendo atrás do Congresso, em contraponto com todos os roxos, rosas e púrpuras do resto de por do sol atrás da Torre. Grupos e mais grupos coloridos de pessoas desciam da Rodoviária pelo canteiro central da Esplanada até os taludes gramados do Congresso, se acomodando à vontade: pipoqueiros, algodão doce e um comentário a meu lado: "Brasilia é bom porque teve o papa e agora tem Roberto Carlos!". O espetáculo começa com a lua cheia soberana, enorme, abençoando a cidade e nós todos que estávamos ali, e termina com uma bela queima de fogos e a multidão, satisfeita e romanticamente nutrida, se levantando aos poucos, já noite, e caminhando de volta, Esplanada acima. Fiquei um tempo sozinha, sentada na grama, olhando na direção da Rodoviária; as pessoas andando, os luminosos piscando, as luzes todas, a Torre, os edifícios. E de repente me toquei que eu tinha sido a primeira pessoa a saber, ainda estudante de arquitetura, como é que aquela cidade ia ser alguns dias antes de entregar o plano-piloto meu pai me chamou ao terraço de trás, onde trabalhava, e pela primeira vez mostrou e descreveu Brasilia a alguém. E só naquela noite, mais de 20 anos depois, ali, no meio da Esplanada, é que me dei conta do quão extraordinário era este fato: eu já não era mais uma moça, mas ainda não uma velha; tinha visto, num pedaço de papel, como seria a cidade a ser construida naquele quadradinho que tinha no mapa do Brasil escrito "Futuro Distrito Federal" agora estava ali, dentro dela, viva, real, definitiva. Um privilégio ter vivido essa experiência, e mais ainda ter tido a consciência desse privilégio.

Observando a obra de meu pai anterior a Brasilia é fácil identificar seus prenúncios e perceber o quanto o plano-piloto é uma espécie de síntese do seu percurso: 0 embriāo da Espanada aparece no projeto da Cidade Universitária, de 1936, que seria construída onde hoje fica o Jardim Zoológico, no Rio; o Parque Guinle, dos anos 40 , com seus blocos alongados no meio das árvores, 6 andares e pilotis livres, é evidentemente $o$ "pai" da Superquadra; a proposição feita, também nos anos 40, ao diretor do Detran, Menezes Cortes, para desatar o nó do trânsito no centro do Rio - que conseguiu fazer o trấfego fluir de um dia para o outro, sem nenhuma obra - certamente induziu à abordagem rodoviária; a infância na Inglaterra trouxe os gramados generosos e as árvores, conferindo ao paisagismo papel fundamental na própria concepção urbana; do "souvenir amoureux de Paris" vieram as grandes perspectivas. E 0 conhecimento intimo, profundo e continuado da arquitetura brasileira de sempre se fez presente na "saúde plástica" e no jogo das escalas urbanas - é, a meu ver, o que faz com que a coisa nova não seja por isso uma coisa estranha, é como se a "novidade" encerrasse em seu âmago uma verdade conhecida na pele, sem necessidade de raciocínios teóricos.

O sintoma mais forte do quanto o plano-piloto respondeu precisamente ao momento histórico que o Brasil atravessava é o fato de Brasília - com a sua cara, o seu jeito e esse céu que vem até o chão - ter sido tão rápida e naturalmente assimilada pela população como a capital do país. o "gesto primário de quem assinala um lugar ou dele toma posse" foi cravado no sertão como uma marca de gado, para ficar, para lembrar ao longo do tempo uma maneira de ver a nação, de crer na nação, de confiar no talento brasileiro. A mim parece, inclusive, que a retomada deste olhar nãc é saudosismo nem utopia - é a única saída. Sobretudo porque, como diz meu pai," Brasil não tem vocação para a mediocridade".

\section{Maria Elisa Costa}

Rio, 28/01/92

\section{Dos Amigos e Companheiros de SPHAN}

Em abril de 1957 encontrei Lucio Costa. Era recém formado e começava minha vida profissional. Brasília, o desenvolvimento do plano piloto, a responsabilidade de responder tão cedo pelo urbanismo da nova capital. Durante dez anos, sem me dar conta, sutilmente, aulas de urbanismo, de arquitetura mais sobretudo de vida; aprender a ouvir, a prestar atenção a cada detalhe, a cada interlocutor.

Obrigado Dr. Lucio.

Jayme Zettel.

Presidente do IBPC 


\section{LUCIO COSTA E O PATRIMÓNIO HISTÓRICO E ARTÍSTICO}

Estas breves notas escritas por ocasião dos noventa anos de Dr. Lucio (como nós o chamávamos quando, ainda jovens começamos, em 1949/50, a frequentar e, depois, a trabalhar no Patrimônio e como até hoje o chamamos, apesar de sermos, agora, dos mais idosos do IBPC); essas notas estão impregnadas pela amizade, carinho e imenso respeito por tudo quanto nos deu e ensinou de sabedoria, de sensibilidade e de compreensão pelos menos conhecedores e experientes no trato com o Patrimônio Histórico e Artístico e, mesmo, com a Arquitetura e as Artes em geral.

Não vamos aqui analisar a figura do iniciador da nova arquitetura no Brasil, desde quando, em 1930, assumiu a direção da Escola Nacional de Belas Artes, reformulando seu ensino; depois, do formador e coordenador da equipe de arquitetos que projetou o Edifício sede do antigo Ministério da Educação e Saúde, hoje Palácio da Cultura, Edificio Gustavo Capanema; do professor que redigiu, em 1934, as Razões da Nova Arquitetura, e nem do arquiteto que projetou, entre outros, o Parque Hotel de Nova Friburgo, os três primeiros blocos do Parque Guinle; nem, muito menos do urbanista criador de Brasilia e que, com Oscar Niemeyer, compôs seus principais elementos constitutivos, paisagisticos, urbanisticos e arquitetônicos e que, pouco depois, delineou a ocupação da Barra da Tijuca. São temas que vêm muito analisados e exaltados e não cabem neste curto espaço.

Vamos tentar fazer, através de um depoimento o mais possivel pessoal, o retrato do homem e do profissional que, com Rodrigo Mello Franco de Andrade, deu estrutura teórica à preservação dos monumentos históricos e artísticos do nosso pais, ao Serviço, depois Diretoria, Instituto e Secretaria do Patrimônio Histórico e Artístico Nacional e que, em seguida, mesmo aposentado, acompanhou a atuação de Aloísio Magalhães e de seus sucessores na Fundação Nacional Pró-Memória.

Dr. Lucio é um dos maiores conhecedores do acervo arquitetônico e artistico do Brasil, na sue grande maioria, através das fotos e documentação do arquivo da repartição. Sua memória, notadamente a visual, é excepcional; sua acuidade na análise das edificações e de seus recheios de talha e de pinturas é máxima. Assim, seus comentários e criticas de aspectos os mais minunciosos de uma edificação baseiam-se em um profundo exame que pode ter acontecido ontem ou há vários anos.

Estas observaçöes podem ser comprovadas em sua correspondência mantida com colegas, arquivada na sede e nas Diretorias Regionais, como as cartas trocadas com Luiz Saia e Ayrton Carvalho que nos mostram, ao extremo, essa capacidade de análise e de leitura dos monumentos, assim como a clareza que sempre demonstra na definição e proposição de critérios para as restaurações. Critérios não apriorísticos mas, sim, definidos para cada caso, a partir das situações e da compreensão e análise dos problemas que vão surgindo no curso das intervenções, do maior ou menor grau de sua amplitude ou do estado de degradação que apresente o bem cultural a ser preservado e revalorizado.

Outra faceta que sempre nos encanta em Dr. Lucio é sua capacidade de entender a posição do outro nas discussões orais ou através das correspondências: ele defende suas idéias até o extremo mas, convencido pelos argumentos contrários, aceita-os e endossa-os calmamente, sem qualquer ressentimento, com extrema humildade.

O estudo minucioso, e acurado e crítico do acervo brasileiro de valor cultural, a postura clara, sem preconceitos face às ações e projetos de restauração, ligados à sua sensibilidade excepcional na leitura de obra de arte e de arquitetura, dão a Dr. Lucio Costa a posição que sempre teve no Patrimônio, de mentor maior, de orientador principal na atuação básica de preservação dos bens culturais.

Augusto Carlos da Silva Telles Em 06/02/92

\section{SAUDAÇÃO}

Saudamos Lucio Costa, o brasileiro que mais contribuiu para a integração do meio artístico e cultural de nossa terra.

Como Diretor da Escola Nacional de Belas Artes atualizou seus cursos em dezenas de anos.

Com o Salão de 31 revelou e uniu os novos talentos de todo o pais.

Estabelecendo os critérios de tombamento, conservou os valores característicos de nosso passado.

Em Brasilia atingiu o traçado urbano mais original de nossa época.

A inteligência, a sensibilidade e a cultura de Lucio Costa dificilmente se reunem em uma só pessoa.

\section{Alcides da Rocha Miranda} Arquiteto 


\section{LUCIO COSTA}

Duas pessoas foram responsáveis pelo renome do PHAN no. Pais e fora dele. De tal forma se articularam e se completaram que não podemos dissociar uma da outra na construção de um órgão que se ombreou com os congêneres europeus no que diz respeito ao nivel das realizaçōes: Rodrigo $M$. F. de Andrade e Lucio Costa. Rodrigo, o organizador administrativo, jurídico, histórico e documental da instituição a que se dedicou ao longo de 30 anos. Lucio, por três décadas e meia seu mentor técnico e científico: estabeleceu para o Patrimônio normas e conceitos, definiu-lhe o caminho, deu-lhe as bases de conhecimento, corrigiu-lhe desvios. Alertou para possiveis tropeços, ajudou a resolver os problemas. Pelo acerto de seus prognósticos, pela consistência de seus argumentos e visão maior das conclusões, desempenhou no órgão papel singular.

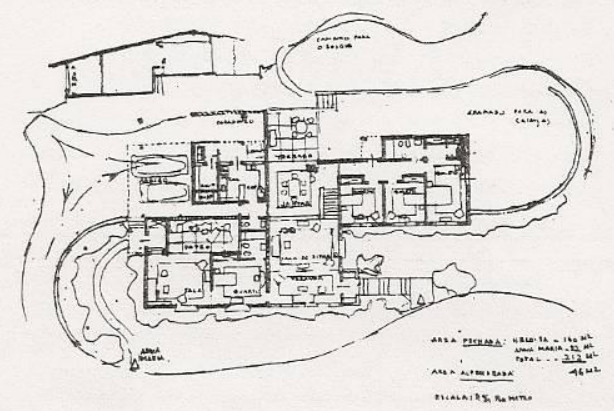

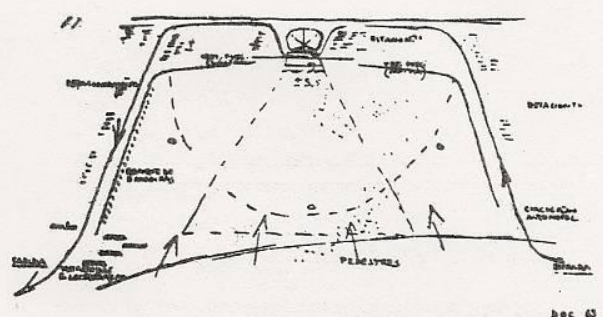

sec os

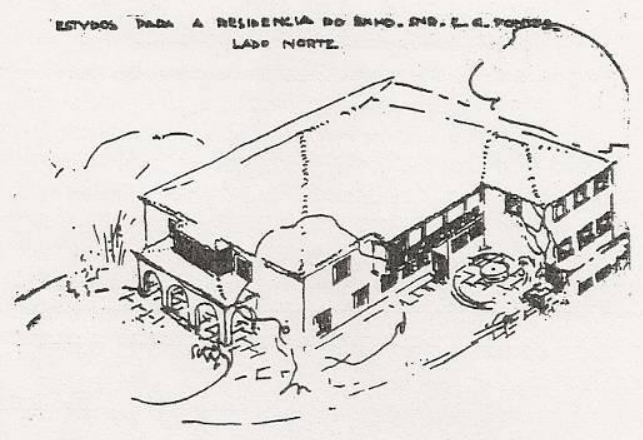

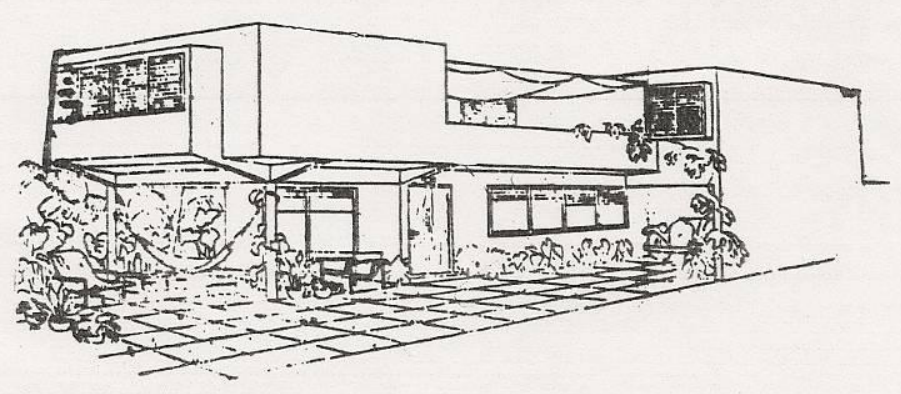




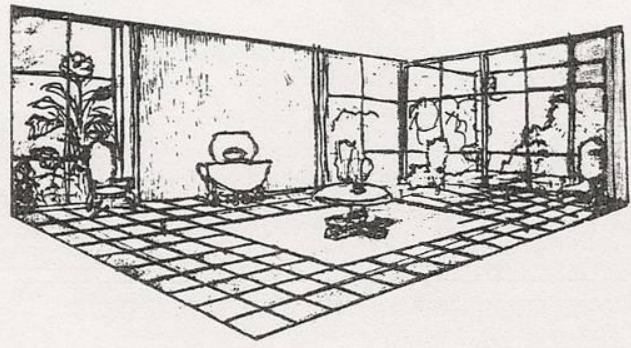

Responsável pela vertente científica - a mais abrangente - de fato abarcou toda a orientação técnica, consultado que era nas questões mais difíceis de conservação e restauro. Além dos serviços peculiares à sua própria área, concebeu dois programas fundamentais. Um, de estabelecimento das condições necessárias ao levantamento e ao inventário de nosso patrimônio cultural e ao preparo dos técnicos a trabalharem nos seus vários campos de conhecimento. O outro, uma sistemática de classificação da arquitetura civil, referência básica para os arquitetos preservacionistas e de esclarecimento para os que estudam nossa arquitetura antiga.

A percepção rápida do essencial, a capacidade de abstração, concentração e criação de soluções novas adequadas, aliam-se nele a uma sólida cultura e ao domínio da arte nacional e internacional, fundamentado sobretudo - no que Ihe dá o toque - na observação penetrante, na memória privilegiada e no elevado senso estético. Pensador, crítico, escritor e artista, Lucio Costa apresenta um currículo extremamente rico. Não de cargos, mas de reflexão e trabalho.

Com clareza de exposição e limpidez de idéias publicou estudos absolutamente originais nas áreas de arquitetura colonial, da do século XIX e da contemporânea; da comprensão do espaço arquitetônico, com análise da evolução morfológica dos retábulos e do tratamento dos forros pintados das igrejas antigas; da orgânica do mobiliário no Brasil, hoje inteligivel a qualquer um. Estudos esses, de especulação intelectual e sistematização, pioneiros no mundo luso. $E$ noutro setor, beneficiou o Rio com soluçōes engenhosas e apuradas de agenciamento urbano-paisagístico, como as da entrada do Palácio Guanabara, da subida do Outeiro da Glória e o monumento a Estácio de Sá.

Paralelamente foi o responsável pela renovação arquitetônica no País, dada inicio com a tentativa de reformulação do ensino na Escola Nacional de Belas Artes e com o projeto e construção do edifício do MEC. Prosseguida, em plano mais complexo, nas concepções urbanísticas de Brasilia-que Ihe valeu respeito internacional - e da Barra da Tijuca, que, sem a perda do aspecto natural, contrapôs áreas densamente povoadas com outras de ocupação rarefeita.

Esse, consultor de ontem e de hoje, a todos acessivel. A individualidade, silenciosa e discreta, cujos 90 anos se festeja, de justiça.

Rio, 30/01/92

Lygia Martins Costa 
LUCIO COSTA

40 anos depois...

Minhas lembranças, desde que o conheci? Um depoimento sobre as suas lições? Sintese dificil assim, de repente. Melhor alinhavar o que me vier à cabeça, o que sei de cor - de coração.

Estávamos num transatlántico inglês (o Alcántara) e não adivinhei, na lista de passageiros, quem eram Mr. L. Costa, sua mulher e filhas. Trinta e cinco anos depois, a revista "ELLE" pediu-me matéria com Dr. Lucio, intitulada assim: Mr. L. Costa. Eu estudava no 18 ano da Faculdade; tinha a idade do sarcasmo e da auto-suficiência; devo ter divertido Dr. Lucio ao descrever os descaminhos do curso - herdeiro perdido do que ele seguira na Escola de Belas Artes. Lembro-me de que seu maior espanto foi saber que ninguém recorria ao Choisy, para História ou Arquitetura Analítica. Doze anos depois, já com dois de Sorbone e quatro no Escritório de Oscar Niemeyer em Brasilia, fui por este indicado para a Secretaria Executiva da Arquitetura, na UnB de Darcy e Dr. Anisio, o que acumularia com a disciplina de História e Teoria. Sabia então que Oscar também destacava a História de Choisy: chegara a traduzir o primeiro volume (e o segundo, com o avanço dos vãos góticos, é que o fascinava... A dupla lição frutificou; durante os primeiros e verdadeiros anos da UnB, cada um de nossos alunos estudava o seu Choisy. A turma do Marçal e do Birunga levou um SS - a maior menção - por um samba que cantava as abóbodas, contrafortes e arco-botantes que "absorviam o impuxo lateral". Foram tempos inesqueciveis, esses da juventude de professor, depois da adolescência de estudante. Ai, sempre trabalhando com Oscar, eu já conhecia bastante e gostava irremediávelmente de Dr. Lucio: conservava, sedento de ouvir mas sempre atado por uma cerimônia que nunca perdi, nem adiantou sua mulher, $D$. Leleta, perguntar-me francamente: "porque não o chama de Lucio? Porque ficou Oscar e Darcy mas Dr. Augusto (Meyer) Dr. Rodrigo e Dr. anísio (Teixeira).

Se eu pudesse, gostaria de estudar as idéias que o Dr. Lucio sintetizou em alguns ensaios e têm a marca definitiva do seu pensamento e do seu tempo. Fica a sugestão para o IBPC e os pesquisadores, esses "espiões da vida". O Choisy, no tombadilho da Mala Real Inglesa, já dera a dica: o finca-pé do seu pensamento, no fundo, é positivista; a evolução das formas se explica pelo desenvolvimento das técnicas construtivas. Mas Lucio Costa nunca é stricto sensu. É sempre livre, até mesmo das suas próprias opiniões. $E$ progressista e determinista, historicista e lógico, utópico, cético e sentimental. Consideraçōes Sobre Arte Contemporânea (53). Depoimento de um Arquiteto e a Sociedade Contemporânea (à
UNESCO, 1952) e O Novo Humanismo Científico e Tecnológico (ao MIT-Massachussets Institute of Techonology, 1961), entrevistas, depoimentos, pareceres, etc. Em nada disso, Lucio Costa é um erudito, um intelectual que coleciona idéias, como diria Darcy Ribeiro, ou que sabe o que é sabido mas não o modo como o saber foi adquirido, na definição de Anísio Teixeira. Como - dualismo básico dos eixos geoculturais, bem definidos quanto à concepção plástica da forma, o da concepção estática

(mesopotamio-mediterrâneo) e o da concepção dinâmica (nórdico-oriental); com as trocas e predominâncias, através da História - como que se juntaram as múltiplas e insatisfatórias teorias da arte que o antecederam (na época em que ele se sentiria bem, o decisivo século $X I X \ldots)$ : a einfuhlung (empatia subjetiva pelas formas), a pura visibilidade objetiva, o materialismo simples de Taine ou a Kunstwollen, ou vontade de forma (que justamente viria a superar as condições construtivas de Choisy). Tudo desabrochando, finalmente, no sentimento, critério final capaz de escolher entre as determinações técnicas e fundamentais para garantir a intenção plástica original e a unidade da obra. Revendo,

entretanto, o século $X X$, a gente se indaga se em Gaudi, Aalto ou Niemeyer, a imaginação criadora não ultrapassou a mera opção entre soluções "igualmente válidas do ponto de vista funcional". Se, na prática, ficou mesmo conciliada a dualidade milenar, como anunciado pelo wishful thinking de 1952. De resto, o design, o urbanismo e o patrimônio artistico foram sempre encarados como diferentes dimensões da arquitetura, sob o lema de uma frase definitiva: "a boa arquitetura de um determinado período vai sempre bem com a arquitetura de qualquer período anterior - o que não combina com coisa nenhuma é a falta de arquitetura".

E a sociedade? E o nosso mundo, onde não será pela generosidade ou espírito de solidariedade humana que a justiça social será finalmente alcançada mas "por simples imposição das técnicas de produção em massa"? Quando "os homens da ciência e os donos da tecnologia levarão a humanidade de volta ao paraíso perdido". O que a gente vê hoje é a metade sul do planeta habitada pelos proletários e os camponeses da parte desenvolvida, e suspeita-se que o paraiso global esteja cada vez mais perdido. Mas a mensagem a Massachussets é francamente humanista quando diz que o objetivo último é o bem estar de todos os homens, na idéia básica de libertar a humanidade.

"Libertá-la integralmente".

Tomara.

\section{ITALO CAMPOFIORITO,}

antigo Secretário do PHA Nacional, Professor

Titular da Universidade de Brasilia

Niterói, fevereiro de 1992. 


\section{ALGUMAS NOTAS BIOGRÁFICAS}

Arquiteto e urbanista, Luico Costa nasceu em Toulon, na França, em 1902, educou-se na Suiça e na inglaterra. Em 1923 formou-se na Escola Nacional de Belas Artes, no Rio e, em 1903, foi nomeado diretor dessa mesma Escola pelo então Ministro da Educação e Saúde, Gustavo

Capanema, cargo que ocupou durante um ano, durante o qual transformou substancialmente estrutura de ensino da Escola não só na área da arquitetura mas também nas de pintura e escultura, inclusive com a criação do Salão Livre de Artes Plásticas que abriu espaço para as obras dos modernistas.

Em 1936, ainda a convite de Gustavo Capanema, coordenou a equipe de arquitetos responsável pelo projeto e construção do Ministério da Educação, no Rio de Janeiro.

A partir de 1937, como consultor do Patrimônio Histórico e Artístico Nacional, foi um dos responsáveis pela política de preservação do patrimônio arquitetônico e urbanístico, orientando trabalhos de recuperação de monumentos coloniais brasileiros, definindo critérios de vizinhança, de integração de edifícios novos no entorno de bens culturais ou no âmbito de núcleos históricos. Como diretor da Divisão de Estudos e Tombamento do SPHAN, destaca-se seu projeto para o Museu das Missões (Igreja e aldeamento jesuítico do século XVII em São Miguel, Rio Grande do Sul) e a Rampa de Acesso e Ambiência da Igreja de Nossa Senhora da Glória do Outeiro, no Rio de Janeiro.

Em 1939, em colaboração com Osca Niemeyer, projetou o pavilhão do Brasil na Feira Mundial de Nova lorque.

Em 1948 projetou o conjunto de edificios do Parque Guinle, no Rio de Janeiro (Grande Prêmio da I Bienal de São Paulo, 1951) e o Parque Hotel São Clemente, em Nova Friburgo.

Em 1956 participou decisivamente das propostas elaboradas para o edifício-sede da UNESCO, em Paris, num grupo do qual fazia parte, entre outros, Le Corbusier. Ainda na França, elaborou o ante-projeto da futura Casa do Brasil, na Cidade Universitária de Paris.

É de sua autoria o ante-projeto do altar erguido à beira da Baía da Guanabara, por ocasião do XXXVI Congresso Eucarístico Internacional, em 1956.

Em 1957 Lucio Costa viu aprovado por um júr internacional o seu Plano Piloto para Brasília. Além do plano urbanístico projetou a Torre de Rádio e Televisão e a Estação Rodoviária de Brasilia.

Em 1969 elaborou o Plano de Urbanização da Baixada de Jacarepaguá e o da Barra da Tijuca, ambos no Rio de Janeiro.

São de sua autoria, ainda no Rio de Janeiro, os projetos para a sede social do Jockey Club, a sede do Banco Aliança, o monumento a Estácio de Sá, no Parque do Flamengo.

Entre as premiações e títulos que the foram atribuidos, destacam-se:

- Doutor Honoris Causa, pela Universidade de Harvard, 1960

- Membro Honorário do Real Instituto de Arquitetos Britânicos

- Membro da Association d'Architectes de Paris e da AIA (Washington)

- Comendador da Légion d'Honneur, 1971

- Prêmio da Parson School of Design, 1956

- Prêmio Kalouste Gulbenkian, 1970

Esta edição foi realizada por:

Editado pela Coordenadoria de Editoraçāo e Projetos Especiais

Departamento de Promoção

Instituto Brasileiro do Patrimônio Cultural

Secretaria de Cultura da Presidencia da República

\section{Editor Responsável}

Maria Luiza de Carvalho

Redator

Marcus De Lamônica

Registro TRT-DF 556/04/71

\section{Entrevista}

Entrevistador: Lauro Cavalcanti

Colaboração e Transcrição: Cláudia Coutinho

Pesquisa: Cláudia Coutinho

Seleção dos Textos: Jayme Zettel, Lauro

Cavalcanti, Cláudia Coutinho

Fotos: Julieta Sobral

Revisoras e Secretárias de Redação

Ann-Maj Beckman Meireles - Lúcia Ribeiro Dantas - Maria Leticia de Salles Redig de Campos - Theresilda G. T. Ribeiro de Oliveira e Souza

\section{Produção Gráfica}

José Eduardo P. de Abreu

Matérias e correspondência para publicação devem ser enviadas para:

Coordenadoria de Editoração e Projetos

Especiais

Departamento de Promoção

Instituto Brasileiro do Patrimônio Cultural

SBN Quadra 02 - Ed. Central Brasilia, 48

andar

Brasília, DF 70040 


\section{ANEXO II \\ Palácio Monroe \\ Por que foi demolido?}

Fonte: http://www.almacarioca.com.br/monroe.htm

Já se passaram quase trinta anos desde a sua demolição, mas o Palácio Monroe continua despertando polêmica. O atual prefeito do Rio de Janeiro, César Maia, aventou a hipótese de reconstruí-lo. E muito concordam com ele. O Palácio Monroe foi projetado pelo general Francisco Souza Aguiar para a Exposição Internacional de Saint Louis, em 1904. Seu projeto foi premiado. Era a primeira vez que uma obra da arquitetura brasileira era reconhecida internacionalmente.

Terminada a exposição, o Palácio foi reconstruído no Rio de Janeiro, sendo este o primeiro edifício oficial inaugurado na Avenida Central, em 1906.

O nome foi uma homenagem ao Presidente americano James Monroe, por sugestão do Barão do Rio Branco, Ministro das Relações Exteriores. Monroe foi o criador do Pan-Americanismo e, naquele local, realizou-se a "Terceira Conferência Pan-Americana".

Até 1914 o magnífico palácio continuou sendo usado como pavilhão de exposições.

Após algumas reformas passa a abrigar a Câmara de Deputados, que ali permanece até 1922.

De 1925 a 1930 é ocupado pelo Senado Federal. A "Revolução de 30" dissolveu o Senado, encerrando um ciclo.

"Por volta de 1970 tem, junto com outros edifícios da Avenida Rio Branco, o pedido de tombamento federal negado pelo IPHAN, conseguindo-o apenas no âmbito estadual.

A falta do aval federal para sua preservação levaria a uma verdadeira batalha em 1976.

Com as obras do metrô, é pedida sua demolição, apoiada por baluartes da arquitetura moderna como Lúcio Costa, e pelo Jornal "O GLOBO", que o atacava veementemente através de editoriais.

Por outro lado, o IAB e o Clube de Engenharia, através do Jornal do Brasil, tentavam de todas as maneiras preservar o edifício. Contudo, nem mesmo alterações no traçado do metrô foram suficientes para salvar o Palácio, que viria a ser demolido no mesmo ano."

Sobre o Palácio Monroe, assim se manifesta o site oficial do

Senado Federal: 


\section{O Palácio Monroe - Segunda Sede do Senado}

Construído em 1904 para ser o "Pavilhão do Brasil" na Exposição de Saint Louis, de 30 de abril a $1^{\circ}$ de dezembro de 1904 (comemoração do centenário de integração do Estado de Louisiana aos EUA), durante o regime republicano do Presidente Francisco de Paula Rodrigues Alves, com o intuito de firmar o Brasil perante a situação mundial que vivia a euforia da "Belle Époque".

O autor, Coronel e Engenheiro Francisco Marcelino de Souza Aguiar, desenhou o palácio usando uma estrutura metálica, capaz de ser totalmente desmontada e re-aproveitada no Brasil, conforme determinação do Aviso $n^{\circ} 148$ de 03/07/1903, cláusula $1^{\text {a: }}$ "Na construção do Pavilhão se terá em vista aproveitar toda a estrutura, de modo a poder-se reconstruí-lo nesta capital".

A imprensa americana não poupou elogios, destacando o "Pavilhão do Brasil" pela beleza, harmonia das linhas e qualidade do espaço, condecorando-o com o maior prêmio de arquitetura da época: "Grande Prêmio Medalha de Ouro".

Os elementos de composição inscrevem-se na linguagem geral do ecletismo, num estilo híbrido, caracterizado por uma combinação liberal de diversas origens que marcou uma época de transição na arquitetura. Rompendo o Brasil com os laços tradicionais da arquitetura de Portugal e descobrindo novas tendências.

Em 1906, foi remontado no Brasil, com $1700 \mathrm{~m}^{2}$ de área construída, para sediar a " 3 a Conferência Pan-Americana".

\section{A demolição}

O início da campanha para a demolição do Palácio Monroe foi detonado em 04/07/1974, pelo jornal "O Globo", justificando atrapalhar o trânsito e a construção do metrô, qualificando-o como uma mera cópia, desprovido de qualquer valor artístico. Começa a elencar pareceres favoráveis à demolição.

O Palácio, que fora motivo de orgulho nacional, passa a ser chamado de monstrengo do passeio público, sem importância histórica. O local passa a ser especulado pela iniciativa privada para a construção de um edifício garagem, mas a proposta de uma grande praça para a estação do metrô da Cinelândia, rodeada de áreas verdes, ganha adeptos.

O Senador Magalhães Pinto, Presidente do Senado, pressionado pela opinião pública e pelos ataques do jornal "O Globo", dispõe-se a desocupar definitivamente o prédio.

Em 11 de outubro de 1975, o Presidente Ernesto Geisel autorizou o Patrimônio da União a providenciar a demolição do Palácio Monroe. 


\section{Datas Importantes}

- $\quad$ 23/07/1906 - Inaugurado no Rio de Janeiro para a "3a Conferência Pan- Americana" - O orador, Barão do Rio Branco, batiza o então "Pavilhão do Brasil" como "Palácio Monroe", em homenagem ao Presidente dos EUA.

- $\quad$ Agosto, 1909 - Serve de sede para o "4º Congresso Médico Latino Americano - Exposição Internacional de Higiene.

- $\quad 1910$ - É palco de várias reuniões e banquetes oficiais.

- 1911 - Utilizado como sede do Ministério da Viação.

Jurisconsultos".

- 1912 - Acolhe o "Congresso Internacional de

- 1914 - Sede da Câmara dos Deputados.

- 1920 - Sessão Solene - Visita do Rei Alberto da Bélgica.

- 1921 - Convenção Nacional.

- 1922 - Comissão Executiva - Centenário da Independência.

- $\quad 1925$ - Sede do Senado Federal.

- 1960 - Estado Maior das Forças Armadas.

Manifesto de Protesto de Engenheiros, Arquitetos e Paisagistas, contra a Demolição do Palácio Monroe

Fonte: SOUZA AGUIAR, L. Palácio Monroe: da glória ao opróbrio. Rio de Janeiro: Arte Moderna, p. 173-85, 1976.

\section{Palácio Monroe}

"Os que subscrevem o presente documento desejam apenas firmar perante nossos pósteros, sobretudo aqueles que investigaram os fatos desta época, que a demolição do Palácio Monroe provocou a advertência seguida de veemente apelo para que fosse evitada a destruição de um edifício que, ale de sua significação histórica, integra o conjunto da mais alta expressão como patrimônio arquitetural representativo do implante da República em nosso país.

Trata-se dos poucos edifícios que ainda restam, entre os mais representativos, da abertura da Avenida Central, hoje Avenida Rio Branco, a obra de urbanização mais significativa da remodelação do Rio de Janeiro, fato, sem dúvida, dentre os de maior importância para esta cidade, dos que assinalaram aquele período histórico. 
Nossa preocupação não é de definir o Palácio Monroe, nem nenhum outro dos edifícios do mesmo conjunto, como obra prima de Arquitetura, mas considera-la no sue todo, reconhecendo o significado e a relevante presença que representariam para a posteridade, da mesma maneira que hoje lamentamos a destruição, em tempos passados, de edificações características de nossos períodos históricos.

E desse conjunto, o de maior significação, sob esse aspecto, é precisamente o Palácio Monroe que, por muitos anos, até a inauguração de Brasília, foi sede do Senado Federal, além de ter sido sede da Câmara dos Deputados.

Não podemos deixar de assinalar que esse edifício, fielmente construído aqui no Rio por decisão do Presidente da República, Rodrigues Alves, obteve na Exposição da Saint Louis, nos Estados Unidos, em 1904, a maior láurea, frente aos pavilhões concebidos pelos principais arquitetos do mundo, que representavam a grande maioria das nações concorrentes.

Era, enfim, a Arquitetura da época, em todo o mundo. A demolição do Palácio Monroe não se justifica por nenhuma utilização posterior imediata. Não constitui embaraço ao tráfego naquela área, conforme comprovado por estudos técnicos recentemente realizados e sua preservação até há pouco admitida, sofrendo o traçado do "metrô" um desvio a fim de não atingi-lo.

Diante da notícia de sua demolição e paralelamente aos apelos para que fosse conservado, pela sua significação, surgiram também iniciativas para seu aproveitamento em face da carência de edifícios para instalações de serviços estaduais, municipais e mesmo federal, havendo quem como o Conselho Regional de Engenharia, Arquitetura e Agronomia do Estado do Rio de Janeiro, se propusesse a realizar as obras necessárias à sua instalação sem ônus para o Governo.

Sua importância mereceu a significativa homenagem de figurar nas notas de 200 mil réis. Sempre admirado em sua magnificência, hoje, apesar de desfigurado, é um belo "fecho" para a Praça Marechal Floriano, limite esse, urbanisticamente perfeito, configurando de modo inteligente a escala humana.

Sem o Palácio, a vista não terá limite, perdendo essa Praça, desse modo, sua virtude que era exatamente proporcionar o equilíbrio entre seus lados.

Tudo, portanto, recomendava o aproveitamento do Palácio Monroe coma condição especial de existirem todos os elementos do projeto que permitiriam, em qualquer oportunidade, colocar o edifício nas mesmas condições que tinha ao ser inaugurado em 1906, para sede da $3^{\text {a }}$ Conferência Panamericana, honrado que foi o Brasil com essa escolha.

Diversas sugestões foram suscitadas para a utilização do Palácio Monroe, depois de restaurado em suas estruturas, espaços e decoração originais, inclusive como unidade museológica especializada para a cidade e época de seu implante.

Com sua demolição, já decidida, restará aos usuários do "metrô" perceberem que, onde foi o Monroe, haverá uma misteriosa curva, cuja explicação 
lembrará a ponderação do problema por parte dos administradores que temeram destruir esse Palácio e souberam fazer o progresso - neste caso, a linha subterrânea do metropolitano - sem danificar, ou comprometer, as bases de uma patrimônio histórico e artístico.

Aquela misteriosa curva será a memória da data deste documento."

(As páginas 177 a 185 do livro acima citado apresentam as assinaturas deste Manifesto).

\section{INSTITUTO HISTÓRICO E GEOGRÁFICO BRASILEIRO}

\section{"PALÁCIO MONROE"}

1. O Presidente de Clube de Engenharia, por ofício datado de 15 de maio de 1975, encaminhou ao Presidente do Instituto Histórico e Geográfico Brasileiro um volumoso Relatório contendo os resultados dos estudos lá realizados, pela Divisão Técnica Especializada de Urbanismo, como um dos órgãos constitutivos do Departamento de Atividades Técnicas do Clube de Engenharia, sobre o "momentoso problema ligado à manutenção ou demolição do antigo Palácio Monroe."

Pelo referido ofício, é solicitada a atenção do Presidente do nosso Instituto para a Resolução aprovada em 20 de fevereiro do corrente ano, pelo Conselho Diretor do Clube de Engenharia, no sentido da preservação do Palácio Monroe. Finalizando, o Presidente do Clube de Engenharia declara que a Resolução aprovada "revela exaustivamente as razões que levam esta Entidade àquela decisão de votar pela não demolição e sim pela restauração daquele imóvel."

2. A opinião do Clube de Engenharia coincide exatamente com o parecer da Comissão do nosso Instituto, designada para opinar sobre a questão do Palácio Monroe, a qual apresentou o seu Relatório em 14 de agosto de 1974, com a seguinte parte conclusiva: "Em consequiência, a Comissão designada pelo Presidente do Instituto Histórico e Geográfico é de parecer, por maioria dos votos, que o Palácio Monroe não deve ser demolido e que devem ser envidados esforços para que o edifício seja restaurado de modo a retomar, o mais possível sua forma original; assim procedendo, estaremos preservando um notável valor histórico e arquitetônico brasileiro e estaremos salvaguardando uma obra, que há setenta anos atrás projetou, gloriosamente, o nome do Brasil no estrangeiro."

3.Voltando ao Relatório apresentado pelo Clube de Engenharia, vemos que, em setembro de 1974, foram designados os engenheiros José de Oliveira Reis e Ferdinando Gomes Lavinas para estudarem o caso do "Palácio Monroe", cabendo ao primeiro o estudo do aspecto histórico e ao segundo o exame das questões relacionadas com o tráfego de veículos nas proximidades do "Palácio Monroe". O Engenheiro José de Oliveira Reis, antigo Mestre da Faculdade de Arquitetura e Urbanismo da Universidade Federal do Rio de Janeiro, ex-Diretor do Departamento de Urbanismo da Prefeitura do 
antigo Distrito Federal , combate a idéia da demolição do "Palácio Monroe", principalmente quanto à questão de conquista de espaço para acréscimo de área verde. $\mathrm{O}$ Engenheiro Ferdinando Gomes Lavinas em seu parecer mostra que o "Palácio Monroe" em nada atrapalha o tráfego e que a sua demolição em nada o melhora.

4. Do Parecer do Engenheiro Durval Lobo, que relatou o assunto na Divisão Técnica Especializada de Urbanismo do Clube de Engenharia, destacamos os seguintes trechos? A - "Esse Palácio Monroe teve sua fase áurea; se foi mascarado, descaracterizado, pela incúria dos que o usaram, ignorantes do seu valor histórico, como glória da arquitetura brasileira, vencedora frente aos arquitetos de maior renome das grandes nações, nada impede que num sopro de bom senso e respeito aos grandes nomes que o idealizaram e o construíram, volte ele para seu estado de origem, quando, por certo, terá os dias de esplendor que já teve." B - "Vê-se, assim, que o Monroe não prejudica o tráfego; no terreno que ocupa seria ridículo pensar-se em área verde, diante do aterro do Flamengo, a maior extensão ajardinada da cidade e, ainda, ao lado do Passeio Público." C - "O Palácio Monroe não deverá ser demolido e sim restaurado, pois considero isto um imperativo da inteligência brasileira."

5. Vemos, portanto, que o Clube de Engenharia e o Instituto Histórico e Geográfico Brasileiro, dois órgãos da mais alta importância para opinarem no caso em questão, foram perfeitamente concordantes nos seus pareceres; ambos opinaram contra a demolição do Palácio Monroe e recomendaram a sua restauração. O Palácio Monroe só pode ser salvo por um movimento de opinião bem conduzido; esse movimento de opinião poderia ter por base os pareceres de dois órgãos respeitáveis: o Clube de Engenharia e o Instituto Histórico e Geográfico Brasileiro. Rio de Janeiro, 4 de junho de 1975. NELSON FREIRE LAVANÈRE-WANDERLEY

(Texto transcrito integralmente do livro: SOUZA AGUIAR, Louis de. PALÁCIO MONROE: a glória ao opróbrio. Rio de Janeiro,1976. p.155-7

Fonte: http://www.fotonadia.art.br/monroe/manifesto.htm

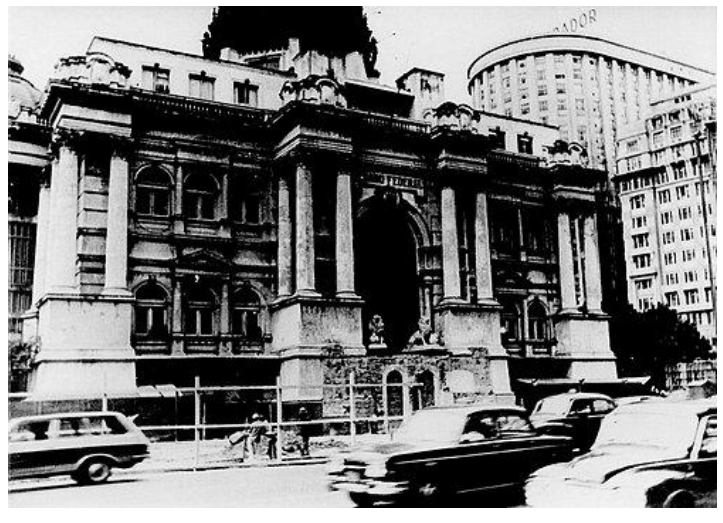

Figura A: Fachada Palácio Monroe. S.D.

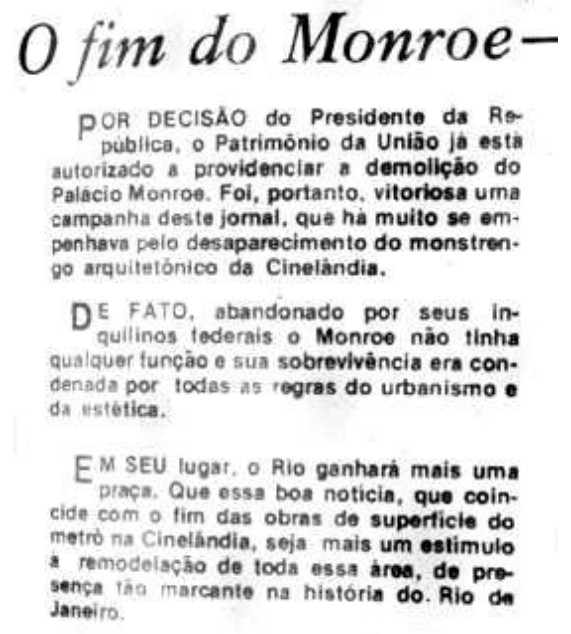

Figura B: Notícia do Jornal $O$ Globo, S.D. 


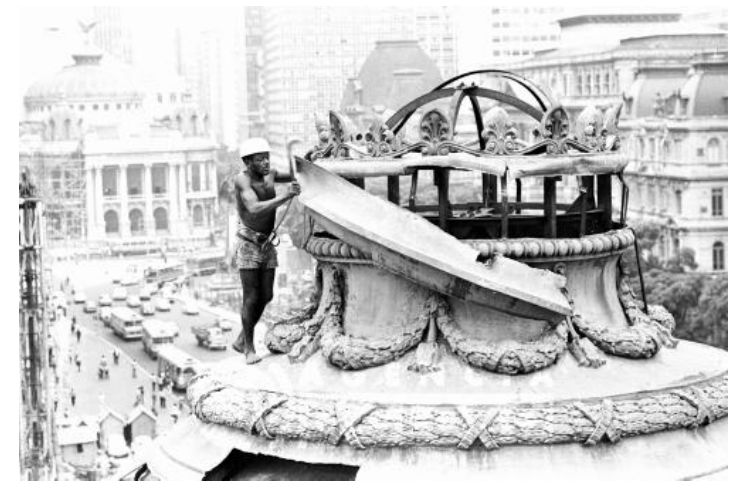

Figura C: Desmontagem do Palácio. 1975.

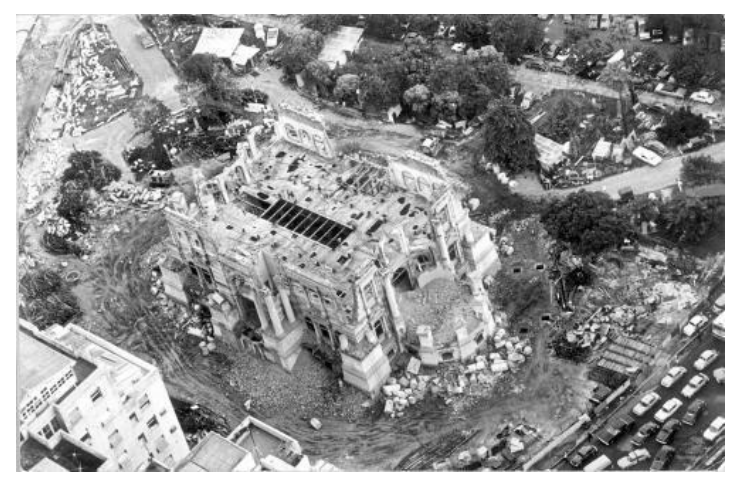

Figura D: Desmontagem do Palácio. 1975. 


\section{ANEXO III}

\section{Entrevista com Aldo van Eyck}

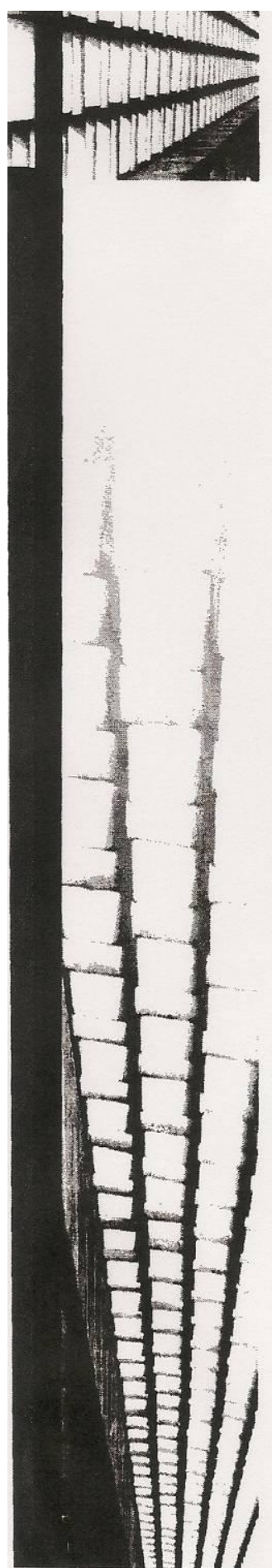

\section{CLARO E LABIRÍNTICO}

O arquiteto Aldo Van Eyck realizov em 1996 um sonho que guardava há 27 anos: conhecer a Bahia! A finais dos anos 60, de passagem por São Paulo, foi levado à casa de Lina Bo Bardi, que lhe falou dos mistérios e do povo da Bahia. Aldo nunca mais a esqueceu: nem a Bahia, nem Lina, nem a Casa de Vidro, nem os breves momentos deste contato.

O balanço desta espera entre o que ele sonhov e o que encontrou na Bahia e, ainda, suas impressōes sobre a obra de Lina Bo Bardi, por quem guarda profunda admiraçâo, sua participaçāo no Team Xe no CIAM, a atuação dos situacionistas franceses $\mathrm{e}$ a arquitetura contemporânea são alguns dos temas tratados na entrevista que realizamos com Aldo sob o "teto verde" do Restaurante da Casa do Benin.

Van Eyck esteve em Salvador, acompanhado de sua esposa, também arquiteto, do arquiteto Paul Meurs, a quem agradecemos o empenho para esta entrevista, e de uma equipe de televisão holandesa que realizou um vídeo sobre a sua obra e a de Lina Bo Bardi. A breve passagem de Aldo Van Eyck pela Bahia deixou uma bela recordação àqueles afortunados que o puderam conhecer.

(Entrevista realizada por Anete Araújo e Olivia Fernandes)

Olivia Fernandes. Como e quando você conheceu o trabalho de Lina? ALDO VAN EYCK. Eu voltava de Buenos Aires, indo para casa, e por curiosidade fiquei uns dias em São Paulo; alguns arquitetos lá sugeriram para eu ficar, sem mencionar Lina. Então, quando eu cheguei em São Paulo, Lina era um fator desconhecido. Eu vinha de Buenos Aires, de um congresso muito emocionante, selvagem, um congresso de estudantes, um contracongresso. Havia um congresso mundial, da UIA, estavam lá centenas de pessoas do mundo todo discutindo o problema de habitação. Eu estava lá convidado pelos estudantes para o congresso para o qual outros arquitetos europeus também

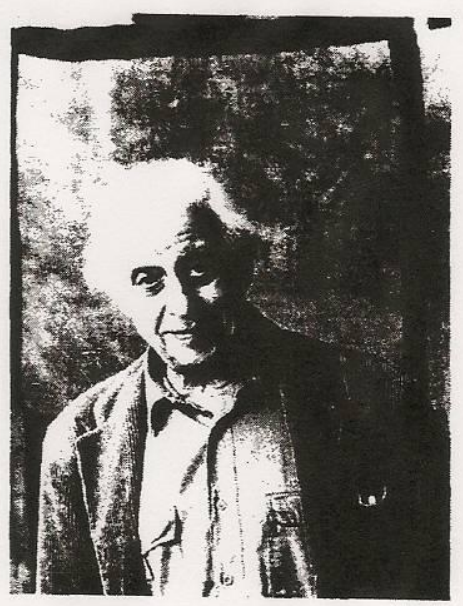

foram convidados. Eu menciono isto porque o contracongresso é muito interessante, o congresso de estudantes. O tema era naturalmente o problema de habitação para os pobres. Quando nós chegamos no congresso oficial, notamos logo que a favela, a barriado não era absolutamente o seu tema, era sobre habitação oficial, do governo, e fotos dos bulldozers empurrando tudo o que já estava construído para adiante. Então, no primeiro dia, no edifício em que nós estávamos, que os estudantes depois ocuparam, aqueles estudantes selvagens disseram: "Este é o congresso errado. Vocês foram enganados, vocês foram enganados! $O$ verdadeiro congresso está lá em cima na universidade, no prédio da faculdade que nós ocupamos. Há 2500 estudantes lá. Por que vocês estâo aqui em baixo?"

Opa, o que é isto de congresso principal e de um outro congresso? $\mathrm{O}$ congresso para o qual nós fomos convidados pelos estudantes era um congresso falso porque estava na "dependência do outro", dos outros que permitiram aos estudantes participarem sob determinadas condições. Então, aqueles estudantes que nos permitiram assistir ao grande congresso, eles e outras pessoas, inclusive alguns professores, nos convidaram, eu, Boffil, algumas pessoas da Inglaterra, Bakema. Nós ficamos, então, totalmente informados; 
nós nos juntamos ao grupo crítico. Terminou de uma forma completamente diferente.

Anete Araújo. Quando foi isto? nos anos 60?

VE. Em 1968, no governo de Videla. Depois disso nós viemos para cá, porque eu estava interessado em habitação, auto-ajuda, favelas, o que foi ou não foi realmente construído, as barriadas no Peru. Assim, quando eu cheguei em São Paulo, uma das minhas primeiras coisas que eu queria ver eram as favelas, e eu mencionei isto para alguns arquitetos jovens que me acompanhavam (o Joaquim Guedes era um deles). Nós saímos para ver os arredores, e eu me divertia passeando por ali. Naturalmente passamos pelo Museu [MASP]; então, paramos e saímos do carro. Eu me lembro de que a minha primeira impressão foi de descrédito: " $O$ que é isto? O que este arquiteto quer? Como isto apareceu?" Eu me lembro que, em seguida, nós descemos para a praça (eu não sabia que existia construção sob ela) e subimos as escadas. E me lembro que a única coisa que fiz foi ver de cima, nunca de baixo. Apenas 20 anos depois é que apreciei aquela visão de baixo. Eu não sabia, então, que podia ver de baixo.

Descemos do carro e subimos a escada para aquele enorme espaço de cima, o espaço da exposição que está suspenso e o lugar onde está localizada a administração. O que vi foi aquele enorme espaço embaixo (a praça) e o espaço em cima. Mas nunca tive conhecimento do tráfego por baixo do Museu. Foi somente dois anos depois, em uma loja de Amsterdã, que vi, entre uma série de catálogos sobre museus no mundo, um contendo cinco páginas sobre o Museu de São Paulo. Aí, pela primeira vez, eu vi o que havia abaixo da praça. Foi espantoso ver aquilo. Espantoso, também, é que, durante cinco, oito ou 10 anos, eu não vi aquele edifício novamente em nenhum outro livro. E eu vejo muitos livros. Nunca ninguém mencionou aquele edifício novamente, mas eu o menciono, muitas vezes, todo o tempo. E eu o aprecio muito dentro daquele contex to significativo.

AA. Então, naquele dia, em São Paulo, você perguntou às pessoas quem era o arquiteto do Museu, e alguém disseque era Lina?

VE. Sim, naquele mesmo dia. E no dia seguinte nós fomos a um almoço na casa de Lina. Eu estou um pouco esquecido, naturalmente, mas nós nos dirigimos para almoçar na casa de Lina. Lembro-me dando a volta naquele platô arredondado. Fiquei perplexo: o panorama, o penhasco. Lembro-me bem da curva e da chegada na escada. Lá estava aquela senhora elegante, uma pessoa maravilhosa. Fiquei impressionado: "Não é deste mundo esta senhora." Lembro-me dela imponente, lembro-me da mesa redonda, muito grande. Só depois vi a lareira. Na mesa, uma grande mesa, havia em cada prato um buquê de flores azuis. Fiquei perplexo. Nunca tinha visto aquela quantidade de concreto, poderoso concreto que eu jamais tinha visto. $O$ concreto de Corbusier é angélico, é suave perto daquilo; mesmo o beton brut de Corbusier, naquele período, é gentil diante daquilo. Aquilo é completamente inflexível, absolutamente firme. A escada, com aquele corrimão achatado, e a sensibilidade e a gentileza das flores me surpreenderam numa mesma pessoa; se você faz uma coisa não pode fazer a outra.. Uma cesta enorme, então, apareceu. Não sei se foi uma bandeja de madeira ou uma cesta, não lembro. De qualquer forma estava no meio da mesa, e não sei se ela continha pão, queijo ou frutas. Eu fui imediatamente confrontado com aquilo a que chamo "gestos". Alguém sabe como se comportar, alguém sabe fazer as coisas funcionarem, sabe tratar as pessoas. Daí começou a conversa sobre arquitetura.

AA. Foi sobre arquitetura moderna que vocês conversaram?

VE. Provavelmente. Eu falei sobre Buenos Aires, as coisas terríveis da polícia, provavelmente sobre minha afinidade com as pessoas das barriadas, minha atração pela beleza das favelas. Logo a discussão se desviou para a arte primitiva, o grande hobby da minha vida, a chamada arte primitiva, arte indígena ou arte tribal. Sim, Lina também tinha em casa a chamada arte popular. Ela logo começou a falar da Bahia, e não pudemos fazê-la parar de falar. Ela desprezava todas as cidades italianas que deixou para trás. "Terminou, terminou", dizia. "A Bahia é a melhor cidade. É, literalmente, a melhor cidade do mundo. Fantástica!" AA. Isto foi em 1968. Eu poderia perguntar sobre a situação política e fazer uma ponte com os situacionistas que estavam fazendo um trabalho, mais ou menos naquele mesma época, na França, e se foi antes, ou depois, que você teve contato com eles?

VE. Esta pergunta sobre os situacionistas apareceu aqui, nesta mesma mesa, três ou quatro dias atrás, com o outro grupo. Nãoé, infelizmente, uma conversa que prometa muito. Não é cômoda, pois minha relação com os situacionistas, o meu contato com eles, foi muito oblíquo, muito tangencial. Estou surpreso com esta pergunta que vocês estão fazendo. Eu retorno a pergunta para você, que deve saber por que está me perguntando isto.

AA. Pelo menos para mim, eles colocavam, naquele tempo, algumas questões que estão emergindo atualmente. Não sei se é correto ou não, mas são questões presentes hoje no discurso do deconstrutivismo em arquitetura. De fato, parece que o Ivan Chtcheglov [Gilles Ivain] abordou a discussão relacionada com ausêncialpresença, sobre as dicotomias abertolfechado, pertollonge, interiorlexterior. Estas dicotomias foram 
tratadas desde os anos 60 , e você também discutiu sobre este assunto, sobre as dicotomias, no Time X Primer; eu me lembro. Assim, alguns anos atrás parece que você estava falando sobre um tema que agora aparece como uma grande novidade.

VE. Onde você leu isto?

AA. Em revistas de arquitetura ou em algum livro [artigo de Kenneth Ray intitulado "The situation of Deconstructions: Ivan Chtcheglov as a precursor of Deconstruction"].

VE. Minha relação com o Time X sempre foi muito direta, a mais direta que poderia ser, como direta foi, também, a minha relação nos últimos anos do CIAM. E minha relação com o Cobra, um grupo de pintores dinamarqueses, holandeses e belgas, também foi muito intensa. Lá no Cobra fomos amigos, todos os dias, durante anos. Constant que, depois do Cobra, inventou aquele conceito de Nova Babilônia era alguém interessado em arquitetura, urbanismo, planejamento, a seu modo, naturalmente. Tinha também Vascayam, um grande pintor dinamarquês. Juntos eles começaram a me falar sobre aquele novo grupo do qual participavam. Lá estavam números da revista Situacionist Times, com capa impressa em caracteres metálicos, e estranhas fotografias, em situações bem especiais, com detalhes da vida na cidade, $\mathrm{e}$ muitos discursos políticos. Também havia um outro homem que encontrei certa vez, Plínio Galício. Era um importante situacionista. Ele morreu. Poderia ser italiano ou libanês, qualquer coisa assim. Um homem muito provocador. Um líder. Eu posso falar muito pouco para vocês sobre os situacionistas.

AA. Haveria alguma ligação entre aqueles trabalhos do Archigram, Instant City, Walking City, os britânicos que projetaram aquele tipo de arquitetura que não era estática, que não era fixa no espaço e podia mover-se, com a Nova Babilônia?

VE. Sim, pode haver certa afinidade entre Archigram e Constant. Você pergunta minha opinião sobre esses grupos... Constant tem uma dimensão muito diferente do Archigram. Constant é completamente desconhecido; o Archigram é... exatamente aqueles brinquedos infantis, eles são interessados naqueles truques juvenis, Peter Cook e Fred Crampont. Mas é uma história, de qualquer forma, estimulante.

AA. Você sabe que o Peter Cook esteve aqui e, de certa forma, disse que nós deveríamos demolir o Pelourinho? Isto antes da intervenção, porque depois, até podia...

VE. Peter Cook tem idéias, teve idéias em toda sua vida idéias sobre máquinas. Ele ensina, mas ele não constrói nunca. Você tem de fazer melhor, você tem de construir Constant é um grande pintor, Constant é um artista relegado, um dos nossos grandes pintores, e foi sempre consistente.
Constant é um intelectual continental, não um inglês medroso que não faz nada. Constant é um intelectual continental, real, $100 \%$ comunista, dedicado. Ou você é comunista ou não é. Você não tem que ser um comunista... agora já é muito tarde.

O Archigram era um grupo terrível, teve um começo interessante. Eu sou a pessoa errada para lhes falar sobre o Archigram. Mas eu lhes digo que a distância entre mim e o Archigram é de 200 milhas; a distância entre o Archigram e Lina Bo Bardi é astronômica. Como estas duas pessoas, estes dois movimentos puderam existir ao mesmo tempo? É impossível. Tudo que eles disseram é engraçado, frio, é nada. Tudo o que Lina falou faz sentido, é completamente diferente. Ela é completamente realista, absolutamente realista.

OF. Voltando a falar sobre sua experiência chegando ao MASP e depois à casa de Lina. Você poderia falar um pouco como você vê a articulação de espaços na arquitetura de Lina? Porque parece que, na sua arquitetura, você também está preocupado com isto também, em como articular os espaços.

VE. Se você menciona o Museu, a primeira coisa que eu digo é que eu não tenho nenhuma idéia de como eu faria. Nunca ninguém me pediu para fazer um grande espaço, nunca projetei um espaço público na minha vida. Portanto minha reação, se me fosse pedido para fazer um grande espaço, seria propor uma sequiência, uma multiplicação de espaços menores, uma estratégia que foi, equivocadamente, chamada de estruturalismo. Trata-se de uma multiplicação de espaços pequenos puramente acidental. Um cliente havia pedido para fazer o projeto de um Lar para Crianças (Orfanato Municipal de Amsterdã), dez grupos, oito grupos de crianças, nove cada, o que resultou em uma multiplicidade de pequenos espaços. E o Museu não é uma multiplicação de pequenos espaços, é um grupo de três ou quatro espaços amplos. Neste sentido, falar de diferenças entre uma multiplicidade de espaços e os edifícios de Lina é falar de dois estilos. Eu tenho quase certeza de que ela saberia fazer uma multiplicidade de pequenos espaços magnificamente, mas seu grande trabalho são enormes espaços. Nas menores coisas que fez, ela é igualmente brilhante. Esta é a grande coisa sobre ela. Ela seria igualmente brilhante. O Museu é um espaço público, como também o Sesc Pompéia; ambos são públicos. Neste sentido, Lina deve ter gostado muito de projetá-los. Também ela diz que não gostaria, particularmente, de fazer casas menores.

OF. Você pode explicar isto?

VE. Ela disse que só fez casas para pessoas de quem gostava, para evitar a conversa arbitrária com a madame sobre o tamanho da piscina ou a cor do papel de parede. "Eu nunca me submeto", disse ela. Disse também que nunca 
poderia fazer um banco, jamais poderia fazer aquele tipo de edifício. Mas, se lhe fosse pedido para projetar habitação, novamente a multiplicidade de espaços, multiplicidade de espaços em um contexto urbanístico, para isto ela estaria preparada. "Eu penso", disse ela, "que eles não me pediriam, poderia ser trágico".

Bem, existe ainda uma esperança. Estou com quase 80 anos, mas ainda espero que a sociedade holandesa (se é que pode ser chamada sociedade, pois acho que não merece ser chamada assim) me peça para fazer um edifício público. Também os brasileiros não pediram a Lina para projetar uma multiplicidade de casas. Este, sim, seria um tema real, importante, o "habitat pour les plus grand hommes", habitação em massa, habitação para o povo.

OF. De qualquer maneira, este espaço de Lina tem uma clareza: é esta coisa da clareza labiríntica de que você fala, ou é outra coisa?

VE. É outra coisa. Clareza labiríntica tem a ver com um conceito completamente diferente; tem a ver com ordem ou caos, por exemplo; tem relação com a cidade, não com um edifício isolado. Então, clareza labiríntica é simplesmente combinar o que é aparentemente incompatível; aquilo que é claro com o que é labiríntico; aquilo que é aberto com aquilo que é fechado ou o simples com o complexo. Lina é muito simples, não é complexa. Seus trabalhos são muito claros, simples. Mas sua mente, no fundo, é muito complexa; ela devia ter uma mente muito complexa. Mas a complexidade, no caso do Museu, está no lugar onde ele se situa: um grotão. Ela dispõe uma ponte apoiada em ambos os lados. E lá está ele, está lá, de pé, como uma jóia. E aquela grande volta $\mathrm{e}$, imediatamente em torno, a água. A água tão importante. A água isola os carros que a rodeiam. O sítio é impossível... embaixo... não se pode construir naquele sítio. É completamente genial construir ali. É absolutamente incrível, os carros vão por baixo. A idéia de conceber aquele espaço é absolutamente inteligente.

OF. E a casa dela?

VE. Ela traduz insights ou julgamentos acurados como ilustrações, na cabeça dela, que resultam em soluções. Aliás, não sei se podemos chamar de soluções. Os arquitetos hoje encontram soluções. Solução é uma palavra quase vazia. Encontrar uma solução seria como seguir A, B, C, D. Lina traduz com gestos. Ela produz um diagnóstico quase emocionalmente. Intelectualmente faz o diagnóstico do lugar e, então, imediatamente, ela tem uma idéia de como fazer aquilo. No caso da Fábrica [Sesc Pompéia], ela diz: "Não se pode demolir, a fábrica é uma construção bonita" e, imediatamente, ela tem a solução. Ela vê as pessoas lá; imediatamente concebe uma edificação para as pessoas. $\mathrm{Na}$ sua forma de conceber a liberdade, ela pensa nas pessoas, seja o que for, ela pensa nas pessoas. Se for uma cadeira bonita, ou uma coisa pequena, ou uma fabriqueta, $o$ que importa são as pessoas. Esta crença indestrutível nos seres humanos é uma força motriz que ela traduz imediatamente em uma forma, em uma construção arquitetônica.

Note que não há uma assinatura, não há uma estética; é como se a arte não tivesse um papel aí, não estivesse presente. Ela não parece trabalhar com intenção artística embora em cada linha você sinta a artista. Tanto que ela teve problemas, nunca demonstrou que era uma artista, isto nunca a interessou. Ela vai direto ao assunto. Direta. Enormemente direta. Não sei como ela consegue isto. Ela toma uma decisão, daí surge uma forma, uma construção, uma idéia, tudo ao mesmo tempo. Corbusier também tinha esta qualidade, esse sentimento, mas dificilmente desenhava. Vocês sabem, os italianos desenham maravilhosamente, eles são todos desenhistas. Eles desenham tudo, e tudo na Itália é muito bonito. Eles querem ser belos. E têm muito sucesso. Eles fazem muitas coisas belas. Mas tenho a impressão de que eles não se preocupam muito que sejam belas, apenas são cuidadosos.

Eu não sei como Lina trabalha. Seu edifício tem aquelas duas torres. Bem, não se pode construir em cima da água. Então ela constrói duas torres e as conecta. E ela cria o Museu. E então o que acontece com o meio das torres? Ela o entrega às pessoas, centenas de pessoas. No espaço entre as torres ela cria um espaço público. Também o espaço da exposição de pinturas é incrível, isto é, o próprio Museu. Aquela concepção de pessoas que veriam as pinturas, sem terem muito conhecimento sobre História da Arte. resultado é um achado. Mesmo se você projetasse aquele espaço em um país onde as pessoas conhecem arte seria maravilhoso. Estes dois gestos juntos, o espaço e a arte, todas aquelas pinturas suspensas no espaço, misturadas. Todas as pinturas, todos os tempos, todos os lugares na mesma mente que pensou os dois gestos. Eu acho aquela fotografia dela com um Van Gogh sob aquele espaço, um espaço que não é mediado... Ela está lá com um painel de vidro, uma pintura. De quem? É um gesto fantástico, um gesto muito fantástico. E o melhor habitat para exposição de pinturas que eu já vi no mundo: as pinturas no espaço e não contra a parede, e todas juntas neste espaço. Isto muda o foco visual. Um pano de fundo dinâmico! Eu estava lá vendo um Cézanne com Franz Halls, misturados, todas as pinturas ali. Você não pode vê-las agora. Agora é terrível. Os espaços estão divididos em três, com painéis indo direto, uma enorme tela de Goya, Velasquez de um lado, do outro lado Poussin. Absolutamente achatados, eles estão mortos. Eles deviam tombar aquele edifício. Falei demais... 


\section{ANEXO IV \\ TORRES P. MINISTÉRIO PUBLICO FEDERAL - 1996}

FOLHA DE S.PAULO

terça-feira, 3 de dezembro de 1996 ilustrada 4 =9

BRASILIA O urbanista Lúcio Costa, parceiro do arquiteto na criação da cidade, diz que projeto "é uma brutalidade"

\section{Torres de Niemeyer causam polêmica}

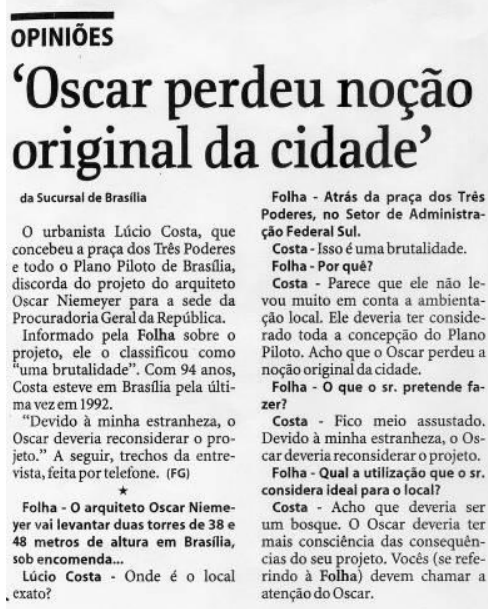

\section{'Problema pareceu improcedente'}

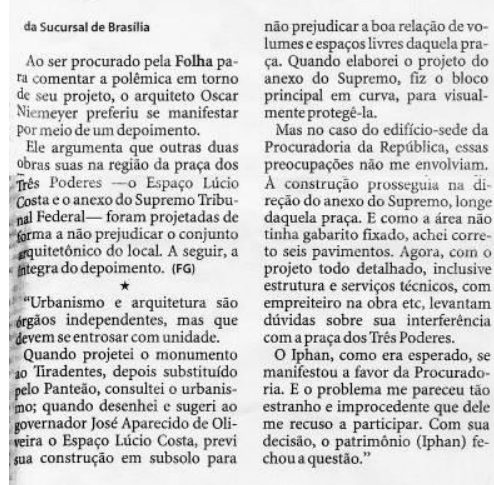

FERNANDO GODINHO
da Sucursal de Brasilia
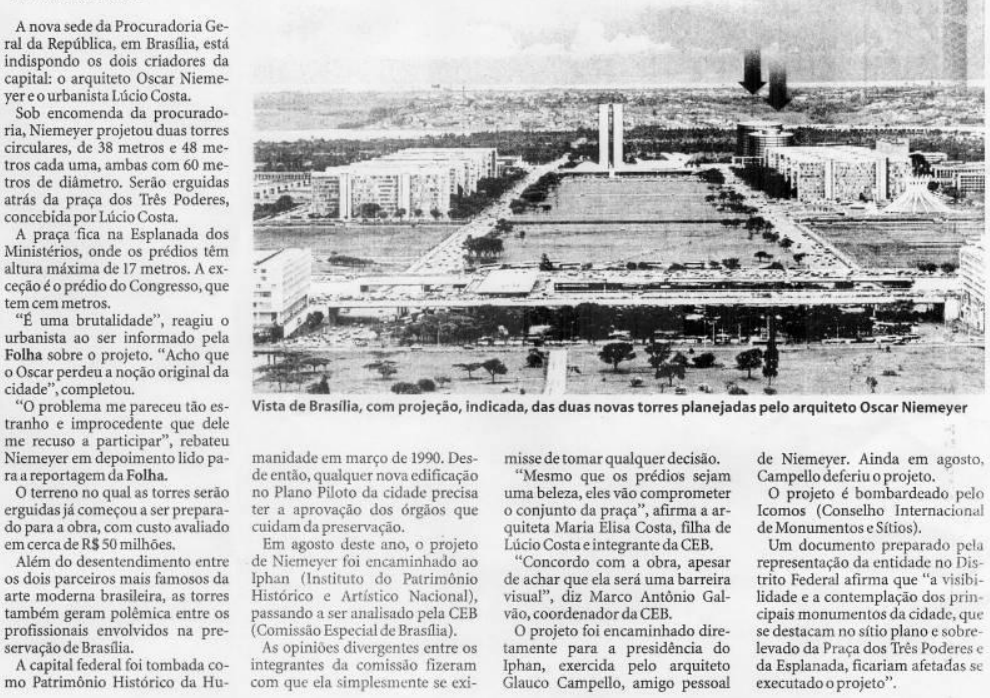

Brecha permiteaprovação

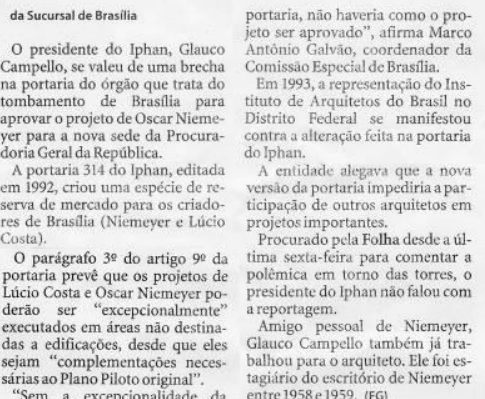




\section{Praça da Soberania}

\section{Brasília: Oscar Niemeyer projeta nova praça na Esplanada dos Ministérios}

Fonte: http://mdc.arq.br/2009/01/10/brasilia-oscar-niemeyerprojeta-nova-praca-na-esplanada-dos-ministerios/

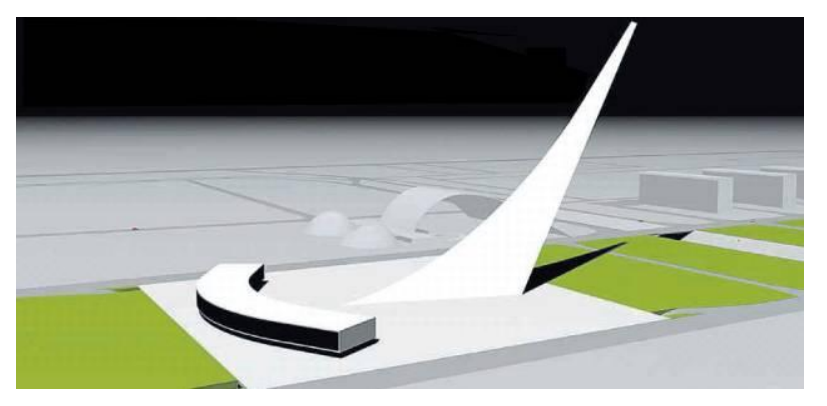

Toda capital tem que ter uma praça aonde o povo chega e se espanta. (...) Será um grande monumento em triângulo para mostrar o progresso de nosso país. É para causar perplexidade em quem vê.

Oscar Niemeyer

Toda capital tem que ter uma praça aonde o povo chega e se espanta. (...) Será um grande monumento em triângulo para mostrar o progresso de nosso país. É para causar perplexidade em quem vê.

Oscar Niemeyer

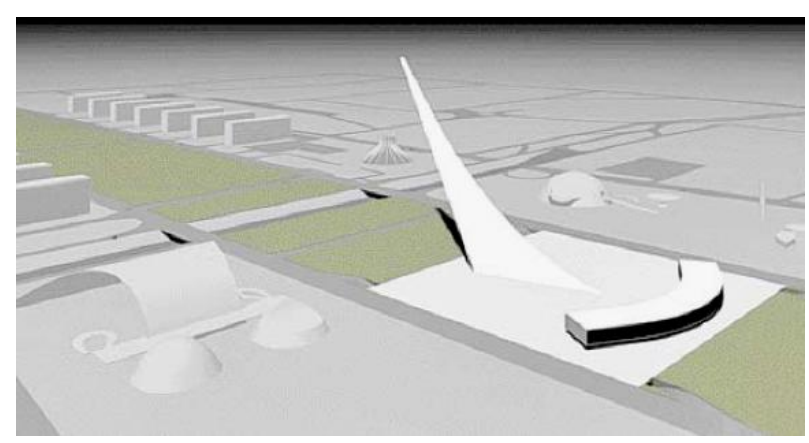

$\mathrm{O}$ arquiteto Oscar Niemeyer apresentou ontem ao governador do Distrito Federal, José Roberto Arruda, o Estudo Preliminar para um novo conjunto de edifícios aninhados no canteiro central da Esplanada dos Ministérios, em Brasília. O projeto teria surgido a partir de quatro demandas: a necessidade de estacionamento para veículos na região, um pedido do atual Presidente da República por um Memorial dos Presidentes, um pedido do governador do DF por um Monumento ao Cinquentenário de 
Brasília (que será comemorado em abril de 2010), e a necessidade de um espaço de convívio na Esplanada.

A resposta do arquiteto foi um estacionamento subterrâneo para três mil automóveis, um edifício curvo abrigando o Memorial dos Presidentes, oposto a uma torre de mais de cem metros de altura - correspondente ao Monumento ao Cinquentenário. A área pavimentada entre as edificações - à semelhança do Complexo Cultural adjacente - foi batizada de Praça da Soberania, e destina-se ao convívio da população.

O Secretário de Cultura, Silvestre Gorgulho, - ainda no escritório de Niemeyer no Rio de Janeiro - concluiu: "Monumental!". O governador Arruda, também presente, assegurou: "Vamos fazer!".

\section{Oscar Niemeyer e Brasília: criador versus criatura} criador-versus-criatura/

Fonte: http://mdc.arq.br/2009/01/12/oscar-niemeyer-e-brasilia-

Sobre o projeto da Praça da Soberania, de Oscar Niemeyer,conforme publicado no Correio Braziliense, de 10 de janeiro de 2009.

Sylvia Ficher

Coitada de Brasília, Oscar Niemeyer não gosta mais dela. Infelizmente, não dá mais para ignorar a realidade que aí está. Infelizmente, não dá para encontrar outra explicação para o estrago que o grande arquiteto federal vem fazendo, já há algum tempo, em sua principal obra, aquela que lhe rendeu suas mais altas honrarias, aquela que lhe garantiu uma posição ímpar no ranking dos arquitetos do século XX.

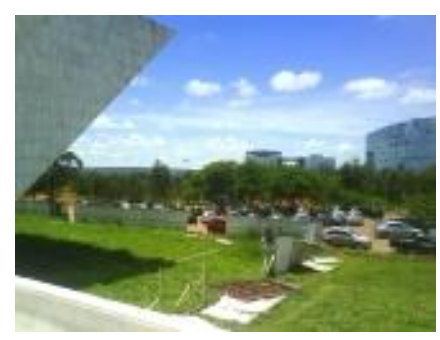

Tudo começou devagarzinho, primeiro a Praça dos Três Poderes sendo comida pelas bordas com o Panteão da Pátria, predinho sem graça e sem uso, verdadeira câmara escura que só serve para atravancar o espaço e impedir a vista... O Superior Tribunal de Justiça, a Procuradoria Geral da República e o Anexo do Supremo vieram na seqüência, bem mais pretensiosos e ainda mais fora de escala, com suas formas gratuitas e suas metragens gigantescas - afinal, quantos mais metros quadrados, melhor o honorário... 
E assim, de projeto em projeto, cada vez mais intervindo na escala monumental da cidade, cada vez mais rompendo a graça e elegância da Esplanada dos Ministérios, chegou a vez do Complexo Cultural da República, com sua nanica biblioteca - nanica, talvez, por conta de um inconsciente desinteresse por edifícios úteis - e sua cúpula-museu - nem tão cúpula assim, menos ainda museu. De quebra, a bela Catedral Metropolitana perdeu sua ambientação urbana e, para piorar, foi estrangulada pela gravata de concreto que lhe dá uma rampa sem rumo ou razão.
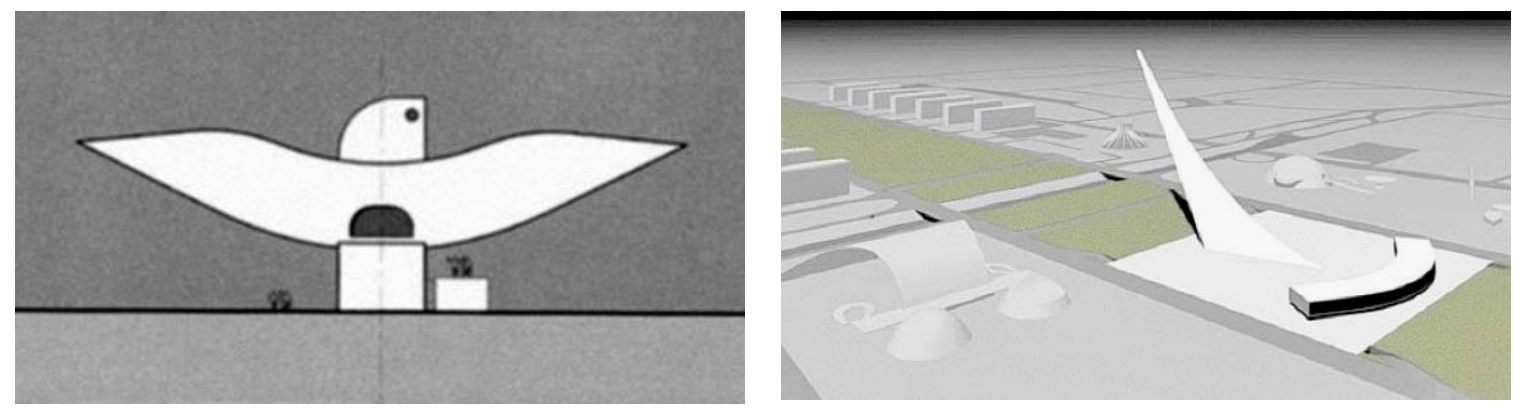

Há coisa de dois anos, uma robótica pomba - isto mesmo, uma pomba! - seria o principal elemento da praça que, segundo o arquiteto, estava faltando no Plano Piloto: a Praça do Povo. Repetindo a ausência de paisagismo do vizinho complexo cultural, a cidade iria ganhar mais um árido calçadão, mais um inóspito vazio onde desde sempre havíamos convivido sem maiores problemas com um modesto gramado... $\mathrm{E}$ lembremos o que fora previsto para o local por seu legítimo idealizador: um espaço desimpedido destinado a atividades ocasionais, como paradas militares, desfiles esportivos ou procissões; nas próprias palavras Lucio Costa, "o extenso gramado destinase ao pisoteio..." (“O tráfego de Brasília”, 1960).

Ao que parece, Oscar Niemeyer se esqueceu da sua dileta pomba, aquela que, como afirmara veementemente à época, deveria ser a sua derradeira contribuição para Brasília e sem a qual o seu opus brasiliense estaria inconcluso. E parece que se esqueceu também do "povo"; agora, no mesmo local a praça será da "soberania". Lá deverá ser erigido um prédio imprescindível, seja para o povo, seja para a soberania: o Memorial dos Presidentes. E um Monumento ao Cinqüientenário de Brasília, a ser comemorado em 2010; para que ninguém deixe de entender a sua complexa simbologia, nada melhor do que um chifre de concreto, de cem metros altura, descrito como obra de grande ousadia tecnológica... Tanta construção apenas para encobrir um estacionamento subterrâneo... De quebra, na maquete eletrônica (incidentalmente, o novo tipo de empulhação arquitetônica que nos oferece o maravilhoso mundo da informática) é contrabandeado um antigo projeto vetado pelo IPHAN por desrespeitar em muito o gabarito estabelecido legalmente para o local - uma altíssima cobertura curva para abrigar shows de música popular, a qual implacavelmente lembra "as curvas do corpo da mulher amada", só que com redondinhos seios de silicone e já buchuda.

Coitada de Brasília. Afinal, apesar de tombada, há uma portaria do IPHAN que autoriza tudo isso: 
Excepcionalmente, e como disposição naturalmente provisória, serão permitidas quando aprovadas pelas instâncias legalmente competentes, as propostas para novas edificações encaminhadas pelos autores de Brasília - arquitetos Lucio Costa e Oscar Niemeyer - como complementações necessárias ao Plano Piloto original ... $\left(\right.$ Portaria $n^{\circ} 314,8 / 10 / 1992$, Art. $9^{\circ}, \S 3^{\circ}$ ).

Tal qual o bordão de uma famosa personagem de programa humorístico, "Oscar Niemeyer pode!!"“

Coitada de Brasília. Para Oscar Niemeyer, ela está aí tão somente para manter ocupado o seu escritório sem risco de concorrência. Coitada de Brasília, cujo plano piloto foi escolhido transparentemente por concurso público, agora sujeita a decisões tomadas nos gabinetes de seus governantes. Coitada de Brasília, fadada a ser conhecida daqui por diante não mais como Patrimônio Cultural da Humanidade, porém como Capital Mundial dos Unicórnios...

Sylvia Ficher

arquiteta, doutora em história e professora da Universidade de Brasília

\section{A praça do espanto}

Fonte: http://mdc.arq.br/2009/01/20/a-praca-do-espanto/

Sobre o projeto da Praça da Soberania, de Oscar Niemeyer.

Frederico de Holanda

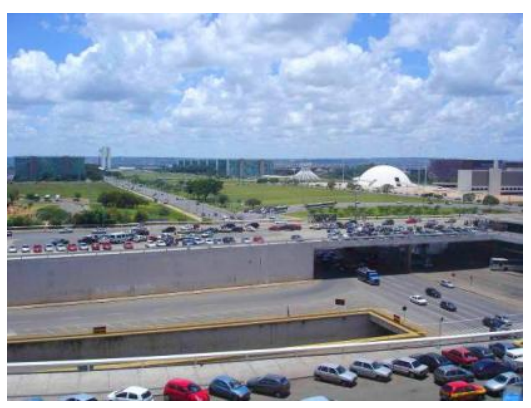

Há alguns anos Oscar Niemeyer projetou um grande edifício em forma de "pomba" para o gramado central da Esplanada dos Ministérios em Brasília. Danificava um dos principais cartões postais da Capital: as vistas da Esplanada e do Congresso Nacional a partir da Estação Rodoviária de Brasília. Não foi aprovado pelo Instituto do Patrimônio Histórico e Artístico Nacional. No dia 10 de janeiro passado soubemos pela imprensa de um novo projeto para o mesmo local, na altura do Conjunto Cultural da República. O arquiteto fala da necessidade, que toda cidade tem, de uma praça “para provocar o espanto”. Praça?! Que praça?! Espanto?! Que espanto?!

Niemeyer já tem lugar garantido entre os maiores arquitetos da história. Seria ocioso assinalar a grande inovação de sua obra na arquitetura moderna brasileira e mundial. Entre os melhores projetos estão os edifícios públicos 
governamentais de nossa capital. Com os palácios, ele contribuiu para conferir a Brasília o prestígio de que ela desfruta. Contribuiu, essa é a palavra. Pois se fala menos do que se deveria que o projeto da cidade é de Lucio Costa, não seu. No princípio, os edifícios de Niemeyer adequaram-se ao projeto de Lucio Costa, um dos fundadores e maiores ideólogos da arquitetura moderna brasileira. É o caso dos prédios da Praça dos Três Poderes.

Infelizmente não é o caso de edifícios mais recentes de Niemeyer, por exemplo, a sede da Procuradoria Geral da República. Dois cilindros de 45 metros da altura, revestidos de vidro negro, contradizem a "escala bucólica", a área ao redor das "asas" residenciais do Plano Piloto, que deveria ser predominantemente natural e ter edifícios de baixo gabarito. Lucio Costa, em matéria publicada na Folha de São Paulo (03.12.1996) considerou o projeto "uma brutalidade", acrescentando: "acho que o Oscar perdeu a noção original da cidade“. Niemeyer, segundo a mesma reportagem, não quis discutir: "o problema me parece tão estranho e improcedente que dele me recuso a

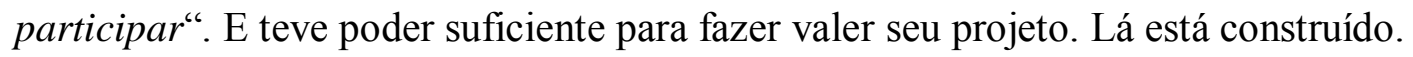

Agora é a vez da "Praça da Soberania". Há dois aspectos a considerar. O primeiro é quanto à ordenação dos seus elementos: eles definem mesmo uma praça? O segundo, é quanto às relações com a vizinhança.

Não devemos agredir o vernáculo. Há vários tipos de praça, formais ou informais, buliçosas ou solenes, animadas ou tranquilas. Quanto ao desenho, elas também variam: podem ter planta quadrada, retangular, poligonal, circular, elipsóide etc. Entretanto, o senso comum sabe (e há bom senso no senso comum) que qualquer praça é um espaço público aberto definido pelas edificações que o cercam.

Que elementos definem a "praça" proposta? Um edifício em arco, voltado para o Congresso, e um imenso monumento que divide o espaço à frente do arco em dois, ambos sobre um cimentado que ocupa toda a largura do gramado central da Esplanada. O conjunto novamente bloqueia a vista da Esplanada a partir da Plataforma Rodoviária, que Lucio Costa queria desimpedida (ver, de Sylvia Ficher, neste mesmo veículo, "Niemeyer e Brasília: Criador versus Criatura“). E onde está a praça? Se não houvesse o tal monumento, a "praça" seria uma estranha "praça de um lado só". Com o monumento, nem isso. Ele é um gigantesco plano de concreto armado que divide o espaço à frente do edifício em dois. Visto da Rodoviária, parecerá muito mais alto que as torres do Congresso Nacional, embora seja da mesma altura. A forma do monumento lembra a das colunas da Igreja Nossa Senhora de Fátima - a Igrejinha - na entrequadra 307-308 Sul, também projeto de Niemeyer, só que... 30 vezes maior! Perde-se a graça e a sutileza do modelo original. As pessoas na "praça" estarão divididas em dois grupos que, na maior parte do espaço, não se veem. O que veem mesmo é o enorme e ofuscante paredão branco do monumento.

E quanto às relações do conjunto com a vizinhança edificada?

Os prédios da Esplanada dos Ministérios têm gabarito máximo de cerca de 30 metros, com exceção das torres gêmeas do Congresso Nacional (o "Anexo 
1"), com 100 metros. Estas sobressaem na silhueta da cidade e sua importância foi definida por Lucio Costa nos riscos iniciais da cidade. Ao projetar o edifício do Congresso (as torres, o bloco-plataforma horizontal, as duas conchas), Niemeyer soube magistralmente desenvolver este elemento estrutural da concepção urbanística de Brasília. Aliás, ele o declara seu projeto predileto. Pela sua volumetria sofisticada e única, e pelo que significa como elemento máximo da democracia representativa, o Congresso Nacional é sabidamente o maior símbolo da Capital e um ícone frequentemente referido, internacionalmente, como símbolo do Brasil. O Congresso, mais o Palácio do Planalto e o Supremo Tribunal Federal, definiam, também desde os riscos iniciais de Lucio Costa, a Praça dos Três Poderes. Os três formam um conjunto admirável. A leveza com que tocam o chão, a simplicidade, a transparência, a relação direta que mantêm com a Praça mediante suaves rampas (as malfadadas cercas atuais não existiam), conferem ao logradouro uma solenidade sem arrogância ou sisudez. A Praça dos Três Poderes nos emociona (evito o verbo "espantar") por sua beleza e originalidade. Ela grava-se indelevelmente em nossa memória. Por que, agora, ela não é mais suficiente? Por que há de se criar um outro espaço para competir com ela, contendo um monumento que, por suas dimensões, enfraquecerá o símbolo maior de Brasília (o Congresso), e modificará não só o espaço da Esplanada dos Ministérios, mas a própria silhueta da cidade pensada por Lucio Costa? Vejam nas imagens da maquete eletrônica publicadas no Correio Braziliense como se tornam nanicos os edifícios da vizinhança, inclusive a Catedral Metropolitana (sintomaticamente, o Congresso não foi incluído nestas imagens...). Niemeyer não danifica somente a imagem da cidade, danifica sua própria arquitetura pregressa.

Talvez Brasília se ressinta da ausência de boas praças informais que o povo frequente rotineiramente, mas isso é outro assunto. Certamente, não precisa de mais um espaço de caráter cívico-monumental (repito, não é uma praça), com funções predominantemente expressivas (pois é para "provocar o espanto"). De espaços expressivos estamos bem servidos. E mediante lugares de excepcional qualidade.

Supondo que os problemas arguidos sejam reais (a necessidade de estacionamento sub-terrâneo, a conexão entre os setores culturais norte e sul etc.), há inúmeras maneiras de solucioná-los sem macular a cidade. Igualmente, se um edifício para guardar a memória dos presidentes da república brasileira mostra-se necessário, também há mil outras formas de fazê-lo. Ou então, que tal utilizar o Panteão da Pátria, que (lamentavelmente) já está construído, e às moscas, para isso?

Talvez os deuses não errem (tenho minhas dúvidas). Os homens mesmo os geniais - podem errar. Espantosamente.

\section{Frederico de Holanda}

Professor Associado da Faculdade de Arquitetura e Urbanismo da Universidade de Brasília, professor de Projeto de Urbanismo, e doutor em arquitetura pela Universidade de 
ANEXO V

Solar do Unhão

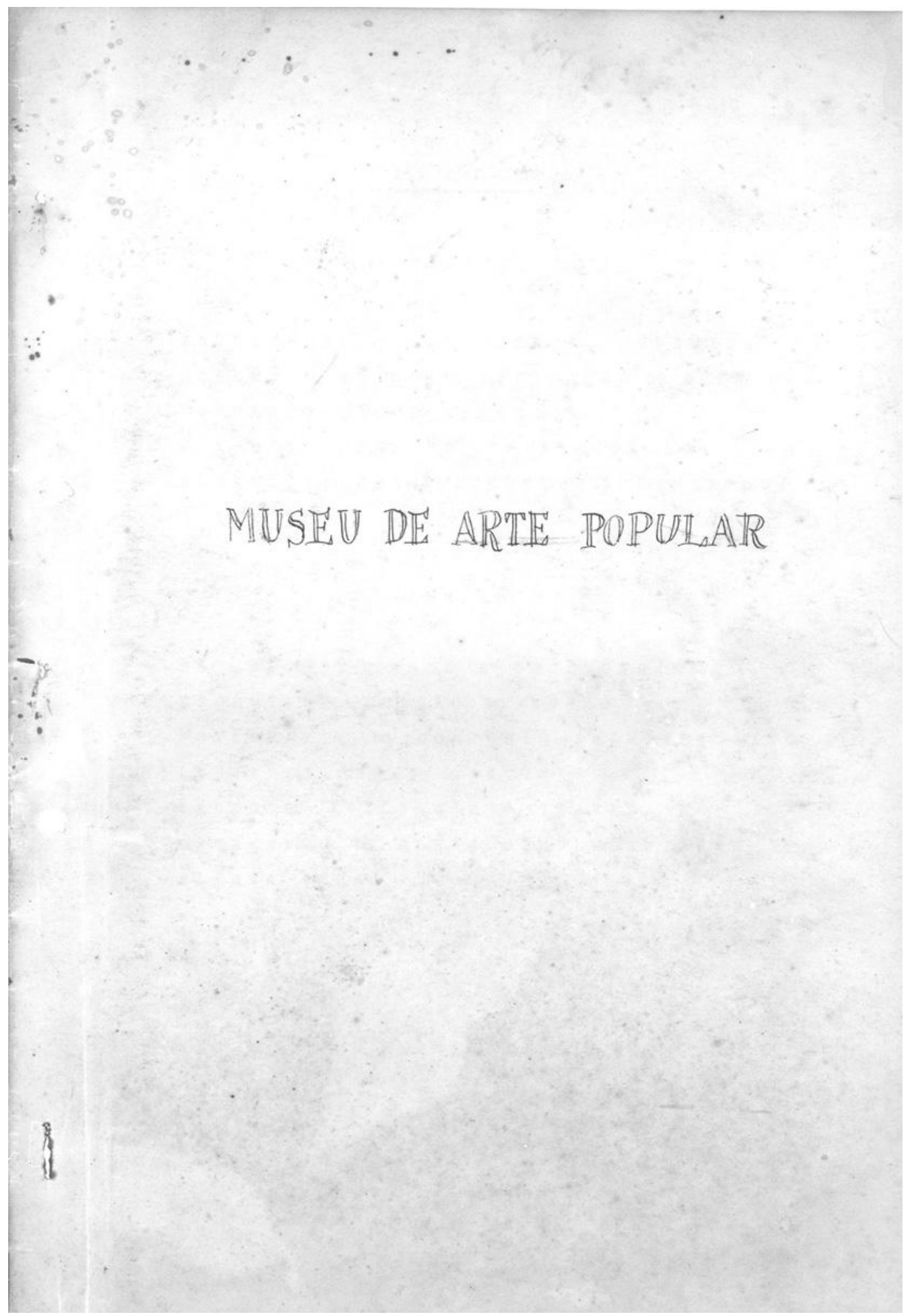




\section{N D I C C E}

$\mathrm{TEX}$ T 0

I - INTRODUC AO-QUALIFICA \& $\mathrm{A} O$ JURIDICA

II-RESUMO DO PLANO DE APLICA G XO DE RECURSOS III-C ONCEITUAC $\AA$ O DO PROGRAMA.

IV-PLANO DE TRABALHO-ETAPAS-PESSOAL - DIVEE $30 \mathrm{~S}$

V-BASES FISICAS EXISTENTES - ELEMENTOS

A INSTAIAR

A N E XOS

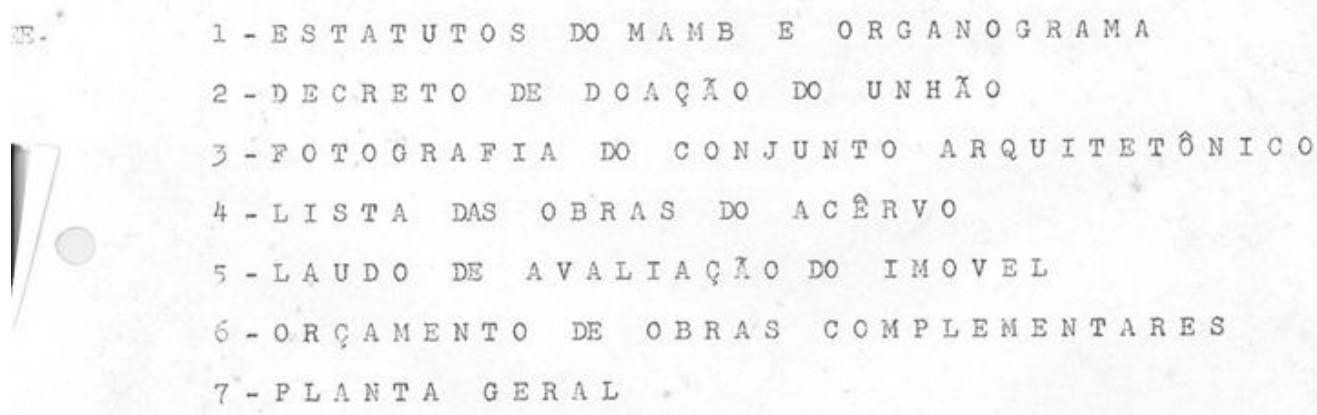




\section{I - INIRODUCAO - QUAL IFICACAO JUR LDICA}

A Fundeçĩo Muscu de Arte Moderns dn Bahia é was entidade de fins culturais, crî rda peln Le1 Estaclual ne 1.152, de 23 du Julho de 1959, con séde en Snlvcdor. Suc adrinistração suporior é exceroida por un Conselho Dirutivo de sois mesbros, nonesdos pelo Governador do Estido o win sćtimo neribro, escolnido pelos dennis e a quun cabe a presidência e sur representaç̃o. Estatutìriamonte, (vor anexo), destina-so o Museu a "promover o estudo o a difundir o conhecinento das artes cu Burul, notadanonte as plísticns, 3ob o critćr1o ropresontativo do sus evolução conteruporânen", devendo "crinr o nunter exposições perannentes o tumporírias, cursos, projoções, espotáculos o conoôrtos, publicações, documentç̨̃̃o e biblloteca"!

As condições encontradas no. Bahio inpuseran ¿. Diroçĩo do Musou ua trabr:lho de pesquisa c anólise, 3 fin de que se dotuminassc qual o sistone de trabalho que poderin conduzir o Museu ao plono curnprimonto do sous objotivos estrtutírios. 0 plano que so apresent? nêste documento é a síntese do que se podo realizar prra tomnr o MAMB un centro culturel nltemonte dinñnico, cumprindo suz nissĩo no plino estético, porén acentuando osforços nos setoros do cursos o de documentacão, anpliando-os inclusive, parc criar tôda uma concepç̃̃o do trabalho.

Como elemento a pesquiser o c. estudar, a riqueza da trsdição artesmnl baians so epresento con míxim inportância; o grande patrimônio físico constituído pe 10 Conjunto do Unhão (propricdade do Museu por doaçño do Estado da Bahic) apresenta-se adequado i organização de atividades de produção artesanal, vinculnd’s a un processo de aprendizado e cporfoicoamento; o critćrio estatutárto, de representação da evolução contemporânea da crte, tinha de ser atendido on estreita sssociação con os problems da evolução sócio-econônica, das trensformnḡous por que passan as estruturas no caninho da industrializaç̃o. Essas considerações levaran portanto ao plano que adiante so delineia e que, en síntese, com preende os seguintes elonentos:

- Criação de un Museu de Arte Popular que realizará cuidadoso programa de pesquise de materiais de artesanato e manifestações associadas de cultura popu' -: lnr, ortanizando inclusive un acêrvo con o material recolhido.

- Instrlaç̃̃o de ur. Centro de Estudo o Trabalho Artusanel, onde mestres artesãos e seus aprendizes esterão en pemanente contito com estudantes de "Industrial design", trocando experiência e tradição por conhecimentos técnicos; dessa conunicação íntima resultarí a formação de novos artesãos com mior amplitude de possibilidades de realização e, principalnente, se transmitirá as projetistas do desenho industrial un efotivo conhecimento dos problems que unen projeto ̀̀ execução e a compreensão dos volores culturais que o artesancto pre servou e depurou, capecitando-os a desenvolver un desenho industrial de cleva do padrão o baseado nos vilores culturais da tradição brasileira. 


\section{II - RESUMO DO PLANO DE APLICACAOO DE RECURSOS}

\section{Sanestre}

Obras Complenentares:

Aquisições:

- Maquinária e Forramentas pare o CETA

- Mnquinas, móveis e utensílios

- Veícula

Estoque inicial de Matérias Primas para o CETA:

Despesas cor Pessonl (inclusive Leis socinis):

- Administração (Superior, nssessoria, secre tária, serviços burocróticos e diversos)

$2 / 3 \times 5 \times 4.000 .000=$

- CETA (nrtez̃̃os, aprendizes, ajudantes)

Plono A: $1 / 2 \times 6 \times 3.000 .000=$

- Pesquiza e Documentação

$2 / 3 \times 6 \times 1.200 .000=$

- Straf Técnico

$5 \times 900.000=$

Despesas Diversns:

$6 \times 1.500 .000=$
16.000 .000

9.000 .000

4.800 .000

$35.445,600$

40.000 .000

10.000 .000

$10.900 .000 \quad 50.900 .000$

5.000 .000

\section{$5.400 .000 \quad 35.200 .000$}

\section{$9.000 .000 \quad 145.545 .600$}

\section{(20) Semestre}

Despesns con Pessonl (inclusive Leis Sociais):

- Adrinistração $6 \times 4.000 .000=$

24.000 .000

- CEPA Plono A $2 \times 3.000 .000=6.000 .000$

Plano B $4 \times 4.700 .000=18.800 .000 \quad 24.800 .000$

- Pesquiza e Docuraentrę̃o

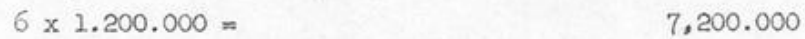

- Staff Técnico $6 \times 1.800 .000=$

$10.800 .000 \quad 65.800 .000$

Despesas Diverses:

$6 \times 1.500 .000=$ 
A Fundação Museu de Arce Moderna da Bahia empenhe-se na implantação de um Museu de Arte Popular, no Conjunto Arquitetônico do Unhão, dando-lhe caráter dinârnico e atuante sôbre o meio sócic-econômico, pela integração de um Centro de Estudo e Trabalho Artesanal onde os valores culturais da tradição artesanal sejam ativados e tècnicamente enobrecilos, e ao mesmo tempo transportados ao " "industrial design", pelo contato direto e interação entre o mestre artesão e o jovem projetista da forma e função do objeto industrial.

O programa distingue-se de outros já experimentados ou em vigor, por nĩo pretender alcancar en têrmos imediatos ceda un dos artesãos ou ventros artesanais pelo processo convencional de fomento econônico-assistencial, objetivando precisamente os aspectos formais da produção artesanal.

0 programa visa o artesaneto precisamente no seu conteúdo estético-cultural, sedimentado em conhecimonto da matéria, em forma, em função, em eficiência e em adaptabilidade ̀̀s condições do meio, no espaço e no tempo, com valores universeis. Salvanco êsses valores, ao recolhê-los, pesquisé-los e dignificé-los, inclusive no mercado, e transferindo-os a serações industriais an formação, o iuseu de Arte Popular e o Centro de Estudo e Trabalho Artesanl serão fator de alta importêncie no processo de desenvolvimento sócio-econômico, atuendo pela ação direta da intelizência e da cuitura sĉbre o povo a sôbre sua produção industrial, usancio valores universais que êsse mesmo povo depurou através do séculos.

A curto prazo, porém, a velorização das fontes atusis de produçño artesanal se verificará. O Museu apresentaré peças selecionadas, ao mercado nacional e inter nacional, divulgando e prestigiando o trabaiho do artesão e proporcionando-lhe re muncração justa. Ao mesmo tempo, o reconhecinento dado pelo Museu aos trabalhos de maior valor estinularão, nos centros artesanais, a melhoria e renovą̃o dos padrões.

Ea aplicação prática de conceitos teóricos, o empreendimento visa superar a fratura artesansto-1nâústria: de um lado, dar-se-á ao projetiata, que será responsível pelo "industrial design", a possibilidade de projetar com efetivo conhecimento dos miteriais que serão utilizados, dos meios de que dispõe o artesão (e similarmente a míquin 1ndustrial) para agir sôbre êsses materiais; simultâneamonte, estará absorvendo a riqueza cultural que a tradição acumulou, decantada, no trabrlho do artesĩo. Nesso contato direto "industrial desicner"/mestre artesక̃o, lucrará também êste, e ñ̃o só en têmnos imodiatos mis, principalmente, no melhor aperfelçoumento dos seus discípulos, nos qunis o jovem projetista transmi tirá, en retribuição, os conhecimentos que o mestre não pudera adquirir: loitu- 
ra e compreensão de plantas e desenhos, conhecimentos mais técnicos sôbre materị ais, absorção de cultura e valores estéticos do homem modemo. Assim, o discípu 10 do mestre artesão escapará de tormar-se, sob as condições atuais do meio, mero executor mecânico, distanciado cono homem de sua tarefa, porque lhe falte a compreensão do próprio trabaliho, de que não participa senão como instrumento.

A existência dessa descontinuidade torn imprescindível implantar, sôbre una rẹ lidado prática e uma efetiva colaboração projeto-execução, a atividade que se anuncia como a mreanto da nossa civilização: a produção de Arte ligada à vida prática - artesanoto transformedo en "Industrial Desion". O Brasil prìticanente não coneçou ainda uma produção nacional de objetos industriais originais, limitando-se, apenas à inporteção de forma e desenhos estrangetros. Uma produção ne cional não deve ser criads sem lígação com a herança cultural e sem ser fundada no terreno da realídade e das necessidudes efetivas do País.

A eliminação da utopia na crinção de un organismo dêsse tipo é o primeiro requisito indispensável so seu sucesso no campo das necessidades práticas do País (umát experiôncia tipo Bauhaus ou Hulm seria inútil a un país jovom, com una civilizã̧̧̃o de fatores fortemente primitivos e ligados ̀̀ terra, aliás, fatores e elemen tos modemíssimos, segundo ó entendimento contemporêneo). Outras diretrizes de. ven igualmente sor observadas: a) a evolução parn um centro de desenho exclusi vamente industrial deveró acompenhor o desenvolvimento da indústria regional, a que deveré servir; as condições históricas atuais apontam para a necessidade de sustentar o trabalho artesanal, até que a estrutura econônico-social seja atingi de e rodificada pelo processo de industrializąão; b) é indispensável tomar co nhecimento da ativichde artesanal ainda fortemente ativa no Nordeste do País, atividade que tem de ser estudads através de un levantanento efetivo," valorizada na sua realidade, nas suns diretas possibilidades econônicas face 30 mercado nacional e internacional, nos seus valores cultureis que deverĩo estar na base da futura fomnẹ̃o estética do futuro desenho industrial nacional.

0 enfoque da situnção do artesanaţo brasileiro no Nordeste (no csso, no Estado da Bahia); a sua selę̧̃̃o sem imposições; a sua transformação sem "artifícios, tudo isso estará ligado ès atividades do Centro de Estudo e Trabalho Artesanal e do Museu de Arte Popular que se pretonde instalar.

Em resumo, o contato, nas oficinas pilôto do Unhão, com a realidade artesanıl, propicierá a atmosfere necessáris ̇̀ integração da experiência humana do artesão e do desenhista industrial, capacitando-os a participar nas transformações econô mico-culturais. Como laboratório, anrá origem à mentalidade técnico-artística ne cussćria a transformação do artesanato cm pequena indústria. O Mercado de Artesensto do Unhão (a ser instalado nos arcos da Avenida do Contôrno) servirá à com provação econômica da eficiêncis do programs. 
Conforme Organograma anteriormente apresentado, o trabalho se desenvolverá em três áreas principais:

- atividade de pesquisa e documentação,

- atividade de trabalho artesanal,

- atividade de integração profissional entre projetista-arquiteto-industrial de signer e artesão-aprendiz.

Embora compreendidas realmente numa só unidade, seria conveniente entender a at1. vidade de pesquisa e documentação no âmbito estrito do Museu de Arte Popular; já as funções pertinentes ao trabalho artesanal e ao estudo dos fenômenos de proje to/execução se podem entender como integradas no Museu sob o esquema de Centro de Estudo e Trabalho Artesanal.

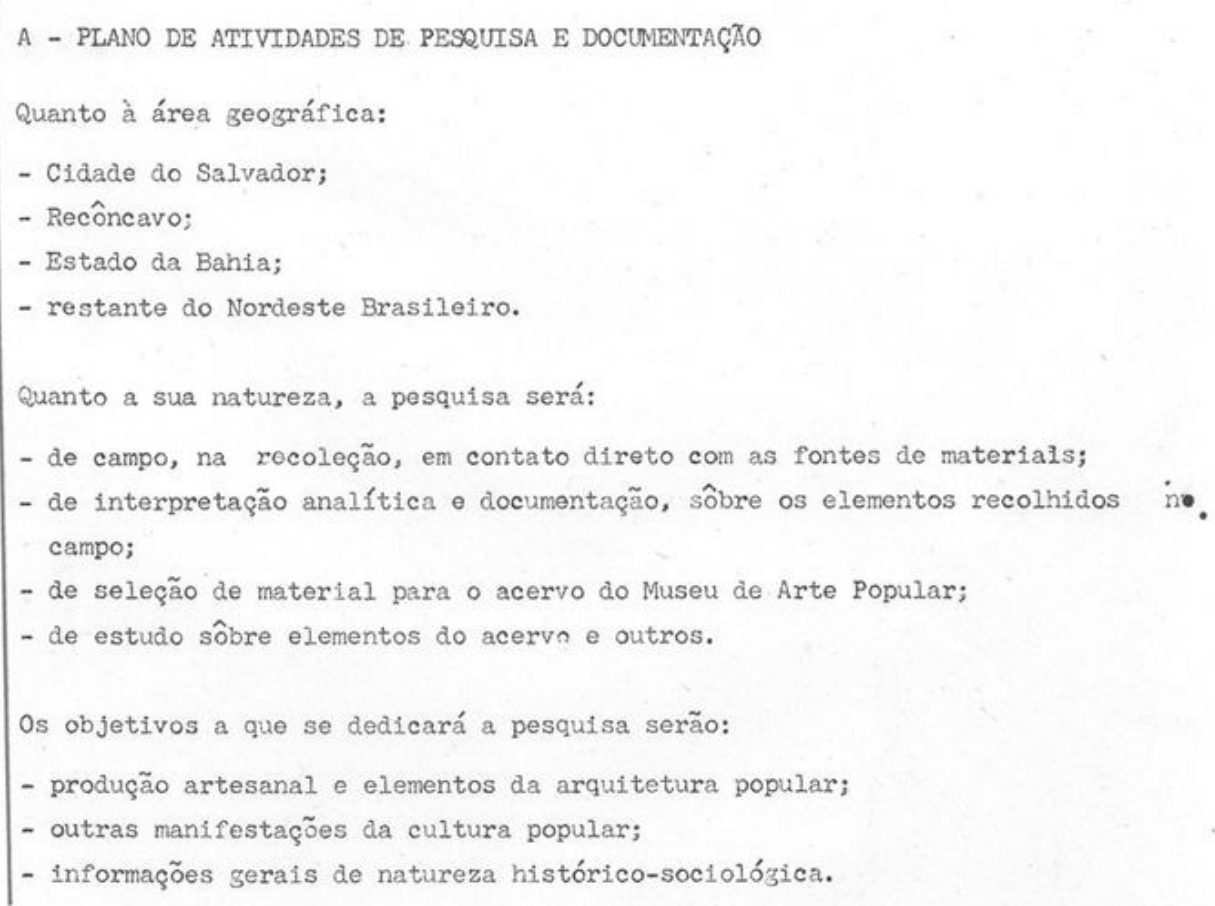


Alzuns dos elementos importantes em que se deverá deter a pesquisa são relaciodos a sezuir:

CLASSES DE PRODUTOS ARTESANAIS, SEGUNDO A ORDEM

1) Cidade do Salvador:

Artefatos executados e vendidos na Cidade:

a) Objetos executados em madelra, compreendendo:marcenaria, carpintaria e entalhe.

b) Objetos executados en motais forrosos e não ferrosos: caldeiraria, "forjaria", lataria, repuxamento (manual ou mecânico), martelado, ouriversaria e fundição.

c) Objetos confeccionados em argila queimada ou sêca ao sol: cerâmica.

d) Objetos confeccionados em vidro e cristal: fundiçã e lapidação.

e) Objetos confeccionados em fibras vegatats: tecelajem, bordados, rendas, esteiras, rêdes e armadilhas para pesca."

f) Objetos impressos: literatura popular, gravuras, artes gráficas em geral.

3) Objetos confeccionados om chifres, ossos, sementes duras etc.

Artefatos executados no interior mas vendidos na Cidade: Todos os artefatos $\theta$ atividades da Cidade, com exceção do item (d).

2) Recôncavo Baiano

Tendo como centros principais as áreas circunvizinhas às Ciajades de Santo Amaro, Feira de Santana, Maragogipe, Aratuipe e Alagoinhas. Encontram-se todos os tipos de artefatos e atividades da Cidade do Salvador, exceção do item (a).

3) Demais núcleos especialmente os do Estado da Bahia, abaixo relacionados: Cidade de Ipirá: artefatos de couro em geral, especialmente d.a zona do Rio Peixe. Cidade de Itiúba: chapéus de palha, esteiras, cestas.

Cidade de Cipó: algodão sedoso, ou melhor, artefatos de algodão sedoso, tais co mo chapéus, bolsas de vários tamanhos, tapetes, panos para cama e e mesa etc., espanadores de sisal, rêdes de caroá, cerâmica.

Cidade de Serrinha: cerâmica popular, produtos de sisal tais como capachos, ta petes, cordas etc.

Cidade de Monte Santo: Ex-votos e cerâmica.

Paulo Afonso: cerâmica, tecelagem e artefatos de fibras vegetais.

Cidade de Barra: cerâmica (potes, moringas e talhas), bonecas de pano, rêdos de dormir e de pescar.

Cidade de Lençois: lapidação em geral (pedras preciosas e semi-preciosas).

Cidade do Rio de Contas: artefatos de níquel, punhais, artefatos metálicos de montaria, cerâmica popular, artefatos de couro.

Cidade de Brumado: tecelazem de lã (em fuso).

Zona do "Sudoeste": artefatos, tecidos para montaria, cobertas. 
6) Impressos - literatura popular, gravuras, artes gráficas

7) Peças de:

Osso
Figas
Grampos
Agulhas
Anéls
Espátulas
Fivelas
Dominós
Fibras
Armadilhas, munzuás, etc.
Cesta
Balaíos
Mocós e bocapius
Cassuás
Artefatos de Papel
Máscaras de carnaval
(papel mache)
Arraias, Cą̧os, periquitos
Balóes
Chapéus e enfeites
Cataventos
Papel recortado
(enfeite para móveis)
Combinados
Birimbaus
Cuica
Tamborim
Pandeiro
Jereí́
Punhais

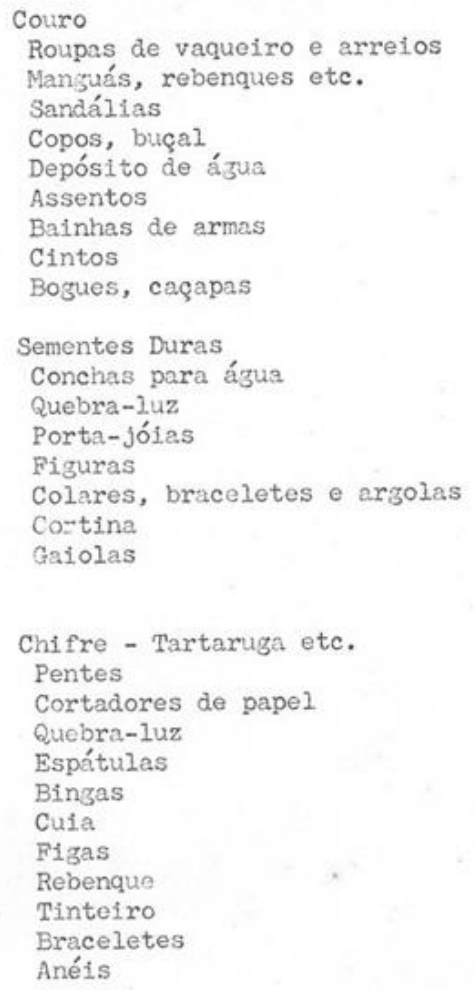

Essas atividades de pesquisa se irão desenvolvendo dentro da sezuinte cronole. jia (os períodos referem-se à fase de instalação de cada um dos setores, prosse zuindo tôdas indefinidamente):

Primeira Etapa: 0 a 6 meses

- organização e planificação das ativiaades de pesquisa;

- levantamento preliminar das fontes de naterial a serem trabalhadas;

- orzanização de fichários e arquivos;

- estabclecimento de uma sistemática de documentação e organização;

- criação de espaço adequado para guarda e preservação do material recolnido

Sezunda Etapa: 6 a 18 meses

- contatos com as fontes;

- Início òas pesquisas nas áreas de Salvador e do Recôncavo.

Terceira Etapa: $\quad 18$ a 30 meses

- intensificação no Recôncavo e início no interior do Estado. 

CETA

A implantação do Centro compreenderá a sua instalação física, a seleção dos mo: tres-artesãos, um períodio de adaptação e de prática tradicional, seleção dos aprendizes, dos prcjetistas, arquitetos e "industrial designers) e funcionamen to normal.

Em plena peração, os diversos setores de trabalho artesanal estarão produzindo objetos e trabalhos diversos; o mestre-ariesão terá possibilidades de enriquo. cimento téenico do sue produção, com materieis e instrumentos que não estavam ao seu n-ar os aprendizes estarão absorvendo do mestre a técnica de execução e o conhecimento da matéria e seus valores intrínsecos, relacionados com o objeto, sua forma e uso. Êsses mesmos ensinamentos serão recebidos pelo "indus trial designer" em formação, no contato direto, embora sem que isso implique, necessàriamente, numa habilitação executiva própria, senão no conhecimento da problenática de execução; em síntese, o estudante de "industrial design" devcrá conseguir a melhoria do padrão de projeto (forma) e do conhecimento do mrial e da técnica de execução, absorvendo ainda valores culturaís destilatos na tradição do mestre-artesão. Ao mesmo tempo, êstes jovens estarão transmitinà 20 aprendiz-executor um conhecimento dos aspectos formais do projetamento e ch.. sinamentos príticos de desenho técnico (leitura de plantas) conhecimentos cicntíficos e matemáticos elementares etc.. Os estudantes de "industrial design" obterão sua experiência estudo/projeto/execução quando o artesão realizar, na oficina, os prototipos de objetos industriais por êle projetados. Para estímulo da ação criadoza, para compıemento de informação e para fonentar valores un: versais, serão promovidos de forma regular, sistemática e objetiva, semiń ios sôbre temas que sejam de importância para os fins do CETA.

Evidentemente, não se deve presumir uma obediência a cronogramas estritos de $c ?$ ráter industrial, Já que a seleção dos mestres-artesãos se terá de fazer por um processo de experimentação e à medida om que se possam ir mobilizando os indivé duos para os diferente setores. 
No Plano A, n ser curaprido nos meses 0 a 12 , espers-se instalnr as oficinos do prédio no nível mais elevodo compreendendo:
1) Ferro e metais nĩo ferrosos
2) Pintura
3) Cerânicica
4) Fornos e esturas
5) Vidro
6) Pedras

O Plmo B deverá ser posto en execuç̃̃o entre os neses 8 a 12, utilizando o cs. paço do prédio en cota mis baixa, onde se instnlnano os setores seguintes:
7) Madeirs
3) Tipografia (+)
9) Estauporia
10) Tecidos e Rendas en Geril
11) Couro
12) Poin?

(+) Os trobrihos de artes gríficas, dndo o alto investimento inicial neceser.

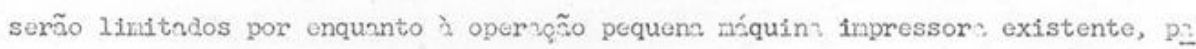
rn pequenos serviços próprios do Museu.

Pars os trobalhos nrtesanais durante os 28 prineiros meses, período en que pròvavolinenté o programs aind não teris atingido un nível suficientenzente elevado de produtividade econônics, serń necessírio dispor de un estoque de naterinis, parn o qual se destron was verbs de 6.5 milhões. 
C - PESSOAL

Pesson] Não Administrativo

A Pin de desenvolver êsses trabslhos seró necessńrio dispor do seguinte pessonl técnico (a remuneraç̃o previst: devendo ser ojustável com as alterações do sn? rio rínino legal).

- Membros do "Stnff" técnico:

Durante os 6 prineiros meses: - 2 × $300.000=600.00$

Tot?l inclusive 50\% leis socinis 900.00

Após os 6 prineiros mêses: $\quad 4 \times \quad 300.000=1.200 .000$

Totnl inclusive $50 \%$ lols sociais $\quad=1.800 .000$

- Pesquis? e Docunentcõ̧̃o (equipe orientads por menbros do "Stafe" técnico):

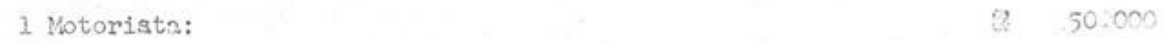

1. Ajudnnte: $\quad 33.00$ ?

1 Foto-cinegrafistn: 200.00 )

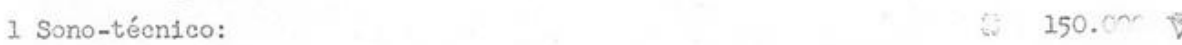

1 Desenhisto: 130.000

1. Estudante de Ciêncins Sociais: fo 80.000

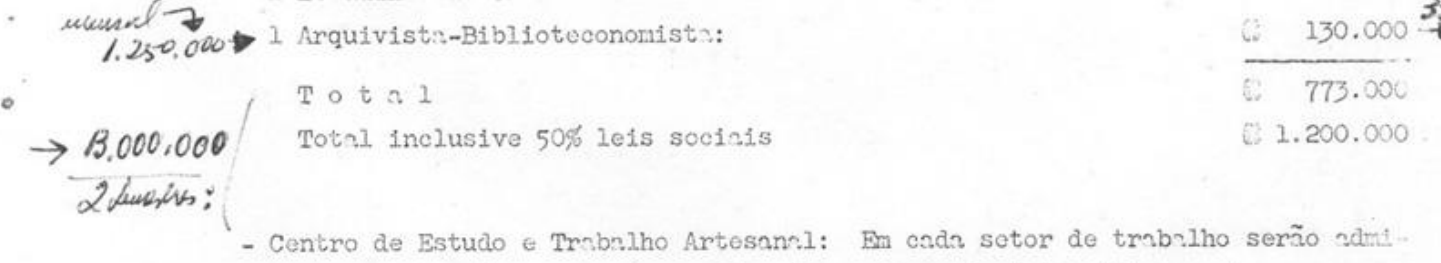

tidos: ure restes̃o, con remunernoño médic, fixs, de 150.000 mensais o un ajy.

dante e três sprendizes, recebendo todos êstes sqlório mínino.

Plano A ( até o oitrvo nês)

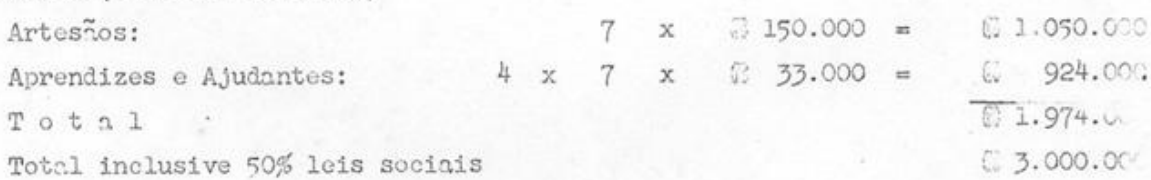

Plano B ( apõs o oitavo mês)

Artes:̃os: $\quad 11 \times \quad 150.000=01.650 .00=$

Aprendizes e Ajudentes: $\quad 4 \times 11 \times 633.000=\quad \mathbb{6} 1.452 .000$

$\begin{array}{ll}T \circ t=1 & 3.102 .000\end{array}$

Totol inclusive $50 \%$ lels soclais 6 4.700.00.

296. 
41)Dois zurtelos pneuríticos, com ccessórios. 730.000 cada.

42)Furodeirs elétrica portátil, potência $3 / 4$ HP, cepacidade para brocas nté $1 / 2$ polegrans. C 450.000 .

43) Serrote elétrico portít1l, de novimento altornativo, con acessórios.

: 225.000 .

44) Conjunto formentas lapidação parr 2 honens. \& 372.000.

45)2 Tornos cerânicos de pé. 300.000 .

46)1. Torno cerânico elétrico. : 500.000.

47) Conjunto para laboratório de cine-fotografia, totalizando 10.650 .000

e compreendendo:

- Máquina filnadora tipo Paillard-Bolex $16 \mathrm{~mm}$ com três objetivas

Q3. 3.000 .000

- Máquina fotográfica tipo Linhor, formato $6 \times 9$ com três objotivas

3.000 .000

- Míquina anpliadore, Pomato 6x9, autorática, condensador

6. 1.000 .000

- Jogo de cubas, tamanhos diversos, sté 40x50, em aço inoxidrvel.

(3) 600.000

- Exanctor de an, elétrico, potência de 0,5 HP

- Jôgo le lâmpades filtro, para trabalho con filmes e papeis orto e pancromatic

(4) 120.000

- Duns pios en aço fnoxidavel

- Nulogios prro teapo termônetos, tnnques p/re velnção, fotônetros, papeis fomnto fiversos +...ns

(6) $\quad 160.000$

$\cdot$

- Máquina focogrrifica $35 \mathrm{~mm}$ tipo Aschi Pentax, con 3 objetives e filtros

- Pequeno zerrigerador pare resfrianento de re veladores e águe pare. lav-gons

- Esmoltraeira elétrica

Sub-Totol

Diversos (nD̃o especiftcarios, fomanentos mnuais, etc)

E. $35.559 \cdot 500$ $4.440 .5 \mathrm{~m}$

Total dos equipamentos porn o CETA

(3) 40.000 .000

Veículo - eninhonets Chevrolet nodêlo C-1416

Q 10.900 .000

Valor Total dos Investinentos a Realizar en Obras, Equipamentos e Instclncõos 


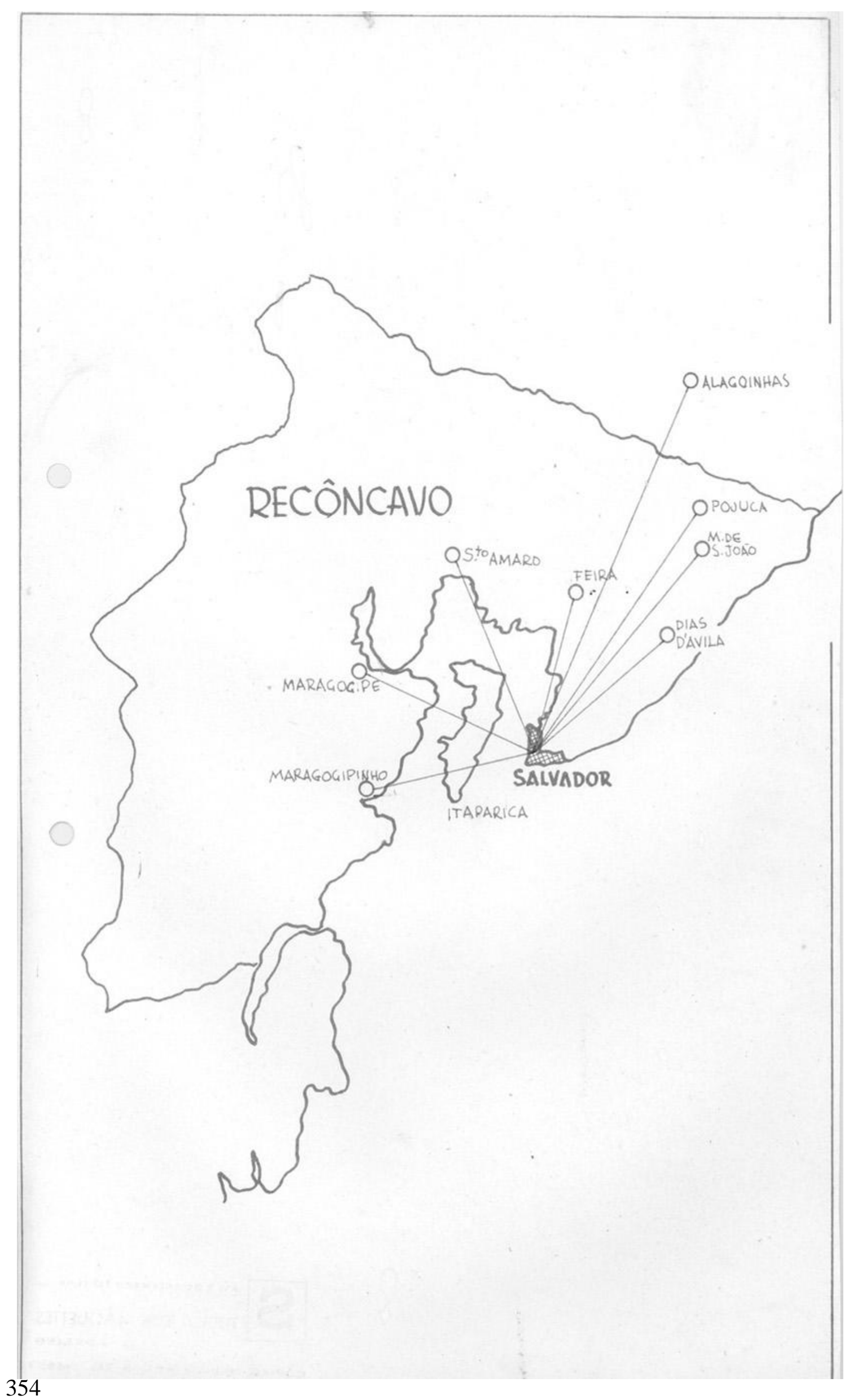




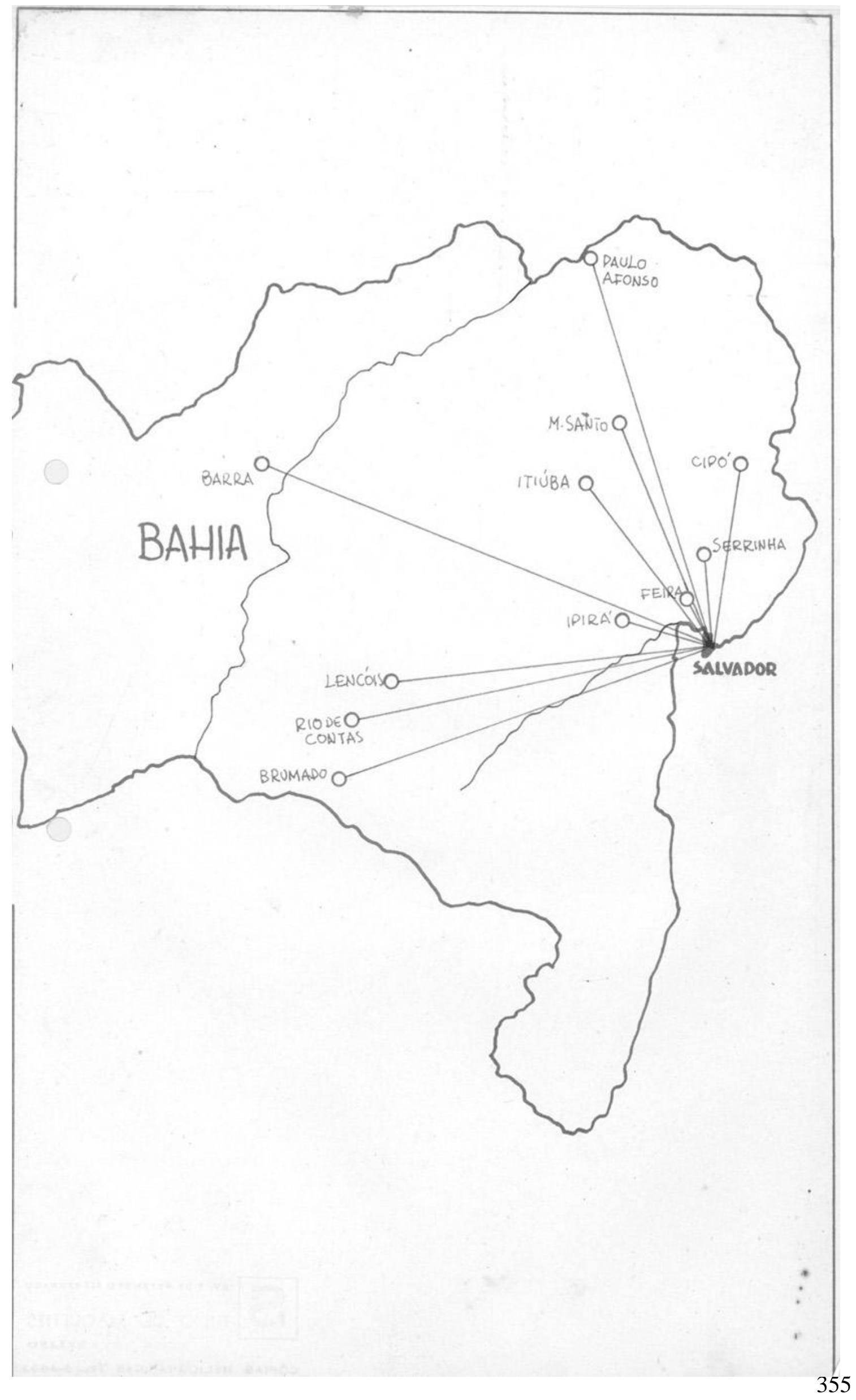




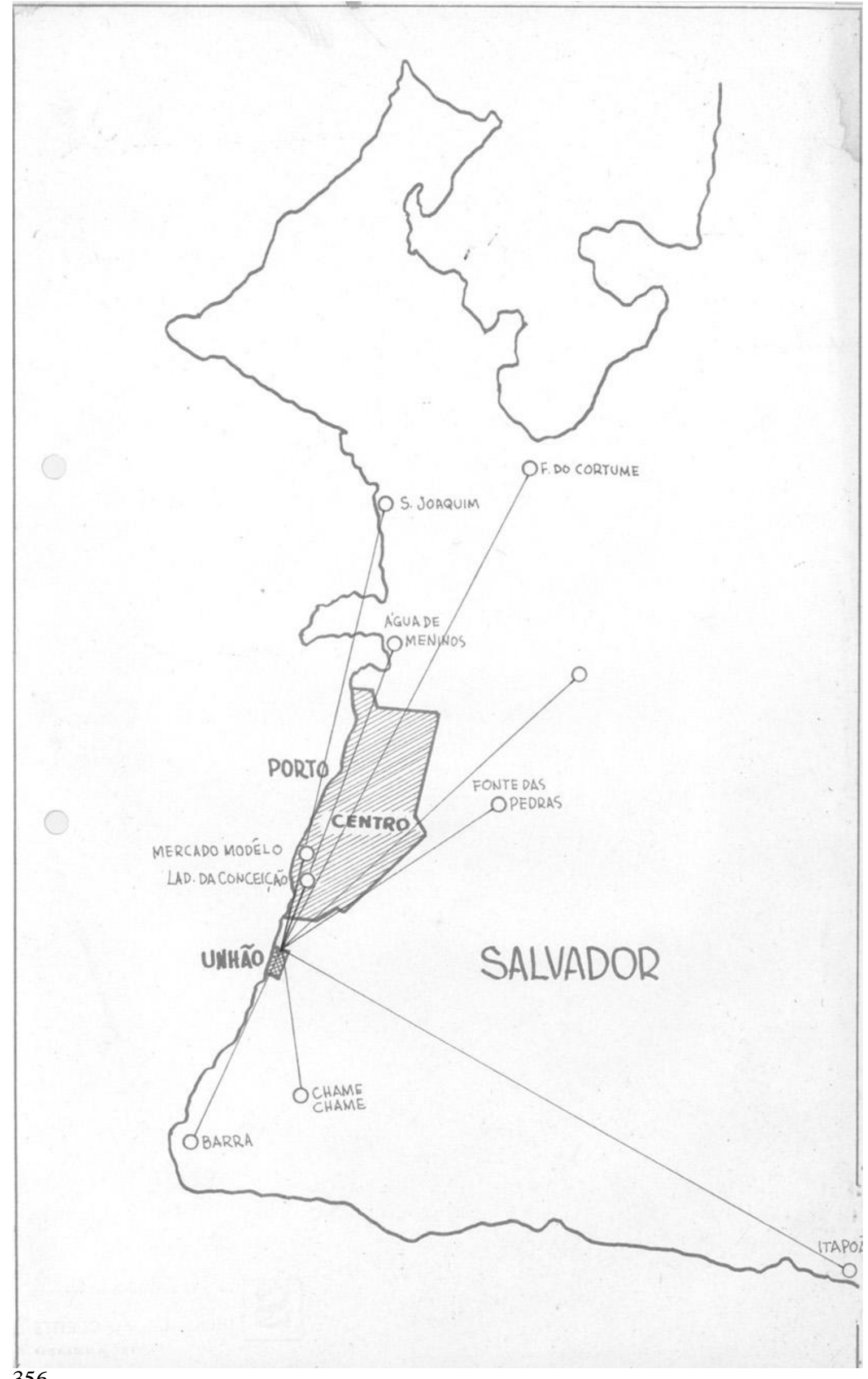




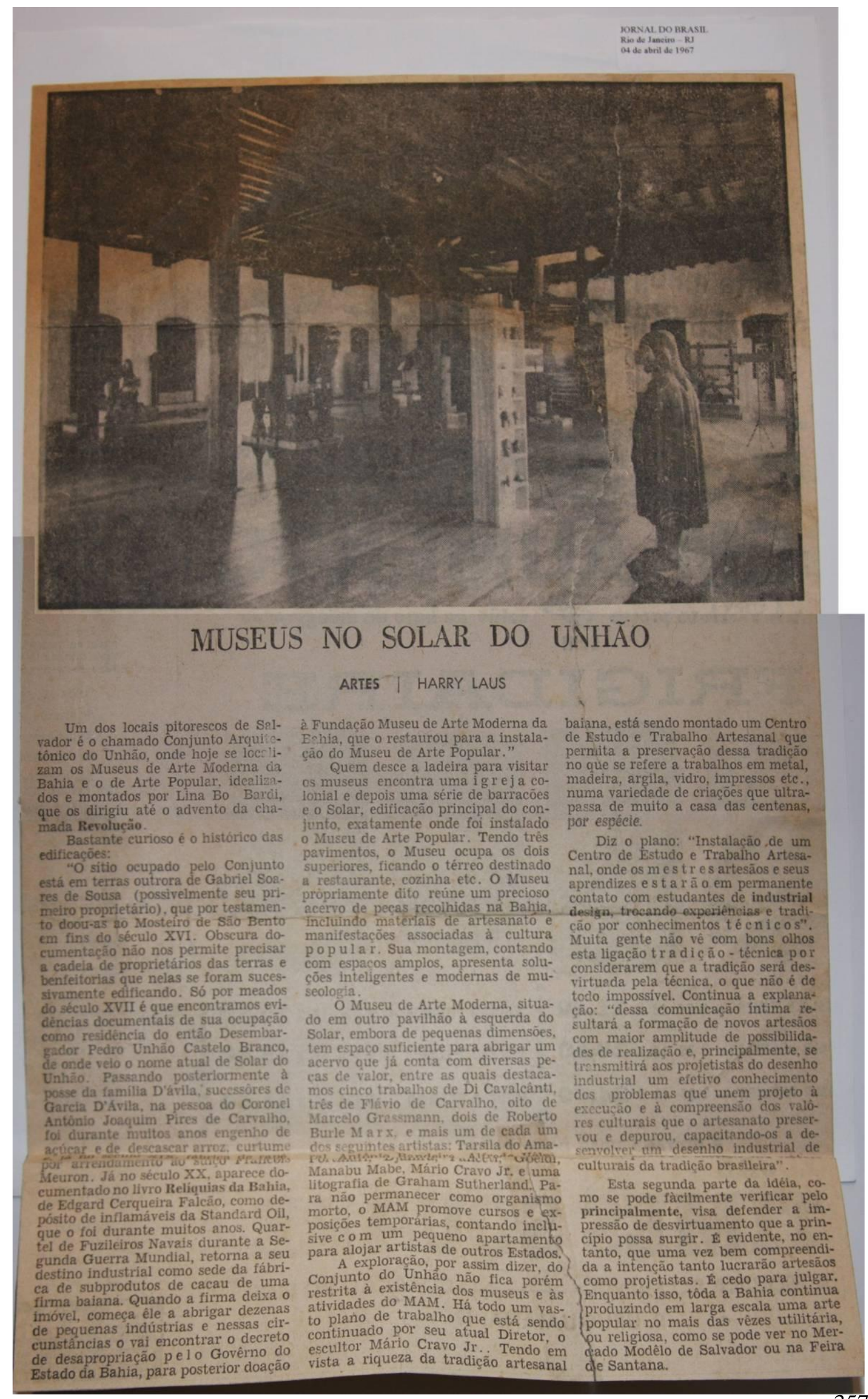




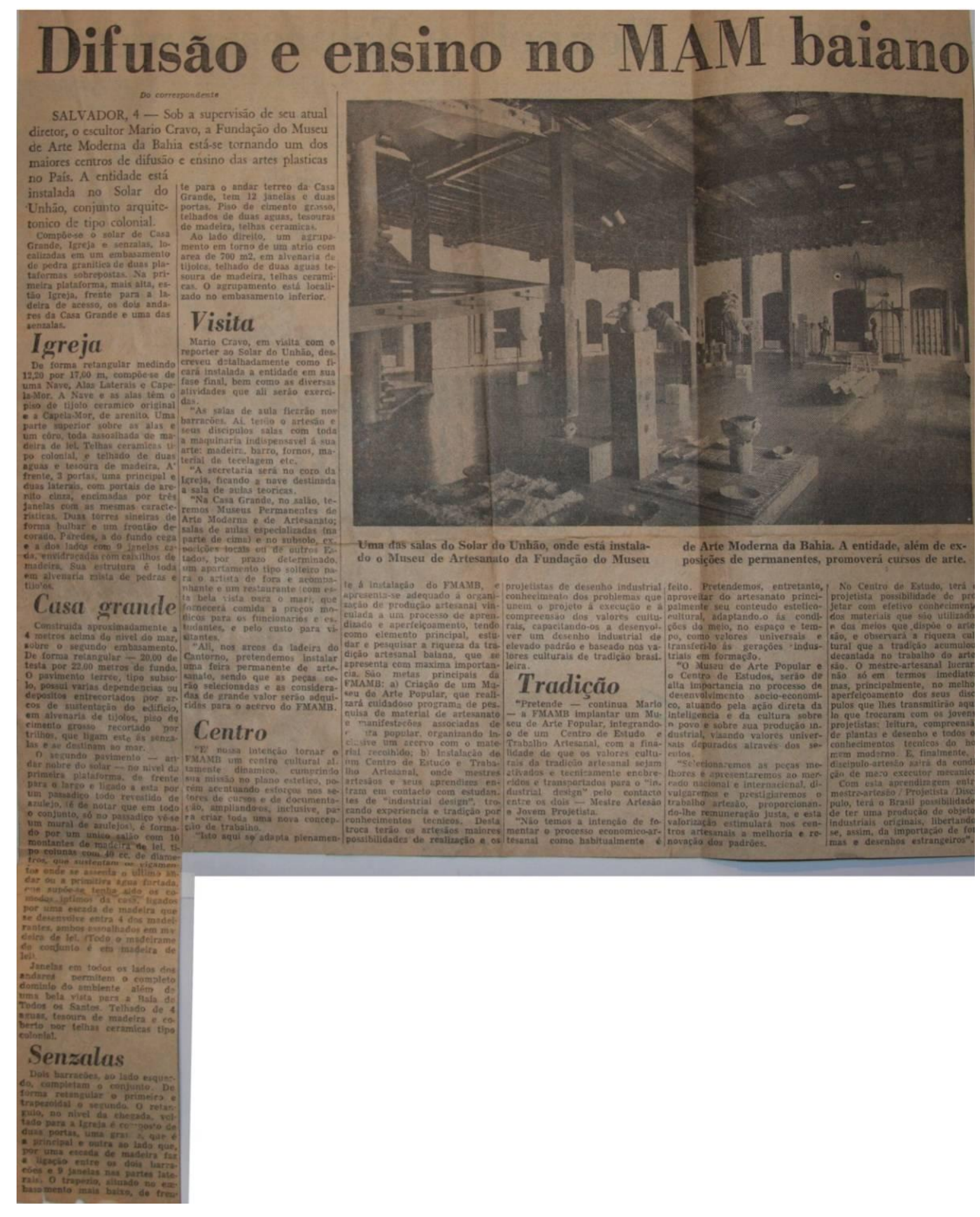




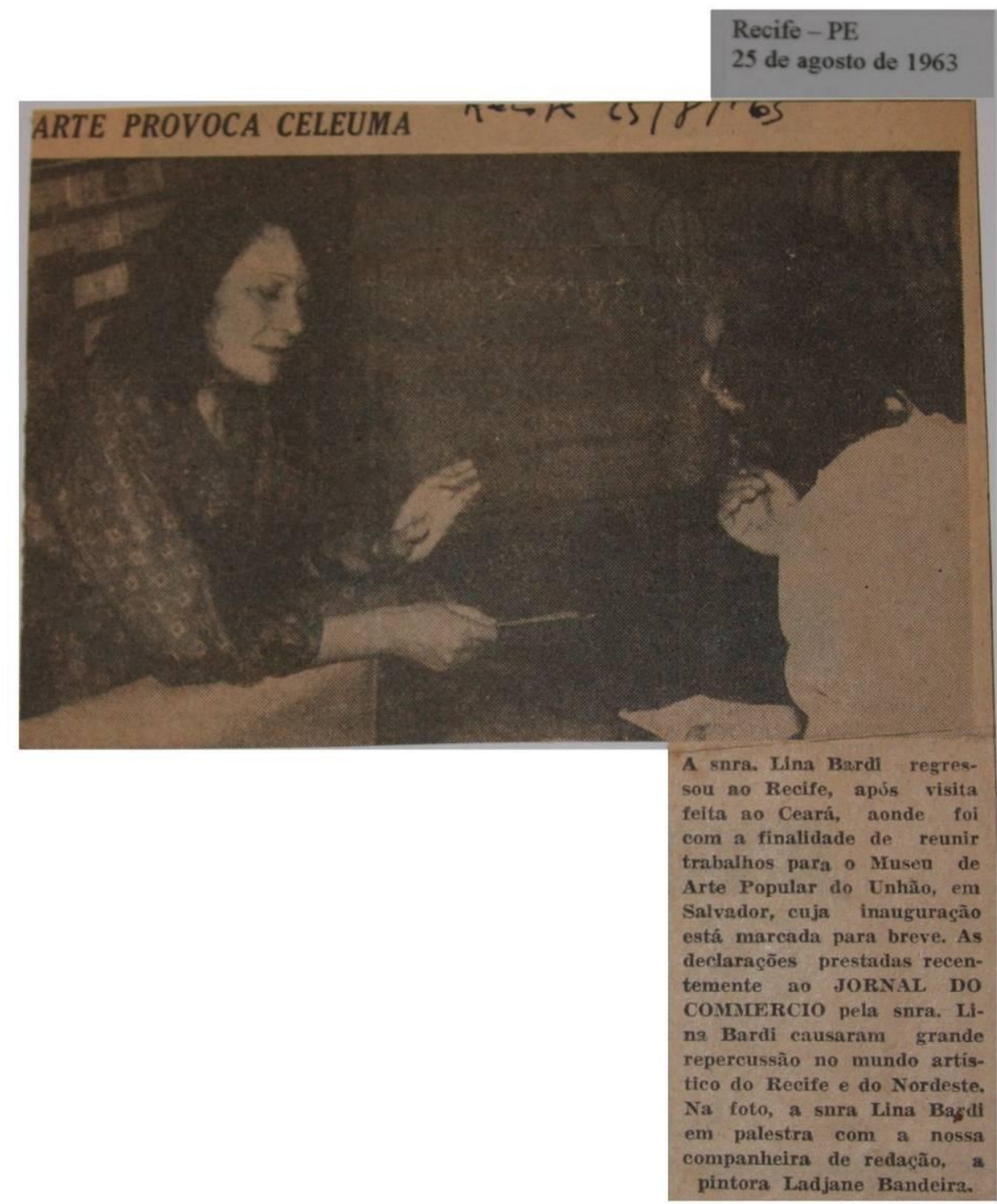

JORNAL DA BAHIA

Salvador-BA

08 de janeiro de 1963

Guilherme SIMOES

Ministro Darcy Ribelto que durante trés cilas esteve entre nos, retornando ontem para o Rio, resolveu no domingo destigar-se um pouco de suas preocupaçues $e$ ver de perto as atividades da Petrobrás, especialmente a Reas atividades da paria de Mataripe. Ati teve oportunidade de visitar as instalaçóes do grupo escoiar da retinaria.

O MINISTRO iniciou os seu domingo onm uma visita. em companhia do governador Estado, ao solar do Unhâo. Onde de está processando uma reforma geral, para transtormá-lo em escola artesanal A reforma (excelente) está a cargo da senhora Lina Barda, aue também lá se encontrava. e que, segundo ¿ at:nistro, é uma das pessoas mais capaze, cue conhece, Lá o ministro se deteve durante cerca de 40 minutos. examinando todas as instalacues. 


\section{ANEXO VI \\ Costa \\ Tredicesima Triennale di Milano}

Cópia do Catálogo Original da Exposição de Lucio

\section{empo libero}

sposizione internazionale

elle arti decorative

idustriali moderne

dell'architettura moderna

'alazzo dell'Arte al Parco

Ailano

2 Giugno

7 Settembre 1964

\section{Loisirs}

Exposition internationale

des arts décoratifs

et industriels modernes et

de l'architecture contemporaine

Palazzo dell'Arte al Parco

Milano

12 Juin

27 Septembre 1964

\section{Leisure}

International exhibition of modern decorative and industrial arts and of modern architecture

Palazzo dell'Arte al Parco Milano

12 June

27 September 1964

78

\section{3/Brasile}

Condulpho A. Borges da Fonseca.

Ordinamento:

arch. Lucio Costa

Allestimento:

archtit Maria Elisa Costa, Sergio Porto, Homero Leite Direttore della sezione:

Jayme Mauricio.
"O tempo livre em termos brasileiros pode ter come simbolo a rede e o violao ".
La nostra partecipazione alla Triennaie dourá costare poco
a causa delle circostanze; potrá tuttavia risultare attraente e utile per la sua singolaritá. Sara sufficiente allestite un ambiente arredato solo da
quattordici amache e da qualche chitarra del tipo piü semplice. questo ambiente potră essere utile ai visitatori che volessero riposare e, per it suo aspetto inusitato, attirerá la curiosí di tutti. ganci che reggono le amache, aggruppas sottili di acciaio tesi orizzontalmente da tiranti in ferro: cosi - Toro appoggi saranno sollevati dal pavimento e questo paricolar del suo garbo di gondoia L'ambiente sara delimito da pannelli di media altezza definiti da listelli. La modulazione in pianta si basera su una serio di dag is Le due fotografie di zattere con le vele gonfie, riprodotte sui pannelli, provengono dalla stessa regione nella quale scomparendo che potrebbero essere utilizzatii nello sp
regionale, attinche una tradizione ed una attivita siano conservate. Le amache di cotone saranno a due color dos Tres Poderes, la piattatorma stradale, if centro nza ara esposta a suggerire che la stessa gente che passa

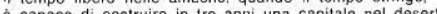
Nella faccia esterna di due altri pannelli sarà scritto BRASL in lettere bianche su stondo verde e giallo e in alto sara

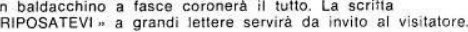
Lucio Costa

NOTIZIA SULL'AMACA BRASILIANA

Ancora oggi, nel Brasile del Nord, it e sertanejo ", ruomo
dei campi e dei deserti. quando si muove, spinto dalla siccita chiama " réde de dormir ". E' tutto it suo mobilio, al quale rinunzia solo in casi disperati. L'amaca è parte integrante
del suo padrone, lo completa, lo culla, ed è ancora lei a

Anche la gente di mare, "Jangadeiros ", pescatori di " "bỏte " e " tresmalho ", é rimasta tedele all'amaca, come in altri tempi
gli indios e i mamelucchi, che nascevano e morivano nellia rete gli indios e i mamelucchi, che nascevano e morrvano nelia rete.
Ogni anno piü di 650.000 amache vengono labbricate e vendute nel Nord Brasiliano. In maglia, lino o cotone le ret
sono talvolta opere raffinate per colore, fattura e rifinitura. sono talvolta opere raftinate per colore, fattura e ritinitura
bianche, gialle, arancione o rosse, come quelle del Ceari Nei portali o sotto alberi ombrosi, sosterute dai ganci aile impugnature o agli anelli, le amache si trastormano
in ietti sospesi, pratici. comodi e puliti. Negli stati del centro-sud l'amaca è diventata cosa da villeggianti,
gradevole appoggio per la siesta, sulie verande delle ville o nei giardini delle fattorie.
Ma la a vecchia madre come era chiamata nei temp: passat
continua ad essere il letto dei poverissimi. anche se neile

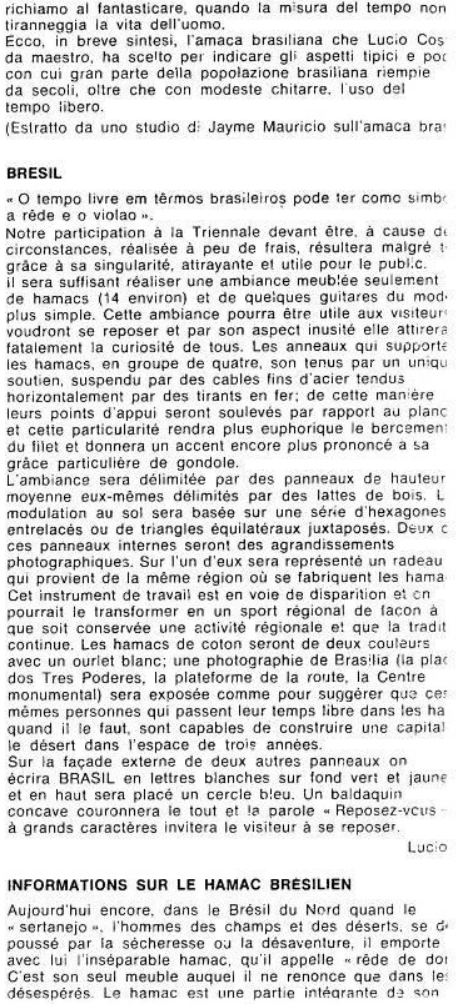


Induire jusqu'au dernier sommeil.

pécheurs de a bôte. ios et les mameluches qui naissaient et mouraient Filet.
* annee plus de 650.000 hamacs sont fabriqués
1us dans le Brésil du Nord. En laine, colon, lin. is sont partois des œuvres raftinées comme couleur, et finition, blancs, Jaunes, oranges, ou rouges

is portails ou, sous les arbres ombrageux, soutenus
5 crochets aux proignees ou aux anneaux, les hamacs es, confortabies Jres.
Is elats du centre Sud le hamac est devenu un article
ersonnes en villégiature, apoui très agréables pour ersonnes en villegiature, appui trés agreables pour In veille mere * comme il était appélé aux époques appel au rève; quand la mesure du temps no

se pas la vie de thomme. homme $s$ et peu connus avec lesquels une grande partie de ta IIon bresilienne remplit, depuis des siecies, avec une étude de Jayme Mauricio sur le han

רpo livre em termos brasileiros pode ter como re since our participation in the Triennale mus 1 little cost by the circumstances.
be sufficient to arrange an environment furnished th hammocks and with some guitars of the simplest model. om will be able to be useful to those visitors who rest and oks bearing the hammocks; grouped four to four sported by an only prop, suspended to steer thin cables. unt horrzom floor and this will make gracefut the swinging vet and will emphasizes the peculiar charm of its

Im will be bounded by middle-height panels finishe of these panels there will be photographic enlargements. 作 Weans of work are disappearing but could be changed the tradition go on. The cotton hammocks will be oured with a white hem, a photograph of Bras:ta res poederes square. The street plattorm, the monume
will be showen to suggest that the same people end leisure on hammocks, when necessary, are able
On the outer surface of two other panels will be written Brasil there will be a blue circle.

A canopy will crown the whole and the inscription " rest

Aousont Lucio Costa

INFORMATION ON THE BRAZILIAN HAMMOCK

In the north of Brazil, we still find nowadays the " sertanejo

calls his - rede de dormir " his inseparable hammo

when the dry weather and his mistortunes oblige him to

it completes him, lulls him to sleep, even in his last sleep

of death.
The sea-tolk also, " Jangadeiros $n$, the a bỏte " and
utresmaliho f fishermen are taithful to the hammock, like

"tresmalion $n$ fishermen are faithtul to the hammock, like
the indios and the mamelukes of the past, who were born

and died in them.

nets are sometimes refined for their colour, make and finish

hey can be while, yeliow, orange or red, like the Ceara on

held by hooks onto grips or rings, become suspended.

practical, comtortable and clean beds. In the central and

as a pleasant bed for the siesta on the verandas of the vill

or in the farm gardens.
But the " old mother $*$, as it was called in the past, is still

resorts and in rest as a pause, a pleasant invitation

to day-dream, without the tyranny of time.

y the expert Lucio Costa to indicate the typical chos and unknown aspects of the use of leisure of most of the guitars

(Taken from a study by Jayme Mauric:o on the Brazilian

'allestimento e l'esposizione

Pannell' fotografici si alternano sulle pareti intonacate di bianco. Nell'ambiente sono collocate quattordici amache a colori diversi sostenute da ganci ancorati a sottili tiranti di acciaio la sua ampiezza. I soggetti delle fotografie

Palme e barca:

Brasilia nel 1961:

almizi e barche:

Jangade sulla spiaggia (quattro toto:

su amaca primordiaie:

Jangada con vela in prossimita della risacca;

.

Quattordici amache dette "Redes Ph:lomeno wander. His Murnture consists in

(nold

94. Pianta della sezione, scala $1: 300$

\section{(1)}
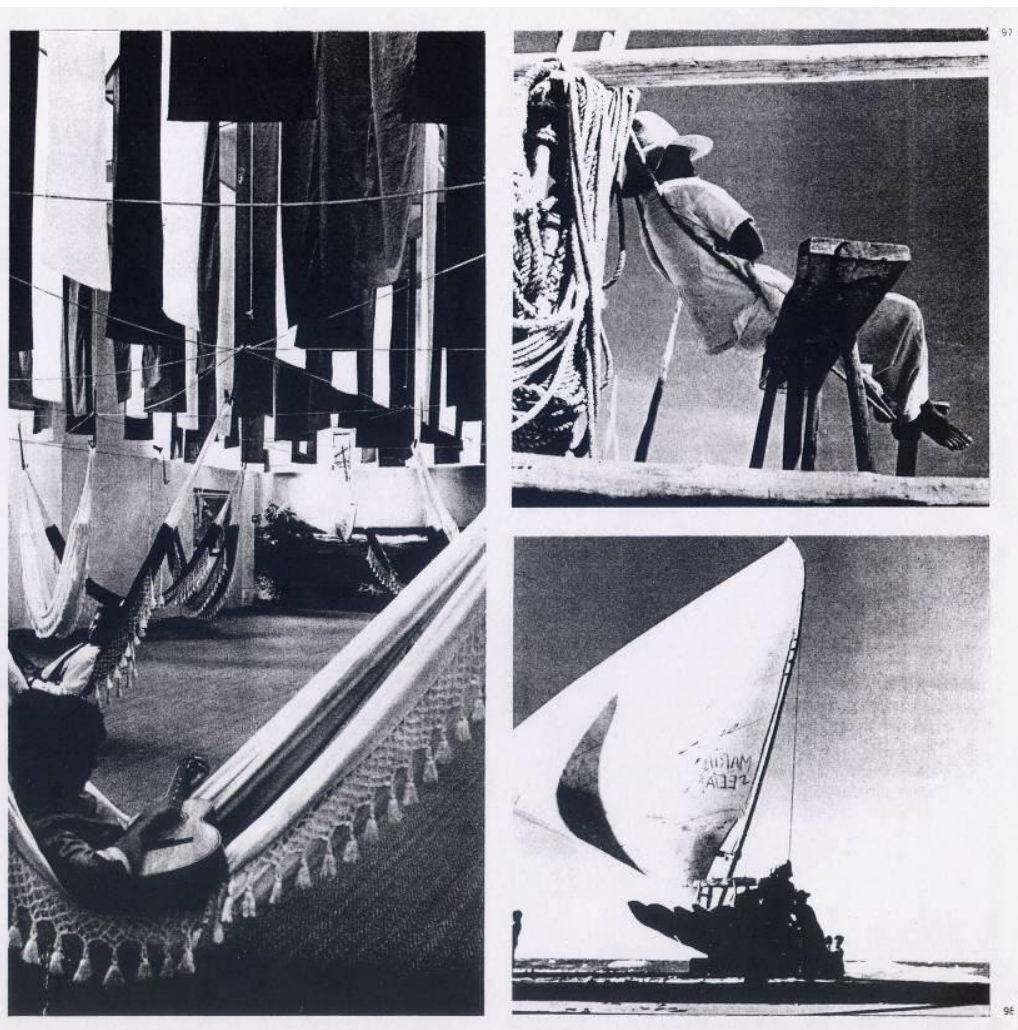
ANEXO VII

\section{Carta de Lina a Celso Furtado - 05/03/1964}

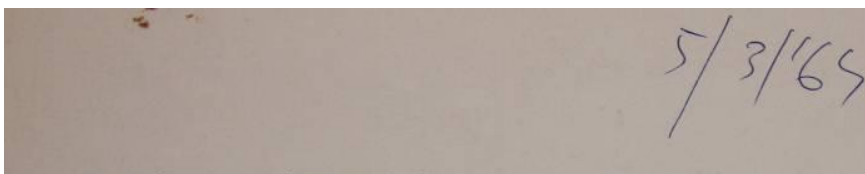

Gentile Dr. Celso Furtado,

voltando duma viajem a Europa vejo que o Itamarati está organizando uma exposição de artesanato do Nordeste "semelhante" à da Bahia, destinada aos paises do Kercado Comum Europeu.

Não posso deixar de lembrar a conversa que tive no Recife com o Senhor. A respeito de -xposições; suas ideias, sua tese da cultura desligada da economia. Sabado passado, convidada pele Universidade de Roma, falei do Nordeste brasileiro, duma cultura popular e não-de-elite a umé auditorio de elite que admitia somente uma cultura de elite.A lingua italiana áulica não correspondia como instrumenło, os slides não conseguiam transmitir uma realidade dura, eneróiea ( no sentido anti-heróic da palavra). Somente num longo debate consegui arrastar os estudantes do mundo abstrato do humanismo literario para a visão duma cultura"pobra", dum humanismo tecnico, duma arte ligada à vida de cada dia è "demitizada". Não pude separar a experiência da universiduce de Roma da lembrança da conversa que tive com o Senhor no $\mathrm{R}_{e}$ cife, embora em sentido contrario; nos dois interlocutores tinha difidência a meu respeito: de carḱter idealístico em Rowa, de carálter tecnico no Recife,e ñ̃o posso deizur ce conctatar com amargura como é dificil commicar e intender-se mesmo quando o caminho é comam. O Sonhor interpretou a exposição da Bahia como uma apologia artisttca pro estatus- quo: a consolação atraves da arte em lugar do planejamento economico e da solugão tecnica.Foi tão grande minh - surpresa naquela ocasião que não soube responder-1he. 0 tinha procurado para pedir o enquadramento tecnico de nosso trabalho na realidade dum planejamento, para "historiciaar" num preeente economico ume realidiade vílicí até hoje somente no plano abstrato e poetico. Se a economie é a base que sustenta a sobreestrutura cultural (o afirmou categoricamente mesmo sem julgamento de valores), a estreita ligação entre as duas poderá produzir modificações na mesma base. A responsabilidade é grande demais.Defronte aos equivocos, deploro que nosso trabalho que desperta hoje interesse nacional, não tenha estrutura tecnica, seja privo dos instrumentos científicos necessarios a uma ação positiva dentro da realidade. A dois meses de minha vinda ao Recife, defronte aos equivocos superpiciais quero esclarecer que minha visita foi motivada anicamente por motivos tecnicos, não financeiros ou de promoção.queremos contituir uma Universidade Popular, para formação de operarios profissionabs, o Museu de Arte Popular será somente o Centro de documentação junto à biblioteca.Mas o "material humano deverá ser ligado à pratica e à realidade. Não adiantaria fundar uma nova"Bauhaus" no nordeste, o mesmo Walter Gropius não corresponderia a uma realidade tão dificil, tão pobre, e Weimar 1918 está longe na historia. Por esta razão procurei o senhor; queria um caminho diferente dos do sofbsticado industrial 
Design, e mesmo do Ministerio da Eduaação.

Conheço seus trabalhos e seu pensamento, e apesar ter afirmado "ser somente um

frio economista", ( oque é rigorosamente necesserio quando a base da cultura dum País

è ainda a formação-bacharel e sue diąletica uma dialetioa literaria deterior), percebi

claramente que sua formaça tecnica não deixa lugar aos equivocos unilaterais que

confundem ą "posição" tecnica, como metodo, com uma tecnica em sí.

Isto nảo somente porque o senhor falou de musice.

o Senhor disse querer visitar a exposiçĩo Arte Popular aquí na Bahía; queria acompanha-lo

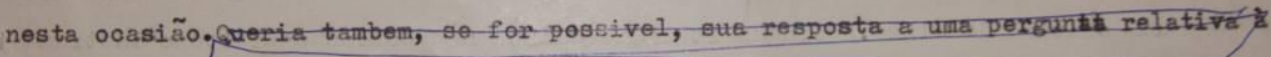

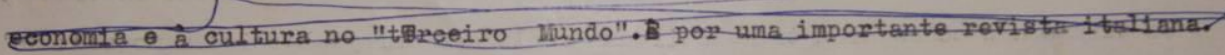

Depois duma serie de equívocos ( alguns dos qua is mortificantes, como os ocorridos com a Artene), sentí, voltando, eo Brisir, a necessidade de esclarecer minha posição. Retomando o trabalho do Unhão, na Bahia, sentí que optei pelo Brasil não por transporte sentimental mas por fria condição historica.

Queira desculpar minha grande carta e queira aceitar com minha estima minha lembrança 


\section{Resposta de Celso Furtado - 05/04/1964}

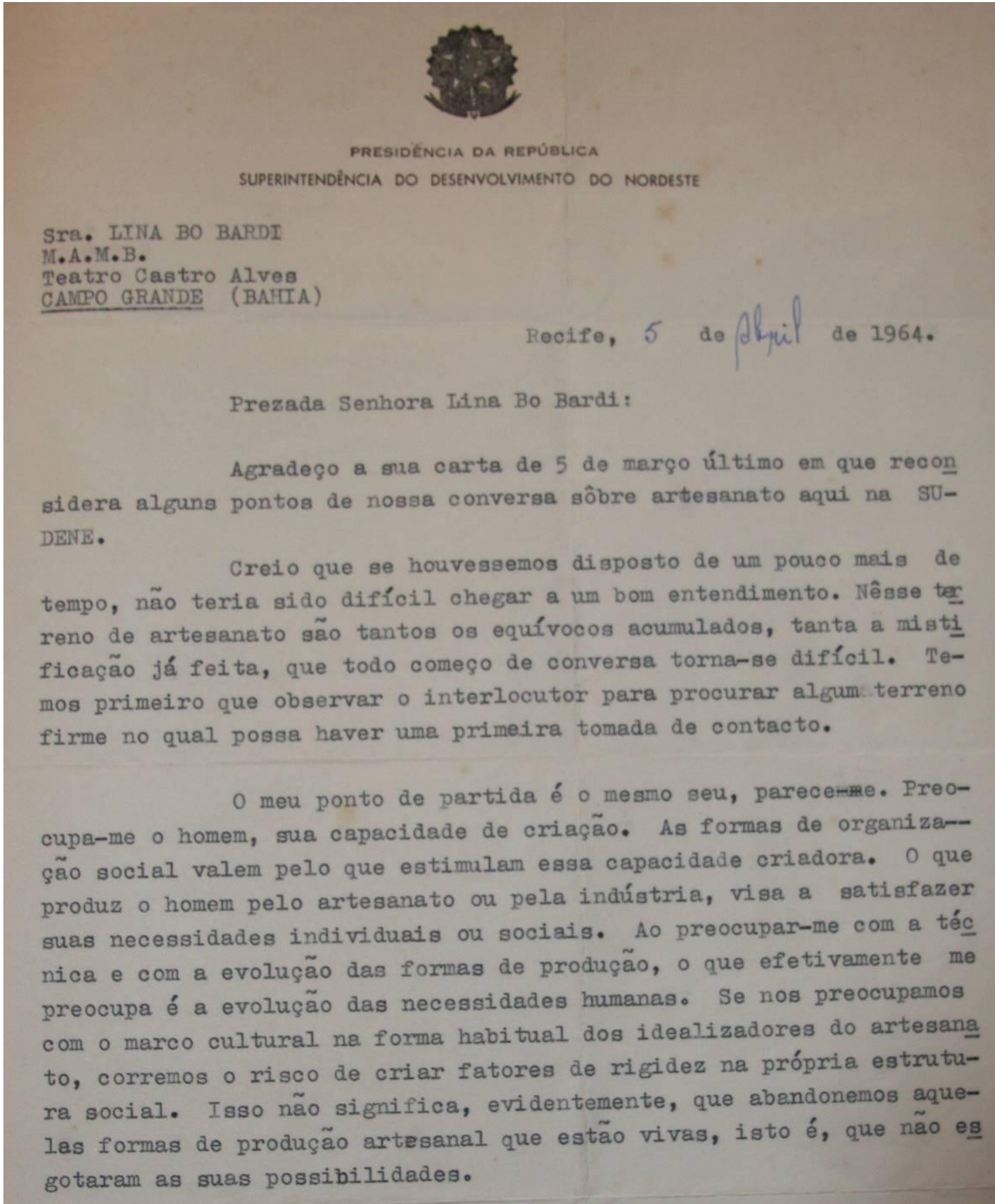

Felicito-a mais uma vez pelo trabalho que está reali-zando e que considero de efetivo valor para o Nordeste. Na primeira oportunidade, visitarei a exposição de Arte Popular, aí em Salvador, avisando-a com antecipação.

Cordialmente,

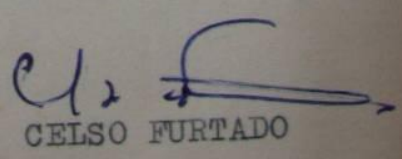




\section{Carta do Ministério da Guerra - 15/07/1964}

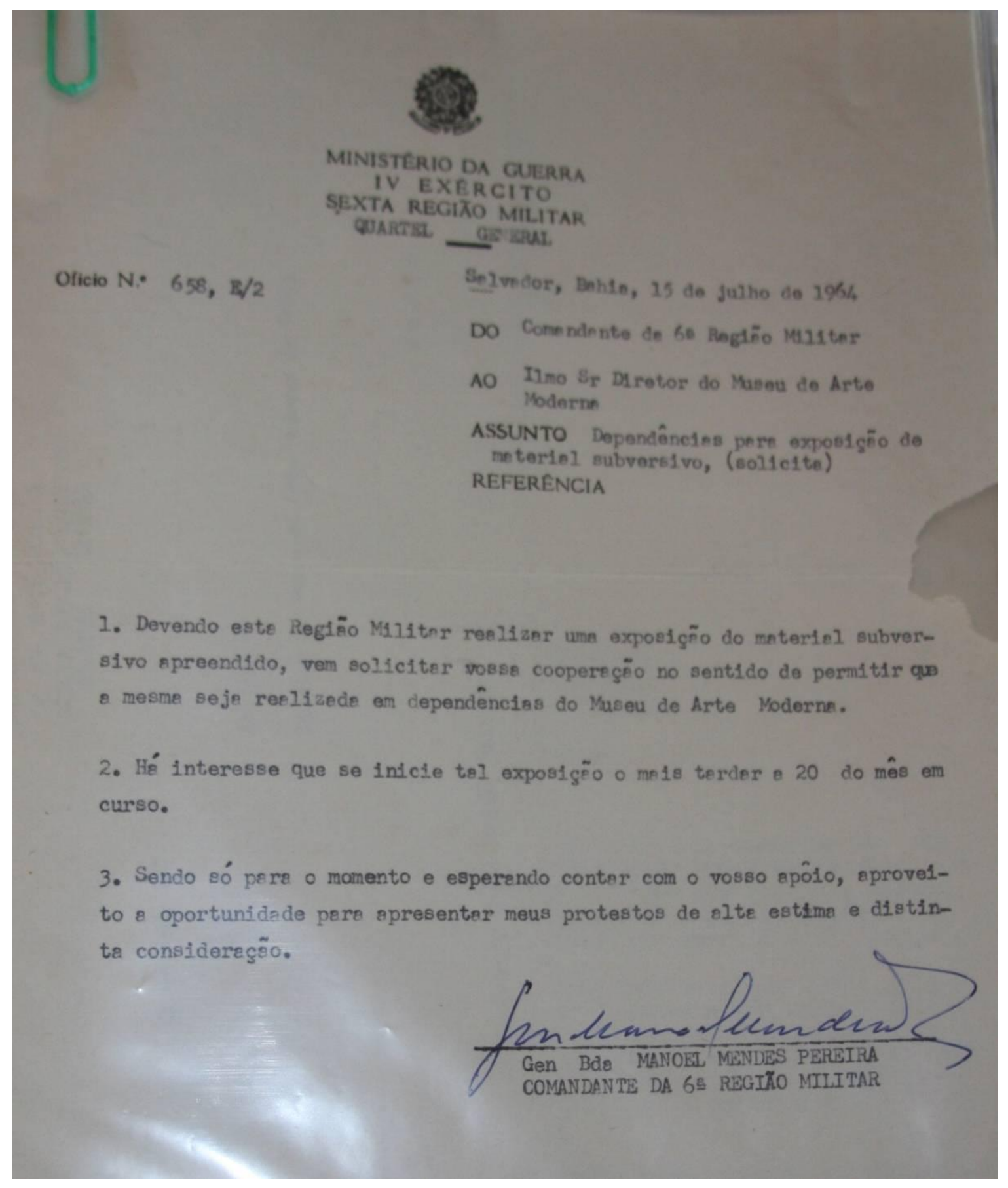




\section{GLOSSÁRIO}

- dos termos técnicos que não tiveram explicações ao longo do texto nos quais foram empregados.

Acropódio: - ou acrotério - terminação de uma prumada no coroamento do edifício em forma de base que serve para sustentação de um ornamento, no caso do acropódio, especificamente estátuas.

Alambor: Escarpa. Face inclinada dos muros de arrimo e de fortificações - Parede alamborada: parede inclinada para defesa dos fortes, a inclinação permite melhor vigilância para quem se encontra dentro da fortificação.

Anastilose: tentativa de reposição de peças originais em seus lugares originais, em restaurações. Seria assim o contrário de prótese, ou de obturação. Recurso utilizado de maneira heterodoxa no Museu das Missões; mesmo em outras situações, recurso que, em qualquer sentido, hoje em dia, refutado pelos especialistas, embora endossem besteiras muito piores, como reconstruções.

Ático: parte superior, que encima o edifício; quando nas fachadas, em edifícios antigos pode ser coroamento e, de uma maneira simplificada platibanda, esta última com o fim exclusivo de ocultar um telhado, enquanto as expressões anteriores são mais abrangentes.

Baldrame: Viga. Mais empregado para vigas, de qualquer material, sob o rés-do-chão.

Brises: corruptela do francês brise-soleil - literalmente quebra-sol. Como se popularizou a partir da evolução da arquitetura moderna no Brasil, passou a ser empregado coloquialmente, dessa forma resumida.

Cafua: antro, lugar sórdido. Depois empregado para porão ou para sótão, inicialmente pelo mesmo motivo: sujo ou quase inabitável.

Cerúleo: - ou cérulo - da "cor do céu". Diz-se, popularmente, que quem diz "cor do céu" está mentindo três vezes.

Combogó: - cobogó - superfície constituída por elementos vazados; na moderna arquitetura do Brasil, herdeira dos muxarabis e teve uso aproximado ao brise-soleil.

Comodulação: modulação composta, mais usual na arquitetura anterior à moderna, onde a modulação única, em virtude da necessidade da industrialização da construção civil, intentou-se a coordenação modular, a partir de medida única, com múltiplos e sub-múltiplos; Lucio: é o confronto harmônico das partes entre si e com relação ao todo. .

Coruchéu: ornamento sobre o acrotério, na Igreja de Nossa Senhora do Outeiro tem a forma de "peão" encima as linhas verticais marcadas nas edificações, mas sem a importância escultórica que encima um acropódio, normalmente uma peça estatuária.

Cunhal: canto, encunhado. Os cantos das edificações são mais rígidos do que as paredes retilíneas, inclusive, nas fortificações, quando em ângulo agudo, mais resistentes ainda. Acentuava-se os cunhais, destacando-os das superfícies, com pedras mais nobres, do que no restante da construção.

Empena: fechamento lateral, de uma maneira geral, cego - sem janelas. Grande plano a prumo.

Escuro: folha de janela sem nenhuma abertura - algumas continham pequenos furos -, feita de tabuado. A evolução da construção leva à sucessiva substituição pelas rótulas e depois por venezianas.

Esteio: suporte, portando confundido ora com viga ora com pilar; mais comumente o pilar do canto, teoricamente o pilar mais forte. Por ser a peça do beiral, às vezes pé-direito.

Estronca: peça sujeita a grande esforço de compressão, em geral a expressão e para o escoramento de valas, travando um lado no oposto, portanto travando-os mas ficando comprimida por eles. Pode ser usado em outras situações onde ocorre essa relação. 
Eurritmia: dir-se-ia ritmo correto; portanto, em arquitetura, comodulação correta de todas as partes componentes em relação a um todo, como na música.

Flambagem: infelizmente os arquitetos costumam empregar o termo para designar deformações que são provenientes de flexão - esforços do tipo alavanca. A flambagem é uma deformação proveniente dos esforços de compressão que uma determinada peça pode sofrer, às vezes em razão de seu próprio peso versus sua esbelteza.

Frechal: equivalente do baldrame, mas ao contrário deste, que está sob o chão, o frechal corre sobre as paredes, uniformizando e distribuindo cargas pontuais para a parede como um todo, de forma a transformála numa superfície portante contínua.

Fuste: tronco da coluna, trecho mais longo da coluna entre a base e o capitel;

Galga: de galgar, pular ou subir; popularizou-se nas obras de construção civil como sendo a medida vertical de qualquer peça.

Gelosia: folha da janela em treliça, ao contrário do escuro. Fica assim intermediária entre o advento da generalização do uso de vidros, em guilhotinas e o fim do muxarabi. Ver também rótula.

Impluvium: os as águas dos telhados são voltadas para dentro da edificação.

Lacunário: vazios criados para aliviar a carga nas coberturas, entre as peças portantes - o entre vigas; da antiguidade restou um exemplo integro no Panteão, em Roma. Um dos mais belos contemporâneos está na cobertura do edifício da FAU, de Vilanova Artigas.

Loggia: arcadas, a como se refere a Faculdade de Direito São Francisco, USP; espaço coberto, mas aberto em uma ou mais direção, mas marcado por um ritmo constante de pilares que sustentam as arcadas, formando uma galeria. Popularizou-se na Itália a partir do Século XVI. Talvez tenha partido do loggiato dos claustros dos conventos, uma varanda interna. Hoje já neologismo: Lógia.

Modenatura: proporções clássicas para todos os elementos componentes das fachadas, escalonados segundo sua ordem de importância, incluindo cheios e vazios, claros e escuros, dimensões dos diversos elementos, inclusive os ornamentais ou escultóricos, entre si. Corresponde à proporção, ou, mais ainda à harmonia musical. Lucio: é o modo peculiar como é tratada, plasticamente, cada uma dessas partes.

Muxarabi: - muxarabie $(\hat{e})$ - herança moura, vinda para o Brasil via colonização ibérica. É um fechamento treliçado - em geral de madeira - sobreposto e saliente ao plano da fachada, que filtram a visão fora-dentro, em substituição - pela falta de, e anteriores a - janela com vidros. Filtra a luz excessiva do exterior, tornando-a agradável na penumbra do interior, enquanto, por esse contraste, de dentro se vê claramente o que ocorre fora, e, de lá, ocorre o oposto.

Oblongo: ovalado, com forma de elipse ou oval.

Pé-direito: corruptela do português arcaico: em pé e direito, em pé correspondendo a a prumo e direito no sentido de certo, de linha reta, portanto a medida de uma vara ou vareta que a prumo toca, ao mesmo tempo, o solo e o sofito - o lado mais baixo - do teto; por extensão, os pilares mais baixos - no interior também chamados de esteios - de um telhado, na chegada do seu beiral.

Peristilo: colunas espaçadas em ritmo constante ao longo do perímetro da cobertura de um edifício; entre as colunas e o edifício propriamente dito ocorre um alpendre ou uma loggia.

Pilotis: do francês - pilar; a partir da evolução da arquitetura moderna no Brasil, passou a designar o pátio livre entre pilares de sustentação de andares superiores.

Pináculo: o ornamento que encima o ponto mais alto do edifício, em geral pontiagudo, sobre a torre mais alta - em igrejas, comumente uma cruz -.

Plinto: pedestal, base de uma estátua, também base de uma coluna;

Proporção: Lucio: é o equilíbrio ou a equivalência no dimensionamento das partes. 
Remanso: Diz-se, de rios com correnteza muito forte, os locais onde as águas se espraiam e se acalmam; lugar sossegado, tranqüilo.

Resplendor: no centro do retábulo, o ornamento principal, dourado ou espelhado.

Retábulo: Plano do fundo do altar ricamente ornamentado em talha ou pedra, com nichos para as imagens.

Rótula: - janela de - gelosia ou treliça, por seu movimento chamada assim, provavelmente a rótula, propriamente dita, era o conjunto de gonzos ou dobradiças.

Septo: elemento transversal a um oco ou vazio; no caso do MASP, travas de reforço do tubo oco das vigas, transversais à elas.

Sóculo: ou Soco: base saliente de uma coluna - como o plinto; base saliente das paredes - como os embasamentos; base saliente de uma bancada, como um ressalto.

Sofito: a face voltada para baixo de um forro, visto de baixo para cima, tal qual Michelangelo pintou o famoso teto da Capela Sistina. Por extensão, qualquer superfície voltada para baixo, como a palma da mão, por exemplo. Superfície emborcada, de ponta-cabeça.

Solar: moradia de uma família importante; talvez assim chamada por sua grandiosidade e um certo isolamento de outras construções.

Sopedâneo: o piso elevado em relação aos demais piso da igreja, onde fica o altar.

Tacaniça: num telhado de três águas, a água menor; num telhado de quatro águas - não sendo ele em pavilhão, que são com todas as quatro iguais -, as duas águas menores.

Taipa-de-mão - ou de sebe - também conhecida por pau-a-pique: sobre a superfície entramada de madeira e palha, preenche-se o vão com barro, a sopapos, daí o nome taipa de mão - ou de sopapo (feito a tapas).

Taipa de pilão: ao contrário da anterior, é feita com formas trepantes, e a cada camada, apiloada com uma mão-de-pilão, no barro entre formas. Como a anterior, e, curiosamente armada como o concreto armado, mas em madeiras e palhas, às vezes estrume, ao invés do aço, chamou a atenção de Lucio pela similaridade do raciocínio.

Talvegue: linha da maior declividade topográfica, que concentram as águas pluviais e de nascentes, como uma calha natural.

Taramela: mais popularmente tramela - borboleta, peça que gira em torno de um eixo, com dois lados proeminentes.

Tardoz: o verso não visível de um elemento da construção, em geral de acabamento rude, em relação à face oposta, a visível.

Tarugo: popularizou-se nas obras de construção civil como sendo um toco de madeira, com finalidades especificas ditas: entarugar ou entarugado - assim como se assentava batentes de portas ou assoalhos, para terem apoios efetivos. Às vezes: taco, mais raro cunha, se usados no sentido da fixação.

Transepto: nas igrejas de planta cruciforme a área correspondente ao cruzamento, onde em geral fica o altar, ligeiramente afastado em direção ao lado menor da perna maior da cruz.

Treliça: no texto não está empregado no sentido estrutural, como são as tesouras (SESC - Fábrica da Pompéia) e sim no sentido da superfície treliçada como as que ocorriam em nossa arquitetura colonial e adotada pela nossa arquitetura moderna: trama relativamente fechada, tradicionalmente $1 \times 1$ ou $2 \times 1$, na relação entre cheios e vazios, em geral feita de madeira; originalmente substituía o papel das persianas e venezianas, mais comuns hoje em dia. Ver: muxarabi e rótula.

Triclínio: como na sala de jantar da Roma Clássica, onde três divãs contituiam u "U", disposição de três partes em "U".

Vedação: fechamento, mas, em construção civil mais popularizado como paredes, em oposição às aberturas: portas e janelas. 
Vidros canelados: apresentam caneluras, em forma de rebaixos tronco-cilíndricos, também perdendo, de propósito, em transparência, por isso mesmo usado em banheiros e áreas de serviço, onde a transparência é indesejável.

Vidros jateados e/ou leitosos - perdem a transparência, mantém somente a translucidez - não chegam a ficar opacos -, o primeiro com superfície áspera por sofrer o jateamento, o segundo por ser esbranquiçado como leite, em sua própria massa.

Vidros lisos: sem texturas, se somados a transparentes, vidros lisos transparentes, são os mais usados e comuns para todos os fins.

Vidros martelados: têm essa aparência, como se tivessem sido marretadas aleatoriamente; perdem em transparência, exatamente por esse processo.

Vidros temperados: existem em todas as versões acima, só que por sofrerem re-têmpera à alta temperatura, são muito resistentes; podem ser coloridos na própria massa, como notou Lucio em relação ao Nova Cintra.

Voluta: ornamento de forma espiralada ou enrolada que quando simétricos tem a forma de pergaminho, quando não, é comum o enrolado ser reverso e de dimensões assimétricas. 


\section{ÍNDICE ICONOGRÁFICO}

\section{PARTE I - INTRODUÇÃO}

\section{Figura 1:}

VALTMAN, E. S. We welcome American affluence, but not influence!, Charge, The Hartford Times, 2 mar. 1969. Disponível em: <http://cdm.lib.usm.edu/cdm_usm/

item viewer.php?CISOROOT $=/$ cartoon\&CISOPTR $=351 \&$ CISOBOX=1\&REC=1>. Acessado em: 31 jul. 2009

Figura 2:

WEISZ, V. "... and here, Mr Dulles, is our little brochure on how to win friends and influence people...", Charge, Daily Mirror, 20 set. 1954. Disponível em: <http://opal.kent.ac.uk/cartoonxcgi/ccc.py?mode=summary\&search=VY0170>. Acessado em: 31 jul. 2009.

Figura 3:

AUTOR não identificado. Desenho representativo da cidade de Dubai. Disponível em: <http://www.paulo-coelho.net/blog/_archives/2007/1/18/2666590.html >. Acessado em: 3 ago. 2009.

\section{Figura 4:}

AUTOR não identificado. Propaganda de condomínio. Captada aleatoriamente na Internet, através de site de busca.

\section{Figura 5:}

SUZUKI, M. SESC Pompéia. Acervo pessoal, 2009.

\section{Figura 6:}

AUTOR não identificado. Entrada principal com logotipo original. In: BARDI, L. B. Lina Bo Bardi. (org. Marcelo Carvalho Ferraz). São Paulo: Instituto Lina Bo e P. M. Bardi, p. 112, figura 1, 1993.

\section{Figura 7:}

KON, N. Entrada principal. Rua Clélia. In: BARDI, L. B. Obra construída. 2G - Revista Internacional de Arquitetura, Barcelona: Gustavo Gili Editorial, n. 23 / 24, p. 115, 2003.

\section{Figura 8:}

AUTOR não identificado. Plataforma rodoviária. In: Revista Acrópole, Brasilia: M. Grunewald, vol 256/257, p. 90, figura 2, abr. 1960.

\section{Figura 9:}

AUTOR não identificado. Plataforma rodoviária. In: Revista Acrópole, Brasilia: M. Grunewald, vol 256/257, p. 90, figura 2, abr. 1960.

\section{Figura 10:}

AUTOR não identificado. Plataforma rodoviária. In: Revista Acrópole, Brasilia: M. Grunewald, vol 256/257, p. 92, figura 1, abr. 1960.

\section{Figura 11:}

AUTOR não identificado. Plataforma rodoviária. In: Revista Acrópole, Brasilia: M. Grunewald, vol 256/257, p. 92, figura 1, abr. 1960.

Figura 12:

SUZUKI, M. Plataforma rodoviária. Acervo pessoal, 2008.

\section{Figura 13:}

SUZUKI, M. Plataforma rodoviária. Acervo pessoal, 2008.

\section{Figura 14:}

SUZUKI, M. Plataforma rodoviária. Acervo pessoal, 2008.

\section{Figura 15:}

SUZUKI, M. Plataforma rodoviária. Acervo pessoal, 2008.

\section{Figura 16:}

AUTOR não identificado. Maquete para a Praça dos Três Poderes. In: COSTA, L. Registro de uma vivência. Maria Elisa Costa (org.). São Paulo: Empresa das Artes, p. 306, 1995. 
Figura 17:

AUTOR não identificado. Torre de TV. In: COSTA, L. Registro de uma vivência. Maria Elisa Costa (org.). São Paulo: Empresa das Artes, p. 307, 1995.

Figura 18:

AUTOR não identificado. Torres da Cidade Satélite, Cidade do México. AMBASZ, E. The architecture of Luis Barragan. New York: The Museum of Modern Art, p. 57, 1980.

Figura 19:

SUZUKI, M. SESC Pompéia. Acervo pessoal, 2009.

\section{PARTE I - ECLETISMO NECESSÁRIO}

Figura 1:

AUTOR não identificado. Bancos em Londres, Inglaterra. Captada aleatoriamente na Internet, através de site de busca. Disponível em: 〈http://www.tracymariesaunders.com/tube/station.php?station= bank $>$. Acessado em: 03 ago. 2009.

Figura 2:

ALBERT Speer, Zeppelinfeld, Nuremberg, 1936. In: CURTIS, W. J. R. Modern Architetcture: since 1900. New Jersey: Prentice Hall, p. 213, 1987.

Figura 3:

GERDY Troost, House of German Art, Prinzregentenstrasse, Munich, 1934-6. In: CURTIS, W. J. R.

Modern Architetcture: since 1900. New Jersey: Prentice Hall, p. 213, 1987.

Figura 4:

V. BALLIO-MORPUGO, clearance around the Mausoleum of Augustus, Rome, 1937. In: CURTIS, W. J.

R. Modern Architetcture: since 1900. New Jersey: Prentice Hall, p. 219, 1987.

Figura 5:

M. PIACENTINI and associates, University of Rome, Senate building, 1935. In: CURTIS, W. J. R.

Modern Architetcture: since 1900. New Jersey: Prentice Hall, p. 218, 1987.

Figura 6:

AUTOR não identificado. Bardi mostra a Mussolini a "Mesa dos Horrores”. In: TENTORI, F. P.M. Bardi: com as crônicas artísticas do "L 'Ambrosiano" 1930-1933. São Paulo: Instituto Lina Bo e P.M. Bardi / Imprensa Oficial do Estado, p. 52, 2000.

Figura 7:

AUTOR não identificado. "Mesa dos Horrores". In: TENTORI, F. P.M. Bardi: com as crônicas artísticas do "L 'Ambrosiano" 1930-1933. São Paulo: Instituto Lina Bo e P.M. Bardi / Imprensa Oficial do Estado, p. 52, 2000.

Figura 8:

FUNDAÇÃO Le Corbusier. Centrosoyus. In: COHEN, J. L. Le Corbusier Le Grand, the man with a Hundred Faces. London: Phaidon Editors, p. 243, figura 2, 2008.

Figura 9:

FUNDAÇÃO Le Corbusier. Fachada principal da Cité de Refuge. In: COHEN, J. L. Le Corbusier Le Grand, the man with a Hundred Faces. London: Phaidon Editors, p. 249, figura 3, 2008.

Figura 10:

FUNDAÇÃO Le Corbusier. Palácio dos Soviets. In: COHEN, J. L. Le Corbusier Le Grand, the man with a Hundred Faces. London: Phaidon Editors, p. 244, figura 4, 2008.

Figura 11:

FUNDAÇÃ̃ Le Corbusier. Palácio das Nações. In: COHEN, J. L. Le Corbusier Le Grand, the man with a Hundred Faces. London: Phaidon Editors, p. 224, figura 1, 2008.

Figura 12:

MEMÓRIA A., CUCHET, F. Pavilhão das Grandes Indústrias. In: BRUAND, Y. Arquitetura

Contemporânea no Brasil. São Paulo: Perspectiva, p. 56, figura 22, 1999. 


\section{Figura 13:}

CARIOCA, O. Projeto de Lucio Costa e Fernando Valentin para a casa de Raul Pedroza. Disponível em: <http://www. skyscrapercity.com/showthread.php?t=1035637〉. Acessado em: 08 jan. 2010.

\section{Figura 14:}

COSTA, L. Parque Guinle. In: COSTA, L. Registro de uma vivência. Maria Elisa Costa (org.). São Paulo: Empresa das Artes, p. 206-207, 1995.

\section{Figura 15:}

MORAES, N. In: PALMA. A. (coord.). Arquitetura do Brasil. São Paulo: Editora Abril, p.107, 1999.

\section{Figura 16:}

GAENSLY, G. Avenida Paulista. In: LIMA, B. de T. Álbum iconográfico da avenida Paulista. São Paulo: ExLibris, 1987.

\section{Figura 17:}

MAIA, P. Esquema Teórico para o Plano de Avenidas de São Paulo, de 1930. In: TOLEDO, B. L. Prestes Maia e as origens do Urbanismo Moderno em São Paulo. São Paulo: Empresa das Artes, figura 206, 1996.

\section{PARTE I - PAVILHÃO E PALÁCIO}

Figura 1:

AUTOR não identificado. Palácio Monroe. Disponível em:

<http://www.almacarioca.com.br/monroe.htm $>$. Acessado em: 15 dez. 2008.

\section{Figura 2:}

AUTOR não identificado. Palácio Monroe. Disponível em:

〈http://www.almacarioca.com.br/monroe.htm>. Acessado em: 15 dez. 2008.

Figura 3:

AUTOR não identificado. Palácio Monroe. Disponível em:

〈http://www.almacarioca.com.br/monroe.htm〉. Acessado em: 15 dez. 2008.

\section{Figura 4:}

AUTOR não identificado. Palácio Monroe. Disponível em:

<http://www.almacarioca.com.br/monroe.htm>. Acessado em: 15 dez. 2008.

\section{Figura 5:}

FERREZ, M. Palácio Monroe, Avenida Central. Rio de Janeiro, 1910. Disponível em: < http://acervos.ims.uol.com.br/cgi-bin/wxis.exe/iah/>. Acessado em: 05 ago. 2009.

Figura 6:

AUTOR não identificado. Os leões do Palácio Monroe. Disponível em:

〈http://www.almacarioca.com.br/monroe. htm〉. Acessado em: 15 dez. 2008.

\section{Figura 7:}

AUTOR não identificado. Os leões do Palácio Monroe. Disponível em:

<http://www.almacarioca.com.br/monroe. htm>. Acessado em: 15 dez. 2008.

Figura 8:

TEIXEIRA, B. L. Os leões do Palácio Monroe, em Uberaba/MG. Acervo pessoal, 2009.

Figura 9:

TEIXEIRA, B. L. Os leões do Palácio Monroe, em Uberaba/MG. Acervo pessoal, 2009.

\section{Figura 10:}

FERREZ, M. Pórtico da Academia Imperial de Belas artes, 1891. Disponível em: < http://pt.wikipedia.org/wiki/Academia_Imperial_de_Belas_Artes>. Acessado em: 04 ago. 2009.

\section{Figura 11:}

SOBRAL, J. Pórtico atualmente no Jardim Botânico do Rio de Janeiro. In: COSTA, L. Registro de uma vivência. Maria Elisa Costa (org.). São Paulo: Empresa das Artes, p. 157, 1995. 
Figura 12:

GRUPO escultórico Progresso, de Nicola Rollo. Foto do arquivo da família Rigoletto Mattei. In:

PALÁCIO das indústrias: memória e cidadania. O restauro para a nova prefeitura de São Paulo. São Paulo: Edição DPH/Método, p. 36, 1992.

\section{Figura 13:}

CADETES em forma, na solenidade de posse de Ruy de Mello Junqueira, eleito Presidente da Assembléia Legislativa, em 1959. Arquivo Agência Estado. In: PALÁCIO das indústrias: memória e cidadania. O restauro para a nova prefeitura de São Paulo. São Paulo: Edição DPH/Método, p. 40, 1992.

\section{Figura 14:}

BARDI, L. B. Estudo para iluminação externa do palácio das Indústrias. In: BARDI, L. B. Lina Bo Bardi. (org. Marcelo Carvalho Ferraz). São Paulo: Instituto Lina Bo e P. M. Bardi / Imprensa Oficial, p. 318, 2008.

Figura 15:

MASCARO, C. Fachada do Palácio das Indústrias. In: BARDI, L. B. Lina Bo Bardi. (org. Marcelo Carvalho Ferraz). São Paulo: Instituto Lina Bo e P. M. Bardi / Imprensa Oficial, p. 319, 2008.

Figura 16:

AUTOR não identificado. Maquete do Conjunto da Nova Prefeitura de São Paulo. In: BARDI, L. B. Lina Bo Bardi. (org. Marcelo Carvalho Ferraz). São Paulo: Instituto Lina Bo e P. M. Bardi / Imprensa Oficial, p. $325,2008$.

Figura 17:

AUTOR não identificado. Jardim Vertical e Maquete. BARDI, L. B. Obra construída. 2G - Revista Internacional de Arquitetura, Barcelona: Gustavo Gili Editorial, n. 23 / 24, p. 197, 2003.

Figura 18:

AUTOR não identificado. Ladeira da Misericórida. In: BARDI, L. B. Lina Bo Bardi. (org. Marcelo Carvalho Ferraz). São Paulo: Instituto Lina Bo e P. M. Bardi / Imprensa Oficial, p. 293, 2008.

Figura 19:

NEGRELOS, E. P. Grande Hotel de Ouro Preto. Arquivo pessoal, 2008.

Figura 20:

POLETO, S. As rampas do outeiro da Glória. Arquivo pessoal, 2006.

Figura 21:

AUTOR não identificado. Ruínas das Missões Jesuíticas. Disponível no Arquivo Noronha Santos. IPHAN.

\section{Figura 22:}

SOBRAL, J. Lucio em uma Superquadra. In: COSTA, L. Registro de uma vivência. Maria Elisa Costa (org.). São Paulo: Empresa das Artes, p. 330, 1995.

Figura 23:

FRIEDRICH, C. D. O peregrino sobre o mar de névoa, 1818. Disponível em: <http://pt. wikipedia.org/wiki/Ficheiro:Caspar_David_Friedrich_032.jpg>. Acessado em: 03 ago. 2009.

Figura 24:

GERICAULT, T. A balsa da Medusa, 1818-1819. Disponível em: <http://pt.wikipedia. org/wiki/Ficheiro:Jean_Louis_Th\%C3\%A9odore_G\%C3\%A9ricault_002.jpg>. Acessado em: 03 ago. 2009.

Figura 25:

AUTOR não identificado. Terraço Palácio Gustavo Capanema. Disponível em: <http://avidaelafora.com.br/ wp-content/uploads/2009/05/palacio-gustavo-capanema-burle-marx.jpg>. Acessado em: 04 ago. 2009.

Figura 26:

AUTOR não identificado. Jogos infantis. In: COSTA, L. Registro de uma vivência. Maria Elisa Costa (org.). São Paulo: Empresa das Artes, p. 128, 1995. 


\section{PARTE I - PAISAGEM CONSTRUÍDA}

Figura 1:

AUTOR não identificado. Vila de Santos. In: REIS, N. G. Imagens de Vilas e Cidades do Brasil

Colonial. São Paulo: Editora da Universidade de São Paulo: Imprensa Oficial do Estado, p. 197, 2001. (Uspiana-Brasil 500 Anos).

Figura 2:

AUTOR não identificado. Vila de Iguápe. In: REIS, N. G. Imagens de Vilas e Cidades do Brasil

Colonial. São Paulo: Editora da Universidade de São Paulo: Imprensa Oficial do Estado, p. 203, figura 2, 2001. - (Uspiana-Brasil 500 Anos).

Figura 3:

AUTOR não identificado. Vila de Cachoeira. In: REIS, N. G. Imagens de Vilas e Cidades do Brasil Colonial. São Paulo: Editora da Universidade de São Paulo: Imprensa Oficial do Estado, p. 55, 2001. (Uspiana-Brasil 500 Anos).

Figura 4:

LE CORBUSIER. Proposta de cidade. In: COHEN, J. L. Le Corbusier Le Grand, the man with a

Hundred Faces. London: Phaidon Editors, p. 357, figura 2, 2008.

Figura 5:

GARNIER, T. Setor de Hidroterapia e Entretenimento. In: GARNIER, T. L'oeuvre de Tony Garnier. Paris: Editions Albert Morancé, p. 14, S.D.

Figura 6:

COSTA, L. Perspectiva para o Projeto de Monlevade. In: COSTA, L. Registro de uma vivência. Maria Elisa Costa (org.). São Paulo: Empresa das Artes, p. 98, 1995.

Figura 7:

COSTA, L. Superquadra de Brasília. In: COSTA, L. Registro de uma vivência. Maria Elisa Costa (org.). São Paulo: Empresa das Artes, p. 309, figura 3, 1995.

Figura 8:

COSTA, L. Superquadra de Brasília. In: COSTA, L. Registro de uma vivência. Maria Elisa Costa (org.). São Paulo: Empresa das Artes, p. 309, figura 2, 1995.

Figura 9:

PARQUE Guinle. Foto retirada no Google Earth.

Figura 10:

COSTA, L. Superquadra de Brasília. In: COSTA, L. Registro de uma vivência. Maria Elisa Costa (org.). São Paulo: Empresa das Artes, p. 309, figura 2, 1995.

Figura 11:

PARQUE Guinle. Foto retirada no Google Earth.

Figura 12:

AUTOR não identificado. Planta $1^{\circ}$ pavimento do Palácio das Indústrias. In: BARDI, L. B. Lina Bo Bardi. (org. Marcelo Carvalho Ferraz). São Paulo: Instituto Lina Bo e P. M. Bardi / Imprensa Oficial, p. 322, figura 3, 2008.

\section{PARTE I - SABER. SABER-FAZER.}

Figura 1:

SMITH, G. E. K. Brises do Ministério da Educação. In: GOODWIN, P. L. Brazil Builds: Architecture new and old 1652-1942. New York: The Museum of Modern Art, p. 85, figura1, 1943.

Figura 2:

SMITH, G. E. K. Brises da Obra do Berço. In: GOODWIN, P. L. Brazil Builds: Architecture new and old 1652-1942. New York: The Museum of Modern Art, p. 86, figura 2, 1943.

Figura 3:

SUZUKI, M. Caixilho do Museu das Missões. Arquivo pessoal, 2005.

Figura 4:

SUZUKI, M. Caixilho da Casa de Vidro. Arquivo pessoal, 2005. 
Figura 5:

SUZUKI, M. Caixilho do Museu das Missões. Arquivo pessoal, 2005.

Figura 6:

SUZUKI, M. Caixilho da Casa de Vidro. Arquivo pessoal, 2005.

Figura 7:

SUZUKI, M. Corrediça do Museu das Missões. Arquivo pessoal, 2005.

Figura 8:

SUZUKI, M. Corrediça da Casa de Vidro. Arquivo pessoal, 2005.

Figura 9:

SUZUKI, M. Corrediça do Museu das Missões. Arquivo pessoal, 2005.

Figura 10:

SUZUKI, M. Corrediça da Casa de Vidro. Arquivo pessoal, 2005.

Figura 11:

AUTOR não identificado. Residência Mario bittencourt em São Paulo. Projeto de Vilanova Artigas. Móveis do estúdio Palma em compensado e material plástico branco, preto e amarelo-limão. In: BARDI, L. B. (org. Marcelo Carvalho Ferraz). Lina Bo Bardi. São Paulo: Instituto Lina Bo e P. M. Bardi / Imprensa Oficial, p. 60, 2008.

Figura 12:

AUTOR não identificado. Mobiliário de Lucio Costa para o Park Hotel. In: COSTA, L. Registro de uma vivência. Maria Elisa Costa (org.). São Paulo: Empresa das Artes, p. 217, 1995.

Figura 13:

ARQUIVO Charlotte Perriand - ADAGP 2008. Capa do livro de Charlotte Perriand. In: COSTA, L.

Registro de uma vivência. Maria Elisa Costa (org.). São Paulo: Empresa das Artes, p. 79, figura 1, 1995.

Figura 14:

ARQUIVO Charlotte Perriand - ADAGP 2008. Charlotte Perriand. Detalhe. In: COHEN, J. L. Le

Corbusier Le Grand, the man with a Hundred Faces. London: Phaidon Editors, p. 194, 2008.

Figura 15:

SHUSTER, J.; SIEGEL, J. Capa de uma revista em quadrinho do Superman. Imagem capturada na Internet.

Figura 16:

SUZUKI, M. João Hugo Machado. Foto tirada no Museu das Missões. Acervo IPHAN. Arquivo pessoal, 2005 .

Figura 17:

AUTOR não identificado. Missões. Disponível no Arquivo Noronha Santos. IPHAN.

Figura 18:

SMITH, G. E. K. Pavilhão do Brasil em Nova Iorque, 1939. In: GOODWIN, P. L.

Brazil Builds: Architecture new and old 1652-1942. New York: The Museum of Modern Art, p. 195, 1943.

Figura 19:

AUTOR não identificado. Igreja de Santa Luzia, antes da destruição do Morro do Castelo. Fonte não identificada.

Figura 20:

AUTOR não identificado. Ministério de Educação e Saúde Pública. In: MINDLIN, H. E. Brazilian Architecture. London: Royal Ocllege of art, p. IV, 1961.

Figura 21:

SMITH, G. E. K. Ministério de Educação e Saúde Pública. In: MINDLIN, H. E. Brazilian Architecture. London: Royal Ocllege of art, p. 106, figura 1, 1961.

Figura 22:

FUTAGAWA, Y. Villa Savoye. In: MEIER, R. Le Corbusier, Villa Savoye, Poissy, France, 1929-31. GA

Global Architecture, Tókio, p. 12-13, 1972. 


\section{PARTE I - TÉCNICAS TRADICIONAIS E MODERNAS}

Figura 1:

AUTOR não identificado. Lina Bo Bardi desenhando no Templo Enkaku (1.200 d.C.).

Kamakura, Japão, déc 70. In: BARDI, L. B. Lina por escrito. Textos escolhidos de Lina Bo Bardi. Silvana Rubino e Marina Grinover (org.). São Paulo: Cosac \& Naify, p. 202, 2009.

Figura 2:

FIALDINI, R. Cestos e instrumentos musicais indígenas. In: BARDI, L. B. Design no Brasil. História e realidade. Catálogo da Exposição inaugural do Centro de Lazer - SESC Fábrica Pompéia. São Paulo: Museu de Arte de São Paulo Assis Chateaubriand, p. 17, 1982.

Figura 3:

POLETO, S. Outeiro da Glória. Arquivo pessoal, 2006.

Figura 4:

DETALHES de final de corrimões e volutas. In: CAMPOFIORITO, I. 60 anos: A Revista. Revista do Patrimônio Histórico e Artístico Nacional, Rio de Janeiro, n. 26, p. 413, 1997.

Figura 5:

AUTOR não identificado. Fonte construída pelos índios. Sem data. Arquivo Noronha Santos.

Figura 6:

AUTOR não identificado. Fonte construída pelos índios. Sem data. Arquivo Noronha Santos.

Figura 7:

LE CORBUSIER. As linhas diretrizes da fachada da casa La roche / Jeanneret em Auteuil [paris]. In: BOESIGER, W. Le Corbusier. Barcelona: Editorial Gustavo Gili, p. 33, 1977.

Figura 8:

OLIVEIRA, D. Q. Ministério de Educação e Cultura. Arquivo pessoal, 2008.

Figura 9:

CASA de Vidro. Caixilho. In: BARDI, L. B. Lina Bo Bardi. (org. Marcelo Carvalho Ferraz). São Paulo: Instituto Lina Bo e P. M. Bardi / Imprensa Oficial, p. 81, figura 3, 2008.

Figura 10:

SUZUKI, M. Painel Athos Bulcão no Brasília Palace Hotel. Arquivo pessoal, 2008.

Figura 11:

SUZUKI, M. Painel de Paulo Werneck na Igreja de São Francisco de Assis. Arquivo pessoal, 2008.

Figura 12:

CARIOCA, O. Ministério de Educação e Cultura. Disponível em: <http://www. skyscrapercity.com/showthread.php?t=1035637>. Acessado em: 08 jan. 2010.

Figura 13:

SMITH, G. E. K. Fachada noroeste do Ministério da Educação. In: GOODWIN, P. L. Brazil Builds:

Architecture new and old 1652-1942. New York: The Museum of Modern Art, p. 84, 1943.

Figura 14:

ARATA, R. Cobogó Parque Guinle. Arquivo pessoal, 2006.

Figura 15:

AUTOR não identificado. Casa Valéria P. Cirell. 1958. In: BARDI, L. B. (org. Marcelo Carvalho Ferraz). Lina Bo Bardi. São Paulo: Instituto Lina Bo e P. M. Bardi / Imprensa Oficial, p. 117, 2008.

Figura 16:

SEGAWA, H. Casa do Chame-Chame. Acervo pessoal de Hugo Segawa. [S.D]

Figura 17:

SUZUKI, M. SESC Pompéia. Arquivo pessoal, 2009. 


\section{PARTE II - MISSÕES}

Figura 1:

AUTOR não identificado. Leleta, Lucio Costa e Augusto Meyer. 1937. Arquivo Noronha Santos.

Figura 2:

DEMERSAY. Gravura das ruínas de S. Miguel Arcanjo. 1846. Arquivo Noronha Santos.

Figura 3:

COSTA, L. Casa construída com material das ruínas. In: PESSOA, J. (org.). Lucio Costa: Documentos de trabalho. Rio de Janeiro: IPHAN, p. 33, 1999.

Figura 4:

COSTA, L. Casa construída com material das ruínas. In: PESSOA, J. (org.). Lucio Costa: Documentos de trabalho. Rio de Janeiro: IPHAN, p. 24, 1999.

Figura 5:

COSTA, L. Levantamento. In: PESSOA, J. (org.). Lucio Costa: Documentos de trabalho. Rio de Janeiro: IPHAN, p. 34, 1999.

Figura 6:

COSTA, L. Levantamento. In: PESSOA, J. (org.). Lucio Costa: Documentos de trabalho. Rio de Janeiro: IPHAN, p. 22, 1999.

Figura 7:

COSTA, L. Consolo. In: PESSOA, J. (org.). Lucio Costa: Documentos de trabalho. Rio de Janeiro: IPHAN, p. 31, 1999.

Figura 8:

COSTA, L. Levantamento. In: PESSOA, J. (org.). Lucio Costa: Documentos de trabalho. Rio de Janeiro: IPHAN, p. 32, 1999.

Figura 9:

SUZUKI, M. Ruínas de São Miguel das Missões. Arquivo pessoal, 2005.

Figura 10:

SUZUKI, M. Ruínas de São Miguel das Missões. Arquivo pessoal, 2005.

Figura 11:

AUTOR não identificado. Chiesa Del Gesú. Arquivo Noronha Santos.

Figura 12:

AUTOR não identificado. Igreja de São Miguel. Arquivo Noronha Santos.

Figura 13:

AUTOR não identificado. Igreja em São José de Chiquitos. Arquivo Noronha Santos.

Figura 14:

CENÁRIO. In: A MISSÃO. Direção: Roland Joffé. Intérpretes: Robert de Niro, Jeremy Irons, Lean

Neeson. Inglaterra: Flashstar. 1986. (121 mim.).

Figura 15:

CENA do filme. In: A MISSÃO. Direção: Roland Joffé. Intérpretes: Robert de Niro, Jeremy Irons, Lean Neeson. Inglaterra: Flashstar. 1986. (121 mim.).

Figura 16:

SUZUKI, M. Ruínas de São Miguel das Missões. Arquivo pessoal, 2005.

Figura 17:

AUTOR não identificado. Porticado. Sem data. Arquivo Noronha Santos.

Figura 18:

CENA do filme. In: A MISSÃO. Direção: Roland Joffé. Intérpretes: Robert de Niro, Jeremy Irons, Lean Neeson. Inglaterra: Flashstar. 1986. (121 mim.).

Figura 19:

CABRER. Desenho da Igreja de São Miguel Arcanjo. 1784. Arquivo Noronha Santos.

Figura 20: 
AUTOR não identificado. Ruínas de São Miguel das Missões. Sem data. Arquivo Noronha Santos.

Figura 21:

AUTOR não identificado. Ruínas de São Miguel das Missões. Sem data. Arquivo Noronha Santos.

Figura 22:

AUTOR não identificado. Ruínas de São Miguel das Missões. Sem data. Arquivo Noronha Santos.

Figura 23:

AUTOR não identificado. Ruínas de São Miguel das Missões. Sem data. Arquivo Noronha Santos.

Figura 24:

MAYERHOFER, L. MAPA de localização das pedras. In: MAYERHOFER, L. Reconstituição do povo de São Miguel das Missões. Tese de Concurso para a Universidade Federal do Rio de Janeiro. Rio de Janeiro, página não identificada, 1947.

Figura 25:

MAYERHOFER, L. MAPA de localização das pedras. In: MAYERHOFER, L. Reconstituição do povo de São Miguel das Missões. Tese de Concurso para a Universidade Federal do Rio de Janeiro. Rio de Janeiro, página não identificada, 1947.

Figura 26:

SIMOM, M. Ruínas. Sem data. Arquivo Noronha Santos.

Figura 27:

SUZUKI, M. São Miguel das Missões. Arquivo pessoal, 2005.

Figura 28:

MAYERHOFER, L. Perspectiva. In: MAYERHOFER, L. Reconstituição do povo de São Miguel das Missões. Tese de Concurso para a Universidade Federal do Rio de Janeiro. Rio de Janeiro, página não identificada, 1947.

Figura 29:

AUTOR não identificado. São Miguel Arcanjo. 1756. Arquivo Noronha Santos.

Figura 30:

AUTOR não identificado. Uso festivo da praça. In: CUSTÓDIO, L. A. B. A Redução de São Miguel Arcanjo. Porto Alegre: Faculdade de Arquitetura da Universidade Federal do Rio Grande do Sul, Dissertação de Mestrado, 2002.

Figura 31:

COSTA, L. As ruínas das Missões. In: COSTA, L.. Registro de uma vivência. Maria Elisa Costa (org.). São Paulo: Empresa das Artes, p. 497, 1995.

Figura 32:

AUTOR desconhecido. Proposta para a casa do zelador. Escritório Técnico de São Miguel das Missões.

Figura 33:

AUTOR desconhecido. $2^{\text {a }}$ Proposta para as ruínas. Escritório Técnico de São Miguel das Missões.

Figura 34:

AUTOR desconhecido. $2^{\text {a }}$ Proposta para as ruínas. Escritório Técnico de São Miguel das Missões.

Figura 35:

AUTOR desconhecido. Proposta para a casa do zelador. Escritório Técnico de São Miguel das Missões.

Figura 36:

AUTOR desconhecido. Proposta para a casa do zelador. Escritório Técnico de São Miguel das Missões.

Figura 37:

COSTA, L. Casa do zelador. In: PESSOA, J. (org.). Lucio Costa: Documentos de trabalho. Rio de Janeiro: IPHAN, p. 42 e 41, 1999.

Figura 38:

SUZUKI, M. São Miguel das Missões. Arquivo pessoal, 2005.

Figura 39:

SUZUKI, M. São Miguel das Missões. Arquivo pessoal, 2005. 
Figura 40:

SUZUKI, M. São Miguel das Missões. Arquivo pessoal, 2005.

Figura 41:

SUZUKI, M. São Miguel das Missões. Arquivo pessoal, 2005.

Figura 42:

RHOE, M. V. der. Pavilhão Barcelona. Foto retirada aleatoriamente da Internet através de site de busca.

Figura 43:

SUZUKI, M. São Miguel das Missões. Arquivo pessoal, 2005.

Figura 44:

SUZUKI, M. São Miguel das Missões. Arquivo pessoal, 2005.

Figura 45:

SUZUKI, M. São Miguel das Missões. Arquivo pessoal, 2005.

Figura 46:

SUZUKI, M. São Miguel das Missões. Arquivo pessoal, 2005.

Figura 47:

MAYERHOFER, L. Reconstituição do povo de São Miguel das Missões. Tese de Concurso para a

Universidade Federal do Rio de Janeiro. Rio de Janeiro, 1947.

Figura 48:

AUTOR desconhecido. São Miguel das Missões. Sem data. Arquivo Noronha Santos.

Figura 49:

AUTOR desconhecido. Museu em obras. Sem data. Arquivo Noronha Santos.

Figura 50:

AUTOR desconhecido. Museu em obras. Sem data. Arquivo Noronha Santos.

Figura 51:

AUTOR desconhecido. Museu em obras. Sem data. Arquivo Noronha Santos.

Figura 52:

AUTOR desconhecido. Museu em obras. Sem data. Arquivo Noronha Santos.

Figura 53:

AUTOR desconhecido. Museu em obras. Sem data. Arquivo Noronha Santos.

Figura 54:

AUTOR desconhecido. Museu em obras. Sem data. Arquivo Noronha Santos.

Figura 55:

AUTOR desconhecido. Museu em obras. Sem data. Arquivo Noronha Santos.

Figura 56:

SUZUKI, M. São Miguel das Missões. Arquivo pessoal, 2005.

Figura 57:

SUZUKI, M. São Miguel das Missões. Arquivo pessoal, 2005.

Figura 58:

SUZUKI, M. São Miguel das Missões. Arquivo pessoal, 2005.

Figura 59:

SUZUKI, M. São Miguel das Missões. Arquivo pessoal, 2005.

Figura 60:

AUTOR desconhecido. São Miguel das Missões. Sem data. Arquivo Noronha Santos.

Figura 61:

AUTOR desconhecido. São Miguel das Missões. Sem data. Arquivo Noronha Santos.

Figura 62:

AUTOR desconhecido. São Miguel das Missões. Sem data. Arquivo Noronha Santos. 


\section{PARTE II - PARQUE GUINLE}

Figura 1:

SUZUKI, M. Inscrição da placa de informações turísticas da Prefeitura do Rio de Janeiro. Arquivo pessoal, 2009.

Figura 2:

SUZUKI, M. Portão de entrada da chácara. Arquivo pessoal, 2009.

Figura 3:

CARIOCA, O. Brasão do portão de entrada do Parque Guinle. Disponível em: < http:// www.skyscrapercity.com/showthread.php?t=1034271 >. Acessado em: 05 jan. 2010.

Figura 4:

AUTOR não identificado. Palácio Forrobo, conhecido como Palácio das Laranjeiras, em Portugal. Disponível em: <http://pessoalissimo.blogspot.com/2007/09/teatro-tlia-no-palcio-farrobo.html>. Acessado em: 12 jan. 2010.

Figura 5:

CARIOCA, O. Torre do Palácio das Laranjeiras. Disponível em: http://www. skyscrapercity.com/showthread.php?t=1034271>. Acessado em: 05 jan. 2010.

Figura 6:

AUTOR não identificado. Cassino Monte Carlo. Disponível em: <http://www.europabrasil.com.br/Monaco/turismo/191-Cassino_Monte_Carlo.html>. Acessado em: 04 jan. 2010 .

Figura 7:

AUTOR não identificado. Palácio das Laranjeiras. Disponível em: < http://www.vivercidades.org.br/publique_222/web/cgi/cgilua.exe/sys/start.htm?infoid=1111\&sid=21>. Acessado em: 04 jan. 2010.

Figura 8:

CHRIS. Museu do Ipiranga. Disponível em: < http://www.arrakeen.ch/brasil6/055\%20

\%20Museu\%20do\%20Ipiranga.JPG>. Acessado em: 12 jan. 2010.

Figura 9:

SUZUKI, M. Flamboyants do Parque Guinle. Acervo pessoal, 2009.

Figura 10:

SUZUKI, M. Portão de entrada do Parque Guinle. Acervo pessoal, 2009.

Figura 11:

CARIOCA, O. O Leão alado. Disponível em: http://www.skyscrapercity.com/

showthread.php?t=1034271>. Acessado em: 05 jan. 2010.

Figura 12:

SUZUKI, M. Cássias no Parque Guinle. Arquivo pessoal, 2009.

Figura 13:

AUTOR não identificado. Park Hotel. In: MINDLIN, H. E. Modern Architecture in Brazil. New York: Reinhold Publishing Corporatino, p. 107, 1956.

Figura 14:

MAPA de localização dos Túneis Velho, Novo e do Pasmado. Rio de Janeiro. Foto retirada no Google Earth.

\section{Figura 15:}

MALTA. Túnel Velho ou Túnel Prefeito Alaor Prata. 1927. Disponível em:

<http://www.rioquepassou.com.br/2008/09/04/tunel-velho-boca-de-botafogo-1927/>. Acessado em: 04 jan. 2010 .

\section{Figura 16:}

AUTOR não identificado. Túnel Novo ou Túnel Engo Marques Porto e Túnel Engo Coelho Cintra. Sem data. Disponível em: <http://www.skyscrapercity.com/showthread. php?t=549178>. Acessado em: 04 jan. 2010. 
Figura 17:

LUIZ, S. Túnel do Pasmado. 2009. Disponível em: <http://www.flickr.com/photos/

35699605@N00/3200065127>. Acessado em: 04 jan. 2010.

Figura 18:

AUTOR não identificado. Praça do Lido. Disponível em: 〈http://www.almacarioca.com.

br/imagem/fotos/rioantigo2/copa.htm>. Acessado em: 26 out. 2009.

Figura 19:

AUTOR não identificado. Avenida Atlântica e Copacabana Palace. Disponível em:

<http://www.almacarioca. com.br/imagem/fotos/rioantigo2/copa.htm>. Acessado em: 26 out. 2009.

Figura 20:

AUTOR não identificado. Copacabana Palace. Disponível em: <http://www.

almacarioca.com.br/imagem/fotos/rioantigo2/copa.htm>. Acessado em: 26 out. 2009.

\section{Figura 21:}

COSTA, L. Plantas Edifício Nova Cintra. In: MINDLIN, H. E. Modern Architecture in Brazil. New

York: Reinhold Publishing Corporatino, p. 92, 1956.

Figura 22:

COSTA, L. Plantas Edifício Nova Cintra. In: MINDLIN, H. E. Modern Architecture in Brazil. New York: Reinhold Publishing Corporatino, p. 92, 1956.

Figura 23:

AUTOR não identificado. Marquise Edifício Nova Cintra. In: MINDLIN, H. E. Modern Architecture in Brazil. New York: Reinhold Publishing Corporatino, p. 93, 1956.

Figura 24:

CARIOCA, O. Fachada do Edifício Nova Cintra. http://www.skyscrapercity.com/

showthread.php?t=1034271>. Acessado em: 05 jan. 2010.

Figura 25:

SUZUKI, M. Pilotis Edifício Nova Cintra. Acervo pessoal, 2009.

Figura 26:

COSTA, L. Perspectiva. In: COSTA, L. Registro de uma vivência. Maria Elisa Costa (org.). São Paulo: Empresa das Artes, p. 213, 1995.

Figura 27:

COSTA, L. Detalhe da Planta do Nova Cintra. In: COSTA, L. Registro de uma vivência. Maria Elisa Costa (org.). São Paulo: Empresa das Artes, p. 213, 1995.

Figura 28:

AUTOR não identificado. Unité d' Habitation, de Le Corbusier. In: Programa de Doctorado "La Forma Moderna". Curso 2003-2004, Curso 2004-2005. Barcelona: Escuela Técnica Superior de Arquitectura de Barcelona / Universidad Politécnica de Cataluña, p. 18, 2005.

Figura 29:

AUTOR não identificado. Sítio do Padre Inácio. In: SAIA, L. Morada paulista. São Paulo: Perspectiva, p. 116, 1972.

Figura 30:

SUZUKI, M. Interior de um dos apartamentos. Acervo pessoal, 2009.

Figura 31:

SUZUKI, M. Interior de um dos apartamentos. Acervo pessoal, 2009.

Figura 32:

SUZUKI, M. Interior de um dos apartamentos. Acervo pessoal, 2009.

Figura 33:

ALBUQUERQUE, F. Rampa do Edifício Louveira. In: MINDLIN, H. E. Modern Architecture in Brazil. New York: Reinhold Publishing Corporatino, p. 95, 1956.

Figura 34:

KON, N. Edifício Louveira. In: KAMITA, J. M. Vilanova Artigas. São Paulo: Cosac \& Naify, p.53, 2000 
Figura 35:

KON, N. Edifício Louveira. In: KAMITA, J. M. Vilanova Artigas. São Paulo: Cosac \& Naify, p.56, 2000

Figura 36:

SUZUKI, M. Mezanino do Edifício Bristol. Acervo pessoal, 2009.

Figura 37:

CASA Lucio Costa. Salão de exposições. In: WISNIK, G. Lucio Costa. Coleção Espaços da Arte

Brasileira. São Paulo: Cosac \& Naify, p. 66, 2001.

Figura 38:

SUZUKI, M. Mezanino do Edifício Bristol. Acervo pessoal, 2009.

Figura 39:

SUZUKI, M. Mezanino e ponte sobre a garagem. Acervo pessoal, 2009.

Figura 40:

SUZUKI, M. Mezanino e ponte sobre a garagem. Acervo pessoal, 2009.

Figura 41:

SUZUKI, M. Ante-sala da sala de estar. Acervo pessoal, 2009.

Figura 42:

SUZUKI, M. Térreo-mezanino vedado com azulejos. Acervo pessoal, 2009.

Figura 43:

SUZUKI, M. Térreo-mezanino vedado com azulejos. Acervo pessoal, 2009.

Figura 44:

SUZUKI, M. Detalhe dos azulejos. Acervo pessoal, 2009.

Figura 45:

AUTOR não identificado. Casas Domino. In: BOESIGER, W. Le Corbusier. Barcelona: Editorial Gustavo Gili, p. 12, 1977.

Figura 46:

SUZUKI, M. Escada em leque. Acervo pessoal, 2009.

Figura 47:

SUZUKI, M. Entrada do estacionamento. Acervo pessoal, 2009.

Figura 48:

SUZUKI, M. Encontro do prédio com a rua. Acervo pessoal, 2009.

Figura 49:

SUZUKI, M. Edifício dos Irmãos Roberto. Acervo pessoal, 2009.

Figura 50:

COSTA, L. Cobertura dos edifícios. In: COSTA, L. Registro de uma vivência. Maria Elisa Costa (org.). São Paulo: Empresa das Artes, p. 213, 1995.

Figura 51:

COSTA, M. E. Diário de Maria Elisa Costa. Arquivo pessoal da arquiteta.

Figura 52:

SUZUKI, M. Cobertura dos edifícios. Acervo pessoal, 2009.

Figura 53:

McKENNA, R. Fachada de um dos edifícios Parque Guinle. In: MINDLIN, H. E. Modern Architecture in Brazil. New York: Reinhold Publishing Corporatino, p. 93, 1956.

Figura 54:

KON, N. Fachada sul do Edifício Nova Cintra. In: WISNIK, G. Lucio Costa. Coleção Espaços da Arte Brasileira. São Paulo: Cosac \& Naify, p. 92, 2001.

Figura 55:

SUZUKI, M. Volumes azul e rosa. Acervo pessoal, 2009.

Figura 56: 
SUZUKI, M. Escadas do Edifício Nova Cintra. Acervo pessoal, 2009.

Figura 57:

KON, N. In: WISNIK, G. Lucio Costa. Coleção Espaços da Arte Brasileira. São Paulo: Cosac \& Naify, p. $88,2001$.

\section{Figura 58:}

SMITH, G. E. K. Castelo d'água. In: GOODWIN, P. L. Brazil Builds: Architecture new and old 16521942. New York: The Museum of Modern Art, p. 158, 1943.

Figura 59:

KON, N. Edifício Jaraguá In: ARTIGAS,R (org). Paulo Mendes da Rocha. São Paulo: Cosac \& Naify, p. 153, 2a . Edição, 2002.

Figura 60:

SUZUKI, M. Marcação dos eixos dos pilares estruturais e dos requadros dos combogós. Acervo pessoal, 2009.

Figura 61:

SUZUKI, M. Detalhe da Fachada que mostra os pilares desalinhados. Acervo pessoal, 2009.

Figura 62:

SUZUKI, M. Requadro da janela. Acervo pessoal, 2009.

Figura 63:

KON, N. Sedes Sapientiae. In: ANELLI, R.; GUERRA, A.; KON, N. Rino Levi arquitetura e cidade. São Paulo: Romano Guerra Editora, p. 81, 2001.

Figura 64:

KON, N. Edifício Pavinil-Elclor. In: EDIFÍCIO Plavinil-Elclor. ANELLI, R.; GUERRA, A.; KON, N.

Rino Levi arquitetura e cidade. São Paulo: Romano Guerra Editora, p. 243, 2001.

Figura 65:

ARQUIVO Carmem Portinho. Conjunto Pedregulho. In: BONDUKI, N. (org.). Affonso Eduardo Reidy.

São Paulo: Instituto Lina Bo e P. M. Bardi; Lisboa: Editorial Blau, p. 93, 1999.

Figura 66:

AUTOR não identificado. Residência Maceió. In: MINDLIN, H. E. Modern Architecture in Brazil. New York: Reinhold Publishing Corporatino, p. 63, 1956.

Figura 67:

PRATGINESTÓS, J; FALCÃO, F. Edifício Residencial. In: BRAGA, A. C.; FALCÃO, F. A. R. Guia de Urbanismo, Arquitetura e Arte de Brasília. Brasília: Fund. Athos Bulcão, p. 48, 1997.

\section{PARTE II - SESC FÁBRICA DA POMPÉIA}

Figura 1:

STAS, R. Mativa Footbridge. Liège. 2007. Disponível em: <http://en.structurae.de/ photos/index.cfm?JS=92492>. Acesso em: 28 jul. 2009.

Figura 2:

MOSSOT, J. Pont Camille de Hogues, Châtellerault. [S.D]. Disponível em:

http://en.structurae.de/photos/index.cfm?JS=4045 > . Acesso em: 28 jul. 2009.

Figura 3:

JANBERG, N. Ponte Del Risurgimiento, Rome. 2003. Disponível em:

<http://en.structurae.de/photos/index.cfm?JS=10310>. Acesso em: 29 jul. 2009.

Figura 4:

CHÂTEAU d'eau de Newton. Illustration extraite de D. Bellet ET W. Darville, Les Plus Grandes

Entreprises du monde, Paris, Flammarion, s.d, p. 18. Photo CCI. In: DESWARTE, S.; LEMOINE, B.

L'architecture ET lês ingénieurs, deux siècles de construction. Paris: Groupe Moniteur, p. 223, 1997.

Figura 5:

ESQUEMA de uma estrutura proposta por Hennebique. In: DESWARTE, S.; LEMOINE, B.

L'architecture ET lês ingénieurs, deux siècles de construction. Paris: Groupe Moniteur, p. 14, 1997.

Figura 6: 
SUZUKI, M. Estrutura da Área de Convivência SESC Pompéia. Arquivo pessoal. 2009.

Figura 7:

SUZUKI, M. Centro de Lazer SESC Pompéia. Arquivo pessoal. 2009.

Figura 8:

FLIEG, H. G. Estrutura hennebiqueana na antiga fábrica de tambores. In: BARDI, L. B. (org. Marcelo Carvalho Ferraz). Lina Bo Bardi. São Paulo: Instituto Lina Bo e P. M. Bardi / Imprensa Oficial, p. 224, 2008.

Figura 9:

BARDI, L. B. Croqui para o Foyer do Teatro. Concepção da Galeria e dos Camarins. Arquivo: Instituto Lina Bo e P.M. Bardi.

Figura 10:

SUZUKI, M. Foyer do Teatro SESC Pompéia. Arquivo pessoal. 2009.

Figura 11:

SUZUKI, M. Acesso às galerias do Teatro SESC Pompéia. Arquivo pessoal. 2009.

Figura 12:

SUZUKI, M. Galeria e Camarins do Teatro SESC Pompéia. Arquivo pessoal. 2009.

Figura 13:

AUTOR não identificado. Teatro SESC Pompéia. In: BARDI, L. B. (org. Marcelo Carvalho Ferraz). Lina Bo Bardi. São Paulo: Instituto Lina Bo e P. M. Bardi / Imprensa Oficial, p. 227, 2008.

Figura 14:

BARDI, L. B. Croqui para o Teatro. Concepção da Galeria. Arquivo: Instituto Lina Bo e P.M. Bardi.

Figura 15:

BARDI, L. B. Croqui para o Teatro. Desenho da estrutura original. Arquivo: Instituto Lina Bo e P.M. Bardi.

Figura 16:

ÁREA de Convivência. In: BARDI, L. B. (org. Marcelo Carvalho Ferraz). Lina Bo Bardi. São Paulo: Instituto Lina Bo e P. M. Bardi / Imprensa Oficial, p. 225, 2008.

Figura 17:

SUZUKI, M. Tesoura com reforço do Teatro SESC Pompéia. Arquivo pessoal. 2009.

Figura 18:

SUZUKI, M. Tesoura com reforço do Teatro SESC Pompéia. Arquivo pessoal. 2009.

Figura 19:

SUZUKI, M. Centro de Lazer SESC Pompéia. Arquivo pessoal. 2009.

Figura 20:

Exposição Design no Brasil: História e Realidade. In: FERRAZ, M. C.; VAINER, A.

Cidadela da Liberdade: Exposição realizada no SESC Pompéia - 19 de novembro a 30

de dezembro de 1999, São Paulo, SESC / INSTITUTO LINA BO E P. M. BARDI, p. 237, 1999.

Figura 21:

AUTOR não identificado. Vista do Conjunto na década de 40. In: BARDI, L. B. (org. Marcelo Carvalho Ferraz). Lina Bo Bardi. São Paulo: Instituto Lina Bo e P. M. Bardi / Imprensa Oficial, p. 220, 2008.

Figura 22:

SUZUKI, M. Vista dos sheds e do lanternim dos Galpões SESC Pompéia. Arquivo pessoal. 2009.

Figura 23:

BARDI, L. B. Estudo para o restaurante. Arquivo: Instituto Lina Bo e P.M. Bardi.

Figura 24:

BARDI, L. B. Croqui de Implantação do SESC Pompéia. In: OLIVEIRA, O.F. Lina Bo Bardi: Sutis Substâncias da Arquitetura. São Paulo: RG / GG, p. 220, figura 1, 2006.

Figura 25: 
BARDI, L. B. Croqui das quadras. In: BARDI, L. B. (org. Marcelo Carvalho Ferraz). Lina Bo Bardi. São Paulo: Instituto Lina Bo e P. M. Bardi / Imprensa Oficial, p. 232, figura 1, 2008.

Figura 26:

BARDI, L. B. Croqui de estudo para a piscina. Arquivo: Instituto Lina Bo e P.M. Bardi.

Figura 27:

BARDI, L. B. Estudo para o desenho do fundo da piscina. Arquivo: Instituto Lina Bo e P.M. Bardi.

Figura 28:

AUTOR não identificado. Vista da piscina. In: BARDI, L. B. (org. Marcelo Carvalho Ferraz). Lina Bo

Bardi. São Paulo: Instituto Lina Bo e P. M. Bardi / Imprensa Oficial, p. 232, 2008.

Figura 29:

AUTOR não identificado. Vista da piscina. In: BARDI, L. B. (org. Marcelo Carvalho Ferraz). Lina Bo

Bardi. São Paulo: Instituto Lina Bo e P. M. Bardi / Imprensa Oficial, p. 232, 2008.

Figura 30:

SUZUKI, M. Ressalto da Torre das Quadras. Arquivo pessoal. 2009.

Figura 31:

BARDI, L. B. Estudo para a Torre das Quadras. Arquivo: Instituto Lina Bo e P.M. Bardi.

Figura 32:

BARDI, L. B. Aquarela da Rua Central do SESC Pompéia. In: BARDI, L. B. (org. Marcelo Carvalho

Ferraz). Lina Bo Bardi. São Paulo: Instituto Lina Bo e P. M. Bardi, p. 221, figura 1, 1993.

Figura 33:

SUZUKI, M. Rua Central SESC Pompéia. Arquivo pessoal. 2009.

Figura 34:

SUZUKI, M. Rua Central SESC Pompéia. Arquivo pessoal. 2009.

Figura 35:

SUZUKI, M. Rua Central SESC Pompéia. Arquivo pessoal. 2009.

Figura 36:

LE CORBUSIER. Desenho à mão. In: COHEN, J. L. Le Corbusier Le Grand, the man with a Hundred Faces. London: Phaidon Editors, p. 346, figura 1, 2008.

Figura 37:

SUZUKI, M. Canaletas de água pluvial SESC Pompéia. Arquivo pessoal. 2009.

Figura 38:

BARDI, L. B. Croqui da canaleta de água pluvial SESC Pompéia. Arquivo: Instituto Lina Bo e P.M.

Bardi.

Figura 39:

BARDI, L. B. Estudo para o Galpão das Oficinas. In: OLIVEIRA, O.F. Lina Bo Bardi: Sutis Substâncias da Arquitetura. São Paulo: RG / GG, p. 220, figura 5, 2006.

Figura 40:

SUZUKI, M. Galpão das Oficinas. Arquivo pessoal, 2009.

Figura 41

SUZUKI, M. Pilar do mezanino. Arquivo pessoal, 2010.

Figura 42:

SUZUKI, M. Pilar do mezanino. Arquivo pessoal, 2010.

Figura 43:

TOTEM de sinalização do MASP. In: BARDI, L. B. (org. Marcelo Carvalho Ferraz). Lina Bo Bardi. São Paulo: Instituto Lina Bo e P. M. Bardi, p. 112, figura 1, 1993.

Figura 44:

SUZUKI, M. Totem de sinalização do SESC Pompéia. Arquivo pessoal. 2009.

Figura 45: 
AUTOR não identificado. Bardi junto à estátua de Chateaubriand. In: TENTORI, F. P.M. Bardi: com as crônicas artísticas do "L 'Ambrosiano" 1930-1933. São Paulo: Instituto Lina Bo e P.M. Bardi / Imprensa Oficial do Estado, p. 199, 2000.

Figura 46:

SUZUKI, M. Buraco. Peitoril. Arquivo pessoal. 2009.

Figura 47:

SUZUKI, M. Buraco. Arquivo pessoal. 2009.

Figura 48:

KON, N. Buraco e muxarabi. In: BARDI, L. B. Obra construída. 2G - Revista Internacional de Arquitetura, Barcelona: Gustavo Gili Editorial, n. 23 / 24, p. 127, 2003.

Figura 49:

SUZUKI, M. Buracos. Arquivo pessoal. 2009.

Figura 50:

AUTOR não identificado. Concretagem da laje das quadras. In: FERRAZ, M. C.; VAINER, A. Cidadela da Liberdade: Exposição realizada no SESC Pompéia - 19 de novembro a 30 de dezembro de 1999. São Paulo: SESC / INSTITUTO LINA BO E P. M. BARDI, p. 64, figura 2, 1999.

Figura 51:

SUZUKI, M. Bloco Esportivo. Arquivo pessoal. 2009.

Figura 52:

SUZUKI, M. Bloco Esportivo. Detalhe. Arquivo pessoal. 2009.

Figura 53:

SUZUKI, M. Detalhe do desvão da passarela do Bloco Esportivo. Arquivo pessoal. 2009.

Figura 54:

SUZUKI, M. Peitoril da passarela do Bloco Esportivo. Arquivo pessoal. 2009.

Figura 55:

SUZUKI, M. Peitoril da passarela do Bloco Esportivo. Arquivo pessoal. 2009.

Figura 56:

SUZUKI, M. Passarela como articulação do Bloco Esportivo. Arquivo pessoal. 2009.

Figura 57:

SUZUKI, M. Desvão, flor de mandacaru e grade no Bloco Esportivo. Arquivo pessoal. 2009.

Figura 58:

SUZUKI, M. Desvão, flor de mandacaru e grade no Bloco Esportivo. Arquivo pessoal. 2009.

Figura 59:

KON, N. Detalhe da flor de mandacaru. In: BARDI, L. B. (org. Marcelo Carvalho Ferraz). Lina Bo Bardi. São Paulo: Instituto Lina Bo e P. M. Bardi, p. 231, figura 3, 1993.

Figura 60:

BARDI, L. B. Croqui da flor de mandacaru. In: BARDI, L. B. (org. Marcelo Carvalho Ferraz). Lina Bo

Bardi. São Paulo: Instituto Lina Bo e P. M. Bardi, p. 231, figura 1, 1993.

Figura 61:

SUZUKI, M. Passarela do Bloco de Quadras. Arquivo pessoal. 2009.

Figura 62:

AUTOR não identificado. Escada Casa de Vidro. In: BARDI, L. B. (org. Marcelo Carvalho Ferraz). Lina Bo Bardi. São Paulo: Instituto Lina Bo e P. M. Bardi, p. 80, foto 2, 1993.

Figura 63:

AUTOR não identificado. Escada MASP. In: BARDI, L. B.; VAN EYCK, A. Museu de Arte de São

Paulo. Marcelo Carvalho Ferraz (org.). São Paulo: Instituto Lina Bo e P. M. Bardi / Editorial Blau, 1997.

Figura 64:

SUZUKI, M. Passarela do Bloco de Quadras. Arquivo pessoal. 2009.

Figura 65: 
KON, N. Exposição Flávio Império, out. / nov. 1997. In: BARDI, L. B. Obra construída. 2G - Revista Internacional de Arquitetura, Barcelona: Gustavo Gili Editorial, n. 23 / 24, p. 132, figura 1, 2003.

Figura 66:

AUTOR não identificado. Centro de lazer. In: BARDI, L. B. (org. Marcelo Carvalho Ferraz). Lina Bo Bardi. São Paulo: Instituto Lina Bo e P. M. Bardi, p. 224, figura 2, 1993.

Figura 67:

AUTOR não identificado. Espaço de estar. Espelho d'água. Rio São Francisco. In: BARDI, L. B. (org. Marcelo Carvalho Ferraz). Lina Bo Bardi. São Paulo: Instituto Lina Bo e P. M. Bardi, p. 225, figura 4, 1993.

Figura 68:

BARDI, L. B. Estudo para a Área de Convivência. Arquivo: Instituto Lina Bo e P.M. Bardi.

Figura 69:

AUTOR não identificado. Espaço de estar. A grande lareira. In: BARDI, L. B. (org. Marcelo Carvalho Ferraz). Lina Bo Bardi. São Paulo: Instituto Lina Bo e P. M. Bardi, p. 225, figura 2, 1993.

Figura 70:

SUZUKI, M. A grande lareira. Arquivo pessoal. 2009.

Figura 71:

KON, N. Exposição Flávio Império, out. / nov. 1997. In: BARDI, L. B. Obra construída. 2G - Revista Internacional de Arquitetura, Barcelona: Gustavo Gili Editorial, n. 23 / 24, p. 133, figura 1, 2003.

Figura 72:

SUZUKI, M. A grande lareira. Detalhe. Arquivo pessoal. 2009.

Figura 73:

BARDI, L. B. Desenho do encaixe da base da lareira. Sem data. Arquivo do Instituto Lina Bo e P.M. Bardi.

Figura 74:

AUTOR não identificado. Vista geral da Exposição África Negra. In: BARDI, L. B. (org. Marcelo Carvalho Ferraz). Lina Bo Bardi. São Paulo: Instituto Lina Bo e P. M. Bardi / Imprensa Oficial, p. 302, 2008.

Figura 75:

AUTOR não identificado. Exposição "Caipiras, capiaus: pau-a-pique". In: FERRAZ, M. C.; VAINER, A. Cidadela da Liberdade: Exposição realizada no SESC Pompéia - 19 de novembro a 30 de dezembro de 1999. São Paulo: SESC / INSTITUTO LINA BO E P. M. BARDI, p. 74, 1999.

Figura 76:

FUNDAÇÃO LE Corbusier. Piso do jardim da Villa Sarabhai, Ahmedabad, 1951-1956. In: COHEN, J. L.

Le Corbusier Le Grand, the man with a Hundred Faces. London: Phaidon Editors, p. 527, 2008.

Figura 77:

LAU, P. Desenho de paisagem de Diamantina para o livro de Aires da Mata Machado Filho: Arraial do Tijuco - Cidade de Diamantina. In: CORONA, E.; LEMOS, C. A. C. Dicionário da Arquitetura Brasileira. São Paulo: EDART - São Paulo Livraria Editora Ltda., p. 108, 1972.

ESPINOSA, M. Tiradentes. In: PALMA, A.; ORAGGIO, L.; GRASSETTI, C. Arquitetura do Brasil. São Paulo: Editora Abril, p.71, 1999.

Figura 78:

AUTOR não identificado. Construção caixa d’água. In: FERRAZ, M. C.; VAINER, A. Cidadela da Liberdade: Exposição realizada no SESC Pompéia - 19 de novembro a 30 de dezembro de 1999. São Paulo: SESC / INSTITUTO LINA BO E P. M. BARDI, p. 64, 1999.

Figura 79:

AUTOR não identificado. Rotina de atividades. In: AZEVEDO, R. M. de. Metrópole: abstração. São Paulo: Perspectiva, p. 76-77, 2006.

Figura 80:

YERBURY, F. R. Karl Ehn, Karl Marx Hof, Vienna, 1927. In: CURTIS, W. J. R. Modern Architetcture: since 1900. New Jersey: Prentice Hall, p. 172, 1987.

Figura 81:SUZUKI, M. SESC Pompéia. Arquivo pessoal, 2009. 


\section{PARTE II - OUTEIRO DA GLÓRIA}

Figura 1:

GUTIERREZ, J. Flamengo e o Outeiro da Glória ao fundo, final do séc XIX. Disponível em: $<\mathrm{http}: / /$ www.almacarioca.com.br>. Acesso em: $15 \mathrm{dez} .2008$.

Figura 2:

AUTOR não identificado. Esplanada, Largo e Outeiro da Glória ao fundo. Déc. 30. Disponível em: <http://www.almacarioca.com.br>. Acesso em: 15 dez. 2008.

Figura 3:

BARTHEL, R. A. Esplanada, Largo e Outeiro da Glória ao fundo. Déc. 40. Disponível em: <http://www.almacarioca.com.br>. Acesso em: 15 dez. 2008.

Figura 4:

AUTOR não identificado. Centro do Rio de Janeiro entre 1929 e 1944. Disponível em: <http://www.almacarioca.com.br>. Acesso em: 15 dez. 2008.

Figura 5:

RUGENDAS, atribuído a. O Outeiro da Glória. s.d. Óleo sobre tela. Disponível em:

<http://www.visgraf.impa.br>. Acesso em: 05 mai. 2007.

Figura 6:

AUTOR não identificado. O Outeiro da Glória. Disponível em: 〈http://www. casadeluciocosta.org>. Acesso em: 22 mai. 2007.

Figura 7:

POLETO, S. F. S. Outeiro da Glória. Arquivo pessoal. 2006.

Figura 8:

AUTOR não identificado. Planta da Igreja de Nossa Senhora do Outeiro. Disponível em: <http://www.casadeluciocosta.org.>. Acesso em: 22 mai. 2007.

Figura 9:

IGREJA Nossa Senhora do Ó. Fonte desconhecida. Arquivo pessoal.

Figura 10:

POLETO, S. F. S. Outeiro da Glória. Arquivo pessoal. 2006.

Figuras 11:

POLETO, S. F. S. Adro restaurado da Igreja. Arquivo pessoal. 2006.

Figura 12:

COSTA, L. In: PESSOA, J. (org.) Lucio Costa: Documentos de trabalho. Rio de Janeiro: IPHAN, p. 48, 1999.

Figura 13:

COSTA, L. In: PESSOA, J. (org.) Lucio Costa: Documentos de trabalho. Rio de Janeiro: IPHAN, p. 49, 1999.

\section{Figura 14:}

AUTOR não identificado. Vista do casario que ocupava toda a encosta. Disponível em: <http://www.casadeluciocosta.org>. Acesso em: 22 mai. 2007.

Figura 15:

AUTOR não identificado. Vista do casario que ocupava toda a encosta. Disponível em: <http://www.casadeluciocosta.org>. Acesso em: 22 mai. 2007.

Figura 16:

CHÁCARA da Floresta, 1921. “Álbum de fotografias do Morro do Castelo”, 1922. FBN, RJ. In:

NONATO, J. A.; SANTOS, N. M. Era uma vez o Morro do Castelo. Rio de Janeiro: IPHAN, p. 240, 2000 .

Figura 17:

AUTOR não identificado. Escadaria de acesso à Praça do Campidoglio, de Michelangelo, Roma, Itália. In: Plaza Southern Europe, Process: Architecture, Japão, n. 16, p. 89, 1980.

Figura 18: 
ESCADARIA de acesso à Igreja Bom Jesus do Monte, de André Soares, Braga, Portugal. Disponível em: < http://www.portugalvirtual.pt/_tourism/costaverde/braga/ptcity.html>. Acesso em: 19 ago. 2009.

Figura 19:

SPECCHI, A.; SANTIS, F. de. Praça da Espanha, Roma, Itália. In: Plaza Southern Europe, Process:

Architecture, Japão, n. 16, p. 96, 1980.

Figura 20:

SMITH, G. E. K. Igreja do Nosso Senhor Bom Jesus dos Matosinhos, de Aleijadinho, Congonhas do Campo, Brasil. In: GOODWIN, P. L. Brazil Builds: Architecture new and old 1652-1942. New York: The Museum of Modern Art, p. 47, 1943.

Figura 21:

COSTA, L. Desenho de Lucio Costa demonstrando a implantação e o trajeto sinuoso previsto. In: COSTA, L. Registro de uma vivência. Maria Elisa Costa (org.). São Paulo: Empresa das Artes, p. 412, 1995.

Figuras 22:

POLETO, S. F. S. Outeiro da Glória. Arquivo pessoal. 2006.

Figuras 23:

POLETO, S. F. S. Outeiro da Glória. Arquivo pessoal. 2006.

Figuras 24:

POLETO, S. F. S. Outeiro da Glória. Arquivo pessoal. 2006.

Figuras 25:

POLETO, S. F. S. Outeiro da Glória. Arquivo pessoal. 2006.

Figura 26:

POLETO, S. F. S. Outeiro da Glória. Arquivo pessoal. 2006.

Figuras 27:

POLETO, S. F. S. Outeiro da Glória. Arquivo pessoal. 2006.

\section{PARTE II - SOLAR DO UNHÃO}

Figura 1:

BARDI, L. B. Lina Bo Bardi. Marcelo Carvalho Ferraz (org.). São Paulo: Instituto Lina Bo e P. M. Bardi, p. $157,1993$.

Figura 2:

AUTOR não identificado. Escada do Solar do Unhão. Sem data. Instituto Lina Bo e P.M. Bardi.

Figura 3:

BARDI, L. B. Croqui da escada para o Solar do Unhão. Sem data. Instituto Lina Bo e P.M. Bardi.

Figura 4:

AUTOR não identificado. Exposição de Calder, durante a montagem. In: BARDI, L. B. Lina Bo Bardi. Marcelo Carvalho Ferraz (org.). São Paulo: Instituto Lina Bo e P. M. Bardi / Imprensa Oficial, p. 46, 2008.

Figura 5:

JORGE, L. A. Carro de boi. Arquivo pessoal, [S.D].

Figura 6:

JORGE, L. A. Carro de boi. Arquivo pessoal, [S.D].

Figura 7:

SUZUKI, M. Bancada de marceneiro. Arquivo pessoal. 2010.

Figura 8:

SUZUKI, M. Bancada de marceneiro. Arquivo pessoal. 2010.

Figura 9:

AUTOR não identificado. Protótipo da poltrona para o Teatro do MASP. In: BARDI, L. B. Lina Bo Bardi. Marcelo Carvalho Ferraz (org.). São Paulo: Instituto Lina Bo e P. M. Bardi / Imprensa Oficial, p. 108, 2008.

Figura 10:

CADEIRAS do Studio Palma. In: BARDI, L. B. Lina Bo Bardi. Marcelo Carvalho Ferraz (org.). São

Paulo: Instituto Lina Bo e P. M. Bardi / Imprensa Oficial, p. 58, 2008. 


\section{Figura 11:}

AUTOR não identificado. A casa Valéria P. Cirell, em 1958. In: BARDI, L. B. Lina Bo Bardi. Marcelo Carvalho Ferraz (org.). São Paulo: Instituto Lina Bo e P. M. Bardi / Imprensa Oficial, p. 117, 2008.

\section{Figura 12:}

AUTOR não identificado. Apoio dos pilares casa Cirell. In: BARDI, L. B. Lina Bo Bardi. Marcelo Carvalho Ferraz (org.). São Paulo: Instituto Lina Bo e P. M. Bardi / Imprensa Oficial, p. 118, 2008.

\section{Figura 13:}

KON, N. Teatro SESC Pompéia. in: OLIVEIRA, O. F. Lina Bo Bardi: obra construída. Barcelona: Editorial Gustavo Gili, 2G n. 23/24, p. 130, 2003.

Figura 14:

BARDI, L. B. Croqui da cadeira do Teatro do SESC Pompéia. Instituto Lina Bo e P.M. Bardi. 1976.

\section{Figura 15:}

SABINO, M. Detalhe do pilar central da escada do Solar do Unhão. Fevereiro 2005. Arquivo pessoal.

Figura 16:

SABINO, M. Detalhe do encaixe da escada do Solar do Unhão. Fevereiro 2005. Arquivo pessoal.

\section{Figura 17:}

SABINO, M. Escada do Solar do Unhão. Fevereiro 2005. Arquivo pessoal.

\section{Figura 18:}

BARDI, L. B. Desenho técnico da escada do Solar do Unhão. In: BARDI, L. B. Lina Bo Bardi. Marcelo Carvalho Ferraz (org.). São Paulo: Instituto Lina Bo e P. M. Bardi, p. 156, 1993.

\section{Figura 19:}

AUTOR não identificado. Escada do Solar do Unhão em construção. Sem data. Instituto Lina Bo e P.M. Bardi.

\section{Figura 20:}

AUTOR não identificado. Escada do Solar do Unhão em construção. Sem data. Instituto Lina Bo e P.M. Bardi.

\section{Figura 21:}

AUTOR não identificado. Planta e corte da escada da Biblioteca Medicea-Laurenziana, de Michelangelo. Imagem capturada aleatoriamente na internet através de site de busca. Disponível em: <http://www.archweb.it/dwg/architetture del_passato/biblioteca_laurenziana/biblioteca_laurenziana.htm. Acessado em: 27 jan. 2010.

\section{Figura 22:}

ESCADA da Biblioteca Medicea-Laurenziana, de Michelangelo. Imagem capturada aleatoriamente na internet através de site de busca. Disponível em: <http://www.wga.hu/framese.html?/html/m/michelan/5archite/early/index.html>. Acessado em: 26 jan. 2010.

\section{Figura 23:}

ESCADA da Biblioteca Medicea-Laurenziana, de Michelangelo. Imagem capturada aleatoriamente na internet através de site de busca. Disponível em: <http://www.wga.hu/framese.html?/html/m/michelan/5archite/early/index.html>. Acessado em: 26 jan. 2010.

\section{Figura 24:}

AUTOR não identificado. Escada encontrada no Solar do Unhão antes da reforma. Sem data. Instituto Lina Bo e P.M. Bardi.

\section{Figura 25:}

BARDI, L. B. Esquema técnico estrutural do MASP. In: BARDI, L. B. Lina Bo Bardi. Marcelo Carvalho Ferraz (org.). São Paulo: Instituto Lina Bo e P. M. Bardi, p. 104, 1993.

\section{Figura 26:}

MONTAGEM de fotos do MASP. In: BARDI, L. B. Lina Bo Bardi. Marcelo Carvalho Ferraz (org.). São Paulo: Instituto Lina Bo e P. M. Bardi / Imprensa Oficial, p. 104, 2008. e Folha de São Paulo. 04 out. 1967.

\section{Figura 27:}

SUZUKI, M. Solar do Unhão. Arquivo pessoal, 2009. 


\section{Figura 28:}

SAMPAIO, A. Solar do Unhão. In: PIRES, F. T. F.; GOMES, G. Antigos engenhos de açúcar no Brasil. Rio de Janeiro: Editora Nova Fronteira, p. 137, 1994.

Figura 29:

BARDI, L. B. Montagem de documento fotografado no Instituto Lina Bo e P.M. Bardi. Arquivo pessoal de Marcelo Suzuki, 2009.

Figura 30:

AUTOR não identificado. Pintura a óleo do Solar do Unhão, século XVIII. In: PIRES, F. T. F.; GOMES, G. Antigos engenhos de açúcar no Brasil. Rio de Janeiro: Editora Nova Fronteira, p. 136, 1994.

Figura 31:

AUTOR não identificado. Pintura a óleo do Solar do Unhão, século XVIII - ampliação. In: PIRES, F. T. F.; GOMES, G. Antigos engenhos de açúcar no Brasil. Rio de Janeiro: Editora Nova Fronteira, p. 136, 1994.

Figura 32:

AUTOR não identificado. Lina ajudando no restauro do Solar do Unhão. In: RISÉRIO, A. Avant-Garde na Bahia. São Paulo: Instituto Lina Bo e PM Bardi, p. 198, 1995.

Figura 33:

AUTOR não identificado. Lina ajudando no restauro do Solar do Unhão. In: BARDI, L. B. Lina Bo Bardi. Marcelo Carvalho Ferraz (org.). São Paulo: Instituto Lina Bo e P. M. Bardi, p. 156, 1993.

Figura 34:

KON, N. Solar do Unhão. In: OLIVEIRA, O. F. Lina Bo Bardi: obra construída. Barcelona: Editorial Gustavo Gili, 2G n. 23/24, p. 85, 2003.

Figura 35:

AUTOR não identificado. São Jorge e o Dragão. BARDI, L. B. Lina Bo Bardi. Marcelo Carvalho Ferraz (org.). São Paulo: Instituto Lina Bo e P. M. Bardi, p. 156, 1993.

Figura 36:

BARDI, L. B. Escritos de Lina. Sem data. Instituto Lina Bo e P.M. Bardi.

Figura 37:

KON, N. Vão do MASP. In: BARDI, L. B. Obra construída. 2G - Revista Internacional de Arquitetura, Barcelona: Gustavo Gili Editorial, n. 23 / 24, p. 11, 2003.

Figura 38:

KON, N. MASP. In: BARDI, L. B. Obra construída. 2G - Revista Internacional de Arquitetura, Barcelona: Gustavo Gili Editorial, n. 23 / 24, p. 63, 2003.

Figura 39:

SUZUKI, M. Solar do Unhão. Arquivo pessoal, 2009.

Figura 40:

BREUER, M. Cadeiras Cesca e Sillón. In: EMERY, M. Muebles disenãdos por arquitectos, Barcelona: Editorial Stylus, p. 69,1984.

Figura 41:

Página do diário de Lina. In: BARDI, L. B. Lina Bo Bardi. Marcelo Carvalho Ferraz (org.). São Paulo: Instituto Lina Bo e P. M. Bardi, p. 152, 1993.

Figura 42:

AUTOR não identificado. Mapa esquemático da Bahia. Parte integrante do material de projeto para criação do Centro de Estudos Técnicos do Artesanato

Figura 43:

GUTHMANN, A. Exposição Civilização do Nordeste. In: Tempos de grossura: o design no impasse:

Lina Bo Bardi. SUZUKI, M. (org.). São Paulo: Instituto Lina Bo e PM Bardi, p. 39, 1994.

Figura 44:

AUTOR não identificado. Vista interna Exposição Nordeste. In: BARDI, L. B. Lina Bo Bardi. Marcelo

Carvalho Ferraz (org.). São Paulo: Instituto Lina Bo e P. M. Bardi, p. 159, 1993.

Figura 45: 
AUTOR não identificado. Lamparina (fifó) de parede e mesa. Folha de flandres e lâmpada queimada. In: Tempos de grossura: o design no impasse: Lina Bo Bardi. SUZUKI, M. (org.). São Paulo: Instituto Lina Bo e PM Bardi, p. 56, 1994.

\section{Figura 46:}

AUTOR não identificado. Vista interna Exposição Nordeste. In: BARDI, L. B. Lina Bo Bardi. Marcelo Carvalho Ferraz (org.). São Paulo: Instituto Lina Bo e P. M. Bardi, p. 159, 1993.

\section{Figura 47:}

AUTOR não identificado. Catálogo da XIII Trienal de Milão, Exposição Internacional de arte decorativa e industria moderna e de arquitetura moderna. Pallazo dell'Arte al Parco Milano, 12 junho 24 setembro1964.

\section{Figura 48:}

VERGER, P. Casa do Benin, vista do edifício nos anos 40. In: BARDI, L. B. Lina Bo Bardi. Marcelo Carvalho Ferraz (org.). São Paulo: Instituto Lina Bo e P. M. Bardi / Imprensa Oficial, p. 283, 2008.

\section{Figura 49:}

AUTOR não identificado. Pilares recobertos de palha e a nova escada ao longo do muro original. In: BARDI, L. B. Lina Bo Bardi. Marcelo Carvalho Ferraz (org.). São Paulo: Instituto Lina Bo e P. M. Bardi / Imprensa Oficial, p. 284, 2008.

\section{Figura 50}

AUTOR não identificado. Vista da exposição de artesanato do Benin. In: BARDI, L. B. Lina Bo Bardi. Marcelo Carvalho Ferraz (org.). São Paulo: Instituto Lina Bo e P. M. Bardi / Imprensa Oficial, p. 284, 2008.

\section{Figura 51:}

AUTOR não identificado. Vista geral da Exposição África Negra. In: BARDI, L. B. Lina Bo Bardi. Marcelo Carvalho Ferraz (org.). São Paulo: Instituto Lina Bo e P. M. Bardi / Imprensa Oficial, p. 302, 2008.

\section{Figura 52:}

Estudo do Teatro Gregório de Mattos. Projeto Barroquinha, 1986. In: BARDI, L. B. Lina Bo Bardi. Marcelo Carvalho Ferraz (org.). São Paulo: Instituto Lina Bo e P. M. Bardi / Imprensa Oficial, p. $278,2008$.

\section{Figura 53:}

AUTOR não identificado. Escada do Teatro Gregório de Mattos. In:BARDI, L. B. Lina Bo Bardi. Marcelo Carvalho Ferraz (org.). São Paulo: Instituto Lina Bo e P. M. Bardi / Imprensa Oficial, p. 278, 2008.

\section{Figura 54:}

AUTOR não identificado. Ponta do pilar doTeatro Gregório de Mattos. In: BARDI, L. B. Lina Bo Bardi. Marcelo Carvalho Ferraz (org.). São Paulo: Instituto Lina Bo e P. M. Bardi / Imprensa Oficial, p. 279, 2008.

\section{Figura 55:}

AUTOR não identificado. Florence Stadium. In: NERVI, P. L. Structures. New York: F.W. Dodge Corporation, p. 22, 1956.

\section{Figura 56:}

ISONO, Y. Municipal Stadium. Florence, Itália, 1932. Disponível em:

<http://en.structurae.de/structures/data/photos.cfm?ID=s0013869>. Acesso em: 09 jun. 2009. 


\section{BIBLIOGRAFIA GERAL}

\section{LIVROS, TESES E DISSERTAÇÕES}

AGUIAR, L. S. Palácio Monroe: da glória ao opróbrio. Rio de Janeiro: Arte Moderna, 1976.

AMARAL, A. (org). Dos murais de Portinari aos espaços de Brasília. São Paulo: Perspectiva, 1981.

AMBASZ, E. The architecture of Luis Barragan. New York: The Museum of Modern Art, 1980.

ANELLI, R. L. S. Arquitetura e cidade na obra de Rino Levi. São Paulo: Faculdade de Arquitetura e Urbanismo, Universidade de São Paulo, Tese de Doutorado, 1995.

ANELLI, R.; GUERRA, A.; KON, N. Rino Levi arquitetura e cidade. São Paulo: Romano Guerra Editora, 2001.bb n

ARGAN, G. C. Arte moderna: do Iluminismo aos movimentos contemporâneos. São Paulo: Companhia das Letras, 1992.

El Arte moderno: 1770-1970. Valência: F. Torres, 1976.

História dei arte como historia de la ciudad. Barcelona: Laia, 1984.

AZEVEDO, R. M. de. Metrópole: abstração. São Paulo: Perspectiva, 2006.

BANHAN, R. Teoria e projeto na primeira era da máquina. São Paulo: Perspectiva, 1975.

BAYÓN, D; GASPARINI, P. Panorámica de la arquitectura Latino-americana. Barcelona: Editora Blume / Unesco, 1977.

BENEVOlO, L. História de La Arquitectura Moderna. Barcelona: Editorial Gustavo Gili, 1974. Introdução à arquitetura. São Paulo: Mestre Jou, 1972.

BOESIGER, W. Le Corbusier. Barcelona: Editorial Gustavo Gili, 1977.

BOITO, C. Os Restauradores. São Paulo: AE Ateliê Editorial, 2002.

BONDUKI, N. (org.). Affonso Eduardo Reidy. São Paulo: Instituto Lina Bo e P. M. Bardi; Lisboa: Editorial Blau, 1999.

BONFANTI, E.; PORTA, M. Città, museo e architettura: II grupo BBPR nella cultura architettonica italiana 1932-1970. Florença: Vallechi, 1973.

BRAGA, A. C.; FALCÃO, F. A. R. Guia de Urbanismo, Arquitetura e Arte de Brasília. Brasília: Fund. Athos Bulcão, 1997.

BRAND, S. How buildings learn. London: Penguin books, 1994.

BRUAND, Y. Arquitetura Contemporânea no Brasil. São Paulo: Perspectiva, 1999.

BULlRICH, F. Nuevos caminos de la Arquitectura Latinoamericana. Barcelona: Editora Blume, 1969.

BURKE, P. Cultura popular na idade média: Europa, 1500-1800. São Paulo: Companhia das Letras, 1995.

CAMPOS, A. Balanço da Bossa Nova e outras bossas. São Paulo: Perspectiva, 1986.

CARDOSO, P. Arquitetura pelas escadas. São Paulo: Estação Liberdade, 2009

CAVAlCANTI, L. P. (org). Quando o Brasil era moderno. Rio de Janeiro: Aeroplano, 2000.

Moderno e brasileiro: a história de uma nova linguagem na arquitetura. Rio de Janeiro: Ed. Jorge Zahar, 2006.

COHEN, J. L. Le Corbusier Le Grand, the man with a Hundred Faces. London: Phaidon Editors, 2008.

CHOAY, F. L'allégorie du patrimoine. Paris: Éditions du Seuil, 1992.

COLQUHOUN, A. Modernidade e tradição clássica: Ensaios sobre a Arquitetura. São Paulo: Cosac \& Naify, 2004. 
CONGRESSO Brasileiro de Arquitetos. Arquitetura, Cidade e Natureza. IAB/DN. Direção Nacional do Instituo de Arquitetos do Brasil (org.). São Paulo: Empresa das artes. 1993.

CURTIS, W. J. R. Modern Architetcture: since 1900. New Jersey: Prentice Hall, 1987.

DEBENEDETTI, E.; SALMONI, A. Arquitetura italiana em São Paulo. São Paulo: Instituto Cultural Ítalo-Brasileiro, 1993.

DEJEAN, J. Antigos contra modernos. Rio de Janeiro: Civilização Brasileira, 2005.

DESWARTE, S.; LEMOINE, B. L'Architecture et les ingénieurs, deux siècles de construction. Paris: Groupe Moniteur, 1997.

FERRAZ, G. Depois de tudo. São Paulo: SMC / PMSP / PAZ E TERRA, 1983.

Warchavcik e a introdução da nova Arquitetura no Brasil. São Paulo: Museu de Arte de São Paulo, 1965.

FILHO, L. W. C. A fortaleza do Salvador na Baía de Todos os Santos. Salvador: Secretaria da Cultura e Turismo, 2004.

FRAMPTON, K. História crítica de la Arquitectura Moderna. Barcelona: Editorial Gustavo Gilli, 1991.

FUSCO, R. História de Ia arquitectura contemporanea. Madrid: Blume, 1981.

GARNIER, T. L'oeuvre de Tony Garnier. Paris: Editions Albert Morancé, S.D.

GAUTHEROT, M.; FROTA, L. C., Bahia: rio São Francisco, recôncavo e Salvador. Rio de Janeiro: Nova Fronteira, 1995.

GRAF, A. B. Tropica. New York: Roehrs, 1978

GIEDION, S. Espacio, tiempo y arquitectura (El futuro de uma nueva tradición). Madrid: Editorial Dossat, 1978.

. La mecanización toma el mando. Barcelona: GG Colección Tecnologia y Sociedad, 1978.

GIOVANNONI, G. Questioni di architettura nella storia e nella vita: edilizia - estetica architettonica ristauri - ambiente dei monumenti. Roma: Società Editrice D'Arte Illustrata, 1925.

GOETHE, J. W. Doutrina das cores. São Paulo: Nova Alexandria, 1993.

GOODWIN, P. L. Brazil Builds: Architecture new and old 1652-1942. New York: The Museum of Modern Art, 1943.

GOROVITZ, M. Os riscos do projeto. São Paulo: Studio Nobel, Brasília: Edunb, 1993.

GRAMSCI, A. Literatura e vida nacional. Rio de Janeiro: Civilização Brasileira, 1978.

Os Intelectuais e a Organização da Cultura. Rio de Janeiro: Civilização Brasileira, 1979.

GROPIUS, W. Bauhaus: novarquitetura. São Paulo: Perspectiva, 1972.

HOLANDA, S. B. de. Raízes do Brasil. Rio de Janeiro: Livraria José Olympio Editora, 1976.

KLINK, A. Linha-d'água. São Paulo: Companhia das Letras, 2006.

KOPP, A. Arquitectura y urbanismo soviéticos de los años veinte. Barcelona: Lúmen, 1974.

LE CORBUSIER. Por uma arquitetura. São Paulo: Perspectiva, 1973.

When the cathedrals were White: A journey to the country of timid people. New York: Reynal \& Hitchcock, 1947.

Precisões: sobre um estado presente da arquitetura e do urbanismo. São Paulo: Cosac \& Naify, 2004.

MINDLIN, H. E. Brazilian Architecture. London: Royal College of art, 1961.

. Modern Architecture in Brazil. New York: Reinhold Publishing Corporatino, 1956.

MONTEZUMA, R. (org.). Arquitetura Brasil 500 anos - vol. 1 e 2. Recife: Universidade Federal de Pernambuco, 2008.

MORSE, R. M. Formação histórica de São Paulo. São Paulo: Difusão Européia do Livro, 1970. 
MOTTA, F. L. Roberto Burle Marx e a nova visão da paisagem. São Paulo: Nobel, 1984.

Textos informes. São Paulo: FAU-USP, p. 3, 1973.

NERVI, P. L. Structures. New York: F.W. Dodge Corporation, 1956.

ORTZ, R. Cultura brasileira e identidade nacional. São Paulo: Brasiliense, 1985.

PALMA. A. (coord.). Arquitetura do Brasil. São Paulo: Editora Abril, 1999.

PEVSNER, N. Os pioneiros do desenho moderno. De William Morris a Walter Gropius. São Paulo: Martins Fontes, 1995.

PIÑÓN, H. Perfiles Encontrados. Prólogo. In: BÜRGUER, P. Teoria de la vanguardi. Barcelona: Península, 1987.

PIRES, F. T. F.; GOMES, G. Antigos engenhos de açúcar no Brasil. Rio de Janeiro: Editora Nova Fronteira, 1994.

PLATO, P. Il modello nel design, la bottega di Giovanni Sacchi. Milão: Hopeli, 1991.

REIS, N. G. Imagens de Vilas e Cidades do Brasil Colonial. São Paulo: Editora da Universidade de São Paulo: Imprensa Oficial do Estado, 2001. - (Uspiana-Brasil 500 Anos).

REIS FILHO, N. G. Quadro da arquitetura no Brasil. São Paulo: Perspectiva, 1970.

RIBEIRO, D. O povo brasileiro o sentido e a formação do Brasil. São Paulo: Companhia das Letras, 1995.

SAIA, L. Morada Paulista. São Paulo: Editora Perspectiva, 1972.

SALLUM JR., B. Sérgio Buarque de Holanda: Raízes do Brasil. In: MOTA, L. D. (org.). Introdução ao Brasil: Um banquete no trópico. São Paulo: Editora SENAC, 2004.

SANTOS, C. R. dos (org). et al. Le Corbusier e o Brasil. São Paulo: Tessela, Projeto, 1987.

SANTOS, P. Quatro séculos de arquitetura. Rio de Janeiro: IAB, 1981.

SEGAWA, H. Arquiteturas no Brasil, anos 80. São Paulo: Projeto Editores Associados, 1988. . Arquiteturas no Brasil 1900 - 1990. São Paulo: EDUSP, 1997.

SEGUIN, J.; NAVARRA, E. Jean Prouvé. Paris: Galeries Josse Seguin / Enrico Navarra, 1998.

SENNETT, R. O declínio do homem público. São Paulo: Companhia das Letras, 1989.

STAROBINSKI, J. 1789. Os emblemas da razão. São Paulo: Companhia das Letras, 1988.

SUBIRATS, E. Vanguarda, midia, metrópoles. São Paulo: Studio Nobel, 1993.

TAFURI, M. Projeto e utopia. Lisboa: Editorial Presença, 1985.

Teoria e história da arquitetura. Lisboa: Presença: Martins Fontes, 1981.

TAFURI, M.; CACCIARI, M.; DAL CO, F. De la vanguardia a la metropoli. Barcelona: Gustavo Gili Editorial, 1972.

TOLEDO B. L. Álbum iconográfico da avenida Paulista. São Paulo: ExLibris, 1987.

Prestes Maia e as origens do Urbanismo Moderno em são Paulo. São Paulo: Empresa das Artes, 1996.

VERGER, P. Fluxo e refluxo do tráfico de escravos entre o Golfo do Benin e a Baía de Todos os Santos, dos séculos XVII a XIX. Salvador: Corrupio, 1987.

VIOLLET-LE-DUC, E. E. Restauração. São Paulo: Ateliê, 2000.

XAVIER, A. et al. Arquitetura moderna paulistana. São Paulo: Pini, 1983. (org.). Depoimento de uma geração. São Paulo: Cosac \& Naify, 2003.

WAIZBORT, L. As aventuras de Georg Simmel. São Paulo: Ed. 34, 2000. 


\section{PERIÓDICOS}

ANDRADE, M. Exposição duma casa modernista (considerações). Diário Nacional. São Paulo, 5 abr. 1930. Disponível em: 〈http://www.vitruvius.com.br/documento/ arquitetos/mario02.asp〉. Acesso em: 28 jul. 2009.

ARTE em revista. São Paulo: Kairós Livraria e Editora, ano 2, n. 4, 1980.

BENTO, A. A Bienal de São Paulo. Diário Carioca, Rio de Janeiro, 4 out. 1959.

CENTENÁRIO. Habitat, São Paulo, n. 6, p. 1, jan./mar. 1952.

CÍCERO, A. Ainda a vanguarda, Folha de S. Paulo, São Paulo, 31 mai. 2008.

A CIVILIZAÇÃO das plumas. Revista Habitat, São Paulo, n.8, p.31-33, jul./set. 1952.

COMAS, C. E. Três variações sobre a domesticidade e a transparência no pós-guerra. Arquitexto 8, 2006. Disponível em: < http://www.ufrgs.br/propar/publicacoes/ ARQtextos/PDFs_revista_8/8_Carlos\%20Eduardo\%20Comas.pdf>. Acessado em: 26 jun. 2009.

CONJUNTO de dança expressiva. Habitat, São Paulo, abr./jun. 1952.

CONSTRUIR é viver. Habitat, São Paulo, n. 7, p. 3-10, abr./jun. 1952.

CZAJKOWSKI, J. A arquitetura racionalista e a tradição brasileira, Gávea, Rio de Janeiro: PUC/RJ, n. 10, p. 24-39, mar. 1993.

CZERNA, R. C. Carta aberta. Habitat, São Paulo, n. 3, abr./jun. 1951.

DOIS objetos. Habitat, São Paulo, n. 5, p. 64, out./dez. 1951.

FERRAZ, G. Arquitetura Brasileira: a palavra de Geraldo Ferraz. (entrevista concedida ao arquiteto Ricardo Forjaz Christiano de Souza e ao estudante de arquitetura Jonas Tadeu Silva Malaco). Revista D’Art, São Paulo, IDART: Divisão de Pesquisa do Centro Cultural São Paulo, n. 02, 1998.

FOLHETOS. Habitat, São Paulo, n. 3, abr./jun. 1951.

GALERIA. Revista de Arte, n. 18, ano 4, fev/mar. 1990.

GIMENEZ, L. E. Tradição e academia, Arquitetura Revista, Rio de Janeiro: FAU / UFRJ, n. 7, p. 56-67, 1989.

MODERN Brazilian Architecture, Process: Architecture, Japão, n. 17, 1980.

PLAZA Southern Europe, Process: Architecture, Japão, n. 16, 1980.

SEGAWA, H. Una vanguardia impregnada de tradición. A\&V, Madrid, n. 13, p.24-27, 1988.

VASCONCELOS, S. Sistemas construtivos adotados na Arquitetura no Brasil. Revista Arquitetura e Engenharia, Belo Horizonte, 1951.

\section{BIBLIOGRAFIA ESPECÍFICA: LINA BO BARDI LIVROS, TESES E DISSERTAÇÕES}

ANELLI, R. L. S. Arquitetura italiana em São Paulo: Gregori Warchavichik, Rino Levi, Lina Bo Bardi, Giancarlo Palanti e Daniele Calabi. Constituição da Arquitetura Moderna em São Paulo: 1930-1970. Projeto Integrado de Pesquisa com apoio do CNPq. Fev., 1996.

AZEVEDO, M. M. M. A experiência de Lina Bo Bardi no Brasil. São Paulo: Faculdade de Arquitetura e Urbanismo, Universidade de São Paulo, Dissertação de Mestrado, 1995.

BARDI, L. B. Contribuição Propedêutica ao ensino da Teoria da Arquitetura. São Paulo: Instituto Lina Bo e P. M. Bardi, 2002.

Design no Brasil. História e realidade. Catálogo da Exposição inaugural do Centro de Lazer SESC Fábrica Pompéia. São Paulo: Museu de Arte de São Paulo Assis Chateaubriand, 1982.

. Lina Bo Bardi. Marcelo Carvalho Ferraz (org.). São Paulo: Instituto Lina Bo e P. M. Bardi, 1993. 
Lina Bo Bardi. Marcelo Carvalho Ferraz (org.). São Paulo: Instituto Lina Bo e P. M. Bardi / Imprensa Oficial, 2008.

Lina por escrito. Textos escolhidos de Lina Bo Bardi. Silvana Rubino e Marina Grinover (org.). São Paulo: Cosac \& Naify, 2009.

Tempos de grossura: o design no impasse. SUZUKI, M. (org.). São Paulo: Instituto Lina Bo e PM Bardi, 1994.

BARDI, L. B.; VAN EYCK, A. Museu de Arte de São Paulo. Marcelo Carvalho Ferraz (org.). São Paulo: Instituto Lina Bo e P. M. Bardi / Editorial Blau, 1997.

BARDI, P. M. História do MASP. São Paulo: Instituto Quadrante / Empresa das Artes, 1992.

CABRAL, M. C. N. O racionalismo arquitetônico de Lina Bo Bardi. Rio de Janeiro: Pontifícia Universidade Católica, Dissertação de Mestrado, 1996.

CAMPELlo, M. F. M. B. As moradas da alma. São Carlos: Escola de Engenharia de São Carlos, Universidade de São Paulo, Dissertação de Mestrado, 1997.

FERRAZ, M. C.; VAINER, A. Cidadela da Liberdade: Exposição realizada no SESC Pompéia - 19 de novembro a 30 de dezembro de 1999, São Paulo, SESC / INSTITUTO LINA BO E P. M. BARDI, 1999.

LIMA, M. A. Marginália: arte e cultura "na Idade da Pedrada". Rio de Janeiro: Salamandra, 1996.

LISSITZKY, El. 1929. La reconstruccion de la arquitectura em la U.R.S.S. Barcelona: Gustavo Gili Editorial, 1970.

LIVROS DO TOMBO do Patrimônio Artístico Nacional. s/a. Brasília, 1982

MIOTTO, L.; NICOLINI, S. Lina Bo Bardi: Aprirsi alláccadimento. Milão: Texto \& Immagine, 1998.

MIYOSHI, A. Entre a origem e a degradação: a primeira reforma do edifício do Museu de Arte de São Paulo. Artigo Disponível em: http://www.unicamp.br /chaa/rhaa/downloads/Revista\%206\%20-\%20artigo\%2011.pdf

OLIVEIRA, O. F. Hacia Lina Bo Bardi. Barcelona: Universidad Politecnica de Catalunã, Dissertação de Mestrado, 1994

Lina Bo Bardi: Sutis Substâncias da Arquitetura. São Paulo: RG / GG, 2006.

Lina Bo Bardi: obra construída. Barcelona: Editorial Gustavo Gili, 2G n. 23/24, 2003.

PALÁCIO das indústrias: memória e cidadania. O restauro para a nova prefeitura de São Paulo. São Paulo: Edição DPH/Método, 1992.

RISÉRIO, A. Avant-Garde na Bahia. São Paulo: Instituto Lina Bo e PM Bardi, 1995.

RUBINO, S.; GRINOVER, M. Lina por escrito: Textos escolhidos de Lina Bo Bardi 1943-1991. São Paulo: Cosac Naify, 2009.

RUBINO, S. B. Rotas da modernidade. Trajetória, campo e história na atuação de Lina Bo Bardi, 1947- 1968. Tese (Doutorado) - Campinas: Instituto de Filosofia e Ciências Humanas da Universidade de Campinas - IFCH/Unicamp, 2002.

TENTORI, F. P.M. Bardi: com as crônicas artísticas do "L 'Ambrosiano" 1930-1933. São Paulo: Instituto Lina Bo e P.M. Bardi / Imprensa Oficial do Estado, 2000.

Una lettera de São Paulo: ritrattini del '900 italiano. Florença: Facoltà de Architettura, Università degli Studi di Firenze, p. 11, 1992.

VELOSO, C. Verdade tropical. São Paulo: Companhia das Letras, 1997.

\section{PERIÓDICOS}

6 pinturas e 2 desenhos de Guttuso, trazidos por Lina, em exposição hoje. Diário de Notícias, Salvador, 8 fev. 1962.

11 Bienal de teatro e exposição Bahia numa primeira visita. A Tribuna, São Paulo, 20 set. 1959. 
A V BIENAL. Diário de Notícias, Salvador, 24 set. 1959.

BIENAL: a mais importante exposição de âmbito nacional. A Tarde, Salvador, 30 dez. 1966.

CASA de 7 mil cruzeiros. Habitat, São Paulo, n. 3, abr./jun. 1951.

BALANÇOS e perspectivas museográficas: um museu de arte em São Vicente. Habitat, São Paulo, n. 8, p. 2-5, jul./set. 1952.

ARTES plásticas. A Tarde, Salvador, 5 nov. 1963.

ARAUJO, A. M. Ex-votos e "premessas”. Habitat, São Paulo, n. 5, p.42-45, out./dez. 1951.

ARRANHA-CÉUS e o espírito. Habitat, São Paulo, n. 8, jul./set. 1952.

ACAYABA, M. SESC Pompéia, um soco no estômago. Revista Projeto, São Paulo, n. 92, n. 149, out. 1986, jan./fev. 1992. In: Cidadela da Liberdade: 19 de novembro a 30 de dezembro de 1999 SESC Pompéia. Livro da Exposição. São Paulo: SESC São Paulo, Instituto Lina Bo e P.M.Bardi, 1999.

ALBINI, F. A arquitetura dos museus e os museus na urbanística moderna. Habitat, São Paulo, n. 15, p. 28-31, mar./abr. 1954.

A ALMA do capoeirista. Habitat, São Paulo, n. 11, p. 62-64, jun. 1953.

AMADO, J.; BARDI, L. B.; GONÇALVES, M. Exposição Bahia. Habitat, São Paulo, n. 56, set./out. 1959.

AMAZÔNAS: o povo arquiteto. Habitat, São Paulo, n. 1, p.68-71, out./dez. 1950.

ANELLI, R.; LUCCHINO, M.; PEREIRA, J. A. Os Museus de Lina Bo e PM Bardi. In: DOCOMOMO: SEMINÁRIO DO GRUPO DE TRABALHO VALE DO PARAÍBA, São José dos Campos: Fundação Cultural Cassiano Ricardo, 1998.

ANTONIO, M. Bahia de todos os santos e orixás no Ibirapuera. Última Hora, São Paulo, 23 set. 1959.

ARTE folclórica baiana. Jornal do Comércio, Rio de Janeiro, 24 set. 1959.

ARTE popular. Habitat, São Paulo, n. 5, p. 55-56, out./dez. 1951.

ARTE popular em exposição amanhã. Jornal da Bahia, Salvador, 2 nov. 1963.

ARTESANATO deverá ressurgir na Bahia. A Tarde, Salvador, 4 jan. 1963.

ARTISTAS argentinos no MAMB. Diário de Notícias, Salvador, 17 nov. 1960.

ARTISTAS israelitas exporão em Salvador. A Tarde, Salvador, 17 fev. 1961.

ASKANASY, M. Teatro: folclore brasileiro. Habitat, São Paulo, n. 2, p. 84-86, jan./mar. 1951.

A TARDE. Salvador, 23 jan. 1960.

Salvador, 05 nov. 1963.

BAHIA: exposição apresentada pela comissão especial do Ibirapuera. O Estado de S. Paulo, São Paulo, 27 set. 1959.

BAHIA ganha hoje seu Museu de Arte Moderna. Diário de Notícias, Salvador, 6/jan/1960

BAHIA, J. Surpreendente Bahia. Jornal do Estado da Sabia, Salvador, 17 abr. 1958.

BAILADO: conjunto de dança expressiva. Habitat, São Paulo, n. 07, p. 83-85, abr./jun. 1952

BARBA, R. F. Mário cravo. Habitat, São Paulo, n. 11, p. 65-67, jun. 1953.

. Os ladrões de ex-votos. Habitat, São Paulo, n. 11, p. 67-72, jun.1953.

Pintor pernambucano: folclore nas artes plásticas. Habitat, São Paulo, n. 12, set. 1953.

Roupa de couro do vaqueiro nordestino. Habitat, São Paulo, n. 12, set. 1953.

BARDI: MASP não tem umidade. Folha de S. Paulo, São Paulo, 1 ago. 1978.

BARDI, L. B. Apresentação-manifesto da exposição de arte popular do Unhão, Folder da exposição, 1963. Bela criança. Habitat, São Paulo, n. 4, 1951. 
Caipiras, capiaus, pau-a-pique. São Paulo: SESC-Pompéia, Catálogo da exposição, 1984.

. Calígula e a crítica teatral. 1961. Texto datilografado.

Casas ou museus. Diário de Notícias, Salvador, n. 5, 05 nov. 1958. Crônicas de Artes, de História, de Costume, de Cultura da Vida / Arquitetura, pintura, escultura, música, artes visuais.

. Cinco anos entre os "brancos": o Museu de Arte Moderna da Bahia. Revista Mirante das Artes, São Paulo, n. 6, nov./dez. 1967.

. Curriculum, 1955. Apresentado no concurso para professor na FAUUSP.

. Exposição didática da Escola de Teatro. Diário de Notícias, Salvador, n. 3, 21 set. 1958. Crônicas de Artes, de História, de Costume, de Cultura da Vida / Arquitetura, pintura, escultura, música, artes visuais.

Francisco Brennand. Diário de Notícias, Salvador, 9 abr. 1961.

. João Alves e Agostinho. Diário de Notícias, Salvador, 2 abr. 1961.

. Nordeste. Salvador: Museu de Arte Popular do Solar do Unhão, Salvador, Folder da Exposição no Museu de Arte Popular do Solar do Unhão, Bahia, Brasil, 1963.

. Lina Bo Bardi ao "DN": reação do povo foi além das esperanças. Diário de Notícias, Salvador, 24 jan. 1960.

. Museu de Arte Moderna da Bahia. Diário de Notícias, Salvador, 18 out. 1959.

. Museu de Arte Moderna da Bahia. Museu de Arte Popular do Unhão. Diário de São Paulo, São Paulo, 8 nov 1959

. Planejamento ambiental: “desenho" no impasse. MALASARTES, Rio de Janeiro, n. 2, dez./jan./fev. 1976.

. Obra construída. 2G - Revista Internacional de Arquitetura, Barcelona: Gustavo Gili Editorial, n. 23 / 24, 2003.

BARDI, L. B.; GONÇALVES, M. Bahia: exposição no Parque Ibirapuera, São Paulo, Folder da exposição, 1959.

. Bahia, esposizione a San Paolo. Revista Domus, Bragança, n.364, p. 32-36, mar. 1960.

BARDI, P. M. Bienal de Veneza: uma antecipação baiana. Diário de São Paulo, São Paulo, 20 ago. 1964.

BELÉM. Habitat, São Paulo, n. 9, p. 47, out./dez. 1952.

BIERRENBACH, A. C. de S. Lina Bo Bardi e o Mausoléu da Família Odebrecht - entre o etéreo e o terreno. Vitruvius, ano 5, vol. 10, p. 132, mai. 2005. Seção Minha cidade: São Paulo. Disponível em: 〈http://www.vitruvius.com.br/minhacidade/ mc132/mc132.asp >. Acesso em: 28 jul. 2009.

BORJA, L. Artes plásticas: Calasans Neto. A Tarde, Salvador, 5 jun. 1962.

Artes plásticas: três inaugurações. A Tarde, Salvador, 26 mar. 1963.

Mário Cravo Filho. A Tarde, Salvador, 24 set 1963.

CALASANS Neto expõem desde ontem no MAMB magníficos trabalhos xilográficos. Estado da Bahia, Salvador, 23 mai. 1962.

CARIBÉ bahiano universal. A Tarde, Salvador, 22 fev. 1963.

CARTOGRAFIA instala exposição no MAMB. Jornal da Bahia, Salvador, 7 nov. 1962.

CELESTINO, A. Museu de Arte Moderna, um problema de fácil solução. A Tarde, Salvador, 24 mar. 1963.

CERÂMICAS do Nordeste. Habitat, São Paulo, n. 2, p. 72-76, jan./mar. 1951.

CERÂMICA dos Carajás. Habitat, São Paulo, n. 7, p. 61-70, abr./jun.1952.

CERTEZA de porvir melhor no conjunto arquitetônico do Unhão, disse Lowenstein. Diário de Notícias, Salvador, 26 mar. 196-?

CIDADE já possuí também Museu de Arte Moderna. A Tarde, Salvador, 7 jan. 1960. 
CRÍTICO vê exposição Nordeste: antibienal. A Tarde, Salvador, 5 nov. 1963.

DIÁRIO DE NOTÍCIAS. Salvador, 10 ago. 1958.

DIÁRIO DE NOTÍCIAS. Salvador, n. 1, 7 set. 1958. Crônicas de arte, de história, de costume, de cultura da vida: arquitetura, pintura, escultura, música e artes visuais.

DIÁRIO DE NOTÍ́CIAS. Salvador, n. 2, 14 set. 1958. Crônicas de arte, de história, de costume, de cultura da vida: arquitetura, pintura, escultura, música e artes visuais.

DIÁRIO DE NOTÍCIAS. Salvador, n. 3, 21 set. 1958. Crônicas de arte, de história, de costume, de cultura da vida: arquitetura, pintura, escultura, música e artes visuais.

DIÁRIO DE NOTÍCIAS. Salvador, n. 6, 12 out. 1958. Crônicas de arte, de história, de costume, de cultura da vida: arquitetura, pintura, escultura, música e artes visuais.

DIÁRIO DE NOTÍCIAS. Salvador, n. 7, 19 out. 1958. Crônicas de arte, de história, de costume, de cultura da vida: arquitetura, pintura, escultura, música e artes visuais.

DIÁRIO DE NOTÍCIAS. Salvador, n. 8, 26 out. 1958. Crônicas de arte, de história, de costume, de cultura da vida: arquitetura, pintura, escultura, música e artes visuais.

DIÁRIO DE NOTÍ́CIAS. Salvador, 6 jan. 1960.

DIÁRIO DE NOTÍCIAS. Salvador, 8 jan. 1960.

DIAS difíceis do museu empacotado. Revista Veja SP, São Paulo, 22 fev. 1989, p. 14-20.

A CULTURA figurativa na infância. Revista Habitat, São Paulo, n.6, p. 47-49, jan./mar. 1952.

CUNHA, A. Outro primitivo. Habitat, São Paulo, n. 10, jan./mar. 1953.

DIRETORA do MAP divulga arte popular: Europa. Jornal da Bahia, Salvador, 27 fev. 1963.

EDIFÍCIO Trianon entra agora em fase de acabamento. Folha de S. Paulo, São Paulo, 4 out. 1968.

EM 20 painéis: vários séculos de história da arte: exposição do MAMB. Diário de Notícias, Salvador, 19 jan. 1961.

A ESCOLA da criança do MAMB. Diário de Notícias, Salvador, 29 abr. 1960.

ESCOLA da criança (música) no Museu de Arte Moderna. Diário de Notícias, Salvador, 19 abr. 1960.

ESCOLAS da criança e técnica das artes estio no programa MAMB. Diário de Notícias, Salvador, 17 dez. 1959.

ESTADO DA BAHIA. Salvador, 9 mai. 1960.

EXPOSIÇÃO Bahia. Diário de São Paulo, São Paulo, 18 set. 1959.

EXPOSIÇÃO Bahia no Ibirapuera. Diário de São Paulo, São Paulo, 24 set. 1959.

EXPOSIÇÃO baiana em São Paulo: artes plásticas. O Jornal, Rio de Janeiro, 4 nov. 1959.

EXPOSIÇÃO cartográfica vai ser inaugurada hoje: foyer do teatro Castro Alves. Estado da Bahia, Salvador, 6 nov. 1962.

EX-VOTOS do Nordeste. Habitat, São Paulo, n. 1, p. 72-74, out./dez. 1950.

FANTÁSTICO é o mundo. Pintor bandeirante chega amanhã e inaugura mostra no Museu de Arte Moderna. Diário de Notícias, Salvador, 21 mai. 1962.

FERRAZ, M. Os espaços de Lina Bardi. Caderno SESC - Video Brasil, n. 4, São Paulo: SESC, 2008.

Numa velha fábrica de tambores. SESC - Pompéia comemora 25 anos. Vitruvius, ano 8, vol. 9, p. 212, abr. 2008. Seção Minha cidade: São Paulo. Disponível em:

<http://www.vitruvius.com.br/minhacidade/mc212/mc212.asp〉. Acesso em: 28 jul. 2009.

. O Pelourinho no Pelourinho. Vitruvius, São Paulo, ano 8, vol. 12, p. 224, jul. 2008. Seção Minha cidade: Salvador. Disponível em: <http://www.vitruvius.com. br/minhacidade/mc224/mc224.asp〉. Acesso em: 28 jul. 2009. 
FIGUEIREDO, Z. G. Lina Bo Bardi. 8 nov. 1963. [S.I.]

FILHO, A. G. Ajustar o novo ao antigo, a preocupação. Jornal Folha de S. Paulo, São Paulo, 11 abr. 1982. In FERRAZ, M. C., VAINER, A. Cidadela da Liberdade: Exposição realizada no SESC Pompéia - 19 de novembro a 30 de dezembro de 1999, São Paulo: SESC / INSTITUTO LINA BO E P. M. BARDI, 1999.

GONÇALVES, M. O índio barroco. Diário de Notícias, Salvador, n. 4, 28 set. 1958. Crônicas de arte, de história, de costume, de cultura da vida: arquitetura, pintura, escultura, música e artes visuais.

GRASSMANN com desenhos e gravuras no MAMB: dia 6. Jornal da Bahia, Salvador, 2 set. 1962.

GRAVADOR cearense expões hoje: MAMB. Jornal da Bahia, Salvador, 14 ago. 1962.

GRAVURAS de Hélio Oliveira no MAMB. A Tarde, Salvador, 11 dez. 1962.

GUITA: Museu do Unhão mostra que arte popular não é exotismo. A Tarde, Salvador, 6 nov. 1963.

Hélio e Betty King mostram no MAMB beleza de sua arte. Diário de Notícias, Salvador, 10 mai. 1962.

IMAGENS da Bahia. Habitat, São Paulo, n. 9, p. 42-46, out./dez. 1952.

INAUGURAÇÃO do Museu de Arte Popular. A Tarde, Salvador, 10 out. 1963.

INAUGURADA no MAMB a exposição de gravuras se Sérvulo, Alda e Sara. Diário de Notícias, Salvador, 15, 16 ago. 1962.

INAUGURADO o MAP com duzentas obras de arte que o povo faz. Jornal da Bahia, Salvador, 4 nov. 1963.

INAUGURA-SE hoje a exposição de Portinari. Jornal da Bahia, Salvador, 10 abr. 1962.

ÍNDIO desenhista. Habitat, São Paulo, n. 1, p.86, out./dez. 1950.

ÍNDIO modista. Habitat, São Paulo, n. 1, p. 87, out./dez. 1950.

INSCREVA já seus filhos na Escola da Criança, no Museu de Arte Moderna da Bahia. Diário de Notícias, Salvador, 27 abr. 1960.

INSTALAÇÃO em princípios de maio. Mostra fotográfica sobre o teatro Norte Americano. Jornal da Bahia, Salvador, 26 abr. 1961.

JAFA, V. Ainda "a ópera de três tostões". Jornal Correio da Manhã, Salvador, 27 nov. 1960.

JORDÃO, V. P. A Bahia na Bienal. O Globo, Rio de Janeiro, 4 nov. 1959. Coluna de Artes Plásticas.

JOUJARD visitou o MAMB. Diário de Notícias, Salvador, 20 jul. 1960.

JURACY vai ver Portinari. 14 quadros de Portinari e desenhos de Leonardo estão expostos no MAMB. Diário de Notícias, Salvador, 11 abr. 1962.

Folclore mágico. Diário de Notícias, Salvador, n. 9, 2 nov. 1958. Crônicas de arte, de história, de costume, de cultura da vida: arquitetura, pintura, escultura, música e artes visuais.

Sobre a problemática da música de nosso. Diário de Noticias, Salvador, n. 5, 5 out. 1958. Crônicas de arte, de história, de costume, de cultura da vida: arquitetura, pintura, escultura, música e artes visuais.

KOELLREUTTER, H. J. E nosso meio musical. Habitat, São Paulo, n. 6, p. 84-85, jan., mar. 1952.

LACERDA, M. Lina do Brasil. A história da italiana que adotou o país e trouxe pra cá uma arquitetura mais humana, feita para pessoas de verdade e repleta de simplicidade. Vida simples. São Paulo: Editora Abril, ed. 33, out. 2005. Seção Personagem. Disponível em: <

http://vidasimples.abril.com.br/edicoes/033/personagem/conteudo_237652. shtml >. Acesso em : 8 jul. 2009.

LEONARDO vai expor suas nuvens no MAMB. Jornal da Bahia, Salvador, 8 abr. 1962.

LINA Bardi diz que museu será escola: provará com estudo: artes não são inúteis. Diário de Notícias, Salvador, 6 jan. 1960.

LINA Bo Bardi fala do museu que criou. O Povo, Fortaleza, 13 set. 1963. 
LINA Bo Bardi: Obra Construída, 2G - Revista Internacional de Arquitectura, Barcelona: Editorial Gustavo Gili, n.23-24, 2003.

MAGANO e Tana com quadros e tecidos já expõe no MAMB. Diário de Notícias, Salvador, 8 mar. 1961.

MAHFUZ, Edson c. Traços de uma arquitetura consistente. Arquitextos 016, setembro de 2001. Disponível em: 〈http://www.vitruvius.com.br/minhacidade/mc224/ mc224.asp>. Acesso em: 28 jul. 2009.

MAIA, P. M. Fotografia e teatro. Jornal da Bahia, Salvador, 7 ago. 1960.

MALAVOGLIA, F. Centro de lazer SESC "Fábrica da Pompéia”. Boletim da Associação Brasileira de Museologia. São Paulo, n. 9, ago. 1995. In: FERRAZ, M. C., VAINER, A. Cidadela da Liberdade: Exposição realizada no SESC Pompéia - 19 de novembro a 30 de dezembro de 1999, São Paulo, SESC / INSTITUTO LINA BO E P. M. BARDI, 1999.

MAMB contará hoje a "história da cadeira”. Jornal da Bahia, Salvador, 23 jan. 1962.

MAP abriu suas portas para a arte que o povo faz. Jornal da Bahia, Salvador, 17,18 nov. 1963.

MAP será instalado amanhã com mil peças de artesanato. Jornal da Bahia, Salvador, 2 nov. 1963.

MÁRIO, C. Bahia procura dar sentido novo de arte às novas gerações. Revista O Cruzeiro, Rio de Janeiro, fev. 1960 .

MÁRIO Cravo e Candida Jorge vão expor amanhã no MAMB às 18 horas. O Estado da Bahia, Salvador, 9 jul. 1962.

MÁRIO Cravo: um ano de trabalho e sucesso na Alemanha. Jornal da Bahia, Salvador, 30,31 ago. 1964.

MARTINS, F. A jangada segundo Albuquerque. Habitat, São Paulo, n. 8, p. 50-57, jul./set. 1952.

MATHIEU hoje no MAMB: pintura bela e polêmica. Diário de Notícias, Salvador, 31 mai. 1960.

MEIRELLES, D. Uma velha paixão cultivada com esperança, Jornal da Tarde, São Paulo, 22 jul. 1985.

MIMAR Architecture in development, Singapore: Concept media Pte Ltd, n. 2, 1981.

MUSEU ganha vigas e lajes vermelhas. Revista Projeto, São Paulo, n. 134, 1990.

LA MOSTRA “Bahia”. Corriere della V Biennale. Fanfulla, São Paulo, 27 set. 1959.

MOSTRA de Mário Cravo foi inaugurada ontem: MAMB. Jornal da Bahia, Salvador, 11 jul. 1962.

MUDA-SE o Museu de Arte. O Estado de S. Paulo, São Paulo, 9 out. 1968.

MUNDOS desaparecidos. Habitat, São Paulo, n. 3, abr./jun. 1951.

MUNIZ, P. Faltam três no MAMB. Jornal da Bahia, Salvador, 16 jan. 1960.

MUSEU Arte Popular do IFB incentiva folclore. A Tarde, Salvador, 21 ago. 1963.

MUSEU de Arte de S. Paulo e Prefeitura fazem acordo. Folha de S. Paulo, São Paulo, 4 nov. 1970.

O MUSEU de Arte de São Paulo. Habitat, São Paulo, n. 1, p. 17, out./dez. 1950.

MUSEU de Arte Moderna da Bahia. Diário de Notícias, Salvador, 11 jan. 1960.

MUSEU de Arte Moderna da Bahia será inaugurado com exposições. Estado da Bahia, Salvador, 5 jan. 1960.

O MUSEU de Arte Popular. A Tarde, Salvador, 5 nov. 1963.

O MUSEU de Arte vence o vão livre. Folha de S. Paulo, São Paulo, 26 mar. 1966.

O MUSEU que a rainha vai inaugurar hoje. Folha de S. Paulo, São Paulo, 7 nov. 1968.

MUSEUS. Habitat, São Paulo, n. 4, jul./set. 1951.

NORDESTE: uma luta para não afundar no desespero. Jornal da Bahia, Salvador, 10,11 nov. 1963.

NORDESTE, centro de gravidade da cultura brasileira: Brennand. A Tarde, Salvador, 6 nov. 1963.

NORDESTE mágico. Habitat, São Paulo, n. 9, p. 35, out./dez. 1952.

NOSSA opinião: um ano de MAMB. Diário de Notícias, Salvador, 8 jan. 1961. 
NOSSOS instrumentos musicais. Habitat, São Paulo, n. 8, p. 42-43, jul./set. 1952.

A NOVA vida do Museu de Arte. Folha de S. Paulo, São Paulo, 9 fev. 1969.

OBRAS de arte recebidas como personagens. Habitat, São Paulo, n. 6, jan./mar. 1952.

AS OITO respostas do Museu. Folha de S. Paulo, São Paulo, 15 dez. 1969.

OLLY Reinheimer veio à Bahia expor no MAMB dia 30: 40 trabalhos. Diário de Notícias, Salvador, 27 jan. 1961.

OSWALD, H. O museu de D. Lina. Jornal da Bahia, Salvador, 6 nov. 1963.

OUTRAS peças no museu Pigorini de Roma. Habitat, São Paulo, p.36-41, n. 9, out./dez. 1952.

PAGLIA, D. Arquitetura na Bienal de São Paulo. I Bienal de São Paulo, São Paulo: Edições Americanas de Arte e Arquitetura, 1952.

PARA presente - embrulhado em plástico, o Masp ganha sua primeira reforma. Revista Veja SP. São Paulo, p. 110, 10 ago. 1988.

POVO vai ao museu: vê modernos, reage, mas sai gostando. Diário de Noticias, Salvador, jan.1960.

PROPAGANDA da Escola da Criança do MAMB. Diário de Noticias, Salvador, 27 abr. 1960.

ROCHA, G. MAMB não é museu: é escola e "movimento" por uma arte que não seja desligada do homem. Jornal da Sabia, Salvador, 21 set. 1960.

SANTOS, C. R. dos S. Uma cidadela Americana. São Paulo, 1993. In: FERRAZ, M. C., VAINER, A. Cidadela da Liberdade: Exposição realizada no SESC Pompéia - 19 de novembro a 30 de dezembro de 1999, São Paulo, SESC / INSTITUTO LINA BO E P. M. BARDI, 1999.

SERÁ a exposição Bahia apresentação de uma cultura e não mostra de exotismo. Diário de São Paulo, São Paulo, 13 set. 1959.

SILVA, H. J. P. MAP é história viva, dinâmica da cultura de um povo (que avança e ganha mundos) abrindo novos caminhos. Jornal Folha da Bahia, Salvador, nov. 1963.

SILVA, Q. Notas de arte: Lina Bo Bardi. 20 mar. 1960.

SIMÕES, G. Sociedade, fatos \& gente. Salvador, 28,29 out. 1962.

SOBRAL, N. Abelardo da hora fala sobre urna experiência pernambucana: o MCP. Jornal da Bahia, Salvador, 10,11 nov. 1963.

MAMB faz seis anos e em abril será centro de artesanato. Jornal da Bahia, Salvador, 8 jan. 1966.

SOCIEDADE. A Tarde, Salvador, 8 jan. 1960.

SOLAR do Unhão afinal encontrou seu destino. A Tarde, Salvador, 22 mar. 1963.

SOLAR do Unhão vai abrigar em definitivo instalações do MAMB. Jornal da Bahia, Salvador, 4 set. 1963.

SOLAR do Unhão vai ser oficina. A Tarde, Salvador, 16 mar. 1966.

SUBIRATS, E. Arquitetura e poesia. Revista Projeto, São Paulo, n. 143, jun. 1991. In: FERRAZ, M. C., VAINER, A. Cidadela da Liberdade: Exposição realizada no SESC Pompéia - 19 de novembro a 30 de dezembro de 1999, São Paulo, SESC / INSTITUTO LINA BO E P. M. BARDI, 1999.

Os gigantes e a cidade. Revista Projeto, São Paulo, n. 92, n. 149, out. 1986, jan. fev. 1992. In: FERRAZ, M. C., VAINER, A. Cidadela da Liberdade: Exposição realizada no SESC Pompéia - 19 de novembro a 30 de dezembro de 1999, São Paulo, SESC / INSTITUTO LINA BO E P. M. BARDI, 1999.

TEATRO agora é apenas uma imensa caixa vazia. Bahia acredita em JM: TCA vai ser concluído. Jornal da Bahia, Salvador, 31 jul. 1960.

TECIDOS. Habitat, São Paulo, n. 8, p. 39-41, jul./set. 1952.

TRIANON será sede do MA. O Estado de S. Paulo, São Paulo, 20 ago. 1968.

TRIENNALE de Milano, 1964, Milão. Catálogo da exposição. 
D. UNA ganha elogios. Folha da Bahia, Salvador, 30 mar. 1963.

UNIVERSIDADE faz doação ao museu. Jornal da Bahia, Salvador, 17 jun. 1959.

VALLADARES, C. P. Aclam Firnekaes: 1960. Jornal Diário de Notícias, Salvador, 5 dez. 1960. Escultura e dimensão tempo-espaço. Jornal Diário de Notícias, Salvador, 31 jan. 1960.

VEGETAÇÃO de Brasília em exposição hoje no MAMB. Jornal da Bahia, Salvador, 9 mai. 1962.

ZANINI, I. No lbirapuera pode-se saber "o que é que a Babia tem". Jornal Folha da Noite, São Paulo, 9 out. 1959.

ZEVI, B. A fábrica dos signos. Revista L’Expresso, Roma, mai. 1987. In: FERRAZ, M. C., VAINER, A. Cidadela da Liberdade: Exposição realizada no SESC Pompéia - 19 de novembro a 30 de dezembro de 1999, São Paulo, SESC / INSTITUTO LINA BO E P. M. BARDI, 1999.

La Mostra dei "Nordeste do Brasil": L'arte dei poveri fa paura ai generali. Jornal L'Espresso, Milán, 14 mar. 1965.

ZOROASTRO. Cadeiras no MAMB. A Tarde, Salvador, 3 fev. 1962.

\section{BIBLIOGRAFIA ESPECÍFICA: LUCIO COSTA} LIVROS, TESES E DISSERTAÇÕES

ANDRADE, RODRIGO M. F, Museus regionais no Brasil: uma experiência - in "Rodrigo e o SPHAN" Rio de Janeiro: MinC, SPHAN/Pró-Memória, 1987

ARANTES, O. B. F. Lucio Costa e a 'boa causa' da arquitetura moderna'. In: ARANTES, O.; ARANTES, P. Sentido da formação. São Paulo: Paz e Terra, 1997.

CATTAN, Roberto Correia de Mello A Família Guinle e a Arquitetura do Rio de Janeiro: Um capítulo do ecletismo carioca nas duas primeiras décadas do novecentos. Dissertação de mestrado. Rio de Janeiro: Pontifícia Universidade Católica do Rio de Janeiro, Departamento de História, 2003.

CAVALCANTI, L. P. Modernistas na repartição. Rio de Janeiro: Ed. UFRJ, MinC / IPHAN, 2000.

COSTA, L. Arquitetura. Rio de Janeiro: José Olympio, 2002.

Com a palavra, Lucio Costa. Maria Elisa Costa (org.). Rio de Janeiro: Aeroplano Editora, 2001.

Lucio Costa: Documentos de trabalho. José Pessôa (org.). Rio de Janeiro: IPHAN, 1999.

Registro de uma vivência. São Paulo: Empresa das Artes, 1995.

Sobre Arquitetura. Alberto Xavier (org.). Porto Alegre: Centro de Estudantes Universitários de Arquitetura, 1962. Idem: revisão fac-símile com comentários de Lucio Costa. Porto Alegre: Editora UniRitter, 2007.

CUSTÓDIO, L. A. B. A redução de São Miguel Arcanjo. Porto Alegre, Faculdade de Arquitetura da Universidade Federal do Rio Grande do Sul, Dissertação de Mestrado, 2002.

CZAJKOWSKI, J. (org). Guia da arquitetura moderna no Rio de Janeiro. Rio de Janeiro: Casa da Palavra, Prefeitura da Cidade do Rio de Janeiro, 2000.

DOUCHKIN, T. (bibliot.). Palácio das indústrias: Memória e Cidadania. O restauro para a nova Prefeitura de São Paulo. São Paulo: Ed. DPH / Método, 1992.

GÖSSEL, P; LEUTHÄUSER, G. Arquitectura no século XX. Alemanha: Taschen, p. 174, 1996.

GUERRA, A. Lucio Costa - modernidade e tradição: montagem discursiva da arquitetura moderna brasileira. Campinas: Departamento de História - UNICAMP, Tese de Doutorado, 2002.

GUIMARÃES, C. de. Lucio Costa: um certo arquiteto em incerto e secular roteiro. Rio de Janeiro: Relume Dumará / Rio-Arte, 1996.

HOLSTON, J. A cidade modernista - uma crítica de Brasília e sua utopia. São Paulo: Companhia das Letras, 1993. 
LISSOVSKY, M.; SÁ, P. S. M. de (org). Colunas da educação: a construção do Ministério da Educação e Saúde (1911-1945). Rio de Janeiro: MinC / IPHAN, Fundação Getúlio Vargas / CPDOC, 1996.

MARTINS, C. A. F. Arquitetura e Estado no Brasil - elementos para uma investigação sobre a constituição do discurso moderno no Brasil; a obra de Lucio Costa (1924-1952). São Paulo: FFLCH - USP, Dissertação de Mestrado, 1988.

. Le Corbusier e Lúcio Costa: Afinidades Eletivas. In: NOBRE, A. L.; KAMITA, J. M.; LEONÍDIO, O.; CONDURU, R. (org.). Um modo de ser moderno: Lucio Costa e a crítica contemporânea. São Paulo: Cosac \& Naify, p. 71-83, 2004.

Razon, ciudad y naturaleza: Ia genesis de los conceptos en el urbanismo de Le Corbusier. Madrid: Esculela Técnica Superior de Arquitectura de Madrid, Tese de Doutorado, 1992.

MAYERHOFER, L. Reconstituição do povo de São Miguel das Missões. Tese de Concurso para a Universidade Federal do Rio de Janeiro. Rio de Janeiro, 1947.

NOBRE, A. L.; KAMITA, J. M.; LEONÍDIO, O.; CONDURU, R. (org.). Um modo de ser moderno: Lucio Costa e a crítica contemporânea. São Paulo: Cosac \& Naify, 2004.

NONATO, J. A.; SANTOS, N. M. Era uma vez o Morro do Castelo. Rio de Janeiro: IPHAN, 2000.

NOTO, F. S. Paralelos entre Brasil e Portugal: a obra de Lucio Costa e Fernando Távora. São Paulo, Faculdade de Arquitetura e Urbanismo - USP, Dissertação de Mestrado, 2007.

SILVA, M. A. As formas e as palavras na obra de Lucio Costa. Rio de Janeiro: Departamento de História - PUC / Rio, Dissertação de Mestrado, 1991.

SOUZA, R. F. C. Trajetória da arquitetura modernista. São Paulo: PMSP / IDART, 1982.

TELLES, S. S. Arquitetura moderna no Brasil: o desenho da superfície. São Paulo: FFLCH - USP, Dissertação de Mestrado, 1988.

VIEIRA, L. G. Salão de 31. Rio de Janeiro: Funarte / Insituto Nacional de Artes Plásticas, 1984.

XAVIER, A.; BRITO, A.; NOBRE, A. L. Arquitetura moderna no Rio de Janeiro. São Paulo: PINI, Fundação Vilanova Artigas, Rio de Janeiro: RIOARTE, 1991.

WISNIK, G. (org.) O Risco: Lucio Costa e a utopia moderna. Rio de Janeiro: Bang Bang Filmes Produções Ldta, 2003.

Lucio Costa. Coleção Espaços da Arte Brasileira. São Paulo: Cosac \& Naify, 2001.

\section{$\underline{\text { PERIÓDICOS }}$}

ABBUD, O. Lúcio Costa: a realidade maior que o sonho na Brasília de 25 anos depois. Jornal do Brasil, Rio de Janeiro, 27 nov. 1984.

ANDRADE, C. F. de. Palácio Capanema: uma das 7 maravilhas do Rio? Vitruvius, São Paulo, ano 8, vol. 2, p. 192, set. 2007. Seção Minha cidade: Rio de Janeiro. Disponível em: < http://www.vitruvius.com.br/minhacidade/mc192/mc192.asp >. Acesso em: 28 jul. 2009.

BRASÍliA: Lúcio Costa aponta as distorções. Folha de S. Paulo, São Paulo, 21 ago. 1974.

BRINO, A. C. Brasília: Superquadas Residenciais, In: $5^{\circ}$ SEMINÁRIO DOCOMOMO BRASIL, São Paulo: USP, v. 1, 2003.

CAMPOFIORITO, I. Brasília revisitada. Arquitetura Revista, Rio de Janeiro: FAU / UFRJ, n. 7, p. 23-41, 1989.

60 anos: A Revista. Revista do Patrimônio Histórico e Artístico Nacional, Rio de Janeiro, n. 26, 1997.

CARrilho, M. J. A Transparência do Museu das Missões. In: $1^{\circ}$ SEMINÁRIO DOCOMOMO SUL, Porto Alegre: PROPAR / UFRGS, 2006

CARVAlHO, L. M. Lúcio Costa dá adeus a Brasília. Jornal do Brasil, Rio de Janeiro, 2 ago. 1988. 
CASCO, A. C. A. J. Sobre a idéia desmiolada de reconstruir o Palácio Monroe. Vitruvius, ano 2, vol. 10, p. 47, mai. 2002. Seção Minha cidade: Rio de Janeiro. Disponível em: <http://www.vitruvius.com.br/minhacidade/mc047/mc047.asp>. Acesso em: 28 jul. 2009.

CAVALCANTI, L. Brasilia: a construção de um exemplo, Revista Arcos, Rio de Janeiro, ESDI/UERJ, v. 1, n. único, p.50-62, out. 1998. Disponível em: 〈http://www.esdi.uerj.br/sobrearcos/artigos/artigo_lauro(50a62).pdf>. Acessado em: 28 jul. 2009.

COMAS, C. E. Lúcio Costa - Da atualidade do seu pensamento. AU - Arquitetura e Urbanismo, São Paulo, v. 39, p. 69-74, 1991.

Protótipo e monumento, um ministério, o ministério. Projeto, São Paulo: Projeto Editores Associados Ltda., n. 102, p. 136-149, 1987.

Simples abrigo, límpida ruína, modernidade real: o museu das Missões de Lucio Costa. In: $1^{\circ}$ SEMINÁRIO DOCOMOMO SUL, Porto Alegre: PROPAR / UFRGS, 2006.

. Uma certa arquitetura moderna brasileira: experiência a reconhecer. Arquitetura Revista, Rio de Janeiro: FAU/UFRJ, n. 5, p. 22-28, 1987.

COSTA, L. Homenagem aos seus 90 anos de vida (entrevista a Lauro Cavalcanti e Cláudia Coutinho), IBPC Notícias, Brasília, fev. 1992. Edição Especial.

. Jesuis comme je suis (entrevista a Ana Luiza Nobre), AU - Arquitetura e Urbanismo, n. 74, p. 71-73, out./nov. 1997.

. Lucio Costa (entrevista a Álvaro Hardy, Éolo Maia, José Eduardo Ferolla, Mauricio Andrés e Paulo Laender), Pampulha, Belo Horizonte, n. 1, p. 16, nov./dez. 1979.

. Lucio Costa por ele mesmo. Jornal do Brasil, Rio de Janeiro, 27 fev. 1988.

. Lucio Costa sobre Aleijadinho (entrevista a Carlos Zilio, Jorge Czajkowski, Maria Cristina Burlamaqui e Ronaldo Brito), Gávea, Rio de Janeiro: PUC-Rio, p. 32-59, jun. 1986.

. Lucio Costa: revelações de 90 anos (entrevista a Alfredo Britto e Ítalo Campofiorito), Piracema, Rio de Janeiro: FUNARTE/IBAC, n. I, p. 69-81, 1995.

Presença de Le Corbusier: entrevista com Lucio Costa (entrevista a Jorge Czajkowski, Maria Cristina Burlamaqui e Ronaldo Brito), Arquitetura Revista, Rio de Janeiro: FAU/UFRJ, v. 5, p. 2-15, 1987.

CUNHA, J. R. da. Diário da Expedição de Gomes Freire de Andrada às Missões do Uruguai. Revista do Instituto Histórico e Geográfico Brasileiro, Rio de Janeiro, 1894.

GODINHO, F. Torres de Niemeyer causam polêmica, Folha de S. Paulo, São Paulo, 3 dez. 1996.

GORELIK, A. Tentativas de comprender la ciudad moderna, Block, Buenos Aires, n. 4, p. 62-77, dec. 1999.

GUERRA, A . A Sustentabilidade cultural em Lucio Costa. Catálogo da Iniciativa Solvin, CIDADE, Romano Guerra Editora, p. 20-31, 2005.Disponível em: <http://www.vitruvius.com.br/romanoguerra/solvin/solvin2005.asp>

Estado, cultura e natureza na origem da arquitetura moderna brasileira: Le Corbusier e Lucio Costa, 1929/1936. Caramelo, São Paulo: FAU/USP, n. 6, p. 129-156, 1993.

Lucio Costa, Gregori Warchavchik e Roberto Burle Marx: síntese entre arquitetura e natureza tropical, Revista USP, São Paulo, p. 18-51, mar. abr. mai. 2002.

LEAL, F. M. São Miguel das Missões: Estudo de estabilização e conservação das ruínas. Revista do Patrimônio, Rio de Janeiro: IPHAN, n. 18, 1984.

LUCIO Costa: a análise de Brasília. Folha de S. Paulo, São Paulo, 06 ago. 1974.

LUCIO Costa homenagem aos seus 90 anos de vida. IBCP Patrimônio Cultural. Notícias Edição especial. Brasília: 27 fev. 1992.

LUCIO Costa: não são graves e têm solução problemas de Brasília. O globo, Rio de Janeiro, 06 ago. 1974.

MARTINS, C. A. F. Estado, cultura e natureza na origem da arquitetura moderna brasileira: Le Corbusier e Lúcio Costa, 1929-1936. Revista Caramelo, São Paulo, n. 6, 1993. 
Identidade nacional e estado no projeto modernista: modernidade, estado e tradição. Revista Óculum: arquitetura, arte e cultura, Campinas, n. 2, set. 1992.

MAYRINK, G. Toque de nobreza. Veja, São Paulo: Editora Abril, 27 jan. 1993.

MEIER, R. Le Corbusier, Villa Savoye, Poissy, France, 1929-31. GA Global Architecture, Tókio, 1972.

NOBRE, A. L. A falta que nos faz. Crítica e Arquitetura no Brasil. Vitruvius, São Paulo, jul. 2000. Seção Arquitextos. Disponível em: 〈http://www.vitruvius.com.br/ arquitextos/arq002/ arq002_02.asp>. Acesso em: 28 jul. 2009.

NOBRE, A. L. (org). Lucio Costa: o primeiro verso. AU - Arquitetura e Urbanismo, n. 38, p. 46-117, out./nov. 1991. Edição Especial.

A razão e as razões de Lucio Costa, AU - Arquitetura e Urbanismo, p.100-103, fev./mar. 2002.

PALÁCIO Monroe. Porque foi demolido? Alma carioca. Rio de Janeiro. Disponível em: <http://www.almacarioca.com.br/monroe.htm>. Acesso em: 28 jul. 2009.

PLATAFORMA rodoviária. Revista Acrópole, Brasilia: M. Grunewald, vol 256/257, p. 90-93, abr. 1960.

ROCHA-PEIXOTO, G. INEPAC: Um perfil dos 25 anos de Preservação do patrimônio Cultural do Estado do Rio de Janeiro. Arquitetura Revista, Rio de Janeiro: FAU / UFRJ, n. 8, 1990.

ROCHA, R. O pavilhão Lucio Costa. Vitruvius, São Paulo, ano 1, vol. 6, p. 10, jan. 2001. Seção Minha cidade: São Miguel das Missões. Disponível em: $<$ http://www. vitruvius.com.br/minhacidade/mc010/mc010.asp>. Acesso em: 28 jul. 2009.

RUBINO, S. B. Gilberto Freyre e Lucio Costa, ou a boa tradição. Óculum 2, Campinas: FAUPUCAMP, 1992.

SEGRE, R. Alvorada Vermelha em Brasília. Vitruvius, São Paulo, jan. 2003. Seção Arquitextos. Disponível em:<http://www.vitruvius.com.br/arquitextos/arq032/arq032_00.asp>. Acesso em: 01 set. 2009.

TELLES, S. S. Lucio Costa: Monumentalidade e intimismo, Revista Novos Estudos, São Paulo: CEBRAP, n. 25, 1989.

VILLA, E. Os puristas são enfadonhos e inúteis. Habitat, São Paulo, n. 7, p. 1-2, abr./jun. 1952.

WISNIK, G. Plástica e anonimato: modernidade e tradição em Lucio Costa e Mário de Andrade. Scielo. São Paulo: Novo Estudos / CEBRAP, n. 79, nov. 2007. Disponível em: <http://www.scielo.br/scielo.php?pid=S0101-33002007000300009\& script=sci_arttext $>$. Acesso em: 28 jul. 2009.

\section{REFERÊNCIAS GERAIS DICIONÁRIOS, ENCICLOPÉDIAS}

ALBERnAZ, M. P., LIMA, C. M. Dicionário Ilustrado de Arquitetura. São Paulo: ProEditores, 1998. ATLAS National Geographic: Brasil em Imagens. Volume 13. São Paulo: Abril, 2008.

BURDEN, E. Dicionário Ilustrado de Arquitetura. Porto Alegre: Artmed, 2006.

CORONA, E., LEMOS, C. Dicionário da Arquitetura Brasileira. São Paulo: Edart, 1972.

FERREIRA, A. B. H. Dicionário Aurélio da Língua Portuguesa. Rio de Janeiro: Nova Fronteira, 1988.

GNONE, T. Dizionario Architettonico. Torino: Societá Editrice Internazionale, 1954.

PEVSNER, N.; FLEMING, J.; HONOUR, H. Dicionário Enciclopédico de Arquitetura. Rio de Janeiro: Artenova, 1977.

\section{DOCUMENTÁRIOS E FILMES EM VÍDEO}

ARQUITETURA da destruição. Direção: Peter Cohen. Narração: Bruno Ganz. Suécia, 1992. (121 min.)

O BANDIDO da luz vermelha. Direção: Rogério Sganzerla. Intérpretes: Paulo Vilaça, Helena Inês e outros. Brasil: Urânio Filmes. 1968. (92 min.) 
DONA Flor e seus dois maridos. Direção: Bruno Barreto. Intérpretes: Sonia Braga, José Wilker, Mauro Mendonça e outros. Brasil: Embrafilme / New Yorker Films. 1976. (110 min.)

LADEIRA da Igreja da Glória. Direção: José Reznik. Direção de Fotografia: Mário Carneiro. Disponível em: 〈http//www.casadeluciocosta.org.>. Acesso em: 22 de maio de 2007.

LINA Bo Bardi. Isa G. Ferraz e Aurélio Michiles. São Paulo: Instituto Lina Bo e P. M. Bardi, 1993. VHS

A MISSÃO. Direção: Roland Joffé. Intérpretes: Robert de Niro, Jeremy Irons, Lean Neeson. Inglaterra: Flashstar. 1986. (121 mim.).

O RISCO: Lucio Costa e a Utopia Moderna. Direção: Geraldo Motta Filho. Rio de Janeiro: Bang Bang Filmes, 2003. 1 DVD (76min.)

DOCUMENTOS SONOROS E POEMAS:

NELSON ALVES. Mistura e manda. in PAULO MOURA: Mistura e manda. Rio de Janeiro: Kuarup Discos, 1986

CARLOS DRUMOND DE ANDRADE. Quadrilha. 1975.

GILBERTO GIL, JOSÉ CARLOS CAPINAN e TORQUATO NETO. Soy loco por ti América: 1966.

GILBERTO GIL. Back in Bahia (música e letra), in Expresso 2222, 1972

CHICO BURAQUE DE HOLLANDA. Flor da Idade. Rio de Janeiro: 1975.

NOEL ROSA. Com que roupa. Rio de Janeiro: 1929.

Três apitos. Rio de Janeiro: 1936.

CAETANO VELOSO. O Estrangeiro: 1989.

Fora da ordem (música e letra) in Circuladô,1991.

SÍTIOS DE INTERNET VISITADOS:

http://en.structurae.de

http://www.casadeluciocosta.org

http://www.usp.br/fau/antigo/depprojeto/gdpa/historico/origemtotal.html

http://www.historianet.com.br/

http://opal.kent.ac.uk/cartoonx-cgi/ccc.py?mode $=$ summary\&search $=\mathrm{VY} 0170$

http://www.tracymariesaunders.com/tube/station.php?station=bank

http://www.paulo-coelho.net/blog/_archives/2007/1/18/2666590.html

http://cdm.lib.usm.edu/cdm_usm/item_viewer.php?CISOROOT=/cartoon\&CISOPTR=351\&CISOBOX=1 $\underline{\text { REC }}=1$

http://www.almacarioca.com.br/monroe.htm 